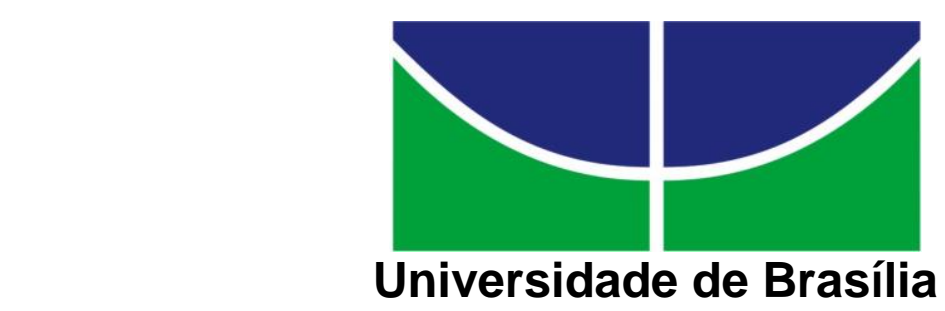

Faculdade de Ciência da Informação

Programa de Pós-Graduação em Ciência da Informação

MARIA DE FÁTIMA COELHO CASTRO

\title{
AVALIAÇÃO DE PRODUTOS DE INFORMAÇÃO JURÍDICA DO TRIBUNAL DA CIDADANIA: UM ENFOQUE DA CIÊNCIA DA INFORMAÇÃO
}




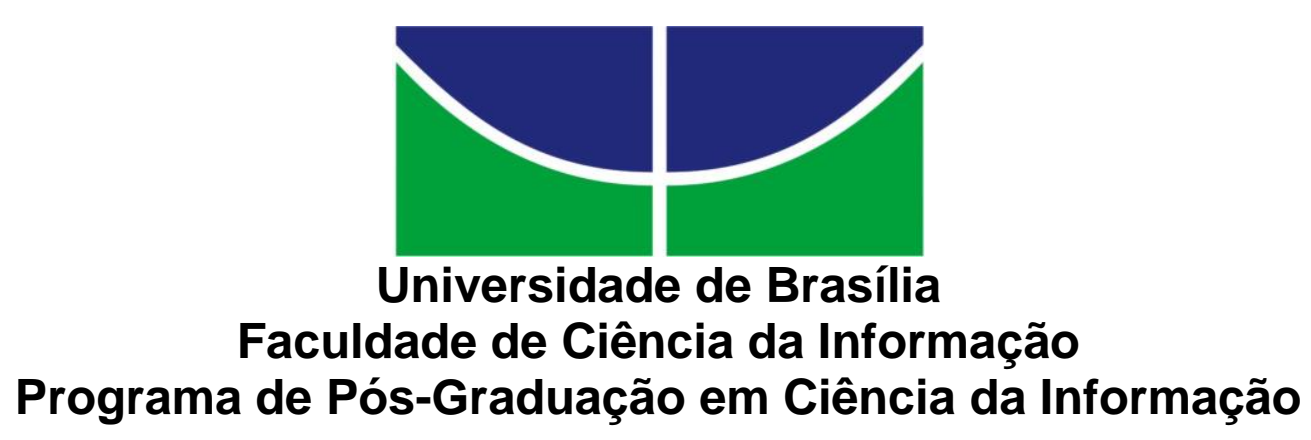

MARIA DE FÁTIMA COELHO CASTRO

\section{AVALIAÇÃO DE PRODUTOS DE INFORMAÇÃO JURÍDICA DO TRIBUNAL DA CIDADANIA: UM ENFOQUE DA CIÊNCIA DA INFORMAÇÃO}

Tese apresentada ao Programa de Pós-graduação em Ciência da Informação da Faculdade de Ciência da Informação como requisito para obtenção do título de Doutora em Ciência da Informação

Área de pesquisa: Comunicação e Mediação da Informação.

Linha de pesquisa: Biblioteca e sociedade

Orientador: Prof. Dr. Emir José Suaiden 
Ficha catalográfica elaborada automaticamente, com os dados fornecidos pelo(a) autor(a)

Castro, Maria de Fátima Coelho
C355aliaça de produtos de informação jurídica do
Tribunal da Cidadania : um enfoque da Ciência da
Informação / Maria de Fátima Coelho Castro; orientador
Emir José Suaiden. -- Brasilia, 2016.
330 p.
Tese (Doutorado - Doutorado em Ciência da
Informação) -- Universidade de Brasilia, 2016.
Produtos de informação jurídica na Web,
avaliação. 2. Metodologia de avaliação de produtos de
informação, Ciência da Informação. 3. Informação
jurídica, uso. 4. Produto de Informaça jurídica,
Superior Tribunal de Justiça. 5. Biblioteca Digital
Jurídica, Superior Tribunal de Justiça. I. Suaiden, Emir
José, orient. II. Título.




\section{FOLHA DE APROVAÇÃO}

Títullo: "Avaliação de produtos de informação jurídica do tribunal da cidadania: um enfoque da ciência da informação".

Autor (a): Maria de Fátima Coelho Castro

Área de concentração: Gestão da Informação

Linha de pesquisa: Comunicação e mediação da informação.

Tese submetida à Comissão Examinadora designada pelo Colegiado do Programa de Pós-graduação em Ciência da Informação da Faculdade em Ciência da Informação da Universidade de Brasília como requisito parcial para obtenção do título de Doutor em Ciência da Informação.

Tese aprovada em: 04 de março de 2016.

Proff. Dr. Emir José Suaiden

Presidente (UnB/PPGCINF)

Bellethrueas

Prof.a Dr.a Elmira Luzia Melo Soares Simeão

Membro Interno (UnB/PPGCINF)

Prof. - Dr ${ }^{\text {a }}$ Lillian Maria de Rezende Alvares

Membro Interno (UnB/PPGCINF)

leculventecenin

Prof. - Dr. - Cecília Leite Oliveira

Membro Externo (IBICT)

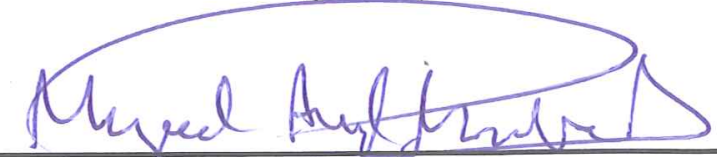

Prof. Dr. Miguel Ángel Márdero Arellano

Membro Externo (IBICT)

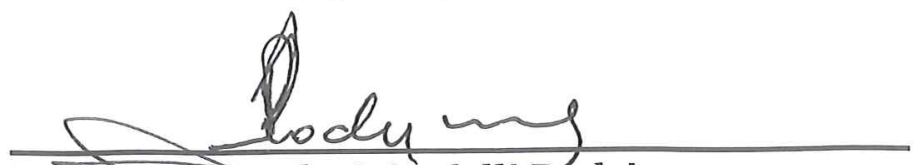

Prof. Dr. Ârear ho Grisafulli.Rodrigues

Suplente (IBICT) 
A Deus, que não me deixou nem desamparou, me reservando esta vitória após longo caminho percorrido. 


\section{AGRADECIMENTOS}

Agradeço a contribuição relevante de todos aqueles envolvidos nas várias etapas de realização desta pesquisa, para que a mesma se desenvolvesse e concretizasse, de modo especial:

Ao professor e orientador Dr. Emir José Suaiden pela oportunidade de pesquisar e aprofundar um tema relevante, com um método criativo e inovador e pela orientação excelente na condução desta pesquisa científica,

Aos componentes da Banca Examinadora, Dr ${ }^{\mathrm{a}}$ Elmira Luzia Melo Soares Simeão, Dr ${ }^{\text {a }}$ Lillian Maria de Rezende Alvares, Dr $^{\mathrm{a}}$ Cecília Leite Oliveira, Dro Miguel Ángel Márdero Arellano, Dro Ricardo Crisafulli Rodrigues, pela análise e observações fundamentais ao desenvolvimento da pesquisa,

Às autoras da Metodologia de Avaliação de Produtos e Serviços de Informação do Instituto Brasileiro de Informação Científica e Tecnológica, IBICT, Eliana da Conceição Rocha e Márcia de Figueiredo Evaristo de Sousa,

A minha irmã Maria de Lourdes Castro Fialho pelo incentivo, apoio e força nos momentos difíceis deste percurso,

A Francely de Fátima Bezerra Rocha pela participação na revisão do texto durante o desenvolvimento da pesquisa e pelo excelente trabalho profissional de design gráfico,

Ao colega José Ronaldo Vieira da Silva, chefe da Seção de Biblioteca Digital - Bdjur, pela colaboração indispensável em várias etapas da pesquisa e pela valiosa contribuição na formulação e elaboração do questionário eletrônico,

À bibliotecária Najla Bastos de Mello por acreditar, pela visão da importância da pesquisa científica nas organizações e pela colaboração na etapa de realização das entrevistas,

À Secretaria de Documentação e à Coordenação da Biblioteca Ministro Oscar Saraiva do Superior Tribunal de Justiça, pelo apoio recebido,

Aos colegas bibliotecários da Seção de Biblioteca Digital - BDJur, da Seção de Doutrina da Biblioteca Digital, e da Seção de Pesquisa da Biblioteca Ministro Oscar Saraiva do Superior Tribunal de Justiça, pela presteza no fornecimento de informações e dados fundamentais na elaboração da pesquisa, pesquisa,

Aos funcionários do IBICT, pelo apoio e valiosas contribuições para esta

À bibliotecária Edilenice J. Lima Passos, da Biblioteca Luis Viana Filho do Senado, pelas preciosas contribuições teóricas sobre a informação jurídica,

Aos professores dos Cursos de Pós-Graduação em Ciência da Informação do Departamento de Ciência da Informação da Universidade de Brasília, pelo conhecimento obtido na área da Ciência da Informação. 


\section{LISTA DE FIGURAS}

\section{Parte I}

Figura 01 Direito como ciência de projeção de comportamento............. 9

Figura 02 Características basilares da ciência do direito....................... 14

Figura 03 Processo interpretativo da ciência do direito........................... 14

Figura 04 Ramificações do direito positivo.......................................... 17

Figura 05 Hierarquia das normas no ordenamento jurídico nacional..... 25

Figura 06 Caracterização da ciência hermenêutica do direito e poder judiciário................................................................. 25

Figura 07 Relações entre os tipos de informação jurídica na geração de conhecimento no Direito.................................................... 42

\section{Parte II}

Figura 01 Metáfora central da abordagem Sense-Making................... 107

Figura 02 Definição operacional das variáveis..................................... 145

Figura 03 Constructos definidos operacionalmente............................. 145

Figura 04 Tipos básicos de projetos para estudo de caso.................... 154

Figura 05 Mapa conceitual com os três momentos da aplicação da Metodologia do IBICT ..................................................... 158

Figura 06 Posicionamento do STJ no judiciário brasileiro...................... 167

Figura 07 Composição e Distribuição do quadro de ministros do STJ... 168

Figura 08 Distribuição dos ministros do STJ por origem....................... 169

Figura 09 Especializações das seções e turmas por área do direito...... 170

Figura 10 Competência Jurisdicional do STJ.................................... 172

Figura 11 Mapa estratégico do STJ para 2010-2014......................... 176

Figura 12 Crescimento do acervo da BDJur..................................... 190

Figura 13 Número de downloads realizados na BDJur (2005-2011)..... 191

Figura 14 Acervo da BDJur......................................................... 196

Figura 15 Opções de filtros para exibição dos itens recuperados na página de resultados da pesquisa........................................ 198

Figura 16 Faixa etária................................................................ 205

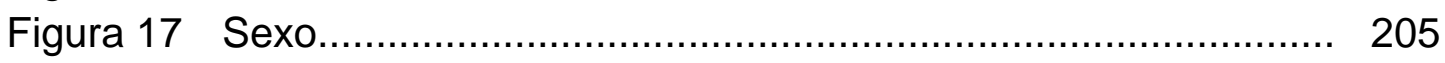

Figura 18 Nível de formação.............................................................. 206

Figura 19 Ano de conclusão do último nível de formação...................... 207

Figura 20 Áreas de formação profissional.......................................... 207

Figura 21 Tempo na função de assessor de Ministro........................... 208

Figura 22 Vínculo empregatício no STJ.......................................... 209

Figura 23 Área de atuação profissional em relação às áreas do direito das seções e turmas do STJ.............................................. 210

Figura 24 Nível de experiência na busca em bases de dados jurídicas. 211

Figura 25 Conhecimento e uso da BDJur como produto de informação 213 disponível na Web. 
Figura 26 Forma de tomada de conhecimento da BDJur

Figura 27 Trequência...

Figura 28

Grau de importância da informação na BDJur, para desempenho da atividade profissional

Figura 29

Finalidade e frequência de utilização da informação da BDJur no desempenho da atividade profissional

Figura 30

Indicador atribuído à BDJur, versus necessidade de busca e uso da informação no desempenho da atividade profissional

Figura 31

Grau de satisfação em relação ao conteúdo das páginas

Figura 32 Textos explicativos da BDJur para pesquisa à informação.....

Figura 33 Frequência de busca à informação na BDJur.

Figura 34 Número de tentativas para localizar informação na BDJur.....

Figura 35 Grau de dificuldade para realização da busca na BDJur........ 223

Figura 36

Tipo de resultado da busca à informação na BDJur. 224 224

Figura 37 Dificuldades encontradas no acesso à informação jurídica na BDJur.

Figura 38 Tempo de resposta da BDJur. 226

Cruzamento das Tabelas Q: 09 - Área de atuação

profissional em relação às áreas do Direito das Seções e

Figura 39 Turmas do STJ X Q: 14 - Tipo de pesquisa na BDJur em relação ao grau de frequência

Cruzamento das Tabelas Q: 09 - Área de atuação profissional em relação às áreas do Direito das Seções

Figura 40 e Turmas do STJ X Q: 15 - Grau de importância da informação na BDJur, para desempenho da atividade profissional.

Cruzamento das Tabelas Q: 09 - Área de atuaçã profissional em relação às áreas do Direito das Seções

Figura 41 e Turmas do STJ X Q: 17 - Frequência de busca informação na BDJur.

Cruzamento das Tabelas Q: 09 - Área de atuação

Figura 42 profissional em relação às áreas do Direito das Seções e Turmas do STJ X Q: 21 - Ocorrência de informação não encontrada na BDJur....

Figura 43

Análise heurística no relacionamento do usuário com interface da BDJur.

Figura 44 Importância do processo de avaliação da BDJur 


\section{LISTA DE QUADROS}

\section{PARTE I}

QUADRO 01 Conjunto de regras que disciplina a vida em sociedade

QUADRO 02 Áreas e disciplinas da ciência da informação e áreas interdisciplinares, destacando-se o Direito............................ 15

QUADRO 03 Ramo do direito $x$ fonte do direito predominante.................... 24

QUADRO 04 Tipologia de referência de informação jurídica....................... 35

QUADRO 05 Produção de legislação no Brasil (1988 a 2007)................... 37

QUADRO 06 Volume de processos judiciais julgados nos tribunais superiores em 2007................................................... 41

QUADRO 07 Citação da jurisprudência na doutrina.................................. 43

QUADRO 08 Adoção de decisão judicial na legislação.............................. 44

QUADRO 09 Proposta de alteração de ato legislativo sob a influência da jurisprudência do STJ......................................................... 44

QUADRO 10 Citação da doutrina na jurisprudência do STJ....................... 44

QUADRO 11 Publicação de títulos novos e edições em direito $x$ outras áreas do conhecimento em 2002 ...................................... 79

QUADRO 12 Comunidade jurídica composta por instituições, entidades e agentes da área do direito........................................... 82

QUADRO 13 Comunidade Jurídica X Instituição X Informação Jurídica......

\section{PARTE II}

QUADRO 01 Características de abordagens com foco no usuário. 109

QUADRO 02 Formulário-amostra para uso na obtenção do objetivo geral...

QUADRO 03 Procedimentos na condução da entrevista com a técnica do incidente crítico.

QUADRO 04 Procedimentos na condução da entrevista com o usuário da informação aplicando a técnica do incidente crítico..

QUADRO 05 Heurísticas formuladas por Jakob Nielsen para avaliação de interface de sites.

QUADRO 06 Exemplo de formulário para avaliação da heurística 4 . (Consistência e padrões).

QUADRO 07 Exemplo de formulário para avaliação da heurística 8. (Estética e design minimalista).

QUADRO 08 Roteiro para realização de entrevistas com aplicação do método Micro moment time line interview, no IBICT. 
QUADRO 09 Relato de uma entrevista com a marcação das variáveis denominadas incidentes críticos (positivos ou negativos) a partir da aplicação do método Micro moment time line interview da abordagem Sense-Making....

QUADRO 10 Exemplo de identificação e quantificação dos incidentes críticos que surgiram a partir das entrevistas com os usuários do portal do IBICT (definição de padrões)

QUADRO 11 As abordagens da aplicação da Metodologia do IBICT x Resultados proporcionados

QUADRO 12 Unidades do STJ envolvidas na gestão e alimentação da BDJur

QUADRO 13 Histórico de atualizações das versões do Dspace da BDJur 


\section{LISTA DE TABELAS}

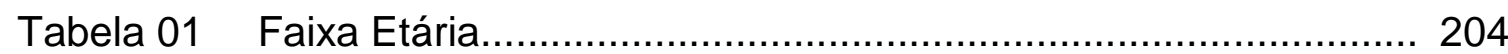

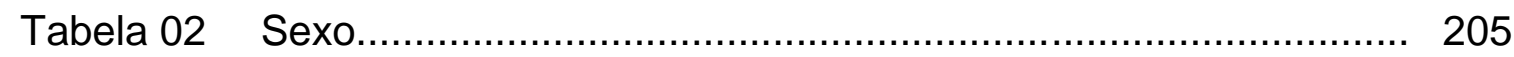

Tabela 03 Nível de formação............................................................... 206

Tabela 04 Ano de conclusão do último nível de formação.......................... 206

Tabela 05 Áreas de formação profissional................................................ 207

Tabela 06 Tempo na função de assessor de ministro................................ 208

Tabela 07 Vínculo empregatício no STJ.............................................. 209

Tabela 08 Área de atuação profissional em relação às áreas do Direito das Seções e Turmas do STJ................................................ 210

Tabela 09 Nível de experiência na busca em bases de dados jurídicas..... 211

Tabela 10 Bases de dados de informação jurídica na internet/intranet usadas no desempenho da atividade profissional..................... 212

Tabela 11 Conhecimento sobre a BDJur..................................................... 213

Tabela 12 Forma que conheceu a BDJur................................................ 214

Tabela 13 Tipo de pesquisa na BDJur em relação ao grau de frequência. 216

Tabela 14 Grau de importância da informação na BDJur, para desempenho da atividade profissional.................................... 217

Tabela 15 Finalidade e frequência de utilização da informação da BDJur no desempenho da atividade profissional.................................. 218

Tabela 16 Indicador atribuído à BDJur, versus necessidade de busca e uso da informação no desempenho da atividade profissional.... 219

Tabela 17 Grau de satisfação em relação ao conteúdo das páginas da

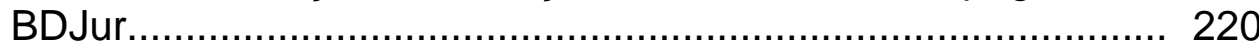

Tabela 18 Textos explicativos da BDJur para pesquisa à informação ....... 221

Tabela 19 Frequência de busca à informação na BDJur........................... 222

Tabela 20 Número de tentativas para localizar informação na BDJur......... 222

Tabela 21 Grau de dificuldade para realização da busca na BDJur ........... 223

Tabela 22 Tipo de resultado da busca à informação na BDJ..................... 224

Tabela 23 Dificuldades encontradas no acesso à informação jurídica na

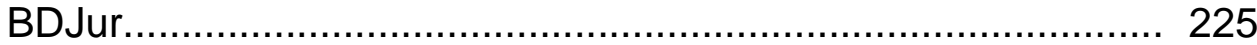

Tabela 24 Tempo de resposta da BDJur ............................................ 226

Tabela 25 às áreas do Direito das Seções e Turmas do STJ X Q: 14 Tipo de pesquisa na BDJur em relação ao grau de frequência.. 227 
Cruzamento Q: 09 - Área de atuação profissional em relação Tabela 26 às áreas do Direito das Seções e Turmas do STJ X Q: 15 Grau de importância da informação na BDJur, para desempenho da atividade e profissional.

Cruzamento Q: 09 - Área de atuação profissional em relação

Tabela 27 às áreas do Direito das Seções e Turmas do STJ X Q: 17 -

Frequência de busca à informação na BDJur

Cruzamento Q: 09 - Área de atuação profissional em relação

Tabela 28 às áreas do Direito das Seções e Turmas do STJ X Q: 21 Ocorrência de informação não encontrada na BDJur

Tabela 29 Análise do campo aberto do questionário eletrônico da avaliação quantitativa........................................................... 232

Tabela 30 Recomendações do usuário para melhoria da BDJur................ 233

Tabela 31 Heurísticas em relação à facilidade de relacionamento do usuário com a interface da BDJur........................................... 241

Tabela 32 Importância do processo de avaliação da BDJur....................... 245 


\section{LISTA DE SIGLAS E ABREVIATURAS}

AALL American Association of Law Libraries Associação Brasileira de Escolas de Biblioteconomia e
Documentação

ABNT

Associação Brasileira de Normas Técnicas

ACV

Avaliação do Ciclo de Vida

ALA American Library Association

BBD Bibliografia Brasileira de Direito

BDJUR Biblioteca Digital Jurídica

BDTD Biblioteca Digital de Teses e Dissertações

BIALL British and Irish Association of Law Librarians

Coordenação de Aperfeiçoamento de Pessoal de Nível

CAPES Superior

CBBD Congresso Brasileiro de Biblioteconomia e Documentação

CBIDJ Comissão Brasileira de Informação e Documentação Jurídica

CBL Câmara Brasileira do Livro

CCN Catálogo Coletivo Nacional

CDD Classificação Decima de Dewey

CDDIR Classificação Decimal de Direito

CDU Classificação Decimal Universal

CEJ Centro de Estudos Judiciários

CFB Conselho Federal de Biblioteconomia

CJF Conselho da Justiça Federal

CLT Consolidação das Leis de Trabalho

CNAE Classificação Nacional de Atividades Econômicas

CNJ Conselho Nacional de Justiça

Conselho Nacional de Desenvolvimento Científico e

CNPQ Tecnológico

DLF Digital Library Federation

DOU Diário Oficial da União

DSI Disseminação Seletiva da Informação

ECA/USP $\quad$ Escola

ENIDJ Encontro Nacional de Informação e Documentação Jurídica

FAPESP Fundação de Amparo à Pesquisa do Estado de São Paulo 


\begin{tabular}{|c|c|}
\hline FEBAB & $\begin{array}{l}\text { Federação Brasileira de Associações de Bibliotecários, } \\
\text { Cientistas da Informação e Instituições. }\end{array}$ \\
\hline GBDIJ/DF & $\begin{array}{l}\text { Grupo de Bibliotecários em Informação e Documentação } \\
\text { Jurídica do Distrito Federal. }\end{array}$ \\
\hline GIDJ & Grupo de Informação e Documentação Jurídica \\
\hline IBBD & Instituto Brasileiro de Bibliografia e Documentação \\
\hline IBGE & Instituto Brasileiro de Geografia e Estatística \\
\hline IBICT & Instituto Brasileiro de Informação em Ciência e Tecnologia \\
\hline INCRA & Instituto Nacional de Colonização e Reforma Agrária \\
\hline INFOTIB & Informação em Tecnologia Industrial Básica \\
\hline INPE & Instituto Nacional de Pesquisas Espaciais \\
\hline INSS & Instituto Nacional do Seguro Social \\
\hline LOMAN & Lei Orgânica da Magistratura Nacional \\
\hline MCTI & Ministério da Ciência, Tecnologia e Inovação \\
\hline NCSC & Centro Nacional de Tribunais Estaduais \\
\hline NDLTD & Networked Digital Library of Theses and Dissertations \\
\hline OCLC & On Line Computer Library Center \\
\hline RVBI & Rede Virtual de Bibliotecas \\
\hline SBRT & Serviço Brasileiro de Respostas Técnicas \\
\hline $\mathrm{SCl}$ & Science Citation Index \\
\hline SNDIJ & $\begin{array}{l}\text { Seminário Nacional de Documentação e Informação } \\
\text { Jurídicas }\end{array}$ \\
\hline SSCI & Social Science Citation Index \\
\hline STF & Supremo Tribunal Federal \\
\hline STJ & Superior Tribunal de Justiça \\
\hline TFR & Tribunal Federal de Recursos \\
\hline TIC & Tecnologia da Informação e Comunicação \\
\hline TRE & Tribunal Regional Eleitoral \\
\hline TSE & Tribunal Superior Eleitoral \\
\hline TST & Tribunal Superior do Trabalho \\
\hline UDESC & Universidade do Estado de Santa Catarina \\
\hline wOS & Web Of Science \\
\hline
\end{tabular}




\section{LISTA DE ANEXOS}

ANEXO 01 Exemplo de formulário completo no formato de apresentação no site do Portal do IBICT...

ANEXO 02 Exemplos das variáveis específicas dos formulários eletrônicos dos produtos CCN e COMUT.

ANEXO 03 Exemplos aleatórios de resultados de análise dos formulários de avaliação quantitativa (Portal do IBICT).......... 263

ANEXO 04 Respostas do campo aberto do formulário da avaliação quantitativa (Portal do IBICT)......................................... 269

ANEXO 05 Exemplo de análise do campo aberto do formulário eletrônico de avaliação quantitativa do (Portal do IBICT)....... 271

Exemplo de gráficos gerados pelo software Zoomerang a ANEXO 06 partir da avaliação quantitativa por formulário eletrônico (Portal do IBICT)

Checklist para aplicação das heurísticas de Jacob Nielsen

ANEXO 07 para análise do portal e sites dos produtos do IBICT (Checklist para avaliação da interface homem-máquina a partir das heurísticas de Nielsen)

ANEXO 08 Checklist para aplicação das heurísticas de Jacob Nielsen para análise do portal e sites dos produtos do IBICT.

ANEXO 09 Carta de Apresentação e Questionário Eletrônico da BDJur.. 279

ANEXO 10 Roteiro para realização das entrevistas................................ 285

ANEXO 11 Entrevistas ............................................................ 286

ANEXO 12 Interfaces da BDJur com a atualização das versões do

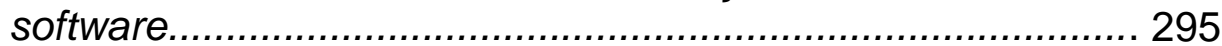

ANEXO 13 Interface e Pesquisa na BDJur.............................................. 297 


\section{SUMÁRIO}

Lista de Figuras................................................................ VII

Lista de Quadros........................................................... IX

Lista de Tabelas......................................................... XI

Lista de Siglas e Abreviaturas................................................. XIII

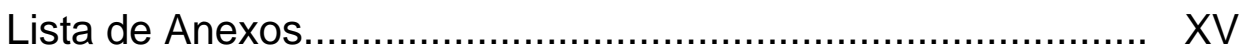

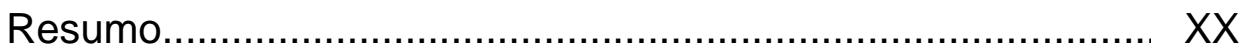

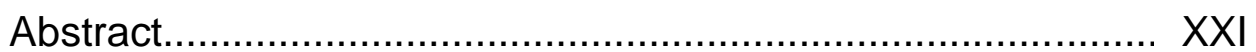

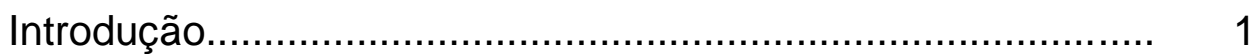

Justificativa e Problema....................................................... 3

Fundamentação Teórica e Conceitual....................................... 6

\section{PARTE I}

A CIÊNCIA DA INFORMAÇÃO E O DIREITO: ACESSO A PRODUTOS DE INFORMAÇÃO JURÍDICA

O DIREITO: ÁREA DA INFORMAÇÃO JURÍDICA.................. 8

$1.1 \quad$ Estrutura do Direito........................................................ 16

$1.2 \quad$ Linguagem Jurídica.......................................................... 20

$1.3 \quad$ Fontes do Direito e Normas Jurídicas..................................... 24

2 CIÊNCIA DA INFORMAÇÃO E O ACESSO À INFORMAÇÃO JURÍDICA................................................ 28

$2.1 \quad$ Informação Jurídica...................................................... 30

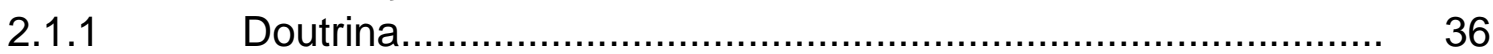

2.1.2 Legislação........................................................................ 36

2.1.3 Jurisprudência.............................................................. 37

2.2 Relações entre os tipos de Informação Jurídica no Direito....... 42

2.3 A Biblioteconomia Jurídica................................................... 45

2.4 O Bibliotecário Jurídico e o usuário operador do Direito........... 49

$3 \quad O$ PODER JUDICIÁRIO: MISSÃO NA SOCIEDADE................ 60

3.1 Organização Judiciária........................................................... 66

3.1.1 A Estrutura do modelo de Corte Superior de Justiça................ 69

3.2 Atividade Judicante ou Jurisdicional e o Acesso a Justiça........ 73

4 BIBLIOTECA DO PODER JUDICIÁRIO: CONTRIBUIÇÃO NA FUNDAMENTAÇÃO DA ATIVIDADE JUDICANTE.......... 76

4.1 Características da Biblioteca Jurídica....................................... 78

4.2 A Comunidade Jurídica como usuária da Biblioteca Jurídica.... 81

$5 \quad$ FONTES DE INFORMAÇÃO JURÍDICA.................................. 87

$6 \quad$ CONSIDERAÇÕES FINAIS................................................. 89 
PARTE II

CIÊNCIA DA INFORMAÇÃO E METODOLOGIAS DE AVALIAÇÃO DE PRODUTOS DE INFORMAÇÃO

PRODUTOS DE INFORMAÇÃO

Produtos de Informação na Web : a biblioteca digital

ABORDAGENS METODOLÓGICAS NA AVALIAÇÃO DE PRODUTOS DE INFORMAÇÃO.

2.1 Métodos Qualitativos e Quantitativos de Avaliação de Produtos de Informação.

O Micro Moment Time Line Interview

A Técnica do Incidente Crítico de John Flanagan.

A Metodologia para Avaliação de Produtos de Informação do Instituto Brasileiro de Ciência e Tecnologia - IBICT.

2.5.2 Processo de Desenvolvimento da Metodologia para Avaliação de Produtos de Informação do IBICT

2.5.3 Elementos da Metodologia de Avaliação de Produtos de Informação do IBICT

2.5.3.1 Construção Metodológica para Aplicação de Estudo Qualitativo.

2.5.3.1.1 Aplicação da Abordagem Sense Making na Metodologia do IBICT.

2.5.3.1.1.1 O uso do Micro Moment Time Line Interview.

2.5.3.2 Construção Metodológica para Aplicação de Estudo Quantitativo

O Levantamento de dados quantitativos. Análise do conteúdo da questão aberta do Formulário Quantitativo.

Aplicação das Heurísticas de Jakob Nielsen em teste de usabilidade.

Considerações sobre a Metodologia do IBICT.

PRESSUPOSTO 
Formação do Superior Tribunal de Justiça: Origem e Histórico

Biblioteca Ministro Oscar Saraiva do Superior Tribunal de Justiça.

Características da atividade profissional do assessor de ministro como usuário da informação jurídica, segundo trinômio operacional do Sense-making.

Produtos e serviços de informação da Biblioteca Ministr Oscar Saraiva do Superior Tribunal de Justiça...

Biblioteca Jurídica do Superior Tribunal de Justiça - BDJur como produto de informação disponível na Web.. autorais

Processo de preservação digital do acervo.

Habilidade e experiência para acessar a informação jurídica na Web......

8.2.3 Uso proporcionado pelo produto ao usuário quanto a conteúdo, operacional, e tempo de resposta........................ 215 quantitativa. 
8.3. Análise das entrevistas................................................ 237

8.3.1 Padrão geral dos incidentes críticos........................................ 238

8.4 Análise da usabilidade (Heurísticas de Nielsen)..................... 239

8.5 Tipologia de avaliação da BDJur realizada pela Biblioteca do STJ....................................................................... 242

8.6 Análise do Pressuposto.................................................. 243

8.7 Considerações sobre a aplicação da Metodologia do IBICT na análise da BDJur 246

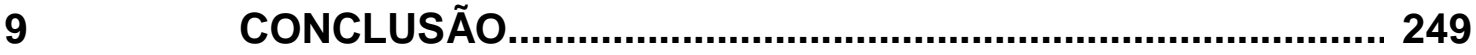

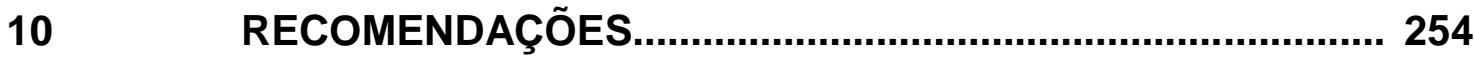

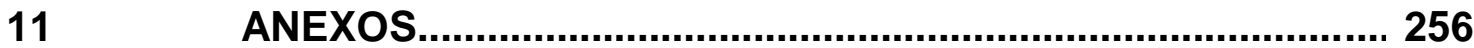

Bibliografia.................................................................... 300 


\section{RESUMO}

Trata do uso e usabilidade de produto de informação jurídica da Biblioteca Ministro Oscar Saraiva do Superior Tribunal de Justiça, STJ, disponível na Web, com enfoque da Ciência da Informação considerando que a utilização de técnicas e metodologias adequadas para avaliação de produtos de informação confere visibilidade à biblioteca no universo jurídico. Aplica a Metodologia para Avaliação de Produtos e Serviços de Informação desenvolvida pelo Instituto Brasileiro de Informação em Ciência e Tecnologia, IBICT, com enfoque no usuário, no estudo da Biblioteca Digital Jurídica, BDJur, que disponibiliza informação doutrinária e legislativa cujo conteúdo visa subsidiar a atividade judicante do Tribunal, compreendendo três procedimentos: a) avaliação qualitativa com base na abordagem do trinômio operacional do Sense-Making, de Brenda Dervin, com entrevistas estruturadas, analisando-se os resultados com a técnica dos Incidentes Críticos de John C. Flanagan, para obter a visão contextualizada das práticas informacionais do usuário assessor de ministro e as condições de uso da BDJur; b) avaliação quantitativa com questionário eletrônico, para conhecer o grau de satisfação dos assessores e a extensão do acesso e uso da BDJur; c) aplicação das heurísticas de Jakob Nielsen para avaliação da usabilidade da BDJur ou, interação homem-máquina. A análise qualitativa trouxe a lume a vivência, no contexto do STJ, da situação, lacuna e uso da informação no trabalho do assessor de análise e fundamentação dos temas jurídicos nos processos judiciais, com doutrina, legislação e jurisprudência, além de identificar incidentes críticos positivos e negativos relativos às três etapas do trinômio operacional. $\mathrm{A}$ análise quantitativa mostrou que há confiabilidade dos assessores na BDJur na busca e recuperação da informação jurídica, sendo utilizada em alguns casos, como fonte principal de informação para realização do trabalho. A análise de nove heurísticas como padrões de usabilidade apresentou resultado positivo para: clareza nas informações de navegação e conteúdo; linguagem objetiva; autonomia das ações realizadas no sistema; e, padronização e identidade visual. Foram obtidos menores índices para as heurísticas referentes a mensagens de erro e, navegação autoexplicativa. Ficou evidenciado que a busca de informação na BDJur pelo assessor de ministro, concorre para subsidiar a atividade judicante no Tribunal. A combinação das três abordagens da Metodologia forneceu maior consistência e integridade dos resultados, com enfoque no assessor de ministro como usuário da BDJur, sobre a relação entre a necessidade e busca de informação jurídica e a atividade judicante desempenhada nos gabinetes de ministro no trabalho do assessor, e sobre o impacto da informação jurídica na atividade judicante do STJ.

Palavras-chave: Produto de informação na Web, metodologia de avaliação, Ciência da Informação; Informação jurídica, Superior Tribunal de Justiça, STJ; Metodologia de Avaliação de Produtos e Serviços de Informação, Instituto Brasileiro de Informação em Ciência e Tecnologia, IBICT. 


\section{ABSTRACT}

The present work addresses the use and usability of legal information resources available online at the Ministro Oscar Saraiva Library at the Superior Court of Justice (STJ). The work focuses on the field of Information Science considering that the use of adequate techniques and methodologies for assessing information products gives visibility to the library within the judicial sector. The research makes use of the Methodology for the Assessment of Information Products and Services developed by the Brazilian Institute of Information Science and Technology (IBICT) and focuses on users of the Digital Legal Library (BDJur). The library provides doctrinal and legislative information to support the Court's judicial activities. This work is developed based on three main procedures: a) a qualitative assessment based on the three operational elements of Brenda Dervin's sensemaking process, using structured interviews and analyzing the results with John C. Flanagan's Critical Incident Technique in order to obtain a contextualized perspective of informational practices undertaken by a justice's assistant (user) and about the use conditions of BDJur; b) a quantitative assessment carried out by means of an electronic questionnaire to know the assistants' level of satisfaction and the scope of access and use of BDJur; c) use of Jakob Nielsen's heuristics to evaluate the usability of BDJur or man-machine interaction. The qualitative analysis within the STJ context brought to light the experience regarding the situation, gap and uses of information in the work of the assistant for analysis and justification of legal issues in judicial proceedings involving doctrine, legislation and jurisprudence. It also identifies critical incidents, both positive and negative, with regard to the three operational stages. The quantitative analysis showed that assistants trust the BDJur when searching and gathering legal information, being in some cases the main source of information for carrying out their work. The analysis of the nine heuristic as usability standards showed positive results for: clarity in the browsing information and content; objective language; autonomy of actions undertaken in the system; standardization and visual identity. Lower scores were seen for the heuristics relating to error messages and self-explanatory browsing. It is clearly shown that the information search carried out by the justice's assistants at BDJur contributes and supports the judicial activity in the Court. The combination of the three methodological approaches - with a focus on the justice's assistant as BDJur user - provided more consistency and integrity to the results regarding the relationship between the need and search for legal information and the judicial activity performed by assistants in the justice's office and the impact of legal information in the STJ's judicial activities.

KEYWORDS: Web-Based Information Product, Evaluation Methodology, Information Science, Legal Information, Superior Court Of Justice (STJ), Methodology For The Assessment Of Information Products And Services, Brazilian Institute for Information in Sience and Technology (IBICT). 


\section{INTRODUÇÃO}

A evolução das tecnologias de informação e comunicação, $\mathrm{TIC}^{1}$, nas organizações suscita mudanças de paradigmas, neste novo milênio, implicando em transformações no conhecimento consolidado das diversas áreas de atividade humana, para que este seja aplicado na Web - parte gráfica da internet. Ou seja, teorias, leis, métodos de investigação, bem como, objetos e problemas de pesquisa e investigação e, os princípios filosóficos, axiológicos e ideológicos de diversas áreas do conhecimento, tendem a ser ampliados, modificados, superados e renovados segundo as características e funcionamento próprios do meio digital. Em função disso, Levacov (1999, p. 261) se refere à predominância das tecnologias de comunicação e informação em diversas atividades na sociedade e nas unidades de informação, em especial as bibliotecas quando afirma que se vive numa época de "transição equivalente àquela que o mundo assistiu quando da passagem do script para o impresso". Tal transformação torna-se particularmente pungente para as bibliotecas, uma vez que cria novas necessidades e altera velhos paradigmas.

Bauens (2003), partindo de percepção semelhante, analisou o papel das tecnologias de informação e comunicação nas unidades de informação no início da década de 1990, distinguindo características de um período de transição e estimando que a informação tornar-se-ia cada vez menos ligada ao objeto físico que a continha com a criação de produtos de informação digitais implicando num maior alcance da unidade de informação além das instalações físicas. Levacov (1997, p. 262) complementa assinalando que, na primeira década do ano 2000 , o conceito de lugar tornara-se secundário tanto para o profissional da informação quanto para o usuário, enquanto ocorria a instantaneidade no acesso à informação nos produtos disponíveis na Web.

Para as organizações, de modo geral, surgem desafios quanto às formas de utilizar e ocupar o novo meio configurado pela Web. Do mesmo modo, para as bibliotecas tal situação dá origem a um conjunto de questões que migraram para este novo ambiente. Segundo Torres (2002, p. 83), a Web é o espaço digital da informática e das comunicações via computador, que possibilita distintas formas de interação entre indivíduos e organizações bem como a oferta de produtos de informação nos sites. A esse respeito, Levacov (1999, p. 262) observa que nos sites na Web há símbolos que mediam a interação sensorial, cognitiva e comunicacional, entre a unidade de informação e o usuário. Naturalmente, num contexto pleno de recursos tecnológicos, o estudo e o conhecimento de aspectos desta realidade abrangem os produtos de informação nos sites na Web, destacando-se as bibliotecas digitais.

A Web possibilita que as organizações desempenhem suas funções, refletindo na forma de atuação e nos resultados que alcançam na sociedade, quer seja oferecendo produtos dos mais variados tipos ou, prestando serviços públicos e

\footnotetext{
${ }^{1}$ Tecnologia da Informação (TI) inclui hardware, software e a disseminação de dados, informação e conhecimento, sendo mais abrangente que processamento de dados, sistema de informação, engenharia de software, informática ou conjunto de hardware e software, envolvendo aspectos humanos, técnicos administrativos, organizacionais e informações (Laurindo, 2002, p. 19). Tecnologia da Informação e Comunicação (TIC): sistema de cinco recursos: pessoas, hardware, software, dados e redes. Recursos humanos incluem usuário e pessoal da organização; hardware abrange máquinas e mídia; software inclui programas e procedimentos; dados formam bancos de dados e bases de conhecimento; e, recursos de rede incluem mídia e redes de comunicações. Os dados são transformados por atividades de processamento de informação em produtos de informação para o usuário. O processamento de informação consiste em atividades de entrada, processamento, saída, armazenamento e controle. (Oliveira, 2003, p. 177)
} 
comerciais. Naturalmente, se ocorrem mudanças no planejamento e criação de produtos nos sites de organizações públicas e privadas, isto também se verifica na avaliação destes produtos de informação na Web. Torna-se evidente que a avaliação de produtos na Web é um processo indispensável na oferta destes produtos tendo como base de ação a orientação para as necessidades de informação do usuário, além de levar em conta o contexto da situação que desencadeou a necessidade, o comportamento de busca e o uso da informação. Segundo Rados [et al] (1999) a qualidade dos produtos depende diretamente do conhecimento prévio da necessidade de informação do usuário, além de estar relacionada ao compromisso contínuo da organização de incrementar a qualidade daquilo que fornece. Este autor considera que "o aumento da qualidade passa pela identificação correta e precisa dos desejos e anseios dos clientes/usuários dos serviços/produtos".

Logo, para as bibliotecas compreender quando e porque o usuário precisa da informação permite perceber e identificar situações prementes de acesso à informação especializada, a relevância e precisão desta e, seu uso, principalmente quando se trata de ações dentro do poder judiciário cujo fim está voltado para contemplar direitos individuais e coletivos, como o acesso à justiça na sociedade. Por isso, no processo de busca à informação jurídica ${ }^{2}$, constituído pela situação específica de necessidade ou lacuna surgida em função de não ter posse desta informação e, na finalidade de aplicação ou uso, encontra-se o que Rados (1999) identifica como valor de uso da informação relacionada a propriedades ou qualidades dos produtos de informação que possibilitam ao usuário o desempenho do trabalho ou a tomada de decisão.

Certamente, tais questões implicam no cuidado de avaliar os produtos de informação disponíveis na Web sob o ponto de vista do receptor ou usuário, com vistas a aferir a adequação dos mesmos a situações de busca, lacunas de conhecimento e usos específicos de informação modelando-os ou ajustando-os, conforme desejável. Ademais, na Web é imprescindível trabalhar funcionalidade dos produtos de informação devendo ser observados aspectos relativos ao acesso, conteúdo e tecnologias, para fazer do ambiente Web um espaço que possa, efetivamente, suprir satisfatoriamente a necessidade de informação. Nessa perspectiva, é importante estudar aspectos envolvidos na avaliação de produtos fornecidos na Web pelas unidades de informação. Por tratar-se de um estudo interdisciplinar, foi necessário buscar em outras disciplinas como informática, administração além de ciência da informação, contribuições teóricas e práticas referentes à natureza digital dos produtos de informação, métodos de avaliação de produtos bem como, necessidade e uso de informação pelos usuários, respectivamente.

A avaliação de produtos de informação disponíveis na Web pode ser realizada conforme óticas distintas envolvendo usabilidade, conteúdo, segurança da informação, qualidade da informação, software, design gráfico e outros aspectos, com aplicação de metodologias de abordagens qualitativas ou quantitativas. Dentre as questões relativas a este tema, investigar, especificamente, como produtos de informação disponíveis na Web suprem as necessidades de informação jurídica para fundamentação da atividade judicante no contexto do poder judiciário nacional,

\footnotetext{
${ }^{2}$ Informação jurídica: de modo geral, constituída por doutrina, legislação e jurisprudência.
} 
consiste no fenômeno da realidade a ser estudado com esta pesquisa. Constata-se que há vários métodos de avaliação de produtos de informação no contexto da Web, dispersos em várias áreas do conhecimento registrado. Tornou-se, então necessário pesquisar metodologias de avaliação aplicadas em organizações que não visam ao lucro, relacionando o uso de tecnologias de informação e comunicação na oferta de produtos de informação na Web, com a ótica do usuário.

\section{JUSTIFICATIVA E PROBLEMA}

$\mathrm{Na}$ última década do século $\mathrm{XX}$ a globalização levou à necessidade de se considerar padrões mundiais de qualidade em produtos, mormente aqueles oferecidos na Web, implicando para as unidades de informação no aumento da produção e disseminação do conhecimento. De fato, ter acesso à informação passou a ser parte indissociável da educação, trabalho e lazer para indivíduo e instituições. Acrescente-se, ainda, que como consumidor do conhecimento, o indivíduo, ao ter acesso à informação, muda sua condição de agente passivo para agente ativo do conhecimento. Isto culminou com a relevância cada vez maior da informação na sociedade, permitindo ver que tanto a qualidade da informação como a produção e disseminação do conhecimento, são fatores ligados à disponibilidade e acesso à informação no tempo preciso, por meio de produtos de informação, como o site.

Por isto, Faqueti e Ohira (1999, p. 49) assinalam que: “(...) as bibliotecas são atingidas pelas modificações tecnológicas de forma inquestionável", reforçando a ideia de que o acesso à estante e aos livros deve ser ampliado pelo acesso a produtos de informação de qualquer lugar. Sem dúvida, o fenômeno da criação e atualização de produtos de informação na Web em organizações privadas e públicas levou bibliotecas a constatar que estar presente na Web é desejável e até certo ponto, obrigatório, e que, o usuário explora os produtos de informação na Web com a expectativa de encontrar respostas para suas necessidades de informação. Em consequência, indivíduos e organizações valorizam aspectos do planejamento, desenvolvimento e avaliação dos produtos de informação neste meio digital, considerando a relevância do conteúdo da informação e, sobretudo, o modo de apresentá-lo na Web para o usuário.

De modo geral, a Web possibilita maior visibilidade às organizações devido aos recursos de comunicação interativa e multimídia existentes para oferecer produtos. A cultura peculiar da Web torna importante repensar como se comunicar, interagir e fornecer produtos de informação bem como, avaliar junto ao usuário aspectos da funcionalidade de cada produto fornecido. Sabe-se que as organizações privadas consideram como vantagens da Web a disponibilidade de produtos durante 24 horas do dia, além da economia de tempo e deslocamento. Evidentemente, nas bibliotecas a integração de recursos tecnológicos e humanos possibilita agilidade e eficácia no ciclo da informação, constituído pela geração, coleta, armazenamento, disseminação e uso. Outra questão a considerar é o fato do espaço digital da Web está incorporado às atividades das unidades de informação que dispõem de recursos tecnológicos, consistindo na essência de bibliotecas digitais. Em resumo, a Web passou a ser a via mais transitável para indivíduos e organizações que procuram informações e dispõem de acesso à Internet. 
Por conseguinte, o intuito de avaliar o uso de produto de informação jurídica fornecido na Web pela Biblioteca Ministro Oscar Saraiva do Superior Tribunal de Justiça, STJ, e compreender o comportamento do usuário da Biblioteca, na busca à informação jurídica para o desempenho das atividades judicantes deste tribunal, mostrou-se um desafio instigante. Neste ponto, cabe mencionar que a necessidade de manter e aprimorar o funcionamento de organizações públicas leva ao uso de metodologias de avaliação dos produtos fornecidos, de acordo com objetivos, metas, atividades ou processos, seja nas instalações físicas, como no ambiente digital. Tais metodologias estão incluídas no processo de gestão das organizações e sua aplicação certamente contribui na comprovação de uso e não uso de produtos, aplicando-se abordagens qualitativas ou quantitativas.

Considerando os novos paradigmas de acesso à informação na Web, predominantes no modo de trabalho das organizações, a Biblioteca do STJ preocupa-se em direcionar seus produtos de informação às reais necessidades dos usuários. Isto porque a missão do STJ se constitui em: "Processar e julgar as matérias de sua competência originária e recursal, assegurando a uniformidade na interpretação das normas infraconstitucionais e oferecendo ao jurisdicionado uma prestação acessível, rápida e efetiva". Isto porque:

\begin{abstract}
A missão é uma declaração concisa da razão de ser da organização. É o propósito básico para o qual são direcionadas as atividades e os valores que orientam os servidores. Diferentemente das empresas privadas, que definem a sua missão conforme o interesse de se posicionar em destaque no mercado, os órgãos do Poder Judiciário possuem missão estabelecida na Constituição Federal. (Regimento Interno do STJ - Cidadania em movimento. Curso à distância, 2013).
\end{abstract}

Como órgão do poder judiciário, o STJ, para desenvolver a sua missão na sociedade, estrutura-se em órgãos julgadores e demais unidades internas, dentre as quais a Biblioteca, tendo como ideal concretizar a cidadania no âmbito de sua competência constitucional. A "ideia de cidadania permeia toda a atividade do Superior Tribunal de Justiça. O STJ tem se aproximado da sociedade ao decidir questões do cotidiano do povo brasileiro". Isto porque "quando o STJ firma um entendimento em decisão final, essa decisão interferirá na vida de grande parcela da sociedade brasileira". Este pensamento se reflete na imagem do STJ disseminada na sociedade, como "Tribunal da Cidadania". Conforme esclarecido pelo ministro Costa Leite, "as grandes causas que interessam à cidadania se resolvem no âmbito do Superior Tribunal de Justiça". (Regimento Interno do STJ - Cidadania em movimento. Curso à distância, 2013).

Estas responsabilidades conferem ao STJ a condição de órgão único na esfera judiciária para promoção das demandas da sociedade, nos casos concretos de sua jurisdição. Esta ação, calcada em sua missão, visão e valores, fica, assim, evidenciada:

Cabe concluir que a missão do STJ permite ao Tribunal acompanhar os diversos fatores que, intervém em seu funcionamento, como novos modelos, ambientes e variáveis internas e externas que repercutem em sua forma de ser e atuar na sociedade. No que concerne à visão, o STJ pretende ser reconhecido pela sociedade como modelo na garantia de uma justiça acessível, rápida e efetiva. (Regimento Interno do STJ Cidadania em movimento. Curso à distância, 2013).

Naturalmente, a Biblioteca do STJ em consonância com a missão, visão e valores do Tribunal, fornece serviços e produtos de informação jurídica com a 
missão de "oferecer informação em doutrina e legislação necessárias a atividade judicante e administrativa do Tribunal". Com este fim, também se preocupa, no desempenhar de suas atividades, em contribuir para a atuação desta Corte de justiça para que a visão do Tribunal se concretize na sociedade. Isto requer trabalhar continuamente com requisitos, por exemplo, como rapidez e efetividade conforme missão do Tribunal, que corresponde, por um lado, à presteza na entrega dos serviços e brevidade no trâmite processual, e por outro lado, no atendimento real às demandas da sociedade e satisfação dos jurisdiscionados, respectivamente. Naturalmente, a responsabilidade de promover o acesso à informação jurídica está associada à necessidade continua de avaliar os produtos de informação fornecidos aos usuários operadores do direito com os mesmos valores do Tribunal, ou seja, preocupando-se em adequá-los às reais necessidades de informação dos usuários, com rapidez, efetividade e presteza.

Neste ponto, cabe mencionar que investido de preocupação similar no contexto científico e tecnológico o Instituto Brasileiro de Informação em Ciência e Tecnologia, IBICT, como unidade de pesquisa do Ministério da Ciência, Tecnologia e Inovação (MCTI) cuja missão institucional constante no seu site, visa ao "desenvolvimento de recursos e a infraestrutura de informação em ciência e tecnologia para produção, socialização e integração do conhecimento científico e tecnológico", idealizou e desenvolveu uma metodologia inédita para avaliação dos próprios produtos, publicada em 2011. Segundo Suaiden (2011, p.11) o IBICT "está disponibilizando para as instituições interessadas uma metodologia inovadora para avaliar produtos de informação". A Metodologia do IBICT, construída com integração de análises qualitativas e quantitativas, visa, nas palavras de Suaiden (2011, p. 12):

\begin{abstract}
(...) obter uma visão contextualizada das práticas informacionais dos usuários e enriquecer as condições de uso dos produtos oferecidos, além de conhecer o grau de satisfação dos usuários e a extensão do acesso e uso dos produtos avaliados, bem como obter informações sobre a facilidade com que os usuários se relacionam com as interfaces desses produtos.
\end{abstract}

Diante do exposto e da importância da avaliação dos produtos de informação jurídica bem como do papel que cabe às unidades de informação no planejamento dos produtos segundo as reais necessidades de informação do usuário, decidiu-se estudar como a Biblioteca do STJ, realiza a oferta de produto de informação na Web. Considerou-se o interesse que o tema escolhido desperta, na área de Ciência da Informação, ao contribuir para a compreensão das características da avaliação de produtos de informação no meio digital, com foco no usuário. A escolha da Biblioteca Ministro Oscar Saraiva do Superior Tribunal de Justiça deveu-se à experiência que reúne, há mais de seis décadas, como unidade de informação integrante da instância superior da justiça comum do poder judiciário do país, ocupando uma posição consolidada no cenário nacional da informação jurídica. Trata-se de uma unidade de informação, cujo posicionamento está essencial e estrategicamente voltado para o acesso à informação jurídica em nível nacional e internacional. Neste sentido é uma biblioteca singular, não existindo outra unidade de informação idêntica no país. Por conseguinte, o conhecimento obtido com esta investigação pode contribuir com informações sobre experiências de uma instituição importante no contexto nacional de acesso à informação a serem aplicadas em outras bibliotecas.

Dessa forma, pesquisar aspectos envolvidos com o conteúdo, interação homem máquina e comportamento de busca e uso da informação jurídica na Web, 
visando conhecer o grau de satisfação, as condições de uso do produto e o atendimento das reais necessidades de informação do usuário no ambiente Web, aplicando a Metodologia do IBICT para avaliação de produtos de informação, poderá contribuir no estudo sobre o tema nas unidades de informação. Por ser uma área de estudo com impacto decisivo no desempenho final da unidade de informação e, por se tratar da aplicação de uma metodologia especificamente desenvolvida na Ciência da informação, constatou-se a importância de estudar práticas informacionais no contexto da informação jurídica, indagando-se:

Como a oferta de produto de informação da Biblioteca do STJ, disponível na Web, concorre para subsidiar a atividade judicante, de acordo com a necessidade específica de informação jurídica das Seções julgadoras do Superior Tribunal de Justiça, na fundamentação doutrinária e legislativa dos processos judiciais?

\section{FUNDAMENTAÇÃO TEÓRICA E CONCEITUAL}

$\mathrm{Na}$ revisão de literatura procurou-se investigar sobre avaliação de produto de informação disponível na Web com enfoque no usuário, fornecidos por unidades de informação como a biblioteca, verificando conceitos e posicionamentos dos autores que trataram de cada aspecto deste tema. Para tanto, buscou-se analisar diferentes enfoques sobre metodologias e resultados alcançados e, destacar autores de outras áreas do conhecimento que abordaram o tema no contexto da unidade de informação, visando encontrar na literatura sobre avaliação de produtos, mormente nas metodologias qualitativas e quantitativas, os princípios e procedimentos para avaliar produtos digitais das unidades de informação. Foi realizado procedimento similar com os autores da área do Direito no que se refere à função do poder judiciário na sociedade e a importância do acesso à informação jurídica na atividade judicante no âmbito dos tribunais, visando à compreensão do cenário e campo de atuação do qual faz parte a biblioteca jurídica.

Para tanto, explorou-se características da Biblioteconomia jurídica, área interdisciplinar e especializada da Ciência da Informação e, que se ocupa dos fenômenos referentes à oferta, acesso e uso de produtos de informação jurídica para a comunidade jurídica, o cidadão e a sociedade. Isto porque a realização de uma pesquisa científica pressupõe um marco filosófico claramente delimitado para proporcionar à mesma, base e unidade. Contudo, a Ciência da Informação é considerada como uma área de origem interdisciplinar, que conforme lembra Cintra (1996, p. 38), é função da articulação do conhecimento de diferentes disciplinas na composição de sua especificidade. De acordo com Oliveira (2002, p. 15), o termo interdisciplinaridade é polissêmico, levando a distintas significações. Fazenda (1979, p. 45) considera a interdisciplinaridade como a busca de uma grande teoria, reunificando o saber, ou seja, a fragmentação do conhecimento é um problema a ser superado com a interdisciplinaridade. Porém, Japiassu (1976, p. 74) a caracteriza segundo a intensidade das trocas entre os especialistas e pelo grau de integração das disciplinas no interior de um projeto específico de pesquisa.

Assim, na Ciência da Informação encontram-se recortes de outras áreas do conhecimento, fato evidenciado por Saracevic (1970, p. 252), que conceitua a Ciência da Informação como: "(...) um ramo de pesquisa que toma sua substância, seus métodos e suas técnicas de diversas disciplinas para chegar à compreensão das propriedades, comportamento e circulação da informação". Boyce (1985, p. 155) 
complementa, observando que o desenvolvimento da Ciência da Informação depende da síntese de inputs provenientes de outras ciências. Nesse sentido, a interdisciplinaridade da Ciência da Informação pode ser compreendida no pensamento de Gusmão (2010), ao prefaciar o livro de Japiassu (1976): "A exigência interdisciplinar impõe a cada especialista que transcenda sua própria especialidade, tomando consciência de seus próprios limites, para acolher as contribuições das outras disciplinas".

Portanto, conforme a natureza interdisciplinar desta pesquisa buscou-se na Informática, Administração, Ciência da Informação e Direito, aportes teóricos e práticos que possibilitassem a análise de aspectos relativos à criação e avaliação de produtos de informação jurídica fornecidos pela unidade de informação na Web. Por outro lado sabe-se que o produto de informação disponível na Web pode ser estudado a partir de diversos aspectos, envolvendo usabilidade, conteúdo, segurança da informação, quantidade e qualidade da informação, software ou, estrutura de informação disponível. E, dentre tais questões relativas ao tema, investigar por um lado, as necessidades de informação do usuário no planejamento e criação dos produtos de informação na Web, e por outro, avaliar também com foco no usuário estes produtos de informação com uma metodologia interdisciplinar e inovadora, consiste no fenômeno da realidade a ser fundamentado na revisão de literatura.

Cabe destacar que a informação jurídica tem sido alvo de pesquisas de pósgraduação e publicação de artigos científicos, destacando-se os estudos pioneiros das bibliotecárias Cecilia Andreotti Atienza $^{3}$ e Doris Queiroz de Carvalho sobre características deste tipo de informação e necessidades informacionais da comunidade jurídica ${ }^{4}$. No trabalho com a informação jurídica, Loureiro $(2005$, p. 2) revela que "a compreensão do sistema jurídico nacional, construído sobre os pilares do Estado Democrático de Direito, é condição sem a qual o bibliotecário não consegue dimensionar o alcance dos institutos jurídicos".

Como os vários aspectos do tema encontram-se dispersos na literatura, realizou-se buscas em fontes bibliográficas impressas e digitais. Foram usadas bases de dados como: Web of Science (WoS) do Institute for Scientific Information (Webofscience.fapesp.br); Scielo (http://www.scielo.br), revistas científicas eletrônicas de Ciência da Informação e, o Law Library Journal da American Association of Law Libraries. Outras fontes de informação pesquisadas foi a Rede de Bibliotecas RVBI, gerenciada pelo Senado Federal, composta por 12 bibliotecas dos três poderes; a Biblioteca Digital de Teses e Dissertações do IBICT (http://www.ibict.br); e, o Portal da Capes, além de mecanismos de busca como Google Acadêmico, bem como textos eletrônicos publicados em anais de congressos de informação jurídica. A este respeito, é importante acrescentar que existem trabalhos sobre informação jurídica, realizados e não publicados, conforme relata Passos (2004, p. 191) ao realizar um levantamento sobre a produção bibliográfica do bibliotecário jurídico, encontrando dificuldade no acesso a textos, devido principalmente a não publicação dos anais dos eventos pelos patrocinadores.

\footnotetext{
${ }^{3}$ Cujo nome foi posteriormente modificado para Cecilia Andreotti Atienza Alonso.

${ }^{4}$ Conforme Passos (2004, p. 8), a primeira escreveu, em 1979, o clássico 'Documentaçao jurídica: introdução à análise e indexação de textos legais', obra de referência para bibliotecários jurídicos. A segunda, em 1948, publicou a Classificação Decimal de Direito (Cddir), expandindo a classe 340 da Classificaçao Decimal de Dewey. Em 2002, com a Subchefia para Assuntos Juridicos da Casa Civil da Presidência da República, trabalhou na atualização desta Classificação.
} 
Ademais, foram consultados textos que fundamentaram a Metodologia do IBICT para Avaliação de Produtos de Informação, com funcionários do IBICT que participaram do desenvolvimento desta metodologia. Por outro lado, explorou-se, ainda, a literatura sobre as três componentes da Metodologia do IBICT relativas à abordagem Sense-Making com a técnica do Micro moment time line interview, os incidentes críticos de John Flanagan e as Heurísitcas de Jakob Nielsen.

A revisão de literatura está estruturada em dois eixos temáticos principais: o primeiro trata da Ciência da Informação e Direito, incluindo aspectos sociais e jurídicos do acesso a produtos de informação jurídica. Explora características do Direito como campo de geração da informação jurídica. Aborda o Direito na sociedade da informação - alicerçada nas tecnologias de informação e comunicação - bem como a importância do acesso à informação pela comunidade jurídica, no intuito de compreender o papel das bibliotecas do poder judiciário na oferta, busca e uso de produtos de informação jurídica para o desempenho da atividade judicante. A segunda parte trata de produtos de informação na Web, considerando que o meio digital modifica e repercute na forma da unidade de informação ofertar produtos. Trata de abordagens sobre o processo de avaliação dos produtos de informação de acordo com demandas e necessidades de informação do usuário. Para tanto, expõe características, fundamentos e aplicação das abordagens qualitativas e quantitativas de avaliação de produtos de informação, que integram a Metodologia do IBICT.

Cumpre ressaltar que a temática da tese está inserida no grupo de pesquisa Informação e Sociedade, na linha de pesquisa Comunicação e Mediação da Informação.

\section{PARTE I}

\section{O DIREITO: ÁREA DA INFORMAÇÃO JURÍDICA}

O termo Direito se origina da junção do latim: dis (muito, intenso) com rectum (reto, justo) significando "muito reto" ou "muito justo". Referindo-se ao termo directum, derivado desta junção, Nascimento (1998) apud Nascimento e Guimaraes (2004, p. 47) esclarece que provém do latim popular ou baixo-latim. Enquanto que no latim clássico, estes autores explicam que:

\footnotetext{
Direito qualifica-se por ius ou jus, originado do sânscrito ios ou yos relativos a ius, que, por sua vez, forma os vocábulos iussum que significa ordem, comando e iustum significando justiça. Com isso, é possível relacionar o termo direito com o termo jurídico, visto que derivado do latim juridicus, de jus (direito) e dicere (dizer), compreende-se o termo jurídico com a mesma acepção de direito por estar ambos exprimindo o mesmo sentido, ou seja, de justo, de legal dentro das circunstancias judiciárias. (SILVA, 1993 apud Nascimento e Guimaraes (2004, p. 48)
}

A noção deste conceito é bem exemplificada no estudo terminológico feito por Ferini (2006, p. 15) que extrai do Dicionário Houaiss da Língua Portuguesa (2001) dois conceitos do termo jurídico: a) relativo ao direito; b) em conformidade com os princípios do direito; que se faz por via da justiça; lícito, legal. Com base nos dois conceitos, Ferini (2006, p. 15) infere que:

Podemos identificar, analisando e comparando os verbetes acima, duas acepções do termo jurídico: 1) relativo ao judiciário (ou seja, à justiça como instituição); 2) relativo ao Direito como um todo, sobretudo na esfera legal (no sentido da lei), do legítimo, lícito. 
Neste ponto, cabe ressaltar que no desenvolvimento da tese, foram adotadas ambas as concepções do termo jurídico, seja pela necessidade de trabalhar conceitos e características dos produtos de informação das bibliotecas jurídicas e, conforme a segunda acepção, para identificar a natureza da informação jurídica que está em conformidade com Direito positivo ou objetivo.

Doutrinariamente, o Direito integra a vida social e tem como função regular condutas relativas a interesses fundamentais do homem como vida, família, propriedade, integridade física e outros. Uma vez que a efetivação plena dos interesses se manifesta em sociedade, ou seja, depende da presença, colaboração e participação coletiva, isto implica que quanto maior é a relação entre indivíduos mais imprescindível se faz a presença do Direito. De forma concisa, "o Direito existe para realizar a justiça, que é o seu fundamento. E, desta última, o fundamento é a pessoa humana." (GYRÃO, 2007, p. 126)

Depreende-se, então que o Direito a partir do mundo real, ou mundo do ser, projeta um comportamento ideal como meta instituída a ser mantida, conforme pensamento de Friede (2009, p. 276) ilustrado na Figura 1:

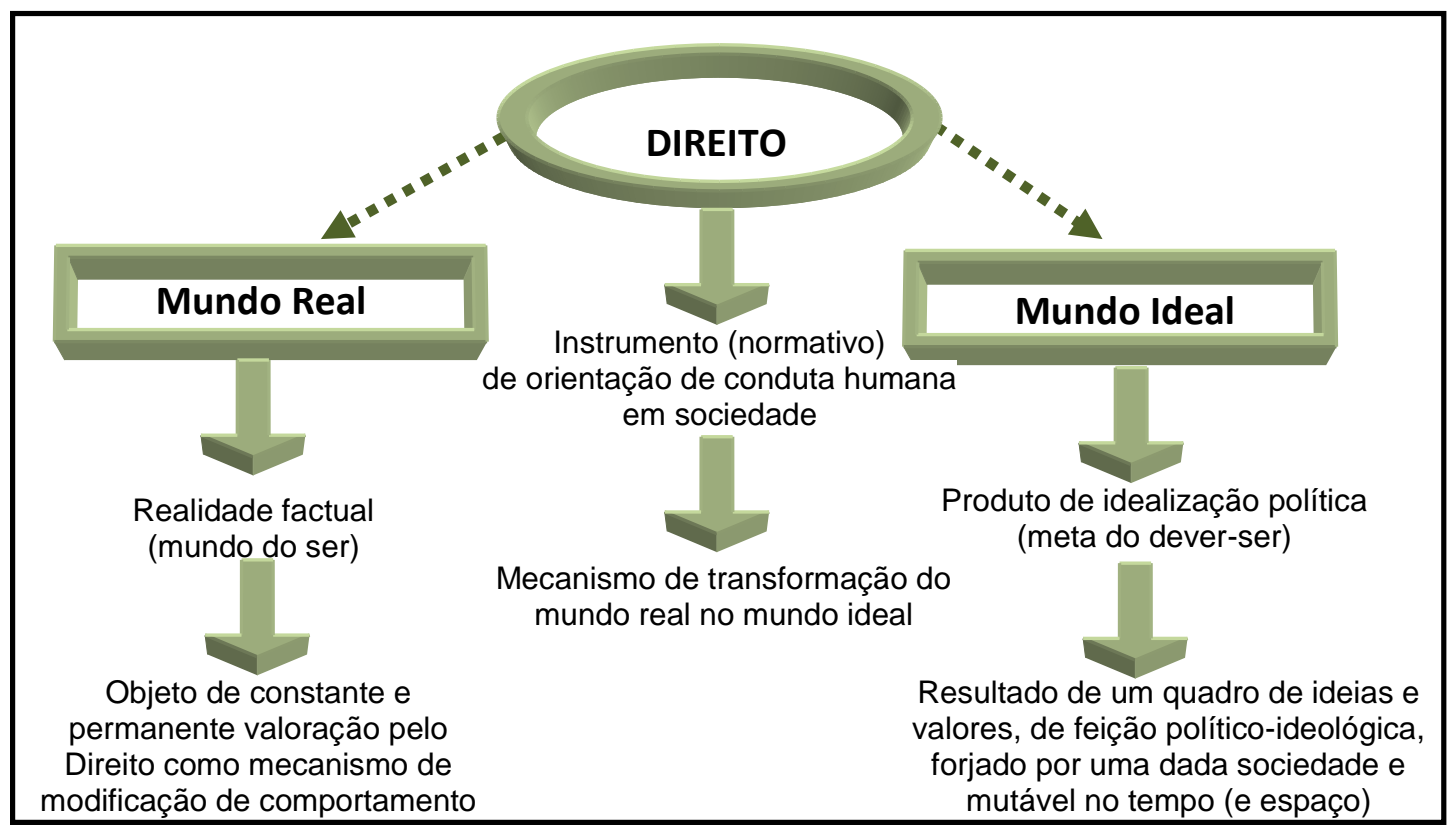

Fig. 1 - Direito como ciência de projeção de comportamento. (Adaptado de Friede - 2009, p. 276)

Gonçalves (2012, p. 35) assinala que: "Não há um consenso sobre o conceito do direito. A esse respeito divergem juristas, filósofos e sociólogos, desde tempos remotos", acrescentando que:

\begin{abstract}
A palavra "direito" é usada, na acepção comum, para designar o conjunto de regras com que se disciplina a vida em sociedade, regras essas que se caracterizam: a) pelo caráter genérico, concernente à indistinta aplicação a todos os indivíduos, e b) jurídico, que as diferencia das demais regras de comportamento social e Ihes confere eficácia garantida pelo Estado. (grifos do autor)
\end{abstract}

Em linhas gerais, Coelho (2005, p. 222) assinala que o Direito se apresenta em duas instâncias na tutela do relacionamento humano na sociedade:

As relações entre as pessoas, na vida formal, são regidas pelo Direito de $1^{\circ}$ grau, chamado Direito substantivo, porque constitui a substância básica da disciplina do relacionamento humano. É de $1^{\circ}$ grau, porque existe antes de 
qualquer outro (...). Todavia, nem sempre as pessoas cumprem as obrigações que assumem com as outras (..) interpretam de modo idêntico normas jurídicas (...) [ou, se] entendem para resolver suas divergências quanto às normas de direito do $1^{\circ}$ grau. Surge, então, a necessidade de se recorrer ao Estado, exigindo-Ihe sua prestação jurisdicional, que se realiza por meio da aplicação das normas de Direito de $2^{\circ}$ grau, o chamado direito adjetivo.

Contudo, na literatura da área jurídica há unanimidade de que o Direito tem como finalidade a coexistência pacífica dos homens. Para Gyrão (2007, p. 95) isto:

(...) resulta do respeito à pluralidade, às diferenças de cada pessoa, compondo grupos distintos, em um espaço público, [onde] se prestigia a liberdade e a igualdade das pessoas que são diferentes em suas origens, mas o ordenamento jurídico deve lhes assegurar a cidadania.

Historicamente, a criação do Direito é abordada por Ripert (1966, p. 78) num texto publicado em $1955^{5}$ :

Nem a transformação da economia pelas descobertas da ciência, nem a mudança de costumes a cada nova geração impõem inelutavelmente o nascimento de um Direito novo. Direito é criado pela vontade do homem. Para prevenir ou regular os conflitos que nascem em sociedade, várias soluções são sempre possíveis e é necessário escolher. A diversidade das legislações em países de idêntica civilização basta a provar que as regras de Direito constituem obra desejada pelo legislador num determinado espírito peculiar.

Com isto Ripert (1966) quer dizer que a regra jurídica não é imposta pelos fatos, e sim que a vontade humana a determina, devendo os governantes formular regras que sejam desejadas. Tal fato é constatado no papel que os movimentos sociais em prol de defesa de direitos e proteção de minorias, das relações de consumo ou de classes sociais, por exemplo, desempenham na evolução e refinamento do Direito. Porém, ressalta que "esta vontade não é puramente arbitrária", ficando, em última análise, determinada pela aceitação da sociedade, como milhões de vontades individuais que se coadunam ou se opõem. (RIPERT, 1966, p. 78). Daí porque, no processo de geração e transformação do Direito, Ripert (1966, p. 79) considera que: "Toda regra nova, modificando algo na norma estabelecida, aproveita a uns e prejudica a outros. É necessário tentar uma conciliação de interesses opostos tendo em vista uma aceitação geral".

No Quadro 01, Gonçalves (2012, p. 35) resume os quatro pilares básicos das normas de conduta que regem a vida em sociedade:

QUADRO 1 - Conjunto de regras que disciplina a vida em sociedade

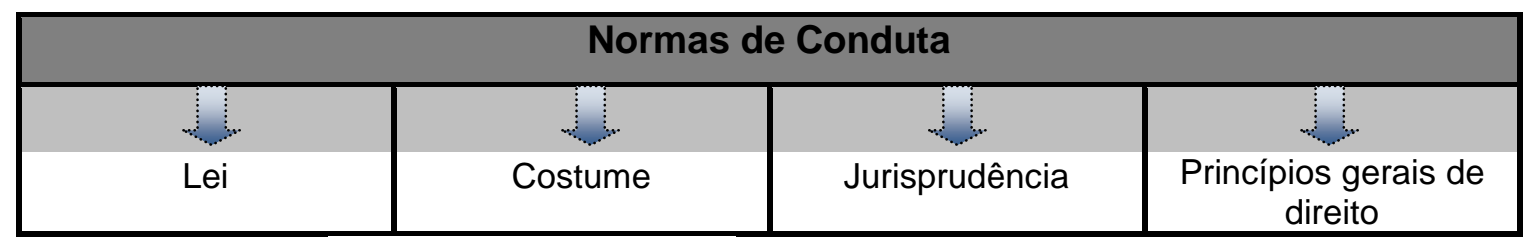

Fonte: Adaptado de Gonçalves (2012, p. 35)

\footnotetext{
${ }^{5}$ Texto extraído de Les forces créatrices du droit, p. 71-92. Librarie Générale de droit e de jurisprudence, Paris, 1955 e publicado na coletânea $O$ Direito e a vida social : leituras básicas de sociologia jurídica A. L. Machado Neto, Zahidé Machado Neto, [org]. São Paulo : Ed. Nacional, Ed. da Unesp, 1966. 209 p. p. 78-86. Biblioteca Universitária. Série 2. Ciências Sociais, n. 18. Direção, Florestan Fernandes.
} 
Portanto, o relacionamento entre legislador, justiça e sociedade adquire a conotação de luta pela resolução do conflito e pela proteção dos direitos desejados, ensejando a realização do Direito, num processo de disputa tanto subjetivo como coletivo, como visto nas palavras de Ripert (1966).

\begin{abstract}
Os verdadeiros motivos da regra, os interesses que satisfaz, as paixões que inspira, a resistência que suscitou, a luta que foi preciso sustentar, tudo isto é cuidadosamente ocultado sob alguns parágrafos que lhe elogiam a justiça e a utilidade. Na realidade, a regra jurídica não foi editada senão porque uma força social Ihe exigiu a existência como força vitoriosa, em face das que a tal se opunham, ou tirando proveito de sua indiferença. (RIPERT, 1966, p. 81).
\end{abstract}

A instância responsável pela criação e edição das leis é o poder legislativo, não podendo interpretar e aplicá-las, ao passo que a interpretação das leis é atribuição do poder judiciário, que só pode fazê-lo com base na norma legitimamente produzida pelo legislador:

(...) vale consignar que não é só o julgador que aplica e interpreta a norma jurídica. Muito pelo contrário, todos os operadores do Direito e até mesmo os cidadãos são potenciais aplicadores e intérpretes [os primeiros de forma técnica, e os últimos de modo leigo], sendo certo que, no eventual conflito, no entanto, a última palavra será sempre do Judiciário (RIPERT, 1966, p. 81).

De modo específico, a sociedade enquanto força condutora na modificação do Direito é igualmente expressa por Reale $(2006$, p.2) ao referir-se à lição retirada de um antigo brocardo jurídico, ubi societas, ibi jus, isto é, "onde está a sociedade está o Direito", revela que a recíproca também é verdadeira, ou seja, "não se pode conceber qualquer atividade social desprovida de forma e garantia jurídica que não se refira à sociedade". Assim, esse autor conclui que "o Direito é um fato ou fenômeno social" que só existe em sociedade, fazendo parte da realidade jurídica.

Por outro lado, na análise da gênese do Direito, Nardi-Greco ${ }^{6}$ (1966, p. 97) indaga: "quais as causas gerais dos fenômenos jurídicos?", ou, "quais os fatos necessários e suficientes ao surgir e permanecer o Direito em todo tempo e lugar no qual existiu e existe?". Ele argumenta que o Direito não é decorrência somente de reações coletivas psicossociais, mas depende das faculdades mentais humanas que convertem tais reações em "reações jurídicas." (NARDI-GRECO, 1966, p. 97). Como fatores historicamente fundantes do Direito este autor aponta 0 aumento demográfico dos grupos sociais associado a atividades sociais constantes que "requerem tutela eficaz" em detrimento de somente reações coletivas. Então, para Nardi-Greco (1966, p. 97), é evidente que a "produção humana" de bens e serviços é "causa condicional sine qua non de todo fato social humano", originando-se o Direito quando se tornou necessário a "cooperação para aumentar a subsistência e satisfação da população crescente".

Nesta linha de raciocínio, Nardi-Greco (1966, p. 97) justifica que as reações coletivas preliminares tornam-se "fatos jurídicos verdadeiros" quando "há necessidade de garantir o exercício de certas atividades coletivas e o gozo de certos

\footnotetext{
${ }^{6}$ Texto extraído de Sociologia jurídica (contributo) p. 441-446, Fratelli Bocca Editori, Turim, 1907 e publicado na coletânea 0 Direito e a vida social : leituras básicas de sociologia jurídica A. L. Machado Neto, Zahidé Machado Neto, [org]. São Paulo : Ed. Nacional, Ed. da Unesp, 1966. 209 p. p. 11-15. Biblioteca Universitária. Série 2. Ciências Sociais, n. 18. Direção, Florestan Fernandes.
} 
bens coletivos" e, quando as condições sociais até então atuantes são insuficientes para assegurar isto. Este autor justifica que como a produção foi a "primeira atividade social na linha do tempo", atrelada a ela foi preciso garantir que o desenvolvimento econômico não sofresse impedimento pela ação de indivíduos ou grupos. Isto se tornou possível mediante normas estatuídas, afim de que a "representação mental da sanção agisse sobre a psique dos membros da sociedade como inibidor da conduta individual, impedindo o ato danoso" (NARDI-GRECO, 1966, p. 98). Assim, ele confirma que os "primeiros traços de normas jurídicas, encontrados nas sociedades humanas mais simples, têm em vista a garantia da produção." (NARDI-GRECO, 1966, p. 98).

Nardi-Greco (1966, p. 100) ilustra as causas originárias do Direito, da seguinte forma: a) causas condicionais: produção; b) causas eficientes: atividades psíquicas individuais determinantes dos sentimentos de ódio, vingança, revanche, etc; temor; atividades psicossociais referentes às reações coletivas; faculdades intelectuais como linguagem e reflexão sobre os efeitos das reações coletivas; c) causas teleológicas: economia e, família. Deste conjunto, Nardi-Greco (1966, p. 100) identifica as causas produção; atividades psíquicas individuais determinantes dos sentimentos; atividades psicossociais referentes às reações coletivas; e, economia como:

(...) essenciais porque sem elas não há qualquer fato jurídico; suficientes, porque sem que intervenha qualquer outro fato social humano elas podem determinar a formação de fatos jurídicos bem distintos; gerais, porque em todo tempo e lugar elas concorrem para a produção do fato jurídico.

O conjunto de fatores psicológicos e sociais, na formação do Direito levou Malinowski ${ }^{7}$ (1966, p. 122) a analisar os motivos que levam indivíduos se submeter a tabus, regras e leis por vezes duras, fastidiosas e incômodas, para que a ordem seja garantida, incluindo-os numa escala de possibilidades como: "razões de ordem moral, sentimental, prática ou espontânea". Este autor acrescenta ainda fatores ligados à presença indispensável da autoridade, para que a lei tenha força.

Por outro lado, na seara da Economia, a contribuição no surgimento e transformação do Direito estar segundo Gomes $^{8}$ (1966, p. 141) na localização deste na superestrutura da sociedade, recebendo, incontestavelmente, o influxo causal da estrutura econômica:

As normas jurídicas tiveram, sempre, a função precípua de proteger e garantir as várias formas de produção adotadas pela Humanidade no transcurso dos séculos. Prova irrefutável dessa fundamental finalidade da lei é a própria evolução do Direito. Em todos os tempos ele refletiu fielmente as condições econômicas dominantes.

Linton $^{9}$ (1966, p. 113), de outro ponto de vista, admite que o fenômeno jurídico esteja intrinsecamente ligado ao surgimento das cidades, quando ocorreu a

\footnotetext{
${ }^{7}$ Texto extraído de Moeurs et costumes des mélanésiens, p. 13-18, Payot, Paris, 1933 e publicado na coletânea O Direito e a vida social : leituras básicas de sociologia jurídica A. L. Machado Neto, Zahidé Machado Neto, [org.]. São Paulo : Ed. Nacional, Ed. da Unesp, 1966. 209 p. p. 121-126. Biblioteca Universitária. Série 2. Ciências Sociais, n. 18. Direção, Florestan Fernandes.

${ }^{8}$ Texto extraído de A crise do Direito, p. 51-59, col. De Cadernos jurídicos, v. 1, Papelaria Vera Cruz, Bahia, 1945 e publicado na coletânea $\mathbf{O}$ Direito e a vida social : leituras básicas de sociologia jurídica A. L. Machado Neto, Zahidé Machado Neto, [org.]. São Paulo : Ed. Nacional, Ed. da Unesp, 1966. 209 p. p. 141-146. Biblioteca Universitária. Série 2. Ciências Sociais, n. 18. Direção, Florestan Fernandes.

${ }^{9}$ Texto extraído de The tree of culture, p. 122-123, N. York, 1956 e publicado na coletânea O Direito e a vida social : leituras básicas de sociologia jurídica A. L. Machado Neto, Zahidé Machado Neto, [org.]. São Paulo : Ed. Nacional, Ed. da Unesp, 1966. 209 p. p. 114-116. Biblioteca Universitária. Série 2. Ciências Sociais, n. 18. Direção, Florestan Fernandes.
} 
necessidade de lidar com pessoas e litígios em massa, afirmando: "parece altamente provável que, quando apareceu, pela primeira vez, toda a concepção de Direito formalizado e processo legal, isto foi, na realidade, um subproduto da situação urbana". Diversos juristas, ainda, conceituaram o Direito, como Clovis Bevilácqua (1929, p. 12), autor clássico, que o define como "uma regra social obrigatória, quer sob a forma de lei, quer sob a forma de costume". Maria Helena Diniz (1993, p. 219) vê o direito como "conjunto de normas estabelecidas pelo poder político, que se impõe e regula a vida social de um dado povo em determinada época". Por sua vez Bourdieu (2003, p. 212) define o direito como campo jurídico de "disputa de saberes e poderes simbólicos (...) pelo monopólio de dizer o direito (...) por agentes investidos, de competência para interpretar um corpus de textos que consagram a visão legítima, justa, do mundo social".

De forma abrangente, Miguel Reale (2006, p.5) esclarece que há subtendido no comportamento humano em relação a outros indivíduos, a presença, mesmo que indireta, do fenômeno jurídico, fato confirmado pelas inúmeras atividades na sociedade que estão sob a proteção do Direito, sendo realizadas no exercício de uma faculdade jurídica, ou seja, exerce-se o poder de agir, tutelado pelo Direito. Este autor exemplifica com a atuação de um médico que está no exercício de uma profissão garantida por lei, na atuação da tutela de um bem que é a saúde pública. Em função disso, afirma que "O Direito é, de certo prisma, um manto protetor de organização e de direção dos comportamentos sociais", existindo "tantas espécies de normas e regras jurídicas quantos são os possíveis comportamentos humanos". (REALE, 2006, p. 6).

Percebe-se que o Direito visa ao bem comum definido por Reale (2006, p.59) como a "(...) ordenação daquilo que cada homem pode realizar sem prejuízo do bem alheio, uma composição harmônica do bem de cada um com o bem de todos". Reale (2006) identificou uma estrutura tridimensional dinâmica e dialética no Direito, resultante da interação de três aspectos básicos compreendidos como norma, fato e valor: a) normativo - ordenamento jurídico e sua respectiva ciência; b) fático - fato em sua efetividade social e histórica; c) axiológico - valor de justiça. (REALE, 2006, p. 64).

Para Ripert (1966, p. 82) há um antagonismo atuante no processo interno entre as forças criadoras ou transformadoras do Direito em duas categorias principais: "forças conservadoras, que tentam manter o Direito existente e, forças reformadoras cujo objetivo é modificar ou transformar. Há subdivisões, em função de diferentes modos de conservar ou reformar". Cabe acrescentar, ainda, outros fatores que influenciam o desenvolvimento do Direito, classificados por Lévy-Bruhl ${ }^{10},(1966$, p. 108) como de natureza política, cultural e religiosa. Conforme este autor, "desde que o Direito é a expressão das vontades do corpo social, tudo o que age sobre a sociedade repercute sobre seu Direito". Mesmo estando em contínua evolução, Lévy-Bruhl, (1966, p. 112) adverte que isto não ocorre no mesmo ritmo em todas as partes, distinguindo três grandes categorias de processos: "estagnação, evolução regular e mutações bruscas".

Do ponto de vista político - porém tendo em mente que o "direito pertence a uma dimensão da civilização" - Grossi (2005, p. 31) detecta que o este regula as

\footnotetext{
${ }^{10}$ Texto extraído de Sociologie du droit, cap. 3, p. 80-86. Presse Universitaires de France (Que-sais-je?), Paris, 1961 e publicado na coletânea $O$ Direito e a vida social : leituras básicas de sociologia jurídica A. L. Machado Neto, Zahidé Machado Neto, [org.]. São Paulo : Ed. Nacional, Ed. da Unesp, 1966. 209 p. p. 108-113. Biblioteca Universitária. Série 2. Ciências Sociais, n. 18. Direção, Florestan Fernandes
} 
relações cotidianas estando intimamente ligado ao poder político, sendo criação do Estado:

O Estado não só pretende criar o Direito, mas também se afirmar como o único sujeito produtor do mesmo, com a consequência imediata e grave de se colocar também como único ente em condições de conferir uma regra social genérica: a impressão e o privilégio da juridicidade, transformando-se em norma jurídica.

Gomes (1966, p. 142) concorda que o Direito tem correspondência com o estado econômico, mas também com o grau de civilização social, podendo, às vezes, não acompanhar o ritmo das forças produtoras, dando origem à revoltas contra a lei. Reunindo elementos e características de todas as percepções até aqui elencadas, a concepção da ciência do Direito representada por Friede (2009, p. 276) revela a importância da jurisprudência como interpretação e aplicação da lei, no acesso à justiça na Figura 2:

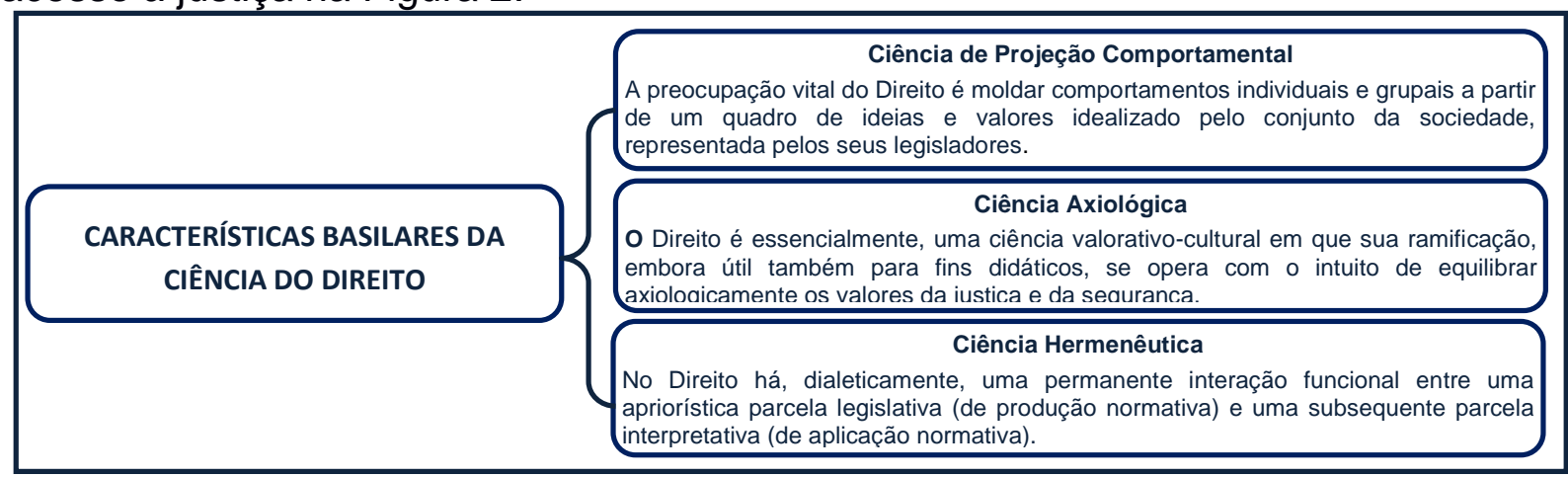

Fig. 2 - Características basilares da ciência do Direito. (adaptado de Friede - 2009, p. 276)

Esta dialética subjacente às funções legislativa $e$ interpretativa da hermenêutica do Direito representa a ligação entre as funções do poder legislativo e judiciário, fazendo alusão à estrutura tridimensional do Direito, constituído de fato, valor e norma, ilustrado na Figura 3:

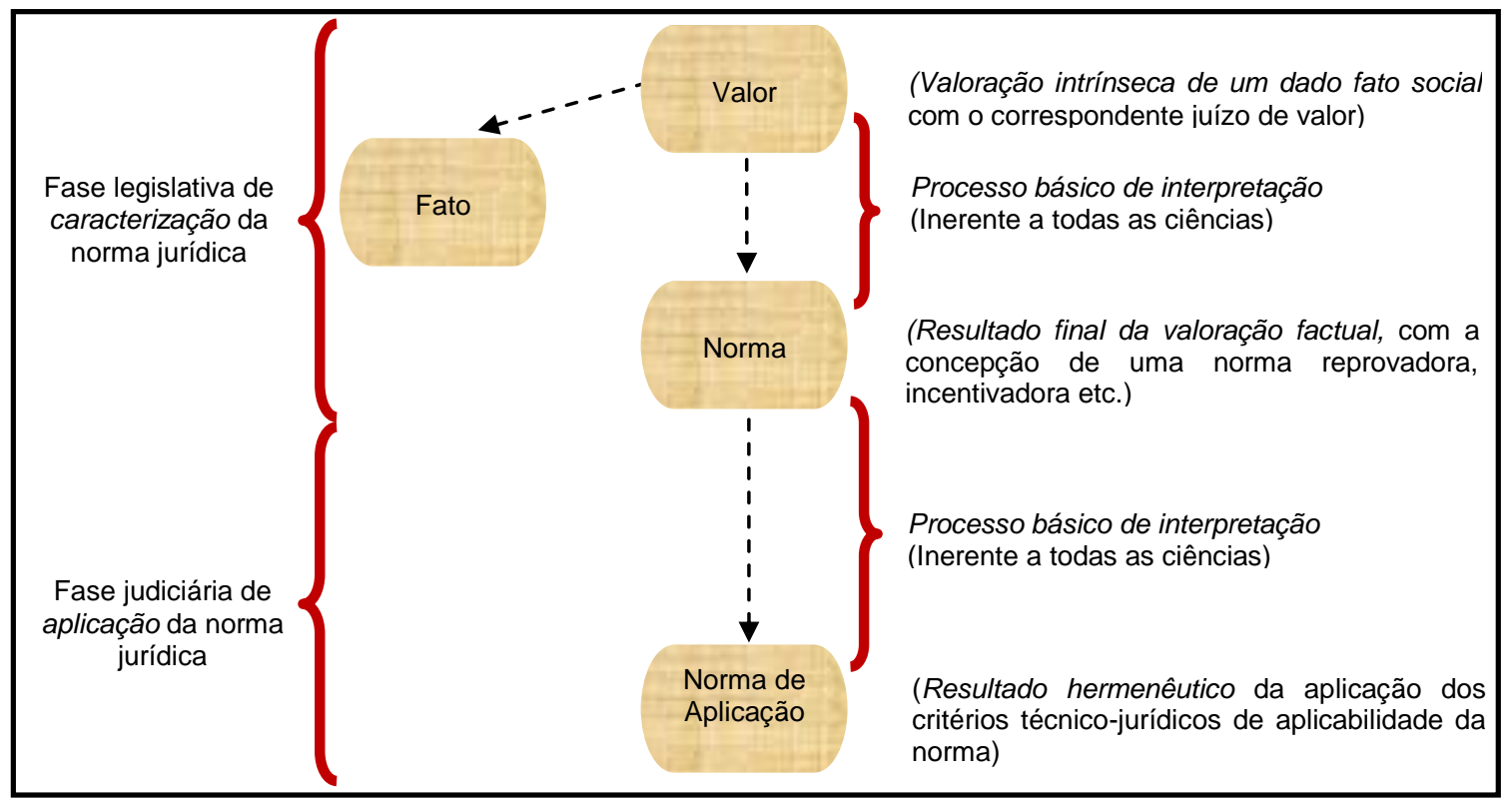

Fig. 3 - Processo interpretativo da ciência do Direito.(Adaptado de Friede, Reis. 2009, p. 275) 
Como visto, a literatura do direito é bastante profícua sobre sua origem e evolução, havendo ampla gama de conceitos e definições, observando-se, no entanto, uma convergência e semelhança entre os autores apresentados nesta revisão de literatura, que podem ser considerados representativos da realidade jurídica.

$\mathrm{Na}$ área da Ciência da Informação, a contribuição para o desenvolvimento do Direito esta calcada no valor social da informação neste novo milênio. De fato, é notória a mobilidade do Direito provocada pela sociedade da informação, quando tornar a informação tangível constitui-se numa significativa função social. Nessa mudança de paradigma na sociedade, o Direito passa por alterações similares. A esse respeito Moraes (2013, p. 3) trata de uma "nova teoria do direito" calcada nos aspectos constitucionais, sobressaindo-se o direito de acesso à informação, que no Brasil, teve início com a Constituição federal de 1988. Para Moraes (2013, p. 4), tal "transformação do mundo jurídico acarretou a expansão da jurisdição constitucional, passando a constituição para o centro do sistema jurídico".

De acordo com os objetivos desta pesquisa, cumpre agregar outros fatores de importância para o desenvolvimento e modificação do Direito dentre as quais, as atividades de organizações na sociedade voltadas para a realidade jurídica, cujo objetivo é a proteção dos mais variados interesses materiais coletivos ou, a defesa de interesses materiais e morais. Nesta missão, encontram-se as bibliotecas, organizações que há milênios acumulam, agregam e fornecem a produção do conhecimento, bem imaterial de interesse coletivo, em nível individual, profissional e social. Tratando-se do conhecimento jurídico, as bibliotecas, arquivos, museus e centros de documentação jurídica, como organizações especializadas na informação jurídica, contribuíram de forma incontestável, ao longo do tempo, para a disponibilidade e acesso a todo o conhecimento gerado e desenvolvido no Direito. Estas organizações fazem parte de uma área interdisciplinar designada de Biblioteconomia jurídica. A título de ilustração, vale lembrar que Pinheiro $(2000$, p. 1) ao estudar desdobramentos interdisciplinares da Ciência da Informação identificou 17 subáreas e disciplinas. Dentre estas, o Direito encontra-se na quarta e oitava áreas listadas no Quadro 2.

QUADRO 2 - Áreas e Disciplinas da Ciência da Informação e Áreas Interdisciplinares, destacando-se o Direito.

\begin{tabular}{|c|c|}
\hline SUBÁREAS/DISCIPLINAS & ÁREAS INTERDISCIPLINARES \\
\hline 1. Sistemas de informação & Administração; Ciência da Computação \\
\hline 2. Tecnologia da informação & Ciência da Computação \\
\hline 3. Sistemas de recuperação da informação & $\begin{array}{l}\text { Biblioteconomia; Ciência da Computação; } \\
\text { Linquística }\end{array}$ \\
\hline 4. Políticas de informação & Administração; Ciência Política; Direito \\
\hline 5. Necessidades e usos de informação & $\begin{array}{l}\text { Arquivologia; Biblioteconomia; Museologia; } \\
\text { Psicologia }\end{array}$ \\
\hline 6. Representação da informação & $\begin{array}{l}\text { Arquivologia; Biblioteconomia; Filosofia; } \\
\text { Linguística; Museologia }\end{array}$ \\
\hline 7. Teoria da Ciência da Informação & $\begin{array}{l}\text { Epistemologia; Filosofia; Filosofia da Ciência; } \\
\text { Matemática }\end{array}$ \\
\hline 8. Formação e aspectos profissionais & Educação; Ética; Direito \\
\hline 9. Gestão da informação & Administração; Economia; Estatística \\
\hline 10. Bases de dados & Ciência da Computação \\
\hline $\begin{array}{l}\text { 11. Processamento automático da } \\
\text { linguagem }\end{array}$ & $\begin{array}{l}\text { Biblioteconomia; Ciência da Computação; } \\
\text { Linguística }\end{array}$ \\
\hline 12. Economia da informação & Administração; Economia \\
\hline
\end{tabular}




\begin{tabular}{|c|c|}
\hline 13. Bibliometria & $\begin{array}{l}\text { Estatística; História da Ciência; Matemática; } \\
\text { Sociologia da Ciência }\end{array}$ \\
\hline $\begin{array}{l}\text { 14. Inteligência competitiva e Gestão do } \\
\text { conhecimento }\end{array}$ & Administração; Economia \\
\hline 15. Mineração de dados & Ciência da Computação \\
\hline 16. Comunicação científica eletrônica & $\begin{array}{l}\text { Ciência da Computação; Comunicação; } \\
\text { História da Ciência; Sociologia da Ciência }\end{array}$ \\
\hline 17. Bibliotecas digitais/virtuais & $\begin{array}{l}\text { Biblioteconomia; Ciência da Computação; } \\
\text { Comunicação }\end{array}$ \\
\hline
\end{tabular}

*Fonte: Adaptado de PINHEIRO (200-, p. 25)

Percebe-se, no Quadro 2, a conexão das subáreas Políticas de Informação e, Formação e Aspectos Profissionais com o Direito. Contudo, nota-se que o acesso à informação jurídica nas organizações do poder judiciário origina questões a serem exploradas pela Biblioteconomia Jurídica. Pinheiro (200-, p. 25) analisa áreas que mais "importam ou exportam" conhecimentos na formação do campo interdisciplinar, concluindo que:

\begin{abstract}
Circunstâncias históricas e sociais são determinantes, por exemplo, os fenômenos que impulsionaram a Sociedade da Informação, a globalização e as tecnologias de rede, foram o motor para o surgimento da Inteligência Competitiva e Gestão do Conhecimento, e de Bibliotecas Virtuais e Digitais. (...) o campo interdisciplinar da Ciência da Informação vai se movendo e gradativamente adquirindo novas configurações (...). Disciplinas e subáreas do campo e seus problemas, que exigem soluções de outras áreas, promovem transformações interdisciplinares (...).
\end{abstract}

Pelo exposto até aqui, é possível dizer que o Direito é uma ciência que possui autonomia própria, visão peculiar do mundo que se traduz em autonomia de um saber específico, de um estatuto epistemológico, de conceitos próprios e de uma linguagem, produzindo a informação jurídica a ser acessada e aplicada pela comunidade jurídica em benefício do cidadão e da sociedade. Outra característica do Direito é a divisão tradicional em privado e público. Enquanto este trata do predomínio do interesse coletivo e das relações com o Estado, o primeiro rege as relações em nível particular. O Direito público e o Direito privado subdivide-se em inúmeros ramos, que não existem independentemente, formando o que Reale (2006, p. 6) denomina de complementaridade do Direito. Esta divisão é determinante das competências dos tribunais e da organização da informação jurídica pelas bibliotecas.

\title{
1.1 Estrutura do Direito
}

Segundo Passos e Barros $(2009$, p. 1) a divisão do Direito em ramos e subramos em áreas gerais e específicas, de forma hierarquizada, procede de Roma Antiga, tendo como princípios básicos a ordenação e localização de determinada matéria no universo jurídico. O Direito como consagrado na literatura jurídica, pode ser natural e positivo. O direito natural prescinde do legislador na elaboração de leis e aplicação de sanções para satisfazer necessidades individuais ou coletivas ou para impor a ordem na sociedade correspondendo a um conjunto de princípios universais, imutáveis, superiores ou normas jurídicas inerentes à própria condição humana, anterior ao ser humano, situando-se acima dele. É apriorístico e fundamentado no Direito positivo. (DINIZ, 2002, p. 43). Por sua vez, o direito positivo é segundo Diniz (2002, p. 43) aquele imposto obrigatoriamente pelo Estado, por meio de leis, decretos, códigos, entre outras normas jurídicas, e cujo objetivo é regular a convivência social humana, ou seja, "é próprio da criação humana, 
composto por um conjunto de normas reconhecidas e aplicadas pelo Poder Público." O direito positivo divide-se em dois grandes ramos, segundo Diniz (2002, p. 44):

Direito público - subdivide-se em interno e externo, regendo as relações do Estado e do interesse público ou coletivo, serviços e bens públicos, licitação, tombamento de prédios históricos e outras num amplo escopo de aspectos da sociedade; Direito privado - disciplinador de interesses individuais, ou relação entre particulares. A doação, compra e venda de bem móvel ou imóvel, partilha de bens entre herdeiros ou cônjuges, são exemplos de atos regidos por esta espécie de Direito.

O mapa conceitual do Direito ilustrado na Figura 4 é consenso entre a maioria dos autores da área jurídica, sendo possível observar acréscimos de subáreas, tais como a inclusão do direito autoral e direito falimentar no campo do direito comercial ou, o acréscimo do direito agrário, como parte do direito civil. Outras subáreas correspondem a derivações incluídas no direito público, como o direito ambiental e o direito eleitoral. Silva $(2010$, p. 66) lembra que "algumas áreas não se enquadram em Público e Privado por regularem, simultaneamente, interesses privado e público, constando na classe de Direito Misto." Neste caso, segundo a autora, encontram-se o Direito aeronáutico e o Direito marítimo. Silva (2010, p. 66) ressalta que o Direito comparado que faz o cotejo entre ordenamentos jurídicos nacionais e internacionais, também não se localiza na categorização pública e privada. Silva $(2010$, p. 68) salienta que existem outras relações na área jurídica e que os ramos do Direito se interligam.

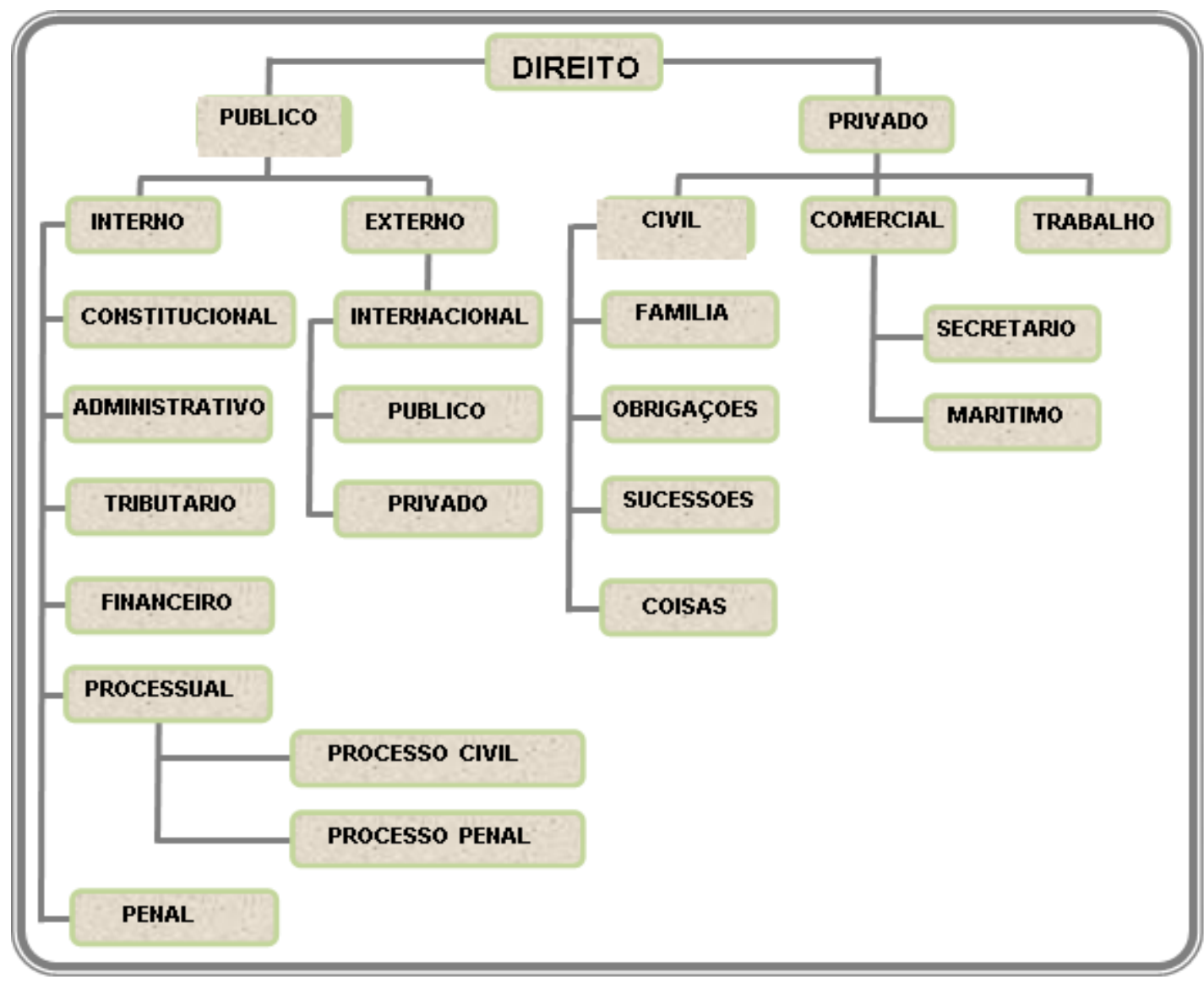

Fig. 4 - Ramificações do Direito Positivo. (Adaptado de SILVA (2008) apud Anízio (2010), p. 24.) 
Com base na estrutura do Direito, a Ciência da Informação, dividiu o conhecimento jurídico em estrutura hierárquica de classes e subclasses de assuntos, por meio de uma categorização fundamentada em classificações científicas e filosóficas, resultando na criação das classificações bibliográficas, como a Decimal de Dewey, CDD e Decimal Universal, CDU. Tal fato é confirmado por Passos e Barros (2009, p. 2):

\begin{abstract}
Do ponto de vista da organização e sistematização da informação jurídica, constituída de documentos doutrinários, legislativos e jurisprudenciais, a classificação do direito também resulta em grande importância. Neste caso, em termos biblioteconômicos, a classificação de assuntos tem por objetivo principal permitir o agrupamento dos diversos documentos da biblioteca ou da unidade de informação, a fim de tornar mais eficientes a busca e localização dos temas pesquisados pelos usuários e operadores da área jurídica.
\end{abstract}

Estes autores reforçam a importância de conhecer os assuntos incluídos nos ramos do direito para a organização e acesso à informação jurídica:

\begin{abstract}
Assim, a biblioteconomia procurou acompanhar a doutrina jurídica no que diz respeito à classificação dos ramos do direito. Uma dessas preocupações pode ser traduzida na criação da Classificação Decimal de Direito, (CDDir), aplicada à documentação jurídica. (...) Esta iniciativa consolidou a prática de organização dos materiais de informação jurídica e conquistou grande aceitabilidade entre os usuários, ao permitir o agrupamento de temas específicos em direito(...) (PASSOS e BARROS, 2009, p. 2)
\end{abstract}

De modo similar, à divisão do direito em público e privado, na Classificação de Direito (CDDir), os ramos e sub-ramos do direito são agrupados segundo o conteúdo, recebendo números de classificação, conforme ilustrado por Passos e Barros (2009, p. 2-3):

\title{
340 DIREITO
}

341 Direito público

\$ 341.1 Direito internacional público

\& 341.2 Direito constitucional

341.3 Direito administrativo

341.4 Direito processual

341.5 Direito penal

341.6 Direito previdenciário

341.7 Direito militar

341.8 Direito aéreo
342 Direito privado

\$ 342.1 Direito civil

\$ 342.2 Direito comercial

\# 342.3 Direito internacional privado

\$ 342.4 Direito do consumidor

\$ 342.5 Direito do trabalho

A CDDir foi adotada em várias bibliotecas para organização da informação jurídica como no Senado, Supremo Tribunal Federal e Presidência da República, além de outras bibliotecas integrantes da Rede RVBI, gerenciada pelo Senado. Na Presidência da República, o Subchefe para assuntos jurídicos da Casa Civil, ao redigir a apresentação da atualização da CDDir, em trabalho conjunto entre operadores do direito e bibliotecários refere-se ao contexto histórico desta classificação bibliográfica do direito, confirmando sua importância no acesso à informação jurídica:

Em 1948, a bibliotecária e bacharela em direito Doris de Queiroz Carvalho (...) constatou a necessidade de detalhar a Classificação Decimal de Dewey 
na classe 340 , referente ao Direito. Disto surgiu a obra Classificação Decimal de Direito, editada pelo Ministério da Fazenda. (...) constatou-se a necessidade de atualização da obra para incorporar as novas áreas da Ciência do Direito que surgiram e se desenvolveram nesse período. A atualização procurou acrescer novos ramos do Direito. Espera-se que esta nova edição contribua para melhor organização dos repositórios jurídicos, com a consequente facilitação do acesso às obras de Direito por todos os interessados. (BRACKS, 2002)

O Advogado-Geral da União também reconheceu a necessidade e importância da CDDir no universo das bibliotecas jurídicas do país, relatando as dificuldades no uso da CDD, devido a questões específicas da divisão do direito brasileiro:

Quando a Dra. Doris de Queiroz Carvalho (...) iniciou a classificação das obras de Direito na biblioteca do Ministério da Fazenda, constatou a deficiência da Classificação Decimal de Melvil Dewey para o adequado cadastramento das obras jurídicas da tradição Romano-Germânica. Assim, recorreu a diversas outras classificações (...). No entanto, a Classificação Decimal de Bruxelas [CDU] também teve de ser adaptada ao Direito Pátrio, pois não era concebível (...) incluir o Direito Processual Civil dentro do Direito Civil e o Direito Processual Penal dentro do Direito Penal, já que na tradição brasileira ambos são ramos autônomos do Direito Público. (ANDRADA, 2002)

Andrada (2002) relata questões ligadas à divisão do direito em público e privado, na organização da informação jurídica em bibliotecas governamentais, destacando o uso da CDDir na indexação da base de dados do Ministério da Previdência e Assistência Social, na internet:

Quando era Consultor Jurídico do Ministério da Previdência e Assistência Social, em 1995, reorganizei a biblioteca da Consultoria Jurídica, porquanto a do Ministério havia perdido o seu acervo nas diversas fusões e separações que teve do Ministério do Trabalho. Com isto, a biblioteca da Consultoria Jurídica veio a se tornar a biblioteca do Ministério da Previdência e Assistência Social. Naquela ocasião, tive contato com as questões ligadas com a biblioteconomia e tomei conhecimento da existência da "Classificação da Doris". Esta classificação foi a que melhor atendeu às necessidades daquela biblioteca (...). Achei a "Classificação da Doris" um trabalho notável que estava a carecer de atualização pelo surgimento de alguns novos ramos do direito (...). Na Subchefia para Assuntos Jurídicos da Casa Civil da Presidência da República, adotamos a "Classificação da Doris" para indexar a base de dados de leis e decretos, que hoje se encontra disponível na "internet" (...).

Andrada (2002) constatou a necessidade de atualização da CDDir de acordo com o conhecimento jurídico do século XXI.

Fizemos, então, para uso interno, atualização informal da "Classificação da Doris". Concluído o trabalho, ocorreu-nos submetê-lo à autora como proposta de atualização [que] concordou em, juntamente com a Subchefia para Assuntos Jurídicos da Casa Civil da Presidência da República, atualizar a obra para reedição [e], com a disponibilização pela "internet". Acreditamos que a atualização, reedição e divulgação por meio eletrônico (..) é relevante e meritório serviço prestado à sociedade brasileira e às demais comunidades de língua portuguesa. De outra parte, não menos relevante será o valioso auxílio que a obra prestará a todos que se dedicam à organização de repositórios jurídicos. (ANDRADA, 2002).

A necessidade de atualização do conhecimento jurídico nas organizações que trabalham com a informação jurídica configura-se em fator indispensável para 
criação, desenvolvimento e indexação do conteúdo de produtos de informação na Web, devido à atuação e competência de cada instituição jurídica nos ramos e subramos do direito. A este respeito, Passos e Barros $(2009$, p. 3) lembram que a área do direito tem dinâmica propícia ao surgimento e desenvolvimento de ramos e subramos que passam, posteriormente a figurar como direito autônomos, como é o caso dos: "direitos difusos, direitos individuais e coletivos, direitos das minorias, direito alternativo, direitos humanos, (...) para citar alguns exemplos das ramificações em processo de formação ou de consolidação". Em decorrência, estes autores adotaram a filosofia CDDir:

Devido a sua importância pedagógica e como forma de reconhecimento do trabalho de Doris de Queiroz Carvalho, em prol do engrandecimento da biblioteconomia jurídica, passamos a adotar a quarta versão da CDDir para expressar os conceitos dos principais ramos da ciência jurídica, com a divisão clássica do direito (público e privado), bem como suas subdivisões principais.

Portanto, é imprescindível que o bibliotecário conheça os principais conceitos e noções do Direito, além das ramificações do direito público e privado, no objetivo de tornar acessível a informação jurídica para a comunidade jurídica, cidadão e sociedade, segundo o ramo do direito contemplado pela instituição no qual trabalha, mormente, nas bibliotecas dos tribunais. De igual importância é conhecer a linguagem técnica e especializada da área jurídica, denominada linguagem jurídica.

\subsection{Linguagem jurídica}

A linguagem jurídica, segundo Sytia (2002, p. 19) "é mediadora entre o poder social e as pessoas, ela há de expressar com fidelidade os modelos de comportamento a serem seguidos, evitando, desta forma, distorções na aplicação do Direito". Para Damião e Henriques (2007, p. 29), no mundo jurídico, o ato comunicativo deve se resguardar da diversidade linguística dos seus usuários, "porque o Direito é uma ciência que disciplina a conduta das pessoas, portanto, o comportamento exterior e objetivo, e o faz por meio de uma linguagem prescritiva e descritiva". Estes autores observam que com o surgimento do conflito de interesses ou, se a norma jurídica é ferida, dá-se a formação da lide, criando uma relação polêmica entre as partes. Segue-se que, no confronto de posições, a linguagem torna-se mais persuasiva e lógica por perseguir o convencimento do julgador, que por sua vez deixa claro, na motivação da sentença, os motivos da decisão tomada. (DAMIÃO e HENRIQUES, 2007, p. 28),

Em linhas gerais, para Gubert (2004, p. 21) "a linguagem é o instrumento pelo qual se comunicam os comandos das regras jurídicas. É através dela que são estatuídas as leis, é com ela que o juiz profere seu veredicto, é ela que confere sentido e significado aos termos de um contrato". Por sua vez, Brasil (2002, p. 17) prefaciando o livro de Sytia (2002, p. 15) evidencia que o profissional da área jurídica utiliza-se, primordialmente da palavra como instrumento de trabalho uma vez que ela "instaura o Direito e o torna específico; é a palavra que solicita, é a palavra que concede ou nega. Tudo se resolve pela palavra e com a palavra". Acrescenta, outrossim, que embora a linguagem jurídica como instância linguística seja regida pelos mesmos princípios da linguagem comum, o que a especializa é o "valor vinculante e jurígeno da palavra do magistrado". Assim, sintetiza que "a palavra jurídica e, mormente, a palavra escrita, é instauradora, constituidora, declaradora" (BRASIL, 2002, p. 16). 
Sabe-se que as funções gerais da linguagem, aplicam-se também à linguagem do Direito, estando esta última impregnada de múltiplas funções de expressividade, enunciadas por Damião e Henriques (2007, p. 24) em diferentes formas: a) função emotiva - linguagem marcadamente subjetiva do acusado em seu depoimento; b) função referencial - presente na informação jurídica que tem como características ser precisa, objetiva e denotativa; c) função poética - presente no texto jurídico rebuscado; d) metalinguística - encontrada nos dicionários e vocabulários jurídicos estando centrada nos códigos; e) função conotativa - presente no texto jurídico persuasório convencendo coercitivamente o receptor a mudar de comportamento com estímulo para alterar condutas estabelecidas e provocar reações.

Como cada ciência exprime-se numa linguagem, para se alcançar a visão unitária do Direito, torna-se necessário adquirir um vocabulário. Grizzuti (2006) numa perspectiva retroativa agrega que "desde a visão positivista a linguagem do direito é a linguagem das normas, portanto, segundo os primeiros positivistas esta é uma linguagem normativa”. Em contrapartida, Maciel (2001, p. 21) atesta a importância do conhecimento da terminologia jurídica além do domínio do Direito:

Ora, a terminologia jurídica é de capital importância tanto dentro do universo do Direito, como fora dele, porque é através da linguagem que os conceitos que presidem o ordenamento da sociedade se conformam, se estabilizam e se transmitem. Para o profissional, a familiaridade com o conteúdo e a forma dos termos jurídicos permite o acesso à área; para o leigo, sua compreensão contribui para a observância das normas que garantem a ordem e a convivência harmônica na sociedade.

Grizzuti (2006) esclarece ainda que:

O Direito nos é dado a conhecer por meio de palavras manifestadas (...): nas leis, nos actos judiciais e em outras formas diversas (...). A linguagem deve ser precisa, pois existem palavras que tem um significado geral e outro tipicamente jurídico (..). Com efeito, muitas vezes se fala pejorativamente de um "juridiquês" e de um "legalês", mas nos sistemas legais predomina a ideia que os termos devem ser precisos, pois a redacção jurídica deve ser clara já que não está dirigida a população em geral.

Não obstante, a consciência do distanciamento entre linguagem jurídica e a sociedade Grizzuti (2006) adverte que:

(...) o hermetismo da linguagem jurídica justifica-se pelo tecnicismo desta, sendo necessário um engajamento dos aplicadores do Direito para em diversas e criativas medidas tornar mais acessível a linguagem jurídica ao conhecimento da sociedade, tendo em vista que o conhecimento do Direito como acesso à Justiça é direito fundamental dos cidadãos.

Nardi-Greco (1966, p. 99) ao tratar de fatos que remontam à formação do Direito, considera que a linguagem de forma geral, foi um fenômeno extraordinário de regulação social que possibilitou o surgimento da área jurídica, uma vez que possibilitou a "comunicação das experiências, a formulação de normas, o julgamento, a transmissão a gerações sucessivas dos hábitos e crenças jurídicas".

Petri (2008, p. 32) de outra ótica acrescenta:

No seio da língua nacional, a linguagem jurídica se singulariza por alguns traços que a constituem como linguagem especializada. A especificidade dessa linguagem refere-se (...) à existência de um vocabulário jurídico e às particularidades do discurso jurídico. (...) A linguagem do direito é (...) uma linguagem de grupo, técnica e tradicional. Esta ambiguidade resulta de ser a linguagem jurídica ao mesmo tempo culta (na sua origem), popular (por 
destinação), técnica (na produção). Sua juridicidade a especializa quando sua finalidade é a de se destinar a todos.

Para este autor, "a linguagem do direito é principalmente marcada por aquele que 'fala' o direito: aquele que o edita (legislador), ou que o diz (juízes) [e], por todos aqueles que concorrem para a criação e realização do direito". Por sua vez, é uma linguagem profissional porque é a "linguagem pela qual os membros das profissões da área do Direito desempenham suas funções". Petri (2008, p. 33) acrescenta ainda que "se trata de linguagem pública, social e cívica, pois realiza a comunicação do direito a todos a ele sujeitos". Petri (2008, p. 33) caracteriza a linguagem jurídica como técnica em virtude de "nomear todos os níveis dos poderes públicos, todas as formas de atividade econômica, as bases da vida familiar, os contratos, as convenções". Além disso, infere que "o direito nomeia igualmente as realidades naturais e sociais que ele apreende e transforma em 'fatos jurídicos', atribuindo-lhes efeitos de direito. Assim, nomeia os delitos e as situações jurídicas" e, de modo geral, os enunciados técnicos do Direito seguem o pensamento jurídico em suas operações mais trabalhosas e difíceis como a "interpretação, apreciação, pressuposição, qualificação, raciocínio”, dentre outras. (PETRI, 2008, p. 33).

Petri (2008, p. 35) ainda considera que a linguagem jurídica se renova continuamente, sendo o neologismo no vocabulário jurídico a principal manifestação dessa evolução. Ademais, a linguagem do direito é definida por este autor como "plurifuncional" por ser instrumento de elaboração da lei, do julgamento, das convenções, da literatura jurídica, da criação doutrinária, da ação administrativa, da atividade contratual. Portanto, Petri (2008, p. 35) assinala que a linguagem jurídica "circula em todos os canais da criação e da realização do direito". No seu conjunto, a linguagem jurídica é integrada pelo que Petri (2008, p. 35) denomina de cinco "níveis linguísticos", havendo pontos comuns entre os mesmos quer no vocabulário jurídico quer na estrutura dos enunciados:

1. Linguagem legislativa - dos códigos e normas, com finalidade de criar 0 direito;

2. Linguagem judiciária, forense ou processual - dos processos, para aplicar o direito;

3. Linguagem convencional ou contratual - dos contratos onde se criam direitos e obrigações entre as partes;

4. Linguagem doutrinária - dos mestres e doutrinadores, cuja finalidade é explicar os institutos jurídicos e ensinar o direito;

5. Linguagem cartorária ou notarial - registra os atos de direito.

No pensamento de Brasil (2002, p. 15) o profissional do direito usa a palavra por excelência no exercício da profissão, particularmente no quotidiano do foro ele afirma que a palavra escrita assume função inquestionável. Damião e Henriques (2007, p 212) lembram que é na fase judicial que o profissional do Direito imprimirá nos autos a "exuberância do discurso jurídico" reunindo em sua tese a "demonstração da lei como amparo legal a seu ponto de vista e a jurisprudência como alicerce de todo o seu argumento. Aquela retrata a legitimidade recursal, esta, a sabedoria na aplicação da lei”. Já na literatura de Ciência da Informação Passos e Barros (2009, p. 86) avaliam a linguagem jurídica na ótica necessária à comunicação e acesso à informação jurídica, numa leitura peculiar:

A linguagem jurídica pode ser estudada por dois ângulos: a forma de expressão que os operadores do direito utilizam para manifestar seu 
pensamento, o juridiquês, e os termos jurídicos utilizados por eles, o seja, a terminologia jurídica propriamente dita.

O "juridiquês" a que os autores se referem, corresponde à linguagem de estilo requintado e pomposo praticada pelos operadores do direito na argumentação oral e redação forense. Vale lembrar a observação feita por Passos e Barros (2009, p. 90) sobre a existência de vocabulários específicos, fato imprescindível à inteligência e criatividade no direito, bem como à precisão terminológica jurídica. Além disto, estes autores adiantam que "a linguagem jurídica tem um cunho mandatório e imperativo, utilizando-se de verbos no imperativo como permitido, proibido, facultado, sempre em busca de um dever ser ou dever fazer". Em vista disso, consideram que a despeito do uso necessário de termos técnicos e jurídicos, devem ser evitadas barreiras linguísticas na comunicação entre justiça, jurisdicionado e sociedade.

A propósito, ao profissional da informação, mormente o bibliotecário, cabe buscar a significação da linguagem jurídica. Na realidade, o domínio da linguagem no campo do Direito pelo profissional da informação abrange todas as etapas de necessidade, busca e uso da informação jurídica, desde a formulação das leis, sistematização, interpretação e aplicação do direito. A linguagem é por si só, um fator indispensável na inclusão do mundo jurídico dos tribunais, e outras organizações jurídicas públicas e privadas. Isto porque, os termos, vocábulos técnicos, expressões de uso e linguagem exata requerem um conhecimento e aplicação específica da comunidade jurídica, cabendo ao profissional da informação organizar e disponibilizar a informação precisa com propriedade, de acordo com as necessidades específicas deste usuário. A par disso, Passos e Barros (2009, p. 91) afirmam que:

\begin{abstract}
É necessário que os operadores do direito tenham pleno conhecimento do vocabulário que utilizarão, do mesmo modo que os bibliotecários jurídicos. Estes, para se comunicar sem risco de ruído, precisam compreender este vocabulário. Não podem confundir remissão com remição. Sutil diferença há entre contrabando e descaminho. O primeiro é a importação ou exportação de mercadoria proibida. Descaminho é a importação ou exportação de mercadoria legal, mas sem o recolhimento de impostos. O descaminho pode ser sanado com o pagamento de impostos; por outro lado, contrabando é crime contra a ordem penal e tributária.
\end{abstract}

Da mesma forma, ter domínio conceitual e terminológico da informação jurídica é fator de sucesso na criação e desenvolvimento de produtos de informação na Web, bem como na comunicação com a comunidade jurídica e com o cidadão. Ademais, o entendimento das características da linguagem jurídica é essencial para a compreensão da informação jurídica em sua complexidade. Fogl (1979, p. 23) ao definir o termo informação, confirma ser esta constituída de conteúdo, suporte e linguagem. Logo, a informação jurídica é composta de conteúdo peculiar (doutrina, legislação e jurisprudência), suporte impresso e digital e linguagem jurídica.

Na prática, a compreensão da linguagem jurídica é evidenciada na indexação da informação, processo mais importante para obter êxito no momento da recuperação da informação pelo usuário na biblioteca. Nas bibliotecas especializadas em Direito, corresponde ao tratamento temático da informação jurídica pelo bibliotecário, sendo de natureza complexa devido à terminologia técnica, exigindo domínio da linguagem jurídica no momento da tradução e representação do assunto em bases de dados, bibliotecas digitais, catálogos on line e outros produtos de informação a Web. Isto se verifica também na avaliação destes produtos de informação, ao aferir o grau de precisão e clareza terminológica e o 
nível de linguagem adequado ao usuário da comunidade jurídica e ao cidadão, nos produtos de informação no site da biblioteca jurídica.

\title{
1.3 Fontes do direito e normas jurídicas
}

Originariamente, Gusmão (1997, p.44) informa que o Direito brasileiro integra o bloco do Direito codificado composto por vários países europeus, diferentemente de países como os Estados Unidos e a Inglaterra, onde vigora o sistema da Common Law. Este autor esclarece que Direito codificado é apresentado sob a forma de codificações ou códigos, enquanto o Direito da Common Law está calcado "na jurisprudência escrita (precedentes judiciais), sem apresentar-se em forma de leis ou códigos". No século XVI, época das grandes navegações e expansão do comércio europeu, Gusmão (1997, p.44) descreve que o Direito consolidava-se na codificação, ultrapassando uma base de costumes para validar as relações jurídicas internas e internacionais que surgiram com o mercantilismo:

\begin{abstract}
A França liderou na Europa com um movimento codificador, que repercutiu em muitos países. Após a Revolução Francesa foi formulado o Code civil de 1804 de Napoleão, ainda hoje em vigor, sendo um marco jurídico da modernidade. A sua promulgação confirmou a maior parte das conquistas sociais alcançadas pela sociedade civil burguesa depois da Revolução de 1789. Da mesma forma, afirmou o reconhecimento das novas relações socioeconômicas provenientes dos acontecimentos posteriores à queda da Bastilha. Desde sua criação, a influência do Código civil francês passou a ser universal, lançando as bases do Direito Privado moderno.
\end{abstract}

Tal percurso histórico de influência é descrita por Gusmão (1997, p.45-46) na formação do direito brasileiro:

O Código civil português, datado de 1868 , foi totalmente inspirado no francês. Ainda no século XVI, por influência francesa em relação, sobretudo, ao Direito privado, os doutrinadores portugueses foram substituídos por leis. As leis portuguesas, chamadas de ordenações reais (Afonsinas, Manuelinas e Filipinas), em muito influenciaram o Direito brasileiro. Nossa tradição jurídica e toda construção doutrinária sofreu influência do Direito romano, do Direito germânico, canônico e da moral cristã, trazidos para nosso território por essas famosas ordenações reais.

A partir da década de 1960, de acordo com Gusmão (1997, p.45) passou a ocorrer influência estrangeira de outros países. O século XX se caracterizou pela pluralidade de Direitos, sendo que, Azevedo apud Ferini (2006, p. 22) avalia que "em cada ramo do Direito brasileiro, predomina a influência de um país", originando um conjunto complexo de normas jurídicas destinadas a regularem diferentes esferas da vida social, conforme visto no Quadro 3:

QUADRO 3 - Ramo do Direito X Fonte do Direito Predominante

\begin{tabular}{|l|l|}
\hline RAMO DO DIREITO & FONTE DE DIREITO PREDOMINANTE \\
\hline Direito processual & Itália \\
\hline Direito penal & Itália \\
\hline Direito administrativo & França \\
\hline Direito Internacional & França \\
\hline Direito civil & França, Alemanha e Portugal \\
\hline Direito constitucional & França e outros países \\
\hline Direito comercial & Estados Unidos \\
\hline
\end{tabular}

Fonte: Adaptado de Ferini (2006, p. 22) 
Por sua vez Reale (2006, p. 139), se refere à importância da norma jurídica afirmando que: "o ordenamento jurídico de um Estado é um processo resultante da produção de norma jurídica". Este autor complementa que: "as formas nas quais as normas jurídicas se positivam com força legítima são o processo legislativo, atividade jurisdicional, usos e costumes jurídicos e o ato negocial". (REALE, 2006, p. 140). Constata-se, então, que uma função da norma jurídica é compor o ordenamento jurídico de uma região ou país, originando o ordenamento jurídico interno e externo. Em texto clássico do Direito publicado em 1953, Tomaso Perassi, elucida que "todo ordenamento jurídico é uma superestrutura de uma determinada sociedade". A Figura 5 exemplifica a hierarquia das normas no ordenamento jurídico nacional, tendo como vértice a Constituição Federal como norma fundamental:

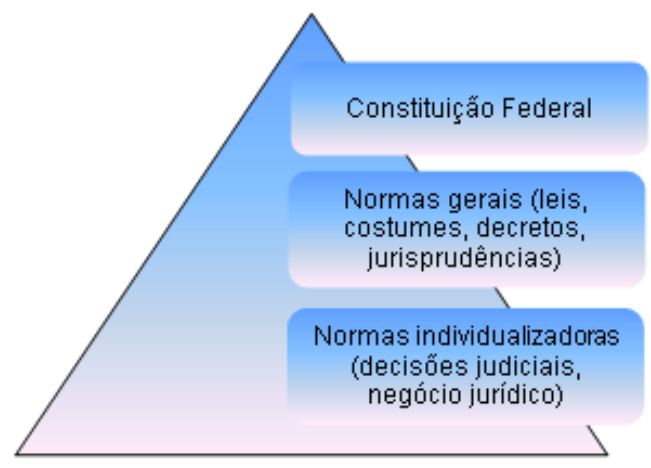

Fig. 5 - Hierarquia das normas no ordenamento jurídico nacional. (Adaptado de Kelsen, 1987, p. 240).

Na pirâmide, a constituição ocupa posição superior dentre as normas no ordenamento jurídico, sendo, conforme Kelsen (1987, p. 240) "o fundamento supremo de validade da ordem jurídica inteira". Por outro lado, a apreensão do fenômeno jurídico, pressupõe a hermenêutica jurídica como processo do poder judiciário a ser compreendido pela comunidade jurídica, bibliotecário e sociedade, conforme Figura 6:

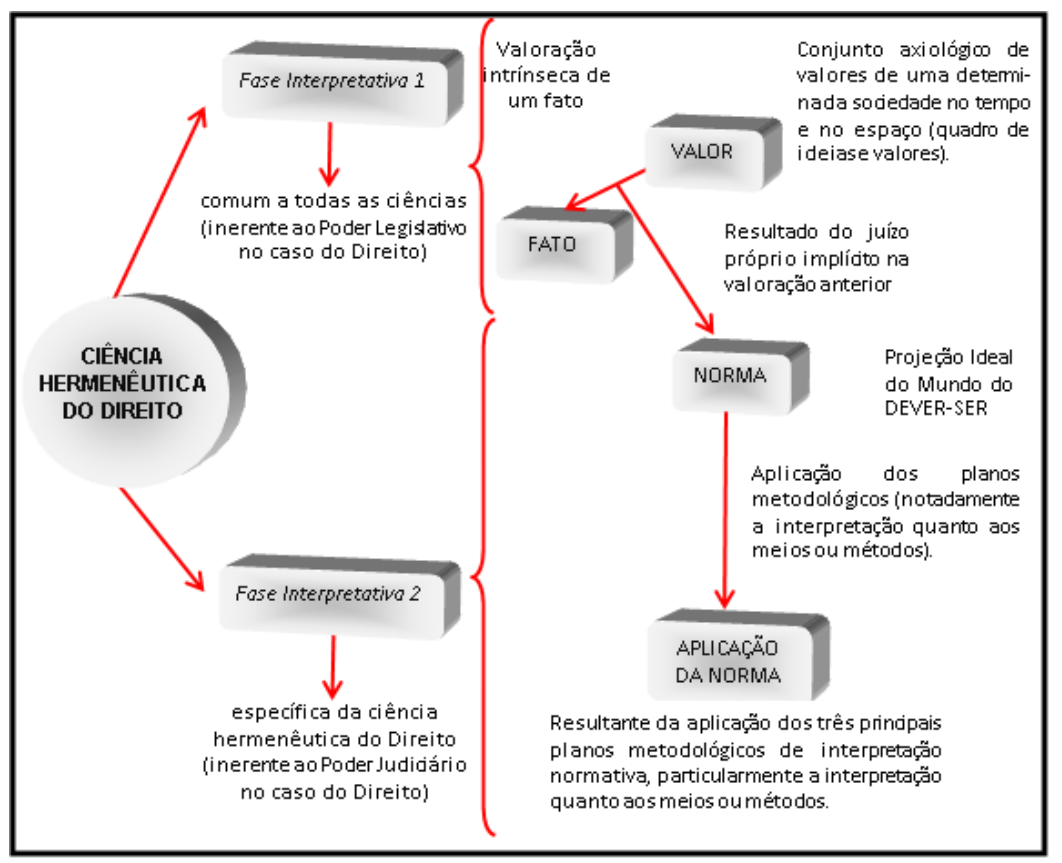

Fig. 6 - Caracterização da ciência hermenêutica do direito e o poder judiciário. (Adaptado de Friede, Reis. 2009, p. 271) 
Com base em Schneider e Wackereitt (1992) Barros (2004, p. 203-204) esclarece que as "(...) as fontes do direito constituem a ordem jurídica de uma sociedade e formam o alicerce da ciência do direito", sendo classificadas em "fontes formais e fontes históricas". As primeiras consistem nas formas pelas quais o direito se manifesta tais como as leis dos códigos e legislações específicas, a jurisprudência nas súmulas, acórdãos e recursos especiais e extraordinários entre outros além da doutrina publicada em livros e periódicos científicos especializados no Direito. As fontes históricas serviram originalmente de base ao direito de cada nação, sendo que no Brasil consta o direito romano, canônico, americano, francês e alemão. Atienza (1998, [p. 8]) como profissional da área da informação, recorrendo ao vocabulário jurídico, adiciona outras características:

Fontes do Direito - (...) texto em que se funda o Direito (...). Como fonte principal do Direito tem as leis; e como fontes subsidiárias do Direito (...) a Jurisprudência, o Direito Costumeiro, o Direito Estrangeiro, o Direito Romano e a Doutrina.

Prossegue assinalando que:

Por Fonte do Direito se designa os processos ou meios em virtude dos quais as regras jurídicas se positivam com legitima força obrigatória, isto é, com vigência e eficácia no contexto de estrutura normativa. O Direito resulta de um complexo de fatores que a Filosofia e a Sociologia estudam, mas se manifestam, como ordenação vigente e eficaz, através de certas formas, diríamos mesmo de certas fôrmas ou estruturas normativas, que são: o processo legislativo, os usos e costumes jurídicos, a atividade jurisdicional e 0 ato negocial. (ATIENZA, 1998, [p. 8]) (grifo nosso)

De forma sucinta, elucida que fonte de direito:

(...) se constitui em fonte de regras obrigatórias, dotadas de vigência e de eficácia e que precisa de um poder capaz de especificar o conteúdo devido para exigir o seu cumprimento. (ATIENZA, 1998, [p. 8])

Atienza (1998, [p. 8]), fundamentada na obra "Lições preliminares do direito" de Miguel Reale aprofunda o conceito de fonte do direito identificando quatro formas de poder vinculadas a estas fontes:

As Fontes do Direito produzem modelos jurídicos prescritivos, (...) isto é, estruturas normativas que, com caráter obrigatório, disciplinam as distintas modalidades de relações sociais. As fontes do Direito são em número de quatro conforme as formas de poder: Poder Legislativo, Poder Judiciário, Poder Social, Poder Negocial: a) Processo legislativo - fonte do direito do Poder Legislativo incluindo Emendas à Constituição, Leis Complementares, Leis Ordinárias, Leis Delegadas, Medidas Provisórias, Decretos Legislativos, Resoluções; b) Jurisdicão - fonte do direito do Poder Judiciário, compreendendo Julgados de Tribunais, Atos Processuais, Enunciados Normativos ou, Súmulas Jurisprudenciais; c) Usos e costumes jurídicos fontes de direito que exprimem o poder social, ou poder decisório anônimo do povo. O Direito costumeiro não tem origem certa. Geralmente não se sabe onde e como surge determinado uso ou hábito social, que, aos poucos, se converte em uso jurídico; d) Fonte negocial - expressão do poder negocial ou da autonomia da vontade. A experiência jurídica não é disciplinada somente por normas legais ou leis, de caráter genérico, mas também por normas particulares e individualizadas. Entre estas estão normas negociais $e$, as normas contratuais, comumente denominadas cláusulas contratuais. (ATIENZA, 1998, [p. 8])

Atienza $(1998$, p. 6) expõe a posição de alguns autores da área do direito sobre o papel consolidado da doutrina como fonte do direito: 
A Doutrina não é considerada, por muitos autores, uma fonte do direito, porque ela não se desenvolve numa 'estrutura de poder' que é um requisito essencial ao conceito de fonte; mas, nem por isso deixa de ser uma das molas propulsoras, e a mais racional das forças diretoras, do ordenamento jurídico. $\mathrm{O}$ fato de não ser considerada fonte de direito não priva, todavia, a doutrina de seu papel relevantíssimo no desenrolar da experiência jurídica. $\mathrm{Na}$ realidade, a sua função é de outra natureza, como se depreende do confronto entre o que é produzido pelas fontes e o que é revelado pela doutrina. raciocínio:

Ainda Atienza (1998, p. 10) explica os argumentos que sustentam este

Enquanto as fontes revelam modelos jurídicos que vinculam os comportamentos, a doutrina produz modelos dogmáticos, isto é, esquemas teóricos, cuja finalidade é determinar: a) como as fontes podem produzir modelos jurídicos válidos; b) o que estes modelos significam; c) como eles se correlacionam entre si para compor figuras, institutos e sistemas, ou seja, modelos de mais amplo repertório.

Noronha (1988, p. 93), na área do direito aponta que:

Só existem três modos de produção do direito: a legislação, o costume e a jurisprudência. (...) A lei é o modo de formulação de normas ditadas pelo poder político; a regra consuetudinária é o modo de formulação de normas geradas espontaneamente na sociedade, através de práticas uniformes e reiteradas, com a convicção de sua obrigatoriedade; a norma jurisprudencial é o modo de formulação das normas elaboradas pelos juízes, em especial os dos tribunais superiores, a partir da 'consciência jurídica geral'.

Por sua vez, na Ciência da Informação Barros (2004) assinala ser predominante e aceito na literatura jurídica o conceito de fontes do direito ou jurídicas como:

(...) legislação é a reunião de leis, isto é, um conjunto de diplomas legais ou disposições emanadas de autoridades em seus diversos níveis de atuação. jurisprudência é o conjunto de decisões reiteradas de juízes e tribunais sobre determinada tese jurídica, revelando o mesmo entendimento, orientando-se pelo mesmo critério e concluindo do mesmo modo; doutrina, elaboração teórica sobre a jurisprudência e legislação É interpretação de autores, juristas e escritores acerca de uma norma ou decisão jurídica. Influi na elaboração de regras do direito podendo ainda ser entendida como a interpretação de estudiosos sobre determinada norma ou manifestação judicial, resultando em comentários de lei, interpretação de códigos, anotações sobre decisões das cortes, etc. (BARROS, 2004, p. 203)

Transpondo estes conceitos para a ótica da Ciência da Informação Passos e Barros (2009, p. 94) constataram que a informação jurídica pode ser criada, registrada, processada e recuperada de três formas distintas, segundo as fontes do direito: normativa, pela legislação; interpretativa, pelo emprego da jurisprudência; e, analítica, por meio da doutrina. De acordo com Siches (1966, p. 93) em países de Direito predominantemente legislado como na Europa e Hispano-América, a defesa dos interesses individuais indica a elaboração de leis redigidas por jurisperitos provenientes da área do Direito, ou não. Neste sentido, este autor esclarece que:

Há múltiplas oposições entre diversos grupos de jurisperitos e ideólogos sociais, entre positivistas e cristãos, entre intervencionistas e liberais, entre socialistas e individualistas. Assim, em nosso tempo uns combatem em prol da ética cristã, outros contra ela, uns em favor da propriedade privada, outros contra, estes pela liberdade de contratar, outros pela direção da 
economia, aqueles pela empresa privada, outros ainda, pela nacionalização das empresas industriais e mercantis, etc. (SICHES, 1966, p. 93)

Diante do exposto, é possível localizar a atividade judicante ou jurisdicional exercida nos tribunais como uma fonte de direito que se manifesta no interior do ordenamento jurídico, tendo como norma jurídica máxima a Consttuição federal.

\section{CIÊNCIA DA INFORMAÇÃO E O ACESSO À INFORMAÇÃO JURIDICA}

A Ciência da Informação surgiu no contexto das sociedades modernas tendo como princípios a organização social e a consolidação da democracia e cujo objetivo foi, inicialmente, o de investigar e resolver fenômenos e questões relacionados ao acesso à informação científica. Em sua trajetória de amadurecimento, esta disciplina apresentou um desenvolvimento científico célere e original, construindo um campo de visão peculiar no entendimento das transformações da sociedade, de forma ainda não realizada por outra disciplina científica. A necessidade crescente de busca e acesso à informação resultou de acontecimentos como a urbanização, a industrialização, o surgimento da sociedade de massa - ao que se pode ainda acrescentar, nas duas últimas décadas, o ciberespaço possibilitado pelo desenvolvimento das tecnologias de informação e comunicação - o que suscitou interesse no estudo do comportamento individual no contexto coletivo e digital.

Dessa forma, a nova área de conhecimento, denominada Ciência da Informação, buscou o reconhecimento social tornando-se um campo que, nos âmbitos acadêmico e social incluem, respectivamente, um conjunto de instituições de nível superior e de pesquisa onde é produzida a teoria e, de outro lado, instituições da sociedade como bibliotecas, museus, centros de documentação, arquivos e outros onde se realiza a prática nas atividades dos profissionais da informação numa sociedade essencialmente dependente do acesso à informação.

A Ciência da Informação revela singularidades, mas a diversidade de contribuições de disciplinas que foram assimiladas e integradas à área evidencia a pluralidade teórica, ou seja, o campo foi sendo formado dos entrecruzamentos de múltiplas fenomenologias, problemas e metodologias oriundas de diferentes disciplinas científicas. A partir da Antropologia, por exemplo, se pode analisar a influência da cultura na formação da necessidade de informação pelo individuo e sociedade. A Psicologia, ao identificar os fenômenos do comportamento humano, foi utilizada na modelagem de sistemas de informação para atender a necessidades de informação para o individuo e coletividade. A Sociologia evidenciou que a comunicação da informação, incluindo a geração, armazenamento e acesso, desencadeia a interação social.

Analisada como ciência social, a Ciência da Informação contribuiu para a construção de uma nova perspectiva e desenvolvimento científico da área. Segundo Araújo [et al] (2007, p. 97) a Ciência da Informação "não surgiu como uma ciência social, mas identificou-se gradativamente com o escopo das Ciências Sociais quando passou a ver o sujeito como o principal ator e objetivo dos sistemas de informação". Araújo [et al] (2007, p. 98) destacam que alguns autores consideram que esta natureza social provém do fato da Ciência da Informação "utilizar métodos, teorias e processos das Ciências Sociais, para lidar com um objeto de estudo essencialmente social". Ademais, González de Gomez (2000) apud Araújo (2003 p. 
21) constata que "a Ciência da Informação recebeu das ciências sociais seu traço identificador como um sintoma das mudanças em curso que afetariam a produção e direção do conhecimento no Ocidente" (González Gomez, 2000, p. 2 apud Araújo 2003 p. 21). Neste ponto, Suaiden (2007, p. 27) condensa aspectos sociais e históricos precursores do surgimento da Ciência da Informação:

Em cada período histórico as sociedades humanas têm elementos que caracterizam a base de sua organização social. Quando esses elementos se convertem em princípios de ação, ou em princípios organizadores do comportamento humano e da forma como as organizações e as instituições sociais funcionam, eles se constituem em valores que caracterizam o seu entorno social e o período histórico que estão construindo. Criado pela necessidade que tem o homem de entender e explicar o meio em que vive, esse é o papel que a informação e o conhecimento desempenham no mundo hoje.

É compreensível, então, que no processo de desenvolvimento da Ciência da Informação, surgissem correntes de pensamento sobre diversos aspectos relacionados ao conceito e uso da informação, enfocando-se, nesta pesquisa aqueles que se referem ao significado e uso da informação para a comunidade jurídica, por entender-se que a informação tem relevância diferente para cada indivíduo, além de está sujeita às interações indivíduo-indivíduo, e indivíduosociedade, ou seja, ao que o meio social proporciona e no qual a informação é produzida, buscada, usada e trocada. O domínio investigativo da ciência da informação foi consideravelmente ampliado dando origem a novas teorizações e investigações sobre problemas de ordem prática dentre os quais o acesso à informação jurídica. No que se refere ao acesso à informação da área do Direito pela comunidade jurídica Atienza (1998, p. 27) ao fazer reflexões sobre a globalização da informação jurídica no início deste século, considera que a modernidade exige dos profissionais da área do Direito em relação à Ciência da Informação, posturas como:

(...) conscientização quanto às questões referentes às pesquisas $e$ recuperação das informações de legislação e jurisprudência e, até, porque não dizer, da doutrina; imprescindibilidade dos profissionais da área da informação: desde que a qualidade do produto e da prestação de serviços faça parte dos objetivos principais no que refere ao bom atendimento aos clientes, ou seja, maior fornecimento de dados e informações oferecidas, agilidade e precisão nas respostas e tomadas de decisões, oportunidades de bons questionamentos, andamentos de processos de clientes, etc.

Em contrapartida, esta autora preconiza o que a modernidade exige dos profissionais da área da informação jurídica:

Necessidade de criar novos mecanismos de tratamento da informação, e, necessidade de organizar os sistemas de busca disponíveis de modo a otimizar o tempo de acesso e melhorar a relação entre o número de referências levantadas e o número de referências relevantes localizadas - a quantidade exorbitante da informação disponível torna-se um transtorno quando oculta o que se procura num emaranhado de dados irrelevantes. (ATIENZA, 1998, p. 27)

As reflexões de Atienza (1998) incluem muitos outros pontos a considerar sobre o impacto de mudanças tão marcantes que ocorrem na sociedade, como o uso de novas tecnologias de informação e comunicação no processo de organização e acesso à informação, os direitos constitucionais e de cidadania de acesso à informação e de acesso à justiça e outros efeitos da globalização, não só para a comunidade jurídica, mas para o Poder Judiciário, o Direito e a Ciência da Informação. É função do Direito garantir o acesso à justiça, bem como é função da 
Ciência da Informação proporcionar o acesso à informação jurídica pela comunidade jurídica, para embasamento de decisões judiciais, votos, acórdãos e outros resultados da atividade judicante ou jurisdicional dos tribunais, o que irá contribuir, em última análise, para o acesso à justiça pelo cidadão.

\subsection{Informação jurídica}

$\mathrm{Na}$ compreensão da necessidade de informação da comunidade jurídica, fazse necessário, em primeiro plano conceituar a expressão informação jurídica, segundo a literatura. Para Passos (2004, p. 189) a "informação jurídica esta relacionada a duas profissões muito antigas: o Direito e a Biblioteconomia". Esta autora avalia que há uma lacuna na realização de pesquisas sobre a informação jurídica indagando: "será que foi tão investigada quanto a informação cientifica e tecnológica ou outra qualquer?". Alonso (1998, p. [7]) a conceitua com base em dois pontos:

sob o aspecto genérico, (...) qualquer dado ou fato, extraído de toda e
qualquer forma de conhecimentos da área jurídica, obtido por todo e qualquer
meio disponibilizado e que pode ser usado, transferido ou comunicado sem a
preocupação de estar integrado a um contexto. É um dado ou qualquer
elemento identificado em sua forma bruta que por si só não conduz a uma
compreensão de determinado fato ou situação. sob o aspecto de
documentacão organizada, é o produto da análise dos dados existentes em
toda e qualquer forma de conhecimentos obtidos na área jurídica,
devidamente registrados, classificados, organizados, relacionados e
interpretados dentro de um contexto para transmitir conhecimento e permitir a
tomada de decisões de forma otimizada. A disponibilização desses dados,
devidamente trabalhados, é feita através de meios
manuais/mecânicos/magnéticos aos interessados.

Por seu turno, Barité e Chaves Guimarães (1999, p. 11) conceitua informação jurídica, em livro dedicado a este tema como:

(...) el conjunto de contenidos pertencientes al universo conceptual de la Ciencia Juridica, que se expresan por médio de las formas documentarias reveladoras de la actuacion jurídica. En esse contexto, se debe recordar que el Derecho, em cuanto área del conocimiento, revela dos vertientes que no solo se interrelacionam sino que estan em continuo processo de retroalimentacion: la vertiente teórica y la vertiente pragmática o social. La vertiente teórica se constituye em la caracterizacion cientifica del Derecho em cuanto conjunto de conceptos, princípios y metodologias que permiten la reflexion sobre su propia esencia, asi como tambien la transmision de esos conocimientos. Se verifica asi, uma informacion de caracter eminentemente cientifico y pedagógico, revelada, basicamente, por la Doctrina. La vertiente social o pragmática revela las maneras por las cuales esse corpus teóricoconceptual tiene su aplicacion em la sociedade, persiguiendo dos objetivos fundamentales: la concretizacion del 'bien comum' y la garantia de los ideales de justicia de uma sociedade dada. Em ese âmbito, se registra la informacion sobre los derechos, las prerrogativas y los deberes que se inponem e uma sociedad dada (Legislacion), asi como las formas para garantir la aplcabilidad, el cumplimiento, em fin, la vida de tales reglas (Jurisprudencia)

Passos (2009, p. 93) define informação jurídica como:

(...) toda unidade de conhecimento humano que tem a finalidade de embasar manifestações de pensamentos de jurisconsultos, advogados, legisladores, desembargadores, juízes e todos aqueles que lidam com a matéria jurídica, quando procuram estudar (do ponto de vista legal) ou regulamentar, 
situações, relações e comportamentos humanos, ou ainda, quando interpretam e aplicam dispositivos legais.

De acordo com a opinião de Silva (2010b, p. 33), informação jurídica "é todo e qualquer conhecimento produzido com 0 intuito de fundamentar as atividades profissionais desenvolvidas pelos operadores do Direito". Sarmento, Rosa e Ferreira (2005) apud Silva (2006, p.6) corroboram enfatizando o aspecto estratégico da informação jurídica para a fundamentação do voto e decisões nos julgamentos:

\title{
A informação jurídica, sob o ponto de vista do valor agregado, enfatiza aspectos novos sobre a relevância da informação. Uma unidade de documentação de um tribunal gerencia o recurso informação documental para dar suporte à tomada de decisão dos magistrados, na elaboração de votos e decisões. (grifo nosso)
}

Evidenciando que a informação jurídica é fundamento para decisões dos operadores do Direito Silva (2006, p. 6) assinala que:

\begin{abstract}
Pode-se, então, compreender que a informação Jurídica trata de conteúdos especializados e sob a ótica do seu gerenciamento, esta, tem a responsabilidade de nortear as decisões dos Magistrados e demais Serventuários, nos processos e atividades jurisdicionais, a fim de prestar serviços de informação com a maior especificidade e eficiência possível. (grifo nosso)
\end{abstract}

Daí porque Miranda (2004, p. 138) concorda que "a informação jurídica é elemento imprescindível para que se alcancem os objetivos no âmbito jurídico". A propósito do uso do termo para significar também informação legislativa, Sow (2013, p. 6) distingue com clareza a natureza diversa de ambas, afirmando que:

A informação jurídica possui uma estreita relação com a informação legislativa tratada dentro do processo legislativo, porém, às vezes, os dois conceitos são confundidos pelo público leigo, que os consideram como sinônimos. No entanto, a informação legislativa é aquela produzida no ambito do processo legislativo ${ }^{11}$ (proposições, emendas, pareceres, relatórios).

Por sua vez Passos (2009, p. 8) chama atenção para a principal diferença entre informação jurídica e informação legislativa: "a informação jurídica normativa preocupa-se em regular a vida das pessoas que vivem em sociedade, e a informação legislativa não tem nenhuma força para impor aos cidadãos que façam ou deixem de fazer algo". Outro ponto abordado por Passos e Barros (2009, p. 94) é a diferença entre informação jurídica e informação legal: "A expressão 'informação legal' não é sinônima de informação jurídica, trata-se apenas de uma tradução inadequada de 'legal information', que na maioria dos casos significa apenas a base legal ou legislação que ampara determinado ato ou decisão". Passos e Barros (2009, p. 93) refletem sobre a relevância e alcance da informação jurídica na sociedade, corroborando o que foi dito por autores da área jurídica:

\begin{abstract}
(...) praticamente todos os tipos de conhecimento humano estariam relacionados ao direito, pois se este rege a vida em sociedade, regulando as relações humanas, procurando estabelecer a disciplina social, então todos os eventos que envolvem o homem, mesmo antes do nascimento, como os direitos do nascituro ou a utilização das células-tronco em pesquisas, até as obrigações geradas após a morte, como as matérias referentes à sucessão, estariam diretamente ligadas ao direito.
\end{abstract}

\footnotetext{
11 Conjunto de ações realizadas pelos órgãos do poder legislativo com o objetivo de elaboração da lei constitucional, complementar e ordinária e as resoluções e decretos legislativos. Disponível em: <http://www2.camara.gov.br/atividadelegislativa/processoLegislativo>. Acesso em: 13 out. 2013.
} 
As formas de geração, registro e recuperação da informação jurídica enunciada por Passos e Barros (2009, p. 94) seguem uma tipologia: analítica (doutrina); normativa (legislação) e interpretativa (jurisprudência). Os autores explicam que a informação analítica é a emissão de uma opinião particular fundamentada sobre determinado assunto e protegida pela Lei de direitos autorais. Já a normativa tem como características, segundo Passos e Barros (2009, p. 94).

- ser produzida apenas pelo poder estatal competente;

- ter natureza pública, podendo ser utilizada, coletada, arranjada, selecionada ou reproduzida por qualquer pessoa;

- ser insubstituível, uma vez que cada dispositivo legal é único sobre o caráter normativo que regulamenta;

- ter caráter imperativo devendo ser obedecida por todos;

- ter caráter geral, aplicando-se a todos indiscriminadamente;

- possuir validade geográfica e temporal delimitada;

- possuir regras próprias de redação.

Por último, a interpretativa também é de natureza pública aplicando a legislação a casos concretos. Outra classificação amplamente aceita tanto na literatura do direito como na Ciência da Informação e, especificamente na Biblioteconomia, foi formulada por Courbe apud Passos e Barros (2009, p. 95), que divide a informação jurídica em oficial e, privada ou doutrina. No caso, a primeira é resultante da atividade reguladora das autoridades públicas, correspondendo à legislação e jurisprudência. A segunda é publicada em bibliografia jurídica, com dupla finalidade: informativa (sistematização e atualização do conhecimento jurídico); e crítica ou de análise (reflexão sobre o direito). Martinho (2006) apud Passos e Barros (2009, p. 95) aponta como características da informação jurídica:

- grandes volumes de informação e rapidez de desatualização, face a um contínuo crescimento e criação de novas fontes (leis, áreas do direito, produção de doutrina)

- grande diversidade de fontes de informação;

- proliferação de suportes de informação (bases de dados, CD-ROMs, www);

- interação com outras áreas do conhecimento (filosofia, sociologia, economia, história, informática, política, etc);

- público-alvo exigente e diversificado (pluralidade de finalidade da informação pretendida);

- necessidade de rigor e precisão da informação no documento jurídico, independente do suporte;

- necessidade de rapidez na transmissão, para assegurar utilização e aplicação corretas, segundo as últimas alterações ocorridas, garantindo a fiabilidade da mensagem transmitida.

A despeito da rapidez de desatualização da informação jurídica - levando à necessidade de atualização das coletâneas de legislação - paradoxalmente, Passos e Barros (2009, p. 95) destacam a longevidade em alguns casos deste tipo de informação, que vigora por anos e até mesmo séculos, a exemplo dos Códigos 
comercial (1850) e civil (1940). Este último, segundo Passos e Barros (2009, p. 95) mesmo revogado pelo Código civil de 2002, "todos os atos realizados durante a sua vigência continuam sendo estudados sob sua ótica Assim, durante muitos anos ainda se produzirá jurisprudência (informação jurídica interpretativa) baseada em seu texto." Este fenômeno é comentado por Passos e Barros (2009, p. 96): "o fato de a informação jurídica não ser usada durante certo tempo, mesmo longo, não significa que a informação não tenha valor ou utilidade ou que não seja eficaz" Tal efeito é também sublinhado por Wolthers (1985) apud Passos e Barros (2009, p. 96):

Ao contrário de outras ciências, em que as informações se tornam ultrapassadas e obsoletas, quando substituídas por outras mais atuais, o texto jurídico é eterno em nível de consulta, de referência e de precedente e também em nível de aplicação a fatos e situações ocorridas em épocas regidas por institutos legais distintos. Logo, nada pode ser destruído e o armazenamento é constante, contínuo e permanente.

Outro autor que reforça tal constatação é López-Muñiz (1984) apud Passos e Barros (2009, p. 96) para quem:

A informação jurídica tem uma validade quase permanente, interessando ao jurista não apenas a última que foi publicada, ou a que foi legislada, mas também a anterior, ainda que a revogação de uma norma legal deixe sem efeito estas disposições, seus preceitos serão aplicáveis àqueles atos jurídicos que tenham nascido sob a sua vigência e, portanto, a eficácia perdura além da própria revogação, Daí que não se pode prescindir de documentos jurídicos sob o pretexto da antiguidade.

Em função disto, Passos e Barros (2009, p. 96) comentam que o universo da informação jurídica é descomunal, resultado do extraordinário número de documentos, dados e informações, produzidos nesta área. Alertam que o "bibliotecário jurídico necessita dar especial atenção ao volume de informações que podem ser recuperadas, porque a abundância de informações pode tornar ainda mais difícil a recuperação da informação procurada". Obviamente, isto é válido para a criação, acesso e avaliação de produtos de informação jurídica nos sites das bibliotecas, seja pelo bibliotecário, operador do direito da comunidade jurídica ou, pelo cidadão. Ao constatar tal realidade, López-Muñiz (1984) apud Passos e Barros (2009, p. 96) complementam que:

No mundo onde se produz um documento jurídico a cada minuto, nunca se pode estar seguro de ter encontrado a totalidade da informação relativa ao problema que se estuda. O jurista, para chegar a uma resolução, deve dedicar um bom número de horas de trabalho a documentar a decisão, buscando a lei pertinente, a jurisprudência que interpreta e a bibliografia que oferece soluções; com tudo isso nas mãos, é fácil obter uma decisão e, sobretudo saber que ela está de acordo com a legislação vigente e a interpretação dos tribunais.

Vale acrescentar o pensamento de Passos (2009, p. 38) para quem o acesso à informação jurídica encontra-se no rol de direitos e garantias para cidadania, devendo ser amplo e irrestrito, ou seja, não só uma necessidade da comunidade jurídica, mas de toda a sociedade:

O acesso à informação jurídica atualizada é um direito da sociedade, e promove a cidadania, sendo uma das atribuições do bibliotecário jurídico a promoção da cidadania e a função ética de zelar pelo acesso irrestrito à informação jurídica, sem imposição de barreiras por parte daqueles que não são operadores do direito. 
De idêntica importância é a tipologia documental jurídica no acesso à informação jurídica. Segundo Silva (2010, p. 19). A tipologia documental está relacionada com a estrutura textual "que atende a uma superestrutura" formada pela doutrina, legislação e jurisprudência. (SILVA, 2010, p. 17). Esta autora esclarece que "cada gênero textual possui particularidades extrínsecas e intrínsecas", como "disposição do texto na página, estruturação do conteúdo, as preferências léxicas e sintáticas, sinais tipográficos, espaçamento, numeração das seções e páginas" que consistem em detalhes formais únicos e inconfundíveis (SILVA, 2010, p. 17). Cabe acrescentar que, para tornar acessíveis produtos de informação jurídica na Web é imprescindível que o bibliotecário entenda o funcionamento dos trâmites legais, conheça os gêneros documentais da área e compreenda o significado dos conceitos jurídicos. (SILVA, 2010, p. 19)

Em obra consagrada na Biblioteconomia, Atienza (1979, p. 19) publicou um livro sobre documentação jurídica, com o seguinte conceito:

Entende-se por 'Documentação Jurídica' a reunião, analise, e indexação da
doutrina, da legislação (leis, decretos, decretos-leis, atos resoluções,
portarias, projetos de leis ou de decretos-legislativos, ou de resoluções
legislativas, ordens internas, circulares, exposições de motivos etc.), da
jurisprudência (acórdãos, pareceres, recursos, decisões etc.) e de todos os
documentos oficiais relativos a atos normativos ou administrativos.

Em texto posterior, Atienza com o sobrenome modificado para Alonso (1998, [p.7]) amplia o conceito de documentação jurídica, considerando-o sob dois pontos de vista, um de natureza geral e outro com foco na recuperação da informação:

\begin{abstract}
sob o aspecto de generalidade - (...) conjunto de documentos da área jurídica que, independentemente de sua natureza ou do suporte apresentado, são reunidos por acumulação ao longo das atividades de pessoas físicas ou jurídicas, públicas ou privadas. sob o aspecto sistêmico, voltado para a recuperação da informação (...) reunião dos documentos existentes sobre as várias modalidades componentes da área jurídica (doutrina, legislação, jurisprudência e outros insumos gerados pela ação do Direito) independentemente do suporte em que esse tipo de conhecimento é apresentado (...)
\end{abstract}

Atienza (1979, p. 20) observa que na década de 1970 a documentação jurídica como reflexo do mecanismo jurídico-legal da nação incluia: coletâneas de textos de disposições legais, índices e ementários de legislação ou jurisprudência. Passadas mais de quatro décadas, a documentação jurídica além do suporte impresso, também esta disponível em meio digital. Alonso (1998, p. 10) inclui na tipologia da documentação jurídica:

$\Rightarrow$ Produção jurídica emanada dos poderes e autoridades competentes:

- Atos emanados dos Poderes Executivo, Legislativo e Judiciário.

Atos emanados do poder negocial ou da autonomia da vontade.

Textos doutrinários sobre conceitos, teses, opiniões, pareceres, informes, etc. publicados em livros, periódicos, processos, folhetos, separatas e outros.

- Atos emanados de empresas públicas ou privadas.

$\Rightarrow$ Produção jurídica impressa em órgãos oficiais ou não:

- Publicações impressas da área jurídica: livros, periódicos, coletâneas de textos de disposições legais e jurisprudenciais, repertórios, índices, 
ementários, dicionários, bibliografias, vocabulários jurídicos, súmulas de jurisprudência, códigos, diário oficial, catálogos.

$\Rightarrow$ Produção jurídica armazenada e divulgada em meio magnético e ótico:

* Bancos de dados em CD-ROMs, bancos de dados via Internet

$\Rightarrow$ Produção jurídica armazenada e divulgada pelas instituições de informação jurídica:

Serviços de consultoria referencial, públicos e privados;

Bibliotecas e Centros de Documentação e Informação da área jurídica e instituições similares.

(ALONSO, 1998, p. 10)

Por último, a informação jurídica, presente nas fontes de informação jurídica como doutrina, legislação e jurisprudência tanto do ponto de vista de um autor uruguaio como de um brasileiro, ambos profissionais do direito, bibliotecários e docentes da disciplina Tratamento Temático da Informação é vista como:

(...) conjunto de conteúdos pertencentes ao universo conceitual da Ciência Jurídica, que se expressam por meio das formas documentárias reveladoras da atuação jurídica. (BARITÉ e GUIMARÃES, 1999, p. 11) (tradução nossa).

Para Rezende (2004, p. 175) legislação, doutrina e jurisprudência são informações registradas ou publicadas que "traduzem o dia-a-dia do Direito. São pertinentes nas peças processuais, fundamentais como resultado registrado do exercício do Direito; são bússolas e regulamentos para toda a comunidade jurídica". Atienza (1979, p. 65) acrescenta à doutrina, legislação e jurisprudência, os atos normativos ou administrativos. A título de exemplo, o Quadro F contém referências bibliográficas da informação jurídica:

QUADRO 4 - Tipologia de referência de informação jurídica*

\begin{tabular}{|l|l|}
\multicolumn{1}{|c|}{$\begin{array}{c}\text { FONTE DE } \\
\text { INFORMAÇAO JURIDICA }\end{array}$} & \multicolumn{1}{c}{$\begin{array}{c}\text { TIPO DE } \\
\text { REFERÊNCIA }\end{array}$} \\
\hline Doutrina & $\begin{array}{l}\text { CINTRA. [et al]. Teoria geral do processo. São Paulo: Malheiros, } \\
\text { 1996. 364 p. }\end{array}$ \\
\hline Jurisprudência & $\begin{array}{l}\text { BRASIL. Supremo Tribunal Federal. Ação de consignação em } \\
\text { pagamento. Recurso Extraordinário no 114.968-SP. Pablo } \\
\text { Flores Sanches e sua mulher e Caixa Econômica do Estado de } \\
\text { São Paulo. Relator: Ministro Celio Borja. 20 de maio de 1988. } \\
\text { Revista Trimestral de Jurisprudência, [Brasilia], v.135, p. 764- } \\
\text { 766, fev. 1991. }\end{array}$ \\
\hline Legislação & $\begin{array}{l}\text { PARÁ. Decreto } n^{\circ} \text { 2076, de 3 de dezembro de 1933. Declara de } \\
\text { utilidade pública para fins de desapropriação o domínio e } \\
\text { benfeitorias do terreno edificado sito a Av. Magalhaes Barata no } \\
\text { 1041 no Municipio de Castanhal neste Estado. Diário Oficial do } \\
\text { Estado, Belém, v. 102, n. 27.608, p. 26, 6 dez. 1993. Cad. 1. }\end{array}$ \\
\hline
\end{tabular}

${ }^{*}$ Fonte: Extraido de Barros (2004, p. 207)

Constata-se que a informação jurídica é "originada fundamentalmente por um tripé informacional: legislação, doutrina e jurisprudência”. Miranda (2004, p. 138) 


\title{
2.1.1 Doutrina
}

Miranda (2004, p. 138) explica que a doutrina diz respeito ao "conjunto de princípios expostos nas obras do direito, em que se firmam teorias ou se fazem interpretações sobre a ciência jurídica". Para esta autora, na recuperação da doutrina, geralmente não é exigida, "uma recuperação exaustiva, mas no mínimo razoável o que igualmente demonstra-se em grande volume de informações que necessitam ser atualizadas". Já na literatura jurídica Noronha (1988, p. 113) afirma que doutrina, conhecida como direito científico, é constituída "pelas construções jurídicas elaboradas pelos estudiosos do Direito", lembrando que historicamente se reconhecia a eficácia vinculante às opiniões de alguns "doutores" do direito. Este autor complementa que:

\begin{abstract}
A doutrina trabalha em estreita associação com a jurisprudência. É esta que fornece àquela os casos concretos, os problemas sociais que é preciso regular e as soluções práticas que lhes deu ao considerar os interesses em jogo e os valores ético-jurídicos. A doutrina vai trabalhar sobre tais dados, vai sistematizá-los, vai criticar cientificamente as soluções encontradas e as fundamentações apresentadas e, finalmente, proporá o direito que entende adequado. A jurisprudência se estiver de acordo ou, o legislador, transformará, em Direito as propostas doutrinárias. (NORONHA, 1988, p. 114)
\end{abstract}

Santiago e Barreira (2011) esclarecem que, como categoria da informação jurídica, a "doutrina provém de todos os produtores do mundo jurídico, ou seja, toda e qualquer discussão técnica sobre questões legais". Tal discussão, intrínseca à natureza da atividade jurídica, provém, segundo Passos e Barros (2009, p. 97) da "necessidade de comentar e analisar as novas normas jurídicas, [e da] crescente facilidade de publicar, especialmente documentos eletrônicos". No que concerne especificamente à produção nacional de informação jurídica incluindo livros, artigos de revistas, capítulos de livros e artigos de jornais, a Bibliografia Brasileira de Direito, BBD, gerenciada pela Biblioteca do Senado é alimentada diariamente por 12 bibliotecas pertencentes a organizações dos três poderes do Estado, integrantes da Rede RVBI. Acrescente-se, ainda que, segundo dados informados por Passos e Barros (2009, p. 98), o IBICT registrou, na primeira década do século XXI, o número de 562 periódicos editados na área do direito, na sua base de dados de ISSN.

\subsubsection{Legislação}

Noronha (1988, p. 94) designa a legislação ou direito legal como "norma escrita, editada pelo poder político" e que é "acertada nos escalões superiores da sociedade pelo poder político, reduzido a escrito e depois baixado sobre os cidadãos". Miranda (2004, p. 138) traduz legislação como "conjunto normativo que regula a convivência social". Esta autora relata que:

O volume de informação jurídica gerada e demandada tem aumentado rapidamente, em decorrência da constante atualização da legislação, o que consequentemente altera o conjunto sistemático do Direito.

Segundo Passos e Barros (2009, p. 98) a "proliferação de atos normativos [legislação] acaba provocando um verdadeiro caos, pois dificulta o trabalho de advogados, pesquisadores e a vida dos próprios cidadãos" Quanto a este fato, informam que:

Amaral [et al] fizeram um levantamento e descobriram que, no período de $5 / 10 / 1998$ a 5/10/2007, foram editadas ' 3.628 .013 normas que regem a vida 
dos cidadãos brasileiros. Isto representa, em média, 523 normas editadas todos os dias ou, 766 normas editadas por dia útil'. (PASSOS e BARROS, 2009, p. 98)

Isto levou Passos e Barros (2009, p. 98) a concluírem que "nem mesmo os operadores do direito ou o maior especialista é capaz de conhecer todas as normas do seu campo de atuação". O crescimento exponencial da legislação em nível nacional é contabilizado no Quadro 5:

QUADRO 5 - Produção de legislação no Brasil (1988 a 2007)*

\begin{tabular}{|l|l|}
\hline \multicolumn{1}{|c|}{ TIPO DE NORMA } & QUANTIDADE \\
\hline Emenda constitucional de revisão & $>6$ \\
\hline Emenda constitucional & $>55$ \\
\hline Lei delegada & $>2$ \\
\hline Lei complementar & $>69$ \\
\hline Lei ordinária & $>3.792$ \\
\hline Medida provisória & $>1.012$ \\
\hline Medida provisória reeditada & $>5.491$ \\
\hline Decreto & $>9.240$ \\
\hline Decreto legislativo & $>6.668$ \\
\hline Norma federal de hierarquia inferior & $>128.909$ \\
\hline Norma estadual & $>956.695$ \\
\hline Norma municipal & $>2.522 .741$ \\
\hline
\end{tabular}

*Fonte: Amaral [et al] (2007) apud Passos e Barros (2009, p. 99)

Constata-se, assim, a necessidade de atualizar e avaliar os produtos de informação jurídica do site das bibliotecas, com foco na comunidade jurídica, bibliotecários e sociedade. Além disso, Passos e Barros (2009, p. 101) avaliam o impacto do crescimento da legislação no funcionamento dos tribunais: "A multidão das leis é também uma das causas da morosidade da justiça, pois a legislação é confusa, contraditória e múltipla".

\subsubsection{Jurisprudência}

Delgado (2009, p. 17), ministro do Tribunal Superior do Trabalho, expõe com clareza a diferença conceitual entre legislação e jurisprudência:

Em sua relação com a dinâmica social, o Direito tende a atuar, essencialmente, de duas maneiras (que podem, obviamente, combinar-se): ou antecipa fórmulas de organização e conduta para serem seguidas na comunidade ou absorve práticas organizacionais e de conduta já existentes na convivência social, adequando-as às regras e princípios fundamentais do sistema jurídico circundante. Enquanto a primeira maneira é cumprida, em geral, pelo legislador, ao editar novos diplomas normativos, a segunda tende a ser cumprida, em geral, pela jurisprudência, ao interpretar a ordem jurídica e encontrar nela soluções normativas para situações aparentemente não tratadas pelos diplomas legais disponíveis. 
Para Reale (2006, p. 63) há conexão entre doutrina, legislação e jurisprudência como partes integrantes e complementares do fenômeno jurídico em sua complexidade. Na concepção de Noronha (1988, p. 98) a jurisprudência é "constituída por normas criadas pela via judicial, através de decisões reiteradas num certo sentido, que em novos julgamentos passam a ser acatadas como razão de decidir", ou seja, emana da autoridade judiciária. Acrescenta ainda que: "Hoje, a jurisprudência é praticamente o único modo de criação de novas normas jurídicas para além da lei". Em suma, evidencia que o processo de criação da jurisprudência pressupõe que: "Hipóteses sem solução na lei e hipóteses com solução prevista, mas manifestamente inadequadas, são precisamente as duas categorias de casos em que se torna necessária a criação judicial de Direito". Tal criação deve respeitar algumas condições ou balizamentos, discriminadas por Noronha (1988, p. 164):

\begin{abstract}
As 'necessidades sociais' a satisfazer, a adequação à 'natureza das coisas' (a própria estrutura dos fatos naturais, sociais ou mesmo espirituais abrangida na situação normativa) o respeito pelos 'princípios gerais de direito' [ou], (...) o que é legítimo fazer.
\end{abstract}

Noronha (1988, p. 167) exemplifica este processo com o caso da alienação fiduciária em garantia:

Na Alemanha, apresenta-se como exemplo clássico de 'inovação jurídica determinada por uma necessidade do comércio jurídico', a da alienação fiduciária em garantia, criada a partir de um expediente destinado a instituir um penhor sem posse, impossível pelas leis na Alemanha. [No Brasil], (...) no âmbito do direito das obrigações, necessidades semelhantes justificaram a criação de institutos como o da cessão de contrato, assunção de dívida, (...) figuras jurídicas em que existe circulação de uma obrigação de uma pessoa a outra, sem novação - o que seria inconcebível à luz da concepção tradicional, de origem romana, vendo na obrigação um laço estritamente pessoal, pelo que a mudança de credor, ou de devedor, só seria possível através da extinção da obrigação anterior e da constituição de uma nova obrigação (novação).

Na literatura da Ciência da Informação, Miranda (2004, p. 138), aborda outras questões relativas às funções específicas da jurisprudência: "(...) interpretação e aplicação das leis a todos os casos concretos que se submetem a julgamento da justiça, que produz sentenças no primeiro grau, ou acórdãos e súmulas nos Tribunais". É também Miranda (2004, p. 138) que citando Machado (2000) adverte sobre a responsabilidade envolvida na busca e recuperação da informação jurídica, afirmando que este autor: "chama atenção no tocante a Legislação e a Jurisprudência, cuja recuperação inadequada ou incompleta gera insatisfação aos seus usuários, assim como pode causar danos, tanto aos juristas como as partes".

Enquanto, segundo Cunha (2010, p. 129), a jurisprudência "é o conjunto de decisões proferidas pelos tribunais nos casos concretos de sua responsabilidade; no sentido restrito, refere-se às decisões dos tribunais sobre um determinado ponto do direito". Por sua vez, Passos e Barros, $(2009$, p. 95) destacam que a jurisprudência caracteriza-se por "ser pública e pela forma como é produzida, ou seja, 'pela sua repetição longa, diuturna, uniforme e constante' e difere da informação jurídica normativa (legislação) por ser mais flexível". A leitura de Passos e Barros (2009, p. 70) revela a natureza renovadora da jurisprudência:

As leis são criadas, envelhecem e, embora permaneçam inalteradas por um longo período, a jurisprudência lhes dá um novo contorno conforme assente determinado juízo. Nesse sentido, os órgãos jurisdicionais do Estado dão à letra da lei um novo espírito à medida que deixam de existir suas 
circunstâncias motivadoras, sendo então rejuvenescidas pela interpretação jurisprudencial.

Quanto à origem do termo, Passos e Barros (2009, p. 70) esclarecem:

O termo 'jurisprudência' é originário do latim 'juris', direito, e 'prudentia', sabedoria. Seu significado desdobrou-se com o tempo e encontrou diversas leituras, sendo a mais comum a que interpreta como a aplicação de estudos de casos jurídicos na tomada de decisões judiciais.

Neste sentido, Passos e Barros (2009, p. 70) acrescentam que o termo é empregado no sentido de orientação uniforme dos tribunais na decisão de casos, semelhantes, com função de fonte secundária do direito. Estes autores complementam que, além de se tratar de interpretar e aplicar a lei a casos de julgamento da justiça, a jurisprudência corresponde:

(...) ao conjunto de decisões reiteradas de juízes e tribunais sobre determinada tese jurídica, revelando o mesmo entendimento, orientando-se pelo mesmo critério e concluindo do mesmo modo. Em outras palavras, entende-se por jurisprudência, o conjunto uniforme e constante de decisões judiciais sobre casos semelhantes.

Isto fica claro quando se tem em mente que:

Tecnicamente, a jurisprudência é conhecida como a ciência da lei, pois se fundamenta em conhecimentos baseado na lei e articulados com outros princípios jurídicos relevantes para se chegar a uma decisão judicial, a fim de solucionar demandas e litígios caso por caso. À medida que os casos concretos se repetem, é natural que sentenças e acórdãos passem a consolidar uma orientação uniforme, de tal forma que se pode depreender, antecipadamente, e com segurança quase total, como decidirão os tribunais a respeito de casos concretos que a eles foram submetidos. (PASSOS e BARROS, 2009, p. 70)

Aprofundando as características e funções da jurisprudência, Passos e Barros (2009, p. 71) compreendem com maior amplitude as atribuições e poderes dos tribunais, nas diferentes instâncias:

Há na jurisprudência, essa uniformidade e passividade de decisões sobre determinado caso. Seu conhecimento pelo advogado e demais operadores do direito é indispensável, pois, ao tomarem conhecimento de uma lide submetida às suas apreciações, indagarão se existe, a respeito, uma decisão uniforme assentada. Havendo entendimento sobre o caso, não precisarão descobrir a motivação necessária à fundamentação da sentença, podendo repetir o que se acha assentado pelos tribunais.

Com isso, contata-se que a jurisprudência é produto de um conjunto de interpretações e decisões sobre determinado tema ou demanda na justiça, e que o acesso à mesma é imprescindível para fundamentar processos judiciais e para o devido julgamento da matéria em questão pelos magistrados, inclusive é fator de agilidade e rapidez da justiça e da atividade judicante. Por conseguinte, verifica-se a importância do acesso à informação jurídica interna e externamente aos tribunais, responsabilidade, em última análise de profissionais que trabalham com a informação, como os bibliotecários. Conforme Passos e Barros (2009, p. 71) dentre as decisões expedidas pelos tribunais constam:

precedentes - única decisão em determinado sentido, diferentemente do termo 'jurisprudência' cujo significado é o agrupamento de diversas decisões no mesmo sentido. Ex: um processo ajuizado por pessoa física ou jurídica em primeira instância tem como decisão a sentença ou o 
precedente. Concomitantemente, outras pessoas entram com processos sobre o mesmo assunto. Os processos julgados em primeira instância enunciam a jurisprudência que será referência, apenas, para outros julgamentos. Tais decisões podem vir a serem objetos de recursos e, julgados pelos tribunais, produzirão novas decisões, ou jurisprudência destes tribunais. Caso sejam possíveis novos recursos, os processos podem ainda ser encaminhados para o Superior Tribunal de Justiça e, em última instância, quando couber, para o Supremo Tribunal Federal, formando cada tribunal, sua jurisprudência;

súmula - resulta do processo de uniformização de jurisprudência, pelo qual são condensados vários acórdãos (decisões de tribunais) que adotaram o mesmo entendimento e decisão;

$\Rightarrow$ julgado - termo usado genericamente para decisões e que difere de 'coisa julgada' (processo jurídico que percorreu todas as etapas previstas na lei, não cabendo mais recursos;

$\Rightarrow$ enunciado - geralmente usado no sentido de súmula, como ocorre com as decisões consolidadas pelo Tribunal Superior do Trabalho.

(PASSOS e BARROS, 2009, p. 71)

A despeito da autonomia dos juízes e tribunais, os juízes de tribunais de instâncias inferiores, geralmente, acatam a jurisprudência exarada nos colegiados superiores, à exceção da súmula vinculante proferida pelo STF, obrigatória como decisão definitiva de mérito, conforme lembrado por Passos e Barros (2009, p. 71). Neste último caso, com o efeito vinculante, o objetivo é validar e interpretar de forma eficaz normas cujo teor seja alvo de controvérsia entre órgãos do judiciário ou entre esses e a administração pública, que acarrete insegurança jurídica e aumento de processos sobre questão idêntica.

Outro ponto visto por Passos e Barros (2009, p. 72) diz respeito ao uso pelos tribunais de recursos tecnológicos de informação e comunicação possibilitando que a sociedade tenha acesso às decisões dos tribunais incorporadas ao ordenamento jurídico bem como, à comunicação oficial dos atos processuais (assegurados autenticidade, integridade e validade jurídica). Evidentemente, neste cenário, o bibliotecário jurídico além de atuar na criação de produtos de informação jurídica no meio digital, deve saber explorar e extrair de todos os tipos de recursos eletrônicos disponíveis, a informação demandada pelo usuário. Passos e Barros (2009, p. 72) especificam inclusive que o "bibliotecário jurídico poderá ser requisitado a acompanhar a tramitação de processos nos órgãos judiciários".

Constata-se que a jurisprudência constitui importante e significativa parcela da informação jurídica, além da doutrina e legislação, sendo um conhecimento continuamente criado em função da necessidade de novos casos de direito que surgem em litígios cujo desfecho final é o acesso à justiça. Tendo como foco o campo de pesquisa deste estudo, no âmbito do Superior Tribunal e Justiça as decisões jurisprudenciais emanadas incluem:

- Ação cível originária

- Agravo

- Agravo regimental
Mandado de injunção

Mandado de segurança

- Petição 
Agravo de Instrumento

Ação penal

Ação rescisória

- Conflito de competência

- Embargos de declaração

- Embargos de divergência

- Embargos infringentes

- Habeas corpus

- Inquérito

- Medida cautelar
- Reclamação

- Recurso extraordinário

- Recurso em habeas corpus

- Recurso extraordinário em mandado de segurança

- Sentença estrangeira

- Suspensão de liminar

- Suspensão de segurança

- Suspensão de tutela antecipada

Complementando, Passos e Barros (2009, p. 74) abordam a jurisprudência na esfera administrativa que são decisões jurisprudenciais que "tramitam na esfera extrajudicial" e "resultam de decisões cujo objetivo é resolver um conflito na esfera administrativa de um órgão, colegiado, conselho ou tribunal, de caráter puramente administrativo". Podem originar-se, por exemplo, do "Conselho Nacional de Justiça, Conselho Nacional do Ministério Público, Procuradoria da Fazenda Nacional, Advocacia Geral da União e outros órgãos com perfil administrativo". (PASSOS e BARROS, 2009, p. 74). Ao tratar do universo da informação jurídica, no que se refere exclusivamente à jurisprudência, Passos e Barros (2009, p. 74) relatam a proliferação deste tipo de conhecimento gerado na área do direito em função dos poderes e atribuições dos tribunais em todas as instâncias da justiça no Brasil:

Sempre que se fala da reforma do judiciário ou das causas da morosidade da justiça são apresentados os dados sobre os processos que tramitam no judiciário dos Estados, na Justiça Federal e nos tribunais superiores. Para alguns especialistas, além do volume de processos, as causas da morosidade seriam a própria legislação processual, número insuficiente de juízes e a estrutura do poder judiciário, entre outras.

Nos tribunais superiores, inclusive no STJ, o volume de processos fica evidenciado, no Quadro 6.

QUADRO 6 - Volume de processos judiciais julgados nos tribunais superiores em $2007^{*}$

\begin{tabular}{|l|r|r|}
\hline \multicolumn{1}{|c|}{ TRIBUNAL } & \multicolumn{1}{|c|}{$\begin{array}{c}\text { PROCESSOS } \\
\text { DISTRIBUÍDOS }\end{array}$} & JULGAMENTOS \\
\hline Supremo Tribunal Federal & 112.938 & 159.522 \\
Superior Tribunal de Justiça & 313.364 & 330.257 \\
Superior Tribunal Militar & 736 & 655 \\
Tribunal Superior Eleitoral & 2.195 & 4.300 \\
Tribunal Superior do Trabalho & 105.901 & 153.592 \\
\hline
\end{tabular}

*Fonte: Adaptado de Passos e Barros (2009, p.102). 
Dados apresentados na Sessão da Corte Especial em 19/12/2013 atualizam o volume da atividade judicante no STJ: 344.034 processos distribuídos sendo que 78.932 julgados em sessão, enquanto 265.102 decididos monocraticamente. Comparando o total de processos recebidos pelo STF e a Corte alemã, entre 1951 a 2002, Passos e Barros (2009, p. 102) revelam que a demanda deste período na Alemanha, corresponde ao total anual de pleitos no STF. Por fim, cabe acrescentar o pensamento de Silva (2010, p. 70) ao afirmar que "é com base na jurisprudência que os operadores do Direito fundamentam suas petições, pareceres e conhecem a linha de julgamento dos magistrados".

\subsection{Relações entre os tipos de informação jurídica no Direito}

Silva (2010, p. 101) na literatura de Ciência da Informação, apresenta ligações entre os tipos de informação jurídica através da "participação da doutrina na jurisprudência, da jurisprudência na legislação e da legislação na jurisprudência". Isto é fundamental na dinâmica de geração, circulação, acesso e uso da informação jurídica resultando na produção da informação na área do Direito, integrando um processo que pode ser visto como o ciclo da informação jurídica. Nas interconexões, os três tipos de informação jurídica são insumos que podem fundamentar nova doutrina, a alteração de legislação, o voto num processo judicial ou, a formação de jurisprudência sobre tema específico por um tribunal, resultando em novo conhecimento jurídico, como ilustrado na Figura 7.

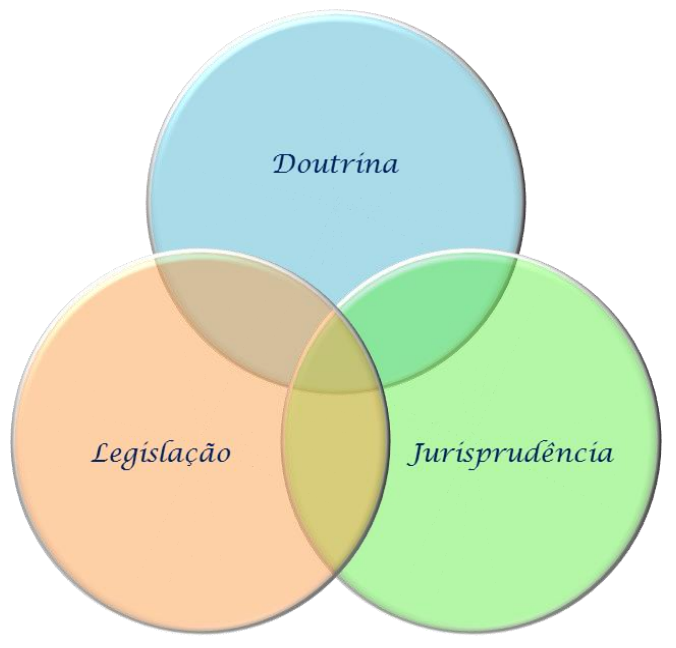

Fig. 7 - Relações entre os tipos de informação jurídica na geração de conhecimento no Direito.

Silva (2010, p. 101) exemplifica a influência entre os tipos de informação jurídica na dinâmica de criação e evolução do direito e, de modo específico, como etapa de fundamentação da atividade judicante citando o caso da legislação que:

(...) estando desatualizada e incompatível com a dinâmica e a realidade da sociedade não poderá alicerçar as decisões jurisprudenciais. Consequentemente, ela será alterada ou revogada pelo legislador, que criará um novo ato normativo com base nas respostas da jurisprudência.

Processo semelhante ocorre com a doutrina em relação à jurisprudência, vivenciado na prática profissional da pesquisa jurídica demandada às bibliotecas devido a uma situação de necessidade e de lacuna de informação por parte de magistrados e operadores do direito, como assessores de ministros e oficiais de gabinete, para uso em casos concretos a serem julgados no tribunal. 
No caso particular da doutrina é comum encontrar citações dos juristas e pareceristas na fundamentação dos acórdãos e, de modo contrário, há os doutrinadores que utilizam a jurisprudência para comprovar seus argumentos e decisões. Ademais, a doutrina, também opera nas fontes legislativas, através dos autores e estudiosos que se propõem a comentar, analisar e 'traduzir' as regras e normas contidas nas leis. (SILVA, 2010, p. 101).

Convém acrescentar a relevância da doutrina como conhecimento registrado existente nos acervos das bibliotecas para o embasamento da jurisprudência e, a importância do serviço de pesquisa pelo profissional da informação. Com o mesmo entendimento Silva (2010, p. 102) respaldada na literatura jurídica, depreende que "ninguém elabora leis sem os conhecimentos, entendimentos, pontos de vista e definições estabelecidas pela doutrina" acrescentando ainda que: "Além disso, a doutrina é fonte de pesquisa para os legisladores, assim como para os juristas, formularem seus textos legais e decisões judiciais". (grifo nosso). Silva (2010, p. 102) fornece quatro exemplos de reciprocidade entre doutrina, legislação e jurisprudência, sendo que três demonstram o poder indutivo da jurisprudência do STJ na formulação de doutrina, na alteração de ato legislativo além de citação da jurisprudência do STJ na doutrina, respectivamente, nos Quadros 7, 8, 9 e 10:

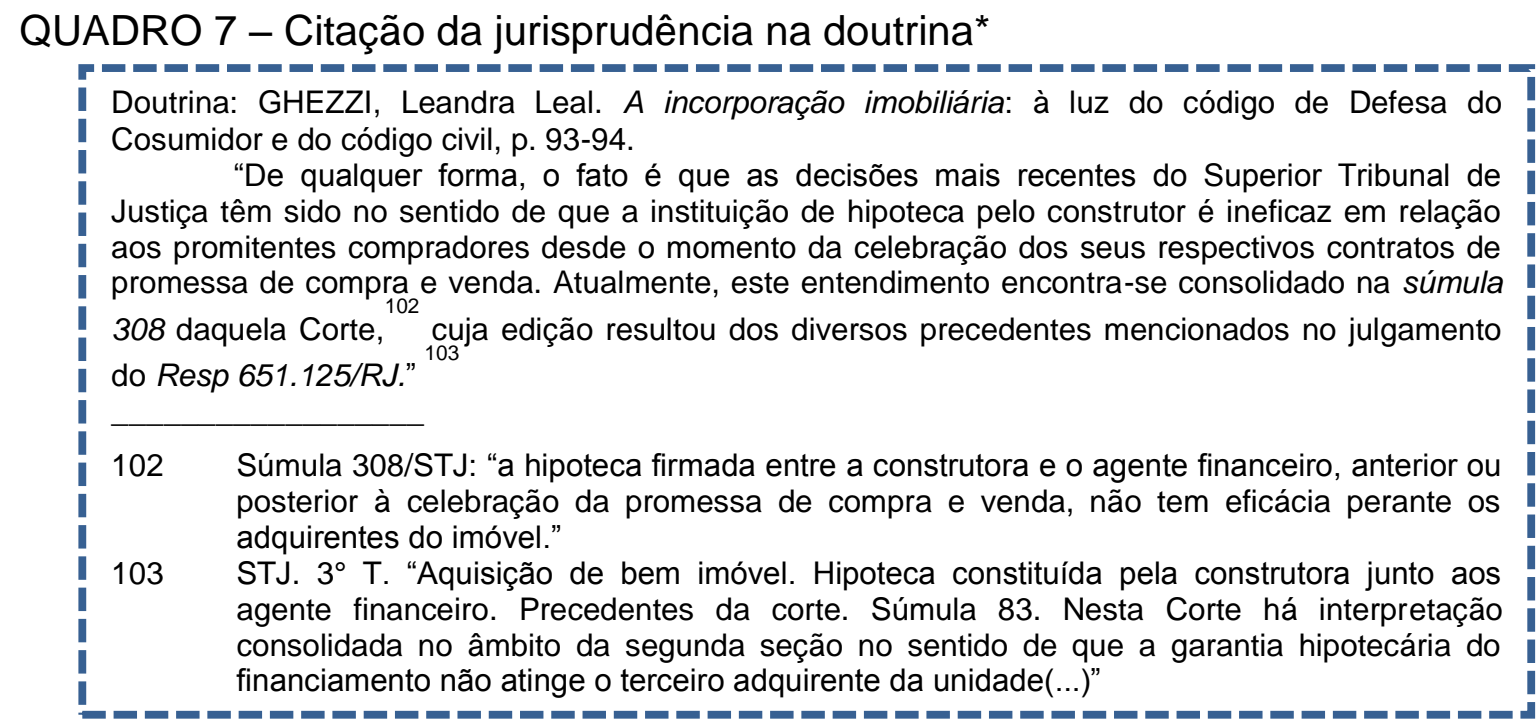

*Fonte: Silva (2010, p. 102).

Conforme Silva (2010, p. 102) salienta o autor do exemplo em questão "usou um acórdão do STJ para comentar o instituto da hipoteca". Isto pode significar uma posterior alteração na teoria sobre o assunto, resultante da interpretação específica do STJ, seja por uma lacuna ainda não contemplada na doutrina em voga e que se manifesta num caso concreto de demanda de justiça, ou pela inadequação desta doutrina a um determinado caso em julgamento. Este entendimento é encontrado em Reale (2006, p. 167):

A jurisprudência, muitas vezes, inova em matéria jurídica, estabelecendo normas que não se contém estritamente na lei, mas resultam de uma construção obtida graças à conexão de dispositivos, até então considerados separadamente, ou, ao contrário, mediante a separação de preceitos por largo tempo unidos entre si. Nessas oportunidades, o juiz compõe, para o caso concreto, uma norma que vem completar o sistema objetivo do Direito.

No exemplo seguinte, Silva (2010, p. 103) constata que "a Portaria do Ministério da Justiça alterou o Código de Defesa do Consumidor, complementando o 
elenco das cláusulas abusivas com base nas decisões judiciais". No caso, as cláusulas previstas na Lei n. 8.078, de 11 de setembro de 1990, sofreram significativa mudança e abrangência no conceito de abusividade.

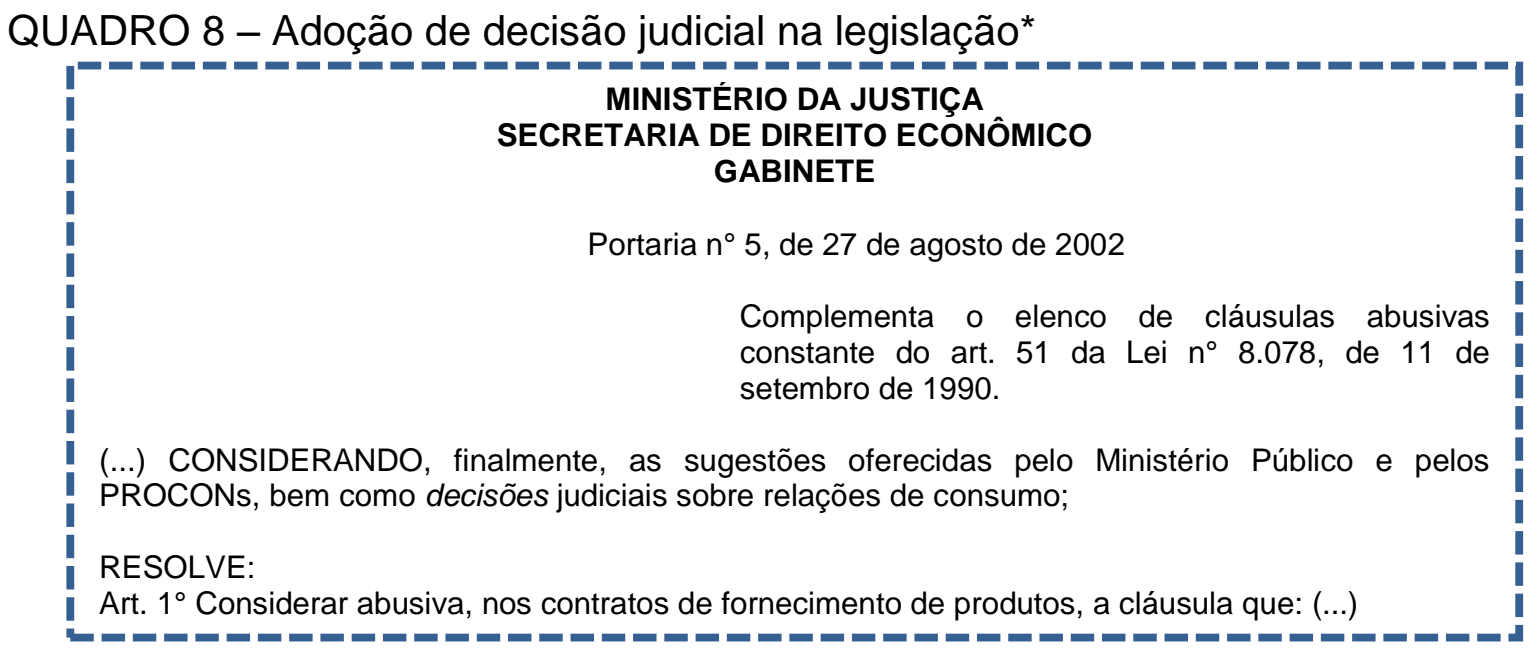

${ }^{\star}$ Fonte: Silva (2010, p. 103).

No terceiro exemplo, Silva (2010, p. 103) cita o efeito da jurisprudência do STJ no Código civil, que passou a vigorar de forma totalmente diferente do que vinha sendo regulamentado sobre o regime de bens no casamento.

QUADRO 9 - Proposta de alteração de ato legislativo sob a influência da jurisprudência do STJ*

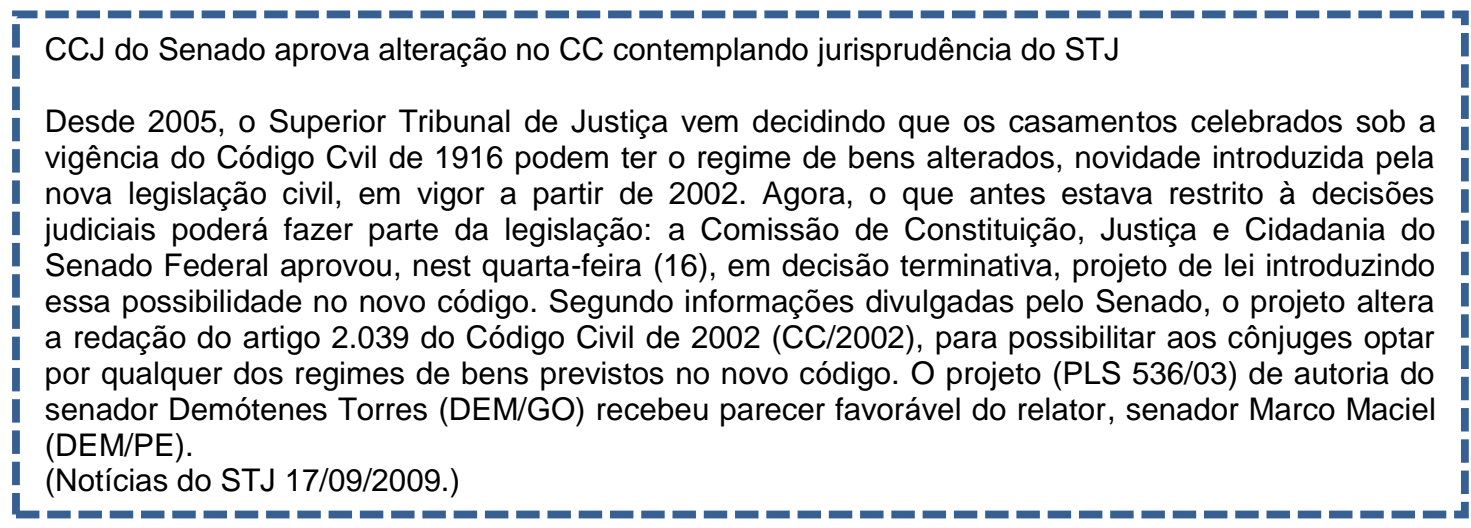

${ }^{*}$ Fonte: Silva (2010, p. 103).

O último exemplo faz alusão a controvérsias existentes na literatura jurídica, sobre tema específico:

QUADRO 10 - Citação da doutrina na jurisprudência do STJ *

Jurisprudência - RESP 408.122-PR - $3^{\circ}$ T - j. 20/06/2006 - Relatora Ministra Nancy Andrighi
Voto: (...) "Esta relatora não desconhece a existência de opiniões em sentido contrário ao ora
defendido. Por exemplo, Carlos Klein Zanini, em sua excelente obra "A dissolução judicia da
sociedade anônima" (Rio de Janeiro: Forense, 2005, pág. 233), observa que "a observância das
condicionantes postas na LSA deve estar presente não apenas no momento da propositura da
ação, mas também quando da prolação da sentença. É exatamente nesse sentido que dispõe o art.
462 da CPC, prescrevendo a obrigatoriedade de o juiz tomar em consideração qualquer fato
constitutivo, modificativo, ou extintivo do direito capaz de influir no julgamento da lide." *Fonte: Silva (2010, p. 104). 


\title{
2.3 A Biblioteconomia Jurídica
}

A Biblioteconomia Jurídica é uma área especializada da Biblioteconomia aplicada à Ciência do Direito, que utiliza as teorias e praxis da Biblioteconomia na organização, análise, recuperação e acesso à informação jurídica. Como reflexo do grau de crescimento e amadurecimento a produção bibliográfica desta área interdisciplinar do conhecimento ainda não é bastante expressiva. Passos (2004, p. 189-200) ao mapear a produção bibliográfica na Biblioteconomia Jurídica referencia dois levantamentos ${ }^{12}$ concluindo que:

A produção intelectual dos profissionais da documentação jurídica não esta exclusivamente direcionada para os periódicos da área. O que está publicado encontra-se disperso entre as revistas de biblioteconomia e documentação, anais de congresso/seminários e publicações avulsas. (ARAÚJO e ALMEIDA, 1992, apud PASSOS, 2004, p. 189)

Passos (2004, p. 189) menciona cinco recomendações propostas, a época, pelas autoras:

\begin{abstract}
a) Estimular programas de pesquisa e treinamento na área jurídica, para a inovação e o aperfeiçoamento das técnicas de trabalho, no gerenciamento nos centros de informação de documentação jurídica; b) incentivar o profissional da informação jurídica a apresentação de soluções para o tratamento da documentação jurídica, frente às novas tecnologias; c) elaborar bibliografia nacional dos trabalhos individuais e dos grupos jurídicos; d) disseminar estudos e pesquisas dos GIDJ nas revistas de biblioteconomia e documentação; e) criar mecanismos de divulgação dos trabalhos produzidos pelos GIDJ e/ou individualmente. (ARAÚJO e ALMEIDA, 1992, p. 323).
\end{abstract}

Quanto ao levantamento de Ohira [et al] (1998), Passos (2004, p. 190) informa que os aspectos contemplados foram: "números de artigos publicados em periódicos e eventos, ano de maior produção e temática dos trabalhos." Os resultados apurados com a pesquisa de Ohira [et al] (1998) aludida por Passos (2004, p. 190) revelaram mudanças significativas e promissoras em relação ao quadro da situação anterior :

(...) o bibliotecário jurídico divulga mais frequentemente em eventos científicos da área; o ENIDJ e o CBBD são os eventos mais escolhidos para apresentação de estudos; a Revista de Biblioteconomia de Brasília destacase como o periódico que mais publicou trabalhos da área; a década de 90 aparece como a mais produtiva e 'base de dados' e o assunto mais abordado pelas pesquisas.

Partindo destes levantamentos bibliográficos, Passos (2004, p. 190) realizou trabalho com diretrizes similares incluindo novas variáveis de investigação e análise, para elaborar bibliografia nacional da produção individual e de grupos jurídicos e divulgar os trabalhos produzidos com os recursos da internet. Nos últimos anos a estrutura teórica da área vem crescendo sendo que, segundo Ohira e Orengo (1996) - Encontro Nacional de Informação e Documentação Jurídica, SNDIJ, é o evento científico significativo da área e "representa um acontecimento de significância para os bibliotecários, analistas de sistemas, advogados e demais interessados no desenvolvimento da informação jurídica", uma vez que são apresentados e publicados aspectos sobre a "organização e automação do acervo, serviços e

\footnotetext{
12 Realizados por Araújo e Almeida, em 1992, e por Maria de Lourdes Ohira com alunos do Curso de Biblioteconomia da Universidade do Estado de Santa Catarina (UDESC) sobre trabalhos publicados entre 1973 a 1997, em periódicos especializados e eventos científicos.
} 
produtos, linguagem e recuperação da informação, desenvolvimento de bases de dados, indexação automatizada de documentos e uso de novas tecnologias aplicadas à área jurídica" (OHIRA e ORENGO, 1996)

Em nível internacional ocorrem eventos similares como o Annual Courses on International Law Librarianship promovido pela International Association of Law Libraries, IALL, cujo tema em 2013 foi sobre características do "Direito Catalão e Informação Legal num Contexto Global”. Conforme informações constantes no site desta instituição, a Associação Internacional de Bibliotecas Jurídicas é uma organização norte-americana, fundada em 1959, constituída na década de 2010 por mais de 600 membros em mais de 50 países nos cinco continentes. É uma organização sem fins lucrativos, visando à cooperação entre bibliotecas parlamentares, de ministérios, tribunais, acadêmicas, nacionais, e do setor privado, no acesso e uso de informações de órgãos jurídicos. Esta associação publica o periódico International Journal of Legal Information. (INTERNATIONAL ASSOCIATION OF LAW LIBRARIES, 2013)

A realização de eventos nacionais tem buscado o desenvolvimento e consolidação da Biblioteconomia Jurídica conforme informação de Passos (2004):

\begin{abstract}
Nas últimas três décadas, foram realizados outros eventos específicos de âmbito nacional, regional ou estadual: Encontro Sul Brasileiro de Documentação e Informação Jurídica; Seminário de Documentação e Informação Jurídica do Rio de Janeiro; Simpósio Paraibano de Informação Jurídica; Encontro dos Documentalistas dos Tribunais do Trabalho; Seminário Paraense de Informação e Documentação Jurídica. Alguns ainda estão na sua primeira edição, mas há outros que se destacam por sua constância: Seminário de Documentação e Informação Jurídica do Rio de Janeiro e Encontro dos Documentalistas dos Tribunais do Trabalho.
\end{abstract}

Mais recentemente, aconteceram outros eventos como o Seminário Nacional de Documentação e Informação Jurídicas, SNDIJ, em sua quarta edição; o 6을 Encontro da Rede de Bibliotecas da Justiça Eleitoral; e, o $2^{\circ}$ Encontro de Profissionais da Informação da Justiça Federal, todos realizados no decorrer do ano de 2013. Em 2004, Passos (2010, p.1) realizou um estudo sobre a produção intelectual na área para "mostrar o que tem sido a biblioteconomia jurídica no Brasil". Em levantamento com este fim, identificou o trabalho mais antigo publicado no país, a primeira edição da Classificação Decimal de Direito, de Dóris Queiroz de Carvalho, em 1948. Após 22 anos, surgiu Novos Métodos de Pesquisa Legislativa, da professora Cordélia Robalinho Cavalcanti, em 1970. Esta década foi marcada pelo início do controle automatizado da informação jurídica, com a criação de bases dados pelo Senado Federal. Ainda, "no final dessa mesma década, foi lançado o livro Documentação Jurídica, de autoria de Cecília Atienza, que se transformou em marco bibliográfico" para atuação de bibliotecas na área do Direito. (PASSOS, 2010, p. 1)

Esta pesquisa de Passos (2010, p.1) teve caráter pioneiro além de evidenciar a Biblioteconomia Jurídica. Esta autora acrescenta: "minha pesquisa fez parte de uma coletânea de artigos sobre o assunto. Mas dei continuidade ao levantamento e mantive no meu site Infolegis (www.infolegis.com.br) uma bibliografia sobre a Biblioteconomia Jurídica Brasileira". Prosseguindo no histórico que realizou, Passos (2010) constatou que o volume de trabalhos publicados na primeira década do século XXI já ultrapassou o número de itens publicados nas três últimas décadas do século passado. Além disso, um aspecto importante sobre a biblioteconomia jurídica é ressaltado por Passos (2010, p. 2): 
A pesquisa original identificou que a grande motivação para a preparação de estudos, pesquisas e artigos é a participação em eventos profissionais da área, como este do qual agora participamos. Confesso que no início da organização do $1^{\circ}$ SNDIJ fui agradavelmente surpreendida quando foi feita a chamada de trabalhos. Imaginei que seria uma etapa em vão, mas, ao contrário, recebemos vários trabalhos de muito bom nível.

A realidade do desenvolvimento de uma área ainda incipiente, onde as linhas de pesquisas estão sendo definidas pode ser constatada na afirmativa de Passos (2010, p. 2):

(...) ficou evidenciado que a maioria dos textos tem autoria individual e a análise da produtividade dos autores mostrou que a quase totalidade escreveu um único trabalho. Muito interessante se revelou o estudo das linhas de pesquisas adotadas, de todos os autores analisados apenas um tinha linha de pesquisa claramente delineada. Também é evidente que o número de livros é muito menor que o de artigos de periódicos ou trabalhos apresentados em eventos. Esses dados indicam que o bibliotecário jurídico publica razoavelmente, mas é preocupante que os pesquisadores não deem continuidade às suas pesquisas e que não tenham uma linha de pesquisa definida.

Com a pesquisa de Passos (2010, p. 1) fica evidente que no estado da arte da biblioteconomia jurídica os seus fundamentos se apresentam como intrinsecamente ligados às ações e atuação da prática dos profissionais da informação, configurando um saber produzido principalmente no âmbito do trabalho.

Outro aspecto é que a Biblioteconomia Jurídica não conta com um periódico especializado como fonte de referência para os profissionais e não há curso de especialização presencial ou à distância. $O$ bibliotecário jurídico aprende na lida diária sobre os ramos do Direito e suas subdivisões, o "juridiquês" e a terminologia jurídica, as fontes de informação jurídica e todo o conjunto de ferramentas necessárias para o desenvolvimento do seu trabalho. A consolidação da área exige produção científica cada vez mais qualificada que reflita sobre as questões próprias desta área de conhecimento, inclusive considerando a necessidade dos profissionais da informação como idealizadores de produtos nas bibliotecas jurídicas. É indiscutível que no desenvolvimento de uma área científica o pensar-teorizar é trabalhar, assim como o realizar a prática é trabalhar para produção de linhas de pensamento e teorias. Na biblioteconomia jurídica o pensar-fazer pressupõe o fazerpensar. No que concerne à formação profissional há universidades voltadas para a biblioteconomia jurídica. Dados da pesquisa de Passos (2010) evidenciam que na Universidade Federal do Pará é ministrada a disciplina "Documentação jurídica", como optativa, na graduação de Biblioteconomia. Lucivaldo Barros (2007, p. 2) apud Passos (2010) identificou duas outras universidades onde são ofertadas disciplinas relacionadas à área jurídica:

\footnotetext{
A Universidade do Paraná, que oferece a disciplina obrigatória "Fontes de Informação em Ciências Jurídicas", no Curso de Gestão da Informação; e a Universidade Federal do Rio Grande do Sul, que possui uma disciplina eletiva do Curso de Biblioteconomia, intitulada "Gestão de Sistemas de Informação Jurídica".
}

Passos (2010, p. 2) acrescenta, ainda, o interesse de alunos de graduação na área, devido ao aumento do número de monografias sobre informação jurídica, principalmente por estudantes da Universidade de Brasília, levando esta autora a concluir que talvez isto se dê pelo fato deles "estagiarem em tribunais ou outras instituições que lidam com o Direito". Em nível de pós-graduação, se observa o 
crescente interesse pela análise e compreensão dos fenômenos, paradigmas e problemas pertinentes à informação jurídica segundo a ótica da Ciência da Informação. A educação continuada é possibilitada com a participação em seminários, congressos e eventos especializados destacados por Passos (2010, p. 2) tais como o Seminário Nacional de Documentação e Informação Jurídica, em 2007 e o Encontro Nacional de Informação e Documentação Jurídica (ENIDJ), de 1984 a 2003. Outros encontros ocorrem eventualmente chegando à segunda ou terceira edição com dificuldades para manter a continuidade. Conforme experiência relatada pela autora, há muita dificuldade na estruturação de eventos deste porte, cujo trabalho é voluntário entre profissionais da área da informação jurídica.

$\mathrm{Na}$ trajetória da Biblioteconomia Jurídica um fato importante no credenciamento científico e institucional na sociedade brasileira ocorreu em 1971, com a criação da Comissão Brasileira de Documentação Jurídica, pela Federação Brasileira de Associações de Bibliotecários, Cientistas da Informação e Instituições (FEBAB). Esta comissão tem ação distribuída no Rio Grande do Sul, Pernambuco, Rio de Janeiro, São Paulo e Santa Catarina. (PASSOS, 2010, p.3)

A Biblioteconomia Jurídica brasileira também teve importante contribuição no controle bibliográfico especializado com a publicação da Bibliografia Brasileira de Direito (BBD), inicialmente pelo Instituto Brasileiro de Informação em Ciência e Tecnologia (IBICT) e, posteriormente, pela Biblioteca do Senado Federal que disponibiliza a versão eletrônica na internet. Passos (2010, p. 3) destaca que há "fontes de informação consistentes e já tradicionais, como as bases de dados bibliográficas, de normas jurídicas, e de jurisprudência", como também aquelas eletrônicas como o "Portal LexML que pretende ser um ponto unificado de acesso para toda a informação jurídica brasileira”. Além disso, a terminologia jurídica está representada em tesaurus jurídicos gerais e específicos, como o Macrothesaurus Brasileiro de Direito Constitucional, o VCBS da Rede RVBI gerenciada pelo Senado Federal, Thesaurus em Direito do Trabalho, Tesauro da Justiça Eleitoral, Tesauro Jurídico da Justiça Federal, Webthes entre outros. (PASSOS, 2010, p. 3)

Segundo iniciativa de Passos (2010, p. 3) foi criada, em 20 de março de 2002, na Internet a lista de discussão "Infolegis: bibliotecários jurídicos reunidos", reunindo cerca de 600 profissionais bibliotecários e advogados. Esta lista divulga "decisões recentes dos tribunais brasileiros, informações sobre vagas de trabalho, ou solicitações de cópias de artigos de periódicos e busca por uma informação específica".

Outro ponto é que as mudanças de paradigmas, que ocorrem neste início de milênio apontadas por Passos (2010, p. 4) alcançam igualmente a biblioteconomia jurídica, citando-se o registro da informação antes somente impresso e agora eletrônico que modifica o formato do acervo das bibliotecas. Existem editoras jurídicas que publicam somente em meio eletrônico, em suporte impresso ou, nas duas modalidades. Ademais, há editoras que comercializam tanto o conteúdo como o acesso à informação jurídica. Outro paradigma em mudança é o desenvolvimento de bases de dados inicialmente criadas para fornecer acesso à informação gerada pela organização mantenedora, alterada para um modelo que possibilita interoperabilidade, isto é, o padrão open source, permitindo a reutilização e rearranjo de dados e informação pelos usuários. A pesquisa à informação jurídica igualmente passou por significativas modificações de paradigmas exigindo conhecimento da área jurídica e das fontes de informação disponíveis no meio digital. (PASSOS, 2010, p. 4) 
De modo geral, para Passos (2005, [p. 1]) “(...) a Biblioteconomia Jurídica está estreitamente ligada à informática. O exemplo mais recente é a modernização tecnológica que os tribunais vêm realizando". Quanto a isso, esta autora acrescenta que: "O fato é que a tecnologia foi eleita o mais importante instrumento de modernização do Judiciário. É a principal parceira de fóruns e tribunais na tentativa de desburocratizar os trâmites judiciais e otimizar o trabalho de juízes e advogados." (HAIGAR, 2005 apud PASSOS, 2005). Em relação a outros países Passos (2010, p. 5) acrescenta que:

Em comparação com a Biblioteconomia Jurídica americana estamos engatinhando. Nos Estados Unidos, a classe possui uma associação própria, a American Association of Law Libraries, fundada em 1906, possui mais de cinco mil membros, realiza, anualmente, um encontro que já está na 104a edição e possui um veículo oficial de divulgação, o Law Library Journal, que vem sendo publicado desde 1908.

Constata-se, assim, que a biblioteconomia jurídica é uma área em formação e expansão onde fenômenos, questões, paradigmas e soluções existentes evidenciam a cientificidade desta área interdisciplinar entre Direito e Ciência da Informação, situando suas funções de especialidade no contexto jurídico e social da biblioteca jurídica, como locus de interação entre bibliotecário e comunidade jurídica, composta pelos operadores do direito.

\subsection{O Bibliotecário jurídico e o usuário operador do direito}

Com todo o volume de informação existente em forma impressa e na Web, bem como a necessidade de agilidade e habilidade de busca e recuperação da informação, o bibliotecário é o profissional de informação com a competência indispensável para realizar o processo de seleção, organização e acesso à informação na sociedade. De modo específico, na biblioteca jurídica, a criação de produtos deve estar voltada às necessidades de informação dos operadores do direito que fazem parte da comunidade jurídica como, ministros de tribunais superiores, juízes, juristas, jurisconsultos, promotores públicos, desembargadores, advogados de escritórios ou, servidor público, assessores de gabinete, legisladores, funcionários de cartórios e outros. Por outro lado, há usuários da informação jurídica em diferentes segmentos da sociedade como os professores e alunos dos cursos de direito, pesquisadores científicos, líderes comunitários, sindicais e outras organizações da sociedade que lidam com o direito, além do cidadão.

Segundo Pinheiro, Mourão e Raso (2006) nos escritórios de advocacia as mudanças ocorridas a partir da década de 1970, como a globalização "levaram à modificação nos modelos de advocacia, passando do atendimento pessoal do advogado ao cliente, para o atendimento por sociedades de advogados, constituídas por equipes multidisciplinares de profissionais", incluindo os bibliotecários. Rosa e Crivellari (2007, p. 1) revelam que:

(...) nestas equipes interdisciplinares, encontram-se os 'Paralegais', como são denominados os profissionais que atuam no campo jurídico e não possuem diploma em Direito. Entre estes profissionais estão os Bibliotecários, que são chamados a atuar em parceria com os operadores do Direito na busca pelo bom andamento da atividade fim do escritório que é a advocacia.

Rosa e Crivellari (2007, p. 1) em pesquisa de mestrado sobre as relações de trabalho da atuação conjunta entre profissionais da Biblioteconomia e do Direito, 
caracterizaram o trabalho do bibliotecário no campo jurídico em Belo Horizonte, incluindo entre outros aspectos: a qualificação do Bibliotecário para atuar no contexto da Sociedade da Informação; relações de trabalho estabelecidas entre os bibliotecários e profissionais do Direito; e, percepção de ambos os profissionais sobre esta atuação em organizações jurídicas públicas e privadas. No universo da pesquisa constavam bibliotecários e advogados atuantes em escritórios de advocacia, órgãos públicos e que trabalham em faculdades e universidades de Direito. A pesquisa explorou segmentos públicos do mercado de trabalho da área jurídica ligados diretamente ao Poder Judiciário como o Ministério Público, Tribunal de Justiça e Tribunal Regional do Trabalho; escritórios de advocacia na inciativa privada; e, instituições de ensino superior em Direito. Nestas organizações, foram entrevistados um bibliotecário e um profissional do direito, com "(...) a intenção de analisar a atuação do Bibliotecário sob a ótica dos profissionais dos dois campos: Biblioteconomia e Direito", sendo que as categorias analisadas incluíram "mercado de trabalho, relações de trabalho e, percepção e valor simbólico do profissional Bibliotecário no campo do Direito". (ROSA e CRIVELLARI, 2007, p. 2)

Esta análise foi realizada com o uso da Classificação Nacional de Atividades Econômicas (CNAE), como um dos instrumentos oficiais de registro e controle estatístico de informações econômicas, sociais e profissionais do país. Isto porque no Brasil, o mercado formal do trabalho do bibliotecário no campo jurídico é identificado com base nesta classificação, instituída em 1995 pelo Sistema Estatístico Nacional, com base na Resolução n.54, de 19/12/1994 do IBGE, publicada no Diário Oficial da União n. 244, em 26/12/1994 e, reconhecida e adotada pelos órgãos da administração pública federal. Nesta classificação, no campo jurídico constam duas atividades econômicas: as atividades jurídicas e as atividades de justiça. De acordo com o CNAE as atividades jurídicas compreendem: "Todos os serviços relacionados à representação legal dos interesses de uma parte contra a outra, diante de tribunais ou outros órgãos judiciais, realizada por advogado ou sob sua supervisão." Neste universo, o IBGE inclui: "serviços advocatícios, escritórios de advogado, assessoria e assistência jurídica, serviços de assistência em registro de patentes e, escritórios jurídicos". Por outro lado, no rol das atividades de justiça, encontram-se órgãos ligados ao poder judiciário como: "serviços da justiça, justiça do trabalho, justiça federal, justiça militar e ministério da justiça" (ROSA e CRIVELLARI, 2007, p. 9).

O resultado da pesquisa mostrou que os advogados "julgam ser fundamental estabelecer um trabalho de parceria com o bibliotecário que tem como diferencial" o conhecimento e prática no trato com a informação jurídica. E, ainda que, "a demanda pelos serviços prestados pelo bibliotecário é grande, uma vez que, socialmente ele ainda é reconhecido como o profissional que possui graças a sua formação, um 'conjunto específico de saberes' que lhe qualifica para o tratamento da informação jurídica" (ROSA e CRIVELLARI, 2007, p. 9). Em contrapartida, para os bibliotecários as relações profissionais com os advogados significam um processo de consolidação de "jurisdições profissionais" dentro da área da informação jurídica, mas que, o bibliotecário é "reconhecido e se reconhece no campo jurídico, exatamente pela formação que obteve e que o qualifica para o exercício de suas funções na unidade de informação na qual está inserido" (ROSA e CRIVELLARI, 2007, p. 9).

Já, Santiago e Barreira (2011) em estudo de caso identificaram as habilidades de pesquisa dos procuradores e analistas processuais, que atuam na Procuradoria 
Regional do Trabalho da 5 ${ }^{\text {a }}$ Região, Bahia. O objetivo foi analisar a competência informacional na pesquisa jurídica verificando "as práticas investigativas; como as pesquisas jurídicas são planejadas; as fontes de informação mais utilizadas independente de suporte, bem como quais os sites mais acessados". A proposta de estudo destas autoras se estendeu aos aspectos de avaliação, apropriação e uso da informação jurídica. A fundamentação da pesquisa teve por base a teoria sociológica do Habitus e dos Campos formulada por Pierre Bourdieu (1983, 1989, 1990) que define o "campo jurídico com uma lógica interna de relações, inclusive para legitimar, autorizar e consagrar determinados "operadores do direito". (BOURDIEU, 1989, apud SANTIAGO e BARREIRA, 2011). Para Bourdieu (1990) apud Santiago e Barreira (2011) o campo jurídico faz parte de um campo mais amplo, que é "um lugar hierarquizado, estruturado segundo uma determinada lógica de interesses, um grupo específico de atores que nele se agrupa, sob a qual interage, se complementa e entra em conflito". Em contrapartida o habitus é:

Um sistema de disposições, modos de perceber, de sentir, de fazer, de pensar, que levam a agir de determinada forma em face de circunstâncias apresentadas. É um conhecimento adquirido, como um haver, um capital, e indica a disposição incorporada, quase postural de agente em ação (BOURDIEU, 1989, apud SANTIAGO e BARREIRA, 2011).

As autoras concluem do conceito de habitus, que o processo investigativo tem a ver com o "querer saber", e que a habilidade tem a ver com o campus, isto é, "saber fazer". Tal conceito implica na qualificação ou competências do bibliotecário e está subtendido também na pesquisa de Rosa e Crivellari (2007) que igualmente constataram que:

(...) existe um 'capital simbólico' adquirido pelo Bibliotecário nas relações de trabalho que mantém com os profissionais do Direito. Este capital é representado pelo reconhecimento do seu saber, do prestígio que as qualificações que possui thes conferem e foi claramente expressado pelos dois grupos de profissionais entrevistados. (ROSA e CRIVELLARI, 2007, p. 10).

O capital preconizado no habitus de Bourdieu (1989) apud Santiago e Barreira (2011) e captado por Rosa e Crivellari (2007) está embutido no conceito de competência informacional da American Library Association, ALA, (1989, p. 1) que é a "capacidade de reconhecer quando uma informação é necessária e a habilidade de localizar, avaliar e usar efetivamente a informação". Num contexto maior, a competência informacional para Le Boterf (2003) apud Santiago e Barreira (2011) "é um saber agir responsável e como tal, reconhecido pelos outros. Implica saber como mobilizar, integrar recursos e transferir conhecimentos, com habilidades em um determinado contexto profissional". Segundo Dudziak (2003, 29-30), a competência informacional é composta pelo processo investigativo, ou de pesquisa; aprendizado ativo; aprendizado independente; pensamento crítico; aprender a aprender; aprendizado ao longo da vida. Por sua vez, Santiago e Barreira (2011) destacam o uso adequado de fontes de informação, uso da biblioteca, conhecimento de métodos de pesquisa, saber acessar a informação a partir de diferentes meios e aferir ou avaliar esta informação. Santiago e Barreira (2011) concluem que "uma pessoa competente em informação domina as habilidades necessárias para desenvolver 0 processo de pesquisa".

No que tange à competência informacional jurídica (Legal Informarion Literacy) Santiago e Barreira (2011) acrescentam ser uma vertente da competência informacional, aplicada inicialmente nos currículos dos cursos de direito. Quanto a 
isto, para Pengelley (2005) apud Santiago e Barreira (2011) os bibliotecários jurídicos e as bibliotecas jurídicas são importantes no preparo de estudantes de direito para a pesquisa jurídica, cujo fim maior é a prática jurídica, porém são subutilizados. Contudo, se as funções do bibliotecário na área jurídica são evidentes, de outro lado, persiste uma realidade de desconhecimento das atividades deste profissional por parte de operadores do direito, como ilustrado em dois depoimentos transcritos da pesquisa de Rosa e Crivellari (2007):

(Advogado entrevistado 1): Eu acho que vocês só vão abrir o campo em uma área nova como o Direito se os escritórios começarem a perceber a importância do trabalho de vocês, do contrário, eles não vão saber disto. (...) Então, a importância do papel de vocês em uma organização na área jurídica tem que ser disseminada dentro da escola.

(Advogado entrevistado 2): Você pode, no seu trabalho, desenvolver alguma coisa na direção de ascender, de levantar a importância, eu substituiria até pela indispensabilidade deste tipo de trabalho nos escritórios de advocacia. Eu tenho certeza de que (...) temos ótimos, grandes e médios escritórios de advocacia e eles ainda não perceberam a necessidade da Biblioteconomia como um agente, como parte integrante de bem atender a clientela, todos correm para os softwares, só que o software não atende.

Naturalmente, estas questões estão relacionadas com a formação do bibliotecário jurídico, que no Brasil, segundo Passos (2005):

A maioria dos profissionais egressos dos cursos de Biblioteconomia 'especializa-se' em função do emprego. Aqueles que passam a prestar serviços em bibliotecas jurídicas aprendem no trabalho diário as noções básicas do Direito e seu vocabulário próprio. Alguns profissionais sentem a necessidade de dupla formação voltam então à universidade para graduarse em Direito. Não existem estatísticas nacionais sobre a dupla formação do bibliotecário que atua na área jurídica.

Em outros países, a realidade se configura da seguinte forma:

Nos Estados Unidos, de acordo com a American Association of Law Libraries (AALL), $85 \%$ dos profissionais que trabalham nas bibliotecas jurídicas têm formação em Ciência da Informação, 30\% também têm formação em Direito. Por outro lado, menos de $20 \%$ dos empregadores exigem a dupla formação. No Reino Unido, a British and Irish Association of Law Librarians (BIALL) orienta seus associados que a graduação em Direito é uma vantagem a mais para aquele que busca seu primeiro emprego.

Além disso, Passos (2005) acrescenta que "a competência do bibliotecário jurídico varia de acordo com o local que trabalha (universidade, bibliotecas governamentais, escritórios de advocacia) ou mesmo em relação a sua especialização (bibliotecário de referência, indexador, no desenvolvimento da coleção)". Esta autora se refere a uma pesquisa sobre o bibliotecário jurídico, realizada nos Estados Unidos, que identifica as competências deste profissional, explicando que:

A American Association of Law Libraries (AALL) procurou estabelecer as competências do bibliotecário jurídico. O Professional Development Committee aprovou em março de 2001 documento que relaciona as competências do bibliotecário jurídico. $\mathrm{O}$ documento está dividido em seis seções. A primeira, chamada competências básicas seriam aquelas que se aplicariam a todos os bibliotecários jurídicos e que deveriam ser adquiridas no início da carreira. 

jurídico:

Assim, desta-se de Passos (2005) algumas competências do bibliotecário

- Demonstrar forte compromisso com a excelência do serviço ao cliente;

- Reconhecer a diversidade dos clientes e da comunidade;

- Entender e apoiar a cultura e o contexto da biblioteca e das instituições similares;

- Demonstrar conhecimento do sistema legal e da profissão jurídica;

- Entender o contexto sócio-econômico-político em que o sistema legal existe;

- Demonstrar conhecimento da teoria da Ciência da Informação e do ciclo documentário;

- Aderir aos princípios éticos da American Association of Law Libraries (AALL), apoiar e compartilhar dos valores da Biblioteconomia;

Vale ainda citar, quatro características do bibliotecário jurídico, identificadas por Alvin Podboy (2000) apud Passos (2005) neste novo milênio:

- Onipresença - não significa está disponível pessoalmente e sim os produtos que cria (catálogo on line, sites, biblioteca digital);

- Inovação - olhar a tecnologia disponível hoje e determinar como será usada no futuro. Isto foi feito com os catálogos e redes;

- Mutação - mudar rápido, assumindo riscos e erros. Lidar com fontes tradicionais e novas tecnologias. Pesquisadores ofuscados pela tecnologia perdem tempo navegando na Internet à procura de informação facilmente obtida num dicionário, enciclopédia ou telefonema. O pesquisador persistente não desiste ou recua diante da primeira resposta negativa. Pesquisar significa desafio encerrado quando a resposta adequada é localizada.

Naturalmente, domínio da pesquisa da informação jurídica, oferta e avaliação de produtos e relacionamento com o usuário na Web, estão incluídos no rol de conhecimentos do profissional da informação jurídica. Por isto, Passos (2005) com base em recomendações do Grupo de Trabalho sobre Bibliotecas Virtuais do Comitê Gestor da Internet-Brasil, no documento "Orientações estratégicas para implementação de bibliotecas virtuais no Brasil", a serem seguidas pelas bibliotecas de modo geral, vê esta mesma necessidade para as bibliotecas jurídicas:

\begin{abstract}
A participação ativa das bibliotecas brasileiras na Internet requer recursos humanos capazes de promover, inicialmente, a transição dos processos, métodos, produtos de informação tradicionais para sua operação plena na Internet e, posteriormente, a criação e operação de produtos somente viáveis no espaço de bibliotecas virtuais. Bibliotecários e profissionais da informação afins formados nos currículos tradicionais necessitam atualização radical e continuada de seus conhecimentos para exercer um papel de liderança neste processo de transformação das bibliotecas tradicionais.
\end{abstract}

De acordo com Passos (2005), o ambiente da Web é o meio por excelência de difusão da informação jurídica, fato que nesta segunda década do século XXI, está completamente consolidado, mesmo considerando que a pesquisa a fontes impressas se mantém:

A Internet é um maravilhoso e poderoso instrumento para a pesquisa legal. Com o advento da Internet, as editoras encontraram um novo modo de oferecer seus serviços. Os principais produtores de informação jurídica (Senado Federal, Câmara dos Deputados, Assembleias Legislativas, 
Tribunais, Câmaras Legislativas, Prefeituras, Ministérios Públicos, entre outros) criaram seus sites e passaram a disponibilizar mais rapidamente as informações. Advogados, órgãos de classe tomaram a mesma atitude. Tanto que os advogados estão cada vez mais conectados ao mundo virtual, tornando-se o segmento profissional mais presente na Rede. Com uma rapidez incrível, surgiram sites jurídicos que oferecem bases de dados com doutrina, texto integral de normas e jurisprudência, acompanhamento processual, noticiário jurídico (...)

No entendimento destas mudanças, que geram o excesso de oferta de informação, Passos (2005) recorre ao parecer emitido pela FAPESP em 2001 sobre a modernização de bibliotecas do Estado de São Paulo, que vê nestas alterações, um processo de transformação de conceitos realizado em base tecnológica, mormente ao papel do bibliotecário:

Há dados demais circulando pela rede e o usuário, nem sempre, tem tempo para caçar aquilo do que precisa em longas buscas na Internet. Surge então, um dos novos papéis do bibliotecário, o de poupar etapas e indicar caminhos para os veios mais ricos de dados. (FAPESP, 2001 apud PASSOS 2005).

Passos (2005) considera que, de fato o que ocorre é a transformação no modo de organizar e disseminar a informação do suporte impresso para o digital, sendo que um não exclui o outro, porém, o papel do bibliotecário permanece:

\begin{abstract}
Seria mesmo um novo papel para o bibliotecário? $\mathrm{Na}$ verdade, 0 bibliotecário estaria fazendo o mesmo serviço que historicamente sempre desenvolveu, mas apenas utilizando outro instrumento. Antes sua função era selecionar livros e periódicos que deveriam incorporar o acervo. Agora seleciona também os sites ou páginas na Internet que trariam informações atualizadas e confiáveis de interesse para seus usuários. É muito comum nos sites de universidades a seleção e indicação de outros sites que facilitam o acesso à informação jurídica estrangeira por país ou por assunto, sites de organismos internacionais, de periódicos eletrônicos, e outros.
\end{abstract}

No entanto, para o bibliotecário jurídico surgem papéis adicionais com as novas tecnologias de informação e comunicação, segundo Passos (2005): "Na verdade, o bibliotecário jurídico exercerá três funções em relação à Internet: usuário, professor e produtor de informação". Conforme esta autora, a função de usuário é exercida pelo bibliotecário quando explora sites especializados para atender demandas de informação dos operadores do direito: "É imperiosa a utilização do site do Senado Federal, para consulta da base de dados de legislação; da Presidência da República para conseguir o texto consolidado da legislação federal; os sites dos tribunais para localizar a jurisprudência e outros". A segunda função do bibliotecário evidenciada por Passos (2005) refere-se ao papel didático de motivação, orientação e treinamento do usuário no uso dos recursos de pesquisa da Internet. O papel de produtor de informação, corresponde à participação do bibliotecário jurídico no planejamento, criação, desenvolvimento e avaliação de sites e produtos de informação. Para Passos (2005), no desenvolvimento de sites jurídicos o bibliotecário jurídico pode ser de grande auxílio por que:

(...) eles sabem que páginas na Web estão pobremente organizadas ou difíceis de navegar ou que não atualizadas. Por causa do uso diário da Internet para encontrar informação, ele mergulha nos sites, então o bibliotecário conhece os elementos para criar com sucesso uma página na Web, pois irá concentrar-se mais na boa organização, no uso fácil das informações disponibilizadas do que nos recursos gráficos e sonoros." (OGDEN, 2000 apud PASSOS 2005) 
Cabe, ainda, acrescentar do pensamento de Passos (2005) que as características e tendências das funções do bibliotecário jurídico persistem nesta segunda década do século XXI:

\begin{abstract}
É absolutamente certo que as novas mídias trouxeram grandes transformações para o trabalho do bibliotecário jurídico e mais certo ainda que trarão outras. (...) Vivemos um momento de transição. Convivemos com informações em suporte tradicional e digitais/eletrônicos. Certas categorias de usuários resistem à utilização de novas mídias. O bibliotecário jurídico precisa saber navegar com segurança nesses dois mundos. Retirando de cada um deles o que de melhor tem a oferecer. Não deve menosprezar nenhuma fonte de informação por mais antiquada que possa parecer. Mas, também não deve resistir à modernidade.
\end{abstract}

Loureiro (2005) ao se deter na integração do trabalho do bibliotecário jurídico com o usuário operador do direito indaga: "Quais as práticas que ele pode adotar para incrementar o processo de criação de novos conhecimentos jurídicos, servindose do disponível compartilhamento de redes?". Inicialmente, Loureiro (2005) considera que as funções deste profissional de "organizar massas documentais, habilitando-o com as técnicas de tratamento da informação geral ou específica" o credencia para atuar na Internet. A isto, este autor soma a função do bibliotecário de intermediário entre informação e usuário, estando imbuído do que chama de a "função democrática de atender a uma comunidade com interesses heterogêneos". No entanto, na biblioteca especializada em Direito, Loureiro (2005) vê condições que extrapolam a intermediação entre indivíduo e informação jurídica, por ser esta um recurso fundamental para a interpretação da lei e jurisprudência ou, para criar um novo entendimento sobre direitos ou sobre o Direito, devendo atender às demandas da comunidade jurídica de forma confiável. Noutros casos, as decisões a serem tomadas pelos operadores do direito implicam consulta e acesso a fontes de informação jurídica em tempo hábil, dentro de prazos específicos e, com alto grau de precisão, o que levou Loureiro (2005) compreender que o "métier do bibliotecário" jurídico:

(..) amplia-se a partir do momento em que, ao manejar frequentemente a informação jurídica, adquire o status de 'especialista' dessa informação, o que cria a possibilidade de Ihe conferir a prerrogativa de 'colaborador' do usuário no desenvolvimento de seus estudos, agregada àquela consagrada de 'intermediário'. Para contextualizar a informação-objeto de seu trabalho, o bibliotecário necessita buscar o conhecimento jurídico, que pode ser adquirido pela educação formal ou não. (LOUREIRO, 2005)

De modo similar, no contexto do escritório de advocacia, os bibliotecários Gonçalves e Santos (2009), vêem que:

A biblioteca jurídica é um departamento de importância crescente dentro dos escritórios de advocacia, pois para estas empresas ela é um dos repositórios de conteúdo técnico doutrinário de cunho decisório. A gestão do conhecimento jurídico requer do profissional bibliotecário aptidão nas técnicas biblioteconômicas, bem como de vasta expertise nos assuntos que estão em volta do ambiente de atuação da empresa jurídica e que sobre ela incide influência. É importante que o bibliotecário detenha a competência e o Know-how que possibilite criar e estabelecer formas de gerar, armazenar, distribuir e utilizar o conhecimento, tornando sua utilização passível de agregar valor à tomada de decisão pelo usuário final. (GONÇALVES e SANTOS, 2009, p. 4)

Tudo leva a crer, que trabalhar na biblioteca jurídica pressupõe que o bibliotecário tenha um entendimento nocional do sistema jurídico em nível nacional 
bem como dos institutos jurídicos, pois, de acordo com Loureiro (2005, p. 3) "é esse conhecimento que vai instrumentá-lo para definir as estratégias de busca da informação e, com a previsível precisão dos resultados obtidos, garantir a credibilidade de sua relação com o usuário". Ainda nas palavras de Loureiro (2005) a contribuição do bibliotecário jurídico junto ao operador do direito se observa também na representação da informação jurídica e na elaboração de estratégias de busca com garantia de alto índice de precisão no resultado, afirmando que:

\begin{abstract}
Essa interação pessoal é o diferencial que se imprime ao corriqueiro processo de demanda-oferta dos sistemas de informação, pois ela vai além dos procedimentos elementares da pesquisa. É um processo que, antes de promover a interação homem-máquina, passa necessariamente pela interação homem-homem. (LOUREIRO, 2005)
\end{abstract}

Este ponto de partida no diálogo entre bibliotecário jurídico e operador do direito é condição indispensável no processo de gestão da informação jurídica nos sites das bibliotecas e produtos de informação na área do direito, pois o compartilhamento da informação "envolve tarefas intrinsecamente humanas exatamente para dar sentido à massa de dados processados pelas máquinas", levando Loureiro (2005) a concluir que "nas bibliotecas e centros de documentação jurídica as estratégias de busca da informação têm seu ponto de partida no diálogo (interação homem-homem), seguido da atividade de consulta ao sistema informatizado (interação homem-máquina)" (LOUREIRO, 2005). Estes mesmos elementos atuantes através de interações é visto por Rezende (1998) como presentes também na biblioteca de escritório de advocacia:

\footnotetext{
Nos escritórios de advocacia, vistos como indústrias que processam e transferem conhecimento, na busca de soluções para os problemas do cliente, a essência do trabalho é a manipulação, reelaboração e transferência de informações. O conhecimento acumulado e transferido num escritório de advocacia envolve tecnologia, conteúdo informacional e, principalmente, interação entre pessoas. (REZENDE, 1998, p. 23)
}

A importância do papel do bibliotecário jurídico é verificada no paradoxo da sociedade da informação - já consagrada em países desenvolvidos e um ideal a alcançar nos países em desenvolvimento por meio de políticas de inclusão digital onde, quanto maior o volume de informação em circulação na Web, em sites e redes de computador, maior a desinformação e dificuldade para acessar a informação relevante em face desse universo de crescimento impressionante, pois o tempo que indivíduo dispõe para acessar essa produção é inversamente proporcional ao crescimento da mesma. Certamente, isto consiste num desafio para diferentes áreas do conhecimento, contudo na Ciência da Informação, Loureiro (2005) aponta que "tal situação requer dos profissionais da informação novas práticas de trabalho, direcionadas para a estruturação de serviços que dêem suporte analítico ao pesquisador", ou seja, como transformar a informação desprovida de significado, lançada diariamente no meio digital por meio de tecnologias de comunicação e informação em produtos de informação de acordo com as necessidades dos usuários. Segundo esta autora, a ênfase não deve estar na tecnologia de conexão de dados para circulação em rede da informação no mundo, mas nas conexões conceituais, base para a criação de novos produtos e conhecimentos. Também defende ser imprescindível o bibliotecário dominar processos do sistema de informação em rede da biblioteca que trabalha. Esta autora acredita que:

Proporcionar meios de compreensão e associação desses conceitos, esta, sim, é uma tarefa eminentemente humana, inerente ao bibliotecário da era 
digital. E este não poderá cumpri-la se não tiver o conhecimento específico da área com a qual trabalha. Conhecer os conceitos de uma especialidade, portanto, é condição sine qua non para o desenvolvimento de sistemas de recuperação da informação especializada; é, também, o fator de excelência no processo de interação homem-homem e homem-máquina, ou seja, a informação que se recupera por meio de uma busca estruturada por conexões conceituais para suprir uma necessidade específica é matéria prima qualificada para a geração de bons e sólidos conhecimentos. (LOUREIRO, 2005)

O processamento da informação jurídica como matéria prima e não somente sua disponibilização em meio digital é igualmente apontada por Davenport (1958, p. 151) apud Rezende (2000, p. 52): "(...) a informação só será significativa se vier acompanhada de oportunidade, exatidão e relevância. Isto demonstra a importância entre se trabalhar a informação, e não apenas carregar bases informatizadas com dados primários". Tal ponto de vista amplia o campo de ação do bibliotecário na organização, representação e acesso da informação jurídica na Web. Para que haja a necessária coordenação e adequação entre os produtos de informação na Web e o processamento da matéria-prima com a necessidade e demanda do usuário, o trabalho do bibliotecário pressupõe a função cognitiva exercida pelo conhecimento de conceitos da teoria do direito chegando ao produto final:

Em resumo, (...) de nada adianta ter a posse dos mais ágeis instrumentos formais de pesquisa se não temos o conhecimento do conceito que um termo revela. Como agentes da informação especializada em ciência jurídica não se pode reduzir nosso trabalho a uma mera intermediação. Antes de "encontrar" o Direito, é preciso "pensar" o Direito. Para enquadrar-se nesse novo perfil, o bibliotecário jurídico deverá arrojar sua atuação profissional buscando incrementos, primeiramente, no estudo do Direito. De posse da compreensão dos conceitos jurídicos e de suas inter-relações ele poderá desenvolver com maior habilidade os serviços de sua competência, e trafegar entre os especialistas da área interagindo em prol da criação de novos conhecimentos. (LOUREIRO, 2005)

Esta conexão conceitual vista por Loureiro (2005) como indispensável para o desempenho do bibliotecário jurídico resultou numa lista de serviços a serem desenvolvidos nas unidades de informação jurídica, "tendo como pré-requisito, para bem executá-los, o conhecimento do Direito":

- Selecionar sites da internet (acesso gratuito ou pago) com conteúdos substanciais para o usuário e disponibilizar links de acesso na página da biblioteca;

- Ler, selecionar e editar atos normativos publicados no Diário Oficial da União e Diário da Justiça, divulgando aos usuários no dia da publicação, antecipando a demanda.

- Complementar uma informação agregando valor. Ex.: ao informar a publicação de uma nova lei, acrescentar a redação anterior, conferindo agilidade à pesquisa do usuário;

- Atualizar endereços eletrônicos de juízes, servidores e outros usuários para assegurar a disseminação da informação;

- Criar e manter atualizado um site da Biblioteca na internet e intranet, concentrando pesquisas de legislação, doutrina e jurisprudência, bem como o acesso direto a outros links congêneres e normas de documentação da ABNT. Conferir credibilidade ao site e torná-lo atraente com criatividade e competência técnica; 
- Selecionar artigos de periódicos que comentam as atualizações legislativas e encaminhá-los aos usuários;

- Promover a divulgação da produção intelectual interna do Órgão, dando destaque à iniciativa e estimulando a geração de novos conhecimentos;

- Disponibilizar um sistema amigável de recuperação da informação, que possibilite a independência e satisfação do usuário;

- Criar links para formação e comunicação de grupos de estudos jurídicos;

- Criar serviços que promovam o detalhamento virtual do acervo, selecionando periodicamente um de seus itens e seu conteúdo, apresentando-o como sugestão de leitura. $\mathrm{Na}$ impossibilidade de ir ao acervo da Biblioteca, este é um serviço de grande utilidade para usuários remotos.

- Avaliar frequentemente produtos e serviços para conquistar a fidelidade do usuário pela garantia de qualidade dos serviços e atualização dos dados.

(LOUREIRO, 2005)

Cabe lembrar, a exemplo de Rezende (2000, p. 52), que profissionais da informação, com a missão diária e contingencial de organizar a informação jurídica relevante dispersa na Web devem identificar, filtrar, interpretar e integrar informações produzindo um refinamento especializado, procurando não se deter somente no processo automatizado e tecnológico. Do ponto de vista do usuário operador do direito é fundamental analisar a busca, uso e avaliação dos produtos de informação jurídica feita por ele como receptor final. Rocha (2011) realizou pesquisa de mestrado na Universidade de Brasília, sobre estes aspectos em relação à necessidade de informação jurídica, no universo de assessores de ministros do Supremo Tribunal Federal, STF. Neste trabalho foi realizado o perfil deste usuário especializado concluindo que a necessidade de informação dos assessores está relacionada ao perfil do ministro ao qual eles estão vinculados e a busca da informação jurídica baseia-se nesta necessidade. A avaliação dos usuários, sobre os produtos oferecidos pela biblioteca mostrou-se positiva.

Loureiro (2005) considera a interação entre o bibliotecário jurídico e o usuário operador do direito, na busca e acesso à informação, como sui generis e distinta de interações ocorridas entre outros usuários e bibliotecas, por apresentar características intrínsecas ao ambiente jurídico. A posição de Loureiro (2005) amplia a teoria e prática do estudo de usuários e a avaliação de produtos de informação, uma vez que acrescenta à ótica da Ciência da Informação o ponto de vista jurídico, na análise:

Nas bibliotecas especializadas em ciências jurídicas, no entanto, as práticas de atendimento ao usuário têm vislumbrado ações que transpõem a execução dos procedimentos básicos que mapeiam uma situação de demanda-oferta. O operador do direito, ao buscar os serviços da biblioteca, o faz movido pela angústia de ter de debelar o conflito para o qual foi acionado. Imbuído desse estado de espírito, não é raro observar que ele procura a biblioteca não apenas para localizar as informações de que carece, mas também com a expectativa de que, ao demandar a colaboração do bibliotecário, possa encontrar neste 0 conhecimento e percepção indispensáveis, para que se instale o processo de interação entre ambos. Nesse sentido, não é bastante afirmar que a interação entre bibliotecário e usuário encerra-se na identificação de perfil de interesse seguida da recuperação de informações relevantes - ainda que extremamente relevantes - adequadas a esse perfil. 
Loureiro $(2005$, p. 1) ainda pondera que:

Pesquisas desse teor são realizadas frequentemente por meio de consagradas metodologias, e, no entanto, seus resultados demonstram dados que, embora relevantes por retratar parte da realidade, são insuficientes para configurar a interação pretendida. Assim sendo, o que mais pode fazer o gestor da informação jurídica para potencializar a satisfação e o desempenho de seu usuário, além de constatar perfis de interesse, estruturar sistemas de informação e lançar mão de técnicas de marketing para atrair clientes?

Para Loureiro $(2005$, p. 2) quando se trata de compreender a interação entre bibliotecário e usuário na biblioteca jurídica existem condições que importam em uma releitura do papel do bibliotecário, não apenas como intermediador entre 0 usuário e a biblioteca, na busca e acesso à informação demandada, mas que consiste em uma 'ação recíproca', segundo acepção do termo interação. Nesta abordagem, Loureiro (2005, p. 2) abstrai que:

\begin{abstract}
A interação vai além das pesquisas de interesses e da correspondente estruturação dos sistemas de informação. É ação bilateral que tem como sujeitos bibliotecários e usuários, com responsabilidades igualmente indispensáveis no processo de transferência da informação jurídica. Portanto, a satisfação do usuário não pode atrelar-se apenas ao fato de ele ter sido suficientemente elucidativo ao formular sua questão, tampouco à complexidade do sistema informacional que utilizou para atender a sua demanda. Isso, por si só, não promove a interação. Nossa inquietude está orientada para o necessário estabelecimento do vínculo de confiança entre bibliotecários e usuários da informação jurídica.
\end{abstract}

Percebe-se, com apoio no pensamento de Loureiro (2005), que existem condições de cunho profissional indispensáveis a serem praticadas pelo bibliotecário na organização, busca e acesso à informação jurídica, ressignificando assim, o conceito de interação bibliotecário-usuário que prevalece na literatura de estudo de usuário. O aporte significativo de tal contribuição elucida como este vínculo de confiança é um obstáculo a ser vencido:

O fortalecimento desse vínculo ocorre ao tempo em que os bibliotecários se
conscientizam da importância de ampliar seus estoques internos de
conhecimento nas áreas do direito e da tecnologia da informação, criando,
assim, novos canais de comunicação com o seu usuário. Para tanto, ele
deve desprender-se das tarefas de cunho generalista e concentrar-se na
especialidade dos conteúdos com os quais realiza suas atividades
profissionais.

Assim é que, destacando uma especialização que vê necessária ao desempenho do bibliotecário em unidades de informação na área do Direito, a qual extrapola o manejo da "informação jurídica como matéria-prima", Loureiro (2005, p. 2) afirma que este bibliotecário "deve conhecer os conceitos que ela [a informação jurídica] revela, para, ao relacioná-los, garantir a relevância do resultado da pesquisa, e assim, indiretamente, também operar o direito". A despeito de reconhecer o papel tradicionalmente existente de intermediador do bibliotecário "no processo de transferência da informação em bibliotecas e centros de documentação jurídica", Loureiro aprofunda a responsabilidade profissional do bibliotecário no âmbito das bibliotecas do Poder Judiciário acrescentando ainda que:

Ao mesmo tempo em que se reconhece a imprescindibilidade de sua missão inquestionável de intermediador, alerta-se para a necessidade premente de sua especialidade nos conteúdos que habitam a massa de 
informações a que dá tratamento, adicionando valor ao seu status profissional. (LOUREIRO. 2005, p. 2)

Por último, cabe acrescentar que o conhecimento da informação jurídica é pressuposto da competência e desempenho do bibliotecário jurídico, sendo elemento chave no papel que desempenha como profissional especializado junto ao operador do direito no acesso a este tipo de informação e, indispensável na criação e avaliação de produtos de informação jurídica na Web, no universo do poder judiciário.

\section{O PODER JUDICIÁRIO: MISSÃO NA SOCIEDADE}

Lazzarin (2009, p. 191) ao analisar a importância cada vez maior do poder judiciário no mundo, examina as razões sociológicas desse fenômeno apontando tendências geradas pelas exigências e incertezas da era contemporânea. Dentre os principais fatores elenca: "(...) a crescente juridicização dos conflitos sociais, bem como o (...) novo perfil sociológico do juiz para que o Estado, mediante o Judiciário, possa dar efetividade ao princípio da dignidade da pessoa humana e a concretização da cidadania". Por outro lado, novos direitos individuais ocasionam demandas por justiça, estimulando a procura do cidadão por organizações do poder judiciário, que por sua vez buscam encontrar soluções céleres para os conflitos e criar modelos jurídicos novos para efetiva aplicação do direito. Neste propósito, as organizações judiciárias, onde se inserem as unidades de informação jurídicas, procuram estruturar-se visando adequar missão, visão, objetivos e valores em consonância com a missão do poder judiciário. Tanto em âmbito internacional como nacional, percebe-se o movimento para alcançar maior qualidade nos serviços judiciários, o que repercute na criação e avaliação pelas bibliotecas jurídicas de novos produtos de informação jurídica que fundamentem a atividade judicante, conforme necessidades de informação de operadores do direito, indivíduos e sociedade.

Segundo publicado em livro comemorativo aos 25 anos de criação do STJ (2013, p. 15), "no Brasil, o poder judiciário é integrado por órgãos julgadores aos quais são atribuídas distintas funções jurisdicionais e de controle da constitucionalidade." O judiciário nacional tem como órgãos da justiça comum os tribunais e juízes estaduais, os tribunais regionais federais e os juízes federais. A justiça especial é formada pelos tribunais e juízes do trabalho, eleitoral e militar. Os tribunais superiores são o Supremo Tribunal Federal, Superior Tribunal de Justiça, Tribunal Superior Eleitoral, Tribunal Superior Militar e Tribunal Superior Militar, compostos por ministros nomeados pelo Presidente da República e previamente aprovados pelo Senado Federal, exceto o ministro do TSE. Cabe notar que, tal estrutura judiciária hierárquica tem 25 anos de existência e é resultante da promulgação da CF de 1988 - e da Emenda constitucional n. 45/2004 - que além de modificar a organização judiciária do país, criou tribunais que até então não faziam parte do sistema judicante brasileiro. (SUPERIOR TRIBUNAL DE JUSTIÇA, 2013, p. 15)

Neste sentido, é importante acrescentar a visão de conjunto de Bacellar (2013, p. 121-122) sobre a missão, visão, valores, metas e objetivos do poder judiciário na sociedade.

a) Missão de realizar justiça 
Como missão primordial do poder judiciário, a realização de justiça consiste num fenômeno de hipercomplexidade, compreendendo por um lado ampla gama de fatores internos do campo jurídico como filosofia do direito, deontologia jurídica, organização judiciária, natureza da legislação e da jurisprudência, formação de juízes entre outros, bem como de fatores externos como mudanças sociais e culturais, necessidades e anseios da sociedade pela resolução de conflitos e, de modo específico, do acesso à informação jurídica organizada em redes e bancos de dados digitais disponibilizadas por organizações judiciárias e pelas unidades de informação, como por exemplo, bibliotecas integrantes de órgãos públicos federais, estaduais e municipais dos poderes judiciário, legislativo e executivo.

Segundo Bacellar (2013, p. 121) a missão de realizar justiça do Poder Judiciário "(...) passa por uma análise de múltiplos fatores, dentre os quais a própria concepção de justiça como valor". Neste ponto, destaca que a estrutura vigente do poder judiciário nacional funciona com base na "(...) solução em modelos tipicamente adversariais, com soluções impostas e heterocompositivas". Dito em outras palavras, o modelo adversarial é fundamentado "(...) no pensamento dialético, onde um conflito entre pessoas é analisado sob o prisma da lide em disputa, resultando sempre em vencedores e vencidos". Com isto, este autor quer dizer que há um tratamento superficial do universo de "conflitualidade social", isto é, "se por um lado se dirime controvérsias, por outro, nem sempre os conflitos são de fato resolvidos". Em função disso, defende que na justiça, de forma geral, o foco do julgamento restrito ao pedido, não contempla os verdadeiros interesses do indivíduo como jurisdicionado e, por isso, "(...) afasta-se do postulado maior, princípio e finalidade do direito, do processo e do próprio Poder Judiciário, que é a pacificação social". Para este autor tal modelo "(...) ao iluminar a lide processual, deixa fatos, argumentos, justificativas e razões que, na perspectiva do jurisdicionado, representariam a realização da verdadeira Justiça". Daí porque em número expressivo dos casos, "(...) o Poder Judiciário não soluciona o conflito, não resolve ou não dá atenção aos verdadeiros interesses das partes, mas apenas extingue, com ou sem julgamento de mérito, a lide processual". (BACELLAR, 2013, p. 121).

Nesta análise, Bacellar (2013, p. 121) conclui que, se por um lado a natureza "adversarial e heterocompositiva se atrela à verdade formal dos autos, em contrapartida os métodos consensuais e autocompositivos, trazem a perspectiva dirigida à verdade real dos fatos". Enquanto nos primeiros há sempre "vencedores e vencidos (ganha/perde), nos últimos, por haver negociação, mediação e conciliação, se busca soluções vencedoras (ganha/ganha)". Opinião semelhante demonstra Gyrão (2007, p. 120) ao citar Guimarães (2001) para quem "a decisão resultante da atividade de julgar é cisão, bipartição, dilaceramento, é opção entre uma e outra hipótese (...)". Assim, conforme este autor, desempenhar a missão de pacificação social no poder judiciário é incentivar processos consensuais e autocompositivos uma vez que:

A verdadeira justiça só se alcança quando os casos 'se solucionam' mediante consenso. Não se alcança a paz resolvendo-se só parcela do problema (controvérsia); o que se busca é a pacificação do conflito, com a solução de todas as questões que envolvam o relacionamento entre os interessados. Para o alcance da pacificação (...) o conflito deve ser analisado sempre na sua integralidade com visão holística, global e transdisciplinar, abrangendo todos os prismas relacionais, a fim de que possam resultar apenas vencedores (ganha/ganha). (BACELLAR, 2013, p. 67) 
Convém, ainda, incluir o pensamento de Cappelletti e Garth (1988, p. 8) para quem a missão de realizar justiça, significa acesso à justiça pela sociedade:

\begin{abstract}
A expressão acesso à justiça é reconhecidamente de difícil definição, mas serve para determinar duas finalidades básicas do sistema jurídico - 0 sistema pelo qual as pessoas podem reivindicar seus direitos e/ou resolver seus litígios sob os auspícios do Estado. Primeiro, o sistema deve ser igualmente acessível a todos; segundo, ele deve produzir resultados que sejam individual e socialmente justos. (...) Sem dúvida, uma premissa básica será a de que a justiça social, tal como desejada por nossas sociedades modernas, pressupõe o acesso efetivo.
\end{abstract}

Por sua vez, na missão do poder judiciário constata-se que o acesso à justiça está intrinsecamente conectado ao acesso à informação jurídica pelo cidadão, conforme expresso abaixo:

\begin{abstract}
É possível, entretanto, do ponto de vista da gestão administrativa, satisfazer o usuário, propiciando um atendimento de qualidade. A satisfação máxima possível do usuário pode ser alcançada a partir de sua percepção de que recebeu um atendimento adequado, foi respeitado, ouvido, recebeu todas as informações necessárias de maneira clara, a duração do processo foi razoável, o juiz atuou com imparcialidade, independente de sua satisfação pessoal de ter ganhado o pleito perante a outra parte. A busca da paz é a razão da existência do Poder Judiciário. A pacificação social é o resultado que se almeja quando se procura o Estado-Juiz e na pacificação está o valor "Justiça". (BACELLAR, 2013, p. 67)
\end{abstract}

Percebe-se, assim, que efetuar a justiça, pressupõe a ação de ampla gama de fatores e aspectos intervenientes, o que implica na atuação de profissionais de áreas distintas do conhecimento, conforme assinalado.

Para o cumprimento da missão do Poder Judiciário de Realizar Justiça, ele depende de um trabalho interdisciplinar/transdisciplinar de racionalização, para bom desenvolvimento de suas atividades. O juiz tem de ser uma pessoa do seu tempo, capacitada, preparada para uma visão holística, que saiba prestigiar o conhecimento da psicologia, da filosofia e da administração, dentre outras. (BACELLAR, 2013, p. 123)

Certamente, nas outras áreas apontadas por Bacellar (2013), encontra-se a Ciência da Informação, mormente a Biblioteconomia Jurídica, na aplicação do conhecimento sobre a geração, circulação, organização, armazenamento, busca, disponibilidade, acessibilidade e uso da informação jurídica para a atividade judicante e consequente acesso à justiça pelo cidadão e sociedade, contribuindo com o corpus de conhecimento interdisciplinar no poder judiciário.

\title{
b) Visão e valores do poder judiciário
}

A visão é a idealização do sonho do Poder Judiciário, que:

(...) deseja ser reconhecido pela sociedade como instrumento de justiça, equidade e paz social. Por muitos anos, o Poder Judiciário não se preocupou com a sua imagem, fechou-se em um casulo de tecnicismo, hermetismo, complexidade formal com pouca ou nenhuma comunicação com a sociedade. (BACELLAR, 2013, p. 67)

Importante salientar que para este autor o alcance da visão depende de um conjunto de valores e princípios de cunho eminentemente social, de amplo espectro:

O alcance dessa visão será viável com o resgate da legitimação social, possível com ações efetivas de transparência, imparcialidade, ética, probidade, rapidez no atendimento, modernidade, acessibilidade e 
responsabilidade social, além de construção de políticas voltadas ao melhor atendimento do jurisdicionado. (BACELLAR, 2013, p. 118)

Há outros aspectos elencados por Bacellar (2013, p. 118) como a segurança jurídica, a opinião pública como fator de posicionamento e visibilidade do poder judiciário e ainda, a importância da base informacional e banco de dados dos tribunais norte-americanos. Sobre estes aspectos Bacellar (2013, p. 118) argumenta:

\begin{abstract}
Os prazos, a quantidade de recursos, a possibilidade de reexame das decisões e as várias possibilidades de manifestação nos processos são justificados pela necessidade de que, com segurança, se alcance aquele valor maior: justiça nas decisões. O absurdo volume de serviço dos juízos há vários anos, e a necessidade de observar todos os meandros procedimentais destinados a garantir a segurança jurídica, têm conduzido os magistrados a uma triste realidade: "entre a cruz e a espada", [ou seja, entre quantidade e qualidade nas sentenças].
\end{abstract}

Para Bacellar (2013, p. 122) isto acarreta em decisões satisfatórias ou insatisfatórias para o jurisdicionado, devido ao fluxo processual. Outra questão levantada por este autor é quando o juiz, por imposição da lei, deve se ater ao foco do pedido e este não retrata o verdadeiro interesse das partes. Bacellar (2013, p.123) expõe que nessa situação específica, a mediação realizada por profissionais capacitados poderá contribuir na solução final do conflito, pois dependendo do caso a decisão judicial pode acentuar o grau de adversidade das partes. Bacellar (2013, p. 123) exemplifica com as relações de vínculos tais como familiares, de vizinhança, empresas de família, e outras, onde os conflitos emocionais são comuns.

c) O tempo na solução dos conflitos interna e externamente

Bacellar (2013, p. 123) assinala que neste novo milênio, "o tempo tornou-se um valor tão importante quanto inestimável". Em decorrência, conclui que: "a capacidade de ser atendido com rapidez e confiabilidade passou a ser mais importante do que a referência de onde advém o serviço prestado", significando que:

Concomitantemente ao monopólio jurisdicional, que é indispensável à segurança jurídica na resolução de alguns conflitos por sentença "produzida" em processo judicial (quando não alcançadas soluções conciliatórias), é necessário e recomendável abrir a possibilidade de que outros meios extrajudiciais e complementares de solução das controvérsias sejam implementados. (BACELLAR, 2013, p. 123).

Na realidade do sistema jurídico no país, Bacellar (2013) analisa que:

(...) depois de cumpridos todos os passos processuais - a decisão, a sentença, o veredicto - não se observam as garantias de segurança prometidas pelo sistema. Eficiência quantitativa, na maioria das vezes, retrata deficiência, com decisões que põem fim ao processo, mas, muitas vezes, não solucionam o conflito. (BACELLAR, 2013, p. 123).71

\title{
d) Quantidade e qualidade do serviço jurisdicional
}

Aborda o paradoxo entre redução de trabalho versus aumento da eficácia. As questões do volume de processos e qualidade da prestação jurisdicional permitem entrever problemas subjacentes:

Quando se discute a possibilidade de delegar ou transferir algumas questões para solução extrajudicial, privada, fora do âmbito do Poder Judiciário, surge, de imediato, uma primeira prevenção: haverá perda de poder e, portanto, um desprestígio aos juízes, se o Poder Judiciário permitir solução privada para alguns conflitos. (BACELLAR, 2013, p. 124) 
Porém, neste ponto, o autor mostra o contrário, apontando para soluções que parecem inovadoras, ou culturalmente de difícil aceitação:

(...) a maior perda de prestígio e poder decorre da absoluta incapacidade de solucionar as demandas que são ofertadas aos tribunais. Note-se que se afigura possível, sem qualquer quebra ao estado de direito e à segurança jurídica, que algumas atividades administrativas negociais, consensuais e enunciativas sejam desenvolvidas por outros servidores, administradores e não só por juízes. Várias atividades, relacionadas com as atividades principais do Poder Judiciário, prescindem da atuação direta dos juízes e podem ser praticadas por auxiliares da justiça dentro ou fora do ambiente do Poder Judiciário, até porque, um especialista em direito, um jurista experiente e experimentado (...) é muito caro ao Estado para "perder seu precioso talento jurídico" e, porque não dizer, "perder tempo" com questões operacionais e administrativas diversas da atividade jurisdicional. (BACELLAR, 2013, p. 124)

\section{e) Importância da opinião pública}

Bacellar (2013, p.101) lembra que até poucas décadas, "o poder público, não imaginava ser necessário trabalhar com sua imagem e pouco se importava com a opinião pública". Numa cultura sem consciência da transparência e do direito de acesso à informação, este autor corrobora que no poder judiciário, a prática de não "justificar, orientar, informar e bem atender ao povo, gerou uma generalizada percepção negativa, parcial e, muitas vezes, incompleta da realidade". Para o autor o hermetismo do poder judiciário e o distanciamento da sociedade e do cidadão é mais acentuado que no legislativo e executivo, provavelmente em face da necessidade de contato direto destes últimos com a sociedade para a renovação periódica de parte do quadro funcional e dos mandatos populares. Quanto a isto, Bacellar (2013, p. 101) expõe que o regime democrático e o processo eleitoral permitem que a administração pública dos poderes legislativo e executivo seja acompanhada pelos eleitores. A necessidade do apoio popular para manter o poder levou políticos se posicionar em função da opinião pública. Tal não ocorre no poder judiciário "estabelecido constitucionalmente para ter quadros permanentes, investidos por concurso público e não por eleição, como nos demais poderes". Contudo, faz-se importante a opinião pública nos três poderes:

Em face dessa legitimação legal e ingresso na magistratura por concurso público, o Poder Judiciário não teve a mesma preocupação dos demais poderes em mostrar seus atos para a sociedade. Os concursos públicos, que, na essência, deveriam prestigiar os cidadãos de maior capacidade, durante anos, foram vistos pela sociedade como concursos elitizados e de cartas marcadas. (BACELLAR, 2013, p. 102)

De fato, para Siches (1966) apud Bacellar (2013, p. 102) todo "o sistema da ordem jurídica positiva vigente está calcado e é dependente do apoio da sociedade, repousando, em última instância sobre a opinião pública", recebendo influência quanto ao conteúdo, manutenção, reforma e evolução.

\section{f) Monopólio jurisdicional e o posicionamento público competitivo}

A constatação do distanciamento entre poder judiciário e opinião pública, ocasionaram mudanças nos sistemas de gestão dos tribunais, adotando-se modelos estratégicos na administração judiciária:

O Poder Judiciário, por ser detentor do monopólio jurisdicional, pouco se incomodava com a visão do povo, principal destinatário das decisões judiciais. Embora o Judiciário não tenha seus quadros compostos por eleição, atualmente, começa a despertar, no âmbito dos tribunais, uma 
preocupação com a percepção da comunidade retratada pela opinião pública. (...) há uma rápida promoção de mudanças estratégicas para atingir os melhores resultados. (BACELLAR, 2013, p. 103)

\title{
g) Responsabilidade social como fator de posicionamento e visibilidade pública
}

Fato relevante acenado por Bacellar (2013, p. 104) relaciona-se à forma de comunicação e ação das organizações na sociedade. Neste sentido, afirma que: "Não só as organizações como o poder público são desafiadas na sociedade moderna, a adotar novos padrões de comportamento social" e adverte ser necessário para as organizações judiciárias:

\begin{abstract}
(...) reavaliar suas missões e seus objetivos e, nesse contexto, analisar os fatos preponderantes (técnicos ou institucionais) na formulação de suas estratégias. Há de se constituir o conceito de responsabilidade social a partir da ideia central de que é possível fazer mais do que a simples obrigação, e, ainda assim, agregar valor à instituição.
\end{abstract}

h) Importância da base informacional e do banco de dados dos tribunais norteamericanos

Bacellar (2013, p. 117) refere-se à importância das bases de dados como produto ou serviço do site da biblioteca e demais unidades de informação, bem como, do acervo bibliográfico da mesma, seja na formação da magistratura, ou na administração da justiça nos Estados Unidos o que, naturalmente se aplica a todos os países:

\begin{abstract}
Com o passar dos anos, o Centro Nacional de Tribunais Estaduais (NCSC) passou a ser um banco de informações que conta com mais de 35 mil volumes de livros sobre administração de tribunais. A cada ano, o Centro responde a aproximadamente 3 mil perguntas (...) sobre administração judiciária (...). [Em] 2001, o [NCSC] realizou aproximadamente sete mil conferências de tecnologia e variados cursos. (...) uma vez provocado, o NCSC analisa o problema e sugere, inclusive, modificações na forma de administração dos tribunais analisados.
\end{abstract}

Este autor complementa que na conferência de 1999, o tema versou sobre formas de melhorar a imagem do poder judiciário na sociedade em relação aos serviços judiciários. Outra iniciativa, segundo Bacellar (2013, p. 117) na década de 1970, em Nova Jersey, foi criar cursos de mestrado em administração de tribunais. Neste escopo de iniciativas congêneres de aprimoramento do judiciário norteamericano, Bacellar (2013, p. 117) elenca atividades de divisões internacionais do NCSC, no desenvolvimento de "projetos e programas de consultoria, assistência técnica, gerenciamento judiciário, redução de atrasos na prestação jurisdicional, métodos alternativos de resolução de conflitos, desenho de instalações judiciárias, tecnologia e segurança, e outros serviços".

\section{i) Biblioteca e a globalização do conhecimento em administração judiciária}

Vale ressaltar na visão de conjunto de Bacellar (2013, p. 121-122) sobre a missão, visão, valores, metas e objetivos do poder judiciário na sociedade, a importância capital da biblioteca, na disseminação da informação em administração judiciária, em nível internacional. Isto, na verdade, só vem comprovar o caráter vital da existência de informação que fundamente todo o conhecimento gerado e comunicado à comunidade jurídica, particularmente aos juízes, para o desempenho individual e institucional de atividade judicante na sociedade.

Por contar com a maior biblioteca do mundo, dedicada exclusivamente à administração judiciária, e com base na experiência adquirida nas 
pesquisas e treinamentos ofertados para todos os 56 sistemas judiciários dos estados e territórios dos Estados Unidos, o NCSC passou a prestar assistência técnica internacional e desenvolver projetos de treinamento variados [em diversos países]. O Banco Mundial é o maior financiador dos projetos desenvolvidos nos sistemas judiciários no mundo. No Brasil, até o término da pesquisa ainda não havia formalmente projetos coordenados e desenvolvidos pelo NCSC.

\subsection{Organização judiciária}

A organização judiciária diz respeito ao funcionamento e a estrutura do poder judiciário no país com a finalidade maior da garantia constitucional do acesso à justiça. Está prescrita na Constituição Federal que distribui competências para o exercício do poder judiciário em nível federal. Assim, a Carta Magna formaliza o poder judiciário federal e faculta que cada Estado-membro organize a justiça em suas jurisdições, delineando a estrutura do poder judiciário local nas Constituições de cada Estado-Membro. Conforme instituído no art. $2^{\circ}$ da Constituição de 1988: "São poderes da União, independentes e harmônicos entre si, o Legislativo, o Executivo e o Judiciário." Esta independência confere autonomia ao poder judiciário na organização da justiça que deve estar voltada para necessidades de cada contexto regional do país autorizando a criação de órgãos da justiça pelos Estados. Assim, cabe ao poder judiciário, garantir a administração da justiça, a supremacia da lei e, salvaguardar a Constituição, principalmente pelo controle da constitucionalidade. No entanto, Gusmão (2010) esclarece que a despeito da autonomia de diferentes instâncias do poder judiciário no território nacional, "a jurisdição é una, ou seja "a justiça é subdividida devido à 'organização judiciária' para otimizar o trabalho jurisdicional, no entanto, ela é una, pois é nacional, ou seja, administrada pelo Estado, que é uno".

A organização judiciária consta no art. 92 da CF/88, sendo órgãos do Poder Judiciário:

I. o Supremo Tribunal Federal;

I-A o Conselho Nacional de Justiça; (EC no 45, de 8.12.04)

II. o Superior Tribunal de Justiça;

III. os Tribunais Regionais Federais e Juízes Federais;

IV. os Tribunais e Juízes do Trabalho;

V. os Tribunais e Juízes Eleitorais;

VI. os Tribunais e Juízes Militares;

VII. os Tribunais e Juízes dos Estados e do Distrito Federal e Territórios."

O texto constitucional estabelece como competência da União dirigir justiças especializadas como Trabalho, Eleitoral e Militar, como também as cortes máximas de justiça do país, ou seja, o Supremo Tribunal Federal e o Superior Tribunal de Justiça. Inclui-se ainda nesta competência a justiça comum federal e o Distrito Federal e Territórios. Bacellar (2013, p.6-7) aborda o funcionamento do poder judiciário nacional e os poderes e atribuições dos juízes, fornecendo a apresentação estrutural e sistêmica, da macroestrutura jurídica do país:

Dentro da hierarquia judiciária nacional, o Supremo Tribunal Federal (STF) é o órgão jurisdicional de mais elevado grau, composto por 11 Ministros. Em escala decrescente está o Superior Tribunal de Justiça (STJ), órgão jurisdicional constituído por 33 Ministros. O STF e o STJ localizam-se em Brasília e são tribunais de superposição na estrutura do Poder Judiciário Nacional. No âmbito federal, distribuídos em várias regiões do País, estão 
os Tribunais Regionais Federais (compostos por desembargadores federais); e em todos os Estados (mais o Distrito Federal), os Tribunais Estaduais e o do Distrito Federal (constituídos por desembargadores dos estados e do Distrito Federal).

Expondo as instâncias seguintes, este autor explica que:

Logo abaixo, na estrutura judiciária nacional, estão os juízes de primeiro grau federais e estaduais. A justiça do trabalho conta com o Tribunal Superior do Trabalho (TST), sede em Brasília, e com os Tribunais Regionais do Trabalho (compostos por desembargadores do trabalho). Em nível inferior da estrutura judiciária, estão os juízes do trabalho de 1a instância, com quase toda a estrutura composta de magistrados federais. A justiça eleitoral conta com o Tribunal Superior Eleitoral (TSE), composto por, no mínimo, sete membros, e com sede em Brasília, bem como os Tribunais Regionais Eleitorais (TRE's), na capital de cada Estado brasileiro e no Distrito Federal, com os juízes e as juntas eleitorais. Estas últimas são compostas por um juiz de direito (presidente) e por dois ou quatro cidadãos de notória idoneidade. (BACELLAR, 2013, p. 6-7)

Complementando, com o exercício das funções administrativas, este autor acrescenta que:

A atuação administrativa e financeira do Poder Judiciário nos Estados é controlada (controle externo) pelos Tribunais de Contas dos Estados (órgãos auxiliares do Poder Legislativo) e a atuação funcional dos juízes, pelas Corregedorias Gerais de Justiça (controle interno). Como órgão de superposição está o CNJ, composto por 15 membros (art. 103-B da Constituição da República) e presidido pelo Presidente do STF, atuando concorrentemente no controle da atuação administrativa e financeira do Poder Judiciário e no cumprimento dos deveres funcionais dos magistrados integrantes de primeira e segunda instância dos tribunais locais e regionais. (BACELLAR, 2013, p. 6-7)

De acordo com Beltrame (2010):

A magistratura nacional é o conjunto de juízes que forma o poder judiciário. É regida pelos dispositivos constitucionais que organizam a estrutura do judiciário brasileiro e ainda pela Lei Complementar no 35, de 14 de março de 1979 - Lei Orgânica da Magistratura Nacional, LOMAN, que estabelece garantias, prerrogativas, deveres, direitos, vencimentos, vantagens, forma de ingresso e outras questões do judiciário.

Os cargos jurídicos para o funcionamento da Justiça e defesa dos entes estatais e respectivas autarquias são:

Juiz de Direito (primeiro grau) - atua nos processos da justiça estadual comum, sendo o magistrado que profere a primeira decisão no processo.

- Juiz Federal - julga causas em que a União ou autarquias federais são parte ou interessada

- Juiz do Trabalho - julga litígios entre empregados e empregadores.

- Desembargador - magistrado, membro de tribunal, na instância de segundo grau que reforma as decisões do juiz de primeiro grau, com poder político e grande poder administrativo no judiciário, sendo órgão de cúpula no âmbito estadual, contudo, a decisão final pode caber ao STJ ou STF. Não existe concurso para este cargo, sendo cargo de carreira de juiz.

- Ministro - Magistrado de tribunal superior ou supremo. Os ministros do STF tem poder político no âmbito do Estado brasileiro. Os ministros do STJ e do TST podem reformar decisões do segundo grau. Não há concurso para ministro, sendo nomeados de acordo com a Constituição. 
- Procurador da República - âmbito federal (conhecido como promotor público). Membro do Ministério Público, que atua principalmente na área penal, processo penal e ação civil pública.

- Promotor de Justiça - atua em âmbito estadual.

- Advogado ou Procurador da União, Estado, Município, ou Autarquia - Há três cargos que compõem a Advocacia Geral da União:

1. Procurador da Fazenda - advogado da União nas causas tributárias.

2. Advogado da União - atua em causas remanescentes.

3. Procurador Federal - advogado das autarquias federais (foram extintos os cargos de Procurador do INSS, do INCRA etc)

No nível estadual:

1. Procurador do Estado

2. Procurador de Autarquia com corpo jurídico próprio.

- Procurador de Justiça - Cargo de instância de segundo grau.

- Procurador Regional da República - Cargo de instância de segundo grau.

- Procurador-Geral da Justiça - Chefe do Ministério Público Estadual.

- Procurador-Geral da República - Chefe do Ministério Público Federal.

- Técnico Judiciário - nível técnico.

- Analista Judiciário - nível superior em direito ou outra área. Na área do direito tem como atribuição carregar os autos dos processos. Pode ocupar cargo de assessor de desembargador ou de ministro, redigir mandados e outras peças, preparar as publicações, elaborar os despachos do magistrado com conteúdo decisório mínimo.

- Oficial de Justiça - cumpre mandados do juiz, normalmente fora do fórum.

- Registrador/Notário - dono de cartório. Não é servidor público, mas exerce função pública.

(Extraído de SILVA, 2013)

As competências e exercício destes cargos são descritas por Passos e Barros (2009, p. 75) esclarecendo que a justiça comum é formada pela Justiça Federal e justiça estadual, sendo para ambas o Superior Tribunal de Justiça corte recursal máxima. Enquanto a primeira é composta pelos juízes federais e tribunais federais, a segunda é integrada pelos juízes estaduais, ou juízes de direito e pelos tribunais de justiça. Além disso, Passos e Barros (2009, p. 75) acrescentam que a competência da justiça estadual é de julgar processos sobre questões de propriedade, família, acidente de trânsito, consumidor ou matérias criminais, e outras. Nesta primeira instância da justiça, em caso de recurso, a decisão será obtida na segunda instância, e julgada por desembargadores do tribunal de justiça. Assim, de forma sintética, Passos e Barros (2009, p. 76) expõem que o poder judiciário é representado de acordo com uma forma hierárquica de poder:

Em nível federal é representado pelos juízes, desembargadores e ministros dos tribunais superiores. Nos estados, atuam os juízes e desembargadores dos tribunais estaduais. Não há poder judiciário na estrutura dos municípios, que são tutelados pelo poder jurisdicional federal ou estadual.

Quanto à forma de atuação de magistrados e juízes, segundo Bacellar (2013, p. 3) se investe marcadamente de cunho social como evidenciado em trabalho realizado pela Escola Nacional de Formação e Aperfeiçoamento de Magistrados, Enfam. Esta instituição ao definir as linhas básicas de atuação na atividade judicante de magistrados federais e estaduais realizou eventos destinados a definir, a partir de um ponto de vista interdisciplinar, "as aptidões, habilidades e atitudes necessárias 
ao exercício dessa judicatura integral e humanística". Como resultado "foram identificadas três linhas e esferas principais de atuação: a) jurisdicional; b) de representação (social/política); c) de gestão (em sentido amplo)". A atuação social dos magistrados e juízes, conforme Bacellar (2013, p. 3) deve-se à sociedade exigir "um magistrado integral, que além das características de julgador é um verdadeiro agente de transformação social, servidor, administrador e mediador". Tal atuação jurídica deve estar em consonância com valores de amplo espectro como:

\begin{abstract}
Justiça (e seu acesso), Segurança Jurídica, Acessibilidade, Rapidez (celeridade), Modernidade, Transparência, Imparcialidade, Probidade, Ética e Efetividade são alguns que compõem o "pacote" de ideais que o Poder Judiciário promete, formalmente, oferecer ao cidadão e que, efetivamente, são atributos de valor para a sociedade. (BACELLAR, 2013, p.7)
\end{abstract}

Por fim, a criação e funções do Conselho Nacional de Justiça na estrutura do judiciário brasileiro, com a EC 45 de 2004, é uma iniciativa de modernização do poder judiciário, reforçando a conexão necessária com 0 desenvolvimento econômico e social do país, considerando-se a relevância da solução de conflitos para atração de investimentos.

\title{
3.1.1 A estrutura do modelo de Corte Superior de Justiça
}

Para caracterizar o contexto da competência jurídica e a atividade do STJ no poder judiciário, vale recorrer às reflexões de Mitidiero (2013) e Marinoni (2013) sobre a instância de vértice ou cúpula da justiça brasileira. É justamente a satisfação da demanda jurídica do indivíduo e da sociedade, que constitui o objetivo do STJ, cabendo à Biblioteca Ministro Oscar Saraiva, como unidade de informação pertencente a este Tribunal, tornar acessível e disponível a informação jurídica no ritmo premente e correspondente à necessidade de embasamento e fundamentação da matéria em julgamento, numa contribuição à atividade judicante. Apresentando concepção e funções das cortes suprema e superior de justiça na atividade judicante na sociedade, Mitidiero (2013, p. 11-12) pondera que a corte superior:

(...) parte de uma perspectiva cognitivista ou formalista da interpretação jurídica e encara a corte de vértice como uma corte de controle da legalidade das decisões recorridas, que se vale da sua jurisprudência como um simples parâmetro para aferição de erros e acertos cometidos pelos órgãos jurisdicionais das instâncias ordinárias na decisão dos casos a ele submetidos. A atividade da corte é reativa e preocupa-se com o passado. (...) Estruturalmente, a corte superior é formada exclusivamente por membros da carreira judiciária, sendo competente para controlar a legalidade de todas as decisões a ela submetidas. (MITIDIERO, 2013, p. 33).

Em contrapartida, a corte suprema difere da corte superior por que:

Parte de uma perspectiva antiformalista da interpretação jurídica, notadamente na sua versão lógico-argumentativa e encara a corte de vértice como uma corte de adequada interpretação do Direito, que se vale dos seus precedentes como um meio para orientação da sociedade civil e da comunidade jurídica a respeito do significado que deve ser atribuído aos enunciados legislativos. A atividade da corte é proativa e encontra-se endereçada para o futuro. A interpretação do Direito é o fim da corte de vértice (...). No modelo de Cortes Supremas, a formação do precedente tem um papel central, de modo que a violação à interpretação ofertada pela corte de vértice que compõe a própria corte e por aqueles que se encontram nas instâncias ordinárias é vista como uma grave falta institucional que não pode ser tolerada dentro do sistema jurídico. (MITIDIERO, 2013, p. 11). 
Mitidiero (2013, p. 11) faz uma análise crítico-comparativa entre os dois modelos de instâncias jurídicas do ápice da organização judiciária nacional dando primazia à necessidade da instância suprema no funcionamento tanto do STF quanto do STJ, para que estas cortes de justiça cumpram com os ideais do Estado Constitucional. Além disso, revela que, ao se enxergar os dois modelos, o "Supremo Tribunal Federal e o Superior Tribunal de Justiça pendem mais para o modelo de Cortes Superiores do que para de Cortes Supremas" (MITIDIERO, 2013, p. 11). Ele aponta como problemática nesta realidade o fato desta tendência se constituir num obstáculo na "adoção de técnicas processuais imprescindíveis para o adequado funcionamento" do STF e STJ, justamente na concretização da igualdade, segurança jurídica e tutela efetiva dos direitos no Estado Constitucional. Mitidiero (2013, p. 12) defende ser preciso que:

(...) o Supremo Tribunal Federal e o Superior Tribunal de Justiça sejam pensados como cortes de interpretação e precedentes - e não mais como cortes de controle e de jurisprudência. Vale dizer: como verdadeiras Cortes Supremas e não mais como simples Cortes Superiores.

Assim, Mitidiero (2013, p. 12) considera que, na realidade brasileira o modelo de corte de vértice adotado pode afetar, em última análise, favorável ou desfavoravelmente a execução dos objetivos do Direito e, de modo especial, a atividade judicante e o acesso à justiça como garantias constitucionais, por que:

Sendo o processo civil um meio para tutela dos direitos - tanto em uma dimensão particular, mediante decisão justa e adequada efetivação, como em uma dimensão geral, mediante a formação de precedentes voltados para unidade do Direito - e o direito ao processo justo um direito à organização de procedimentos que permitam a sua obtenção, é imprescindível que o Supremo Tribunal Federal e o Superior Tribunal de Justiça sejam vistos como Cortes Supremas. Fora daí, é pouco provável que o sistema jurídico brasileiro seja capaz de fazer frente às duas tarefas mínimas inerentes a todo e qualquer Estado Constitucional - tratar as pessoas de forma isonômica e propiciar um ambiente seguro para desenvolvimento da vida social. (MITIDIERO, 2013, p. 12).

Neste ponto, como a organização judiciária esta atrelada ao tipo de Estado vigente, Mitidiero (2013, p. 16), afirma que:

A República Federativa do Brasil constitui-se em um Estado Democrático de Direito fundado na dignidade da pessoa humana (art. 1ำ da CF/1988). Nessa condição, consubstancia-se em um Estado Constitucional, sintética e expressiva fórmula, sendo o "Estado de Direito" e o "Estado Democrático" seus dois corações políticos. No que agora interessa, importa ter presente, que como Estado de Direito, funda-se na segurança jurídica (art. 1ำ, caput da CF/1988). Dignidade da pessoa humana e segurança jurídica são dois princípios fundamentais da nossa ordem jurídica.

O ponto de vista de Mitidiero (2013, p. 16) é importante por conduzir à compreensão da extensão da função do Direito na sociedade, por meio do processo judicial, compreensão esta necessária para profissionais de outras áreas afins com o campo do Direito, ou interdisciplinares como a Biblioteconomia Jurídica, contribuindo de alguma forma para que o Direito alcance a sociedade:

Esses dois princípios fundamentam a organização de um processo destinado à tutela dos direitos mediante a prolação de uma decisão justa e a formação de precedentes judiciais. Do ponto de vista do Estado Constitucional, o fim do processo civil só pode ser reconduzido à tutela dos direitos mediante a prolação de uma decisão justa e a formação e respeito aos precedentes. Daí que a tutela dos direitos que deve ser promovida pelo 
processo, tem uma dupla direção - dirige-se às partes no processo e à sociedade em geral. (MITIDIERO, 2013, p. 17).

Com o fito de apreender o Direito como área do conhecimento em que há geração contínua de informação jurídica num processo peculiar - na forma de doutrina, legislação e jurisprudência - necessária à consecução dos seus objetivos junto à sociedade, cabe recorrer ao pensamento de Mitidiero (2013, p. 18), sobre o posicionamento das instâncias superiores de justiça:

\begin{abstract}
Uma adequada organização das cortes judiciárias em determinada organização judicial é de fundamental importância por inúmeras razões. Duas, no entanto, merecem desde logo, menção. (...) de uma perspectiva interna, uma adequada distribuição das competências entre as cortes judiciárias promove a economia processual ao viabilizar a racionalização da própria atividade judiciária. Importa que os tribunais trabalhem na medida necessária para a consecução dos fins a que se encontram vinculados do ponto de vista da estrutura judiciária. (...) de uma perspectiva externa (...) a abertura de determinadas instâncias judiciárias (...) só se justifica à luz do escopo para que foram pensadas dentro da organização dos tribunais.
\end{abstract}

Segundo Mitidiero (2013, p. 39), a corte superior, entendida como uma corte de vértice da organização judiciária tem como característica, entre outros aspectos, "pressupor, do ponto de vista da teoria do direito, a identificação entre texto, norma e regra jurídica e, a adoção da teoria cognitivista da interpretação judicial." Este autor trata de aspectos da composição e competência deste tipo de tribunal, elucidando que a constituição do mesmo "requer um perfil específico de magistratura para sua formação" no intuito de reunir "um corpo de magistrados profissionalizado, compacto e homogêneo". Quanto a isso, Mitidiero (2013, p. 40) complementa que "a antiguidade na carreira judiciária (...) é o critério orientador para seleção dos membros que devem compor este modelo de corte". Sobre a composição da corte superior, este autor adverte que tal estrutura organizacional judiciária "permite tendencialmente maior ascendência do poder político sobre a magistratura", entendendo que o efeito da centralização e burocracia subliminares a este modelo "tende a reproduzir com maior facilidade as diretrizes normativas ditadas pelo poder político". Quanto à competência do tribunal superior, Mitidiero (2013, p. 40) é enfático afirmando que a "realização do controle jurídico sobre a decisão recorrida" é o núcleo das atribuições deste tipo de corte. Em outras palavras, "a corte controla se o órgão jurisdicional de base interpretou de forma exata a lei e aplicou-a corretamente". Isto significa que:

É um controle sobre o controle - um controle exercido pela corte superior sobre o controle exercido pelos demais órgãos do Poder Judiciário a respeito da conduta das pessoas à luz da legalidade. $O$ parâmetro do controle é a lei e o seu objeto é a decisão judicial. (MITIDIERO, 2013, p. 17).

Um ponto importante destacado por Mitidiero (2013, p. 93) sobre a competência do STJ, é que o tribunal ao "interpretar a legislação infraconstitucional federal à luz da Constituição", pode interpretar, em última análise a própria Constituição. Porém, conclui não ser atribuição do STJ "realizar controle de constitucionalidade", uma vez que esta é competência do STF. "Os dois conceitos pertencem a campos temáticos distintos, embora estreitamente ligados" (MITIDIERO, 2013, p. 93). A composição da corte suprema, por sua vez, se diferencia por formar-se, segundo Mitidiero (2013, p. 53), de juristas oriundos de diferentes segmentos sociais como "magistrados de carreira, advogados, membros do Ministério Público e professores universitários", escolhidos por indicação política. 
Na visão de Mitidiero (2013, p. 63), a corte suprema tem como competência o "papel político" de "orientar a aplicação do Direito (...) visando a sua unidade". A indicação política dos ministros do STF e do STJ se afina com o direito comparado no que tange à composição das cortes supremas no mundo:

A exigência de notável saber jurídico e de reputação ilibada, aliada a uma idade mínima para nomeação, coloca em evidência o fato de a função de julgar especialmente no âmbito do Supremo Tribunal Federal e do Superior Tribunal de Justiça exigir mais do que formação técnica apurada na área do Direito. E isso por uma razão muito simples: como cortes supremas, esses tribunais estão encarregados de enfrentar e dar a última palavra sobre questões eticamente sensíveis, além de terem de cotidianamente valorar e escolher entre significados concorrentes dos enunciados linguísticos para outorga de unidade ao Direito. (...) [a] reputação ilibada [deve-se ao objetivo] de assegurar a necessária prudência no processo de tomada de decisões. (MITIDIERO, 2013, p. 17).

Em termos sucintos, se pode extrair de Mitidiero (2013, p. 79) que o Supremo Tribunal Federal e o Superior Tribunal de Justiça são cortes "responsáveis por dar a última palavra a respeito da interpretação da Constituição e da legislação infraconstitucional federal na ordem jurídica brasileira", com a função de fornecer "soluções coerentes aos problemas ligados à interpretação judicial no Estado Constitucional". Em função disto, este autor defende que o STF e STJ devem "ser pensados como cortes de interpretação e não como cortes de controle". Marinoni (2013, p 54) é outro autor que identifica o exercício da atividade de corte suprema pelo STJ, ou seja, a emissão da última e decisiva palavra na interpretação da legislação federal - devido à possibilidade de interpretações divergentes nos demais tribunais e juízos de primeiro grau no país. Por isto, Marinoni (2013, p. 77) propõe uma "recompreensão do sistema processual" judiciário defendendo caber ao STJ "identificar entre as várias normas jurídicas extraíveis do texto legal, aquela que está de acordo com os valores da sociedade e do Estado, sempre mediante 'as melhores razões"'. Em função disso, observa que:

(...) é imprescindível que a interpretação definida pelo STJ 'como de acordo com a Constituição' se projete sobre os tribunais e juízes inferiores. É que a interpretação de acordo com a Constituição como o próprio nome indica, exclui outras interpretações - que não estão de acordo. Permitir a outros tribunais ordinários utilizar as interpretações excluídas pelo STJ é afrontar a coerência do direito, a segurança jurídica e a igualdade perante as decisões judiciais. (MARINONI, 2013, p. 97-98)

Quanto a isso, Mitidiero (2013, p. 77) acrescenta que:

O Judiciário deixa de estar submetido ao legislador, passando a dele ser colaborador para a instituição de um direito adequado à justa organização social. Nessa dimensão, a decisão do Superior Tribunal de Justiça, ao definir o sentido do direito, integra a ordem jurídica vinculante, constituindo 'precedente obrigatório'. A Corte passa a ser uma Corte de Precedentes, deixando de ser uma corte de correção. O seu objetivo é definir a interpretação, mediante a instituição de precedente, para a tutela da igualdade de todos perante o direito.

Neste ponto, o pensamento de Marinoni (2013, p. 97-98) e Mitidiero (2013) são convergentes:

(...) os precedentes devem ter caráter universalizante; ou seja, o precedente deve ter capacidade de servir à generalidade dos casos similares. O caráter universalizante se relaciona com a necessidade do precedente abarcar, 
desde logo, o maior número possível de casos similares, evitando-se futuras decisões distintas para casos iguais (...) [garantindo] a coerência do direito.

Segundo observações de Mitidiero (2013, p. 78) o STJ tem se deparado com óbices na execução destas funções de onde derivam a atribuição de sentido e o desenvolvimento último do direito, ressaltando "a autoridade dos precedentes interpretativos e os fundamentos que estão à base da sua força obrigatória." Nas considerações finais sobre características das cortes superior e suprema, Mitidiero (2013, p. 129) pondera que:

\begin{abstract}
Um projeto para a Justiça Civil que ambicione uma verdadeira reforma do nosso sistema jurídico, tornando-o idôneo para a tutela efetiva dos direitos tanto em uma dimensão particular como em uma dimensão geral, não pode deixar de promover a passagem do Supremo Tribunal Federal e do Superior Tribunal de Justiça do status de cortes superiores ao de Cortes Supremas. Vale dizer: não pode prescindir de incentivar a transformação dessas cortes de vértice em Cortes de Interpretação e de Precedentes, colocando-as ao lado de cortes tão importantes no panorama comparado como a Supreme Court estadunidense e Bundesgerichtshof alemão.
\end{abstract}

Nesta mesma linha de raciocínio Marinoni (2013, p. 113) defende que o STJ como corte de vértice da organização judiciária nacional deve seguir uma trajetória institucional com função suprema indo: "da Corte que define a exata interpretação da lei para a Corte que atribui sentido ao direito. Da interpretação uniforme como meio de controle à autoridade para o direito como tutela da igualdade. Da Corte que controla para a Corte que interpreta".

\title{
3.2 Atividade judicante ou jurisdicional e o acesso à justiça
}

A palavra judicante é definida por Diniz $(2002$, v. 3) como: "Aquele que julga por exercer função de juiz; órgão que julga ou atividade de julgar". Assim, a atividade judicante corresponde à atividade da magistratura, sendo também denominada de atividade jurisdicional. Numa visão geral, Weber e Chedid (2004, p. 78), informam que:

Dentro dos limites de um determinado território, o poder político do Estado é
único, uma vez que expressa a soberania deste povo. Já o seu exercício é
distribuído entre órgãos do próprio Estado, representados da seguinte
forma: Poder Legislativo ao qual cabe a função de legislação; Poder
Executivo, cuja tarefa é a administração pública e o Poder Judiciário, que
sendo formado por vários órgãos instituídos na Constituição federal, está
incubido da atividade jurisdicional.

Segundo, ainda, Weber e Chedid (2004, p. 68), "a atividade jurisdicional é uma atividade provocada. Não há jurisdição sem ação, (...) depende de iniciativa da parte interessada, mediante o ajuizamento da ação". Este autor acrescenta que, "pressupõe como causa um litígio, uma lide, para cuja eliminação é aplicada a lei". Esta ação resulta no processo, destacado por Alvin (2006, p. 17-18) como etapa mais recente na evolução dos métodos de solução de litígio. Este autor prossegue afirmando que: "O processo é o instrumento de que se serve o Estado para, no exercício da função jurisdicional, resolver os conflitos de interesses, solucionandoos". Observa-se, então, que no processo a lide é resolvida por um terceiro sujeito, o juiz, ou, segundo Alvin (2006, p. 23): "Estado-juiz", o qual dele participa na qualidade de órgão estatal e investido da atividade judicante, ou jurisdicional. Assim, segundo este mesmo autor, a atividade jurisdicional, como atividade essencial do Estado, desempenhada por juízes e magistrados, visa ao interesse comum, isto é, interesses 
tutelados pelo direito, e "é a realização deste escopo que ele se propõe através da atividade jurisdicional". Carvalho (2001, p. 279), traça um paralelo, entre a atividade do educador e a atividade do juiz brasileiro, aproximando magistério e judicatura, referindo-se à eficácia e democracia na atividade judicante, do ponto de vista de juiz. Inspirado em Paulo Freire, quando afirma "não haver docência sem discência", Carvalho (2001, p. 279) completa que "sem o jurisdicionado não há judicatura":

A transferência dos ensinamentos de Paulo Freire, originalmente destinados à formação de uma consciência crítica e democrática no meio educacional, tem adequação, também, à atividade judicante, especialmente ao Poder Judiciário brasileiro. Com efeito, a prestação da tutela jurisdicional não pode ser enxergada apenas como a desincumbência, por um dos componentes do Estado-tripartite, de uma tarefa que lhe é ínsita. É muito mais que isso. Além de perseguir a pacificação social, ao instante em que diz a quem pertence o direito, tem a atividade jurisdicional um plus deveras salutar: a pedagogia de mostrar aos jurisdicionados como deve ser a conduta destes nas suas relações interpessoais e interinstitucionais.

As considerações de Carvalho (2001, p. 279) congregam diversas questões do poder judiciário destacando-se de um lado, a função pedagógica do juiz na formação de uma consciência crítica de direitos e deveres na sociedade e, de outro, a função social de prestação jurisdicional com solução de conflitos, demandas e direitos em nível individual e coletivo:

Assim, ao prolatar uma sentença, é imperioso que o juiz tenha consultado, além do que friamente está posto nos autos, os anseios dos destinatários da sua decisão e a carga de valores individuais e sociais por estes comportadas. (CARVALHO, 2001, p. 279)

De fato, a mudança de mentalidade e de valores na sociedade globalizada e tecnológica se estende ao cotidiano das pessoas, levando indivíduos e grupos a questionarem sobre o direito e a atividade judicante:

A discutibilidade das sentenças nos foros formais (tribunais recursais) é o óbvio. É preciso, entretanto, ampliar-se o questionamento das decisões judiciais em instâncias não-estatais e, quem sabe por isso mesmo, mais legítimas. [ou seja, a sociedade]. (CARVALHO, 2001, p. 282)

Uma vez que sentenças, acórdãos, súmulas e a jurisprudência são produtos finais da atividade judicante, caberá também ao juiz, como indivíduo e agente da justiça, extrair para si, ensinamentos pautados na aplicação da decisão proferida e do efeito benéfico ou não que esta causou:

\begin{abstract}
É dever do juiz, acompanhar os resultados práticos advindos do seu pronunciamento, para daí tirar lições que permitam, se possível, a revisão ou a readequação de uma nova decisão para o mesmo caso ou, pelo menos, uma mais apurada adequação das suas próximas decisões, em casos semelhantes. Em resumo, ao julgar o magistrado não "põe uma pedra" sobre o caso. Mesmo que o seu pronunciamento tenha o timbre da coisa julgada para aquela situação concreta, é preciso que seja aferida a eficiência da intervenção estatal. Essa eficiência pode ser retratada, por exemplo, na modificação da conduta dos atores sociais mais afetados pela decisão. (CARVALHO, 2001, p. 279)
\end{abstract}

Neste ponto, cabe abordar o acesso à justiça como início e fim da atividade judicante. Para Cappelletti e Garth (1988, p. 8) que consideram o acesso à justiça como longa batalha histórica que se reflete nos sistemas jurídicos modernos, esta expressão é reconhecidamente de difícil definição mais permite entrever duas finalidades básicas de qualquer sistema jurídico: servir para que as pessoas 
reivindiquem seus direitos ou, resolvam litígios sob a tutela do Estado. Para tanto, estes autores afirmam que o sistema jurídico "deve ser igualmente acessível a todos [e] deve produzir resultados que sejam individual e socialmente justos". Cappelletti e Garth (1988, p. 10) relatam que historicamente, o acesso à justiça dependia da capacidade de arcar com os custos inerentes, ou seja, o acesso era formal, mas não plenamente efetivo e, a igualdade de direitos preconizada, mas não efetiva. Com isto, o sistema judiciário encontrava-se afastado da relidade e necessidades reais da maioria da população. Cappelletti e Garth (1988, p. 10) lembram que à medida que os relacionamentos assumiam caráter coletivo as sociedades modernas abandonaram declarações de direitos dos séculos XVIII e XIX reconhecendo os "direitos e deveres sociais dos governos, comunidades, associações e indivíduos". Esta nova visão foi necessária para "tornar efetivos, quer dizer, realmente acessíveis a todos, os direitos proclamados" estabelecendo-se nas constituições o direito ao trabalho, saúde, segurança material e educação. (CAPPELLETTI e GARTH, 1988, p. 8-10)

A partir de então, a atuação do Estado tornou-se necessária para assegurar o gozo de todos os direitos sociais básicos legalmente prescritos. Por isto, para Cappelletti e Garth (1988, p. 11) o direito de acesso à justiça ganhou atenção em função de reformas que atribuiam "aos indivíduos novos direitos na qualidade de consumidor, locatário, empregado e, cidadão". Com isto, o direito de acesso à justiça adquiriu importância capital uma vez que a titularidade de direitos é destituída de sentido na ausência de mecanismos para sua efetiva reivindicação. Portanto, Cappelletti e Garth (1988, p. 12) frisam que: "O acesso à justiça pode ser encarado como o requisito fundamental - o mais básico dos direitos humanos - de um sistema jurídico moderno e igualitário que pretenda garantir, e não apenas proclamar o direito de todos". Evidenciando a ligação entre a atividade judicante e o acesso à justiça na sociedade, Cappelletti e Garth (1988, p. 12) destacam que: "O enfoque sobre o acesso - o modo pelo qual os direitos se tornam efetivos - também caracteriza o estudo do moderno processo civil" e que, "os juristas precisam, reconhecer que as técnicas processuais servem a funções sociais". No alcance deste fim, os autores defendem que o direito processual onde se insere a atividade judicante, deve receber contribuições da sociologia, política, psicologia e economia por que:

O 'acesso' não é apenas um direito social fundamental, crescentemente reconhecido; ele é, também, necessariamente, o ponto central da moderna processualística. Seu estudo pressupõe um alargamento e aprofundamento dos objetivos e métodos da moderna ciência jurídica. (CAPPELLETTI e GARTH, 1988, p. 13)

Cappelletti e Garth (1988, p. 15) identificam obstáculos a transpor no acesso à justiça em função dos sistemas jurídicos, os quais são mais pronunciados nas pequenas causas - especialmente para o cidadão de menos condição econômica e social - e menos difíceis para litigantes organizacionais. Logo, a atividade judicante nas organizações judiciárias visando o acesso à justiça:

Por um lado, envolve esforços para apoiar os cidadãos contra os governos; os consumidores contra os comerciantes; o povo contra os poluidores; os locatários contra os locadores; os operários contra os patrões. Por outro lado, o interesse econômico de qualquer indivíduo - como ator ou réu será provavelmente pequeno. (CAPPELLETTI e GARTH, 1988, p. 29)

Como o acesso à justiça envolve também a defesa dos interesses difusos e coletivos leva à necessidade da comunidade jurídica e da sociedade refletirem sobre 
os objetivos da atividade judicante e do papel dos tribunais. Isto porque, conforme Cappelletti e Garth (1988, p. 49) o processo judicial era visto apenas como um assunto entre duas partes, destinado à solução de uma controvérsia a respeito de interesses individuais. A representação dos interesses coletivos depende também do sistema judiciário vigente exigindo em determinados períodos reformas que contemplem alterações no procedimento judicial, mudanças na estrutura dos tribunais e outras inovações na prestação dos serviços jurídicos de acordo com a diversidade e complexidade dos litígios e das singularidades das partes envolvidas. (CAPPELLETTI e GARTH, 1988, p. 101). Quanto a isto, os autores lembram que as reformas judiciais e processuais não substituem a necessidade de reformas políticas e sociais. Em suma, a atividade judicante ou jurisdicional responde aos anseios sociais por justiça, tendo por objetivo conflitos de interesses concretos.

Vale acrescentar que a atividade judicante pressupõe o acesso à informação jurídica constituída por doutrina, legislação e jurisprudência fundamentando o processo judicial e a tomada de decisão do juiz para o efetivo acesso à justiça, sendo a missão da biblioteca jurídica tornar este tipo de informação disponível na comunidade jurídica e sociedade.

\section{BIBLIOTECA DO PODER JUDICIÁRIO: CONTRIBUIÇÃO NA FUNDAMENTAÇÃO DA ATIVIDADE JUDICANTE.}

Historicamente, Saldanha (1993, p. 62), bacharel em Direito e licenciado em Filosofia, ao tratar do racionalismo moderno e da teoria do direito, revela que as bibliotecas particulares de magistrados e de outros operadores do direito que compõem a comunidade jurídica, concorreram decisivamente no fenômeno de secularização da sociedade, isto, certamente considerando aspectos relacionados ao poder e à posse da informação jurídica na época. De modo similar, ele atribui ao advento do livro - como fenômeno anterior ao surgimento destas bibliotecas especializadas - o impacto sobre a expansão do humanismo durante o final dos quatrocentos e início dos quinhentos. Tal conexão entre o surgimento das bibliotecas jurídicas particulares e o impacto na sociedade daquela época, é avaliada por Saldanha (1993, p. 63) "como um aspecto nada negligenciável no processo geral de secularização", respaldado no pensamento de Lucien Febvre e Henri-Jean Martin, para quem:

\footnotetext{
O crescimento numérico das bibliotecas revela, naqueles anos, uma perceptível afirmação das gens de robe (principalmente, advogados e notários), cujas bibliotecas ultrapassam a dos eclesiásticos em escala expressiva. Logo em seguida, começam a surgir bibliotecas em maõs de profissionais diversos.
}

Contemporaneamente, as bibliotecas do poder judiciário ao reunir informação jurídica são instrumentos de apoio ao acesso à justiça e exercício da cidadania. Um dos motivos é que a doutrina, legislação e jurisprudência exercem influência e modificam o pensamento jurídico, levando à criação de novos fundamentos jurídicos, que por sua vez conduz a aplicação da justiça. Neste sentido, complementa que: "Mais do que quaisquer outros centros de informação estas instituições, pelo conteúdo documental que guardam se tornam importantes instrumentos de justiça e cidadania". E conclui que dada à importância da informação para a área jurídica, as bibliotecas jurídicas preocupam-se em "identificar as necessidades informacionais do seu público-alvo para dar suporte as suas atividades" e, "ser ambiente de estudo e formação do pensamento jurídico". Por conseguinte, este autor confirma que: 
A razão de ser das bibliotecas jurídicas, todo o seu trabalho é desenvolvido para dar suporte às atividades da instituição a qual pertence. À medida que torna acessíveis leis, decretos, decisões judiciais, pensamentos jurídicos, ela permite a reflexão e contribui com a tomada de decisões de seus legisladores, juízes, desembargadores que se apoiam nos estudos da informação jurídica para interpretar e aplicar os dispositivos legais.

Segundo o ministro aposentado do STJ, Ruy Rosado Augusto, ao prefaciar o livro de Passos e Barros (2009, p. xiii):

\begin{abstract}
O trabalho do jurista depende da pesquisa bibliográfica, pois o advogado, juiz, professor entre outros que atue na área jurídica, ao emitir um parecer ou conselho, preparar uma aula, elaborar um trabalho acadêmico, promover ou julgar uma ação, iniciará pelo recolhimento dos dados informativos que permitirão aproximar-se do caso ou da questão. Essas informações são encontradas em fontes apropriadas que devem ser verazes, atualizadas, adequadas e completas. (AUGUSTO, 2009, p. XIII)
\end{abstract}

Para Ruy Rosado (2009, p. xiii) o trabalho do jurista tem duas vertentes: "o uso do argumento de autoridade para convencimento do acerto da tese defendida no arrazoado ou no julgamento" destacando, por exemplo, "o peso da opinião de um jurisconsulto como Pontes de Miranda ou, de um julgado do Supremo Tribunal Federal" e, em segundo lugar, particularmente no Brasil, "a fundamentação de opinião nas investigações científicas dos países europeus, principalmente da França, Alemanha, Itália e Portugal", ou seja, o embasamento no direito comparado e ensinamentos de professores estrangeiros (AUGUSTO, 2009, p. xiii). O ministro, como usuário da Biblioteca do STJ, ressalta a necessidade de acesso e uso da informação pelo usuário da informação jurídica assinalando que:

Para recolher esses elementos com a segurança necessária, o advogado,
juiz e professor deverão recorrer ao auxílio do bibliotecário, profissional
especializado na classificação, catalogação, armazenamento, busca e
recuperação dos dados (...) sendo absolutamente inviável, que o operador
do direito atue sem contar com a colaboração do bibliotecário, por mais
simples que seja a sua tarefa. Isso porque cresceu espantosamente a
produção legislativa, com milhões de normas vigentes no país, a par do
aumento da produção científica, em decorrência da expansão do material
legislado e da produção dos cursos de pós-graduação, tudo contribuindo
para o natural desenvolvimento da ciência jurídica, com a publicação de
livros, teses e artigos. Os tribunais julgam a cada dia milhares de recursos
cujos acórdãos formam jurisprudência sobre os mais diversos aspectos da
vida social. Acrescentando-se a esse expressivo volume de material de
pesquisa, os recursos da informática como a internet, obtém-se um quadro
revelador da dificuldade com que se depara o profissional do direito para
encontrar a informação que mais interessa. (AUGUSTO, 2009, p. XIII)

De fato, a mudança e crescimento contínuos da área do direito acarretam situações de busca e acesso à informação, porém, na constatação desse ministro:

São tantos os dados, informações e as vias de acesso, que o encontro da resposta procurada somente acontecerá em tempo útil, e com a confiança necessária, se houver um trabalho prévio de seleção e depuração, tanto das fontes como do resultado da pesquisa. Por isso, é preciso reconhecer que, hoje, assim como não é mais possível o trabalho do profissional do direito sem o uso da informática, também se tornou indispensável a presença do bibliotecário ao lado do jurista, fornecendo-lhes os elementos de informação necessários ao seu trabalho. (AUGUSTO, 2009, p. xiv).

Além disso, Augusto (2009, p. xiv) considera que há questões que: 
Interessam diretamente a duas categorias de profissionais envolvidas na pesquisa jurídica. Aos bibliotecários os conceitos da ciência do direito, nomenclatura utilizada, a estrutura jurídica do país para viabilizar o trabalho de classificação, recuperação e de aconselhamento ao pesquisador e, aos juristas a importância da linguagem clara e acessível, as dificuldades a vencer para obtenção de bom resultado na busca das informações, a compreensão da natureza do trabalho da pesquisa jurídica, sob a perspectiva do bibliotecário e pesquisas em ambientes virtuais. (AUGUSTO, 2009, p. xiv).

É importante destacar a função do bibliotecário neste processo no ponto de vista do ministro:

Confesso que grande parte do meu trabalho devo aos bibliotecários desde os tempos em que pesquisava nos acervos das bibliotecas da Procuradoria Geral da Justiça, do Tribunal de Justiça, da Faculdade de Direito da Universidade Federal do Rio Grande do Sul e, nos últimos anos, nas bibliotecas de Brasília, do Superior Tribunal de Justiça, do Supremo Tribunal Federal, do Senado Federal, da Câmara dos Deputados e do Conselho da Justiça Federal". [Há qualidades exigidas para exercer a função de bibliotecário]: conhecimento, disposição de busca incessante, ainda que a informação seja de difícil acesso, seriedade e lhaneza de trato. (AUGUSTO, 2009, p. xv).

Por último, assim como as bibliotecas nacionais participam no crescimento do Estado nacional moderno o mesmo pode ser dito no âmbito do poder judiciário: "Quanto mais antigo e mais politicamente forte o Estado, maior e mais influente a biblioteca. Há um forte elo entre maturidade democrática e amplitude dos serviços de bibliotecas e informação". (MCGARRY, 1999, p. 114). Assim, quanto mais atuante o poder judiciário, maior o elo entre acesso à informação jurídica e o acesso à justiça.

\subsection{Características da biblioteca jurídica}

As bibliotecas jurídicas têm por objetivo disseminar e tornar acessível a informação jurídica, especialmente para a instituição mantenedora, que pode ser órgão governamental, universidade e escritório de advocacia, com o intuito de subsidiar as decisões processuais em fluxo e auxiliar os juristas no cumprimento da justiça. Segundo Gonçalves e Santos (2009, p. 4):

A biblioteca jurídica passa por grandes transformações: os padrões estabelecidos que determinam os rumos que uma biblioteca deve tomar como objetivos relacionados aos seus usuários (produtos); a formação de acervos; as políticas de administração e, inclusive, a sua própria estrutura física e a formação do corpo de funcionários - são fundamentais para sua sobrevivência enquanto instituição ou departamento capaz de reunir condições para atrair usuários com interesses em pesquisas e recursos necessários à própria manutenção. (GONÇALVES e SANTOS, 2009, p. 4)

De natureza híbrida, na biblioteca jurídica conforme Rezende (2000, p. 51) ocorre a potencialização do sistema de informação pela conexão com bancos e bases de dados, redes eletrônicas e de bibliotecas, ampliando o acesso a fontes de informação jurídica e completando os recursos do acervo físico. De fato, Passos (2005, [p. 1]) confirma esta realidade assinalando que: "as bases de dados, as publicações jurídicas em novos suportes, a Internet, o correio eletrônico trouxeram modificações profundas no desenvolvimento das coleções, na formação do bibliotecário jurídico." Contudo, no que se refere aos usuários da informação jurídica, principalmente nos tribunais, Passos (2005, [p. 1]) observa que na biblioteca jurídica: 
O juiz gosta de receber o material, que solicita à biblioteca, em sua sala de trabalho. Não é comum ver juízes, ministros, parlamentares e outros operadores do Direito pesquisando ou utilizando o espaço da biblioteca para leitura. Até mesmo porque muitos deles utilizam seus assessores ou estagiários para fazer a busca preliminar.

Barité (1999, p. 77-78) propõe uma tipologia de biblioteca jurídica conforme áreas do direito e tipo de informação jurídica:

- Biblioteca jurídica geral - reúne documento de qualquer tipo, fonte ou procedência referente ao Direito;

- Biblioteca jurídica especializada por ramo do Direito - especializada em direito comercial, direito penal, e outros;

- Biblioteca jurídica especializada no tipo de informação jurídica - concentra documentos de legislação;

- Biblioteca jurídica mista - além da informação jurídica, inclui áreas afins como Administração, Economia, Sociologia e outras;

- Biblioteca jurídica especializada em outras áreas de conhecimento - há predominância dos documentos na área do Direito.

No que se refere ao acervo físico da biblioteca jurídica, Passos (2005) com base em informações da Câmara Brasileira do Livro (CBL), em 2002, mostra que "foram publicados, em papel, 920 títulos de livros na área do Direito, em primeira edição." Ao comparar este número com áreas de produção bibliográfica significativa como Sociologia, Administração, Economia e Ciência Política, a autora constatou que a soma do total de publicação nas quatro áreas foi equivalente ao publicado na área do Direito, no período. Ademais, se a publicação de títulos jurídicos novos é alta, a republicação de edições atualizadas, evidencia que os lançamentos jurídicos sobressaem em relação a outras áreas. Constata-se certa disparidade na publicação bibliográfica na área do Direito, em comparação com outras áreas, inclusive Biblioteconomia, como demonstrado no Quadro 11.

QUADRO 11: Publicação de títulos novos e edições em Direito $X$ outras áreas do conhecimento em 2002

\begin{tabular}{lcc}
\hline \multicolumn{1}{c}{ Assunto } & Títulos em 1a edição & Títulos Republicados \\
\hline Direito & 920 & 1.250 \\
\hline Sociologia & 370 & 480 \\
\hline Administração & 280 & 610 \\
\hline Informática & 270 & 250 \\
\hline Economia & 160 & 360 \\
\hline Ciência Política & 120 & 90 \\
\hline Biblioteconomia & 15 & 10 \\
\hline
\end{tabular}

Fonte: Câmara Brasileira do Livro - CBL

Passos (2005) acrescenta que a publicação em suportes digitais também se mostra notória tendo editoras jurídicas, lançado periódicos, dicionários, CLT, códigos, repertórios de legislação e jurisprudência neste formato. Algumas editoras estão oferecendo publicação pay-per-view para aquisição apenas do volume ou capítulo de interesse do usuário enviado pelo correio eletrônico ou Internet. Naturalmente, no desenvolvimento do acervo da biblioteca jurídica as publicações eletrônicas são parte significativa, apesar da constatação de que muitos operadores do Direito preferem publicações em papel. Aparentemente, a aceitação de obras de referência em formato digital é maior que de artigos ou livros. A experiência mostra 
que mesmo quando o usuário localiza na Internet ou base de dados o texto que procura, prefere ler o material impresso. O texto digital se presta mais para fazer transcrições. O livro ou periódico passa por um intensivo processo de seleção, sendo que muitas vezes o título foi sugerido por usuários capazes de julgar o conteúdo da obra. (PASSOS, 2005). Quanto aos produtos e serviços da biblioteca jurídica, Passos (2005) detalha alguns aspectos no contexto jurídico:

a - Criação de homepages - a facilidade de publicar na Internet foi requisito para que os sites jurídicos oferecessem bases de dados com doutrina, texto integral de normas e jurisprudência, acompanhamento processual e noticiário jurídico. Por outro lado, o excesso de dados na Internet faz com que o usuário despenda tempo em buscas, cabendo ao bibliotecário poupar etapas e indicar caminhos para acesso à informação, considerando que as informações disponibilizadas pelas bibliotecas se diferenciam daquelas encontradas na Internet pela confiabilidade.

b) Disseminação Seletiva da Informação - O êxito do serviço de DSI está no levantamento acurado do perfil do usuário. As bibliotecas jurídicas, exceto a biblioteca jurídica universitária, tem número restrito de usuários facilitando o conhecimento do mesmo. O bibliotecário jurídico deve estar atento aos processos julgados no Tribunal onde exerce sua profissão; às ações trabalhadas pelos advogados no escritório de advocacia; aos empréstimos de livros pelo usuário; aos pedidos de cópia de artigos de periódicos, mantendo contato com o usuário sobre o trabalho que realiza, tais como os assessores que trabalham diretamente com ministros. No DSI cabe ao bibliotecário jurídico procurar constantemente na Internet material, principalmente nos sites do poder legislativo e dos tribunais; deve participar de listas de discussões em Direito e Biblioteconomia e cadastrar-se nos sites que fornecem remessa gratuita de mensagens com novidades.

c) Empréstimo em domicílio - As bibliotecas jurídicas, por ter público reduzido, podem oferecer o serviço de empréstimo externo de material bibliográfico para escritórios de advogados ou instuições.

d) Chat - bate-papo - Bibliotecas jurídicas americanas oferecem o serviço de chat permitindo a comunicação entre usuário e bibliotecário em tempo real, para questões rápidas e factuais, e na pesquisa em bases de dados. Recebem nomes como "Ask a Law librarian", "Live help", "AskLaw live", "24/7 Reference Update".

e) Treinamento do usuário - no uso de catálogos, localização do material na estante, bases de dados, pesquisas na Internet e outros. Não existe padronização na interface das bases de dados, devendo o bibliotecário jurídico saber explorá-las ao máximo e dominar o uso dos motores de busca, para treinar o usuário.

f) Acompanhamento da legislação federal, estadual/distrital e municipal - a legislação é matéria-prima dos operadores do Direito, não sendo fácil acompanhar sua publicação. O bibliotecário jurídico deve selecionar e editar os atos normativos publicados nos Diários Oficiais eletrônicos da Justiça e da União, divulgando-os no dia da publicação, antecipando-se à demanda.

g) Acompanhamento das proposições legislativas em tramitação no congresso nacional, assembléias legislativas e câmaras municipais - As proposições legislativas em tramitação são relevantes para os operadores do Direito, no acompanhamento das mudanças na legislação, caso a proposição seja aprovada. Os sites do Senado Federal e da Câmara dos Deputados oferecem o serviço de acompanhamento de matérias. 
h) Coleta e organização da produção intelectual da entidade mantenedora Loureiro (2005) sugere "a divulgação da produção intelectual interna do Órgão, dando destaque à iniciativa e estimulando a geração de novos conhecimentos." O Centro de Estudos Judiciários (CEJ) do Conselho da Justiça Federal (CJF) organizou o Projeto Memória Documental da Justiça Federal, para manter em banco de dados a produção doutrinária dos juízes federais brasileiros.

\title{
4.2 A Comunidade jurídica como usuária da biblioteca jurídica
}

Atienza, no final da década de 1990, reuniu características e expôs conceitos e definições de termos e categorias, tais como informação jurídica, documentação jurídica, agentes da informação jurídica, fontes do direito, instrumentos da documentação jurídica, destacando-se para os objetivos desta pesquisa, especificamente, o conceito de comunidade jurídica. Contudo, faz-se necessário, inicialmente, recorrer a esta autora no que concerne ao contexto da informação jurídica, para então se deter na comunidade jurídica. Neste intuito, cabe destacar no pensamento de Atienza (1998, [p.1]) a repercussão do fenômeno mundial da explosão da informação na área do Direito:

\begin{abstract}
Nos últimos anos, uma série de fatores contribuiu para alterar de forma radical as diferentes áreas da atividade jurídica configurando uma nova era caracterizada pela diversificação de suportes materiais na apresentação das informações jurídico-legais e, a validade jurídica desses novos suportes apresentados pelas tecnologias avançadas (...).
\end{abstract}

Atienza (1998) alerta que a explosão informacional levou ao evento da revolução informacional caracterizada pela expectativa de acesso e disponibilidade irrestrita de informação, porém, diferentemente do que o senso comum poderia supor, junto com a maior capacidade de armazenamento e acesso à informação, surgiram tanto soluções como problemas ainda desconhecidos, inclusive no contexto da informação jurídica:

\begin{abstract}
A revolução informacional não irá proporcionar soluções para os problemas característicos deste final do Século XX, pelo contrário, pode até, em alguns aspectos concorrer para seu agravamento. E, se existe essa problemática com o mundo da informação, consequentemente, a informação jurídica além de estar nesse mesmo contexto ainda tem a responsabilidade jurídica sobre os problemas a serem resolvidos no futuro perante a globalização que caracteriza o final do século.
\end{abstract}

Naturalmente que para aqueles que lidam com a informação jurídica, todas estas mudanças repercutem no seu fazer profissional e na concretização da cidadania na sociedade. O conjunto composto de profissionais do Direito, da biblioteconomia jurídica e o cidadão na busca à informação jurídica, incluem-se na comunidade jurídica. Passos (2002, p. 1) de forma geral considera que "os usuários típicos dos serviços de uma biblioteca jurídica são juízes, juristas, legisladores, professores e alunos do curso de Direito e o cidadão comum que tem como objeto de pesquisa: leis, doutrinas, jurisprudências e julgados dos mais diversos Tribunais". Em estudo que se mostrou o mais completo do gênero, Atienza (1998) categoriza os dois tipos principais de profissionais da comunidade jurídica: profissionais, empresas e instituições da área do Direito e profissionais da área da informação jurídica subdivididos em: 
a) Profissionais da Área do Direito:

* Advogados, juristas, consultores, professores;

* Juízes, promotores, agentes da justiça;

b) Profissionais da Área da Informação Jurídica:

* Bibliotecário, arquivista, documentalista com conhecimento da área do

Direito;

* Bacharel em Direito com conhecimento da área da informação jurídica.

Contudo, a comunidade jurídica delineada por Atienza (1998) é mais extensa englobando pessoas físicas e jurídicas se estendendo aos três poderes do Estado e a outras organizações públicas e privadas, como exposto no Quadro 12.

QUADRO 12 - Comunidade jurídica composta por instituições, entidades e agentes da área do direito.

\section{1. ÓRGÃOS GOVERNAMENTAIS}

\begin{tabular}{|c|c|c|}
\hline & PESSOA JURÍDICA & PESSOA FISICA \\
\hline PODER JUDICIÁRIO & $\begin{array}{l}\text { - Supremo Tribunal Federal } \\
\text { - Superior Tribunal de Justiça } \\
\text { - Tribunais Regionais Federais } \\
\text { - Tribunais do Trabalho } \\
\text { - Tribunais Eleitorais } \\
\text { - Tribunais Militares } \\
\text { - Tribunais dos Estados }\end{array}$ & $\begin{array}{l}\text { - Juízes federais } \\
\text { - Juízes do trabalho } \\
\text { - Juízes eleitorais } \\
\text { - Juízes militares } \\
\text { - Juízes dos Estados }\end{array}$ \\
\hline PODER LEGISLATIVO & $\begin{array}{l}\text { - Congresso Nacional } \\
\text { - Senado Federal } \\
\text { - Câmara dos Deputados } \\
\text { - Assembleias legislativas } \\
\text { - Câmaras municipais }\end{array}$ & $\begin{array}{l}\text { - Senadores } \\
\text { - Deputados federais } \\
\text { - Deputados estaduais } \\
\text { - Vereadores }\end{array}$ \\
\hline PODER EXECUTIVO & $\begin{array}{l}\text { - Presidência da República } \\
\text { - Governadorias Estaduais } \\
\text { - Prefeituras Municipais }\end{array}$ & $\begin{array}{l}\text { - Presidente da República } \\
\text { - Ministros de Estado/ outros } \\
\text { - Governadores do Estado } \\
\text { - Secretários de Estado/ outros } \\
\text { - Prefeitos municipais } \\
\text { - Secretários municipais/outros }\end{array}$ \\
\hline $\begin{array}{c}\text { ÓRGÃOS COM } \\
\text { FUNÇÕES ESSENCIAIS } \\
\text { À JUSTIÇA }\end{array}$ & $\begin{array}{l}\text { - Ministério Público } \\
\text { - Ministério Público da União } \\
\text { - Ministério Público Federal } \\
\text { - Ministério Público do Trabalho } \\
\text { - Ministério Público Militar } \\
\text { - Ministério Público do DF e } \\
\text { territórios } \\
\text { - Advocacia Geral da União } \\
\text { - Advocacia e Defensoria Pública }\end{array}$ & $\begin{array}{l}\text { - Promotores públicos } \\
\text { - Advogados }\end{array}$ \\
\hline
\end{tabular}

2. ÓRGÃOS NÃO-GOVERNAMENTAIS

\begin{tabular}{|c|c|}
\hline PESSOA JURÍDICA & PESSOA FISICA \\
\hline $\begin{array}{l}\text { - TABELIONATOS } \\
\text { - CARTÓRIOS } \\
\text { - ÓRGÃOS DE CLASSE } \\
\text { - ORDEM DOS ADVOGADOS DO BRASIL } \\
\text { - ASSOCIAÇÃO DOS ADVOGADOS } \\
\text { - ESCRITÓRIOS DE ADVOCACIA } \\
\text { - DEPARTAMENTOS JURÍDICOS DE } \\
\text { EMPRESAS PÚBLICAS/PRIVADAS } \\
\text { - FACULDADES DE DIREITO }\end{array}$ & $\begin{array}{l}\text { - Tabeliães } \\
\text { - Cartorários } \\
\text { - Juristas } \\
\text { - Procuradores } \\
\text { - Advogados } \\
\text { - Consultores } \\
\text { - Professores }\end{array}$ \\
\hline
\end{tabular}




\section{AGENTES DA INFORMAÇÃO JURÍDICA}

\begin{tabular}{|c|c|c|}
\hline & PESSOA JURÍDICA & PESSOA FÍSICA \\
\hline PRODUTORES & $\begin{array}{l}\text { - Congresso Nacional } \\
\text { - Senado Federal e Câmara dos } \\
\text { - Aeputados } \\
\text { - Assembleias Legislativas } \\
\text { - Gâaras municipais } \\
\text { - Presidência da República } \\
\text { - Prefeituras municipais } \\
\text { - Tribunais } \\
\text { - Ministérios públicos } \\
\text { - Advocacia Geral da União } \\
\text { - Advocacia e Defensoria Pública } \\
\text { - Órgãos de classe } \\
\text { - Tabelionatos } \\
\text { - Cartórios } \\
\text { - Escritórios de advocacia } \\
\text { - Departamentos jurídicos de } \\
\text { empresas públicas/privadas }\end{array}$ & $\begin{array}{l}\text { - Agentes do poder legislativo } \\
\text { (senadores, deputados } \\
\text { federais/estaduais, vereadores) } \\
\text { - Agentes do governo federal, estadual, } \\
\text { municipal do poder executivo e } \\
\text { judiciário } \\
\text { - Agentes dos órgãos não- } \\
\text { governamentais (advogados, juristas, } \\
\text { procuradores, professores, consultores, } \\
\text { tabeliães, cartorários }\end{array}$ \\
\hline $\begin{array}{l}\text { INTERMEDIÁRIOS/ } \\
\text { FORNECEDORES }\end{array}$ & $\begin{array}{l}\text { - } \text { Bibliotecas } \\
\text { - Centros de documentação e } \\
\text { informação e Instituições similares } \\
\text { - Livrarias } \\
\text { - Editoras } \\
\text { - Escritórios e gabinetes jurídicos }\end{array}$ & $\begin{array}{l}\text {-Profissionais na área da informação } \\
\text { jurídica: } \\
\text { - Agentes da informação com } \\
\text { conhecimentos na área jurídica. } \\
\text { - Bibliotecário, Arquivista, } \\
\text { Documentalista. } \\
\text { - Agentes da área do Direito com } \\
\text { conhecimentos na área de informação. } \\
\text { - Bacharel em Direito com } \\
\text { conhecimentos em Ciência da } \\
\text { Informação. } \\
\text { - Profissionais na área do Direito: } \\
\text { - Advogados e demais agentes com } \\
\text { formação na área jurídica }\end{array}$ \\
\hline CONSUMIDORES & - Cliente/Usuário & - Cidadão em geral \\
\hline
\end{tabular}

Fonte: Extraído de Alonso (1998).

Atienza (1998, [p.4]) define os agentes da informação jurídica, como: "pessoas que atuam na produção, intermediação e no consumo de todo e qualquer documento jurídico". Podem ser subdivididos em:

$>$ agente produtor - (profissionais da área do Direito) - atua na produção/promoção/execução de um ato jurídico, podendo ser representado por agentes do poder legislativo, executivo e judiciário ou profissionais da área do Direito.

$>$ agente intermediário - (conhecido como fornecedor da informação) profissional da área da informação jurídica que pratica a função de intermediário, não podendo atuar na produção de um ato jurídico. Sua função é intermediar a informação jurídica entre produtor e consumidor, possuindo a capacidade de localizar a informação correta e precisa para fornecer ao interessado, no menor tempo possível.

$>$ agente consumidor - (cliente/usuário) - pessoa que adquire informação jurídica, seja de que natureza for, para uso profissional ou particular, com o fim de satisfazer uma necessidade.

Detendo-se especificamente na descrição do agente intermediário da informação jurídica, Atienza (1998, [19-22]) conceitua tanto os profissionais da área do Direito, como aqueles que atuam na área de informação jurídica: 


\title{
1) Profissionais da área do Direito:
}

a) Advogados, juristas, professores da área jurídica.

Podem ser produtores e intermediários/fornecedores da informação jurídica:

fazem uso de diversas informações para exercer sua profissão e como não poderia deixar de ser, esses profissionais da área do Direito, que manipulam um considerável volume de informações, descobriram no computador, uma excelente e indispensável ferramenta de apoio, na medida em que propicia rapidez e precisão nas tarefas repetitivas e de coleta de dados (...). (ATIENZA, 1998, [p. 14])

Quanto à forma deste profissional lidar com a informação jurídica Atienza (1998, [p. 18]) explica que:

\begin{abstract}
Antes do computador, o advogado se informava quase que exclusivamente através de leitura de textos. Petição, requerimento, citação e outros documentos referentes à ação processual ou não, legislação, jurisprudência e doutrina eram apresentados aos consulentes [em] texto, dentro de um emaranhado de papéis que requeriam do advogado uma memorização quase impossível.
\end{abstract}

Assim, as tecnologias de informação e comunicação modificaram o proceder destes profissionais com a informação jurídica em diversas etapas do trabalho na atividade administrativa, jurídica ou processual. Ademais, a conexão a redes entre profissionais da comunidade jurídica como pessoas físicas e jurídicas permite a estes operadores do direito aplicar informações obtidas de tribunais, por exemplo, e atender às necessidades de informação sobre processos e direitos e deveres aos usuários/clientes. Atienza (1998, [p. 19]) conclui que: "na atividade jurídica, o computador entrou para valer. Desde petições até a fase final do processo, tudo ocorre com a participação dos equipamentos eletrônicos."

\section{b) Juízes, promotores, agentes da justiça}

Para estes profissionais Atienza (1998, [p. 21]) esclarece que as tecnologias de informação e comunicação são imprescindíveis:

O judiciário é o segmento do poder público que está mais compelido pela sociedade para enfrentar 0 desafio da modernidade. $O$ gigantesco movimento forense não pode dispensar o uso dessa tecnologia de ponta, embora a Administração da Justiça tenha sido o ponto mais fraco em todo esse contexto. Não é apenas adquirindo equipamentos de informática que a missão está sendo cumprida. Há algo mais, que inclusive transcende os limites destes comentários iniciais. Embora seja grande a utilização do computador na atividade jurídica, no campo específico da administração da Justiça, muita coisa ainda está para ser feita, notadamente na racionalização das atividades forenses.

Atienza (1998, [p. 21]) acrescenta ainda que:

A importância maior da informatização nessa área está no inesgotável manancial dos precedentes jurisprudenciais, dada a grande quantidade de Tribunais existentes no País, suas respectivas áreas de atuação e especialidade, como também na indispensabilidade de citação de precedentes específicos, seja pelos advogados, seja pelos julgadores. A verdade é que a tecnologia computadorizada entrou na atividade judiciária para ficar. 


\section{Profissionais da Área da Informacão Jurídica}

a) Bibliotecário, Arquivista, Documentalista com conhecimento da área do Direito

b) Bacharel em Direito com conhecimento da área da Informação Jurídica

Não obstante Atienza (1998) não especifique características de cada uma destas categorias, pode-se incluir os profissionais com dupla formação em Biblioteconomia e Direito. Atienza (1998, p. 21-22) discorre, ainda sobre as funções dos profissionais como intermediários entre a informação jurídica e usuários/clientes considerando:

b.1 comodidade do usuário - a ação do intermediário pode ser mais cômoda que a realização da busca pessoalmente; o fator tempo é importante na busca minuciosa de informação, consistindo em considerável carga de trabalho.

b.2 Percepção pelo usuário da "pseudo-independência" - o usuário da área do Direito que usa a informação jurídica percebe que tem condição de fazer uso direto de fontes e programas disponíveis no ambiente digital. A facilidade de manuseio permite sentir-se capaz de resolver pesquisas de forma independente sem o auxílio do profissional da área da informação jurídica. Contudo, desconhece que na maioria das vezes, essa "pseudo-independência" não traz a qualidade da informação procurada. Os contatos com vários utilitários da área jurídica evidenciam a dispersão dos dados num mundo eletrônico da informação quantitativa (e não seletiva). Os usuários, então se perdem no emaranhado de informações apresentadas e constatam que a maioria delas não interessa aos propósitos de suas pesquisas, no exato momento que estariam precisando de uma resposta certa e eficaz. Percebem que o trabalho de pesquisa pode ser ingrato, pois despende tempo até a obtenção da informação procurada. Constata, então, a utilidade do intermediário e profissional da área de informação jurídica, para realizar o trabalho de identificação dos pontos de interesse e a posterior disponibilização da informação desejada.

b.3 Necessidade de recuperação da informação jurídica com qualidade - a utilização da intermediação de um profissional especializado pode dever-se à falta de resultados positivos quando o próprio usuário realiza a busca. Nesse caso, ao optar pela intermediação o usuário buscou a maximização dos resultados com níveis dificilmente atingidos de especificidade e precisão da informação jurídica.

A título de acréscimo vale mencionar a categorização da comunidade jurídica de Silva (2010, p. 27-28), na literatura de ciência da informação, relacionando usuário, instituição e informação jurídica demandada: 
QUADRO 13 - Comunidade jurídica X instituição X informação jurídica*

\begin{tabular}{|l|l|l|}
\hline \multicolumn{1}{|c|}{ INSTITUIÇÃO } & \multicolumn{1}{|c|}{ USUÁRIO } & \multicolumn{1}{c|}{ TIPO DE } \\
INFORMAÇÃO
\end{tabular}

*Fonte: Adaptado de LICDA [et al] (1991) apud Silva (2010, p. 28).

O usuário da comunidade jurídica tem características peculiares em conformidade com atividades que desempenha, necessitando acessar a informação de especialidade com integridade e precisão em fontes de informação jurídica. 


\title{
5. FONTES DE INFORMAÇÃO JURÍDICA
}

Passos e Barros (2009, p. 121) citam a classificação das fontes de informação de Beckman e Silva (1967) em primárias - contêm a informação original na sua totalidade, não sendo condensada, resumida, selecionada ou abreviada. São documentos de transmissão em primeira mão. As fontes secundárias contém informações retiradas das fontes primárias, apresentando o conteúdo de forma sintética ou analítica, visando à consulta. Por último, as fontes ocasionais correspondem às seções de divulgação, que segundo Passos e Barros (2009, p. 122) "são de excepcional importância para as bibliotecas e serviços de informação no atendimento ao pesquisador". De outro ponto de vista, Mueller (2000, p. 31) dividiu as fontes de informação em primárias, secundárias e terciárias, conforme o conteúdo. Passos e Barros (2009, p. 121) comentando esta classificação consolidada na ciência da informação, ponderam que as primárias estão "dispersas e desorganizadas quanto à produção, divulgação e controle". As secundárias informam sobre o conteúdo das fontes de informação primárias, com o fim de possibilitar acesso às mesmas, enquanto as terciárias registram informações sobre as duas anteriores. No que se refere especificamente às fontes de informação jurídica, o conceito de Beckman e Silva (1967) apud Passos e Barros (2009, p. 121) é que:

Constituem o lugar de origem, donde a informação adequada é retirada e transmitida ao usuário. Seu conhecimento não é atributo privativo do bibliotecário, porém só este tem obrigação de conhecê-las todas, nas suas características intrínsecas, no seu modo de utilização em relação aos pedidos das diferentes categorias profissionais.

Passos e Barros (2009, p. 122) reforçam o pensamento de Beckman e Silva (1967) acrescentando ainda outros aspectos:

Entende-se por fonte de informação jurídica o local onde o bibliotecário ou
pesquisador adquire uma informação útil ao desenvolvimento de seu
trabalho, indispensável que é para o bom desempenho de suas atividades
cotidianas (são exemplos de fontes: Coad, Jurid, Data legis, Sicon, LIS,
JUIS entre outras). As fontes de informação jurídica podem ser
representadas por pessoas, instituições, empresas, cartórios, obras de
referências, serviços e sistemas de informação, bases de dados, etc.,
podendo estar fisicamente presentes ou não na biblioteca. Um diário oficial
onde se encontra uma lei impressa; uma base de dados em CD-ROM
contendo milhares de sentenças; um disquete com inteiro teor de um livro
jurídico, ou um sítio jurídico onde se possa capturar um parecer na internet
são exemplos de fonte de informação jurídica.

É importante observar que "no caso específico do direito é preciso considerar que algumas fontes não possuem eficácia probante, ou seja, o reconhecimento da autenticidade e integridade de conteúdo" (PASSOS e BARROS, 2009, p. 122). A importância das fontes de informação é assinalada por Passos e Barros (2009, p. 122) tanto pelo prisma jurídico como da ciência da informação:

\begin{abstract}
As fontes de informação jurídica desempenham um papel fundamental no desenvolvimento das ações do profissional de direito. Para fins documentários, os sistemas de informação e as bases de dados funcionam como excelentes auxiliares tanto para o bibliotecário quanto para o usuário final na busca e recuperação da informação jurídica.
\end{abstract}

Passos e Barros (2009, p. 122) classificam as fontes de informação jurídica em primárias (diários oficiais) e secundárias (livros, periódicos e coleções). 
As fontes primárias compreendem o Diário Oficial da União, DOU, os Diários Oficiais dos Estados e o Diário da Justiça, DJ, e versões eletrônicas, publicadas pela Imprensa Nacional. a) $\underline{\mathrm{DOU}}$ - contém três seções com matérias estabelecidas no Decreto n. 4.250, de 16/12/2002 abrangendo atos dos três poderes do país. Em 2000, passou a ser publicado em meio eletrônico; b) DJ - publicação dos atos judiciais possuindo três seções. Os órgãos da justiça publicadores e a matéria a ser publicada no DJ são fixados pelo Decreto n. 4.520, de 16/12/2002, regulamentado pela Portaria n. 310, de 16/12/2002, da Imprensa Nacional, constando os tribunais superiores, como o STF e o STJ. Foi instituído por meio de legislação autonomia a todos os tribunais para criar diários eletrônicos com autoridade e capacidade probante. O STJ instituiu seu diário eletrônico em 20 de setembro de 2007, com a resolução n. 8 , sendo que os atos judiciais do Tribunal deixaram de ser veiculados na versão impressa do DJ em 29 de fevereiro de 2008. (PASSOS e BARROS, 2009, p. 124-126)

As fontes secundárias compreendem livros, periódicos e teses em formato impresso ou digital. A maioria das fontes secundárias de suporte impresso migrou para a internet, havendo aquelas que coexistem nos dois formatos, e outras, unicamente na internet. As coleções de jurisprudência são exemplo de publicação em meio impresso e digital, concomitantemente. Diferentemente das coleções de leis, as coleções de jurisprudência, segundo Passos e Barros (2009, p. 141) podem ser publicações oficiais "se forem consideradas repositórios autorizados pelos tribunais", visto que as condições para que as editoras sejam habilitadas é estabelecido no regimento interno de cada tribunal. Dados de 2015 mostram que há 29 periódicos nacionais habilitados pelo STJ para publicar sua jurisprudência. Além destas fontes tradicionalmente reconhecidas na literatura de ciência da informação, Passos e Barros (2009, p. 121) incluem instituições como bibliotecas; grupos de documentação e informação jurídica (como a Comissão Brasileira de Informação e Documentação Jurídica, CBIDJ); listas de discussão e eventos científicos.

Quanto ao suporte, segundo Passos e Barros (2009, p. 121-153) as fontes de informação jurídica podem ser: a) impressas - livros, periódicos, teses, coletâneas de leis, jurisprudência, obras de referência como dicionários jurídicos e vade-mécuns. Passos e Barros (2009, p. 135) elucidam que "os livros na área da documentação jurídica são conhecidos como doutrina". A publicação do livro na área do direito fez surgir editoras fortes e consagradas no mercado editorial jurídico. Há, também, a produção bibliográfica jurídica de órgãos públicos como Senado Federal, Câmara dos Deputados, Ministérios e Secretarias às quais "o profissional de biblioteconomia ou de direito devem se familiarizar com os produtos que essas instituições oferecem". b) digitais - livros, periódicos e obras de referência em formato eletrônico, bases de dados de legislação e de jurisprudência, bases de dados estrangeiras, sites institucionais, portais, catálogos on line, listas de discussão, portal e biblioteca digital;c) instituições - de direito público e privado dentre as quais as bibliotecas, organizações públicas e os cartórios. (PASSOS e BARROS, 2009, p. 135-148). 


\section{CONSIDERAÇÕES FINAIS}

O conjunto de temas abordado na revisão de literatura possibilitou compreender a partir da ligação entre Direito, justiça e sociedade a missão de organizações como os tribunais e o sentido da atividade judicante ou jurisdicional no universo do Poder Judiciário. Este significado encontrado na busca pelo acesso à justiça evidencia que além do magistrado, todos os profissionais do Direito e os cidadãos são intérpretes e aplicadores potenciais das leis e normas jurídicas, sendo que no conflito e defesa de direitos individuais e coletivos, a decisão, cabe ao Judiciário. Por outro lado, a compreensão da estrutura e funcionamento do Poder judiciário possibilitou verificar que a satisfação da demanda jurídica do cidadão e da sociedade, consiste no objetivo do Superior Tribunal de Justiça, sendo imprescindível que a interpretação, segundo a Constituição federal, definida pelo STJ, como corte de justiça de vértice, se projete nos tribunais e juízes de instâncias inferiores, em nível nacional.

Constatou-se que no contexto social da atividade judicante, o Direito é uma ciência que produz a informação jurídica a ser acessada e aplicada pela comunidade jurídica, em benefício do cidadão e da sociedade. Nesta realidade, cabe à Biblioteca Ministro Oscar Saraiva, como unidade de informação pertencente ao STJ, tornar acessível e disponível a informação jurídica específica e precisa, para embasamento e fundamentação da matéria em julgamento, numa contribuição à atividade judicante. Por conseguinte, o bibliotecário como profissional que trabalha com a informação jurídica, faz parte deste contexto, estando no exercício de uma profissão garantida por lei, na atuação da tutela de um bem comum, o acesso à informação. Além disso, o acesso à informação jurídica, essencial para a atividade judicante nos tribunais, é missão de organizações como as bibliotecas que trabalham na realidade jurídica, visando à proteção de interesses individuais e coletivos, relacionados a este bem imaterial. Com tal finalidade as bibliotecas jurídicas acumulam, agregam e fornecem a produção do conhecimento em Direito para a comunidade jurídica e sociedade. Estas organizações fazem parte da área de conhecimento interdisciplinar entre Ciência da Informação e Direito designada de Biblioteconomia jurídica, que investiga na realidade empírica aspectos relacionados ao acesso à informação jurídica.

Trata-se de fenômeno que abarca amplo espectro de questões, como a organização da informação jurídica constituída de documentos doutrinários, legislativos e jurisprudenciais; a classificação bibliográfica dos ramos do direito visando à representação e localização do conteúdo da informação jurídica; a necessidade de domínio pelo profissional da informação, da linguagem jurídica empregada na formulação das leis, interpretação e aplicação do direito, como fator de inclusão no universo dos tribunais; além de questões relativas ao ciclo da informação incluindo a oferta, uso e avaliação de produtos de informação jurídica. Foi destacado que quando os produtos de informação jurídica possuem conteúdos direcionados para as reais necessidades de informação da comunidade jurídica, podem contribuir para tomada de decisão de magistrados, na elaboração de votos e decisões, adquirindo valor estratégico na fundamentação doutrinária, legislativa e jurisprudencial da decisão judicial na atividade judicante. Um aspecto evidenciado na oferta e demanda de produtos de informação jurídica na Web, é a interação entre bibliotecário e usuário operador do direito, como diferencial que prioriza a interação homem-homem em relação a homem-máquina. Isto envolve a tarefa humana de agregar sentido ao grande volume de informação jurídica existente na Web. 
Os autores pesquisados frisaram a influência da informação jurídica no pensamento jurídico dentro do processo de aplicação do direito na sociedade. Tal fato permite perceber que na atividade judicante do poder judiciário, existe um elo subjacente entre acesso à informação jurídica e acesso à justiça. Assim, as considerações realizadas na revisão de literatura sobre temas que congregam aspectos sociais e jurídicos entre Direito e Ciência da Informação, formaram um conjunto de abordagens necessárias para o desenvolvimento da pesquisa, numa área que exige produção científica sobre problemas e soluções na criação, desenvolvimento e avaliação de produtos de informação da biblioteca jurídica na Web.

\title{
PARTE 2 \\ CIÊNCIA DA INFORMAÇÃO E METODOLOGIAS DE AVALIAÇÃO DE PRODUTOS DE INFORMAÇÃO
}

O significado etimológico da palavra avaliação é o ato de medir o valor de uma atividade ou objeto. Lancaster $(2004$, p. 1) assinala que "autores que tratam do tema afirmam que avaliação é um ramo da pesquisa - a aplicação do 'método científico' para determinar, por exemplo, a qualidade de desempenho de um programa", acrescentando ainda:

\begin{abstract}
Outros destacam seu papel no processo decisório: a avaliação reúne dados necessários para determinar quais dentre várias estratégias alternativas parecem ter mais probabilidade de obter um resultado almejado. E ainda outros consideram a avaliação como componente essencial da administração - mais exatamente, os resultados da avaliação podem ajudar o administrador a alocar recursos de modo mais eficiente. (LANCASTER, 2004, p. 1)
\end{abstract}

Evidentemente, esses pontos de vista são complementares, revelando que além da natureza sistematizadora da avaliação, ela consiste em exercício intelectual, fundamentada em teorias e metodologias, possibilitando a concepção e redimensionamento de produtos ao solucionar problemas ou tomar decisões de acordo com necessidades específicas dos usuários. Uma tendência recente, segundo Loureiro (2005, p. 1) é a "realização de numerosos estudos de usuários dos serviços de bibliotecas e centros de documentação", que incluem a avaliação de produtos disponíveis nos sites de bibliotecas, no "intuito de constatar perfis de interesse e, com base nestes, estruturar sistemas que possam suprir necessidades de informação provenientes de questões múltiplas". Isto porque neste contexto, a informação é um recurso para atender às demandas de forma confiável:

Figuram, nesse processo, dois polos de ação. De um lado está o usuário, cuja satisfação é o fim último desses estudos e a quem cabe elucidar ao máximo os termos da pesquisa. Do outro, o bibliotecário, ou gestor da informação, cuja função é investigar o desejo do usuário e aparelhar o sistema de forma a dotá-lo de mecanismos eficazes de recuperação de dados. (LOUREIRO, 2005, p. 1).

Uma proposta de avaliação de fontes de informação foi idealizada por Barros (2010) aplicando as cinco leis de Ranganatham (1928) na recuperação da informação jurídica na Internet, visando seu uso efetivo pelo usuário.

Ainda hoje, em plena era da informação, é possível extrair das cinco leis de Ranganathan elementos muito significativos, que ajudam a compreender porque não basta criar uma biblioteca, ou - falando numa linguagem mais 
moderna, colocar na Web uma fonte virtual de pesquisa, sem refletir ou avaliar a utilidade do seu conteúdo pelo usuário.

Fica evidente no pensamento de Barros (2010) a importância da avaliação dos produtos digitais de informação jurídica: "Por essas e outras razões, as fontes de informação para busca de documentos jurídicos na Internet devem sofrer, periodicamente, um processo avaliativo no que diz respeito a sua efetiva utilização". $\mathrm{Na}$ realidade, por um lado, as unidades de informação como as bibliotecas utilizamse de técnicias e metodologias para avaliação de produtos e serviços que oferecem com a realização de estudos de usuários, enquanto de outro lado, estudos acadêmicos sobre processos de avaliação buscam aportes de outras áreas do conhecimento como administração, psicologia e comunicação e outras, visando aprimorar este processo de avaliação, cujo campo empírico de aplicação têm sido as unidades de informação de organizações públicas e privadas.

\section{PRODUTOS DE INFORMAÇÃO}

As organizações, conforme área que atuam, geram algo como motivo que justifique sua existência, tendo como atividade final a venda, doação, troca ou outra forma de negociação, resultando na criação e fornecimento de produtos. Tarapanoff (2001) apud Gonçalves, Gouveia e Petinari (2008, p. 44) conceitua produto como "qualquer coisa oferecida a um mercado para aquisição, atenção, uso ou consumo, a qual possa satisfazer uma necessidade ou desejo." Portanto, os autores inferem que os produtos podem satisfazer, ou não, demandas específicas dos usuários. Da mesma forma, os produtos informacionais, podem ser úteis em determinado momento e noutro inócuos. Ou seja, podem ter influência e efeitos nulos em ambientes decisórios, ou, altamente relevantes, satisfazendo os usuários. (GONÇALVES, GOUVEIA e PETINARI, 2008, p. 43)

Os produtos são resultado do trabalho das organizações no fornecimento de suporte às resoluções de problemas e de atendimento a necessidades específicas. $\mathrm{Na}$ unidade de informação segundo Gonçalves, Gouveia e Petinari (2008, p. 44) o produto pode estar agregado a serviços: "Os produtos informacionais estão interrelacionados, e derivam do trabalho intelectual que resulta no atendimento de uma demanda para sociedade a quem são dirigidos". Segundo Moresi (2000) apud Gonçalves, Gouveia e Petinari (2008, p. 44) os produtos "estão ligados fortemente ao desejo e à satisfação que o individuo tem a partir do uso destes em suas tomadas de decisão". Para Gonçalves, Gouveia e Petinari (2008, p. 45) "produto pode ser compreendido como o resultado de um serviço ou de um conjunto de serviços oferecidos a uma comunidade e que, como serviço, tem propriedades específicas". No que tange à informação como produto estes autores consideram que o "produto informacional é informação tratada a ser transformada em conhecimento estratégico" tendo como base que:

\footnotetext{
(...) uma informação solta, não contextualizada, não é um produto. Para que seja reconhecida e compreendida como produto, primeiramente, precisa estar focada em determinada direção e objetivo. Então, depois de direcionada, a informação será um produto e poderá, como qualquer outro nas mesmas condições, alcançar o seu sentido natural, o motivo pelo qual existe, ou seja, aumentar o grau de certeza em uma tomada de decisão. (GONÇALVES, GOUVEIA e PETINARI, 2008, p. 45)
}

Não obstante as considerações de Gonçalves, Gouveia e Petinari (2008, p. 46) estejam direcionadas para decisões mercadológicas, podem ser aplicadas no contexto da informação jurídica para a tomada de decisões: 
Para a elaboração de produtos informacionais, as instituições necessitam não somente tratar a informação. Isto já vem sendo feito ao longo de décadas. As informações são adquiridas e indexadas de forma a serem armazenadas em determinado lugar para uma possível utilização que nem sempre ocorre. Elas sejam públicas ou privadas, gerais ou especializadas, devem ser organizadas visualizando-se sempre a sua utilização, de forma que possam oferecer o subsídio ideal às tomadas de decisões.

Em contrapartida, Rozados (2004) apud Borges (2007, p.23) define serviço de informação como "todo processo de auxílio ao usuário na busca de informação ou satisfação de necessidades informacionais". Considera como interface direta entre informação e usuário destinada à identificação, aquisição, processamento e transmissão de informação e seu fornecimento. Tem como função assegurar que qualquer informação requerida pelo usuário esteja à disposição, no momento em que for solicitada. De acordo com Lovelock e Wright (2002) apud Borges (2007) diferentemente do produto, o serviço de informação apresenta duas características: "intangibilidade e a participação dos usuários. O usuário vivencia o serviço que lhe é prestado e o avalia de acordo com as suas crenças, valores e expectativas". Enquanto os produtos de informação são estruturas informacionais resultantes de serviços caracterizados pela tangibilidade (formato, apresentação, suporte, etc) (BORGES, 2007).

\subsection{Produtos de informação jurídica na Web : a biblioteca digital}

Web, ou www é a forma abreviada de World Wide Web, parte da Internet com interface gráfica permitindo a navegação em hipertexto com um programa de navegação, ou browser, como o Internet Explorer, Mozila, Google Crome. De acordo com Hortinha (2001, p. 57), "é na Web que a maior parte das pessoas pensa, quando se refere à Internet". Este autor esclarece que o formato HTML (Hypertext Markup Language) da Web disponibiliza hyperlinks que permitem ao utilizador mover-se rapidamente de um documento ou site para outro, procedimento conhecido como navegação. Os recursos da Web tornam os documentos fáceis de ler, permitem a integração de gráficos e animações bem como a disponibilização de formulários para captar dados pessoais do usuário num processo interativo. Há recursos tecnológicos de grande capacidade de relacionamento social como as redes sociais, facebook e twitter. A Web conduz uma economia eletronicamente processada que cria oportunidades para países, organizações e indivíduos. De fato, a e-economia adquiriu peso e importância comparáveis a setores com séculos de atividade como energia, transporte e, recentemente, telecomunicações. $\mathrm{O}$ impacto da economia via Web é global, atingindo o mercado e o governo, além do que, o mercado internacional reconhece o papel estratégico da Web na capacidade da organização sobreviver e manter agilidade e vantagem competitiva. Isto também ocorre nas organizações públicas, onde a informação tem papel determinante no posicionamento no contexto da Nova Economia.

Constata-se que, ao longo do desenvolvimento da Web as organizações públicas e privadas utilizaram os recursos tecnológicos para oferta ou venda de produtos, acesso à informação e, comunicação diretamente com usuários ou clientes respectivamente. Dentre as vantagens usufruídas estão redução no custo de atendimento e, oportunidade para criar e fornecer produtos inovadores, sem barreiras de tempo e espaço. Por isso, toda organização seja corporativa, sem fim lucrativo ou empresarial precisa determinar o objetivo a ser alcançado com a presença global na Web. Isto significa saber o que se propõe alcançar com o site 
como forma de assegurar objetivos e avaliar o sucesso. Naturalmente, a Web gera um conjunto de oportunidades e desafios e, concentra grande potencial para armazenar, divulgar, disponibilizar, fornecer e realizar transações a longa distância de produtos, sejam materiais ou imateriais como a informação. Outro ponto importante no meio digital é a capacidade de resposta e a base de sustentabilidade das organizações dependerem essencialmente da habilidade de obter informação sobre as necessidades, expectativas e reclamações dos usuários nas demandas, acesso e uso de produtos. Fator decisivo, ainda é a forma de apresentar a organização ou, como elas são visualizadas pelos usuários na Internet. Finalizando este processo, avaliar os produtos com enfoque no usuário, agrega valor à oferta das organizações na Web.

Sterne (2000, p. 48-55), do ponto de vista mercadológico, identifica atividades realizadas com os sites na Web: obtenção de imagem; relações públicas; relações com os investidores, serviço e educação ao usuário; venda de produtos; interação e feedback com o cliente; comunicação na intranet. Além disso, no processo de avaliação do site e dos produtos, os recursos tecnológicos fornecem dados e informações sobre número de visitantes, hora de acesso, caminho percorrido no site, palavras usadas na busca, ofertas que capturam atenção e, as transações efetuadas. Em organizações que visam ao lucro, e que pode ser aplicado em parte nas organizações públicas, Modahl (2000, p. 13) identifica: (a) venda de bens: os clientes reais ou potenciais utilizam a Web para satisfazer as necessidades por produtos; (b) venda de serviço e de informação: inclui jornais, revistas, instituições e indivíduos, que fornecem informação e conhecimento, atendendo à demanda de um segmento de mercado; (c) divulgação institucional: apresentação de características das organizações e dos produtos explorando o alcance global e mantendo presença e marca na Web. Evidentemente, os produtos na Web necessitam de identidade, apresentação e outras características para atrair usuários e consumidores.

Entre os benefícios proporcionados pela Web para as organizações, Sterne (2000, p. 48) aponta: melhorar a imagem corporativa; melhorar o atendimento ao cliente; encontrar clientes potenciais; aumentar a visibilidade; realizar transações ou trocas; expandir mercados; e, ir ao encontro das expectativas do cliente. Contudo, observa que muitas organizações, que visam e que não visam ao lucro, criaram sites apenas para mostrar uma vitrine no ciberespaço. Se isto ocorreu no início dos anos 2000, na década seguinte o uso dos sites pelas organizações públicas e privadas se desenvolveu consideravelmente, sendo que muitos produtos, mormente os de informação, pelo volume e pela necessidade de rapidez de acesso, só estão disponíveis na Web. Na primeira metade da década de 2010, as organizações públicas e privadas criaram sites para fornecer produtos na Web. No entanto, fazer com que pessoas tenham hábito de frequentar um site é um desafio. Se o objetivo de um site público na Web, por exemplo, é disseminar informação técnica, o número de novos visitantes poderá não ser importante. Se o objetivo for aumentar o número de consultas, deverão ser adotadas técnicas de visitação repetida. Portanto, determinar a finalidade do site, desde o princípio, é fundamental, uma vez que há grande potencial de recursos para o sucesso da oferta de produtos na Web (STERNE, 2000, p. 60).

$\mathrm{Na}$ área de Ciência da Informação, Cunha (2009, p. 5) observa que "a Web será a fonte provedora da maior parte da informação daquelas pessoas que têm acesso à internet" No que tange, à oferta de fontes de informação jurídica na Web, Passos e Barros (2009, p. 143) incluem pessoas, instituições, serviços e produtos de 
informação como livros, periódicos, obras de referência como dicionários, enciclopédias e vade-mécuns em formato eletrônico, bases de dados de legislação e de jurisprudência, bases de dados estrangeiras, sites institucionais, portais, catálogos de acesso público, listas de discussão, bibliotecas digitais e sistemas jurídicos como o Bacen-Jud, criado como parte integrante do processo de execução de débitos trabalhistas. Entre estes, destacam-se de Passos e Barros (2009, p. 143):

a) periódico eletrônico - possui artigos com texto integral em rede e com acesso on line. Há títulos somente digitais, e outros digitais e impressos. Passos e Barros (2009, p. 137) destacam o Jus Naveganti, publicação periódica em linha, criada em 1996 por um advogado, possuindo o "maior conteúdo de trabalhos jurídicos publicados, atualizados diariamente. Todo o conteúdo é de acesso livre. Conta com mais de três mil colaboradores".

b) banco e base de dados - dentre as bases de dados que se sobressaem na área jurídica encontram-se as de teses e dissertações. Passos e Barros (2009, p. 138) comentam que em 2008 existiam 83 cursos de pós-graduação em Direito, reconhecidos pelo Ministério da Educação, sendo 62 de mestrado e 21 de doutorado, com uma produção de "teses e dissertações que constituem fonte relevante de doutrina" e o estado da arte no conhecimento científico no direito. Estes autores lembram que o IBICT foi pioneiro na criação de bases de dados bibliográficas em rede, como o Sistema de Informação sobre Teses, acessível na rede Antares, em 1993, antes do advento da Internet no Brasil. O IBICT coordena a Biblioteca Digital de Teses e Dissertações (BDTD) com o objetivo, conforme Passos e Barros (2009, p. 139) de integrar sistemas congêneres das instituições de ensino superior no Brasil, com texto completo fornecido pelo Comut. Ademais, a BDTD está integrada a uma rede internacional que congrega várias bibliotecas digitais, chamada Networked Digital Library of Theses and Dissertations (NDLTD).

c) lista de discussão - Louis-Jacques (1994) apud Passos e Barros (2009, p. 151) define 'lista jurídica', como o recurso da internet, surgido no fim da década de 1980, para: "discussão substantiva dos assuntos relacionados ao direito. As listas jurídicas podem, ainda, prover a disseminação da informação acerca de recursos impressos e digitais sobre computação e biblioteconomia". Passos e Barros (2009, p. 151) acrescentam que: "as listas podem ser vistas, como ambiente para discussão, mas também como fonte de informação e meio de colaboração entre bibliotecários situados em locais diversos". O conteúdo destas listas foi dividido por Terra (1998) apud Passos e Barros (2009, p. 151) em divulgação de informação, pedido de informação e discussão sobre um tema. Não obstante, Passos e Barros (2009, p. 151) alertam que na busca à informação jurídica, "a lista de discussão deve ser vista como o último recurso [e] nunca deve ser entendida como transferência de responsabilidade pela pesquisa". Há listas de discussão reunindo especialistas em direito, destacando-se para estes autores a "Infolegis: bibliotecários jurídicos reunidos". Para Passos e Barros (2009, p. 152) a lista de discussão possibilita uma "reunião imprescindível, tendo em vista as diferenças de formação acadêmica e as diferenças na quantidade e qualidade de fontes de informação jurídica disponíveis em cada unidade da Federação". Os autores relatam que até o fim de 2007, participavam da Infolegis 530 assinantes, sendo $90 \%$ de bibliotecários jurídicos. As vantagens de rapidez na comunicação e acesso a respostas são fatores importantes na Infolegis:

Servir como fórum de discussão; permitir a comunicação entre os assinantes; compartilhar experiências; solicitar ajuda nas pesquisas; divulgar serviços oferecidos por bibliotecas, arquivos, serviços de 
informação diretamente relacionados com informação jurídica; informar sobre conferências, cursos, workshops, palestras, exposições e demais eventos ligados ao tema; sugerir sítios e publicações na área de informação jurídica. (PASSOS E BARROS, 2009, p. 152)

d) biblioteca digital - De modo específico, a biblioteca digital é vista por Passos e Barros (2009, p. 147) como fonte de informação jurídica, destacando a BDjur (Biblioteca Digital Jurídica), criada pelo STJ.

De acordo com Sayão $(2008$, p. 7$)$ no contexto de rápidas transformações da Web são oferecidas condições para o "estabelecimento de uma infra-estrutura técnica que viabiliza o surgimento de diversas atividades centradas no conhecimento e na informação globalmente distribuídos". No ponto de vista deste autor tais características do ambiente da Web são especialmente propícias ao surgimento das bibliotecas digitais:

a ambientação tecnologicamente favorável exerce uma forte influência sobre a reconfiguração dos mercados de conteúdos e no delineamento de uma nova dinâmica para a economia da informação, que rapidamente vai incorporando novos patamares de consumo de conteúdos digitais. Assim sendo, surgem diversos produtos e serviços de informação - resultados de concepções inéditas ou de inovações sobre serviços já consagrados. Dentre eles, impulsionada por um conjunto heterogêneo de forças, está a idéia de biblioteca digital. (SAYÃO, 2008, p. 7)

Sayão (2008, p. 7) lembra que surgindo no final da década de 1990, a idéia de biblioteca digital, se transformou no "paradigma de um número impressionante de iniciativas, que incluem produtos e serviços de informação digital, infra-estrutura técnica, normativa e comercial, consórcios em escala global". Para Serra (2013) a informação na nova economia une Ciência da Computação, Ciência da Informação e Tecnologia de Rede no processamento e organização do conteúdo da biblioteca digital através da interoperabilidade com protocolos, padrões e formatos. Isto porque segundo Cunha (2008, p. 5) "a biblioteca digital combina a estrutura e a coleta da informação, tradicionalmente usada por bibliotecas e arquivos, com o uso da representação digital tornada possível pela informática". Assim, para Cunha (2008, p. 4) as "novas tecnologias provocam mudanças na maneira de prover produtos e serviços informacionais aos usuários"

Contudo, Cunha (2008, p. 5) assinala que na área de Ciência da Informação, o conceito de biblioteca digital é impreciso ponderando que a "não consolidação terminológica pode advir do contexto muitidisciplinar em que a biblioteca digital se insere, desde a concepção até a efetiva implantação". Sayão $(2008$, p. 8) referindose à imprecisão e sobreposição de conceitos conclui que "não se tem um consenso estável do que seja exatamente uma biblioteca digital e das suas vinculações com a biblioteca tradicional e com a biblioteconomia", argumentando que:

O termo 'biblioteca digital' vem sendo aplicado a uma variedade extraordinária de coisas - do catálogo on-line de comércio eletrônico à coleção de programas de computadores - grande parte delas desvinculada do conceito que temos de biblioteca. A busca por uma definição mais precisa e consensual para biblioteca digital esbarra também na existência de três termos - biblioteca digital, biblioteca eletrônica e biblioteca virtual - que possuem diferentes significados, mas que são usados frequentemente para designar a mesma coisa. 
Neste ponto, é particularmente interessante a exposição que Sayão (2008, p. 9) faz de distintas visões sobre a biblioteca digital provindas de profissionais e organizações de diversas áreas do conhecimento. Assim, na biblioteconomia e ciência da informação a biblioteca digital está relacionada com a aquisição, organização e disseminação do conhecimento, possibilitando acesso simultâneo a um mesmo documento digital por vários usuários com uma nova infra-estrutura tecnológica que expande a capacidade de disseminar informação. Para os profissionais da ciência da computação a ótica é de uma extensão dos sistemas de computadores em rede. Na visão dos políticos e governantes a biblioteca digital é parte da infra-estrutura tecnológica necessária para a superação da desigualdade informacional de acesso e recurso de inclusão digital. Os editores consideram que a biblioteca digital é um novo modo de distribuição de conteúdos no mercado da publicação eletrônica. Por sua vez, para os educadores e professores a biblioteca digital é um novo recurso de aprendizado com conteúdo multimídia, interatividade e integração de informações, viabilizando o ensino à distância. Para os pesquisadores a biblioteca digital é um espaço de geração, compartilhamento e disseminação do conhecimento. Do ponto de vista empresarial as bibliotecas digitais estabelecem novo mercado global. (SAYÃO, 2008, p.10-11).

Tammaro e Salarelli (2008, p. 116) corroboram que há multiplicidade de conceitos "sem que se haja logrado chegar a um consenso". Estas autoras destacam o conceito formulado pela Digital Library Federation (DLF):

Bibliotecas digitais são organizações que fornecem os recursos, inclusive o
pessoal especializado, para selecionar, estruturar, oferecer acesso
intelectual, interpretar distribuir, preservar a integridade e garantir a
permanência no tempo de obras digitais, de modo que estejam acessíveis,
pronta e economicamente, para serem usadas por uma comunidade
determinada ou por um conjunto de comunidades (Digital Library Federation
apud TAMMARO e SALARELLI, 2008, p. 120).

As características e funções incluídas nestes conceitos, segundo Sayão (2008, p. 9) desencadearam expectativas sobre as potencialidades da biblioteca digital não só como sistema de informação, mas como "recurso estratégico dentro de contextos altamente institucionalizados como governo, educação, cidadania, negócios e pesquisa científica". De ponto de vista mais abrangente Serra (2013) assinala que a biblioteca digital é uma coleção de informações gerenciadas, com serviços associados e informações em formato digital, cujo acesso ocorre através de redes. Em outras palavras, é constituída de documentos digitalizados de diversos formatos, permitindo o controle destes em repositórios digitais, o controle de acesso remoto através de política de acesso, e a utilização simultânea do mesmo documento por vários usuários.

Tammaro e Salarelli (2008, p. 116) defendem a atuação do bibliotecário na criação e desenvolvimento da biblioteca digital: "a biblioteca como instituição e o bibliotecário para implantar serviços novos ou renovados que as bibliotecas possam tornar disponíveis". Ainda segundo as autoras a atenção "recai sobre as coleções digitais e se baseia na função de mediação das bibliotecas como instituições que contam com pessoal especializado", levando-as a concluir que: "existe agora a oportunidade de as bibliotecas usarem criticamente as tecnologias para ampliar sua função tradicional e prestar serviços mais eficazes, além de novos serviços que tendam a ampliar a clientela habitual" (TAMMARO e SALARELLI, 2008, p. 120). Na realidade, as bibliotecas atendem demandas de informação especializadas, a partir da biblioteca com sede física que usa novas tecnologias de comunicação e 
informação. No ponto de vista da Informática o forte da biblioteca digital é o documento digital e a organização dos metadados:

(...) uma coleção de documentos digitais estruturados sejam os produzidos mediante digitalização de materiais existentes sejam os preparados de modo digital na origem, dotado de uma organização total e coerente de natureza semântica e temática, que se manifesta por um conjunto de relações interdocumentais e intradocumentais de um adequado dispositivo metainformacional. Neste sentido, podemos distinguir uma biblioteca digital de um conjunto não-organizado de informações absolutamente heterogêneas como acontece na World Wide Web, mas também de muitos arquivos textuais que atualmente estão disponíveis na internet e se apresentam muito mais como 'depósitos de textos' do que como verdadeiras bibliotecas. (RONCAGLIA, 2002 apud TAMMARO e SALARELLI 2008, p. 122)

$\mathrm{Na}$ Ciência da Informação trata-se da transposição de itens de informação de uma biblioteca tradicional para a digital que segundo Tammaro e Salarelli (2008, p. 122) pode ser definida como biblioteca híbrida. Para Mazzitelli apud Tammaro e Salarelli (2008, p. 122):

(...) Podemos afirmar que a biblioteca digital é o conjunto de uma ou várias coleções de objetos digitais, da descrição desses objetos, que é feita com o emprego dos chamados metadados, colocadas à disposição de todos os usuários interessados graças a uma interação de tipo eletrônico que pode abranger diversos serviços, como a catalogação, indexação, recuperação de documentos e fornecimento de informações à distância. Nessa biblioteca todos os pedidos dos usuários e as respostas a eles se realizam, portanto, por meio da Rede. A biblioteca digital apresenta-se como um sistema complexo, organizado no qual se colocam à disposição dos usuários, de maneira estruturada conteúdos que, além de terem origem numa coleção em suporte de papel, podem já estar disponíveis em rede ou ser o resultado de uma atividade intelectual original realizada pela biblioteca

Mais uma vez, os pontos de vista se reportam a fenomenologias de distintas áreas do conhecimento, originando um enfoque multifacetado. Enquanto a ótica de outras áreas do conhecimento está centrada no polo das tecnologias de informação e comunicação vendo a biblioteca digital como depósito de informação ilimitado e operacionalizado por sistemas de informação sofisticados, que inclusive dispensam a intermediação do bibliotecário, em contrapartida, a Ciência da Informação vê a biblioteca digital como nova possibilidade de acesso à informação. De modo geral, os conceitos divergem, principalmente, no que tange ao bibliotecário como mediador. Contudo, as bibliotecas digitais desempenham função significativa na sociedade contemporânea, no acesso à informação como um bem social e, segundo Tammaro e Salarelli (2008, p. 123) os dois enfoques são complementares. O tecnológico, por se voltar para "a ampliação e melhoria da abordagem clássica das tecnologias da recuperação de informação, inclusive a estrutura dos objetos digitais e os metadados". O biblioteconômico, por se referir "ao fato de que o projeto, a estratégia e a prática da biblioteca digital devem refletir o contexto social em que se insere o usuário, junto com as necessidades e comportamentos de pesquisa do usuário real", acrescentando-se, ainda, a indiscutível necessidade da mediação do bibliotecário em todo o processo.

Estas autoras identificam como elementos da biblioteca digital:a) usuário público ou indivíduo, que a biblioteca precisa conhecer as necessidades de informação e, que deve estar apto a usar os produtos disponíveis; b) conteúdo objetos digitais organizados e estruturados nas coleções digitais segundo normas próprias e distribuídos em rede; c) serviços de acesso - interfaces ou serviços; d) profissionais e bibliotecas - produtores de conteúdos e bibliotecas como 
organizações que competem ou colaboram. Estas autoras observam que o equilíbrio entre estes elementos varia em função do maior ou menor peso atribuído na biblioteca digital às coleções e organização de metadados, ou, a tecnologias e interfaces de acesso à informação com 0 usuário, resultando em análise multidisciplinar da biblioteca digital. (TAMMARO e SALARELLI 2008, p. 122-123)

Para Serra (2013) estes elementos compreendem a coleção de objetos digitais ou repositório; os metadados como descrições destes objetos; um conjunto de usuários; e, serviços de indexação, catalogação, recuperação, arquivamento e preservação. As funções da biblioteca digital são preservar a integridade do conteúdo e garantir a permanência de coleções no tempo visando o fornecimento de documentos legíveis e acessíveis para conjuntos de comunidades. Serra (2013) enfoca a importância e as etapas de planejamento que devem ser definidas para implantar uma biblioteca digital considerando os recursos que esta propicia para selecionar, estruturar e distribuir conteúdos eletrônicos. Nas políticas de gestão Serra (2013) inclui:

a) política de digitalização - trata da seleção dos documentos e da estratégia de captura envolvendo decisões sobre seleção de documentos analógicos a serem digitalizados; geração ou compartilhamento de arquivos; critérios na ordem de digitalização; seleção de documentos digitais para inclusão na base; aquisição de e-books e periódicos eletrônicos; seleção de obras em domínio público;

b) política institucional - define a política além de estabelecer o responsável pelo projeto e aspectos da preservação digital e backup. Os documentos que compõem uma biblioteca digital são formados basicamente pela produção institucional, documentos em formato digital, documentos a ser digitalizados, obras em domínio público e conteúdo licenciado. A política propriamente dita define: b.1) tipo de conteúdo disponibilizado - textos, imagens, fotografias (éditos ou inéditos); b.2) aspectos legais - direitos autorais, domínio público, material protegido, contato com detentores de direitos (herdeiros, editoras), massa falida; b.3) Inéditos - material sigiloso disponibilização de íntegra; b.4) direito de personalidade e terceiros - correspondências, direito de imagem, fotografias; b.4) Padrões para interoperabilidade - metadados: Marc, Dublin Core etc.; protocolo: OAI-PMH;

c) infra-estrutura - inclui decisões relativas ao repositório; armazenamento; hardware e software

d) serviços oferecidos - são vantagens para a comunidade como: disseminação da informação, preservação de documentos originais, funcionamento ininterrupto, acessibilidade simultânea, diversidade de formatos, otimização de trabalho e recursos, visibilidade e divulgação da instituição.

Segundo ainda Serra (2013) nos projetos de criação da biblioteca digital há desafios no desenvolvimento e manutenção relacionados a todos os elementos do planejamento, citando-se, entre outros, custos, autenticidade, capacidade de armazenamento, volume de informações, acessibilidade, usabilidade, arquitetura da informação, novas necessidades de informação dos usuários e, avaliação e atualização constantes. Em suma, Serra (2013) enfatiza que a criação de bibliotecas digitais exige planejamento prévio e políticas institucionais com definições sobre a política de digitalização, preservação digital, infra-estrutura, serviços, padrões de interoperabilidade; escolha de ferramentas de repositório, além de política de avaliação constante. 
Percebe-se a diversidade de enfoques abordados nos conceitos de biblioteca digital com reflexos na ciência da informação e biblioteconomia, que permite uma visão ampla e complementar sobre o tema, os quais conceituam a biblioteca digital como produto, serviço e instituição. Neste ponto, concorda-se com Sayão (2008, p. 14) ao afirmar:

É necessário trazer, portanto, o debate para dentro dos limites da realidade onde atuam os bibliotecários e demais profissionais do conhecimento e onde se desenrolam pesquisa e as práticas mais importantes para a área. Localizar os possíveis atributos e propriedades das bibliotecas digitais nesse espaço de pesquisas e práticas pode ajudar a definir as vinculações das bibliotecas digitais ao universo das bibliotecas.

$\mathrm{Na}$ realização desta pesquisa considerou-se o enfoque do conceito de biblioteca digital jurídica de Passos e Barros (2009, p. 147) como fonte de informação, por se coadunar com os objetivos específicos da pesquisa na perspectiva de estudo de um produto de informação da Biblioteca Ministro Oscar Saraiva, do STJ, a Biblioteca Digital Jurídica, BDJur, que fornece conteúdo como fonte de informação jurídica e serviços agregados ao usuário, com uso de recursos tecnológicos de interatividade. Ou seja, em conformidade com Vilarino (2003) apud Serra (2013) a biblioteca digital fornece uma coleção de objetos de informação, com organização, estrutura e apresentação que suportam o relacionamento dos usuários com estes objetos de informação, de forma a permitir a consulta e acesso independente de localização física ou geográfica dos pesquisadores e dos documentos, ampliando o alcance da biblioteca e, consequentemente, da instituição mantenedora.

\section{ABORDAGENS METODOLÓGICAS NA AVALIAÇÃO DE PRODUTOS DE INFORMAÇÃO}

Tradicionalmente, nas unidades de informação não se notava a proximidade com o usuário no sentido de descobrir como a biblioteca era vista por ele, ou, sobre o conceito que o mesmo atribuía aos produtos de informação ofertados, ou ainda, sobre suas reais necessidades de informação. Dentro de uma prática predominantemente acumuladora e preservadora do acervo, que mantinha distância entre biblioteca e usuário, não havia o hábito de avaliar metodicamente o uso ou não uso, dos produtos disponíveis, com vistas a adequá-los conforme o perfil de interesse dos usuários. Contudo, o desenvolvimento científico e tecnológico e, o consequente crescimento da produção intelectual, além de fenômenos do mundo contemporâneo, a exemplo da globalização e da customização dos produtos voltados para necessidades individuais, entre outros fatores, transformou esta realidade. A biblioteca passou também a ocupar o espaço digital da Web, integrando os sistemas de informação da atualidade. Com isto, tornou-se imprescindível, além da proximidade entre biblioteca e usuário, estabelecer o convívio com este com o estudo do seu comportamento, hábitos e atitudes, buscando adequar os produtos de informação ofertados.

Tal aproximação entre biblioteca e usuário caracteriza a essência dos estudos de uso e de usuários, assim conceituado pelo Centre for Research on User Studies (CRUS) apud Metchko (1981): "o estudo do usuário é uma área interdisciplinar de conhecimento e abrange $o$ estudo do comportamento dos usuários e não usuários da informação e dos sistemas e serviços de informação, tendo por objetivo básico a interação usuário-informação". O estudo de usuário passou a ser realizado, 
posteriormente, em todos os tipos de bibliotecas, destacando-se as especializadas, devido ao papel desempenhado pelas mesmas no contexto das organizações. No âmbito deste tipo de biblioteca, considerando a informação específica que ela torna disponível, também se verifica o que Metchko (1981) assinala para as bibliotecas universitárias: "os estudos de uso e de usuários da informação científica e tecnológica constituem um dos instrumentos básicos, indispensáveis ao planejamento e avaliação dos sistemas de informação e representam uma constante da literatura biblioteconômica". Como área que se destacou no estudo de usuários, a literatura publicada caracterizando o uso e o usuário da informação científica e tecnológica, foi avaliada já na década de 1980 por Susan Grawford (1978) apud Metchko (1981), como volumosa. Metchko (1981) esclarece, ainda, que:

\begin{abstract}
Levantamentos de preferências de leitores de bibliotecas, com o objetivo de obter dados necessários à tomada de decisões administrativas quanto aos serviços disponíveis, iniciaram os estudos em questão. Os primeiros de natureza empírica, sobre usuários, foram relatados em 1948, na Royal Scientific Conference, quando J.D. Bernal apresentou os resultados de sua investigação sobre o uso de periódicos por cientistas britânicos, em vários institutos governamentais, universitários e de pesquisa privada e Urquhart investigou usuários da London Science Museum Library, visando determinar os tipos de publicações solicitadas.
\end{abstract}

Metchko (1981) acrescenta que a partir desta data, as investigações sobre o assunto proliferaram consideravelmente. Historicamente, conforme John Martyn (1974) apud Metchko (1981), esse desenvolvimento ocorreu em três períodos: trabalhos realizados na década de 1950; investigações de 1960; e, estudos sobre necessidade e usos de informação, executados a partir de 1970. O primeiro período é identificado pela preocupação com os usuários da comunidade científica e tecnológica, pela técnica comumente empregada e pela abrangência da população pesquisada. Os dados obtidos nesta década apresentam um quadro genérico das necessidades de informação dos cientistas e tecnólogos. O objetivo era exploratório e as pesquisas procuraram descrever os usuários, sem, contudo, relacionar suas características às necessidades levantadas. Os resultados em questão deveriam proporcionar bases para o planejamento de um sistema ideal de informações, mas, demonstraram, tão somente, que as necessidades e padrões de busca de informação eram complexos, extensos e variados e que, embora, as referências apresentadas pelos usuários fossem claras, o conjunto era contraditório, não permitindo, por isso, a definição de um planejamento ideal. (METCHKO, 1981)

No segundo estágio os estudos abrangentes tornaram-se raros. Os métodos foram aperfeiçoados e, segundo Herbert Menzel (1956) apud Metchko (1981), o ponto alto das pesquisas, ocorreu em 1963 devido, em parte, à introdução e aplicação da técnica do incidente crítico, para coleta de dados objetivos sobre o comportamento dos usuários. As pesquisas efetuadas nessa época foram, conforme William J. Paisley (1968) apud Metchko, patrocinadas por associações profissionais como a American Psychological Association e o American Institute of Physics. Essas associações tentavam reavaliar seus programas de informação diante do desenvolvimento tecnológico e da conseqüente explosão bibliográfica, para o que subvencionaram projetos como o American Psychological Association Project on Scientific Information Exchange in Psychology, envolvendo estudos sobre inovações na comunicação cientifica e uso da informação. No terceiro período, a partir da década de 1980, os estudos de necessidades e usos da informação são considerados interdisciplinares e dependem da colaboração de psicólogos, sociólogos e de outros profissionais das áreas do conhecimento humano. Passou-se 
a utilizar métodos diretos de observação e indiretos com análises bibliométricas, para obtenção de dados que proporcionem bases à estruturação e inovação de um sistema específico ou para solucionar uma área-problema particular. Além disso, os estudos não estavam mais restritos à ciência e a tecnologia, considerando-se nas pesquisas, populações de organização industriais, laboratórios de pesquisa e desenvolvimento, órgãos governamentais, bem como os grupos minoritários, populações urbanas e cidadãos comuns. (METCHKO, 1981)

Na realidade brasileira, Cunha (1982, p. 17) relata que "foi no início da década de setenta - a partir da influência dos cursos de mestrado do IBICT e da UFMG que apareceram as primeiras pesquisas sistemáticas na área". Cunha (1982, p. 5) aborda as metodologias para o estudo dos usuários de informação científica e tecnológica, apresentando as vantagens e desvantagens de cada método, incluindo: questionário, entrevista, técnica de Delfos, observação, diário, análise de conteúdo, análise de citações e documentos de bibliotecas. Para este autor o estudo de usuários engloba aspectos multidisciplinares não sendo fácil definir seu escopo. Segundo Wilson-Davis (1977) apud Cunha (1982, p. 5) as pesquisas sobre estudos de usuários podem ser de dois tipos: a) estudos centrados na biblioteca: a investigação de como as bibliotecas e os centros de informação são utilizados; b) estudos centrados no usuário: como um grupo particular de usuários obtém a informação necessária para conduzir o seu trabalho. Para Costa, Silva e Ramalho (2009) estas duas abordagens aplicadas aos estudos de usuário correspondem a) abordagem tradicional: estudos dirigidos ao sistema de informação; b) abordagem moderna: estudos dirigidos ao próprio usuário da informação. Estes autores reúnem as principais abordagens do paradigma centrado no usuário:

Wilson (1981) - Modelo baseado nas seguintes proposições: as necessidades de informação têm sua gênese nas necessidades básicas do sujeito, (fisiológicas, cognitivas e afetivas), logo não é uma necessidade primária, mas sim, secundária; e, diante da busca de informação para satisfazer sua necessidade, o sujeito pode deparar-se com barreiras individuais, pessoais, inter-pessoais e ambientais. Wilson propõe um novo modelo a partir do seu modelo anterior e através de um exaustivo estudo em que utilizou teorias de diferentes áreas, como a Ciência da Informação, a Psicologia, a Comunicação, dentre outras, para analisar o comportamento de busca de informação.

Dervin (1977) - Conjunto de premissas conceituais e teóricas para analisar como pessoas constroem sentido nos seus mundos e como elas usam a informação e outros recursos nesse processo. Procura lacunas cognitivas e de sentido expressas em forma de questões que podem ser codificadas e generalizadas a partir de dados diretamente úteis para a prática da comunicação e informação. (situação > lacuna >uso).

Belkin, Oddy, Brooks (1982) - A abordagem do Estado Anômalo do Conhecimento (Anomalous States of knowledge) focaliza pessoas em situações problemáticas, em visões da situação como incompletas ou limitas de alguma forma. Usuários são vistos como tendo um estado de conhecimento anômalo, no qual é difícil falar ou mesmo reconhecer o que está errado, e enfrentam lacunas, faltas, incertezas e incoerências, sendo incapazes de especificar o que é necessário para resolver a anomalia. (situação anômala > lacunas cognitiva > estratégias de busca)

Taylor (1986) - A abordagem do Valor agregado (User-values ou Value-added), de Robert Taylor (1986) focaliza a percepção da utilidade e valor que o usuário traz para o sistema. Pretende fazer do problema do usuário o foco central, identificando diferentes classes de problemas e ligando-os aos diferentes traços que os usuários estão dispostos a valorizar quando enfrentam problemas. É um trabalho de orientação cognitiva em processamento da informação. (problema> valores cognitivos> soluções). 
Ellis,(1989) e Ellis, Cox e Hall, (1993) - Modelo de comportamento de busca de informação que parte do pressuposto de que o processo de busca se dá por meio de aspectos cognitivos, constituído por etapas que não acontecem de forma seqüencial, características gerais que não são vistas como etapas de um processo. Inicialmente se baseia em seis categorias de análise: Iniciar, Encadear, Vasculhar, Diferenciar, Monitorar, Extrair. Posteriormente, esse modelo foi aperfeiçoado pelo próprio Ellis em conjunto com Cox e Hall (1993) que acrescentaram mais duas categorias ao modelo original que são: Verificar e Finalizar. Assim, o Modelo é composto por oito categorias.

Kuhlthau,(1994) - Modelo denominado de Information Search Process e se baseia no conceito de estado anômalo do conhecimento de Belkin (1982). Segundo Kulthau (1994), o Information Search Process é um modelo potencializado pela Teoria do construtivismo em que a aprendizagem de um novo conhecimento se realiza por uma construção individual e ativa e não pela transmissão. $O$ processo se desenvolve em seis estágios: Iniciação. Seleção, Exploração, Formulação Coleta e Apresentação. Cada estágio se caracteriza pelo comportamento do usuário em três campos de experiência: o emocional, o cognitivo e o físico.

Choo (2003) - Modelo que ressalta três propriedades da busca e do uso da informação: a) o uso da informação é estabelecido a partir do significado que o indivíduo lhe impõe, à luz de suas estruturas emocionais e cognitivas; b) o uso da informação é situacional. O indivíduo faz parte de um meio, profissional ou social, que afeta, diretamente, suas escolhas para o uso da informação e c) o uso da informação é dinâmico, interagindo com os elementos cognitivos, emocionais e situacionais do ambiente, que impulsionam o processo de busca da informação, modificando a percepção do indivíduo em relação ao papel de informação e os critérios pelos quais a informação é julgada. sob um dado assunto. A busca se caracteriza por um processo implementado pelo indivíduo para modificar o estágio anterior.

(COSTA, SILVA E RAMALHO, 2009)

Não obstante o desenvolvimento interdisciplinar e aplicação de métodos e metodologias de estudos de usuários prosseguirem ao longo do tempo, incluindo no seu bojo o objetivo específico de avaliar produtos e serviços de informação, Suaiden (2011b, p. 33) observa que, ainda neste novo século, "geralmente o usuário não faz parte do processo de tomada de decisão", observando-se, de forma geral, a predominância dos dois enfoques nas abordagens de metodologias de estudos de necessidades de informação do usuário, que, em última análise, orientam a oferta de produtos e serviços nas unidades de informação. Na Ciência da Informação, Choo (2006) apud Suaiden (2011b, p. 33) mapeou estas abordagens esclarecendo que:

$\mathrm{Na}$ orientação focada no sistema, a informação é vista como algo objetivo, determinada por si própria e, portanto, independente do indivíduo. Nas pesquisas com essa orientação, examina-se como a informação flui pelos sistemas e como podem ser facilitados o acesso e o compartilhamento da informação. Já a orientação focada no usuário parte da premissa de que a informação é uma construção individual, subjetiva, que acontece na mente das pessoas, isto é, nos usuários de sistemas. Uma mesma informação objetiva pode ter várias interpretações, uma vez que essas se originam de concepções subjetivas, que apresentam quadro conceitual prévio e experiências distintas.

Por sua vez, Oliveira e Suaiden (2011) apud Suaiden (2011b, p. 34) acrescentam que as abordagens "focadas no usuário investigam necessidades cognitivas e psicológicas dos indivíduos e como estas afetam a busca, o uso e a forma de transferência e disseminação da informação". Suaiden (2011b, p. 34) acrescenta que "notadamente, um fator determinante é o capital intelectual do indivíduo" considerado usuário crítico do sistema: 
Os usuários têm capacidade de avaliar a informação, criticá-la e até mudar o próprio conceito informacional, e geralmente agregam valor à informação. Essa nova mentalidade de foco no usuário vem se tornando prioritária em todas as atividades do Instituto Brasileiro de Informação em Ciência e Tecnologia (IBICT).

Com a missão de desenvolver redes, sistemas e serviços de informação científicos e tecnológicos no Brasil, o IBICT visando adequar seus produtos e serviços às reais necessidades dos usuários, desenvolveu e disponibilizou para outras organizações uma metodologia inovadora de avaliação, que permite fazer o uso integrado de abordagens qualitativas e quantitativas consolidadas e de padrões heurísticos de usabilidade, na análise dos produtos e serviços de informação, de modo não viabilizado por outras metodologias de avaliação. Isto confere maior capacidade avaliativa em relação às metodologias de estudos de usuários existentes, porque congrega o foco no usuário com os requisitos tecnológicos dos produtos de informação na Web, obtendo-se um conjunto de dados e informações mais amplo e detalhado sobre o uso dos produtos de informação, a partir do relacionamento destes fatores.

\subsection{Métodos qualitativos e quantitativos de avaliação de produtos de informação}

Segundo Minayo (1993, p. 247), no contexto da comunicação o significado e os limites da linguagem matemática e da linguagem empírica são relevantes na formação de metodologias de avaliação quantitativa e qualitativa, respectivamente.

A primeira atua em níveis da realidade, onde os dados se apresentam aos sentidos. A segunda trabalha com valores, crenças, representações, hábitos, atitudes e opiniões. A primeira tem como campo de práticas e objetivos trazer à luz dados, indicadores e tendências observáveis. Deve ser utilizada para abarcar, do ponto de vista social, grandes aglomerados de dados, de conjuntos demográficos, por exemplo, classificando-os e tornando-os inteligíveis através de variáveis. A segunda adequa-se a aprofundar a complexidade de fenômenos, fatos e processos particulares e específicos de grupos mais ou menos delimitados em extensão e capazes de serem abrangidos intensamente (MINAYO, 1993, p. 247).

Ainda com base em indagação de Minayo (1993, p. 247), do ponto de vista epistemológico, nenhuma das duas abordagens é mais científica que a outra: "De que adianta ao investigador utilizar instrumentos altamente sofisticados de mensuração quando estes não se adequam à compreensão de seus dados ou não respondem a perguntas fundamentais?" Ou seja, uma pesquisa, por ser quantitativa, não se torna "objetiva" e "melhor", ainda que manipule sofisticados instrumentos de análise, caso deforme ou desconheça aspectos importantes dos fenômenos ou processos sociais estudados. Da mesma forma, uma abordagem qualitativa em si não garante a compreensão em profundidade dos fenômenos. Isto leva repensar a abordagem quantitativa como correta ou classificar estudos qualitativos como "subjetivismo", "impressões" ou, "atividades exploratórias". É necessário utilizar todo o arsenal de métodos e técnicas que ambas as abordagens desenvolveram ao serem consideradas científicas. No entanto, a relação entre quantitativo e qualitativo, entre objetividade e subjetividade não pode ser pensada como antagonismo. Pelo contrário, para que as relações sociais sejam analisadas em seus aspectos "ecológicos" e "concretos" e, aprofundadas em seus significados essenciais, o estudo quantitativo pode gerar questões para serem aprofundadas qualitativamente, e viceversa. 
De acordo com Costa, Silva e Ramalho (2009), "as pesquisas com usuários da informação iniciam-se com os métodos quantitativos, afeitos a coleta de dados indireta (em relação aos usuários), que possibilita os estudos de citação, de referências, entre outros", como a bibliometria. Posteriormente, estes autores relatam que:

Surge a pesquisa qualitativa como uma alternativa para se realização de estudos de usuários, para possibilitar novas formas de teorizar sobre esses estudos. Podemos considerar a pesquisa qualitativa, como uma tendência emergente nos estudos de usuários. Sem querermos considerar menos importante a abordagem tradicional de estudo de usuários, vemos, como imperativo, uma mudança de foco nos estudos de usuários. O uso de métodos da pesquisa qualitativa se faz necessário para que esses estudos se insiram em contextos comportamentais e organizacionais espelhando-se, assim, nos métodos de pesquisa social que proporcionam metodologias apropriadas para o estudo do comportamento humano na busca de informação. (COSTA, SILVA E RAMALHO, 2009)

Conforme estes autores:

os estudos modernos contemplam uma visão holística e cognitiva. A primeira considera os aspectos cognitivos, afetivos e psicomotores da busca de informação e a segunda procura identificar como os usuários processam a informação e o que constitui um modelo apropriado para representar esse processo. (COSTA, SILVA E RAMALHO, 2009)

\subsection{Abordagem Sense-Making de Brenda Dervin}

Brenda Dervin é graduada em Comunicação Social e pós-graduada em Ciência da Informação. Formulou a metodologia Sense-Making em 1972, como abordagem inicialmente aplicada na área de comunicação e, posteriormente, na Ciência da Informação. Como pesquisadora redimensionou estudos sobre o usuário com foco na necessidade e uso da informação. O reconhecimento das descobertas de Dervin a tornou referência na pesquisa sobre estudos de usuários em sistemas de informação e comunicação, em organizações públicas e privadas, dentre as quais as bibliotecas, com inúmeras citações desde a década de 1970. A metodologia Sense-Making tinha por objetivo analisar a interação entre ser humano e sistemas de informação, ou homem-máquina, consolidando-se na década de 1980, com estudos teóricos e pesquisa de campo. De acordo com Rocha e Souza (2011, p. 19) a metodologia foi apresentada ao público, por Brenda Dervin, em 1983, na International Communications Association Annual Meeting, em Dallas, Estados Unidos. Nesta época, Araújo, Pereira e Fernandes (2009, p. 57) relatam que as temáticas abordadas por Dervin, antes da aplicação da metodologia na Ciência da Informação, estavam relacionadas à pesquisa em Comunicação, abrangendo a comunicação participativa e campanhas de comunicação pública.

Em 1997, Dervin esteve no Brasil, durante a realização de um workshop intitulado "Design de bibliotecas virtuais centrado no usuário: a abordagem sensemaking para estudos de necessidades e comportamento de busca e uso da informação", realizado na Escola de Comunicações e Artes da Universidade de São Paulo (ECA/USP). A proposta desta iniciativa, segundo Ferreira (1997, p. 3) era "apresentar e discutir usos e implantações de abordagens sistêmicas, interpretativas para estudos de usuários e parâmetros norteadores para o design e avaliação de bibliotecas virtuais, partindo dos resultados obtidos com tais estudos". Ademais, havia o objetivo, conforme Ferreira (1997, p. 3) de "motivar estudos e criar uma massa crítica sobre o tema em nível nacional", resultando na capacitação de 
representantes das Coordenadorias Regionais da Associação Brasileira de Escolas de Biblioteconomia e Documentação (ABEBD) e de cursos de pós-graduação em Ciência da Informação (Ancib), para difusão da abordagem. O programa de trabalho contemplava, entre outros assuntos, as necessidades de informação, o processo de produzir sentido e como projetar estudos usando a abordagem Sense-making. (FERREIRA, 1997, p. 3)

Cabe ainda, acrescentar que este workshop representou um marco na divulgação, conhecimento e discussão da metodologia Sense-Making por pesquisadores de várias instituições brasileiras. Com isso, houve grande impacto e mudanças tanto na concepção de produtos de informação como, principalmente, na adoção de novas posturas teóricas e metodológicas para realização de estudos de usuários da informação. Segundo Araújo, Pereira e Fernandes (2009, p. 58):

A metodologia Sense-making tem sido usada na área de Ciência da Informação, inclusive no Brasil, em estudos sobre necessidades, interesses e usos dos meios de comunicação, informação, sistemas de comunicação e mensagens de usuários. (...) Esta abordagem considera a informação como sendo uma construção do sujeito a partir de suas experiências sociais, culturais, políticas e econômicas. Neste sentido, a informação é subjetiva e só se torna significativa no contexto no qual está inserida.

Ferreira (1997, p. 2) complementa:

Dentre as atuais metodologias de estudos de usuários, a mais completa e abrangente com grandes números de adeptos em todo o mundo é a abordagem Sense-Making Approach. (...) Ao definir, amplamente, em termos de uma série de suposições ontológicas e epistemológicas, como a atividade humana de observações, interpretação e compreensão do mundo exterior, inferindo-Ihe sentidos lógicos advindos do uso dos esquemas interiores, Dervin define esta atividade tanto como um comportamento interno (cognitivo), como externo (atitudes, reações em face do meio social) que permite ao indivíduo construir e projetar seus movimentos, suas ações através do tempo e espaço. A busca e uso da informação, portanto, é central para tal atividade.

Tal atribuição de sentido é vista por Piovesan (1977) apud Ferreira (1995, [p. 1]) como atividade subjetiva e coletiva:

A interação social e a organização social são possíveis pela existência de significados culturalmente compartilhados. Entretanto, a significação subjetiva do comportamento de outras pessoas é determinada por sua experiência pessoal passada, bem como pelos seus significados interiorizados, culturalmente definidos. Daí, o significado de uma situação social variar de uma pessoa para outras, inclusive na mesma cultura. Cada participante pode ter significados subjetivos que são únicos, mas, ao mesmo tempo têm significados compartilhados que tornam a interação e comunicação possíveis.

Araújo, Pereira e Fernandes (2009, p. 59) esclarecem que a expressão Sense Making foi concebida por Dervin, em 1983, com dois sentidos:

a) refere-se ao objeto de estudo, ao processo empírico por meio do qual os usuários atribuem sentido às situações em que se encontram, ou seja, de ausência de informação, ou lacuna cognitiva, de necessidade de informação, vivenciadas e do processo de busca à informação, bem como às informações que o usuário encontra, utiliza e das quais se apropria; b) refere-se à forma de estudar o comportamento informacional dos usuários, ou seja, ao tipo de metodologia para analisar os processos pelos quais os usuários atribuem sentido às situações em que se encontram e às informações que utilizam. 
Em função disso, Araújo, Pereira e Fernandes (2009, p. 59) explicam que esta metodologia estabelece categorias ou tipos ideais de situações de necessidade, busca e uso da informação, "aplicadas na realidade diversa e descontínua das vivências e atividades dos usuários". Pode-se então depreender tratar-se de uma abordagem que investiga a natureza subjetiva da necessidade, e das reações de atribuição de significado num determinado momento, no processo de busca e uso da informação, tema que no século XXI motra-se tão relevante como acesso à informação e sistema de informação. Esta investigação da subjetividade contida na situação de necessidade, busca e uso da informação levou Ferreira $(1997$, p. 2) a afirmar que:

O ser humano raramente busca informação com um fim em si mesmo. Ao
contrário, ela é parte de um processo de tomada de decisão, solução de
problemas e/ou alocação de recursos. Portanto, qualquer tentativa de
descrever padrões de busca de informação deve admitir o indivíduo
como o centro do fenômeno e considerar a visão, necessidades,
opiniões e problemas desse indivíduo como elementos significantes e
influentes que merecem investigação, quer seja para o desenvolvimento
de produtos em ambiente eletrônico, ou não. (grifo nosso)

Com esta abordagem, é possível constatar e evidenciar as condições imprescindíveis de cunho essencialmente subjetivo, por parte do usuário - e que cada biblioteca deve identificar - tanto para a oferta de produtos de informação, como para avaliação e controle de eficácia dos mesmos, associado ao desenvolvimento tecnológico e social da sociedade da informação. Ferreira (1997, p. 2) comprova isto, afirmando que:

As tecnologias emergentes oferecem oportunidades para melhorar o
ambiente o gerenciamento de informações, os serviços e a colaboração
interna e externa, bem como de oferecer serviços de acordo com a
conveniência dos usuários traduzindo relevantes informações. Para isto,
todavia, é exigido atualmente que o planejamento de toda e qualquer
atividade de informação seja feito com base em pesquisas centradas nos
indivíduos, partindo-se de uma perspectiva cognitiva, buscando interpretar
necessidades de informação tanto intelectuais quanto sociológicas.

No que se refere, à expressão Sense-Making, o processo individual de necessidade, busca, atribuição de sentido e uso da informação, como fundamento desta metodologia de abordagem, levou Bax e Dias (1997) apud Gonçalves (2012) a traduzi-la como "Construção de Sentido", o que se coaduna com o pensamento de Dervin (1983) apud Ferreira (1997, p. 3), quando afirma que a metodologia SenseMaking "(...) considera o processo humano criativo de compreensão do mundo em um ponto particular no tempo e espaço, limitado pela capacidade psicológica e, ainda, dos acontecimentos presentes, passados e futuros de cada indivíduo." Ferreira (1997, p.2) revela, todavia, que:

A base conceitual do Sense-Making foi desenvolvida com suporte na teoria de vários estudiosos, como Bruner \& Piaget (cognição), Kuhn \& Habermas (constrangimento das ciências tradicionais e alternativas), Ascroft; Beltran \& Rolins (teórica crítica), Jackins \& Roger (teoria psicológica) e principalmente em Carter, teórico da comunicação, afirmando que o homem cria ideias para transpor as lacunas que lhes são apresentadas em decorrência da descontinuidade sempre presente na realidade. (FERREIRA, 1997)

Agarwal (2012, p. 9) extraiu de Dervin (2003) a ilustração da abordagem Sense-Making: 


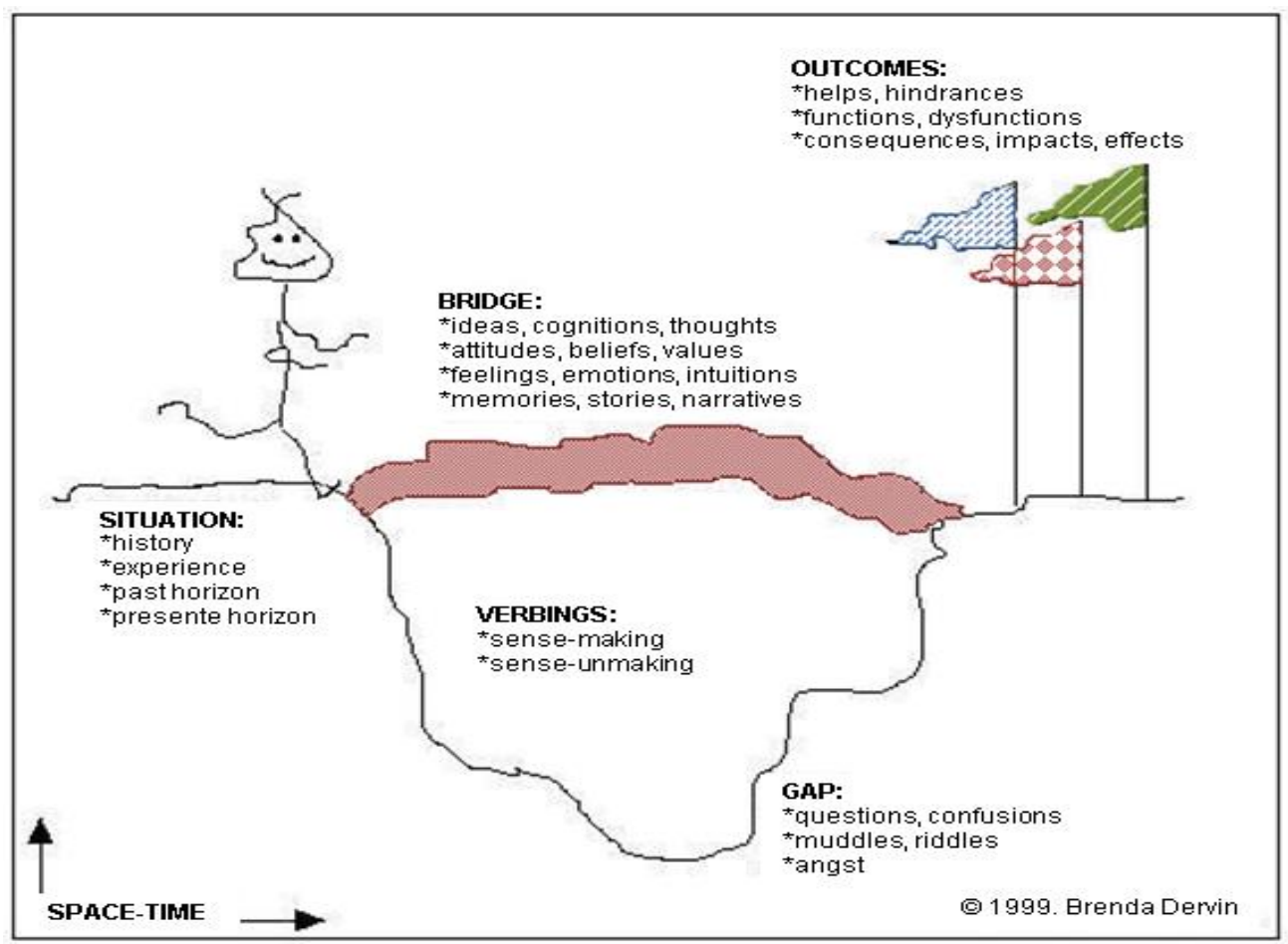

Fig.1 - Metáfora central da Abordagem Sense-Making. (Adaptado de Agarwal, 2012, p. 9)

Gonçalves (2012, p. 6) explicita o significado da ilustração:

Dada uma determinada situação de busca de informação, os pontos:

- S (situação) - conjunto de ideias e conceitos influenciados por restrições, contexto, experiências e história do indivíduo.

- G (lacuna) - problemas ou lacunas do tipo questões, confusões, angústia que impedem que o indivíduo desempenhe a atividade que necessita.

- B (ponte) - conceitos ou ideias que ajudarão a cruzar a ponte sobre as lacunas, ou seja, resultados, consequências, impactos, efeitos, usos e utilidades, com atribuição de sentido e valor pelo individuo,

- $\mathbf{O}$ (uso) - ideias formadas, conclusões alcançadas, emoções e sentimentos que formam a ponte sobre as lacunas.

Em resumo pode-se pensar que a situação é o contexto formado pelo local e espaço de tempo, representando o momento e forma na qual a necessidade de determinada informação surge; a lacuna ou gap pode ser a ausência, parcialidade ou desatualização da informação, bem como questões e indagações do indivíduo ou da sociedade, barreira a ser ultrapassada através de pontes cognitivas - produtos de informação impressos ou digitais ou, outros indivíduos - que ao possibilitar a atribuição particular de sentido, produzem como resultado final uma modificação causada entre o grau de conhecimento anterior e posterior à situação ou, necessidade de informação; por sua vez, o uso é o emprego dado ao conhecimento recém-adquirido, de acordo com o significado que lhe foi atribuído, consistindo na informação certa, útil ou relevante para dada situação.

Baptista e Cunha (2007, p. 175) analisando o pensamento de Dervin se referem ao aspecto metafórico da abordagem sense-making, que permite ver como condição humana, possuir determinado nível ou grau de conhecimento sobre qualquer assunto, sempre a completar ou agregar, em qualquer etapa do transcurso da vida e, em todo o lugar em que estiver. Isto em suma traduz um processo 
interdependente entre informação e ser humano, onde a criação de informação e o sentido que ela tem para indivíduo e sociedade é uma dinâmica que ocorre continuamente na trajetória de vida de cada um, traduzido por Dervin no trinômio situação, lacuna e uso:

Dervin explica que o sense-making promove uma forma de pensar sobre a diversidade, complexidade e a incompletude, utilizando a metáfora de um ser humano atravessando pelo tempo e espaço, caminhando com uma instrução parcial, encontrando lacunas, construindo pontes, avaliando achados e se movendo. (BAPTISTA e CUNHA 2007, p. 175)

A ilustração da continuidade e descontinuidade da necessidade e busca de informação, na metáfora de Dervin é analisada por Ferreira (1995, [p. 2]):

\begin{abstract}
O ser humano move-se na vida questionando, encontrando barreiras, deparando-se com dilemas, envolvendo-se em confusões, sonhando, indo à procura de algo, lidando com desordens, passando o tempo, descansando, recuperando-se ou buscando felicidade. Isso, dentro de uma realidade a qual segundo Carter (1980) é repleta de descontinuidades. Descontinuidade entre a realidade e os sensores humanos, entre os sensores e a mente, entre a mente e a 'língua', entre a língua e a mensagem criada, entre a mensagem criada e o canal utilizado, entre um ser humano agora e o mesmo daqui a instantes, entre diferentes seres humanos no mesmo intervalo de tempo, entre seres humanos e cultura, entre seres humanos e instituições, entre duas ou mais instituições, entre duas ou mais nações e assim por diante. Descontinuidade é uma constante assumida da natureza em geral e da condição humana especificamente.
\end{abstract}

Diante disto, Ferreira (1995, [p. 3]) acrescenta que o "comportamento de busca e uso de informação são também modelados pelo estilo cognitivo do indivíduo", sendo necessário examinar os "fatores que geram o encontro do usuário com os sistemas de informação ou as consequências de tal confronto". Isto significa, com base no pensamento de Ferreira (1995, [p. 3]) que, as bibliotecas não podem focar sua oferta de produtos de informação voltada unicamente para a "localização de fontes de informação" e sim no significado da busca de informação, levando "em consideração as tarefas de interpretação, formulação e aprendizagem envolvidas no processo de busca de informação" pelo usuário. Ferreira (1997, p. 2) transcreve as funções da metodologia de Brenda Dervin afirmando que a mesma se "propõe avaliar como pacientes/audiências/usuários/clientes/cidadãos percebem, compreendem, sentem suas interações com instituições, mídias, mensagens e situações" e usam a informação no processo-fenômeno do Sense-Making, cujo foco é o usuário da informação. Vale observar que a metáfora do Sense-Making é considerada por Cheuk, (1999) como forma de organizar o processo cognitivo humano na necessidade e busca de informação. Miranda (2006) apud Gonçalves (2012, p. 6) apresenta um quadro comparativo com outros autores que trabalharam com a abordagem da construção de sentido, adicionando, ainda, outras abordagens com enfoque no usuário, como mostra o Quadro 1: 
QUADRO 1 - Características de abordagens com foco no usuário*

\begin{tabular}{|c|c|c|}
\hline Abordagem & Autores & Características \\
\hline $\begin{array}{c}\text { Valor agregado } \\
\text { (User-Values ou } \\
\text { Value-Added) } \\
\text { (1984) }\end{array}$ & $\begin{array}{lr}\text { Taylor, } & \text { MacMullin, } \\
\text { Hall, } & \text { Ford, } \\
\text { Garvey, } & \text { Mohr, } \\
\text { Paisley, } & \\
\text { Farradane } & \end{array}$ & $\begin{array}{l}\text { Foco - Percepção da utilidade e valor que o usuário } \\
\text { traz para o sistema. Pretende fazer do problema do } \\
\text { usuário o foco central, identificando diferentes } \\
\text { classes de problemas e ligando-os aos diferentes } \\
\text { traços que os usuários estão dispostos a valorizar } \\
\text { quando enfrentam problemas. É um trabalho de } \\
\text { orientação cognitiva em processamento da } \\
\text { informação. } \\
\text { (problema > valores cognitivos > solução) }\end{array}$ \\
\hline $\begin{array}{l}\text { Construção de } \\
\text { sentido } \\
\text { (Sense-Making } \\
\text { Approach) } \\
(1977,1983,1993, \\
1994)\end{array}$ & $\begin{array}{l}\text { Dervin, } \\
\text { Edelstein, Graser, } \\
\text { Stamm, Atwood, } \\
\text { Palmor, Carter, } \\
\text { Dewdney, Waner, } \\
\text { Chen, } \\
\text { Hernon }\end{array}$ & $\begin{array}{l}\text { Foco - Conjunto de premissas conceituais e } \\
\text { teóricas para analisar como pessoas constroem } \\
\text { sentido nos seus mundos e como elas usam a } \\
\text { informação e outros recursos nesse processo. } \\
\text { Procura lacunas cognitivas e de sentido expressas } \\
\text { em forma de questões que podem ser codificadas e } \\
\text { generalizadas a partir de dados diretamente úteis } \\
\text { para a prática da comunicação e informação. } \\
\text { (situação > lacuna cognitiva/sentido > uso) }\end{array}$ \\
\hline $\begin{array}{c}\text { Anomalia } \\
\text { cognitiva } \\
\text { (Anomalous } \\
\text { States-of } \\
\text { Knowledge) } \\
(1978)\end{array}$ & $\begin{array}{l}\text { Belkin, Oddy, } \\
\text { Ofori-Dwunfuo }\end{array}$ & $\begin{array}{l}\text { Foco - pessoas em situações problemáticas, em } \\
\text { visões da situação como incompletas ou limitadas } \\
\text { de alguma forma. Usuários são vistos como tendo } \\
\text { um estado de conhecimento anômalo, no qual é } \\
\text { difícil falar ou mesmo reconhecer o que está errado } \\
\text { e enfrentam lacunas, faltas, incertezas e } \\
\text { incoerências, sendo incapazes de especificar o que } \\
\text { é necessário para resolver a anomalia. } \\
\text { (situação anômala > lacuna cognitiva > } \\
\text { estratégia de busca) }\end{array}$ \\
\hline
\end{tabular}

${ }^{*}$ Fonte: Miranda apud Gonçalves (2012, p. 7)

Gonçalves $(2012$, p. 7) reforça a tendência de realização de pesquisas com foco no usuário e sistemas de informação, a exemplo da avaliação de produtos de informação, ou interação do usuário com a interface dos sites de bibliotecas:

Podemos perceber que nesta primeira década do século XXI, os estudos de usuários estão voltados tanto para o comportamento informacional, quanto para avaliação de satisfação e desempenho, enfatizando a relação entre usuários e sistemas de informação interativos, no contexto social das tecnologias de informação e comunicação.

Nesta linha de pensamento, Venâncio e Nassif (2008, p. 97) ao aplicarem a abordagem de Dervin, num estudo sobre o comportamento de busca de informação por líderes organizacionais, indicam que tais tendências pressupõem:

a) As situações experienciadas pelos indivíduos em um contexto temporal e espacial no qual surgem as necessidades de informação influenciadas pela experiência e pelas histórias de vida do indivíduo;

b) Os gaps cognitivos enfrentados (necessidades de informação, questões que as pessoas têm quando constroem sentido e movem-se através do tempo-espaço) que são representados pelas angústias, desordens, confusões; 
c) O uso da informação, ou seja, as pontes ou estratégias construídas (ideias, pensamentos, atitudes) para superação dos gaps.

Com base na metáfora do ser humano interagindo num mundo de instabilidade entre necessidades e lacunas de informação, Ferreira (1995, [p.2]) reflete que:

Para a garantia de sua movimentação contínua ante essa realidade permeada de descontinuidade, o ser humano lança mão continuamente [de] esquemas interiores. As transformações materializadas no uso sucessivo de esquemas são movidas pela existência de questões surgidas a partir do esgotamento dos esquemas presentes. À medida que esses esquemas se tornam inoperantes, a busca de novos se impõe. Tal busca está associada à informação.

No histórico da abordagem Sense-Making, Rocha e Souza (2011, p. 20) afirmam que ela foi aplicada nos Estados Unidos para avaliação de serviços na área da saúde e desenvolvimento de sistemas de informação corporativos a partir das reais necessidades dos usuários. Ferreira $(1997$, p. 2) adianta que em âmbito internacional:

\begin{abstract}
Dervin e seus seguidores têm verificado a crescente adoção desta abordagem, tanto nas áreas de comunicação, informação e biblioteconomia, como na educação, assistência social, psicologia, medicina e outras. Tem sido empregada com estudos desenvolvidos com amostras desde 20 a cerca de 1000 elementos - principalmente teses de doutoramento, pesquisas acadêmicas, projetos encomendados e estudos empíricos. De maneira geral, as aplicações abrangem grande quantidade de contextos (em pesquisas de opiniões públicas sobre política, processos de comunicação na área de saúde, estudos acerca de imagens organizacionais, recepção de audiência e, recentemente, sobre uso de telecomunicações) e a uma variedade de níveis analíticos (individual, grupal, organizacional, comunitário, cultural).
\end{abstract}

No Brasil tem sido principalmente aplicada em estudos acadêmicos. A esse respeito, Gonçalves (2012, p. 8-9) fez uma pesquisa bibliográfica, encontrando inúmeros trabalhos realizados na área de Ciência da Informação, no país, que utilizaram a metodologia Sense-Making, na primeira década do século XXI, com diferentes objetivos como investigar comportamento de busca de informação por gerentes de organizações (Venancio e Nassif, 2008); para gerenciar a informação de forma eficaz (Lira, 2007; Cândido, 2007; Araújo e Barros, 2007); na análise de mudanças no serviço de referência sob o impacto das novas tecnologias de informação (Alves e Faqueti, 2002); no estudo da interface com o usuário, sob a perspectiva da interação homem-computador (Costa e Ramalho, 2010; Pereira, 2002), e outros. Cabe ainda acrescentar que Gonçalves (2012, p. 8-9) menciona um estudo de Ferreira e Reis (2008) de análise do perfil do profissional de arquitetura de informação no Brasil como pesquisa de enfoque qualitativo (entrevistas usando a abordagem Sense-Making) e quantitativo (questionário on-line). Para Gonçalves (2012, p. 9):

A intenção do sense-making é fornecer orientações gerais para assegurar que o diálogo seja incentivado em todos os aspectos da comunicação. É uma metodologia para a prática comunicacional. Dar voz ao usuário, quando se quer entender as necessidades e usos que estes indivíduos fazem com a informação, permite a criação de uma comunicação dialógica. A base teórica para a construção desta metodologia de pesquisa, por ter buscado referência na ciência da cognição, na teoria crítica, na terapia psicológica e, principalmente, na teoria da comunicação, demonstra que a 
informação não é algo que exista independente e externamente ao ser humano. Pelo contrário, a informação é um produto da observação humana.

Gonçalves (2012, p. 9) pondera, ainda que:

As redes sociais na internet $\mathrm{e}$ as mídias sociais têm permitido maior participação das pessoas na construção da informação. Como a metodologia é um modo de tratar a necessidade de informação, com base na relevância, ou seja, na informação que produz sentido, o sense-making ganha espaço, por exemplo, para ser aplicado em pesquisas que analisam a informação e o comportamento do usuário no uso de plataformas sociais digitais.

Contudo, Borges (2005, p. 79) comparando diversas abordagens de cognição humana com aplicação no estudo de usuários da informação, mesmo reconhecendo o valor da abordagem Sense-Making, considera-a individualista:

A abordagem sense-making apresenta uma identificação significativa com as abordagens mais recentes sobre o conhecimento ao considerar que a visão de mundo do indivíduo é uma construção subjetiva relacionada com o seu momento. Entretanto, sense-making ainda carrega em suas bases o representacionismo e o computacionismo por basear-se na ideia de que a informação resolve 'gaps' de conhecimento. Além disso, essa abordagem centra-se no processo cognitivo considerando somente o indivíduo subjetivo.

Porém, ao prosseguir em suas conjecturas, pondera que:

Ainda que os usuários da informação experienciem relações e interações sociais vivem ao mesmo tempo experiências individuais. Isto significa que mesmo participando de domínios de ação [empresa, família, lazer, amigos, etc] que influenciam o seu comportamento, há condutas que são exclusivas de cada indivíduo que devem também ser consideradas ao observá-los como usuários da informação.

E, admite que a base cognitiva das abordagens de estudo de usuário, incluindo a abordagem de Dervin, possibilita que características individuais de necessidade, busca e uso da informação do usuário venham à tona, redirecionando a concepção do produto de informação, bem como a forma de realizar a avaliação dos produtos de informação, de uma perspectiva efetivamente mais próxima do usuário:

A perspectiva cognitiva contemporânea oferece a possibilidade de considerarmos não somente os aspectos que são levados em conta pelos estudos de usuários, que têm subjacentes os princípios cognitivos tradicionais, mas outras questões também importantes e provavelmente mais difíceis de serem observadas. É importante observar as condutas (rotina de trabalho, hábitos, etc.) dos indivíduos no domínio da ação, contexto social ou ainda, na situação específica em que estão sendo observados (escola, trabalho, família); os contatos que estabelecem no cotidiano, como e porque eles ocorrem; as pré-disposições e interesses relacionados ao domínio de ação no qual estão sendo observados (assuntos relacionados, publicações específicas, etc.) e a pré-disposição para utilizar os recursos de informação que podem ser pertinentes para um contexto ou situação específico. (BORGES, 2005, p. 80). (grifo nosso)

Cabe concluir, com o pensamento de Gonçalves (2012, p. 9):

Em uma sociedade que está cada vez mais interconectada, os sistemas de informação e as mídias digitais passam a incluir o usuário nas suas criações. Usado em entrevistas qualitativas ou quantitativas, o SenseMaking permite que instituições possam usar esta metodologia para aprender o que não sabiam e poder mudar suas expectativas. As pessoas, 
neste caso, ficam em primeiro plano. Ouvi-las, portanto, contribui para a formação de sistemas de informação interativos mais eficazes. (grifo nosso)

Ferreira (1995, p. [8]) igualmente evidencia que, desde a década de 1990, a mudança de foco na oferta e avaliação de produtos de informação possibilitou a proximidade com o usuário no processo de busca e uso final da informação.

Diante do exposto, percebe-se claramente que o necessário, hoje, não é simplesmente alterar os focos das pesquisas, estudos e avaliações dos sistemas. Exige-se uma mudança mais profunda. Mudança, na verdade na maneira que os profissionais da área visualizam a natureza de seus serviços. O ponto crítico deixa de ser quem usa sistemas de informação e com que frequência e passa a ser com que propósitos os sistemas são utilizados e com ele efetivamente ajudam. Somente assim começaremos a pensar em termos de necessidades de informação e usos da informação.

\section{Por último, Morris $(1994$, p. 15) reúne os aspectos principais da abordagem Sense-Making: \\ O modelo do Sense-making reconhece que a busca de informação envolve um processo cognitivo interno, compreendendo não só aspectos intelectuais, mas emocionais (atitudes, reações em face do meio social). Ele vê a informação como subjetiva, situacional, holística e cognitiva: em resumo, construtivista. O usuário, por sua vez, é visto não como um receptor passivo de informações, mas como um centro ativo.}

Trata-se então, de uma abordagem que partindo da análise de situações peculiares, pensamentos, ações e reações do usuário, prognostica tendências e padrões comuns, extensivos a um contexto coletivo. Isso porque na trajetória de incertezas e tentativas subjetivas do processo cognitivo e de atribuição de sentido próprio a cada individuo, pode-se obter uma padronização a ser aplicada coletivamente.

\subsubsection{O Micro moment time line interview}

De acordo com Cruz e Cunha [et al] (2011, p. 213) além da metáfora de construção de sentido para descrever o comportamento de busca e uso da informação, Dervin (1983) apud Ferreira (1997, p. 3) criou, um modelo de entrevista, a ser realizada no uso da abordagem Sense-Making, para coleta de dados e operacionalização dos conceitos do modelo, chamado de Micro momento cronológico (ou Micro-moment time line interview). Sobre isto, Rocha e Souza (2011, p. 21) esclarecem que o Micro-moment time line interview é um tipo de entrevista que investiga um momento específico de uma situação no qual o entrevistado viveu ou teve participação ativa. Esse momento deve ser detalhado passo-a-passo pelo entrevistado, compreendendo as forças que o impulsionaram a avançar na direção de seus objetivos e, aquelas contrárias ao movimento. Rabelo (2008, p. 82) esclarece que o "micro-momento" destaca a "necessidade de práticas comunicativas para a coleta de dados". Traduzindo o texto de Dervin e Nilan (1983, p. 10) este autor assinala que o Micro moment:

Envolve questionar ao entrevistado, detalhadamente, o que aconteceu passo a passo em uma situação em termos do que aconteceu primeiro, segundo, depois e assim por diante. Na sequência, em cada etapa, o entrevistado é perguntado sobre quais questões ele, ou ela, teve quais as coisas que esperava ou necessitava encontrar, o que aprendeu, ou 
entendeu se ficou confuso ou mais claro. (DERVIN, 1983 apud RABELO, 2008, p. 82)

Referindo-se aos procedimentos adotados na condução da entrevista com o Micro moment, Dworking [et al] (1999) apud (Rabelo, 2008, p. 82) assinalam que:

A metodologia do Sense-Making recomenda que para entrevistas em grupo e individuais sejam formuladas questões simples e universais tais como: 0 que aconteceu? $O$ que você pensou, sentiu, concluiu sobre o que aconteceu? $\mathrm{O}$ que 0 confundiu? Como esses pensamentos, sentimentos, conclusões se relacionam com sua vida até aqui? $\mathrm{O}$ que espera para adiante? O que impulsiona ou limita seu mundo?

Ademais, (Dervin, 2001) apud (Rabelo, 2008, p. 82) considera que a entrevista no Micro moment:

Estimula os entrevistados a investigar seu mundo, a fazer conexões entre experiências passadas e presentes. O processo de interpretação de leitura e posterior tentativa de recuperação de mensagens, a evocação, por intermédio da investigação de 'como' e das circunstâncias de evocação contemplam essa dimensão.

\subsection{A Técnica do Incidente Crítico de John Flanagan}

A Técnica do Incidente Crítico foi criada e desenvolvida inicialmente na área de Psicologia, e segundo Flanagan (1973, p. 99):

Consiste em um conjunto de procedimentos para a coleta de observações diretas do comportamento humano, de modo a facilitar sua utilização potencial na solução de problemas práticos e no desenvolvimento de amplos princípios psicológicos, delineando também procedimentos para a coleta de incidentes observados que apresentem significação especial e para o encontro de critérios sistematicamente definidos.

$O$ autor define incidente como:

Por incidente entende-se qualquer atividade humana observável que seja suficientemente completa em si mesma para permitir inferências e previsões a respeito da pessoa que executa 0 ato. Para ser crítico o incidente deve ocorrer em uma situação onde o propósito ou intenção do ato pareça razoavelmente claro ao observador e onde as suas consequências sejam suficientemente definidas para deixar poucas dúvidas no que se refere aos seus efeitos. (FLANAGAN, 1973, p. 99) (grifo nosso)

Flanagan (1973, p. 100) pondera que o fundamento da técnica do Incidente crítico em si não é novo, existindo ao longo da história humana, na atividade de observar outras pessoas. A diferença, porém, consiste no tipo de observação, ou seja, a comum ou empírica e, a científica ou realizada em condições controladas. $O$ desenvolvimento desta técnica resultou de pesquisas no Programa de Psicologia da Aviação da Força Aérea dos Estados Unidos durante a 2a Guerra Mundial, em 1941, visando desenvolver procedimentos para a seleção e classificação de tripulações. Nesta época, foi realizada uma das primeiras aplicações da técnica do Incidente crítico na pesquisa de razões para o fracasso de pilotos na aprendizagem de vôo, sendo relatadas observações de comportamentos e obtido um conjunto de incidentes fatuais relacionados com a atuação dos pilotos. A técnica também possibilitava a determinação de exigências críticas, isto é, "aquelas que demonstraram ter feito a diferença entre o sucesso e o fracasso na execução de uma parte importante do trabalho." (FLANAGAN, 1973, p. 102).

Kremer (1980, p. 165) ao analisar as vantagens do uso desta técnica no estudo de usuários da unidade de informação como as bibliotecas, relata que ela foi 
formalizada por Flanagan em 1947, o qual publicou o primeiro artigo sobre o assunto em 1954. Esta autora lembra que em 1963 a técnica começou a ser aplicada para investigar as necessidades e usos da informação por cientistas e tecnólogos. Assim, Shirey apud Kremer (1980, p. 166) ressaltam a aplicação em pesquisas que utilizam a observação como instrumento de coleta de dados:

A técnica do incidente crítico consiste num conjunto de procedimentos determinados que foram aplicados à coleta dos dados em estudos de pesquisa onde está envolvida a atividade humana. Os dados coletados são de incidentes do 'mundo real' (isto é, não saíram de um laboratório, não são controlados), que foram observados e registrados por observadores treinados ou por instrumento registradores. Os incidentes observados devem obedecer a uma série de critérios predefinidos para assegurar um grau de validade e confiança. Além disso, um incidente deve ser uma mostra adequada de comportamento para permitir inferências ou predições, ou ambas, que devem ser feitas a respeito do indivíduo ou indivíduos envolvidos. Para um incidente ser crítico o objetivo a intenção do ato de comportamento deve ser claramente refletido para o observador no contexto no qual o incidente ocorre de forma a haver poucas dúvidas a respeito do que vão ser as consequências do ato que ele observa.

Contudo, Kremer (1980, p. 165) alerta que esta técnica também pode ser usada em pesquisas "cujo instrumento de coleta de dados é o diário, o questionário ou a entrevista. Nesses casos, o observador de um incidente não é o próprio pesquisador, mas qualquer pessoa que testemunhou um evento ou que foi o seu agente". Flanagan (1973, p. 102) descreve como principais aspectos de funcionamento desta técnica:

Essencialmente, o procedimento era a obtenção de relatórios de primeira mão, ou relatórios objetivos, da execução satisfatória ou não da tarefa determinada. O indivíduo cooperador descrevia uma situação na qual o sucesso ou o fracasso fora determinado por causas específicas relatadas. Verificou-se que este procedimento era bastante eficiente na obtenção de informação vinda de indivíduos concernente aos seus próprios erros, de subordinados relativamente aos erros de seus superiores, de supervisores a respeito de seus subordinados e, também, dos participantes com respeito aos seus co-participantes.

Referindo-se a vantagens relacionadas à descrição do incidente crítico, especialmente pelo usuário da informação, Kremer (1980, p. 167) argumenta que, tradicionalmente, os instrumentos mais utilizados em estudos de usuários foram entrevista e questionário, onde o usuário descreve o próprio comportamento diante de situações determinadas como a busca de informação. Ocorre que estes procedimentos exigem do usuário memória que em caso de falha, podem comprometer os resultados da pesquisa. Por isto, Kremer (1980, p. 167) defende que "esse problema pode ser contornado com o uso da técnica do incidente crítico", pois é mais fácil para a pessoa lembrar o que fez em uma determinada situação, do que lembrar daquilo que fez 'em geral'. Acrescente-se ainda que de acordo com Kremer (1980, p. 167) é possível utilizar esta técnica com perguntas cujo objetivo é captar opiniões dos informantes, além de poder ser inserida em diários, entrevistas estruturadas, semi-estruturadas e questionários auto-administrados. Segundo Kremer (1980, p. 167):

Resultados interessantes podem ser obtidos quando se pergunta aos usuários de um sistema de informação como eles procederam numa situação determinada (incidente crítico), logo depois de pedir-lhes que descrevam o que fazem 'em geral' quando procuram informações. Dessa forma, pode-se verificar se há concordância entre o que eles pensam que 
fazem e o que eles realmente fazem. (...) Deve-se lembrar que o mais importante nessa técnica é conseguir relatos da vida real dos informantes, descritos com detalhes.

Flanagan (1973, p. 109) ao traçar a trajetória de uso da técnica do incidente crítico, relata que após inúmeras aplicações em organizações públicas e privadas em quase trinta anos, na década de 1970 este autor concluiu que a técnica não consistia em um conjunto rígido de normas para coleta de dados, e que, pelo contrário, deve-se considerá-la como "um conjunto flexível de princípios, os quais devem ser modificados e adaptados para cada situação específica". Ademais, acrescentou que:

A essência da técnica é que somente tipos simples de julgamento são solicitados do observador, apenas relatórios dos observadores qualificados são incluídos, e todas as observações são avaliadas pelo observador em termos de um acordo com a afirmação do propósito da atividade. Naturalmente, a simplicidade, de julgamentos é um assunto relativo. $O$ ponto até o qual uma observação relatada pode ser aceita como fato depende principalmente da objetividade desta observação. Entende-se por objetividade a tendência de um número de observadores independentes a fazer um mesmo relato. Julgamentos de que duas coisas tenham o mesmo efeito ou de que uma tenha mais ou menos efeito do que a outra com respeito a algum propósito definido ou objetivo, representam os tipos mais simples de julgamentos que podem ser feitos. A exatidão e, portanto, a objetividade dos julgamentos depende da precisão com que a característica tenha sido definida e a competência do observador em interpretar esta definição, em relação ao incidente observado. Neste último processo, certos tipos mais difíceis de julgamentos são solicitados com relação à relevância de várias condições e ações sobre o sucesso observado na obtenção de propósito definido para esta atividade.

Flanagan (1973, p. 109) detalha a técnica do incidente crítico ainda em outros pormenores alertando que de modo mais simples, a descrição funcional de uma atividade especifica precisamente o que é necessário fazer e não fazer para que a participação na atividade seja julgada como bem sucedida ou eficaz. Em outras palavras, é impossível relatar que uma pessoa tenha sido eficaz ou não em uma determinada atividade pela execução de um ato específico, a menos que se saiba o que se espera dela, ou, que objetivo busca alcançar. Portanto, os "objetivos da participação na atividade devem, então, ser determinados a partir dos próprios participantes. Em alguns exemplos, estes não podem ser verbalizados em grau suficiente para tornar possível a sua obtenção direta." (FLANAGAN, 1973, p. 111).

Flanagan (1973, p. 111) adverte que:

Infelizmente, na maioria das situações não existe um objetivo geral que seja o correto. Da mesma maneira, raramente existe uma pessoa ou grupo de pessoas que constituem uma fonte de autoridade absoluta no objetivo geral da atividade. (...) [Assim], o critério principal na formulação dos procedimentos para se estabelecer o objetivo geral da atividade seria o uso proposto da descrição funcional da atividade.

$\mathrm{Na}$ obtenção do objetivo geral, é indicada a criação de um formulário de entrevista pelo pesquisador contendo questões para coletar ideias de várias autoridades qualificadas. Flanagan (1973, p. 111) estima que as respostas sobre o objetivo geral sejam bem explicitadas em "declaração razoavelmente longa e detalhada" pelas autoridades. Por outro lado, é também esperado que o pedido para sumarizar o objetivo geral leve os entrevistados a "condensar a declaração de forma mais breve e comum". Com isto, chega-se a uma declaração preliminar do objetivo geral que deve ser testada diante das autoridades participantes, para se conseguir 
uma declaração final. No Quadro 2 estão elencadas modelos para estas solicitações propostas por Flanagan (1973, p. 111):

QUADRO 2 - Formulário-amostra para uso na obtenção do objetivo geral

ESBOÇO DE ENTREVISTA PARA USO NA OBTENÇÃO DO OBJETIVO GERAL

1. Afirmativa introdutória - Estamos fazendo um estudo de (especificar a atividade). Acreditamos que vocês sejam muito bem qualificados para nos falarem a respeito de (especificar a atividade).

2. Pedir o objetivo geral - $\mathrm{O}$ que você pensa ser o principal objetivo da (especificar a atividade).

3. Solicitação de sumário - Em poucas palavras, como você resumiria objetivo geral de (especificar a atividade).

*Fonte: Flanagan (1973, p. 112)

Em termos gerais, Flanagan (1973, p. 112) adianta que o objetivo geral deve ser uma assertiva concorde entre todas as autoridades participantes:

Em resumo, o objetivo geral de uma atividade deve ser uma declaração breve, obtida das autoridades no campo, que expresse em termos simples aqueles objetivos com os quais a maioria das pessoas concordaria. A menos que uma declaração breve e simples tenha sido conseguida, será difícil obter-se a concordância entre as autoridades. Também será muito difícil transmitir uma ideia uniforme aos participantes. Este último grupo terá uma impressão global e esta deve ser tão próxima dos objetivos gerais desejados quanto possível.

$\mathrm{Na}$ aplicação da técnica do incidente crítico é necessário adotar alguns procedimentos indicados por Flanagan (1973, p. 112), para especificação do grupo a ser estudado, formulação da descrição funcional da atividade e, na descrição dos comportamentos das autoridades. Para que isto seja possível é preciso identificar os incidentes críticos vistos de forma mais aprofundada como:

Tais incidentes são definidos como comportamentos extremos, eficientes ou não, em relação ao alcance dos objetivos gerais da atividade. O procedimento tem considerável eficiência somente por causa do uso dos comportamentos extremos. Sabe-se que o os incidentes extremos podem ser mais apuradamente identificados do que o comportamento de caráter mais ou menos médio.

Flanagan (1973, p. 113) lembra que um dos principais objetivos das técnicas científicas é assegurar objetividade para as observações que estejam sendo feitas e relatadas, devendo então tanto o grupo de observadores, se for o caso, como o grupo de autoridades observadas, seguirem o mesmo conjunto de regras consoante as seguintes observações:

a) Situações observadas - delimitar a situação a ser observada incluindo informação sobre: lugar, pessoas, condições e atividades. Por exemplo: observação do 'comportamento de professores em sala de aula, enquanto instruem os estudantes durante o período de aula'.

b) Relevância do objetivo geral - após decidida a situação a ser observada, deve ser fixado o comportamento específico e relevante a ser observado para o propósito geral da atividade. Pode haver certo grau de dificuldade nesta etapa, podendo ser recomendável considerar que qualquer ação que, direta ou indiretamente, seja demandada por um longo período de tempo, pode ter efeito significativo sobre o objetivo geral. Neste caso, 
deve poder ser previsto com alguma certeza um efeito bom ou mau, para ser considerado.

c) Intensidade do efeito sobre o objetivo geral - esta etapa verifica como um incidente observado tem importância sobre o objetivo geral, obtendo-se detalhes sobre dois pontos na escala de importância:

c.1) nível de contribuição positiva para o objetivo geral em termos específicos, de preferência incluindo um exemplo concreto;

c.2) o nível correspondente do efeito negativo sobre o objetivo geral expresso em termos semelhantes. Cabe lembrar que ações que influenciam as atitudes de outros são mais difíceis de ser avaliadas objetivamente.

d) Pessoas para fazerem observações - devem ser selecionados com base na familiaridade com a atividade, relação que mantém com aquelas a serem observadas e, receberem treinamento.

(FLANAGAN, 1973, p. 113-115)

$\mathrm{Na}$ fase de coleta de dados é recomendado pelo autor que o observador proceda ao registro imediato das avalições enquanto os fatos são recentes em sua memória. A coleta de dados para descrição da atividade na forma de incidente crítico pode ser feito por meio de quatro procedimentos apontados por (Flanagan, 1973, p. 116-121):

1. Entrevista - contém aspectos peculiares que devem levar em conta:

-Patrocínio do estudo - expõe responsáveis pela realização do estudo.

- Objetivo do estudo - deve ser exposto de maneira informal. Exemplos: "Desejamos descobrir o que faz um bom cidadão; Estamos querendo saber, em detalhes, simplesmente o que o trabalho bem sucedido, como o de enfermeira inclui". Pode também ser acrescentada explicação sobre o valor, finalidade ou aplicação do estudo;

- Seleção do grupo a ser entrevistado - esclarecimento para os componentes do grupo da causa de escolha de cada um para descrição real da atividade em estudo;

- Anonimato dos dados obtidos - visa assegurar a coleta de dados sobre comportamentos ineficientes, garantindo sigilo sobre a identidade do observado;

- A pergunta - tido como aspecto crucial da coleta de dados, uma vez que, foi comprovado que modificações pequenas nos enunciados das questões podem provocar efeitos sutis de entendimento, produzindo um resultado positivo ou negativo na descrição do comportamento ou da atividade observados. Por isso, a pergunta deve referir-se ao objetivo geral o qual deve estar expresso em uma sentença preliminar. É recomendável que o incidente, comportamento real ou a atitude da pessoa seja desejado. Deve ser especificado brevemente "o tipo de comportamento que é relevante e o nível de importância que este deve alcançar para ser relatado". Outra providência é indagar a ocorrência mais recente evitando-se "somente os incidentes mais vividos ou dramáticos". É útil solicitar às pessoas a serem entrevistadas que expressem nas próprias palavras o que entendem estar sendo perguntado. 
- Conversação - o entrevistador deve evitar perguntas que sugiram respostas depois que a pergunta principal tenha sido apresentada. Seus comentários devem ser neutros e permissíveis e mostrar que aceita 0 entrevistado como perito, permitindo que ele faça a maior parte da conversação. Deve ser encorajado a falar podendo ocorrer, ou não, a citação de detalhes até então desconhecidos para o entrevistador. É importante que o entrevistador use certos critérios para os incidentes enquanto estiverem sendo coletados destacando-se:

a) o comportamento real é relatado;

b) o comportamento foi observado pelo entrevistador;

c) todos os fatores da situação dada eram relevantes;

d) o observador fez julgamento definitivo sobre a característica física do comportamento;

e) o observador tornou isto claro, simplesmente por que acredita ser crítico o comportamento.

(FLANAGAN, 1973, p. 113-120)

No Quadro 3, está representada uma situação modelo na coleta de dados pelo entrevistador:

QUADRO 3 - Procedimentos na condução da entrevista com a técnica do incidente crítico*.

- 'Pense na última vez que viu um subordinado fazer alguma coisa bastante útil para o seu grupo, no esquema de produção'. (Pausa, até que ele indique que tem tal incidente em mente);

'Esta ação resultou num aumento de produção de 1\% para aquele dia, ou outro período?' (Se a resposta for negativa, o entrevistador pode acrescentar: 'Imagino que você possa pensar na última vez em que alguém fez algo que realmente tivesse efeito no aumento da produção?'. (Quando ele indicar que ter tal situação em mente, diga: 'Quais foram as circunstâncias gerais que levaram a este incidente?'

- Em seguida, a sequência de questões pode ser:

'Diga-me exatamente o que fez esta pessoa de útil naquela época?';

'Por que isto foi de grande utilidade para que seu grupo tivesse o trabalho feito?'

'Quando aconteceu este incidente?'

'Qual era o trabalho desta pessoa?'

'Há quanto tempo ela executa este trabalho?'

'Quantos anos ela tem?'

${ }^{*}$ Fonte: Adaptado de Flanagan (1973, p. 119)

2. Entrevista de grupo - consiste na solicitação pelo entrevistador que o grupo de entrevistados redija sobre incidentes em resposta a questões específicas contidas em formulário preparado para este fim.

3. Questionário - apropriado para grupos maiores, adotando técnicas similares às aplicadas na entrevista.

4. Forma de registro do incidente crítico - escritos de duas formas:

a) registro dos detalhes dos incidentes à medida que acontecem;

b) registro dos possíveis incidentes em formulário.

5. Tamanho da amostra - número de incidentes exigidos, não havendo número predefinido, dependendo da complexidade da atividade a ser observada.

(FLANAGAN, 1973, p. 120-121) 
Na área de Ciência da Informação, o exemplo fornecido por Kremer (1980, p. 168-169) é bastante esclarecedor sobre a aplicação da técnica do incidente crítico na busca à informação:

O exemplo seguinte pode ilustrar o uso do incidente crítico durante um estudo de usuários, no qual se procura determinar os hábitos de busca de informações de engenheiros. Uma forma de descobrir quais são esses hábitos seria perguntar-Ihes simplesmente o que eles costumam fazer nesse caso. O problema com este tipo de pergunta é que as respostas não seriam muito válidas, pois refletiram apenas a opinião deles a respeito de seus próprios hábitos. Outro problema é que eles poderiam, inconscientemente tentar dar ao pesquisador a resposta que eles acham que este quer ouvir. Assim, se o pesquisador for um bibliotecário, eles provavelmente irão responder que costumam achar suas informações em determinados livros ou periódicos localizados numa determinada coleção. Isso tudo pode ser bastante relevante, mas os canais informais de comunicação podem deixar de ser mencionados, porque os informantes talvez achem que os bibliotecários só se interessam pelos canais formais.

Com isto, Kremer (1980, p. 168) conclui que:

Os resultados que podem ser obtidos através da técnica do incidente crítico são muito mais precisos. Em vez da opinião dos engenheiros sobre o que eles fazem 'em geral', o pesquisador pode obter amostras aleatórias do seu comportamento na vida real, e o conjunto de incidentes descritos por um número razoável de engenheiros pode indicar padrões de comportamento dessa população durante uma busca de informação.

Logo, Kremer (1980, p. 168-169) formulou perguntas direcionadas para investigação da necessidade de informação pelo usuário, em consonância com a orientação fornecida por Flanagan (1973), conforme suas palavras e registrado no Quadro 4: "A sequência de perguntas para obter-se um incidente crítico que ilustre uma busca de informação por um engenheiro (ou qualquer outro tipo de usuário) pode ser":

QUADRO 4 - Procedimentos na condução da entrevista com o usuário da informação aplicando a técnica do incidente crítico*

\section{MODELOS DE QUESTÕES}

1. Quando foi a última vez que você precisou de uma informação técnica e científica?

() hoje () ontem () esta semana () este mês () há mais de um mês

2. Qual era a informação desejada? (descreva-a brevemente)

3. Para que você precisou desta informação?

4. Qual foi a primeira fonte consultada para procurar a informação? (Se foi uma pessoa, indique seu nome, sua ocupação e onde trabalha)

5. Se a fonte era escrita ou impressa, onde foi localizada?

( ) coleção particular ( ) coleção de colega ( ) biblioteca da empresa onde trabalha

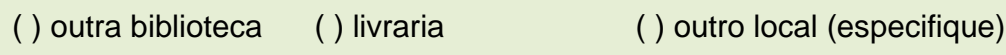

6. O que você conseguiu da primeira fonte de informação consultada?

( ) toda a informação desejada ( ) parte da informação ( ) referência para outra fonte

( ) informação irrelevante ou inapropriada

( ) nenhuma informação

7. Se você consultou mais de uma fonte de informação, qual foi a segunda fonte utilizada?

*Fonte: Kremer (1980, p. 169-170) 
Kremer (1980, p. 170) esclarece que a partir da última pergunta se repete as questões cinco e seis para coleta de dados sobre outras fontes usadas pelo informante, até o término da busca. Pode-se concluir perguntando "se o usuário está satisfeito com a informação obtida, bem como o que tinha feito ou pretendia fazer com ela. Caso não esteja satisfeito, é interessante saber se pretende continuar a busca". Kremer (1980, p. 171) constata a natureza flexível da técnica corroborando que: "Os modelos de perguntas apresentados aqui são apenas exemplos, pois a técnica do incidente crítico permite muitas variações". Outro aspecto relevante previsto por Kremer (1980, p. 170) a ser analisado é "pesquisar como a informação chega ao usuário sem que ele procure por ela", tendo formulado a seguinte questão:

1. Quando foi a última vez que você precisou de uma informação técnica e científica?
( ) hoje
( ) ontem
( ) esta semana
( ) este mês
( ) há mais de um mês

*Fonte: Kremer (1980, p. 170)

Kremer (1980, p. 170) em seu artigo, cita a pesquisa realizada nos Estados Unidos por Rosenbloom e Wolek, com dois mil engenheiros e cientistas, solicitando a eles um relato da última ocasião na qual procuravam por uma informação específica ou, a acharam por acaso. Kremer (1980, p. 170) extrai desta pesquisa norte-americana conclusões reveladoras de Rosenbloom e Wolek, como o fato de que em alguns casos engenheiros e cientistas "não estavam conscientes da necessidade por uma certa informação, até que a encontraram por acaso, ou seja, o reconhecimento da necessidade foi estimulado pelo recebimento da informação, e não o contrário, em um sexto dos casos. Com isso, Kremer (1980, p. 171) infere que: "Evidentemente, um estudo sobre informações importantes para os usuários, mas achadas por acaso, não poderia ser feito sem a técnica do incidente crítico".

Kremer (1980, p. 172) complementa chamando atenção para o fato de que em alguns casos ser relevante explorar o evento mais marcante ocorrido num período de tempo, o incidente mais recente ou, de maior utilidade nos últimos seis meses. Além disso, Kremer (1980, p. 172) observa que a técnica do incidente crítico pode ser usada em pesquisas incluindo populações pequenas, com menos de 100 pessoas, ou grandes, com mais de 1.000 pessoas. No que se refere às potencialidades de aplicação desta técnica Kremer (1980, p. 172) destaca entre inúmeras possibilidades, o estudo do processo de solução de problemas. Como exemplo desta última situação cita outra pesquisa norte-americana onde foi solicitado que os engenheiros de uma empresa registrassem a "probabilidade de adoção de abordagens técnicas para solução de um problema juntamente com as fontes de informação que tinham exercido alguma influência sobre essas estimativas de probabilidade de adoção das alternativas". Uma das perguntas do questionário buscava levantar dados sobre a influência da fonte de informação na tomada de decisão para a solução de um problema numa empresa de energia elétrica nos Estados Unidos:

Você obteve nesta semana alguma informação que teve influência na sua estimativa de adoção dessas abordagens técnicas? Indique a fonte (ou fontes) dessa informação:
( ) conhecimento pessoal (memória, vivência, etc.)
( ) literatura
( ) colega dentro da empresa
( ) colega fora da empresa
( ) consultor
( ) cliente
( ) experimento realizado
( ) outra fonte (especifique):

Comentário (se houver):

*Fonte: Kremer (1980, p. 173) 
Kremer (1980, p. 172) assinala que: "Com o registro de desenvolvimento da solução é possível estudar todo o esforço feito para resolver um problema, que então passa a ser considerado um único 'incidente', mesmo que dure semanas ou meses".

$\mathrm{Na}$ década seguinte, Balboa (2008) publica um artigo traduzindo os fundamentos e procedimentos registrados no artigo de Flanagan (1973) sobre a técnica do incidente crítico para o espanhol e revisa pesquisas que aplicaram esta técnica em muitas bibliotecas com diferentes objetivos, detendo-se num estudo realizado em cinco bibliotecas acadêmicas de universidades privadas no México, já nos anos 2000, com o fim de avaliar a comunicação interpessoal entre bibliotecário e usuário na entrevista de referência. É muito importante a contribuição que Balboa (2008) faz sobre a técnica do incidente crítico quando utilizada em seu aspecto qualitativo:

Usada qualitativamente a técnica do incidente crítico proporciona dados discursivos que podem ser objeto de análise narrativa e podem ser codificados e categorizados de acordo com os princípios da teoria fundamental dos dados (Grounded Theory) e (Straus e Corbin, 1990). segundo os princípios desta teoria, a partir dos dados se pode derivar seis tipos de incidentes:

1. Incidentes proativos - o ator atuou seguindo os objetivos da organização ou pessoais;

2. Incidentes reativos - o ator atuou em resposta a pressões advindas de dentro ou de fora da organização;

3. Incidentes tangíveis - envolvem uma mudança na organização que pode ser observada ou mensurada. Por exemplo: a construção de uma segunda sala de leitura;

4. Incidentes intangíveis - envolvem situações que não podem ser observadas ou medidas e estavam abertas à percepção de diferentes participantes. Exemplo: mudanças no processo gerencial ou problemas de relações humanas;

5. Incidentes positivos - aqueles considerados pelo ator de forma positiva;

6. Incidentes negativos - aqueles considerados pelo ator de forma negativa;

(BALBOA,2008) (tradução nossa)

Quanto aos fatores a serem levados em conta na análise dos dados, Flanagan, (1973, p. 122) observa que pode haver dificuldades em função de:

a) composição de referências - devido a inúmeras maneiras para classificação dos incidentes; b) formulação de categorias: a indução de categorias a partir de dados básicos na forma de incidentes é uma tarefa que requer visão interior, experiência e julgamento; c) comportamentos gerais: fase de determinação do nível mais apropriado de especificidade-generalidade a ser usado no relato de dados. O nível escolhido pode ser o de somente uma dúzia de comportamentos gerais ou de centenas de comportamentos específicos. $\mathrm{Na}$ interpretação dos dados é imprescindível relatar as limitações encontradas bem como o valor dos resultados deve ser enfatizado. Flanagan (1973, p. 127) apresenta a variedade de situações em que a técnica do incidente crítico pode ser aplicada, observando-se, nas décadas seguintes, a expansão para outras áreas além da Psicologia.

Para Flanagan (1973, p. 136) a técnica do incidente crítico é muito flexível e seus princípios básicos encontram muitos tipos de aplicação, destacando-se dois 
deles: a) o relato dos dados relacionados ao comportamento é preferível à coleta de interpretações, avaliações e opiniões baseadas em impressões gerais; b) os relatos devem ser limitados àqueles comportamentos que, de acordo com os observadores competentes, fazem contribuição efetiva para as atividades. Flanagan (1973, p. 136) também salienta que "os incidentes críticos representam somente matéria-prima e não fornecem, automaticamente, soluções para os problemas". Entretanto, tem ampla aplicação em questões como estabelecimento de padrões, determinação de exigências ou avaliação de resultados, tornando possível verificar entre outros aspectos, medida de desempenho típico e medidas de eficiência.

$$
\text { Por último, Flanagan (1973, p. 136) assinala que: }
$$

Em resumo, a técnica do incidente crítico, ao invés de coletar opiniões, 'palpites' e estimativas, obtém o registro de comportamentos específicos para fazer as observações e avaliações necessárias. A coleta destas observações torna possível formular as exigências críticas de uma atividade. A lista de comportamentos críticos fornece base sólida para a feitura de inferências quanto às exigências em termo de aptidões, treinamento e outras características.

\subsection{As Heurísticas de Jakob Nielsen}

Jakob Nielsen é dinamarquês, nascido em 1957 em Copenhague. Possui doutorado em Informática e design de interfaces de usuário pela Universidade Técnica da Dinamarca. Trabalhou em empresas de Informática como a IBM e a Sun Microsystems. Em 1990 publicou seu primeiro livro sobre hipertexto e hipermídia. Tornou-se conhecido como especialista em design gráfico, criando uma empresa de consultoria de acessibilidade e usabilidade, este último termo empregado por ele como sinônimo de acessibilidade de utilização dos sites da Web. É considerado um dos maiores analistas de usabilidade na Web do mundo, e web design e conhecido como "defensor do usuário". (INFOPEDIA, 2013).

Torna-se importante deter-se, um pouco, na definição de usabilidade de forma a entender o papel que desempenha na criação e avaliação de sites pelas organizações para oferecer produtos, bem como no uso destes sites e consequente acesso e aplicação da informação pelo usuário. Conforme a ISO 9241:

\footnotetext{
Usabilidade mede a eficiência, eficácia e satisfação com o qual usuários podem atingir objetivos específicos em um ambiente particular. O sistema deve disponibilizar aos usuários as operações de atalho como: abreviações, teclas de função, duplo clique no mouse, linguagem clara e sem códigos para informar erros e ajudar o usuário a entender o problema.
}

Tratando de aspectos da usabilidade nos sites do e-commerce, Aquino e Campos (2010, p. 1) informam que Jakob Nielsen dividiu a usabilidade classificandoa em cinco critérios básicos: intuitividade, eficiência, memorização, erro e satisfação. Aquino e Campos (2010, p. 1) diagnosticam como alterações que proporcionam boa usabilidade nos sites comerciais e, que certamente são válidos para sites não comerciais:

Apresentar exatamente a informação que o usuário precisa no momento;

A terminologia deve ser baseada na linguagem do usuário e não orientada ao sistema;

> O sistema deve mostrar os elementos de diálogo e permitir que o usuário faça suas escolhas, sem necessidade de memorizar comandos; 
Um comando ou ação deve ter sempre o mesmo efeito;

Cada operação deve ser apresentada no mesmo lugar;

O sistema deve informar continuamente as ações que estão sendo realizadas ao usuário.

Neste sentido, o cuidado com aspectos de usabilidade na criação, desenvolvimento, avaliação e manutenção de um site, torna-se indispensável, levando Maciel [et al] (2004, [p.1]) lembrar que:

Diferentemente do projeto de um software, onde os clientes pagam primeiro e experimentam a usabilidade depois, na Web, os usuários experimentam primeiro a usabilidade e tornam-se clientes depois. Desta forma, é fundamental a atenção com a usabilidade de um sítio em sua fase de projeto.

Percebendo a importância da usabilidade no contexto digital Jakob Nielsen juntamente com Rolf Molich formularam um método de avaliação de usabilidade que permite identificar problemas de interface com o usuário, através da análise e interpretação de um conjunto de princípios, parâmetros ou heurísticas. A palavra heurística é definida no Dicionário Aurélio como: "conjunto de regras e métodos que conduzem à descoberta, à invenção e à resolução de problemas"

Acrescenta-se, ainda que, o desenvolvimento e consolidação de sites na Web exigiram a necessidade de criação de diretrizes e critérios para avaliação contínua dos mesmos. Por conseguinte, na área de ciência da computação, segundo Maciel [et al] (2004, [p.1]), o método de Nielsen (1994) consiste numa avaliação feita com base no julgamento de avaliadores, com a estimativa de evidenciar $75 \%$ dos problemas de usabilidade do site. Nielsen apud Maciel [et al] (2004, [p.6]) sugere que sejam utilizados entre três a cinco avaliadores, para identificar maior quantidade de pontos negativos da interface. A Avalição Heurística foi utilizada pela primeira vez, em 1994, para análise da interface do site da Sun Microsystems, visando inspecionar de forma sistemática sua usabilidade. Para aplicação deste método, o avaliador interage com a interface do site analisando-a em conformidade com dez parâmetros de usabilidade ou heurísticas, formuladas por Nielsen (1994) apud Pádua (2012):

QUADRO 5 - Heurísticas formuladas por Jakob Nielsen para avaliação de interface de sites*

\begin{tabular}{|c|c|}
\hline Heurística & Descrição \\
\hline 1. Status do sistema & $\begin{array}{l}\text { O usuário deve ser informado pelo sistema em tempo razoável } \\
\text { sobre localização e ação que está executando. Ex: cada página e link } \\
\text { devem estar marcados, possibilitando um feedback imediato para o } \\
\text { usuário em ações divididas em etapas. }\end{array}$ \\
\hline $\begin{array}{l}\text { 2. Compatibilidade entre sistema e mundo } \\
\text { real }\end{array}$ & $\begin{array}{l}\text { O modelo lógico do sistema deve ser compatível com o modelo } \\
\text { lógico do usuário, considerando cada tipo de público. Ex: usar } \\
\text { linguagem, conceitos e expressões voltadas para o usuário e não } \\
\text { linguagem informática. }\end{array}$ \\
\hline 3. Controle do usuário e liberdade & $\begin{array}{l}\text { Tornar disponíveis funções que possibilitem saídas de funções } \\
\text { indesejadas. Ex: Inclusão de botão home. }\end{array}$ \\
\hline 4. Consistência e padrões & $\begin{array}{l}\text { Deve haver consistência na simbologia e plataforma de hardware e } \\
\text { software. Ex: Fazer correspondência entre títulos e cabeçalhos das } \\
\text { páginas do site, sem ambiguidades de convenções; Padronizar o } \\
\text { esquema de cores, diagramação, botões e links. }\end{array}$ \\
\hline
\end{tabular}




\begin{tabular}{|l||l||}
\hline 5. Prevenção de erros & $\begin{array}{l}\text { O design deve se preocupar com possibilidades de erro do usuário. } \\
\text { Ex: O usuário acessa por engano uma página. }\end{array}$ \\
\hline $\begin{array}{l}\text { 6. Reconhecimento em lugar de } \\
\text { memorização }\end{array}$ & $\begin{array}{l}\text { As instruções do sistema devem estar visíveis no contexto em que o } \\
\text { usuário se encontra. Ex: Objetos, ações e opções visíveis. O usuário } \\
\text { reconhece onde está sem precisar lembra o caminho percorrido no } \\
\text { site. }\end{array}$ \\
\hline \hline 7. Flexibilidade e eficiência de uso & $\begin{array}{l}\text { O sistema deve prever o nível de proficiência do usuário em relação } \\
\text { ao próprio sistema. Ex: utilização de aceleradores como bookmarks, } \\
\text { pode facilitar a navegação tanto ao usuário experiente como o } \\
\text { inexperiente. }\end{array}$ \\
\hline \hline 8. Estética e design minimalista & $\begin{array}{l}\text { Os diálogos do sistema devem conter somente informações } \\
\text { relevantes ao funcionamento. Ex: usar níveis progressivos de } \\
\text { detalhe, posicionando a informação geral no lugar mais alto na } \\
\text { hierarquia do site. }\end{array}$ \\
\hline \hline $\begin{array}{l}\text { 9. Ajuda ao usuário no reconhecimento, } \\
\text { diagnóstico e correção dos erros }\end{array}$ & $\begin{array}{l}\text { As mensagens de erro devem ser expressas em linguagem clara, } \\
\text { indicando as possíveis soluções. Ex: se a pesquisa de um usuário não } \\
\text { retornou nenhuma resposta, evitar informar apenas que ele deve } \\
\text { ampliar a pesquisa, e sim fornecer um link que ampliará a pesquisa } \\
\text { para ele; }\end{array}$ \\
\hline \hline 10. Ajuda e documentação & $\begin{array}{l}\text { A informação desejada deve ser facilmente encontrada, estar } \\
\text { contextualizada e pouco extensa. Ex: tarefas complexas demandam } \\
\text { ajuda específica de procedimentos para sua realização. }\end{array}$ \\
\hline \hline
\end{tabular}

* Fonte: Adaptado de Nielsen, Jakob (1994). Exemplos extraídos de Pádua (2012).

Segundo esclarece Pádua (2012,), na análise, os problemas são categorizados em escala de menor a maior gravidade "visando-se priorizar soluções".

Maciel [et al] (2004, [p.6]) corrobora a constatação de que a "usabilidade está relacionada à capacidade do site em prover informações ao usuário, na tomada de decisões". Portanto, a partir das heurísticas de Nielsen, Maciel [et al] (2004, [p.6]) informa que outros autores, dentre eles Lynch e Palmiter (2002) acrescentaram outros critérios ao conjunto de heurísticas para avaliação de sites, incluindo, por exemplo: "contexto, organização e estrutura; temas e objetos de páginas e subníveis, entre outros."

No que se refere a outras características do método de Nielsen (1994), Maciel [et al] (2004, [p.6]) relatam que, de modo geral, a solução de problemas de usabilidade visa entre vários objetivos: "a) propor correções em projetos em desenvolvimento; b) propor revisões, ajustes, customização em produtos acabados; c) definir a aceitação ou não, de projetos encomendados". Esses autores também apontam cinco elementos necessários para descrever um problema de usabilidade e sugestão para correção:

Contexto - é a situação de uso em que o problema pode ser verificado ou diagnosticado.

Causa - aspecto do sistema que desencadeia o problema.

Efeito sobre o usuário - consequência da interação do usuário, podendo haver, entre outros problemas, sobrecarga cognitiva, desorientação ou hesitação.

- Efeito sobre a tarefa - decorrente da ação sobre a tarefa executada podendo ocasionar trabalho adicional, perda de dados ou perda de tempo.

Correção possível - indica ao projetista ou responsável, possíveis alterações no sistema. (MACIEL [et al] (2004, [p.3]) 
Outro ponto destacado por Maciel [et al] (2004, [p.3]) é a tipologia do problema de usabilidade descrita pelo Laboratório de Utilizabilidade da Informática da UFSC, com a seguinte classificação:

barreira - aspecto da interface no qual o usuário esbarra sucessivas vezes e não aprende a suplantá-lo;

obstáculo - aspecto da interface no qual o usuário se defronta e aprende a suplantá-lo;

r rúdo - aspecto da interface que causa diminuição do desempenho na tarefa. (LABIUTIL apud (MACIEL [et al] (2004, [p.3]).

Em seguida, Maciel [et al] (2004, [p.4]), descreve características do efeito do problema de usabilidade sobre o usuário, classificado em:

> Geral - interação com todo e qualquer tipo de usuário durante a realização de sua tarefa;

> Preliminar - interação de usuário novato ou intermediário durante a realização de sua tarefa;

D Especial - tipos de usuários especiais (portador de deficiência) durante a realização de sua tarefa.

Por sua vez, o efeito sobre a tarefa pode se apresentar como um aspecto da interface que compromete a realização destas, sendo categorizados por Nielsen (1994) apud Maciel [et al] (2004, [p.4]) em:

$>$ Principal - frequentes ou importantes;

$>$ Secundário - pouco frequentes ou pouco importantes.

Nielsen (1994) apud Maciel [et al] (2004, [p.4]) refere-se também a duas categorias de efeitos relativos à revisão do projeto do sistema, salientando que ao se realizar a avaliação heurística pela primeira vez, esta categoria de problema não deve ser preenchida. São elas:

> Falso problema - refere-se a um aspecto da interface, que apesar de classificado como problema, na realidade não traz qualquer prejuízo ao usuário, nem à sua tarefa;

- Novo problema - refere-se a um novo problema de usabilidade que surgiu como consequência da correção de um problema anterior.

Por último, Maciel [et al] (2004, [p.3]) acrescentam uma lista do grau de gravidade do problema de usabilidade detectado na avaliação heurística da interface, classificados por (Nielsen, 1994):

> 0 -Sem importância - não afeta a operação da interface para todos os usuários, não sendo encarado necessariamente como um problema de usabilidade.

> 1 - Cosmético - não necessita ser reparado, a menos que haja tempo disponível.

2 - Simples - pode der reparado, com baixa prioridade de correção.

3 - Grave - deve ser reparado, com alta prioridade de correção.

4 -Catastrófico - deve ser reparado de qualquer forma antes do produto ser disponibilizado.

Aplicando a avaliação heurística Maciel [et al] (2004, [p.13]) apresentam um formulário usado para análise da interface do site do Instituto Nacional de Pesquisa Espaciais (INPE) referente à heurística 4 (consistência e padrões), que inclui todos os aspectos elencados anteriormente, conforme mostrado No Quadro 6 
QUADRO 6 - Exemplo de formulário para avaliação da Heurística 4 - (Consistência e padrões $)^{*}$

\begin{tabular}{|c|}
\hline H4. CONSISTËNCIA E PADRŌES \\
\hline $\begin{array}{l}\text { Verificação: } \\
\text { Os itens são agrupados logicamente e os padrões de formatação são seguidos consistentemente em } \\
\text { todas as telas da interface? } \\
\text { Grau de severidade: } \\
\begin{array}{lll}\text { ( ) } 0 \text { - sem importância } & \text { ( ) } 1 \text {-cosmético } & \text { (X) } 2 \text { - simples } \\
\text { ( ) } 3 \text {-grave } & \text { ( ) } 4 \text { - catastrófico } & \end{array}\end{array}$ \\
\hline $\begin{array}{l}\text { Natureza do problema: } \\
\begin{array}{ll}\text { ( ) barreira } & \text { ( ) obstáculo }\end{array}\end{array}$ \\
\hline $\begin{array}{l}\text { Perspectiva do usuário: } \\
\text { (X) problema geral } \quad \text { ( ) problema preliminar }\end{array}$ \\
\hline $\begin{array}{l}\text { Perspectiva da tarefa: } \\
\text { ( ) problema principal }\end{array}$ \\
\hline $\begin{array}{l}\text { Perspectiva do projeto: } \\
\begin{array}{ll}\text { ( ) problema falso } & \text { ( ) problema novo }\end{array}\end{array}$ \\
\hline $\begin{array}{l}\text { Descrição do problema: } \\
\text { Contexto: o usuário acessou a página principal da seção "Pós-Graduação" do site e logo em seguida } \\
\text { clicou no link "Cursos de pós-graduação". } \\
\text { Causa: Diferentes páginas do mesmo site possuem padrões visuais diferentes. } \\
\text { Efeito sobre o usuário: Desconforto e breve desorientação. } \\
\text { Efeito sobre a tarefa: Nenhum. } \\
\text { Correção possível: Padronizar as páginas do site, seguindo uma mesma identidade visual. }\end{array}$ \\
\hline
\end{tabular}

*Fonte: Adaptado de: Maciel [et al] (2004, [p.13])

Outro exemplo foi a avaliação do site da Rede Bandeirantes no que se refere à heurística 8 (estética e design minimalista), no Quadro 7:

QUADRO 7 - Exemplo de formulário para avaliação da Heurística 8 - (Estética e design minimalista)*

\section{H8. ESTÉTICA E DESIGN MINIMALISTA}

Verificação:

Os itens são agrupados logicamente e os padrões de formatação são seguidos consistentemente em todas as telas da interface?

Grau de severidade:
( ) 0 - sem importância
( ) 1 - cosmético
( ) 4 - catastrófico
( ) 2 - simples
(X) 3 - grave

Natureza do problema:

$\begin{array}{lll}\text { ( ) barreira } & (\mathrm{X}) \text { obstáculo } \quad(\text { ) ruído }\end{array}$

Perspectiva do usuário:

(X) problema geral ( ) problema preliminar ( ) problema especial

Perspectiva da tarefa:

(X) problema principal ( ) problema secundário

Perspectiva do projeto:
( ) problema falso
( ) problema novo
( ) não se aplica

Descrição do problema:

Contexto: O usuário clicou no hiperlink "História", localizado na barra de navegação superior. A página mostrada foi exibida. Logo em seguida o usuário clicou no botão "História", localizado à esquerda, e a mesma página foi carregada novamente.

Causa: Existem dois hiperlinks na página que possuem representação gráfica e hierarquia diferentes,

mas ambos apontam para a mesma página.

Efeito sobre o usuário: Desconforto.

Efeito sobre a tarefa: Perda de tempo.

Correção possível: Eliminar o botão "História" do menu de navegação à esquerda da página.

*Fonte: Adaptado de Maciel [et al] (2004, [p.14]) *Fonte: Adaptado de Maciel [et al] (2004, [p.14]) 
Maciel [et al] (2004, [p.16]) alerta que o especialista ou responsável pelo site, deve ter em mente o nível mínimo de qualidade a ser alcançada e, concluem fazendo recomendações de cunho geral tais como:

Após cada avaliação, devem-se priorizar as correções mais relevantes, até
atingir o nível de qualidade estipulado pelo especialista. A determinação de
graus de severidade facilita o estabelecimento de prioridades, mas deve ser
analisada em conjunto com os demais critérios (natureza do problema e
perspectivas do usuário, da tarefa e do projeto). Por exemplo, um problema
geral, verificável para qualquer tipo de usuário tem, logicamente, mais
prioridade que outro que se verifique somente para alguns tipos de
usuários. Pode-se considerar também prioritário o problema de usabilidade
que possa causar perda de tempo em tarefas com elevada frequência de
realização ou que cause falhas ou perda de dados em tarefas de elevada
importância.

Nielsen (1995) confirma que a avaliação heurística pode ser aplicada em qualquer etapa do desenvolvimento de uma interface, inclusive na sua fase conceitual. A respeito das Heurísticas de Nielsen (1994) vale ainda lembrar a advertência de Maciel [et al] (2004, [p.16]) sobre o significado da participação do usuário: "cabe salientar que, o não envolvimento de usuários reais pode tornar o teste econômico e rápido, contudo a utilização de "representantes" deles pode gerar distorções na avaliação". Para Nielsen, é importante considerar o conjunto de usuários no desenvolvimento da interface. Nielsen (1995) valida a participação do usuário na avaliação heurística da interface, quando afirma que ele pode ser usado não somente por especialistas como também por não especialistas na detecção de erros e inconsistências nas interfaces dos sites.

\subsection{A Metodologia para avaliação de produtos de informação do Instituto Brasileiro de Informação em Ciência e Tecnologia - IBICT}

Rocha e Sousa (2011, p. 7), tendo em mente, que os novos paradigmas da sociedade da informação e do conhecimento, configuram a necessidade de trabalho e busca da informação em rede de forma compartilhada, atuaram na proposta do IBICT, de realizar a avaliação de seus produtos para atender às reais necessidades de seus usuários. A partir da constatação das características e heterogeneidade da comunidade de usuários e da diversidade dos produtos oferecidos pelo instituto, bem como, ainda, da inexistência de um método de avaliação de produtos de informação, na Ciência da Informação, que possibilitasse investigar, de forma integrada, a natureza qualitativa e quantitativa dos fenômenos de busca e uso da informação apresentou-se um desafio de complexidade significativa a ser resolvido.

Isto deu origem ao pensamento de criar uma metodologia desenvolvida no próprio IBICT que permitisse realizar esta avaliação de forma mais completa, surgindo então uma metodologia híbrida, que segundo Rocha e Sousa $(2011$, p. 7) reuniu e associou métodos qualitativos e quantitativos por meio da aplicação de três procedimentos: 1) avaliação qualitativa com base na abordagem Sense-Making, de Brenda Dervin, por meio de entrevistas estruturadas. Para a análise dos resultados aplica-se a técnica dos incidentes críticos de John C. Flanagan; 2) avaliação quantitativa a partir de formulários eletrônicos disponibilizados nos sites dos produtos avaliados; 3 ) aplicação das heurísticas de Jakob Nielsen para avaliação da usabilidade das páginas Web dos produtos. 
A expectativa de Rocha e Sousa $(2011$, p. 7) com a metodologia do IBICT é assim expressada:

(...) com essa triangulação de métodos espera-se obter uma visão contextualizada das práticas informacionais dos usuários e enriquecer as condições de uso dos produtos oferecidos; conhecer o grau de satisfação dos usuários e a extensão do acesso e uso dos produtos, bem como obter informações sobre a facilidade com que os usuários se relacionam com as interfaces desses produtos.

Em entrevista concedida sobre a Metodologia de Avaliação de Produtos de Informação, em 19 de setembro de 2013, o então diretor do IBICT, Emir José Suaiden, afirmou que:

Trata-se de uma metodologia para avaliar os produtos da ciência da informação, tais como, bibliotecas digitais, revistas eletrônicas, comutação bibliográfica, canal ciência, serviços de inclusão digital para a inclusão social, ciência da informação, etc. A importância dessa metodologia reside no fato de que ela avalia tanto os produtos impressos como os eletrônicos. O fator fundamental é dar a palavra para o usuário principalmente o usuário que utiliza os produtos em tempo real. Portanto a avaliação permite uma atualização progressiva dos produtos ofertados pela ciência da informação.

Segundo Suaiden $(2011$, p. 34) a avaliação de produtos com a Metodologia do IBICT está inserida no Plano Diretor do órgão, com previsão de:

(...) consolidar a avaliação do total de 16 produtos no segundo semestre de 2011. Após a conclusão do trabalho, os resultados serão divulgados para a comunidade científica, e existe o compromisso institucional de adequar, até 2015 , os produtos às necessidades dos usuários a partir dos resultados obtidos.

\subsubsection{O Instituto Brasileiro de Informação em Ciência e Tecnologia - IBICT}

O IBICT é um órgão público federal da administração direta pertencente à estrutura de unidades de pesquisa do Ministério da Ciência, Tecnologia e Inovação (MCTI), cuja missão é "promover a competência, o desenvolvimento de recursos e a infraestrutura de informação em ciência e tecnologia para a produção, socialização e integração do conhecimento científico-tecnológico". O IBICT atua na transferência de tecnologias da informação, sendo referência nesta área no Brasil e no exterior. O seu corpo técnico realiza a absorção e personalização de novas tecnologias, repassando-as a outras entidades interessadas na captura, distribuição e preservação da produção intelectual científica e tecnológica. Como alguns exemplos desse esforço, citam-se a coleta automática de registro e disseminação de teses e dissertações, a editoração de revistas eletrônicas e os repositórios de documentos digitais tornando o Brasil a quinta maior nação em número de repositórios digitais, à frente de potências econômicas como o Japão, França, Itália e Austrália, e a terceira em quantidade de publicações periódicas de acesso livre (INSTITUTO BRASILEIRO DE INFORMAÇÃO EM CIẾNCIA E TECNOLOGIA, 2013).

Em sua trajetória esteve ligado a significativas mudanças na história da ciência e tecnologia no país, como a reorganização das atividades de ciência e tecnologia na década de 1970. Nesta época, o antigo IBBD passa por mudanças, passando a denominar-se Instituto Brasileiro de Informação em Ciência e Tecnologia. O IBICT consolidou-se como órgão nacional de coordenação das atividades de informação em C\&T. Esta transformação do IBBD em IBICT teve como objetivo preencher uma lacuna do Sistema Nacional de Desenvolvimento Científico e 
Tecnológico no fornecimento de informações em ciência e tecnologia. Havia a necessidade de desenvolver uma rede de informação no País, envolvendo entidades atuantes em C\&T, adotando-se para tanto um modelo de sistema de informação descentralizado (INSTITUTO BRASILEIRO DE INFORMAÇÃO EM CIÊNCIA E TECNOLOGIA, 2013).

Ainda como IBBD, um dos primeiros serviços do IBICT, o Catálogo Coletivo Nacional de Publicações Seriadas (CCN) foi criado em 1954. Este serviço passou para a versão eletrônica. Outro produto consolidado no Brasil é o Programa de Comutação Bibliográfica (Comut) que fornece cópias de documentos técnicos científicos disponíveis nos acervos das principais bibliotecas brasileiras e em serviços de informação internacionais (INSTITUTO BRASILEIRO DE INFORMAÇÃO EM CIÊNCIA E TECNOLOGIA, 2013).

Conforme exposto no site do IBICT, o instituto desde então, divulga a informação científica e tecnológica à sociedade. Como resultado dessa iniciativa, podem ser citados o projeto "Ciência às Cinco", lançado em 1987; a Base de Dados de Filmes em C\&T (1987); e, o "Programa de Tecnologias Apropriadas" (1993). Neste novo milênio, o IBICT é referência em projetos voltados para o movimento do acesso livre ao conhecimento. Exemplo desse compromisso é a Biblioteca Digital Brasileira de Teses e Dissertações, (BDTD) lançada em 2002, que utiliza tecnologias de arquivos abertos e integra sistemas de informação de teses e dissertações de instituições de ensino e pesquisa brasileiras. A BDTD dispõe de um acervo de mais de 126 mil teses e dissertações de 90 instituições de ensino, consistindo na maior biblioteca dessa natureza, em número de registros de teses e dissertações de um país.

Em 2002 o IBICT lançou o Canal Ciência, portal para divulgação científica e popularização da ciência, que utiliza as mídias audiovisuais como recurso para inclusão de jovens na Sociedade da Informação. A aproximação com outros segmentos da sociedade levou o IBICT a aprimorar a oferta de produtos, abrangendo usuários carentes que ainda não faziam parte da sua comunidade de usuários. Para tanto, criou o Programa de Inclusão Social e passou a utilizar sua expertise em organização, armazenamento e disseminação da informação para apoiar as políticas públicas voltadas ao campo social, notadamente no que diz respeito à implantação de ações diretas no campo da aprendizagem informacional e digital (INSTITUTO BRASILEIRO DE INFORMAÇÃO EM CIÊNCIA E TECNOLOGIA, 2013).

Dentro de seu amplo espectro de atuação no desenvolvimento de pesquisas, serviços e produtos de informação tecnológica, o IBICT se aproximou do setor industrial e empresarial. Exemplos disso são o Serviço Brasileiro de Respostas Técnicas (SBRT), o projeto Avaliação do Ciclo de Vida (ACV) e o Sistema de Informação em Tecnologia Industrial Básica (Infotib). O IBICT também realiza cooperação internacional disponibilizando o acesso a bases de dados internacionais. Entre estes projetos encontra-se o Bureau Brasileiro para Ampliação da Cooperação Internacional com a União Europeia (B.Bice), que apoia as atividades de cooperação internacional em CT\&I entre o Brasil e a União Europeia (UE). O B.Bice difunde informações, identifica mecanismos financeiros de apoio e auxilia na busca de parceiros brasileiros e europeus para elaboração de propostas em conjunto. Outra ação decorrente de parcerias chama-se Programa Informação para Todos, de cujo Conselho Intergovernamental o Brasil faz parte. Este programa visa diminuir as desigualdades de acesso à informação por meio da tecnologia. A nova prerrogativa 
permitiu ao Instituto revitalizar e dinamizar a realização de um diagnóstico sobre a Sociedade da Informação no país. É ainda fruto de integração internacional a assinatura do contrato com a On Line Computer Library Center (OCLC), que deu visibilidade ao IBICT e permitiu o acesso da comunidade brasileira aos dados de mais de 10 mil bibliotecas em todo o mundo da base de dados World Cat. O IBICT firmou, ainda, acordos de cooperação com instituições de ensino e pesquisa dos Estados Unidos, Colômbia, Cuba, Panamá, Colômbia e Peru, para desenvolvimento de projetos de cooperação em informação científica e tecnológica (INSTITUTO BRASILEIRO DE INFORMAÇÃO EM CIÊNCIA E TECNOLOGIA, 2013).

As parcerias constituem o caminho de consolidação de alguns dos futuros projetos do IBICT. Foi iniciada, em 2009, a execução de projeto, em parceria com o Ministério da Cultura, a Federação Brasileira de Associações de Bibliotecários (FEBAB), o Conselho Federal de Biblioteconomia (CFB) e a Fundação Bill e Melinda Gates para capacitação de profissionais de bibliotecas públicas no Brasil, objetivando o desenvolvimento de habilidades no uso das tecnologias de informação e comunicação e, dessa forma, poderem apoiar e manter o acesso de usuários com excelência.

A criação de bibliotecas digitais, a implantação de repositórios digitais em todas as universidades do Governo Federal e em diversas unidades de pesquisa do $\mathrm{MCTI}$, demonstram que o IBICT favorece o aumento da produção científica e a consequente visibilidade internacional do país.

Possui programas de mestrado e doutorado em Ciência da Informação, no Rio de Janeiro. Dispõe também de programa de pós-doutorado em Ciência da Informação onde são desenvolvidas pesquisas supervisionadas por pesquisadores do Instituto em temáticas que atendam à demanda institucional. Para tanto, conta com um núcleo de pesquisadores-doutores bolsistas do Conselho Nacional de Desenvolvimento Científico e Tecnológico (CNPq). Além disso, coordena o Laboratório Interdisciplinar sobre Informação e Conhecimento (Liinc) em parceria com a UFRJ. Conta com publicações próprias, como a revista Ciência da Informação, que divulga a informação científica e tecnológica no Brasil, desde 1972. Pioneira na área, a publicação quadrimestral edita trabalhos científicos inéditos, relacionados à ciência da informação e estudos e pesquisas sobre as atividades do setor de informação em ciência e tecnologia. Outra importante ação da linha editorial do IBICT foi a reedição da Classificação Decimal Universal (CDU), juntamente com a Unesco. A CDU tornou-se um instrumento importante para o setor de Informação, por ser recurso indispensável à classificação de todos os campos do conhecimento humano. Está previsto o lançamento da CDU em formato eletrônico.

Segundo o então diretor do IBICT, Emir Suaiden (2011, p. 11), o contexto da informação em ciência e tecnologia no Brasil fez com que as políticas governamentais aderissem "às ações voltadas para a construção efetiva de uma sociedade do conhecimento", a disponibilização de tecnologias da informação e comunicação, a convergência tecnológica e o trabalho cooperativo. Nesta realidade, - IBICT como unidade de pesquisa do MCTI, atua na sociedade. como órgão governamental com responsabilidade histórica no desenvolvimento das redes, sistemas e serviços de informação científico-tecnológica no Brasil. Neste sentido, Suaiden (2011, p. 11) expõe que o "IBICT preocupa-se em adequar seus produtos às reais necessidades de seus usuários". Isto fez com que o IBICT atingisse a posição privilegiada de criar uma metodologia inédita para avaliação e crítica destes produtos, conforme assinalado por Suaiden (2011, p. 11): 
Assim, adotou e está disponibilizando para as instituições interessadas, uma metodologia inovadora para avaliar produtos de informação, publicada em livro pelo IBICT, em 2011, na qual a triangulação de métodos qualitativos e quantitativos permite, ao mesmo tempo, obter uma visão contextualizada das práticas informacionais dos usuários e enriquecer as condições de uso dos produtos oferecidos, além de conhecer o grau de satisfação dos usuários e a extensão de acesso e uso dos produtos avaliados, bem como obter informações sobre a facilidade com que os usuários se relacionam com as interfaces desses produtos.

\subsubsection{Processo de desenvolvimento da Metodologia para Avaliação de Produtos de Informação do Instituto Brasileiro de Ciência e Tecnologia - IBICT}

O intuito de verificar e fomentar o acesso e uso da informação segundo sua missão institucional consolidada na sociedade, levou o IBICT a aprimorar a pesquisa de métodos de avaliação de produtos na Ciência da Informação, desenvolvendo uma metodologia própria, cuja aplicação possibilita realizar ajustes na oferta de produtos e amoldar o gerenciamento e disponibilização da informação científica e tecnológica no país, contemplando demandas de produtos de informação, segundo as necessidades específicas de informação de indivíduos e sociedade. Assim, consciente da composição diversa do universo de usuários que atende e, do conjunto de diferentes produtos oferecidos pelo site, o IBICT produziu uma metodologia híbrida para avaliação composta de métodos qualitativos e quantitativos, desenvolvida por Eliana da Conceição Rocha e Márcia de Figueiredo Evaristo de Sousa, duas pesquisadoras do IBICT, sendo a primeira especialista em Administração de Sistemas de Informação e a segunda, Mestre em Ciência da Informação e, Coordenadora de Articulação, Geração e Aplicação de Tecnologia do IBICT.

Esta metodologia foi resultado da busca pelo IBICT de procedimentos eficientes para avaliação dos próprios serviços e produtos institucionais e sua recepção na sociedade, levando em conta, segundo essas autoras, a dificuldade de estabelecer uma metodologia avaliativa voltada para a relação entre usuário e produtos de informação no ambiente virtual da Internet onde "existem zonas de justaposição ou de complementariedade de produtos em diversos canais de informação". (ROCHA E SOUSA, 2011, p. 13). Dito em outras palavras, as autoras, partindo da dificuldade empiricamente constatada de que a multiplicidade de canais de informação na Internet é um desafio para a identificação do usuário e do estabelecimento de amostra ou de um instrumento para análise de resultados à luz das metas, objetivos, produtos próprios de cada instituição, sentiram a necessidade de desenvolver um método "abrangente e inédito" para avaliação dos produtos do IBICT.

Este método teve enfoque nos usuários do IBICT e base teórica interdisciplinar, compreendendo a aplicação de três procedimentos: 1) avaliação qualitativa com base na abordagem Sense-Making, de Brenda Dervin, por meio de entrevistas estruturadas. Para a análise dos resultados, a metodologia do IBICT aplica a técnica dos incidentes críticos de John C. Flanagan; 2) avaliação quantitativa a partir de formulários eletrônicos disponibilizados nos sites dos produtos avaliados; 3) aplicação das heurísticas de Jakob Nielsen para avaliação da usabilidade das páginas Web dos produtos. 
Conforme (Rocha e Sousa, 2011, p. 15-16) a conjunção deste método híbrido possibilitou identificar e avaliar criticamente:
a) práticas informacionais dos usuários;
b) condições de uso dos produtos oferecidos;
c) grau de satisfação dos usuários;
d) alcance do acesso e uso dos produtos;
e) interação usuário/interface dos produtos.

As autoras identificaram dois aspectos fundamentais a serem considerados na metodologia: "a) a heterogeneidade do público usuário de informação em ciência e tecnologia; b) diversidade dos produtos disponibilizados, em todo ou em parte, em ambiente virtual." (ROCHA e SOUSA, 2011, p. 13). Conforme relato das autoras, inicialmente houve certa dificuldade em estabelecer uma metodologia avaliativa sobre a relação do usuário com o IBICT no uso de produtos deste Instituto, na Internet, devido à "multiplicidade de canais de informação no contexto virtual", já mencionados, o que "dificulta o estabelecimento de procedimentos de controle para saber quem acessa a informação". Daí emergiu "a dificuldade de se definir uma amostra ou um instrumento para análise de resultados à luz das metas institucionais e dos objetivos dos serviços oferecidos" (ROCHA e SOUSA, 2011, p. 13).

Por isso, as autoras perceberam a necessidade do IBICT desenvolver um método próprio, interdisciplinar, mas que possibilitasse a "convergência e complementaridade de diferentes abordagens tanto qualitativas como quantitativas". Formularam, então, a ideia de uma "triangulação metodológica alternativa que contemplasse a flexibilização de métodos de natureza quantitativa e qualitativa". Isto porque a abordagem quantitativa possibilita a "mensuração da extensão do acesso, do uso e do grau de satisfação de produtos", enquanto a abordagem qualitativa "permite uma visão contextualizada das práticas informacionais dos usuários", na interface com o IBICT. As autoras ressaltam que nas três abordagens que compõem a metodologia, o foco está no usuário. (ROCHA e SOUSA, 2011, p. 13).

Primeiramente, para instrumentalizar os procedimentos avaliativos, as autoras relatam que realizaram estudo exploratório sobre características de cada produto e serviço que seria avaliado, como exercício preliminar sobre "o que avaliar, como avaliar e qual o método mais adequado para este fim" (ROCHA e SOUSA, 2011, p. 14). Assim, foram testados produtos por meio de procedimentos formais e informais como consultas no site, navegação e análise da recuperação de informação, além de elaboração do levantamento das especificidades técnicas e das rotinas operacionais dos produtos com os coordenadores técnicos dos mesmos. Com isso, as autoras constataram que havia diferenças entre produtos no que se refere, por exemplo, a recursos tecnológicos, navegação e rotinas adequadas para busca e recuperação da informação. Estas observações preliminares possibilitaram detectar alguns dos atributos e variáveis que passariam a integrar a metodologia a ser criada.

Assim, em primeiro lugar, na avaliação qualitativa Rocha e Souza (2011, p. 14) buscaram verificar, em relação ao usuário, aspectos de valor, cognição, movimentos e percursos de busca e uso da informação. Na metodologia do IBICT o termo "uso da informação remete ao acesso e à apropriação de conteúdos informacionais de valor, que pode ser cognitivo ou prático" (ROCHA e SOUSA, 2011, p. 14). Por outro lado, no decorrer do processo de desenvolvimento da 
metodologia do IBICT, as autoras relatam que se mostrou necessário buscar uma abordagem qualitativa complementar, para identificar critérios de levantamento de dados, diferentes daqueles encontrados na literatura, e até então utilizados em estudos de usuários de unidades de informação. As autoras ressaltaram que há controvérsias sobre o uso e aplicabilidade dos critérios já existentes na literatura por autores como Ferreira (1995) e, Baptista e Cunha (2007).

Em segundo lugar, na avaliação quantitativa, as autoras buscaram uma forma de aferir a "extensão do uso e do grau de satisfação dos usuários quanto aos produtos de informação" do IBICT. Com este fim, Rocha e Souza (2011, p. 15) pensaram num instrumental que fizesse coleta de dados de "amplo espectro, mediante avaliação de produtos pela Web", permitindo que todos os usuários tivessem a mesma possibilidade de emitir juízo de valor sobre os "atendimentos e recursos oferecidos pelos produtos em avaliação" (ROCHA e SOUZA, 2011, p. 15). Este levantamento de dados foi feito com uso de formulários eletrônicos disponíveis nos produtos e na página do portal corporativo do IBICT.

O terceiro passo consistiu na avaliação da usabilidade - definida como interface entre o usuário e um sistema ou serviço de informação - das páginas Web. Para isso, Rocha e Souza (2011, p. 15) procuraram identificar o "grau de interatividade homem-computador possibilitado pelos produtos em avaliação" lançando mão das heurísticas de Jakob Nielsen (1992, c2005ª , c2005b, 2001).

Dessa forma, foram traçados a estrutura e a direção que a metodologia em elaboração seguiria, a partir da constatação por Rocha e Souza (2011, p. 15) na pesquisa que realizaram, de não constar na literatura nenhum método completo que atendesse à abrangência da demanda do processo de avaliação dos produtos do IBICT. A partir de então, isso levou as autoras a decidir sobre a criação de um modelo híbrido composto de três métodos distintos que "viesse a confluir em resultados consistentes e íntegros, oriundos da parte do avaliador e da parte de quem usa os recursos de informação a serem avaliados" (ROCHA e SOUZA, 2011, p. 15).

Além disso, Rocha e Souza (2011, p. 15-16) nas explorações preliminares que fizeram no ambiente do site, investigaram a existência de um conjunto de características dos produtos do IBICT, a serem avaliados que podem estar presentes ou não nos sites de uma forma geral, tais como:

a) fornecimento de produtos na Web;

b) fornecimento de produtos tecnológicos na Web;

c) propriedade dos acervos disponibilizados (outra instituição, Biblioteca do IBICT;

d) tipo de acesso ao documento demandado (cópia digital, fotocópia de documentos do acervo de outra instituição);

e) existência do cadastro de perfil dos usuários;

f) adaptação de produtos previamente existentes para o ambiente Web;

g) operação em rede, disponibilização de pacotes tecnológicos de software livre, agregação de provedores de dados dentro dos padrões para interoperabilidade nacional e internacional. 
As autoras relatam que estas características possibilitaram a avaliação quantitativa (observação do grau de satisfação dos usuários); avaliação qualitativa (comportamento de busca e uso da informação pelo usuário e o real atendimento de suas necessidades); e, o grau de interação homem-máquina, a partir da disponibilização dos produtos na Web. (ROCHA e SOUZA, 2011, p. 16). As autoras afirmam, também que a ligação entre as três abordagens permitiu interpretar e analisar as práticas informacionais dos usuários no contexto do IBICT e, expor metodicamente as condições de uso dos seus produtos de informação. Acrescentam, ainda que: "Nos três procedimentos o ator principal é o usuário" (ROCHA e SOUSA, 2011, p. 26). Cabe destacar, que para as autoras, a conjugação das três abordagens forneceu consistência e integridade dos resultados seja do avaliador, como do usuário.

\subsubsection{Elementos da Metodologia de Avaliação de Produtos de Informação do IBICT}

No desenvolvimento da metodologia de avaliação Rocha e Souza (2011, p. 19-26) fundamentaram seu estudo com abordagens qualitativas e quantitativas necessárias à consecução dos seus objetivos. O enfoque qualitativo incluiu a abordagem Sense-Making formulada por Brenda Dervin, e aplicação dos incidentes críticos de Flanagan. A abordagem Sense-Making está consolidada, sendo utilizada em estudos de diferentes áreas de pesquisa e é considerada como mais completa e abrangente por vários autores na Ciência da Informação, como Ferreira (1997a), que realizou pesquisa de doutorado utilizando a abordagem Sense-Making no estudo de comportamento de usuários do Instituto de Física da USP, no ambiente de redes eletrônicas. (FERREIRA, 1995a). Por sua vez, na abordagem quantitativa foram feitos levantamentos de dados com uso de formulários eletrônicos disponíveis nos produtos e na página do portal corporativo do IBICT. Por último, faz parte da Metodologia do IBICT a aplicação das heurísticas de Jakob Nielsen (1992, c2005 c2005b, 2001) para avaliação da usabilidade dos produtos do IBICT na Web, isto é, aspectos relacionados à interação homem-máquina.

\subsubsection{Construção metodológica para aplicação de estudo qualitativo}

A abordagem qualitativa da metodologia do IBICT de avaliação de produtos de informação descrita por Rocha e Souza (2011, p. 19-26) está fundamentada na abordagem Sense-Making formulada por Brenda Dervin, e na aplicação dos incidentes críticos de Flanagan.

\subsection{Aplicação da Abordagem Sense-Making na Metodologia do IBICT}

Para Rocha e Souza (2011, p. 20) os fundamentos do Sense-Making se revelaram totalmente aplicáveis à construção de uma metodologia de avaliação de produtos de informação por ter como pressuposto que toda necessidade de informação gera uma situação que, por sua vez gera uma lacuna; em contrapartida, todos os fatos inerentes à forma em que a lacuna é suprimida, ou seja, a busca da informação necessária e respectivas fontes de informação compõem os elementos inerentes à supressão da lacuna. A supressão de uma lacuna e a aplicação da informação obtida é denominada uso. Em suma, Rocha e Souza (2011, p. 20) constataram que "situação, lacuna e uso formam o trinômio operacional do SenseMaking”, podendo-se considerá-las como variáveis de um processo que abrange a 
necessidade, a busca e uso da informação pelo usuário. Em função disso, estas autoras na criação da Metodologia do IBICT para avaliação de produtos de informação, consideraram o termo situação como "fato gerador da necessidade de informação" afirmando que:

Não existe necessidade de informação sem motivo aparente; a informação existe em decorrência da ação do homem, a partir de determinado comportamento, permeado por eventos que caracterizam uma causalidade, uma situacionalidade e uma temporalidade.

Quanto à variável lacuna, foi julgada como:

Um déficit, conflito ou desordem enfrentado por um agente que gera necessidade de informação. Tais questões e necessidades de informação estão sempre relacionadas ao contexto de práticas e atividades dos agentes, e essas relações entre situação e lacuna são reconstruídas nas narrativas dos entrevistados. Na descrição da lacuna, as perguntas devem ser dirigidas também para responder às questões: quem, o quê, quando, onde, por que ou como está buscando a informação ou o acesso ao documento.

Enquanto que a variável uso:

(...) refere-se à utilidade das informações no processo de supressão da lacuna, os impactos decorrentes, as consequências observadas e os reflexos desse evento em situações diversas.

Para Rocha e Sousa (2011, p. 20) os resultados aferidos "podem ser categorizados e classificados, possibilitando encontrar, dentro do caos, o padrão da ordem (processos cognitivos comuns ou mapa mental dos usuários) sobre o comportamento de busca e uso da informação". A coleta de dados e informações dos entrevistados foi realizada com o Micro moment time line interview, descrito a seguir.

\subsection{O uso do Micro moment time line interview}

De acordo com Rocha e Sousa (2011, p. 21) a ideia do Micro moment time line interview, de Brenda Dervin, foi viabilizar ao entrevistado, realizar:

(...) a narrativa sobre o momento mais recente de necessidade de informação, os caminhos percorridos para obter essas informações, incluindo seus piores e melhores momentos nessa busca, a eficácia da fonte utilizada e o consequente uso da informação obtida no processo da construção do conhecimento.

Desta forma, se obtém a descrição em nível mais aprofundado da necessidade real de informação do entrevistado, em função do tempo e espaço. As autoras esclarecem que com o Micro moment time line interview o "movimento é o elemento chave para a apreensão da mudança da visão de mundo dos indivíduos". Ferreira (1995a, p.79), argumenta com base em Dervin (1995) que o objetivo do método é "(...) generalizar os padrões de comportamento de busca e uso dos indivíduos." Com base nestes princípios, Rocha e Souza (2011, p. 21) desenvolveram um roteiro para a realização dos produtos de informação do IBICT, conforme Quadro 8. 


\section{QUADRO 8 - Roteiro para realização de entrevistas com aplicação do método Micro moment time line interview, no IBICT}

\section{1 - MARCAÇÃO DA ENTREVISTA}

a) Selecionar os nomes dos entrevistados potenciais (pessoas com notório saber ou formadoras de opinião em seu segmento profissional ou estudantil), considerando os critérios a seguir:

- professores da graduação e pós-graduação;

- pesquisadores em geral (indústria, governo, universidade, instituto de pesquisa, ONG);

- alunos de pós-graduação;

- alunos da graduação e de escolas técnicas em fase de elaboração da monografia de conclusão de curso (pedir a indicação de algum professor):

- servidores públicos que desenvolvem atividades que requerem a busca da informação para execução das suas atividades;

- professores de escolas técnicas profissionalizantes;

- alunos de escolas técnicas profissionalizantes.

b) Fazer contato telefônico com os entrevistados potenciais e certificarse sobre qual deles possui o perfil para ser entrevistado para avaliar determinado produto ou serviço de informação.

O perfil para ser um entrevistado requer conhecimento do produto ou serviço a ser avaliado, estar envolvido em alguma situação que requeira a busca e uso de informação e que este ciclo tenha sido realizado, pelo menos uma vez, recentemente (no semestre ou no máximo, no ano corrente).

c) Identificadas as pessoas que possuem o perfil necessário, selecionar um número que possa representar uma amostra que possibilite a identificação do comportamento e necessidades padrão da população de usuários. No caso do IBICT, serão entrevistadas dez pessoas para cada produto ou serviço.

d) Explicar, individualmente, que a entrevista se destina à avaliação de determinado produto ou serviço de informação, que o entrevistado não terá seu nome associado às respostas. Para o levantamento dos dados demográficos e dos referentes ao perfil profissional do usuário, usar as questões do formulário eletrônico, as quais podem ser respondidas por telefone, no momento da marcação da entrevista, ou no momento da própria entrevista.

e) A entrevista exige o trabalho de situar o usuário no contexto da pesquisa,

dando ênfase à importância da sua participação, em que ele irá descrever sua vivência experimentada na busca e uso do objeto em avaliação. Esta ação exige do entrevistador a habilidade de mobilizar o entrevistado para que ele traga à tona sensações, sentimentos, emoções, frustrações, incertezas, angústias e sucessos experimentados; os fatores que o levaram a adotar certos comportamentos no desenvolvimento do seu trabalho ou pesquisa. $O$ entrevistado tem de estar plenamente consciente do que se espera dele e o entrevistador deve ter a habilidade necessária para deixar o entrevistado à vontade.

f) No caso do IBICT, a abordagem foi feita a partir da explicação da missão do Instituto, que criou uma coordenação para implantar um processo contínuo e sistemático de avaliação dos seus produtos. É demonstrado como ocorre uma confluência e aderência da missão institucional ao cenário mundial, onde a mudança de paradigma exige a adequação dos produtos de informação ao usuário da Web, independente e necessitado de maiores recursos que venham permitir a interação homem computador, a navegação lógica e os conteúdos disponibilizados de acordo com as reais necessidades dos usuários.

Fonte: Rocha e Sousa (2011, p. 20)

Outras características do método descritas pelas autoras é que ele permite a aproximação a uma situação de busca por informação diferenciada (micromomento) exteriorizada pelo usuário na entrevista, em contrapartida, foi sentida a necessidade de caracterizar, de forma padronizada, as situações enunciadas e registradas (conjunto das entrevistas) para a configuração de um instrumento norteador na avaliação dos produtos do IBICT. Para Rocha e Sousa $(2011$, p. 21) a necessidade e busca da informação caracteriza uma experiência:

Esta vivência pode ser explicada também sob a ótica da metáfora da espiral que se desenvolve a partir do movimento do pesquisador nos seus constructos. A formação da espiral ocorre a partir da subsequente recorrência de outra ou mais lacunas, a partir da supressão da anterior. O usuário sempre volta à outra necessidade de informação, mas nunca do mesmo ponto, tempo e lugar. Assim ocorre o ciclo de construção do conhecimento (DERVIN apud ROCHA e SOUZA, 2011, p. 21).

\section{Contudo, as autoras alertam que:}

Nesse roteiro, dependendo das peculiaridades do relato de cada entrevistado, talvez surjam outras questões além dos itens que norteiam cada variável. O importante é que se chegue a um nível de profundidade no qual o 
entrevistado considere que os fatos tenham se esgotado quanto à visibilidade de como ele deu sentido ao seu trabalho, em um micromomento na linha do tempo e espaço (ROCHA e SOUZA, 2011, p. 21).

As autoras recomendam, ainda, ser necessário que:

(...) o entrevistado esqueça qualquer termo associado à avaliação tradicional e termos relacionados a ela. Ele precisa entender que fará um relato que deve contemplar, em profundidade, todas as ocorrências e relações com o seu perfil social, cultural, profissional e individual, que surgiram como agentes desse movimento de busca e uso da informação. (ROCHA e SOUZA, 2011, p. 21).

No método do IBICT para avaliação de produtos Rocha e Souza (2011, p. 22) prosseguem descrevendo etapas e procedimentos elucidando que:

\begin{abstract}
$O$ entrevistador deve explicar os conceitos e atributos relativos às três variáveis para que o entrevistado possa entender a especificidade do método e do micromomento a ser relatado. Nesse sentido, o entrevistado deve fazer o seu relato seguindo a estrutura lógica da situação, lacuna e uso, a fim de que o entrevistador possa gravar o áudio da entrevista para a posterior síntese do seu conteúdo, para a elaboração do instrumento, conforme o roteiro. (ROCHA e SOUZA, 2011, p. 22).
\end{abstract}

Neste momento, elas adiantam ser importante ter em conta que:

Apesar de o entrevistador deixar o entrevistado praticamente livre para fazer seu relato, também deve estar atento para que não saia do foco, sempre resgatando a sequência do método, fazendo intervenções em momentos oportunos, sem cortar ao meio alguma explanação. (ROCHA e SOUZA, 2011, p. 22).

A amostra para realização da entrevista na avaliação dos produtos do IBICT foi estabelecida com base no critério do nível de pós-graduação dos pesquisadores, compondo um grupo de dez pesquisadores com especialização, mestrado ou doutorado, concluídos ou em andamento, em áreas do conhecimento diversificadas. (ROCHA e SOUSA, 2011, p. 22).

Por fim, Rocha e Sousa (2011, p. 22) ponderam que:

Se o método Micro moment time line interview permite a aproximação a uma situação de busca por informação diferenciada (micromomento), exteriorizada pelo usuário em cada entrevista, em contrapartida, foi sentida a necessidade de caracterizar, padronizadamente, as situações enunciadas e registradas (conjunto das entrevistas) para a configuração de um instrumento norteador para a avaliação dos produtos do IBICT.

Esta padronização do conjunto de entrevistas registradas pelos usuários que corresponderam a situações particulares ou individuais foi viabilizada no desenvolvimento da Metodologia do IBICT, com a aplicação da técnica do Incidente Crítico de John Flanagan. O intuito foi possibilitar a observação direta e descrição do comportamento do usuário de forma sistematizada, como uma necessidade constatada por Rocha e Sousa (2011, p. 22), nesta etapa de coleta de dados. Rocha e Sousa (2011, p. 22-23) ao fundamentarem-se em Flanagan (1973) transcrevem das palavras deste autor a seguinte explicação:

Conforme explica Flanagan (1973, p. 99), o Incidente crítico [...] consiste em um conjunto de procedimentos para a coleta de observações diretas do comportamento humano, de modo a facilitar sua utilização potencial na solução de problemas práticos e no desenvolvimento de amplos princípios psicológicos, delineando, também, procedimentos para a coleta de incidentes observados, que apresentam significação especial, e para o encontro de 
critérios sistematicamente definidos. (FLANAGAN apud ROCHA e SOUSA, 2011, p. 22)

Outros detalhes do uso dos Incidentes Críticos na criação da Metodologia do IBICT relatados por Rocha e Sousa (2011, p. 22) esclarecem que:

Para auxiliar na avaliação qualitativa dos produtos do IBICT, os incidentes críticos foram selecionados para compor a síntese do relato dos entrevistados. Para avaliação de cada produto, a equipe elaborou um instrumento consolidado com os incidentes críticos das dez entrevistas realizadas.

Rocha e Sousa (2011, p. 42-43) formularam "um exemplo de relato de entrevista com a marcação de incidentes críticos (positivos ou negativos)", que abrange explicações sobre a contextualização da entrevista, o relato dos entrevistados nos momentos de situação, lacuna e uso da informação, conforme expresso no Quadro 9.

QUADRO 9 - Relato de uma entrevista com a marcação das variáveis denominadas incidentes críticos (positivos ou negativos) a partir da aplicação do método Micro moment time line da abordagem Sense-Making

\section{Entrevista de Avaliação do Portal do IBICT}

Possui mestrado em ciência da informação (UnB - 2005) - linha de pesquisa Arquitetura da informação, especialização em Gestão de tecnologia da informação (UnB - 2008) e graduação em biblioteconomia (UnB 1999). É analista de controle externo do Tribunal de Contas da União, e atua como chefe do Serviço de Sistemas de Gestão de Conteúdos.

\section{Contextualização da entrevista}

O projeto de avaliação dos produtos do IBICT foi contextualizado dentro da política institucional e do cenário mundial. Esta avaliação é uma atividade contínua e sistemática dentro da instituição que servirá de instrumento para o processo decisório sobre as melhorias necessárias aos produtos, novos produtos e demais políticas relacionadas à área, consolidando a missão institucional. Para este processo de avaliação foram desenvolvidos instrumentos metodológicos com características híbridas.

Esta entrevista tem seu foco no comportamento de busca e uso da informação do usuário no processo de construção do conhecimento e dos movimentos que ocorrem dentro desse processo, ou parte dele.

O estudo está centrado na vivência do usuário na sua experiência de busca e uso da informação. O método recomenda que o entrevistado relate sua mais recente experiência de busca e uso de informação no Comut (produto ou serviço em avaliação). Esta vivência tem início no fato que gerou a necessidade da informação.

Gostaríamos que você relatasse a sua experiência mais recente de busca e uso da informação, a partir do fato desencadeador que chamaremos, de agora em diante, de situação. A situação geralmente é confundida com a situação de elaboração de uma tese ou dissertação; no nosso entendimento metodológico de construção do conhecimento, a tese é permeada de diversos micromomentos que desencadeiam necessidades de busca e uso de informação. Então, gostaríamos que você nos relatasse sua situação mais recente.

\section{Situação}

\section{Relato do entrevistado}

Necessitava de bibliografia sobre semiótica e arquitetura da informação, para atender à solicitação de uma pesquisadora da Universidade Federal da Paraíba.

\section{Lacuna}

A entrevistada entrou no Portal há uma semana, para uma busca na BDTD, pois se lembrou de uma defesa de dissertação na UnB, no Departamento de Ciência da Informação, cujo tema era esse. Foi primeiro pesquisar no Google, mas não achou o documento na íntegra e aí se lembrou que a BDTD certamente poderia ter o documento para download. Conseguiu localizar a dissertação de André Siqueira sobre "arquitetura da informação e linguagem, algo assim" (título correto: A lógica e a linguagem como fundamentos da arquitetura da informação). Fez a busca pelo nome do autor e encontrou o documento solicitado sem nenhuma dificuldade de navegação na BDTD. Colocou que, na BDTD propriamente, a pesquisa é muito boa. Acha "legal" haver lá o Currículo Lattes. Cita que a BDTD é uma boa referência para a pesquisa; todo mundo a conhece e sabe que as dissertações estão lá. Argumentou que não é fácil encontrar as informações no site. Quanto aos produtos, entende que começa com uma organização (que acha ser) lógica, com dois itens ou três, mas depois vem uma organização alfabética. Para encontrar a BDTD, ela demorou um pouco: foi em produtos - por achar mais lógico - não encontrou; procurou em outros pontos no portal, não achou; voltou em produtos e foi abrir item por item, onde acabou encontrando. Achou a localização da BDTD dentro do Portal um pouco difícil. 


\section{Uso}

A utilização do documento ajudará a mestranda no desenvolvimento de sua pesquisa acadêmica. Espontaneamente, a entrevistada resolveu apontar alguns problemas do portal, independentemente do roteiro, mas a partir da sua experiência. Este exemplo mostra que é necessário sempre ouvir o usuário.

- O portal apresenta um problema de ter o foco em notícias. É o que mais aparece. O ideal é dar destaque aos produtos. A instituição quer fazer divulgação institucional, mas o usuário não quer saber disso. Tem que haver notícia em algum lugar, porque é importante, mas o destaque deve ser menor.

- Problema no esquema de menu "que pula para o lado". O mais indicado é o que "encosta e desce". O menu utilizado hoje pelo IBICT não é indicado porque não é muito bom devido à acessibilidade. Ex.: uma pessoa que tenha uma deficiência motora.

- Listas muito compridas. Pelo menos dispor em ordem alfabética. A recomendação atual é de que se agrupe em listas de, no máximo, sete tópicos. Agrupamento de informações (Nielsen).

- Quem planeja o portal deve conhecer bem os produtos, mas o usuário não conhece. Problema das siglas. Criar nome fantasia ou nomes acessíveis a todas as pessoas. Ou criar formas de, quando "encostar" a seta no produto, mostrar do que se trata. Isso evita ao usuário o trabalho de ficar entrando em todos os itens para saber qual é a informação que o produto está oferecendo.

- Pegar todos os produtos, transformar em ícones e distribuir na página principal seria muito mais útil para quem pesquisa. Sugere tentar oferecer dois caminhos para a mesma informação (menu e ícones com os principais produtos e programas do IBICT).

- Criar espaço de banner para divulgação dos próprios ou novos produtos. Ex.: Saiu a nova edição da revista.

- Verificar a identidade visual: logomarca, cores, designer, combinação, cor de fundo, as fontes, layout mesmo. Ex. de portal hoje tido como bom: GDF.

- Divulgação interna dos programas da Casa e tbm dos seus produtos.

- Criar uma "caixa" (estilo Google) para a pessoa poder pesquisar o produto ou o que lhe interessa.

- "Outros links" de parcerias devem receber destaque menor. Talvez no final da página e fonte menor. Os links de parcerias têm mais destaque que os produtos do IBICT.

- Dentro de "licitações" existe a informação "conforme condições estabelecidas no edital do Pregão na forma Eletrônica $n^{\circ}$ 011/2006 e seus anexos, disponíveis no site www.comprasnet.gov.br". Esta informação de site já podia ser link.

- Já notou que cada produto e serviço do IBICT estão numa base diferente. Buscar um profissional para implantar essa funcionalidade, que possa "apontar" uma mesma busca para as diferentes bases ou "n" fontes de informação. Os produtos são bons, só falta serem apresentados de outra forma. Ex.: o portal da Capes não precisa entrar em cada revista para pesquisar. Permite com uma pesquisa localizar em muitas fontes.

- Informação sobre a instituição onde quem estiver interessado clica e já desce a informação. Ex.: site do GDF.

- É importante ter "fale conosco" e os contatos na primeira página.

- Acha que seria interessante o IBICT usar ferramentas (há muitas que são livres) que possibilitam que todos os usuários publiquem conteúdos (notícias, eventos, etc.) no portal: "Comunidades de colaboração". Ex: CMS (gestão de conteúdos).

- Para não "brigar" com a página, deixar os parceiros mais apagados, e quem tiver interesse, quando clicar em cima do ícone, ele acende e colore.

- Há falta de unidade visual. Está numa página, mas quando entra em outra, de repente ela muda completamente. Sugere:

$1^{\circ}$. ter uma barra de navegação global que seja igual em todas as páginas, onde a pessoa estiver, ela vai saber que está no IBICT;

$2^{\circ}$. manter o menu para que a pessoa possa voltar no momento que quiser;

$3^{\circ}$. um profissional de designer, desenho industrial, para trabalhar com a questão gráfica. Sugere uma consultoria com a UnB.

- O usuário se perde um pouco porque tem muitas informações sem consistência.

Fonte: Rocha e Sousa (2011, p. 42-43).

As autoras mencionam que "a partir desse instrumento se chega aos padrões positivos e negativos de cada componente do trinômio, situação, lacuna e uso". Posteriormente, apresentam um exemplo da identificação dos padrões positivos e negativos a partir da aplicação dos incidentes críticos, que figuram no Quadro 10. 


\title{
QUADRO 10 - Exemplo de identificação e quantificação dos incidentes críticos que surgiram a partir das entrevistas com os usuários do Portal do IBICT (definição de padrões)
}

\author{
Padrão positivo do momento "Situação" \\ A partir da amostragem de 10(dez) entrevistas com usuários pós-graduados e em pós-graduação, tem-se um padrão \\ positivo de situação focado na necessidade de buscar informações nos produtos do instituto e nas notícias publicadas no \\ portal do IBICT.
}

\section{Padrão negativo do momento "Situação" \\ Não foi identificado um padrão negativo no momento "situação".}

\section{Padrão positivo do momento "Lacuna"}

Em relação a este padrão, $80 \%$ dos usuários localizaram as informações desejadas, sendo que $60 \%$ localizaram as informações nos produtos a partir do acesso ao portal, e 20\% localizaram as informações nas notícias; $20 \%$ acham que o portal permite boa navegação.

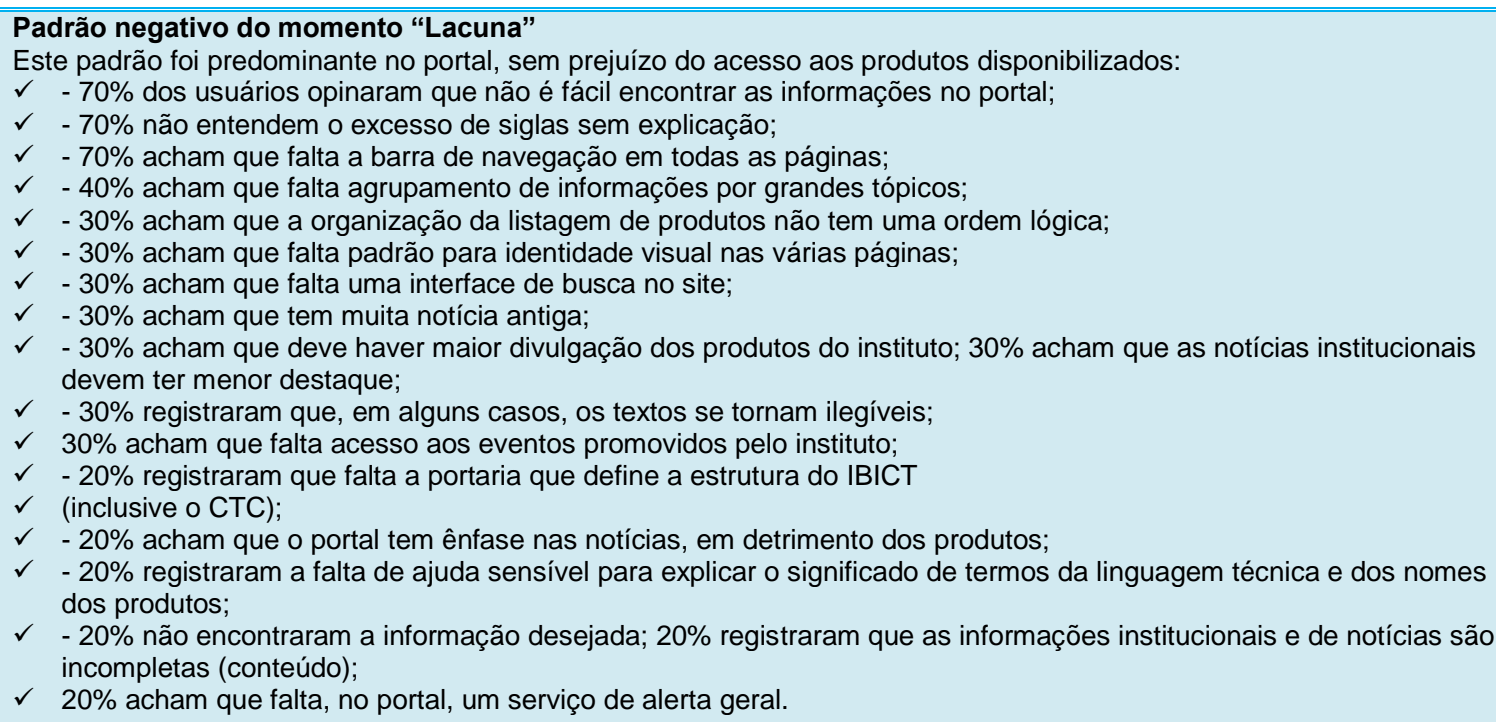

Estão listados, a seguir, os incidentes negativos sobre o portal, os quais, pelo seu baixo percentual, não puderam ser agregados como um padrão, porém devem ser observados pelo gestor:

- o usuário busca a informação em outra fonte, antes de acessar o portal;

- o portal não disponibiliza acessibilidade para pessoa que tem deficiência

- motora;

- os links de parcerias têm um destaque maior que os do portal; o portal não é atraente;

- faltam informações sobre os coordenadores de produtos;

- o portal não é adequado a todos os níveis de usuários; faltam informações sobre o histórico do instituto;

- acham que as notícias que vão se constituir em informações de caráter permanente devem ficar separadas daquelas efêmeras;

- opinam que as notícias institucionais devem ficar separadas das demais, e um usuário não suprimiu a lacuna, ou seja não obteve a informação em nenhuma fonte.

\section{Padrão positivo do momento "Uso"}

1 - Aplicou numa pesquisa sobre arquitetura da informação e semiótica.

2 - Inscreveu-se no seminário.

3 - A informação foi usada na elaboração da sua tese de mestrado.

4 - A informação foi usada como conteúdo das aulas sobre fontes de informação.

5 - A informação foi usada em pesquisas realizadas em Campinas.

6 - Conseguiu enviar os documentos para se candidatar à bolsa do IBICT.

7 - A informação foi usada como conteúdo das aulas sobre Classificação.

\section{Padrão negativo do momento "Uso"}

1 - Não fez uso da informação.

\section{Padrão geral dos incidentes críticos:}

O padrão de comportamento do usuário na busca e uso de produtos de informação é extraído das ocorrências dos incidentes críticos positivos e negativos, categorizados a partir da análise das entrevistas realizadas com a aplicação do método Micro moment time line interview.

No exemplo prático anteriormente apresentado, os atributos sobre o segmento notícias publicadas no portal apresentaram o maior grau de insatisfação dos usuários quanto ao número de ocorrências. Os relatos descreveram as notícias como desorganizadas; de difícil recuperação, desatualizadas e incompletas.

Fonte: Rocha e Sousa (2011, p. 46-48). 


\subsubsection{Construção metodológica para aplicação no estudo quantitativo}

No desenvolvimento da Metodologia do IBICT, na avaliação qualitativa foram estabelecidos padrões de comportamento verificados através de fatos observáveis; por sua vez a avaliação quantitativa visou determinar padrões de comportamento aferidos através de números. Com isso foi possível realizar a quantificação e o dimensionamento do universo pesquisado, sendo os dados coletados, analisados e apresentados estatisticamente. A avaliação quantitativa visou possibilitar a investigação do grau de satisfação do usuário e o alcance do acesso e uso dos produtos

\subsection{O levantamento de dados quantitativos}

No levantamento de dados quantitativos sobre o grau de satisfação do usuário, foram definidas variáveis considerando-se grupos de dados sobre os seguintes aspectos, mencionados por Rocha e Sousa (2011, p. 23):

- perfil demográfico do usuário;

- perfil profissional do usuário;

- habilidades e facilidades para acessar a Internet;

* respostas que o resultado do uso de um produto ou serviço proporciona ao usuário, quanto ao operacional, qualidade e tempo.

\section{5.3.2.2 Definição da amostra para levantamento de dados}

$\mathrm{Na}$ definição da amostra para responder ao levantamento dos dados dessa natureza, Rocha e Sousa (2011, p. 23) seguiram o método probabilístico, "pelo qual todos e quaisquer usuários que acessem um produto ou serviço têm a mesma probabilidade de fazer parte da amostra". Com este fim, foi elaborado um formulário eletrônico disponível em cada página de resultado de busca a cada produto ou serviço do IBICT, como também na página principal do portal corporativo. No Anexo 1 encontra-se o formulário eletrônico que possibilitou proceder à avaliação quantitativa do Portal do IBICT.

Detalhando esta etapa do desenvolvimento da metodologia Rocha e Sousa (2011, p. 24) esclarecem que:

(...) cada produto e serviço têm como instrumento padrão os dados sobre o perfil demográfico e sobre o perfil profissional do usuário. Os formulários variam um do outro no que tange às especificidades de cada objeto a ser avaliado, ao que é e como é disponibilizado na Web, e aos fatores que interferiram, positivamente ou não, nos resultados obtidos na busca da informação nas fontes em avaliação.

Rocha e Sousa (2011, p. 24) fornecem exemplos das variáveis específicas dos formulários eletrônicos estabelecidas para três produtos, como o CCN, Comut e BDTD, ilustrados no Anexo 2.

A ferramenta selecionada para o desenvolvimento e implantação de formulários eletrônicos, foi o software Zoomerang (http://www.zoomerang.com) pela facilidade de permitir a coleta de dados na página Web ou por e-mail, do produto em avaliação, além de possibilitar a geração de tabelas estatísticas, quantificação dos 
dados em percentuais e sua representação em gráficos de tipos variados. O custo para instituições sem fins lucrativos é bem acessível.

Como recomendação, para que o processo avaliativo fique mais leve e menos longo, as autoras sugerem que o avaliador tenha um cadastro de usuários com o seu perfil, a fim de que seja possível uma conexão automática deste com as respostas ao formulário específico, sem ter que repetir as mesmas perguntas sobre o mesmo usuário, numa avaliação de diferentes produtos. O desenvolvimento do instrumento no Zoomerang não apresenta dificuldades, pois é totalmente autoexplicativo e interativo para a construção de surveys (termo utilizado pelo Zoomerang). Concluído o questionário eletrônico, é apresentada uma rotina para geração de link para website ou para e-mail, dependendo do método de levantamento que será adotado. Depois de enviado o questionário, tanto em website ou e-mail, a ferramenta disponibiliza vários tipos de relatórios, sendo um deles destinado ao acompanhamento dos status da coleta de dados, conforme é possível observar no Anexo 3, também usando o Portal do IBICT como exemplo.

\subsection{Análise do conteúdo da questão aberta do formulário quantitativo}

O formulário prevê um campo aberto para que o usuário proponha recomendações para melhoria do Portal do IBICT. As respostas do campo aberto estão exemplificadas no Anexo 4. A partir das recomendações, apresenta-se um relatório de análise das questões que são pertinentes ao Portal do IBICT. As respostas de análise estão baseadas na agregação das questões a uma categoria terminológica relacionada hierarquicamente, ou seja, do geral para o específico (Anexo 5).

Os gráficos foram gerados pelo software Zoomerang, que possibilita a geração automática destes gráficos, os quais ilustram os percentuais dos resultados da avaliação quantitativa por formulário eletrônico constantemente atualizado. $O$ software permite exportar dados para programas como o Excel, Power Point etc. Os gráficos estão exemplificados no Anexo 6.

\subsubsection{Aplicação das Heurísticas de Jakob Nielsen em teste de usabilidade}

Com a oferta na Web verificou-se a necessidade de avaliar aspectos relacionados à usabilidade dos produtos do IBICT, no que se refere ao grau de interatividade homem computador. Adotou-se, para esse fim, o método das heurísticas de autoria de Jakob Nielsen (1992, c2005a, c2005b, 2001). Segundo afirma Nielsen (c2005a), as heurísticas constituem:

\footnotetext{
[...] um método de engenharia de usabilidade usado na detecção de problemas de usabilidade em um design de interface de usuário para que estes problemas possam ser tratados como parte de um processo de design interativo. Uma avaliação heurística implica fazermos um pequeno grupo de avaliadores examinarem uma interface e julgarem se os princípios de usabilidade reconhecidos (a "heurística") estão sendo observados.
}

Além de ser internacionalmente reconhecido, o método garante vantagens pelo seu baixo custo de aplicação e por ser facilmente aplicado para o teste de usabilidade em produtos ou serviços de informação disponibilizados na Web, principalmente, para a adequação de páginas e interfaces Web à interação homemcomputador. Para sua aplicação, Nielsen (2005a; 2005b) recomenda que a 
avaliação heurística seja feita por três a cinco especialistas da área, mas isso não impede que os próprios usuários estudem os critérios de avaliação e realizem a análise. Com fundamentação nestas premissas foi desenvolvido um checklist estruturado nas dez heurísticas propostas por Nielsen (Anexo 7). No entanto, duas delas foram condensadas em uma única heurística, por tratarem do mesmo tema: controle de erros pelo usuário e previsão de erros. Na aplicação do método das heurísticas, as variáveis são preestabelecidas pelo próprio método, identificadas a partir da análise realizada por especialistas treinados para sua aplicação na construção de portais, sites, interface de busca e navegação. O exemplo de aplicação do método de análise heurística pode ser observado no Anexo 8.

\subsection{Considerações sobre a Metodologia do IBICT}

Rocha e Souza (2011, p. 26-28) relatam que o relacionamento das três abordagens metodológicas foi proposto para viabilizar a avaliação de produtos do IBICT com foco nos usuários. A abordagem qualitativa a partir da proposta metodológica Sense-Making de Dervin e aplicação dos incidentes críticos de Flanagan permitiu uma visão contextualizada das práticas informacionais dos usuários e a análise das condições de uso dos produtos de informação. Na avaliação qualitativa a marcação dos incidentes críticos, padrões positivos ou negativos dos produto/serviço foram evidenciados no Portal do IBICT, CCN e Comut (ROCHA e SOUSA, 2011, p. 27). Foi possível detectar padrões comuns aos três produtos. No padrão positivo foi destacada a importância dos produtos oferecidos pelo IBICT, e no negativo, a existência de uma demanda reprimida, dado o desconhecimento de tais produtos por parte dos usuários potenciais.

Com o procedimento quantitativo obteve-se informações sobre o uso e grau de satisfação destes produtos. A pesquisa realizada com formulários eletrônicos na Web apresentou vantagens em relação aos formulários impressos, resultando em maior índice de respostas, rapidez de entrada e análise dos dados, possibilidade de expandir a amostra com os usuários não previsíveis, transmissão direta de dados e atualização contínua. No entanto, os índices de respostas aos formulários eletrônicos dos produtos/serviços do IBICT, já avaliados, têm se mantido baixos. Este fenômeno parece estar relacionado ao desconhecimento dos produtos do IBICT pelos seus usuários potenciais, o que vem sendo sistematicamente detectado pelas entrevistas realizadas para a avaliação qualitativa. (ROCHA e SOUSA, 2011, p. 27). Por sua vez a aplicação das heurísticas explicitou a facilidade de relacionamento dos usuários com as interfaces. Esta avaliação realizada pela equipe com os critérios de Nielsen, contou com a participação dos usuários dos produtos no momento da avaliação qualitativa, nas entrevistas, em função do novo paradigma de busca direta de informação na Web, sem intermediação de profissionais da informação e, pelos dados obtidos das respostas da pergunta aberta do formulário eletrônico de avaliação quantitativa. O padrão dos resultados da avaliação dos três produtos apontou que a nomenclatura utilizada nos sites dos produtos do IBICT está mais voltada para profissionais da área de biblioteconomia e ciência da informação.

Para finalizar, as autoras ressaltam que "nos três procedimentos o ator principal foi o usuário" e que a combinação dos três métodos ofereceu consistência e integridade dos resultados advindos do olhar do avaliador e do usuário. Esperam, com essa combinação, alcançar o principal objetivo da avaliação: adequar os produtos do IBICT às reais necessidades de seus usuários. 


\title{
3. PRESSUPOSTO
}

A utilização de técnicas e metodologias adequadas para avaliação de produtos é fundamental para dar visibilidade à biblioteca jurídica.

\section{OBJETIVOS}

\subsection{Geral}

Analisar como a oferta de produto de informação da Biblioteca do STJ, disponível na Web, concorre para subsidiar a atividade judicante de acordo com a necessidade específica de informação jurídica.

\subsection{Específicos}

Os objetivos específicos em relação à avaliação do produto de informação jurídica da Biblioteca Ministro Oscar Saraiva do Superior Tribunal de Justiça, STJ, com enfoque no usuário, são:

1. Analisar a relação entre a atividade judicante desempenhada nos Gabinetes dos Ministros e a necessidade de informação jurídica dos assessores de ministro, no âmbito do Superior Tribunal de Justiça;

2.Descrever a Biblioteca Digital Jurídica, BDJur, como um produto de informação jurídica disponível na Web.

3. Analisar o impacto da informação jurídica na atividade judicante do Superior

Tribunal de Justiça.

\section{DEFINIÇÃO DAS VARIÁVEIS}

Segundo Trujillo (1974, p. 144), "variável é um valor que pode ser dado por uma quantidade, qualidade, característica, magnitude, traço etc., variando em cada caso individual". Em função disso, a definição das variáveis a serem utilizadas é de particular importância em um trabalho de pesquisa, buscando apresentar da maneira mais precisa possível, o objeto a ser estudado. Para tanto, realiza-se a definição conceitual e operacional das variáveis. Este processo é definido por Tull e Hawkings (1976, p. 214) da seguinte forma:

\begin{abstract}
A 'definição conceitual' define um conceito em termos de outros conceitos. Ela especifica a ideia central ou essência do conceito. Muito frequentemente é o equivalente a uma definição encontrada num dicionário. [Por sua vez], uma 'definição operacional' descreve as atividades que o pesquisador deve completar para associar um valor a um conceito em estudo em um determinado caso. Conceitos são abstrações; tanto que não são observáveis. As definições operacionais traduzem o conceito em um ou mais eventos observáveis.
\end{abstract}

Segundo Kerlinger (2003, p. 48-49), a definição operacional atribui significado a uma variável ou constructo, especificando as atividades ou "operações" necessárias para medi-lo ou manipulá-lo. Marconi e Lakatos (2003, p. 175-176), com base em Kerlinger (1980, p. 48), representa o universo da ciência constituído de três níveis: no primeiro ocorrem as observações dos fatos, fenômenos, comportamentos e atividades reais; no segundo, encontram-se os conceitos ou constructos em forma 
de hipóteses; finalmente, no terceiro surgem teorias, hipóteses válidas e sustentáveis, compostas de constructos e termos teóricos. O trabalho do pesquisador é a passagem do segundo para o primeiro nível, o que ocorre mediante a definição operacional, com a delimitação das variáveis, conforme ilustrado na figura 2:

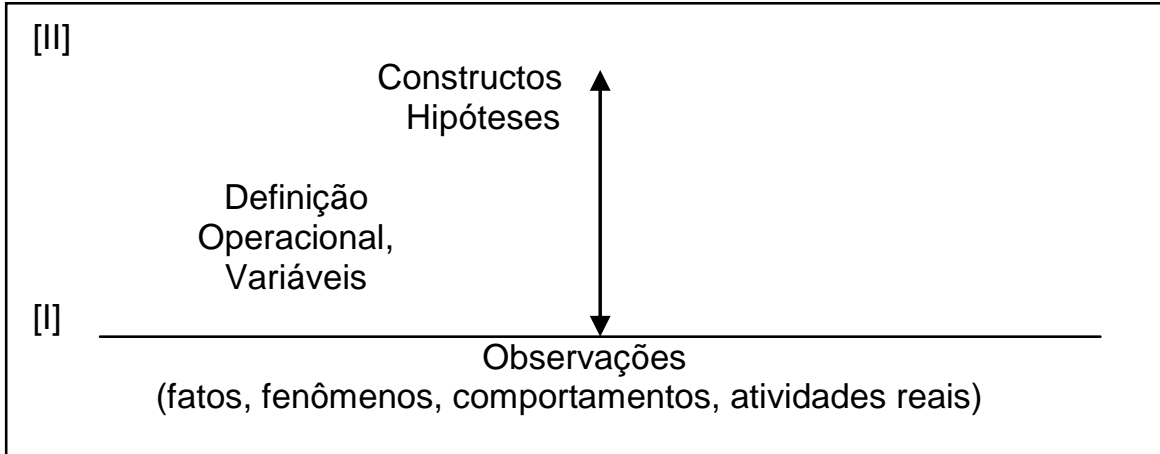

Fig. 2- Definição operacional das variáveis. (Adaptado de MARCONI e LAKATOS, 2003, p. 176)

Portanto, é a definição operacional, por intermédio das variáveis, que torna possível passar do nível constructo-hipótese (II) para o nível de observação (I), fazendo o pesquisador se locomover entre os dois níveis, ou seja, a definição operacional liga os dados observáveis com as variáveis, conforme demonstrado na figura 3.

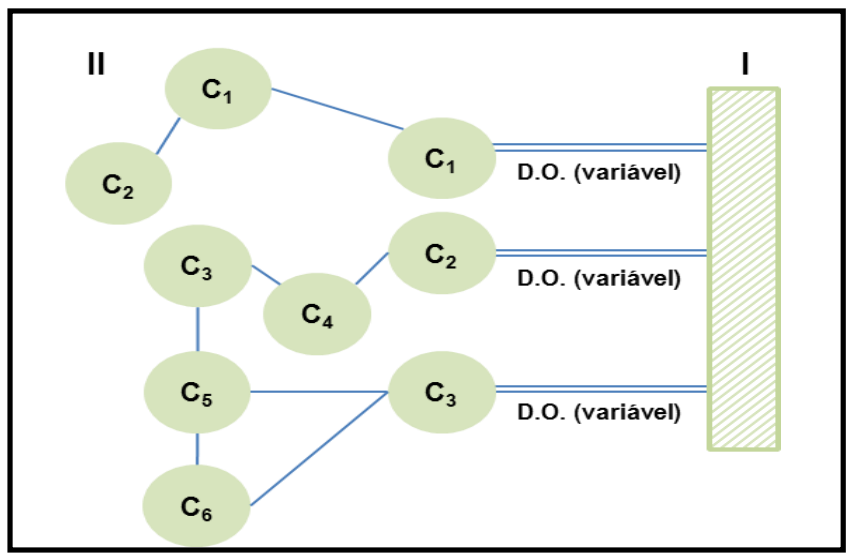

Fig. 3 - Constructos definidos operacionalmente(Adaptado de MARCONI e LAKATOS (2003, p. 174)

\subsection{Variável Independente}

- Oferta de produtos de informação disponível na Web.

\subsection{Variáveis Dependentes}

\section{a) Tipologia dos produtos de informação jurídica}

\section{A.1 Produto de informação}

A.1.1 Produto disponibilizado na Web - Biblioteca Digital Jurídica - BDJur; Conceito: envolve a determinação dos tipos de produtos que a unidade de informação deve possuir e oferecer para proporcionar acesso à informação através 
da Web. Segundo Miranda, (2003) é a capacidade da unidade de informação oferecer produtos por meio do site, permitindo acesso à informação registrada em meio eletrônico e de forma impressa, dependendo da disponibilidade documentária, baseada em registros organizados, fisicamente disponíveis em alguma parte da rede. Físico no sentido de sua materialidade, tanto se referindo à existência de um livro ou periódico na estante, ou de um conjunto de dados depositados numa base de dados institucional. Só está acessível o que existir no ciberespaço e que, necessariamente, possui base física geograficamente determinada. (MIRANDA, 2003).

Operacionalização: foi considerado o produto de informação na Web que fornece maior suporte ao acesso à informação jurídica.

\section{b) Tipo de usuário do produto de informação jurídica}

\section{B.1 Assessor de Ministro}

Conceito: Conforme classificação de Alonso (1998) é o operador do direito e advogado integrante da comunidade jurídica, que no STJ exerce função relacionada à atividade judicante nos gabinetes de ministro do Tribunal.

Operacionalização: Descrição do perfil do assessor de ministro mais antigo do Gabinete exercendo a função comissionada CJ-3, Assessor de Gabinete, identificando aqueles que possuem conhecimento do produto e serviço de informação a ser avaliado; tenham envolvimento em alguma situação que requeira a busca e uso de informação; e, que esse ciclo tenha sido realizado, pelo menos uma vez, recentemente. (ROCHA e SOUZA, 2011, p. 37)

\section{c) Avaliação de produto de informação jurídica}

Conceito - Capacidade da unidade de informação de analisar produtos de informação na Web, para verificar se a oferta de produtos de informação está de acordo com as necessidades de informação dos usuários. Segundo Rocha e Souza (2011, p. 16) as características do processo de avaliação remetem ao estudo quantitativo, em que se busca observar o conhecimento do grau de satisfação dos usuários; ao estudo qualitativo sobre o comportamento de busca e uso da informação pelo usuário e o atendimento de suas reais necessidades; e ao grau de interação homem-máquina a partir da disponibilização dos produtos em ambiente Web.

Operacionalização: avaliação qualitativa e quantitativa com a Metodologia do IBICT para Avaliação de Produtos de Informação.

\section{C.1 Avaliação qualitativa de produtos de informação}

Conceito: Foi considerado um conjunto formado de três aspectos denominados trinômio operacional do sense-making como sendo fundamentais para a avaliação dos produtos de informação. (ROCHA e SOUZA, 2011, p. 20). Segundo estas autoras toda necessidade de informação gera uma situação, que por sua vez produz uma lacuna - cuja supressão é constituída pelos elementos, busca da informação necessária e as respectivas fontes de informação. Enquanto o terceiro aspecto característico é o uso, que consiste na supressão da lacuna e utilização ou aplicação da informação obtida. (ROCHA e SOUZA, 2011, p. 20). 
Operacionalização: A avaliação qualitativa é realizada por meio de entrevista onde o usuário descreve em profundidade no tempo e espaço as características da real necessidade de informação, narrando o momento mais recente de necessidade de informação, os caminhos percorridos na obtenção da informação, incluindo os piores e melhores momentos na busca, a eficácia da fonte utilizada e o consequente uso da informação obtida no processo da construção do conhecimento. Serão seguidos os roteiros para realização da entrevista com aplicação do método Micro moment time line interview e abordagem Sense-Making, para questionamentos sobre a situação, lacuna e uso.

Posteriormente, será aplicado o roteiro de entrevista com a marcação dos incidentes críticos (positivos e negativos) pelos usuários, conforme Metodologia do IBICT, considerando alterações necessárias para a realidade peculiar do STJ. A padronização das situações individuais e diferenciadas de busca a informação pelo usuário, ou micromomentos, é feita pela aplicação do método de Incidentes críticos de Flanagan (1973, p. 99) que na Metodologia do IBICT visa à obtenção de padrões positivos e negativos de cada componente do trinômio composto de situação, lacuna e uso. Isto permite em relação ao produto avaliado, elaborar um instrumento consolidado incluindo os incidentes críticos do total de entrevistas realizadas com os usuários. Este procedimento permite obter o padrão de comportamento dos usuários na busca e uso do produto de informação. (ROCHA SOUZA, 2011, p. 22-23, 48).

C.1.1- Situação

Conceito: É o fato gerador da necessidade de informação. Conforme Rocha e Souza (2011, p. 20) não existe necessidade de informação sem motivo aparente, ou seja, a informação é decorrente da ação do homem, a partir de determinado comportamento, permeado por eventos que caracterizam causalidade, situacionalidade e temporalidade.

Operacionalização: Verificar a causa da necessidade de informação em relação à situação geradora desta necessidade, numa determinada fração de tempo.

\section{C.1.2 - Lacuna ou necessidade de informação}

Conceito: Segundo Rocha e Souza $(2011$, p. 20) refere-se a um déficit, conflito ou desordem enfrentado por um agente que gera necessidade de informação. Tais questões e necessidades de informação estão sempre relacionadas ao contexto de práticas e atividades dos agentes, sendo que as relações entre situação e lacuna são reconstruídas nas narrativas dos entrevistados. Na descrição da lacuna, as perguntas devem ser dirigidas também para responder às questões quem, o quê, quando, onde, por que ou como o usuário está buscando a informação ou o acesso ao documento. (ROCHA e SOUZA, 2011, p. 20)

Operacionalização: Verificar a experiência vivenciada pelo usuário em relação ao modo de busca por uma informação especializada, para a fundamentação de uma atividade judicante específica, num deterninado momento.

C.1.3 Uso

Conceito - Refere-se à utilidade das informações no processo de supressão da lacuna, os impactos decorrentes, as consequências observadas e os reflexos deste evento em situações diversas. (ROCHA e SOUZA, 2011, p. 20)

Operacionalização - identificar processos cognitivos ou mapa mental dos usuários no comportamento de busca e uso da informação e, na atribuição de sentido da informação encontrada, para o seu trabalho. 


\section{C.2 Avaliação quantitativa de produto de informação}

Conceito - Análise da mensuração da extensão do acesso, do uso e do grau de satisfação de produtos de informação. (ROCHA e SOUZA, 2011, p. 15)

Operacionalização - Definição da amostra para levantamentos e dados e realização do levantamento de dados quantitativos sobre os usuários. Nos formulários eletrônicos de avaliação do produto e serviço, disponíveis para os usuários, constam questões sobre o perfil demográfico e profissional destes. O conteúdo do formulário de avaliação inclui peculiaridades e diferenças próprias do produto e do serviço de informação jurídica avaliados, referentes a como é disponibilizado na Web e os fatores que interfiriram positivamente ou não nos resultados obtidos na busca de informação e uma questão aberta para que os usuários proponham recomendações para melhoria do produto (ver Anexo 4).

- Levantamento de dados quantitativos - (ver Anexo 1)

- perfil demográfico do usuário;

- perfil profissional do usuário;

- habilidades e facilidades para acessar informação jurídica na Web;

- respostas que o resultado do uso do produto proporciona ao usuário, quanto ao operacional, qualidade do conteúdo e tempo de resposta.

- Definição da amostra para levantamento de dados - identificação do assessor de ministro mais antigo dos 30 gabinetes do tribunal. $O$ formulário eletrônico para levantamento de dados quantitativos sobre o produto enviado por e-mail possibilitou a participação equânima dos assessores de ministro.

- Uso de software Zoomerang, utilizado na Metodologia do IBICT, apropriado para implantação de formulário eletrônico para coleta de dados em página Web ou por email, geração de tabelas estatísticas, quantificação dos dados e representação em gráficos e tabelas.

- Análise das recomendações dos usuários na questão aberta do formulário eletrônico e categorização conforme o conteúdo. (ver Anexo 5)

\section{C.3 Avaliação da usabilidade de produtos de informação}

Conceito - Identificação do grau de interatividade entre homem-computador nos produtos avaliados (ROCHA e SOUZA, 2011, p. 15). Método de engenharia de usabilidade utilizado na detecção de problemas de usabilidade no design de interface de usuário. (NIELSEN apud ROCHA e SOUZA, 2011, p. 26). Avalia a gravidade do problema em relação à frequência, impacto (grau de dificuldade do usuário em contornar o problema) e persistência (sem possibilidade de ser contornado). Segundo Rocha e Souza (2011, p. 26) os usuários dos produtos de informação podem fazer esta avaliação, com base em dez heurísiticas de interação entre usuário e interface do produto e serviço de informação. (ver Anexo 7)

Operacionalização - Aplicação do método de análises heurísticas em testes de usabilidade de Jakob Nielsen (1992, c2005a, c2005b, 2001). Na Metodologia do IBICT a Heurística 5 (Prevenção de erros) e a Heurística 9 (Ajuda ao usuário no reconhecimento, diagnóstico e correção de erros) foram reunidas em uma única heurísitca por tratarem de erros, resultando em nove heurísticas a serem analisadas, com o envio para o usuário de um checklist estruturado nas dez heurísticas de Nielsen: 
- H1 - Clareza e visibilidade do status do sistema ou site - O sistema deve informar o que ele oferece, quais as suas características temporais, especiais e temáticas, para não criar falsas expectativas.

- H2 - Linguagem - A linguagem do sistema deve ser clara, objetiva, utilizando conceitos, palavras e frases familiares para o usuário, não utilizando jargões de sistema.

- H3 - Autonomia e controle do usuário - o sistema deve permitir que o usuário tenha autonomia para iniciar, interromper, continuar, desfazer, corrigir as ações por ele comandadas.

- H4 - Padronização e consistência - Os elementos de interface de um sistema ou portal devem seguir o mesmo padrão de localização, formato e estética em suas diversas páginas.

- H5 - Prevenção de erros - O sistema deve ser desenvolvido para evitar ou reduzir o número de erros no uso de uma interface. Quando ocorrerem, o sistema deve emitir mensagens de erros claras informando onde ocorre o problema orientando o usuário como reparar o erro.

- H6 - Reconhecimento em lugar de lembrança - o sistema deve minimizar a sobrecarga de memória do usuário, desenvolvendo a interface Web com relações de uma tela para outra facilmente reconhecíveis.

- H7 - Flexibilidade e eficiência - O sistema deve ser desenvolvido de forma a atender os diversos níveis de experiência dos usuários.

- H8 - Estética e minimalismo - Os elementos apresentados devem ser realmente necessários para atender a finalidade da interface, utilizando-se cores apenas para categorizar, diferenciar e destacar, e não para dar informação, especialmente a informação quantitativa, observando-se o uso máximo de 5 a 7 cores diferentes, com o objetivo de melhorar a acuidade visual do usuário.

- H9 - Ajuda e documentação - A operacionalização do sistema deve ser autoexplicativa, sem necessidade do auxílio de documentação ou do sistema de ajuda, utilizando os recursos de interface gráfica, como balões de ajuda, para explicar como realizar uma operação.

\section{d) Tipologia de avaliação do produto de informação realizada pela Biblioteca do STJ}

Conceito - Trata da avaliação da BDJur, realizada anteriormente pela Biblioteca do STJ.

Operacionalização - Averiguação de metodologias, abordagens e técnicas utilizadas pela Biblioteca do STJ para avaliação da BDJur.

\section{PROCEDIMENTOS METODOLÓGICOS}

O estudo do fenômeno da Web como meio digital que visa à usabilidade de produtos e serviços de informação, envolve aspectos de conteúdo, uso e interatividade entre organização e usuário. Por conseguinte, priorizar a necessidade de informação do usuário na análise do uso da biblioteca digital fornecida pela Biblioteca Ministro Oscar Saraiva, do STJ, de acordo com as necessidades de 
informação do assessor de ministro, no desempenho do seu trabalho relacionado à atividade judicante, demanda uma cobertura metodológica interdisciplinar, que contemple aspectos de uso dos conteúdos informacionais e do contexto tecnológico de interface usuário e produto de informação. Segundo Sayão (2001, p. 83), os métodos não incluem todas as observações, mensurações e medições associadas ao objeto de estudo, mas, são valiosos por evidenciarem aspectos fundamentais da realidade estudada e desconsiderarem detalhes secundários. Além disso, este autor observa que, cada método expressa e justifica uma abordagem da realidade física pela Ciência da Informação. Rendón Rojas (1998, p. 23) defende uma flexibilidade necessária para o desenvolvimento da pesquisa na Ciência da Informação, sustentando que o pesquisador deve contar com um método que permita desenvolver sua criatividade, tanto em relação aos processos para realizar uma investigação, como aos temas aos quais dirigi seu exame e atenção.

Não obstante a diversificação de metodologias contemporâneas sobre estudo de usuários, concorda-se com o pensamento de Kunz, Rittel e Schwuchow apud Cunha (1982, p 17) ao notarem que: "frequentemente os resultados de estudos empíricos neste campo têm levado somente a uma acumulação de dados previamente conhecidos e à confirmação de relacionamentos já estudados, e não têm gerado suficiente conhecimento novo". Neste sentido, a triangulação de métodos na composição da Metodologia do IBICT, objetiva possibilitar a descoberta e o relacionamento de ampla gama de fatores e circunstâncias, incluindo desde a identificação de necessidades de informação do usuário, ao aprofundamento da compreensão do comportamento informacional, de modo integrado a padrões técnicos e tecnológicos de interface do usuário com o produto de informação, tudo isto, conjugado num mesmo processo de avaliação. A forma de apresentação dos resultados permite expor a complexidade de fatores atuantes na vivência de trabalho do assessor de ministro, na atividade judicante do Tribunal, de uma forma ainda não realizada na Biblioteca.

Neste sentido, cabe destacar o ponto de vista de Dutra (2005), ao comparar metodologias de avaliação de desempenho das organizações, cujas funções são similares às de metodologias de avaliação de produtos e serviços, nas unidades de informação. Segundo este autor, há três dimensões menos consideradas, contudo fundamentais, nas avaliações dentro das organizações: "'grau de personalização', 'grau de flexibilidade' e 'grau de geração de conhecimento', as quais possibilitam extrair aspectos considerados relevantes na avaliação, tanto para "medir esses aspectos, como para integrá-los numa visão global". A proposta da Metodologia do IBICT, contempla justamente estas dimensões, ao focar a subjetividade do usuário, possuir a flexibilidade de integrar distintas metodologias consolidadas e, gerar um conhecimento original não construído anteriormente dessa forma, proporcionando uma visão coerente e harmônica sobre a necessidade, busca e uso de produtos de informação no ambiente Web.

Acrescenta-se, ainda que, o desenvolvimento da metodologia é em si mesmo um fato novo na Ciência da Informação, pelas inovações e possibilidades que proporciona no campo da avaliação de produtos e serviços de informação, levando em conta o contexto tecnológico contemporâneo. Por outro lado, o seu lançamento para a sociedade consiste num desafio a ser praticado pelas organizações, contribuindo com uma nova perspectiva e valorização do processo de avaliação no planejamento estratégico da oferta de produtos de informação. Outro ponto importante é que a proposta da Metodologia do IBICT aponta para a necessidade de 
realização de pesquisas na área de estudos de usuários, fundamentadas em métodos e técnicas de pesquisa social, indo além do uso consolidado na área, de aplicação do questionário para coleta de dados, sem contudo, prescindir da análise quantitativa. Se a matematização não organiza fatos qualitativos, contudo se faz necessária dentro de pesquisas nas áreas sociais e humanas. A intenção da Metodologia do IBICT é justamente explorar o qualitativo e quantitativo, sendo então uma metodologia distintiva, integrada e que contribui para autonomizar o campo da avaliação de produtos e serviços de informação, na Ciência da Informação. Por outro lado, apesar de existirem métodos de avaliação de produtos e serviços de informação na Web aplicados em estudos e pesquisas na área da Ciência da Informação, a Metodologia do IBICT mostrou ser um instrumental hábil para examinar o uso da BDJur no acesso à informação jurídica na Web, pela forma de abordar a realidade a ser estudada e incluir a análise da interface homem-máquina, com princípios heurísticos de usabilidade.

Considerando a missão da Biblioteca do STJ de "oferecer informação em doutrina e legislação necessárias a atividade judicante e administrativa do Tribunal", mostrou-se relevante estudar a BDJur com uma metodologia que integra aspectos qualitativos e quantitativos envolvidos no fenômeno da necessidade, busca, acesso e uso da informação, no contexto do Tribunal. Dentre os diversos usuários internos e externos do Tribunal que operam com a informação jurídica, o assessor de ministro, na função de fundamentar os temas dos processos judiciais com doutrina, legislação e jurisprudência, têm necessidades exclusivas, como especialista na área do Direito, além de lidar com situações peculiares de busca e acesso a este tipo de informação, em consonância com a atividade judicante do Tribunal. A análise das circunstâncias implicadas no comportamento da necessidade, busca e uso da informação jurídica disponível na BDJur, pelo assessor de ministro no desempenho do seu trabalho junto à atividade judicante, cujo propósito maior no Tribunal é propiciar acesso à justiça na sociedade, integra objetivos geral e específicos desta pesquisa. Esta realidade pode ser apropriadamente explorada com os recursos da Metodologia do IBICT, que segundo Rocha e Souza (2011, p. 16), converge "o estudo quantitativo, em que se busca observar o grau de satisfação dos usuários"; "o estudo qualitativo sobre o comportamento de busca e uso da informação pelo usuário e o atendimento de suas reais necessidades"; e o "grau de interação homem-máquina a partir da disponibilização do produto na Web".

Os produtos de informação da Biblioteca do STJ têm a finalidade de subsidiar a atividade judicante de acordo com a necessidade específica de informação jurídica nos gabinetes de ministros das Seções julgadoras do STJ. Selecionou-se a Biblioteca Digital Jurídica, BDjur, pioneira no gênero, que permite ao usuário a pesquisa e acesso direto à informação, viabilizando a interação homem-máquina na Web. Sabe-se que na busca à informação jurídica com alto grau de relevância, precisão, e rapidez, concorrem outras bibliotecas digitais, especializadas na área jurídica, seja para o uso do bibliotecário à demanda do usuário, ou para uso direto do usuário operador do direito. Para as unidades de informação, mormente as bibliotecas, é de fundamental importância compreender o uso dos produtos de informação fornecidos, facultando ao profissional da informação utilizar dados e informações colhidos com a aplicação de metodologias de avaliação adequadas para aprimorar, customizar, inovar, substituir e desativar estes produtos.

Por isso, ao aplicar a Metodologia do IBICT, desenvolvida especificamente para avaliar produtos de informação institucionais com conteúdo especializado, de 
modo a contemplar um conjunto significativo de fatores, é possível, analisar a importância do da BDJur no âmbito do Tribunal, além de um conjunto de características nas quais o foco no usuário assume valor incontestável, alcançando um nível de análise de valor qualitativo e quantitativo. A escolha da Metodologia do IBICT está em consonância com o objetivo dessa pesquisa de conhecer, a partir de um espectro maior de requisitos, a necessidade de informação do assessor de ministro, as barreiras e êxitos na busca à informação jurídica e os procedimentos utilizados para superar situações de necessidade do conhecimento jurídico, no desempenho do trabalho numa área de informação especializada, a exemplo do que ocorre com o usuário pesquisador ou cientista, na vivência de necessidade, busca e uso da informação científica e tecnológica, no IBICT. Além disso, cabe refletir até que ponto o aporte teórico interdisciplinar da Metodologia do IBICT aplicado numa pesquisa sobre a BDJur, pode contribuir para a visibilidade da Biblioteca do STJ,. uma vez que a metodologia possibilita trabalhar com a natureza singular de cada instituição, incluindo objetivos, missão, serviços e produtos de informação com conteúdo especializado, que fornece à sociedade.

Vale lembrar que o processo de avaliação nas unidades de informação integram objetivos e o corpus de conhecimento da Ciência da Informação, cujo interesse está em investigar, de acordo com Borko (1968, p. 3), “(...) as propriedades e o comportamento da informação, as forças que governam seu fluxo, e os meios de processá-la para otimizar sua acessibilidade e uso". No domínio aplicado da Ciência da Informação a criação, desenvolvimento e avaliação de produtos de informação integram estudos sobre geração, coleta, organização, armazenagem, recuperação, transmissão e uso da informação. Além disso, Minayo e Sanches (1993) apud Rocha e Souza (2011, p. 17) ressaltam que enquanto a investigação qualitativa "(...) trabalha com valores, crenças representações, hábitos, atitudes e opiniões", a investigação quantitativa "(...) atua em níveis de realidade e tem como objetivo trazer à luz dados, indicadores e tendências observáveis." Para Rocha e Souza (2011, p. 17):

Ao discorrer sobre a natureza diferenciada de ambos os métodos, os autores constataram que tais métodos somente congregam função e valor científico e instrumental, se forem exequíveis num dado contexto de pesquisa. Entretanto, ambos os enfoques podem ser relativizados quanto aos seus limites de aplicação diante das especificidades do objeto de estudo. Por fim, essa percepção de insuficiência não redime o "fazer científico" da imprescindibilidade de tais instrumentos.

Por sua vez, Rocha e Souza (2011, p. 17), ao pesquisarem sobre características e objetivos dos dois tipos de métodos, constataram no pensamento de Serapione (2000) que:

(...) algumas estratégias possibilitam a integração de métodos qualitativos e
quantitativos em pesquisa social na área de saúde. Para tanto, o autor
trouxe diferentes perspectivas teóricas que têm buscado superar a
contraposição entre ambos os métodos. Após discorrer sobre as
especificidades e as aplicabilidades de cada método em diferentes
contextos de investigação, o autor desvelou preconceitos e falsos dilemas
nos debates sobre tais abordagens. Propôs, enfim, a superação da
incomunicabilidade de tais métodos.

Para Rocha e Souza (2011, p. 18), a base interdisciplinar da Metodologia do IBICT herdada do pensamento de Dervin (2003b), possibilita ampliação metodológica de maior cobertura dos aspectos envolvidos nos fenômenos em 
estudo, ressaltando que a interdisciplinaridade da Ciência da Informação foi um conceito fundamental no desenvolvimento da Metodologia do IBICT:

\begin{abstract}
Sem uma abordagem coerente e metodologicamente bem informada para a interdisciplinaridade aplicada à área, tornar-se-á impossível, ou mesmo autodestrutivo, considerar as necessidades de informação interdisciplinares de diferentes grupos em meio ao caos da confluência de informação cyberspaced de limites disciplinares. $\mathbf{O}$ ato de atuar como mediador para outras áreas é ele mesmo um ato inerentemente interdisciplinar. (grifos das autoras). (DERVIN, 2003b apud ROCHA e SOUZA, 2011, p. 18).
\end{abstract}

Nesta linha de raciocínio, Rocha e Souza (2011, p. 18) esclarecem que a Metodologia do IBICT buscou ultrapassar a separação entre método qualitativo e quantitativo, privilegiando: "(...) a comunicabilidade entre os parâmetros avaliativos/qualitativos uso e usabilidade". É justamente a combinação de ambas metodologias com finalidade e procedimentos próprios que possibilita:

(...) considerar o uso em seus valores de natureza gnosiológica e prática durante 0 acesso a apropriação de conteúdos informacionais, bem como somar tal parâmetro aos estudos que consideram os contextos tecnológicos de interface entre usuário e um sistema ou serviço que caracterizam qualitativamente a sua usabilidade. (ROCHA e SOUZA, 2011, p. 18)

A forma para desenvolver a pesquisa foi o estudo de caso, pois, segundo Claver [et al] (2001), ele ajusta-se à pesquisa de temas relativamente novos ou em constante mudança, como o uso e avaliação de produtos de informação disponíveis no ambiente Web. Laurindo (2002, p. 24) afirma ser o estudo de caso apropriado na fase exploratória de determinado tema, podendo posteriormente ser complementado por estudos utilizando outras metodologias, quando houver maior entendimento sobre o tema. Segundo Yin (2005, p. 19) o estudo de caso representa "a estratégia preferida quando se trabalha com questões do tipo 'como' e 'por que', quando o pesquisador tem pouco controle sobre os acontecimentos e quando o foco se encontra em fenômenos contemporâneos". Este autor esclarece que como estratégia de pesquisa, utiliza-se 0 estudo de caso no conhecimento sobre fenômenos individuais, organizacionais, sociais, políticos e de grupos, na Psicologia, Sociologia, Ciência Política, Administração, Planejamento Social, inclusive em Economia, na qual a estrutura de uma indústria, ou a economia de uma cidade ou região podem, por exemplo, ser investigadas através da realização de estudo de caso. Para Yin (2005, p. 20), em todos esses campos, a necessidade do estudo de caso surge do desejo de se compreender fenômenos sociais complexos.

Por sua vez, Fachim (2003, p. 42) acrescenta que o estudo de caso tem natureza intensiva, levando em conta vários aspectos do assunto investigado e revelando relações que, de outra forma não apareceriam. Conforme esta autora, o estudo de caso direciona a compreensão e descrição das relações dos fatores envolvidos, em cada conjuntura. Para Fachim (2003, p. 42) o estudo de caso tem como principal função a "explicação sistemática das coisas (fatos) que ocorrem no contexto social e geralmente se relaciona com uma multiplicidade de variáveis". Yin (2005, p. 20) cita como técnicas de estudo de caso a observação direta do acontecimento estudado e entrevista de pessoas envolvidas, por exemplo. Esta estratégia de condução do processo de avaliação, encontra nos procedimentos da Metodologia do IBICT - que incluem questionários e entrevistas - condições que favorecem sobremaneira o estudo de caso, tanto na avaliação global do conjunto de produtos e serviços de informação de uma única instituição, como ocorreu no IBICT, como para avaliar o caso de um serviço ou produto de informação específico, uma 
vez que os mesmos procedimentos avaliativos são extensivos e podem ser aplicados aos demais produtos e serviços de informação, conforme tomada de decisão da unidade de informação. Ademais, para Yin (2005, p. 20) além da capacidade diferenciadora de "lidar como uma ampla variedade de evidências documentos, artefatos, entrevistas e observações", ele vê o estudo de caso como estratégia de pesquisa afirmando que: "A essência de um estudo de caso, a principal tendência em todos os tipos de estudo de caso é que ele tenta esclarecer uma decisão ou um conjunto de decisões, o motivo pelo qual foram tomadas, como foram implementadas e com quais resultados" (YIN, 2005, p. 32)

Trata-se, para Yin (2005, p. 20) de um método de "investigação empírica" que lida com "um fenômeno contemporâneo dentro de seu contexto de vida real, especialmente quando os limites entre o fenômeno e o contexto não estão claramente definidos", além do que o estudo de caso "enfrenta uma situação tecnicamente única" com "muitas variáveis de interesse, baseando-se em várias fontes de evidências, beneficiando-se do desenvolvimento prévio de proposições teóricas para conduzir a coleta e a análise de dados". Yin (2005, p. 60) identifica quatro tipos de estudo de caso: único holístico (unidade única de análise); único incorporado (duas unidades de análise); múltiplo holístico (várias unidades de análise); e, múltiplo incorporado (duas unidades de análise dentro de várias unidades de análise), conforme ilustrado na figura 4:

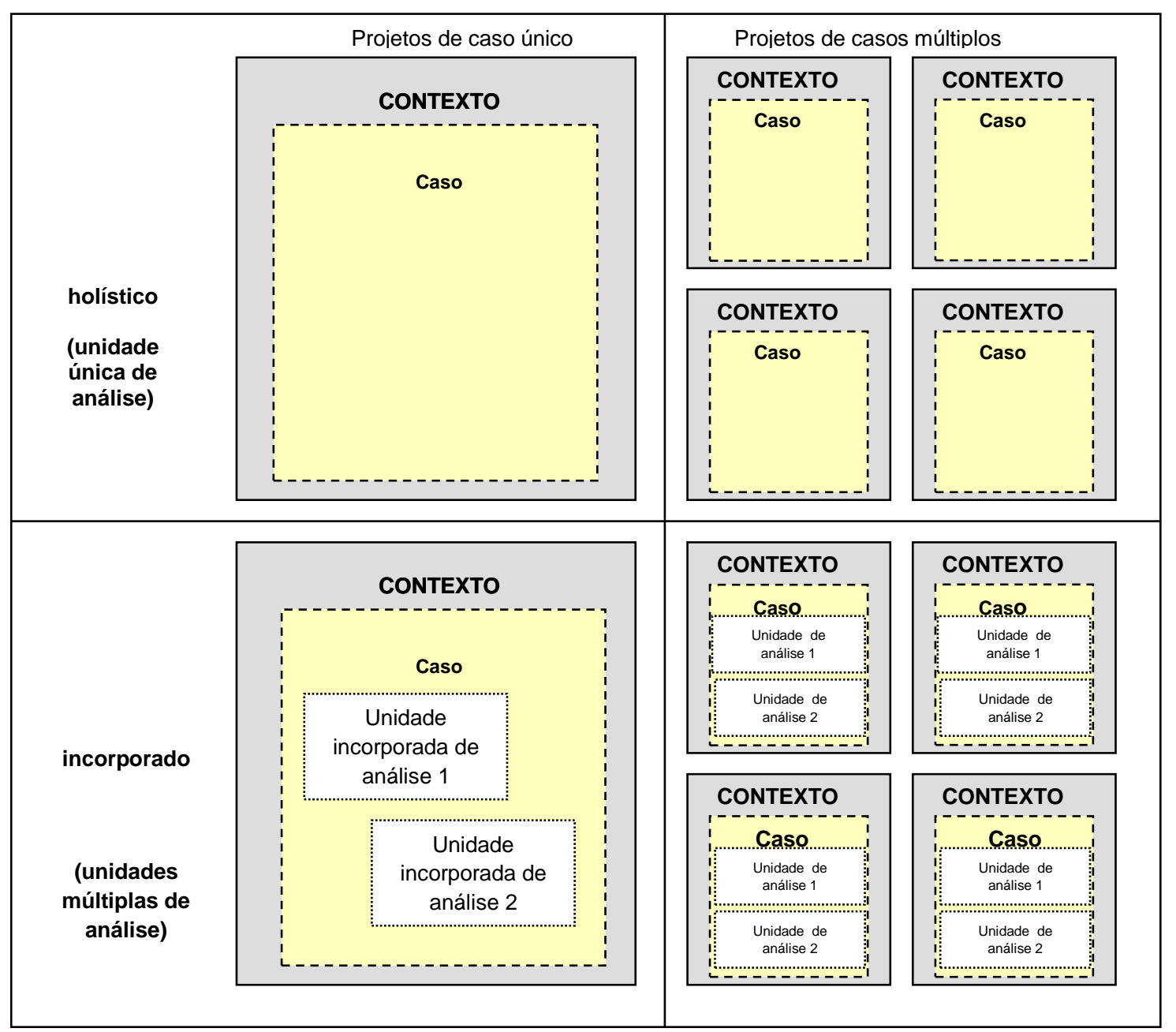

Fig. 4 - Tipos básicos de projetos para estudo de caso. (Adaptado de COSMOS Corporation apud Yin (2005, p. 61) 
Para este autor, o mesmo estudo de caso pode envolver mais de uma unidade de análise, ou seja, dentro de um caso único se enfoca uma subunidade ou várias subunidades. Yin (2005, p. 60) exemplifica com uma pesquisa num hospital, com a seleção de unidades, consistindo em estudo de caso incorporado. Em contraste, o exame da natureza global de uma organização, caracteriza um estudo de caso único holístico. O desenvolvimento deste último tipo é apropriado à investigação de aspectos teóricos em questão, subjacentes a casos específicos, possibilitando o exame da natureza global da organização em foco. De acordo com Yin (2005, p. 62), para realizar uma pesquisa científica por meio de estudo de caso único, existem cinco fundamentos lógicos:

$>$ caso decisivo - testa uma teoria formulada (...) com um conjunto de proposições e circunstâncias nas quais se acredita que as proposições sejam verdadeiras, sendo que para confirmar, contestar ou estender a teoria, deve existir um caso único que satisfaça todas as condições para testar a teoria. O caso único pode ser utilizado para determinar se as proposições de uma teoria são corretas ou, se algum outro conjunto de explanações é mais relevante, ou representar importante contribuição à base de conhecimento e à construção da teoria, podendo, assim, ajudar a redirecionar investigações futuras em uma área inteira. Como exemplo, Yin (2005, p. 62) cita o caso de uma escola onde não havia 'obstáculos a inovações'. Nas teorias vigentes, esses obstáculos haviam sido citados como os principais responsáveis pelo fracasso da implementação de inovações. Ficou demonstrado que nesta escola as inovações também foram mal sucedidas, porém a falta de êxito não estava relacionada a obstáculos, e sim ao processo de implantação das inovações. Com esse estudo houve um 'divisor de águas' na teoria da inovação, isto é, antes do estudo, os especialistas tinham como foco a identificação de obstáculos; a partir do estudo, a literatura deteve-se mais no estudo do processo de implantação;

$>$ caso raro ou extremo - ocorrem, via de regra, no campo da psicologia clínica, na qual uma lesão ou um distúrbio específico pode ser tão raro que é importante documentar e analisar o caso único;

$>$ caso representativo e típico, ou que serve a um propósito - tem por objetivo capturar as circunstâncias e condições de uma situação lugarcomum ou cotidiana. Pode representar um projeto típico entre outros projetos; uma empresa de manufatura considerada típica entre congêneres no mesmo setor industrial; um bairro urbano típico, ou uma escola representativa, por exemplo. Parte-se do princípio de que as lições que se aprendem desses casos fornecem muitas informações sobre experiências da pessoa ou da instituição;

> caso revelador - ocorre quando o pesquisador tem a oportunidade de observar e analisar um fenômeno previamente inacessível à investigação científica. Um exemplo, citado por Yin (2005, p. 63), é o estudo de caso feito sobre o cotidiano de homens desempregados em um bairro de Washington, Estados Unidos, em 1967, que se tornou importante por tratar do problema do desemprego, no qual poucos cientistas sociais tinham pesquisado anteriormente, mesmo sabendo que se tratava de um problema facilmente encontrado em todo aquele país.

$>$ caso longitudinal - estudo do mesmo caso único em dois ou mais instantes diferentes no tempo. A teoria de interesse provavelmente especificaria como certas condições mudam com o tempo, e os intervalos desejados de tempo a serem selecionados refletiriam os estágios presumidos nos quais as alterações devem se revelar.

Por conseguinte, com base na classificação feita por Yin (2005, p. 61) ilustrada na figura 4, esta pesquisa consiste num estudo de caso único holístico 
(unidade única de análise), aplicado à BDJur como produto de informação da Biblioteca Ministro Oscar Saraiva, ofertado no site do Superior Tribunal de Justiça. Como estudo de caso único holístico reúne, ainda, características intrínsecas identificadas por Yin (2005, p. 62) dentre as quais:

- estudo de caso significativo - uma vez que a pesquisa estuda aspectos teóricos e práticos relativos à oferta de produto de informação na Web pela Biblioteca do STJ e que, como caso que se insere no âmbito da informação jurídica, pode ser utilizado para representar uma parcela de contribuição à base de conhecimento sobre este tema, podendo, assim, redirecionar investigações futuras em uma área inteira da biblioteconomia jurídica;

- estudo de caso típico - devido à posição que a Biblioteca do STJ ocupa no cenário nacional como unidade de informação que trabalha com a informação jurídica na esfera do Poder Judiciário, sendo neste sentido uma unidade de informação que torna disponível e acessível a informação jurídica especializada, não existindo outra unidade de informação idêntica. Neste sentido, o conhecimento obtido com a investigação desse caso, fornece informações sobre a realidade de uma unidade de informação que integra a estrutura organizacional de um tribunal, cujo posicionamento é expressivo na estrutura judiciária do país pela missão que desempenha junto à sociedade;

- estudo de caso revelador - considerando que com esta pesquisa serão observados e analisados se os processos de fornecer, acessar e usar a informação, na web - como fenômeno existente em todas as unidades de informação - estão de acordo com as reais necessidades de informação do usuário, aplicando-se uma metodologia da Ciência da Informação própria para este fim, o que certamente poderá ser extensivo a unidades de informação jurídicas, como também a unidades de informação de modo geral.

- estudo de caso inédito - uma vez que aplica uma metodologia própria e específica da Ciência da Informação, desenvolvida pelo IBICT, instituição governamental com competência e responsabilidade no desenvolvimento de redes e sistemas e serviços de informação científico-tecnológicas no Brasil, cuja preocupação é adequar produtos, incluindo os digitais, às reais necessidades dos seus usuários. Com este fim, o IBICT avaliou os próprios produtos no site e, disponibilizou para instituições interessadas, uma metodologia exclusiva para avaliar produtos de informação, na qual, de acordo com Suaiden (2011, p. 12) a:

(...) triangulação de métodos qualitativos e quantitativos permite, ao mesmo tempo, obter uma visão contextualizada das práticas informacionais dos usuários, enriquecer as condições de uso dos produtos além de conhecer o grau de satisfação dos usuários e a extensão de acesso e uso dos produtos avaliados, bem como obter informações sobre a facilidade com que os usuários se relacionam com as interfaces destes produtos.

Vale ressaltar do pensamento de Yin (2005, p. 36) que há casos de pesquisas que podem ser desenvolvidas através de diferentes métodos científicos, ou melhor, que algumas pesquisas podem não apresentar uma estratégia preferível, na medida em que neste caso existe uma sobreposição de pontos fortes e fracos de várias estratégias, resultando que a técnica básica é considerar todas as estratégias de 
uma maneira inclusiva e pluralista como parte de um repertório a partir do qual é possível estabelecer procedimentos de acordo com uma determinada situação, para fazer pesquisa nas Ciências Sociais. Como esta pesquisa trata de um tema passível de transformações constantes, devido ao surgimento de novas tecnologias de informação e comunicação e de novos produtos de informação, acrescido do fato da aplicação da Metodologia do IBICT ser de natureza inovadora e inédita, optou-se por realizar uma pesquisa descritiva e exploratória, a fim de observar, descrever e avaliar, com foco no usuário, o uso e a usabilidade da BDJur.

\subsection{Descrição do método}

Para conhecer a Metodologia do IBICT, inicialmente foram feitos contatos com as autoras da Metodologia, via e-mail e ligação telefônica, constatando que uma autora se encontrava no exterior, enquanto a outra se desligou do IBICT. Foram, então, realizadas duas visitas ao IBICT nos setores à época, envolvidos com o desenvolvimento desta metodologia, ouvindo-se dois funcionários que participaram da aplicação da Metodologia no IBICT para avaliação de produtos e serviços desta organização. Além das informações colhidas nestas visitas, foram coletadas cópias do material bibliográfico usado pelas autoras para fundamentar a metodologia, para leitura e compreensão da metodologia. Pesquisou-se, também, o livro texto das autoras da metodologia, publicado pelo IBICT, e posteriormente, o livro publicado pelo IBICT sobre os resultados obtidos na avaliação de produtos de informação com a Metodologia do IBICT, de autoria de Rabello e Caiado (2015).

$\mathrm{Na}$ Biblioteca do STJ, com a aplicação da Metodologia para Avaliação de Produtos de Informação do IBICT foi investigado o uso pelo assessor de ministro da informação jurídica e, a usabilidade dos produtos de informação, com uma metodologia interdisciplinar, com enfoque no usuário. A investigação quantitativa visou mensurar a extensão do acesso, uso e grau de satisfação do usuário, com aplicação de questionário eletrônico. De outro lado, a análise qualitativa forneceu uma visão contextualizada das práticas informacionais dos assessores de ministro como usuários da Biblioteca do STJ, no uso da BDJur, com a realização de entrevistas fundamentadas na Abordagem Sense-Making de Brenda Dervin e com o método do Micro moment time line interview, o qual focaliza a entrevista numa dada vivência do assessor de ministro na busca de informação na BDJur, para preencher uma situação, lacuna e uso de informação jurídica.

Segundo observação de Rocha e Souza (2011, p. 21) no roteiro da entrevista o importante é alcançar um nível no qual o entrevistado considere como ele deu sentido à busca e uso da informação jurídica em um micromomento na linha do tempo e espaço. Em consonância com a Metodologia do IBICT procurou-se identificar no desenrolar da vivência os movimentos do assessor nos constructos que realizou no decorrer da busca à informação jurídica, detectando-se se houveram, ou não, ocorrências subsequentes de outras lacunas, a partir da supressão da anterior, e se o assessor manifestou outra necessidade de informação subsequente. Conforme, Rocha e Souza (2011, p. 21) o entrevistado foi esclarecido sobre o tipo peculiar de relato que faria sobre as ocorrências do micromomento. Assim, foram explicados os conceitos referentes à situação, lacuna e uso, para que 0 assessor de ministro compreendesse a peculiaridade do método. A análise do produto de informação jurídica da Biblioteca do STJ com aplicação da Metodologia do IBICT visou: 
Descrever a Biblioteca Digital Jurídica, BDJur, como um produto da Biblioteca investigando:

$\checkmark$ no momento da experiência de utilização do produto no processo de busca à informação, o comportamento descrito pelo assessor de ministro em relação aos parâmetros situação, lacuna e uso da informação jurídica no atendimento a suas reais necessidades de informação;

$\checkmark$ os incidentes críticos, positivos e negativos, detectados no relato de experiência do assessor de ministro;

$\checkmark$ a avaliação do grau de satisfação do assessor de ministro sobre o produto de informação;

$\checkmark$ a usabilidade do produto em relação às heurísticas referentes ao grau de interação entre assessor e biblioteca digital, ou interação homem-máquina, com a disponibilização do produto de informação jurídica na Web.

A Figura 05 reúne os três momentos da aplicação da Metodologia do IBICT no mapa conceitual desta pesquisa:

Ambiente Extemo

Ambiente Intemo

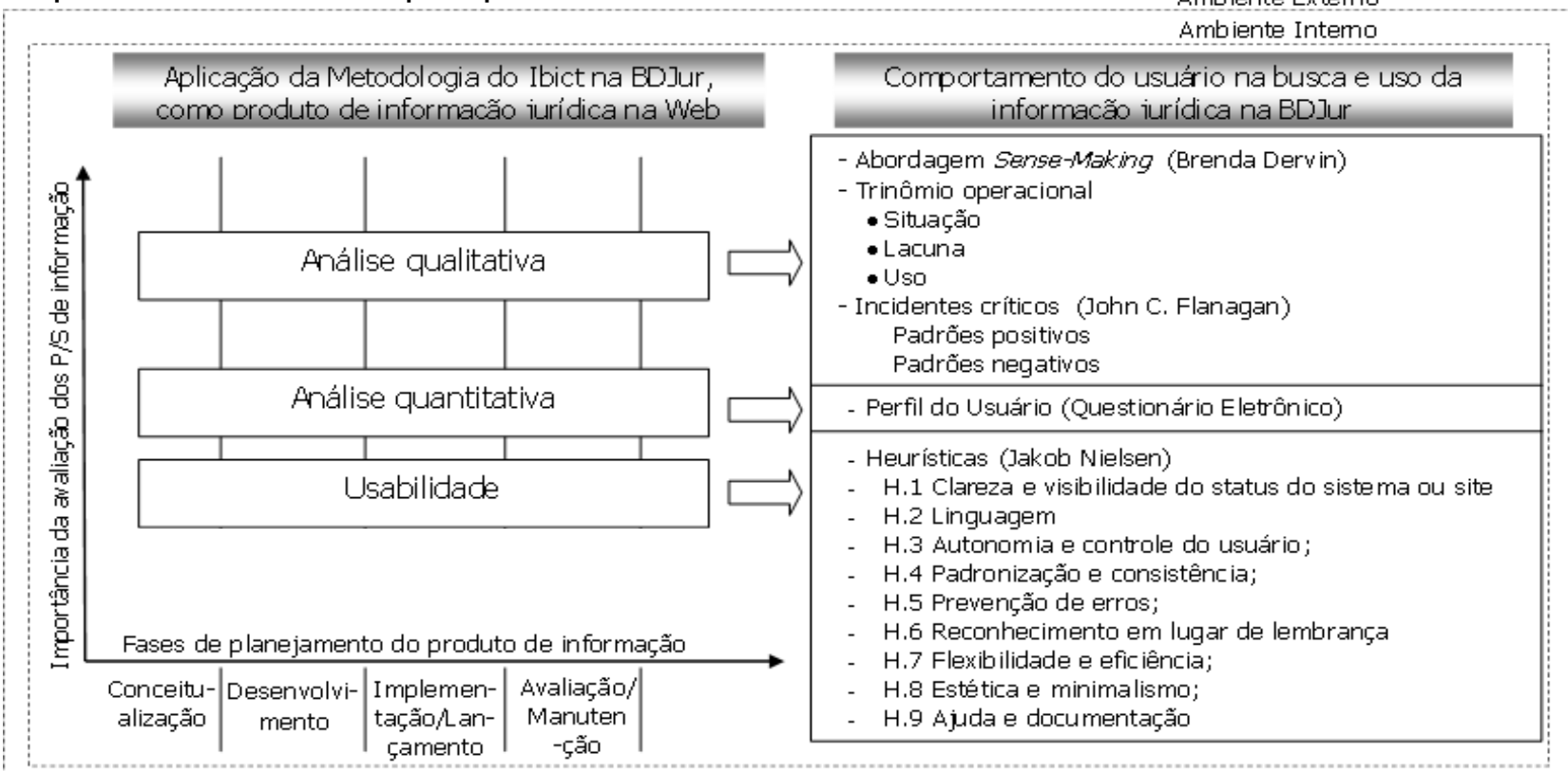

Fig. 5 - Mapa conceitual com os três momentos de aplicação da Metodologia do IBICT

\subsection{Universo da pesquisa}

A tipologia de usuários da Biblioteca do STJ compreende, na área jurídica, o ministro, magistrado convocado, juiz auxiliar, juiz instrutor, chefe de gabinete, assessor-chefe, assessor de ministro; e, na área administrativa, o secretário-geral da presidência; diretor-geral da secretaria do tribunal; secretário, coordenador; chefe de seção; servidor; além do usuário externo da área jurídica, o cidadão, outras bibliotecas e organizações da sociedade. Consiste, assim, em universo de grande dimensão que se desdobra em duas direções principais, a atividade judicante e a atividade administrativa no Tribunal, segundo expresso na missão da Biblioteca do STJ de: "Oferecer informação em doutrina e legislação necessárias à atividade judicante e administrativa do Tribunal". Conforme os objetivos desta pesquisa, selecionou-se o assessor de ministro, como usuário da Biblioteca, cuja atribuição estabelecida em norma do STJ de "examinar os autos conclusos ao Ministro e pesquisar a doutrina, legislação e jurisprudência referentes à matéria versada em cada processo", trabalha dentro de uma dinâmica caracterizada pela necessidade, 
busca e uso da informação jurídica, para fundamentação de temas dos processos judiciais e redação da proposta ou modelo do voto, a ser submetido ao ministro, no procedimento de julgamento destes autos, dentro da atividade judicante fim do Tribunal. No estudo preliminar das características do assessor, como usuário da informação jurídica, observou-se que as exigências do cargo e o ritmo de trabalho deste profissional constituem barreiras consideráveis na participação em pesquisas, mesmo ao constatar-se a motivação e interesse de alguns em participar. Estes fatores, somados à não motivação de outros assessores, dificultam a aproximação e o diálogo com esse usuário, consistindo em condições desfavoráveis à realização de pesquisas de natureza extensiva, que demandam disponibilidade e tempo de participação mais prolongado. Quanto a isto, outros fatores importantes a considerar, são as alterações na permanência do assessor no cargo, em função do encerramento da atividade dos gabinetes devido à aposentadoria de ministros; quando os ministros assumem a presidência ou vice presidência do Tribunal, a cada dois anos, sendo convocados novos ministros e novos assessores, ocupando o gabinete vago; e; quando há dispensa do assessor deste cargo comissionado.

Face a estas circunstâncias de trabalho, bem como à necessidade específica da informação jurídica nas atribuições do cargo, para o desempenho do trabalho do assessor de ministro, o universo da pesquisa compreendeu 30 Gabinetes de ministros do total de 33 gabinetes existentes na estrutura organizacional do STJ. Ressalta-se que três, dos 33 gabinetes existentes, são os Gabinetes da Presidência, da Vice-Presidência e o Gabinete da Revista, os quais possuem atribuições diferentes e específicas, não constando, então, no universo em estudo. Por sua vez, os outros 30 gabinetes tem competência julgadora dos processos judiciais. Visando abranger a totalidade dos Gabinetes de ministros, que compõem as três Seções julgadoras do Tribunal, utilizou-se o critério de antiguidade no exercício da função de assessor, no quadro funcional do Tribunal, selecionando-se 30 assessores que exercem o cargo em comissão há mais tempo, na totalidade dos gabinetes e, que desenvolvem, ao longo de um período maior de exercício no cargo, a busca da informação para fundamentar e redigir a proposta ou modelo do voto nos autos, como função relacionada ao julgamento dos processos judiciais, dentro do propósito maior da atividade judicante do STJ na sociedade. Foi analisado como esta busca específica da informação jurídica para o trabalho do assessor, ocorre com o uso da BDJur, biblioteca digital da Biblioteca do STJ, que fornece acesso a doutrina, legislação e atos administrativos do STJ, na Web. No universo da pesquisa considerou-se a composição dos assessores dos Gabinetes dos ministros do Tribunal relativa ao biênio 2012-2014.

\subsection{Coleta de dados}

Yin (2005, p. 125) reforça como ponto importante da coleta de dados no estudo de caso a possibilidade de se utilizar várias fontes diferentes para a obtenção de dados e informações, permitindo ao pesquisador investigar ampla diversidade de questões comportamentais e atitudes relativas a uma determinada questão ou problema. Em consonância com os objetivos desta pesquisa, foram utilizadas pesquisa à documentação, entrevistas, questionário eletrônico e relato do usuário sobre a vivência de busca à informação, conforme a Metodologia do IBICT. Segundo Chisnall (1980, p. 175) o questionário é um instrumento de trabalho para obter informação específica sobre um determinado problema de modo que, os dados, após análise e interpretação, resultem em melhor apreciação e conhecimento do 
problema. Já, a entrevista segundo Yin (2005, p. 113) por ser direcionada, enfoca o tópico do estudo de caso diretamente além de ser perceptiva, fornecendo inferências causais ao evocar a situação na qual ocorreu a busca à informação, utilizando as próprias palavras do usuário entrevistado para explicar o significado desta situação.

A coleta de dados sobre o STJ foi realizada com análise documental do histórico do tribunal e com a participação no Curso à distância sobre o Regimento Interno do STJ. Visando conhecer a realidade de trabalho nos gabinetes de ministro foi realizada entrevista com uma assessora de gabinete de ministro que não participou da pesquisa. A coleta de dados sobre a Biblioteca do STJ foi fundamentada na análise documental de relatórios, registros históricos, dados estatísticos, gráficos, planos estratégicos e demais documentos técnicos existentes na Cordenação da Biblioteca e no acervo, além de uma visita técnica preliminar à Coordenação da Biblioteca e à Sessão de Pesquisa. O objetivo das visitas foi conhecer hábitos de busca e necessidade de informação dos assessores de ministro do tribunal que serviram de base para elaboração do questionário e do roteiro da entrevista estruturada aplicados junto aos assessores de ministro sobre a BDJur. A coleta de dados sobre a BDJur foi realizada com visitas à Seção de Biblioteca Digital e obtenção de documentos sobre o histórico de implantação e desenvolvimeno da BDJur e informações com o chefe desta seção. $\mathrm{Na}$ descrição de aspectos tecnológicos, técnicos, administrativos e funcionais da BDJur foi consultado o livro sobre a BDJur, lançado por ocasião da comemoração dos dez anos da biblioteca digital, com acesso ao texto antes do fechamento da versão. Foi também realizada observação direta deste produto com acessos no site do STJ.

Com a aplicação da abordagem Sense-Making como procedimento integrante da Metodologia do IBICT, foi considerado que a necessidade de informação jurídica do assessor de ministro gera uma situação, que por sua vez ocasiona uma lacuna. Conforme Rocha e Souza (2011, p. 21) a supressão desta lacuna inclui todos os fatos inerentes à "busca da informação necessária e as respectivas fontes de informação". Neste processo, a supressão da lacuna e a aplicação da informação obtida consistem no uso voltado para a atividade judicante.

\subsubsection{Elaboração do questionário e do roteiro de entrevista}

O questionário como instrumento de coleta de dados, enviado aos assessores de ministro mais antigos do total de 30 gabinetes existentes no Tribunal, foi composto por 28 perguntas, com opções alternativas, incluindo quando necessária, a opção aberta de resposta, oportunizando a manifestação de opiniões, críticas e sugestões dos assessores de ministro. (Anexo 9). A estrutura das perguntas do questionário foi conduzida pelo modelo do questionário da Metodologia do IBICT, visando seguir os passos da Metodologia no processo de avaliação de um produto de informação, direcionada, entretanto, à realidade da Biblioteca do STJ.

No pré-teste do questionário aplicado aos assessores de ministro foram consultados os bibliotecários da Seção de Biblioteca Digital, BDJur, da Seção de Doutrina da BDJur e, duas bibliotecárias e a chefe da Seção de Pesquisa, devido à experiência que detém sobre os usuários da biblioteca, além de uma assessora de ministro que não participou da pesquisa, os quais examinaram o ajustamento necessário entre as questões formuladas e o problema estudado. O pré-teste do questionário possibilitou analisar a coerência e o conteúdo dos enunciados com a realidade do trabalho do assessor no gabinete de ministro, além da funcionalidade 
como instrumento de coleta de dados; e, observar possíveis falhas na formulação das questões - perguntas ambíguas, duplicadas, precisão da terminologia usada bem como verificar a congruência do instrumento em relação aos problemas e objetivos estabelecidos nesta pesquisa. O questionário foi estruturado conforme o modelo da Metodologia do IBICT no levantamento de dados e realização da primeira etapa com a abordagem quantitativa da avaliação, cujo objetivo é a mensuração da extensão do acesso, do uso e do grau de satisfação do usuário com o produto de informação:

a) identificação do perfil do usuário - as questões de n. 1 a 11 objetivaram a obtenção de dados para descrição do perfil do usuário da seguinte forma:

a.1) perfil demográfico do usuário - questões n. 1 a 5

- questões 1 e 2 - visaram apurar, respectivamente, a faixa etária e sexo;

- questão 3 - visou identificar o nível de graduação e pós-graduação na formação profissional;

- questão 4 - indicou o ano de conclusão do último nível de formação profissional;

- questão 5 - identificou a(s) área(s) do conhecimento de formação profissional indagando sobre a formação em outra área do conhecimento além do Direito.

a.2) perfil profissional do usuário no gabinete de ministro - questões n. 6 a 9

- questão 6 - indagou sobre o tempo de exercício na função comissionada de assessor de ministro;

- questão 7 - identificou o tipo de vínculo empregatício do assessor no STJ, entre servidor público do quadro funcional do tribunal, cedido de outro órgão público, sem vínculo com a Administração Pública, acrescido de uma opção aberta de resposta para outra categoria de vínculo;

- questão 8 - visou identificar o gabinete de lotação funcional do assessor;

- questão 9 - teve por fim evidenciar o campo de atuação profissional do assessor em relação às áreas do Direito de competência de julgamento de cada Seção e Turma do STJ.

b) habilidade e experiência para acessar a informação jurídica na Web - questões n. 10 a 13

- questão 10 - possibilitou a auto-avaliação do usuário sobre o grau de experiência para realizar buscas em bases de dados de informação jurídica na internet;

- questão 11 - indagou sobre as bases de dados de informação jurídica na internet/intranet que o usuário utiliza para realização do trabalho como assessor de ministro;

- questão 12 - teve por finalidade evidenciar o conhecimento e uso da BDJur pelos assessores de ministro como produto de informação jurídica do STJ;

- questão 13 - buscou identificar os meios de divulgação e a forma que o usuário tomou conhecimento da BDJur como produto de informação jurídica;

c) uso proporcionado pelo produto ao usuário, quanto ao conteúdo, operacional e tempo de resposta - objetivou à obtenção de dados para descrição da BDJur como produto de informação jurídica - questões n. 14 a 25

c.1 Quanto ao conteúdo da informação jurídica: (questões n. 14,15,16, 18, 23, 24)

- questão 14 - indagou sobre a tipologia de informação jurídica disponível na BDJur entre atos normativos do STJ, doutrina, legislação, jurisprudência comentada publicada em livro e parecer - visando constatar o grau de frequência de busca para a realização do trabalho do assessor; 
- questão 15 - teve por finalidade evidenciar o grau de importância atribuído pelo ususário a cada tipo de informação jurídica - doutrina, legislação, ato normativo e jurisprudência - disponível na BDJur, para o desempenho da sua atividade profissional;

- questão 16 - as alternativas de resposta visaram a constatação do uso, ou não, da informação jurídica disponível na BDJur, relacionado ao objetivo e ao grau de frequência deste uso, pelo assessor de ministro em várias etapas do trabalho na atividade judicante do tribunal, incluindo a análise e fundamentação da matéria do processo judicial; citação na redação do relatório ou de outra parte do processo judicial; sanar dúvida sobre questão específica do Direito; atualização sobre legislação específica; incluindo opção de resposta aberta para outra finalidade e frequência de uso.

- questão 18 - avaliou o conceito e grau de importância atribuído pelo assessor à BDJur em relação à necessidade de busca e uso da informação jurídica na execução do seu trabalho como parte da atividade judicante;

- questão 23 - teve como objetivo apurar o grau de satisfação em relação ao conteúdo disponibilizado nas páginas da BDJur;

- questão 24 - investigou se o teor dos textos explicativos nas páginas da BDJur direcionam a pesquisa no acesso à informação jurídica demandada pelo assessor;

c.2 Quanto aos aspectos operacionais de utilização da BDJur pelo usuário - $(17,19$, $20,21,22)$

- questão 17 - visou indicar com que periodicidade o assessor realiza buscas na BDJur;

- questão 19 - averigua a média de tentativas realizadas pelo assessor para localizar a informação jurídica no processo de busca na BDJur;

- questão 20 - examina a escala do grau de dificuldade necessário para a realização de buscas à informação jurídica pelo assessor e se a dificuldade está relacionada, ou não, ao número de tentativas de encontrar a informação demandada;

- questão 21 - foi questionado se o assessor buscou alguma informação jurídica na

BDJur que não encontrou;

- questão 22 - visou descobrir as dificuldades encontradas no acesso à informação jurídica na BDJur, pelo assessor, com a opção de resposta individual aberta;

\section{c.3 Quanto ao tempo de resposta ao acesso à informacão jurídica (questão 25)}

- questão 25 - investiga como o assessor considera o tempo de retorno da BDJur à pesquisa realizada.

O questionário eletrônico foi enviado duas vezes para o e-mail institucional dos assessores de ministros, havendo necessidade, em alguns casos, de um terceiro reenvio. O índice de resposta foi positivo, contudo, devido à proximidade do período de recesso forense, para que houvesse número efetivo de resposta, além do texto explicativo sobre a pesquisa enviado junto ao questionário, foram feitos contatos telefônicos com os assessores, solicitando a resposta do questionário.

$\mathrm{Na}$ segunda etapa da aplicação da Metodologia do IBICT, a coleta de dados para a abordagem qualitativa da avaliação da BDJur como produto de informação, buscou verificar, em relação ao usuário, aspectos de valor, cognição, movimentos e percursos de busca e uso da informação. Para tanto, considerou-se a acepção do termo "uso da informação" como acesso e apropriação de conteúdos informacionais de valor cognitivo ou prático, conforme a Metodologia do IBICT. Foi realizada com a aplicação de entrevista estruturada com assessores pertencentes a cada uma das três Seções de Julgamento do STJ. Estes assessores foram selecionados entre 
aqueles que participaram da primeira etapa de coleta de dados com o questionário eletrônico de avaliação de dados quantitativos aplicado a todos os gabinetes de ministro e responderam informando que realizam busca frequentemente na BDJur, em período "semanal" ou "mensal", além de ter atribuído os indicadores "muito alto" ou "alto" à BDJur em função da necessidade de busca de informação jurídica, para realização do trabalho de assessor.

Cabe acrescentar que, durante a realização da seleção dos assessores a serem entrevistados entre os respondentes do questionário eletrônico, seis assessores foram excluídos da seleção em função da desativação de quatro gabinetes devido à aposentadoria dos ministros, sendo então substituídos por novos ministros em novos gabinetes; ademais, dois gabinetes foram desativados porque um ministro foi eleito, passando a exercer o cargo de Presidente do STJ, e uma ministra foi eleita a Vice-Presidente do STJ, ambos em novos gabinetes com quadro funcional e funções diferentes do gabinete anterior. Também foram excluídos da entrevista dois assessores: um respondeu no questionário eletrônico que pouco utiliza e outro, que não utiliza a BDJur, totalizando, ao final o número de 14 gabinetes. Na etapa de escolha dos assessores para participar da entrevista, ocorreu dificuldade devido ao fato de alguns relatarem não recordar um caso específico de pesquisa na BDJUr, para fazer a descrição da vivência. Além disso, não foi possível contatar assessores que se encontravam em período de férias ou de licença médica; alguns estavam à disposição do ministro para a execução de suas atividades ou, nas sessões, não dispondo de horário disponível; e, outros não manifestaram interesse em participar da entrevista.

De acordo com parâmetros estabelecidos pela Metodologia do IBICT, a entrevista deve contemplar pessoas com notório saber ou formadores de opinião no seu segmento profissional, considerando-se como um dos critérios constante do rol recomendado por Rocha e Souza (2011, p. 37) o perfil de usuário: "servidores públicos que desenvolvam atividades que requerem a busca de informação para execução das suas atividades", o qual corresponde ao perfil do assessor de ministro do tribunal. Acrescenta-se, ainda, o fator estabelecido na Metodologia do IBICT quanto ao perfil do usuário que "requer conhecimento do produto ou serviço a ser avaliado, estar envolvido em alguma situação que requeira a busca e uso da informação e que este ciclo tenha sido realizado, pelo menos uma vez, recentemente (no semestre ou no máximo, no ano corrente)". (ROCHA e SOUZA, 2011, p. 37). Estes requisitos da Metodologia do IBICT estão presentes na realidade de trabalho do assessor de ministro, sendo determinantes no processo que desencadeia o trinômio operacional do Sense-making, incluindo a situação, lacuna e uso da informação jurídica, uma vez que é imprescindível para o desempenho das atividades deste usuário, o envolvimento no processo de busca e uso da informação.

$\mathrm{Na}$ entrevista, procurou-se identificar, conforme a metáfora do Sense-making de Brenda Dervin, as manifestações dos assessores relacionadas ao micro momento do fato gerador que desencadeou a busca, segundo procedimento da Metodologia do IBICT de "mobilizar o entrevistado para que ele traga à tona sensações, sentimentos, emoções, frustações, incertezas, angústias e sucessos experimentados" (ROCHA e SOUZA, 2011, p. 38). Esta análise qualitativa levou em conta a percepção cognitiva e sensitiva do usuário que interferem no processo de busca de informação, abrangendo fatores comportamentais tais como as reações diante da necessidade de resolver problemas, a consciência de risco e recompensa em situações de dúvida ou incerteza, a preocupação com erros, ou a confiança de 
possuir ou não, a informação na qualidade e quantidade necessárias para suprimento da necessidade gerada no ambiente de trabalho e, a atribuição de sentido ou de valor à informação encontrada.

Assim, após contato por telefone esclarecendo sobre o objetivo da entrevista e marcando a data de realização de cada uma, foi solicitado ao final desta a esses assessores que relatassem a vivência de uma busca de informação na BDJur, incluindo o momento particular de uma situação real de necessidade de informação jurídica, o processo de busca na BDJur como fonte de pesquisa e informação e, o uso da informação para realização do trabalho de assessor. O roteiro da entrevista fundamentou-se no modelo proposto na Metodologia do IBICT, com base no trinômio operacional (situação, lacuna e uso) da abordagem Sense-Making, de Brenda Dervin e, no Micro moment time line interview considerando-se, na condução da entrevista, a realidade organizacional do Tribunal, para alcançar a visão contextualizada das práticas informacionais dos assessores (Anexo 10). Para a análise dos resultados da entrevistas, utilizou-se a Técnica dos incidentes críticos de John C. Flanagan, identificando-se padrões positivos e negativos dos momentos situação, lacuna e uso (Anexo 11).

$\mathrm{Na}$ terceira etapa da aplicação da Metodologia do IBICT foi realizada a análise da usabilidade da BDJur como produto de informação jurídica disponível na Web, verificando-se o grau de interação homem-máquina, por meio de análises com nove heurísticas de Jacob Nielsen (1992, c2005a, c2005b, 2001) apud Rocha e Souza (2011, p. 25) compreendidas na questão n. 26 do questionário eletrônico enviado aos gabinetes de ministros. A pergunta do questionário incluiu aspectos das heurísticas ou princípios de usabilidade, possibiliando ao assessor expressar circunstâncias de interface de busca e navegação na BDJur. De acordo com Nielsen (2005a, 2005b) apud Rocha e Souza (2011, p. 26) "os próprios usuários" podem realizar esta análise, refletindo a participação destes conforme assinalado por Rocha e Souza (2011, p. 27): "nos três procedimentos o ator principal é o usuário". Seguiuse nos moldes da Metodologia do IBICT, o agrupamento de duas heurísticas que tratavam do mesmo tema, em uma só: controle de erros pelo usuário e previsão de erros, resultando no número de nove heurísticas, do total de dez.

$\mathrm{Na}$ parte final do questionário, a questão n. 27, tratou do processo de avaliação da BDJur levantado no pressuposto desta pesquisa: "a utilização de técnicas e metodologias adequadas para avaliar produtos de informação é fundamental para dar visibilidade à biblioteca". Partindo-se do pensamento de que a aplicação de metodologias de avaliação de produtos de informação, com foco no usuário e não no produto, com abordagens que permitem estudos complexos e inovadores pode contribuir na forma como a Biblioteca do STJ é vista pelo assessor de ministro, indagou-se com esta questão sobre a interação do usuário com a BDJur para avaliação da interface, funcionalidade e conteúdo apresentado; além da importância da realização de avaliações periódicas da BDJur e, ainda, sobre a contribuição de um formulário eletrônico permanente de avaliação disponível na BDJur. Nesta pergunta foi incluída a opção de resposta aberta para possibilitar ao assessor expressar outro aspecto observado.

A questão n. 28, encerrou o questionário solicitando as recomendações dos assessores de ministro em relação à BDJur.

De acordo com os objetivos desta pesquisa com a aplicação da Metodologia do IBICT para Avaliação de Produtos de Informação, na coleta de dados foi exposto 
ao assessor de ministro a importância do processo de avaliação da BDJur na realização da missão da Biblioteca do STJ, para que haja a necessária adequação dos produtos de informação jurídica fornecidos, às mudanças constantes no cenário da Web.

As abordagens da aplicação da Metodologia do IBICT na BDJur e, as funções e resultados proporcionados por cada uma, estão apresentados no Quadro 11:

QUADRO 11 - As abordagens da aplicação da Metodologia do IBICT x Resultados proporcionados

\begin{tabular}{|l|l|}
\hline \multicolumn{1}{|c|}{ ABORDAGEM/TÉCNICA/MÉTODO } & \multicolumn{1}{c|}{ ANÁLISE } \\
\hline $\begin{array}{l}\text { Avaliação qualitativa com base na abordagem } \\
\text { sense-making, de Brenda Dervin, com } \\
\text { entrevistas estruturadas. análise dos resultados } \\
\text { com aplicação da técnica dos incidentes críticos } \\
\text { de John C. Flanagan. }\end{array}$ & $\begin{array}{l}\text { Obter visão contextualizada das práticas } \\
\text { informacionais dos usuários e as condições } \\
\text { de uso do produto. }\end{array}$ \\
\hline $\begin{array}{l}\text { Avaliação quantitativa com uso de formulários } \\
\text { eletrônicos disponibilizados aos usuários. }\end{array}$ & $\begin{array}{l}\text { Conhecer o grau de satisfação dos usuários e } \\
\text { a extensão do acesso e uso do produto }\end{array}$ \\
\hline $\begin{array}{l}\text { Aplicação das heurísticas de Jakob Nielsen para } \\
\text { avaliação da usabilidade do produto na Web. }\end{array}$ & $\begin{array}{l}\text { Avaliação da usabilidade do produto. } \\
\text { interação homem-máquina. }\end{array}$ \\
\hline
\end{tabular}

\section{DESCRIÇÃO DO CENÁRIO ORGANIZACIONAL}

A descrição do conjunto de características, incluindo histórico, organização administrativa, composição, missão, competência, jurisdição além de outros aspectos sobre o Superior Tribunal de Justiça, foi realizada com base em documentos administrativos do Tribunal, na leitura de artigos específicos da Constituição Federal de 1988, em vídeos institucionais e no curso à distância oferecido pelo tribunal: "Regimento Interno do STJ - Cidadania em Movimento", cujo primeiro módulo teve por objetivo delimitar a competência originária e recursal do STJ conforme estabelecido na CF e no Regimento Interno do Tribunal. Este curso foi organizado por vários servidores do STJ, sendo conteudistas e ministradores do curso os servidores José Pereira dos Santos, advogado e pós-graduado em direito civil, processual civil e tributário, que atua na Seção de Conferência e Uniformidade, da Secretaria de Jurisprudência; e, Fernanda Rios Amorim, advogada e pósgraduada em direito constitucional, lotada na Seção Educativa da Secretaira de Documentação.

Com a descrição do cenário organizacional tornou-se possível constatar a complexidade e importância do STJ na sociedade brasileira, consistindo numa corte de justiça de relevância e projeção internacional onde sobressai sua atuação como pacificador das questões não constitucionais inerentes ao cotidiano de todos os cidadãos, sendo um tribunal nacional que "precisa ser visto a partir do seu interior, pois é internamente, no seio das suas unidades julgadoras e de apoio, que se efetiva o direito dos juridicionados"13. (Regimento Interno do STJ - Cidadania em movimento. Curso à distância, 2013)

\footnotetext{
${ }^{13}$ Jurisdicionado - indivíduo que foi alvo de jurisdição; pessoa a quem se impõe jurisdição, o direito de julgar.
} 


\subsection{Formação do Superior Tribunal de Justiça: origem e histórico}

O Superior Tribunal de Justiça, STJ, originou-se do antigo Tribunal Federal de Recursos, TRF, como resultado da reforma da organização judiciária do país, em meados do século XX. O antigo TFR foi criado pela Constituição Federal de 1946 e, os seus juízes passaram a receber a designação e o estatuto privilegiado de ministro $^{14}$. Nesta época, o TFR funcionava como órgão de apelação da justiça federal, sendo "incumbido de julgar, em segunda instância, ${ }^{15}$ as causas decididas por esse segmento do Judiciário". Em 1960 com a inauguração de Brasília, o TFR foi transferido do Rio de Janeiro para a nova capital, e instalado na Esplanada dos Ministérios por nove anos. Em 1989 foi extinto, dando origem ao Superior Tribunal de Justiça, que continuou funcionando nas mesmas instalações físicas até 1995, quando foi transferido para a sede própria e atual no Setor de Autarquias Sul. (Regimento Interno do STJ - Cidadania em movimento. Curso à distância, 2013)

A criação do STJ tinha como fundamento ideias de grandes jurista nacionais:

Decidiu-se, sem maior dificuldade, pela criação de um novo tribunal. Seria criado um único tribunal que teria uma função eminente como instância federal sobre matéria que não tivesse, (...) natureza constitucional, ao mesmo tempo que, teria a tarefa de apreciar os mandados de segurança e habeas corpus originários, (...) e os recursos ordinários das decisões denegatórias em última instância federal ou dos Estados. (...) Os recursos extraordinários fundados exclusivamente na lei federal seriam encaminhados a esse novo Tribunal, aliviando o STF. (Regimento Interno do STJ - Cidadania em movimento. Curso à distância, 2013)

Em 1988 com a nova Constituição, foi determinado, nos Artigos 92, 94, $104 \mathrm{e}$ 105, o posicionamento do STJ no âmbito do Poder Judiciário, sua composição e competência. A Constituição de 1988 "cognominada de Constituição Cidadã, criou, o Superior Tribunal de Justiça, que mais tarde seria chamado o Tribunal da Cidadania". Assim, o STJ iniciou os trabalhos em 3 de maio de 1989, quando realizou o primeiro julgamento. (Regimento Interno do STJ - Cidadania em movimento. Curso à distância, 2013) A posição do STJ na organização judiciária nacional pode ser vista na Figura 6:

\footnotetext{
${ }^{14}$ Denominação dos juízes do STJ de acordo com previsão na Lei complementar n. 35, de 14/3/79, que dispõe sobre a Lei Orgânica da Magistratura Nacional - Loman, no Art. 34: "Os membros do Supremo Tribunal Federal, do Tribunal Federal de Recursos, do Superior Tribunal Militar, do Tribunal Superior Eleitoral e do Tribunal Superior do Trabalho têm o título de Ministro; os dos Tribunais de Justiça, o de Desembargador; sendo o de Juiz privativo dos outros Tribunais e da Magistratura de primeira instância". Esta regra foi aplicada ao STJ mesmo sendo editada antes da CF/1988, uma vez que este tribunal herdou algumas competências e ministros do Tribunal Federal de Recursos (Regimento Interno do STJ - Cidadania em movimento, 2013)

15 Instância - Juízo, jurisdição, foro: primeira instância, segunda instância. Loc.adv.: em última instância, em último caso, como último recurso. (Regimento Interno do STJ - Cidadania em movimento, 2013)
} 


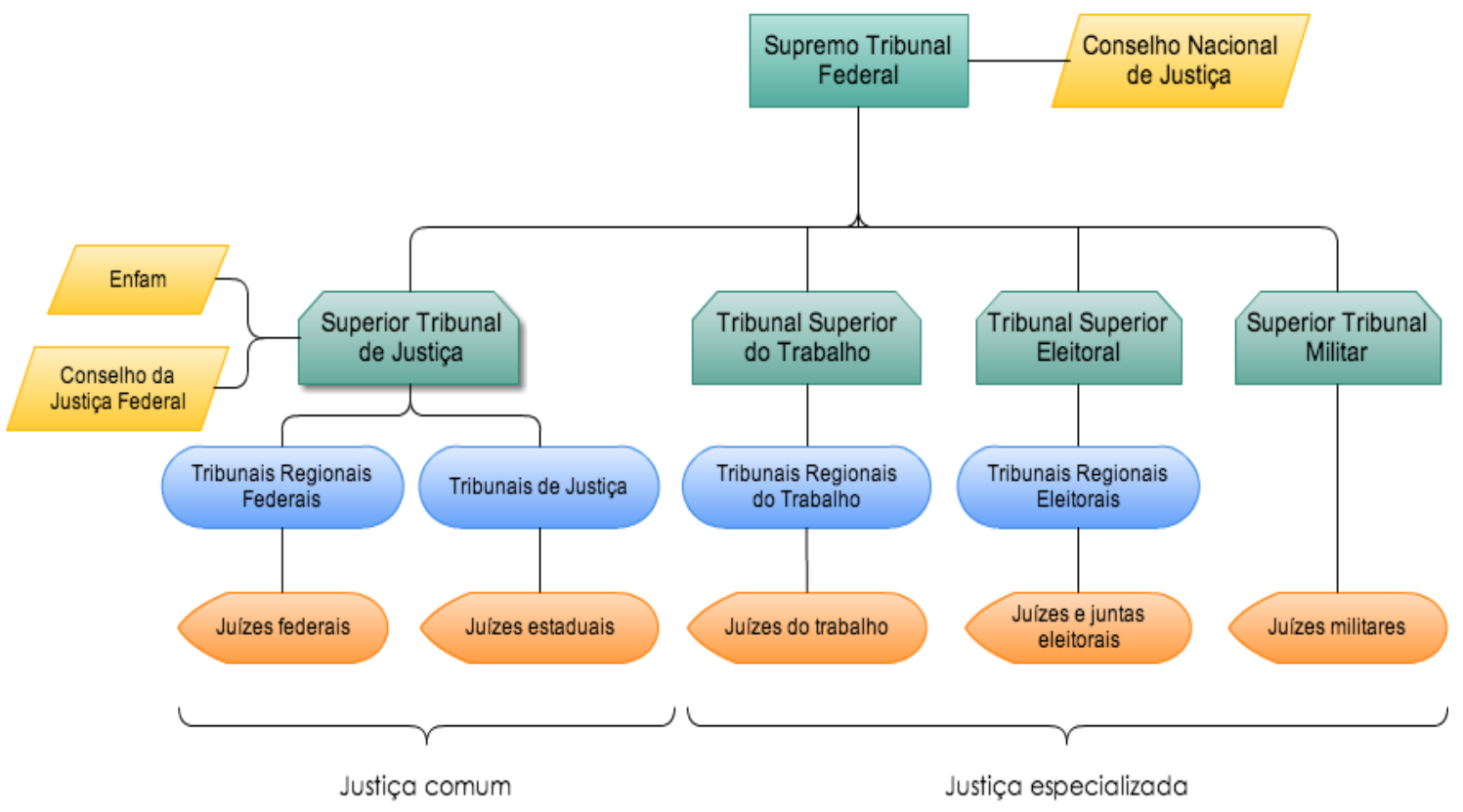

Fig.6 - Posicionamento do STJ no judiciário brasileiro. (Adaptado de: Regimento Interno do STJ - Cidadania em movimento. Curso à distância, 2013)

Segundo informação constante no vídeo do curso de Regimento Interno STJ:

O STJ é responsável por uniformizar a interpretação da lei federal e determinar que as decisões da justiça sejam iguais para todos os cidadãos como prevê a CF. São decisões qualificadas e efetivas para aplicação das leis que regulam o dia-a-dia de todos os brasileiros e que proporcionam soluções fundamentais para o país em todas as áreas do direito público e privado, administrativo, comercial, cível, tributário, penal e internacional. É competente para processar e julgar ações originárias, recursos ordinários e recursos especiais. No julgamento de recursos especiais o Tribunal é a última instância do judiciário para as ações não relacionadas diretamente à Constituição, são as chamadas causas infraconstitucionais ${ }^{16}$. Regimento interno do STJ - Cidadania em movimento. Curso à distância. 2013)

Assim como as decisões tomadas por esta Corte de justiça transformam a vida dos brasileiros, a ação cidadã do STJ alcança na sociedade, crianças, jovens, adultos e idosos. Em função disso, a palavra cidadania reflete a marca que caracteriza o STJ como Tribunal da Cidadania. Os projetos do STJ buscam sintonizar o Tribunal com a formação e educação de diversos públicos, usando a internet. Parte desta comunicação é realizada pelo "Stjunior", uma página que apresenta o mundo jurídico para crianças e adolescentes. Os vínculos com a comunidade são fortalecidos por programas para estudantes de escolas e universitários dos cursos de Direito. Além disso, a sustentabilidade faz parte da ação do STJ, buscando atender exigências contemporâneas de responsabilidade social a exemplo do STJ Solidário voltado para pessoas com deficiência. (Regimento Interno do STJ - Cidadania em movimento. Curso à distância, 2013)

\footnotetext{
16 Infraconstitucionais - Causas em que não se alega violação da Constituição. (Regimento Interno do STJ Cidadania em movimento. Curso à distância, 2013)
} 


\subsection{Composição do quadro de Ministros do Superior Tribunal de Justiça}

Em consonância com a designação de Tribunal da Cidadania, o STJ considera que "promover a cidadania é fortalecer a democracia". Assim, a democracia "está presente nas decisões do STJ e também está expressa na composição e funcionamento da Corte". Neste sentido, a CF de 1988 estabelece o quadro funcional com número mínimo de 33 ministros na Casa, provenientes de todas as regiões do país o que reflete a diversidade da cultura brasileira. Os ministros são nomeados pelo Presidente da República após aprovação pela maioria absoluta do Senado Federal. O cargo deve ser preenchido por brasileiros de faixa etária entre 35 e 65 anos, de notável saber jurídico e reputação ilibada. Esta seleção é feita "entre candidatos provenientes das seguintes classes: Magistratura, federal e estadual, Ministério Público e Ordem dos Advogados do Brasil - o chamado terço constitucional". (Regimento Interno do STJ - Cidadania em movimento. Curso à distância, 2013)

Na Figura 7, está ilustrada a composição do quadro de ministros do STJ distribuída pela proveniência dos magistrados:

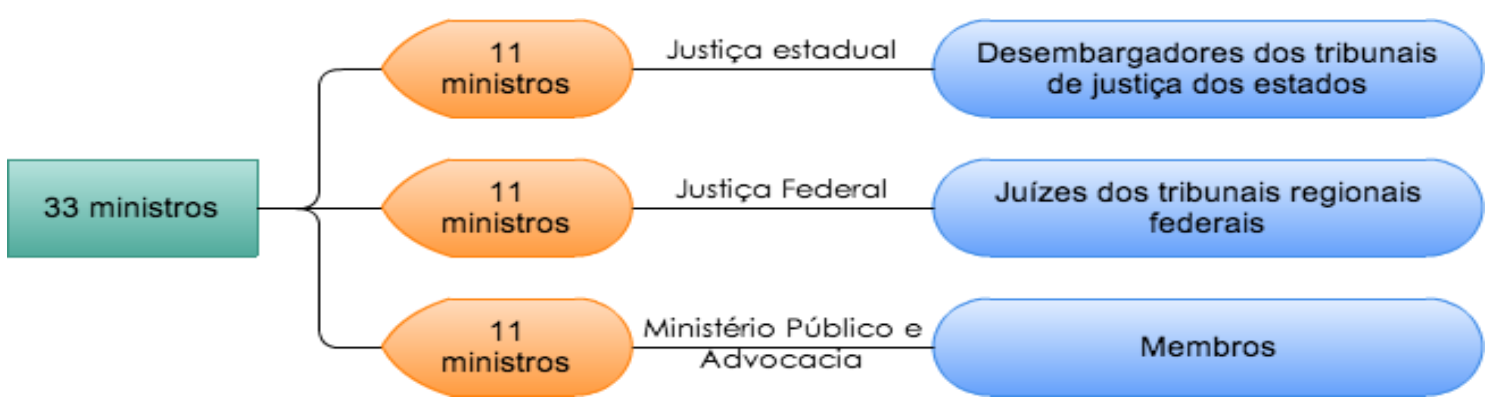

Fig. 7 - Composição e distribuição do quadro de ministros do STJ. (Adaptado de Regimento Interno do STJ - Cidadania em movimento. Curso à distância, 2013)

Conforme mostrado na Figura 7, um terço do quadro é constituído de desembargadores provenientes dos tribunais de justiça estaduais, e um terço, de juízes oriundos dos tribunais regionais federais, indicados em lista tríplice elaborada pelo próprio STJ. O outro terço é constituído, em partes iguais, de advogados e membros do Ministério Público Federal, Estadual e do Distrito Federal e Territórios, alternadamente, de acordo com o art. 94 da CF. (Regimento Interno do STJ Cidadania em movimento. Curso à distância, 2013). Outra forma de representar esta estrutura de funcionamento está na figura 8 , onde os 33 ministros foram divididos entre as categorias profissionais na proporção de $2 / 3$ para os magistrados e $1 / 3$ para a Ordem dos Advogados do Brasil e o Ministério Público. 


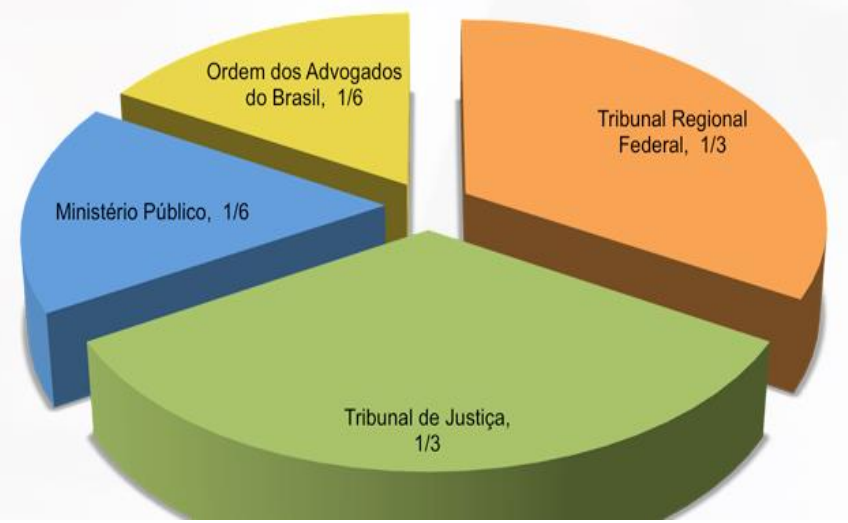

Fig. 8 - Distribuição dos ministros do STJ por origem. (Extraído do Site do STJ, 2013)

Segundo o Ministro Presidente do STJ, Felix Fischer, eleito para o biênio 2012-2014, a estrutura organizacional do Tribunal está voltada para sua função primordial:

É aqui no Superior Tribunal de Justiça onde se congregam de maneira harmoniosa as carreiras da justiça comum, Ministério Público estadual e federal e da advocacia. A nossa tarefa primordial é uniformizar a interpretação da legislação federal infraconstitucional. (transcrito de declaração do ministro realizada no Site do STJ)

\subsection{Estrutura organizacional do Superior Tribunal de Justiça}

A estrutura organizacional do STJ abrange a Corte Judicial, órgão judicial máximo do Tribunal, com atribuição de julgar crimes comuns de governadores de Estados e do Distrito Federal e outras autoridades ${ }^{17}$. A Corte Especial não está sujeita à especialização, e a sua competência consta no Art. 11 do Regimento Interno. Há também o Colegiado, composto por 15 ministros mais antigos e o Plenário, com competência administrativa, que reúne todos os magistrados, sendo ambos dirigidos pelo Presidente da Casa. Os órgãos julgadores do Tribunal são a Corte Especial, as Seções e as Turmas que têm competência jurisdicional ou judicante. Os ministros também proferem julgamentos de forma monocrática, conforme normas processuais. O Gabinete da Presidência exerce funções específicas que diferem dos Gabinetes de Ministros das Seções e Turmas. Segundo depoimento de Santos (2014) em entrevista, o ministro presidente "é o chefe institucional do STJ" e, quando eleito, afasta-se dos órgãos julgadores do Tribunal, "passando a compor a Corte Especial, o Plenário, o Conselho de Administração e o Conselho da Justiça Federal, exercendo atribuições políticas e administrativas, não julgando processos por distribuição ordinária" nos quais os ministros são relatores. Contudo, relata processos por atribuição específicos do cargo, como homologação de sentença estrangeira ${ }^{18}$. O quadro de pessoal do STJ contém cerca de 4.500 profissionais entre servidores, terceirizados e estagiários.

No Tribunal o processo começa por iniciativa da parte - que corresponde ao ligante no processo judicial ou pessoa que trata de interesse individual no órgão

\footnotetext{
${ }^{17}$ bem como dos desembargadores dos tribunais de justiça dos Estados e do Distrito Federal, os membros dos tribunais de conta dos Estados e do Distrito Federal, de tribunais regionais federais, regionais eleitorais e do trabalho, conselhos ou tribunais de contas dos municípios e do Ministério Público

${ }^{18}$ Conforme art. 21 do Regimento Interno publicado em 17 de agosto de 1989.
} 
público - e, se desenvolve por impulso oficial no "movimento realizado através de um conjunto integrado por pessoas, ministros e auxiliares e, por unidades" ${ }^{19}$. Com este fim, as três Seções de Julgamento, cada uma com dez gabinetes, subdividemse em duas Turmas de Julgamento, cada uma com cinco gabinetes, especializadas por áreas do Direito:

1a Seção: Direito público e previdenciário: constituída pela Primeira e Segunda Turma, cada uma com cinco gabinetes;

2ª Seção: Direito privado: constituída da Terceira e Quarta Turma, cada uma com cinco gabinetes;

3ํㅗㄹ Seção: Direito penal: constituída da Quinta e Sexta Turma, cada uma com cinco gabinetes.

(Regimento Interno do STJ - Cidadania em movimento. Curso à distância, 2013)

O Regimento Interno, RISTJ, definiu as áreas de especialização das Seções e Turmas, em Direito Público, Direito Privado e Direito Penal em razão da natureza da relação jurídica litigiosa. As sessões são abertas ao público. A Figura 9 ilustra as especializações das Seções e Turmas por área do Direito.

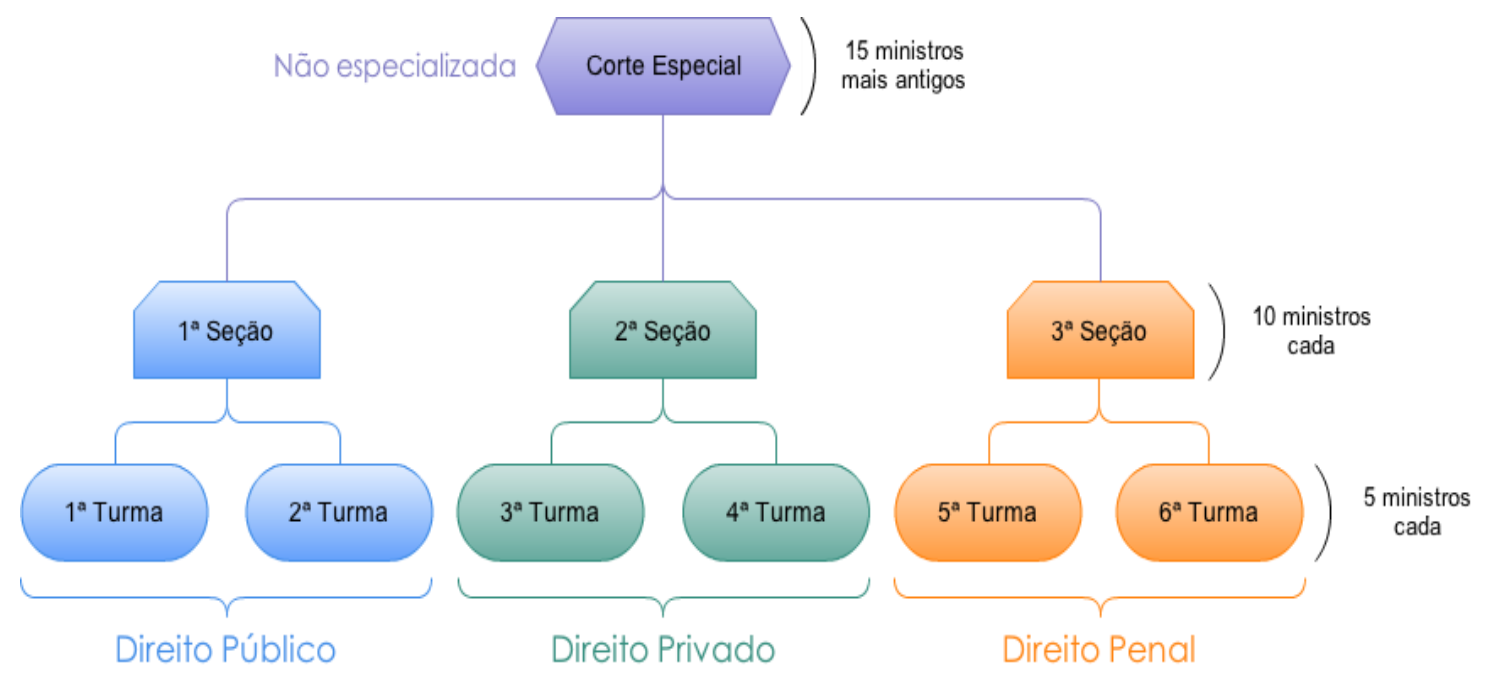

Fig.9 - Especializações das Seções e Turmas por área do Direito. (Fonte: Regimento Interno do STJ - Cidadania em movimento. Curso à distância, 2013)

As Turmas são os menores órgãos colegiados do STJ. Cada uma é constituída de cinco ministros e presidida pelo mais antigo por um período de dois anos, vedada recondução até que todos os componentes tenham exercido a presidência. As turmas possuem competência originária e recursal. Conforme 0 art. 13 do RISTJ compete às Turmas:

I - processar e julgar, originariamente:

a. o habeas corpus, quando for coator Governador de Estado e do Distrito Federal, Desembargador dos Tribunais de Justiça dos Estados e do Distrito Federal, membro dos Tribunais de Contas dos Estados e do Distrito Federal, dos Tribunais Regionais Federais, dos Tribunais Regionais Eleitorais e do Trabalho, dos Conselhos ou Tribunais de Contas dos Municípios e do Ministério Público da União que oficie perante Tribunais;

\footnotetext{
${ }^{19}$ Com atribuições disciplinadas em normas processuais, no Regimento Interno e no art. 96, I, da CF/88.
} 
b. o habeas corpus, quando o coator for Tribunal cujos atos estejam diretamente subordinados à jurisdição do Superior Tribunal de Justiça.

II - julgar em recurso ordinário:

a. o habeas corpus decidido em única ou última instância pelos Tribunais Regionais Federais ou pelos Tribunais dos Estados, do Distrito Federal e Territórios, quando denegatória a decisão;

b. o mandado de segurança decidido em única instância pelos Tribunais Regionais Federais ou pelos Tribunais dos Estados, do Distrito Federal e Territórios, quando denegatória a decisão.

III - julgar as apelações e os agravos nas causas em que forem partes, Estado estrangeiro ou organismo internacional, de um lado, e, do outro, Município ou pessoa residente ou domiciliada no País;

IV - julgar, em recurso especial, as causas decididas em única ou última instância pelos Tribunais Regionais Federais ou pelos Tribunais dos Estados, do Distrito Federal e Territórios, quando a decisão recorrida:
a. contrariar tratado ou lei federal, ou negar-Ihes vigência;
b. julgar válida lei ou ato de governo local contestado em face de lei federal;
c. der à lei federal interpretação divergente da que Ihe haja atribuído outro Tribunal.

Originariamente, elas processam e julgam os habeas corpus contra ato coator de determinadas autoridades e tribunais cujos atos estejam diretamente subordinados à jurisdição do STJ. No âmbito recursal, o principal recurso julgado pelas Turmas é o recurso especial. No entanto, quando se tratar de recurso especial repetitivo, o julgamento será realizado por uma seção ou pela Corte Especial ${ }^{20}$.

\subsection{Competência jurisdicional do Superior Tribunal de Justiça}

O STJ tem competência jurisdicional constitucional que "é a determinação dos limites dentro dos quais os órgãos jurisdicionais podem legalmente julgar". No STJ tal competência se estende ao território nacional, abarcando "matérias advindas da justiça comum, exceto aquelas atinentes à justiça especializada" como as trabalhistas, eleitorais e militares. Cabe ao STJ processar e julgar originariamente determinados tipos de processos, lembrando que "um processo originário é aquele que tem início no próprio STJ, não precisando ter passado por outras instâncias". Há processos julgados na forma de recurso ordinário, ou "recurso que se apresenta como espécie de apelação contra as causas de competência originária do STJ". E, causas julgadas em recurso especial, "um processo existente apenas no STJ e por meio dele é feito o controle da uniformização da jurisprudência nacional". Além disso, o recurso especial, REsp, é o mais importante do Tribunal, existindo em maior número, julgando causas decididas em única ou última instância por tribunais regionais federais ou por tribunais de justiça dos Estados, Distrito Federal e Territórios. (Regimento Interno do STJ - Cidadania em movimento. Curso à distância, 2013)

As decisões colegiadas do STJ são os acórdãos, que podem dar origem aos enunciados de súmulas, os quais são resumos das deliberações da Corte que alcançaram entendimento uniforme. $O$ conjunto de decisões do Tribunal é chamado de jurisprudência, que é sistematizada e disponibilizada ao público via internet no

\footnotetext{
${ }^{20}$ conforme o disposto no art. 1ำ, caput, combinado com o art. 2º, ambos da Resolução n. 8 de 7 de agosto de 2008.
} 
Portal do STJ, site, facebook, twitter, rádio e televisão. O STJ utiliza tecnologia de ponta para acelerar o andamento processual. A cada mês chegam ao Tribunal cerca de 24.000 mil processos de todo o território nacional. Desde 2009 as ações que chegam ao Tribunal são digitalizadas estando disponíveis eletronicamente cerca de 500 mil, com trâmite virtual. Esta mudança inseriu o STJ entre os tribunais com maior índice de informatização do mundo. (Regimento Interno do STJ - Cidadania em movimento. Curso à distância, 2013)

O art. 105 da CF fixa a competência do STJ: no inciso I estabelece que cabe ao Tribunal processar e julgar entre vários tipos de processos, a homologação de sentença estrangeira. A competência jurisdicional de STJ está no inciso II, que lista três tipos de processos, julgados na forma de recurso ordinário que corresponde ao "recurso que se apresenta como uma espécie de apelação contra as causas de competência originária do STJ". Por fim, o inciso III arrola as causas julgadas em recurso especial, que "é um processo existente apenas no STJ e por meio dele se faz o controle da uniformização da jurisprudência nacional". (Regimento Interno do STJ - Cidadania em movimento. Curso à distância, 2013) A Figura 10 apresenta a competência jurisdicional do STJ:

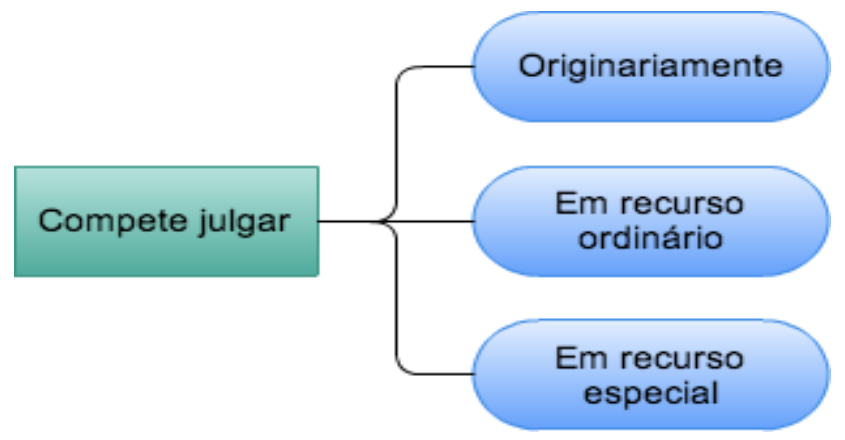

Fig. 10 - Competência jurisdicional do STJ (Extraído de Regimento Interno do STJ - Cidadania em movimento. Curso à distância, 2013)

O recurso especial, ou Resp, é o recurso mais importante do Tribunal e também o mais numeroso. Por ele são julgadas as causas decididas em única ou última instância pelos Tribunais Regionais Federais ou pelos Tribunais de Justiça dos Estados e do Distrito Federal e dos Territórios quando houver interpretação divergente à lei federal em relação a outro tribunal, quando o STJ atuará como uniformizador da jurisprudência nacional. (Regimento Interno do STJ - Cidadania em movimento. Curso à distância, 2013)

\subsection{Direcionamento estratégico do STJ}

A Resolução STJ n. 18 de 6 de agosto de 2012 dispõe sobre o planejamento estratégico do STJ para o quinquênio 2010-2014. Consiste numa atividade administrativa importante para o órgão, pois define os rumos do Tribunal. Possibilita a busca de respostas para questões fundamentais como: "Onde estamos? Aonde queremos chegar? Como fazer para atingir os objetivos definidos?" O direcionamento estratégico do STJ é um instrumento de planejamento que demonstra os compromissos e os objetivos do órgão para determinado período. $\mathrm{O}$ planejamento estratégico deve estar alinhado com os valores da organização, a missão, a visão de futuro, orientando a realização de metas e objetivos. O STJ adota 
o planejamento estratégico como modelo de gestão desde 1998, sendo que o Plano Estratégico para o período de 2010 a 2014 visa à prestação de uma tutela jurisdicional atual, rápida e voltada para a efetivação da cidadania. Elaborado com a participação de magistrados e servidores que conhecem e dominam as rotinas e demandas do Tribunal, o Planejamento Estratégico aponta diretrizes para o cumprimento da missão do STJ, estabelecendo metas de longo prazo, traduzindo estas diretrizes em ações concretas, apoiando-se nos valores mais importantes do STJ. (Regimento Interno do STJ - Cidadania em movimento. Curso à distância, 2013)

Os valores institucionais são ideias fundamentais em torno das quais se constrói a organização. Representam as convicções dominantes, as crenças básicas nas quais as pessoas da organização acreditam, permeando todas as atividades e relações com os clientes. Os valores do STJ são:

$\checkmark \quad$ Autodesenvolvimento - assumir a responsabilidade de desenvolver-se continuamente, contribuindo para o seu crescimento pessoal e profissional, bem como para o desempenho organizacional.

$\checkmark$ Comprometimento - atuar com dedicação, empenho e envolvimento em suas atividades.

$\checkmark$ Cooperação - trabalhar em equipe, compartilhando responsabilidades e resultados.

$\checkmark \quad$ Ética - agir com honestidade e integridade em todas as suas ações e relações.

$\checkmark \quad$ Inovação - propor e implementar soluções novas e criativas para atividades, processos e/ou rotinas de trabalho.

$\checkmark \quad$ Orgulho Institucional - sentir-se satisfeito em fazer parte da instituição.

$\checkmark \quad$ Presteza - entregar resultados com rapidez e qualidade.

$\checkmark \quad$ Responsabilidade Socioambiental - adotar os critérios sociais e ambientais nas ações do dia-a-dia.

$\checkmark \quad$ Transparência - praticar atos com visibilidade plena no desempenho de suas atribuições.

(Manual do Plano Estratégico do STJ, 2010-2014)

De acordo com o Manual do Plano Estratégico do STJ, editado pela Assessoria de Modernização e Gestão Estratégica, a missão é uma declaração concisa da razão de ser da organização. É o propósito básico, para o qual são direcionados as atividades e os valores que orientam os servidores. Diferentemente das empresas privadas, que definem a sua missão conforme o interesse de se posicionar em destaque no mercado, os órgãos do Poder Judiciário possuem missão estabelecida na Constituição Federal. A missão do STJ está assim definida:

Processar e julgar as matérias da sua competência originária e recursal, assegurando uniformidade na interpretação das normas infraconstitucionais, oferecendo ao jurisdicionado uma prestação de qualidade, rápida e efetiva.

Em termos genéricos, a missão é uma declaração sobre o que a organização é de fato, ou, a sua razão de ser, constituindo a diretriz maior que orienta a tomada de decisões, a definição de objetivos e auxilia na escolha das decisões estratégicas. É possível identificar algumas características imprescindíveis que constam na missão de toda e qualquer organização, presentes na missão do STJ:

- $\quad$ finalidade: processar e julgar as matérias de sua competência originária e recursal.

- segmento alvo: jurisdicionado.

- objetivo: assegurar a uniformidade na interpretação das normas infraconstitucionais. 
- valores defendidos: qualidade, rapidez e efetividade.

(Manual do Plano Estratégico do STJ, 2010-2014)

A missão é também uma declaração concisa da razão de ser da organização. É o propósito básico para o qual são direcionadas as atividades e os valores que orientam os servidores. A missão do STJ pode ser desmembrada em conceitos para melhor compreensão:

$\checkmark$ Processar - dar o devido trâmite ao processo judicial.

$\checkmark$ Julgar - dar a decisão sobre o processo.

$\checkmark$ Competência originária - é a competência exclusiva do tribunal para conhecer e julgar os casos declarados na Constituição Federal.

$\checkmark$ Competência recursal - é a competência para rever o julgamento de processos que originaram em outro tribunal, e modificar ou confirmar decisão anterior.

$\checkmark$ Uniformidade na interpretação - proferir julgamentos para padronizar a jurisprudência infraconstitucional.

$\checkmark$ Normas infraconstitucionais - as leis que compõem o ordenamento jurídico, exceto a Constituição Federal.

$\checkmark$ Qualidade - julgamentos sem falhas, observando a razoável duração do processo e o custo adequado.

$\checkmark$ Rapidez - presteza na entrega dos serviços e brevidade no trâmite processual.

$\checkmark$ Efetividade - atendimento real às demandas da sociedade e satisfação dos jurisdicionados, em especial, quanto à uniformização da jurisprudência infraconstitucional.

(Regimento Interno do STJ - Cidadania em movimento. Curso à distância, 2013)

Por sua vez, a visão de futuro define o que a organização pretende ser, porquanto, ela incorpora as aspirações da organização e descreve o quadro que a organização almeja atingir. Assim, enquanto a missão define o que a instituição é no presente, a visão de futuro estabelece o que ela pretende ser ou alcançar a curto, médio e longo prazo. (Regimento Interno do STJ - Cidadania em movimento. Curso à distância, 2013). De acordo com o Manual do Plano Estratégico do STJ (2010), a visão de futuro proporciona o horizonte a ser alcançado, delineando o planejado. A visão de futuro do STJ é: "Consolidar-se como o Tribunal da Cidadania, oferecendo justiça de qualidade, rápida e efetiva".

A visão do STJ tem como conceitos:

$\checkmark$ Tribunal da Cidadania - tribunal de referência no que concerne à prestação jurisdicional com qualidade, rapidez e efetividade e considerando a responsabilidade socioambiental.

$\checkmark$ Qualidade - julgamentos sem falhas, observando a razoável duração do processo.

$\checkmark$ Rapidez - presteza na entrega dos serviços e brevidade no trâmite processual.

$\checkmark$ Efetividade - atendimento real às demandas da sociedade e satisfação dos jurisdicionados, em especial, quanto à uniformização da jurisprudência infraconstitucional.

(Manual do Plano Estratégico do STJ, 2010-2014)

Na prática, as diretrizes da administração, alinhadas à missão do Tribunal, eram traduzidas para as unidades que as utilizavam como ponto de partida para traçarem os seus planos de ação. Houve avanço significativo a partir de 2004, época em que adotou a metodologia Balanced Scorecard - BSC, para execução da estratégia traçada pela presidência da Casa, com um Plano Estratégico bianual, tornando o STJ referência no assunto para diversas organizações públicas. (Regimento Interno do STJ - Cidadania em movimento. Curso à distância, 2013). 
Vale lembrar que o BSC é uma metodologia desenvolvida por Robert S. Kaplan e David P. Norton, professores da Harvard Business School, eficaz para o mapeamento e execução da estratégia. Por se tratar de instrumento de alinhamento e comunicação, ajuda a organização a identificar os objetivos-alvo de sucesso e a monitorar o desempenho por meio de indicadores, subsidiando a tomada de decisões estratégicas e completando o ciclo de gestão. O planejamento estratégico do STJ está incluso na gestão judiciária estratégica em nível nacional. Visando regulamentar as ações no âmbito do Poder Judiciário, voltadas para o Planejamento e a Gestão Estratégica, o Conselho Nacional de Justiça publicou a Resolução n. 70 de 18 de março de 2009 estabelecendo:

Art. $2^{\circ} \mathrm{O}$ Conselho Nacional de Justiça e os tribunais indicados nos incisos II a VII do Art. 92 da Constituição Federal elaborarão os seus respectivos planejamentos estratégicos, alinhados ao Plano Estratégico Nacional, com abrangência mínima de 5 (cinco) anos, bem como os aprovarão nos seus órgãos plenários ou especiais até 31 de dezembro de 2009.

No âmbito do STJ, compete à Assessoria de Modernização e Gestão Estratégica cumprir as atividades relacionadas ao plano estratégico. Para a elaboração deste plano, ajustado à orientação do $\mathrm{CNJ}$, foram cumpridas as seguintes etapas:

- a) Análise do ambiente interno e externo para identificar as variáveis capazes de influenciar os resultados da organização, por meio de um diagnóstico situacional realizado em novembro de 2009, com participação de pessoas das diversas unidades do STJ. A partir dessa análise do ambiente, considerando a missão do STJ e a sua experiência em gestão estratégica, foram estabelecidos os valores que permeam as ações institucionais e a visão de futuro até 2014.

- b) Alinhamento dos objetivos estratégicos existentes aos propostos pelo CNJ, bem como dos indicadores de desempenho, para os quais as metas foram desdobradas por ano, até 2014. Para potencializar os resultados do Plano, foi formada a carteira de projetos estratégicos, vinculadas aos objetivos. Com essas informações ajustadas em uma minuta de plano, os trabalhos foram concluídos. Em fevereiro de 2010, o Conselho de Administração aprovou a primeira versão do Plano Estratégico STJ 2010-2014.

(Manual do Plano Estratégico do STJ 2010-2014)

No primeiro semestre de 2012, foram realizadas reuniões setoriais a fim de promover o refinamento dos indicadores estratégicos. As propostas foram deliberadas em reuniões de análise estratégica, perante o Comitê Gestor da Secretaria do Tribunal e aprovadas pelo Conselho de Administração. Nos termos da Resolução n. 18 de 6 de agosto de 2012, foi publicada a versão 2.0 do Plano Estratégico STJ 2010-2014.

O mapa estratégico do STJ para o período de 2010-2014 apresentado na Figura 14 evidencia uma base sedimentada no orçamento, na infraestrutura e tecnologia e, na gestão de pessoas, recursos indispensáveis ao funcionamento do Tribunal. O Plano inclui o alinhamento e a integração com os demais tribunais do poder judiciário para promover a troca de experiências, compartilhar conhecimentos, práticas e soluções jurídicas e administrativas, fortalecendo relações institucionais. Tornar-se eficiente depende também de uma comunicação interna e externa que alcance cada vez mais o público numa linguagem clara e acessível. O foco é acelerar os trâmites judiciais e aumentar o número dos casos julgados para obter maior produtividade e atender melhor a sociedade, sem descuidar da economia de recursos e da racionalização no uso de materiais, bens e serviços. Responder de maneira ágil a todos os processos que chegam ao Tribunal é o grande desafio do 
STJ. (Regimento Interno do STJ - Cidadania em movimento. Curso à distância, 2013). Estas informações podem ser vistas na Figura 11, que inclui o período de realização desta pesquisa:

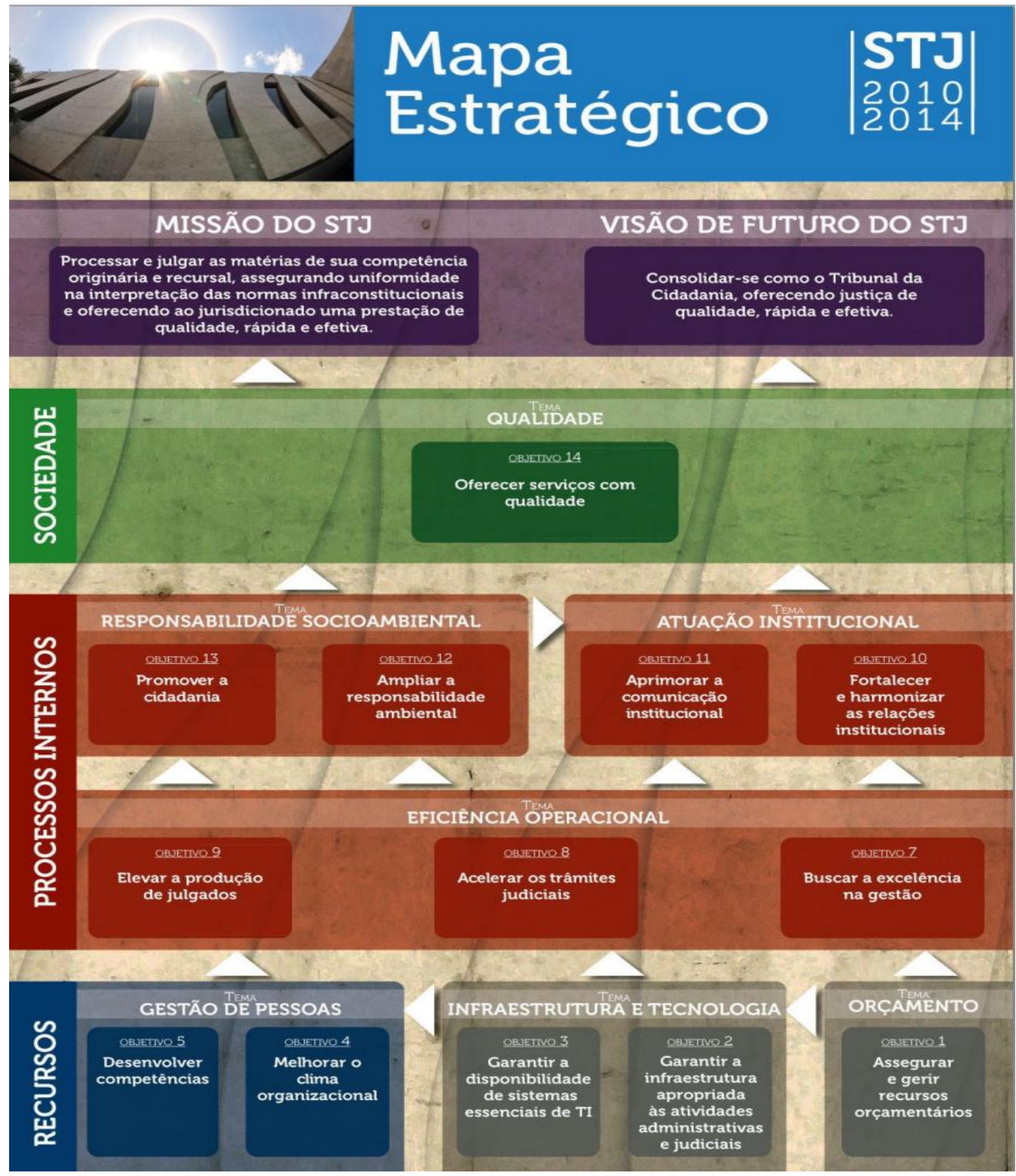

Fig. 11 - Mapa Estratégico do STJ para 2010-2014 (Extraído de Manual do Plano Estratégico, 2010-2014)

Como as pessoas recorrem ao Tribunal em busca de resposta para garantia de seus direitos, é preciso atender de maneira eficaz a crescente demanda e julgar os processos assegurando uniformidade na interpretação da lei federal. Com a reformulação do Código de processo civil, o Tribunal passou a contar com a Lei $11.672 / 2008$ que trata dos recursos repetitivos, prevendo que se existirem vários recursos fundamentados na mesma questão de direito o presidente do tribunal de origem decide se encaminha ao STJ um ou mais casos representativos da controvérsia. Os ministros do STJ também podem determinar em seus gabinetes processos para serem julgados como repetitivos. As outras ações similares ficam suspensas até o pronunciamento do STJ, assim, o número de processos que entra na Corte diminui e isto permite acelerar o julgamento dos que estão em processo de 
análise. (Regimento Interno do STJ - Cidadania em movimento. Curso à distância, 2013).

Aliado a isto, os recursos tecnológicos utilizados pelo STJ no trâmite processual, imprimem maior agilidade à prestação jurisdicional. Os processos chegam ao Tribunal também via rede de computador, sendo o STJ premiado pela iniciativa inovadora de acelerar 0 andamento processual. Todos os recursos disponíveis no STJ como, equipe, infraestrutura, tecnologia e orçamento possibilitam que os processos internos sejam realizados visando atingir o objetivo comum de oferecer serviços com qualidade, julgando com eficiência, de forma sustentável e voltada para a cidadania. Alcançar estes objetivos traçados no plano estratégico vai permitir ao STJ cumprir sua missão e consolidar-se como o Tribunal da Cidadania. O STJ alcança o público em todos os pontos do país em tempo real via internet pelas tecnologias de comunicação de informação como o portal do STJ, facebook, twitter, youtube, rádio e televisão, tornando as decisões dos ministros conhecidas pela sociedade brasileira. (Vídeo institucional, 2, 2013).

Quanto a isto, vale acrescentar que o STJ utiliza recursos tecnológicos para acelerar o andamento processual. A cada mês chegam ao Tribunal cerca de 24.000 mil processos de todo o território nacional, exigindo um planejamento eficiente para atender essa demanda. Desde 2009 as ações que chegam à Corte são digitalizadas, sendo que mais de 500.000 mil estão disponíveis eletronicamente e quase metade tramita virtualmente. Esta mudança inseriu o STJ entre os tribunais com maior índice de informatização do mundo. A digitalização elimina as antigas pilhas de papel, dando agililidade ao processo e economizando espaço. Para executar todo este trabalho e cumprir os desafios que crescem a cada dia o STJ conta com cerca de 4.500 profissionais entre servidores, terceirizados e estagiários. (Vídeo institucional, 2 , 2013). Assim, os recursos repetitivos e o STJ na era virtual são fatores que concretizam os objetivos estratégicos de elevar a produção de julgados e acelerar os trâmites judiciais.

\section{ANÁLISE DOS DADOS COLETADOS}

Após a coleta de dados e informações sobre a Biblioteca do STJ e da BDJur, foram realizadas a descrição das características, produtos e serviços da Biblioteca Ministro Oscar Saraiva do STJ, e da BDJur como produto de informação na Web. Os resultados obtidos com aplicação do questionário eletrônico e das entrevistas possibilitaram realizar a análise descritiva dos dados e o processamento estatístico com a tabulação e digitação dos dados, para elaboração dos gráficos, tabelas, cálculo das porcentagens e contagem das frequências, com o uso do software proprietário Zoomerang, utilizado na Metodologia do IBICT. Este software é considerado por Rocha e Souza (2001, p. 32) de fácil compreensão por permitir exportação de dados para outros programas, propiciando atualização contínua de análise de dados, além de ter sido utilizado para elaboração do questionário eletrônico enviado aos assessores.

Em relação à Biblioteca Digital Jurídica, BDJur, como produto de informação da Biblioteca do STJ, na aplicação da Metodologia do IBICT para Avaliação de Produtos e Serviços de Informação, a análise quantitativa visou mensurar a extensão do acesso, uso e grau de satisfação do assessor, com aplicação de questionário eletrônico. A análise qualitativa forneceu uma visão contextualizada das 
práticas informacionais de assessores de ministro como usuários da Biblioteca do STJ, com a realização de entrevistas fundamentadas na Abordagem Sense-making de Brenda Dervin e com o método Micro moment time line interview, o qual focaliza a entrevista numa dada vivência do assessor de ministro, na busca de informação na BDJur, para preencher uma situação, lacuna e uso de informação jurídica, identificando-se, nestes três componentes do trinômio operacional do Sense-making, os padrões positivos e negativos com a técnica do incidente crítico de Flanagan. E, a análise da usabilidade da BDJur em relação às heurísticas visou conferir o grau de interação entre assessor e BDJur, ou interação homem-máquina, com a disponibilização do produto de informação jurídica na Web.

\subsection{Biblioteca Ministro Oscar Saraiva do Superior Tribunal de Justiça - STJ}

Foi criada em 28 de junho de 1948, no Rio de Janeiro e, posteriormente transferida para Brasília em 1969. Em 1970 iniciou-se a organização e o processamento técnico do acervo. Posteriormente, em 1973, foi denominada Biblioteca Ministro Oscar Saraiva, em homenagem ao magistrado responsável pela construção da sede do então Tribunal Federal de Recursos, TFR. A seguir, com a extinção do TFR e a criação do STJ em 1989, deu-se o início da automação do acervo bibliográfico através do sistema de Informação do Congresso Nacional (SICON), mantido pelo PRODASEN (Centro de Informática e Processamento de Dados do Senado Federal). A partir de então, passou a integrar a Rede Virtual de Bibliotecas do Senado Federal - RVBI, compartilhando o catálogo-on line e realizando o processamento técnico cooperativo em rede dos itens de informação, com mais de dez bibliotecas cooperantes dos poderes executivo, legislativo e judiciário. Em julho de 1995, a Biblioteca transferiu-se para o novo prédio sede construído especialmente para abrigar este Tribunal. (SUPERIOR TRIBUNAL DE JUSTIÇA. Bibloteca Ministro Oscar Saraiva, p. 2)

A Biblioteca Ministro Oscar Saraiva, Biblioteca do STJ, é especializada em Direito, com destaque para o direito civil e processo civil, direito penal e processo penal, dispondo de acervo de cerca 220 mil volumes entre livros, periódicos e obras raras, destacando-se coleções de juristas renomados na história do direito brasileiro como Caio Mário Pereira da Silva, civilista e jurisconsulto que participou da elaboração do Código de processo civil. O acervo é voltado exclusivamente para a atividade judicante e administrativa do Tribunal, cuja política de seleção de itens de informação tem como objetivo a formação de uma coleção com doutrinas essenciais, obras de referência e legislações atualizadas. É considerada referência no mundo jurídico nacional e internacional, além de dispor de recursos tecnológicos aplicados aos processos, produtos e serviços que fornece para a comunidade jurídica e sociedade. Produziu publicações em versão impressa e, posteriormente no site do STJ além de compilar bibliografias de temas do direito de interesse do Tribunal. Em 1998, foi criada a página da Biblioteca na Intranet. Em 2000 disponibilizou o texto integral dos atos normativos do STJ no sistema de legislação. Em 2002, implantou o planejamento estratégico em consonância com o planejamento estratégico do STJ. (SUPERIOR TRIBUNAL DE JUSTIÇA, 2009, p. 30)

Desenvolveu a Biblioteca Jurídica Digital - BDJur, que contém repositório de documentos jurídicos em inteiro teor, tais como capítulos de livros e periódicos, 
teses, dissertações, decisões jurisprudenciais, palestras e discursos. As coleções são atualizadas diariamente. O Consórcio BDJur, criado em 2005, é uma rede de informações digitais do Poder Judiciário Brasileiro. Possibilita a realização de busca unificada em todos os repositórios integrantes do Consórcio. Para aprimorar a eficiência da pesquisa, os documentos foram devidamente tratados, o que permite maior precisão na recuperação. (SUPERIOR TRIBUNAL DE JUSTIÇA. Biblioteca Ministro Oscar Saraiva, p. 2)

A posição da Biblioteca na estrutura orgânica do Tribunal - conforme Resolução no․ 9, de 29/7/2011 - está vinculada à Secretaria de Documentação É gerenciada pela Coordenadoria de Biblioteca, com a seguinte organização administrativa: Seção de Pesquisa, Seção de Biblioteca Digital, Seção de Desenvolvimento de Coleções, Seção de Processos Técnicos, Seção de Doutrina da Biblioteca Digital e Seção de Gestão de Acervos. No Tribunal, a Biblioteca é considerada serviço essencial, conforme designado na Resolução n. 7, de 17 de junho de 2004:

Art $2^{\circ}$ São considerados serviços essenciais para fins desta Resolução, além daqueles a serem estabelecidos pelos respectivos dirigentes das unidades:

I - assessoria e assistência aos Senhores Ministros e ao Diretor-Geral;

II - atividades da Secretaria Judiciária, da Secretaria de Jurisprudência e da Secretaria de Documentação, tais como:
a) autuação, classificação e distribuição de feitos;
b) protocol judicial e baixa;
c) execução judicial;
d) pesquisa de jursiprudência;
e) taquigrafia; e
f) biblioteca;
III - assistência medico-social;
IV - suporte tecnológico de informática
$\mathrm{V}$ - comunicação e segurança.

A Biblioteca do STJ tem como missão: "Oferecer informação em doutrina e legislação necessárias a atividade judicante e administrativa do Tribunal". Tal responsabilidade da Biblioteca é reconhecida pelos usuários, a exemplo do depoimento do ministro Antônio de Pádua Ribeiro (1998, p.1), presidente do STJ na época de comemoração do cinquentenário da Biblioteca, no discurso de abertura, enfatizando o apoio propiciado ao "labor judicante" dos ministros por "fornecer-Ihes subsídios indispensáveis ao exercício do juízo superior, bem como por tornar disponíveis informações tempestivas aos magistrados em geral, advogados, estudantes, servidores e pesquisadores".

O Regulamento da Biblioteca ${ }^{21}$ discrimina o conjunto de usuários da comunidade jurídica e da sociedade: ministro; magistrado convocado para compor Seção e Turma do Tribunal; juiz auxiliar da presidência; juiz instrutor; secretáriogeral da presidência; diretor-geral da secretaria do tribunal; chefe de gabinete,

\footnotetext{
${ }^{21}$ Estabelecido na Portaria GDG n. 448 de 25 de junho de 2014, art. 4.
} 
assessor de ministro; secretário, assessor-chefe, coordenador; chefe de seção; servidor; usuário externo além de outras bibliotecas. Dentre os usuários da Biblioteca do STJ, esta pesquisa teve como foco a necessidade, busca e uso da informação pelos assessores de ministro cuja atividade profissional é considerada sob o ponto de vista da abordagem Sense-making de Brenda Derwin, no cenário de trabalho no Tribunal descrito a seguir:

\subsubsection{Características da atividade profissional do assessor de ministro como usuário da informação jurídica, segundo o trinômio operacional do Sense- making}

Os assessores de ministro exercem as funções do seu cargo nos Gabinetes de Ministro. O Regimento Interno do STJ no Art. 325 estabelece na parte referente aos Serviços Administrativos que: "Cada Ministro disporá de um gabinete para executar os serviços administrativos e de assessoramento jurídico". No que se refere ao assessor, o Art. 325 parágrafo $2^{\circ}$ institui: "O Assessor de Ministro, bacharel em Direito, nomeado em comissão pelo Presidente, mediante indicação do Ministro, poderá ser recrutado do Quadro de Pessoal da Secretaria, ou não, e permanecerá em exercício, enquanto bem servir, a critério do Ministro".

As atribuições dos assessores de ministro estão prescritas no Ato do STJ n. 207, de 12 de junho de 1995, que constitui o Regulamento dos Órgãos de Apoio e Assistência Direta e Imediata à Vice-Presidência, aos Ministros, as Ministro Diretor da Revista e às Comissões Permanentes. Esta norma estabelece a categoria e finalidade, organização, competência das unidades e atribuições dos titulares. Dentre estas últimas o Art. 11 estabelece que:

Aos assessores de ministro incumbe:

I - prestar assessoramento jurídico ao Ministro (art. 325, caput, do Regimento Interno);

II - examinar os autos conclusos ao Ministro e pesquisar a legislação, doutrina e jurisprudência referentes à matéria versada em cada processo;

III - indicar ao Ministro, dentre os processo conclusos, aqueles com jurisprudência firmada na Seção ou compendiada nas súmulas do Superior Tribunal de Justiça (art. 122 do Regimento Interno); ou do Supremo Tribunal Federal, bem como os que devam ir com vistas ao Ministério Público ou cuja matéria recomende urgência;

IV - elaborar minutas de despachos nos casos previstos no Regimento Interno do STJ, submetendo-as à apreciação do Ministro;

V - Classificar os votos proferidos pelo Ministro, elaborando índices necessários à pronta consulta;

VI - executar, sob a orientação do Ministro, outros trabalhos que concorram para a celeridade do julgamento dos processos e da elaboração dos respectivos acórdãos;

VII - selecionar votos e acórdãos para publicação na Revista, no Ementário de Jurisprudência e no Boletim do STJ seguindo recomendação do Ministro;

VIII - orientar a organização e atualização do fichário de jurisprudência e demais arquivos do Gabinete;

IX - desempenhar quaisquer outras atribuições decorrentes do exercício do cargo, ou que lhes sejam cometidas pela autoridade superior.

Conforme se verifica, a maioria das atribuições dos assessores de ministro está relacionada de alguma forma ao trabalho com a informação. Destaca-se, no entanto, para os objetivos desta pesquisa, os artigos II e III onde a ocorrência 
frequente de situações de necessidade, busca e uso da informação permite considerar o trabalho do assessor de ministro sob o enfoque da abordagem Sensemaking de Brenda Dervin. Conforme exposto na revisão de literatura desta pesquisa, dada uma determinada situação de necessidade de informação, incluindo o momento e forma na qual esta demanda surge, concomitantemente, formam-se lacunas decorrentes de problemas, questões, confusões, angústia que impedem que o indivíduo desempenhe a atividade que necessita. Para ultrapassar este estado torna-se necessário buscar, conceitos ou ideias que ajudarão a cruzar a ponte sobre as lacunas, ou seja, resultados, consequências, impactos, efeitos, usos e utilidades, com atribuição de sentido e valor pelo individuo. Finalmente, ao usar a informação na tomada de decisão no trabalho, são aplicadas as ideias formadas, conclusões alcançadas, emoções e sentimentos que formam a ponte sobre as lacunas.

Em resumo pode-se pensar que no trabalho do assessor de ministro a situação dentro do contexto do processo judicial no espaço de tempo, é desencadeada pela necessidade de fundamentação do voto a ser apresentado ao ministro; implicando no surgimento da lacuna de ausência, parcialidade ou desatualização da informação, bem como de questões e indagações do assessor. Tais barreiras são ultrapassadas através de pontes cognitivas - produtos de informação impressos ou digitais ou, outros indivíduos - que ao possibilitar a atribuição particular de sentido, produzem como resultado final uma modificação causada entre o grau de conhecimento anterior e posterior à situação de necessidade de informação. Por sua vez, o uso é o emprego dado ao conhecimento recém-adquirido, de acordo com o significado que Ihe foi atribuído, consistindo na informação certa, útil ou relevante para o caso ou tema específico a ser analisado no processo judicial.

Isto foi evidenciado numa entrevista preliminar com uma assessora de ministra que não participou desta pesquisa, sobre características da dinâmica do trabalho de assessor, visando conhecer os aspectos inerentes ao desempenho do cargo relacionados à necessidade, busca e uso da informação jurídica. Para isto, foi solicitado à assessora de ministro que descrevesse em que consiste o seu trabalho e a prática de busca e acesso à informação:

\begin{abstract}
Nós identificamos processos que tem um tema relevante, que não há precedentes, para indicação para pauta e, no momento que o processo é indicado para pauta, eu identifico o tema, e utilizo os serviços da Biblioteca, eu e outros assessores também. Pesquisamos ou, através da BDJur, muitas vezes, ou através dos funcionários da biblioteca que trabalham com a pesquisa, pedindo doutrinadores de renome na área deste tema. Por exemplo, o tema que for, eu peço os doutrinadores que sei que são relevantes, autores bem conceituados, de peso, e assim o pessoal da Biblioteca, a pessoa que ficou encarregada da minha pesquisa me contata, [informando que foram separados] artigos e livros. Eu vou e estudo o material que eles separaram e também complemento com alguma coisa que eu fiz pesquisa na BDJur e estudo o processo. Então o assessor elabora uma sugestão de minuta de voto para que seja entregue ao ministro para o ministro estudar a sugestão de voto e verificar se aprova ou não, enfim.
\end{abstract}

A assessora esclareceu que esse trabalho de sugestão de voto é da responsabilidade individual de cada assessor. Após análise da matéria em pauta e apresentação para o aval do ministro de que não há precedente sobre tema, ele determina que o assessor estude o caso. No sentido de compreender o significado dos precedentes citados pela assessora, cabe acrescentar o pensamento de Pereira 
(2014, p. 17) quando assinala que os mesmos estão relacionados à uniformização de direitos na sociedade:

O Estado de direito $^{22}$ requer que as regulamentações estatais e as controvérsias jurídicas sejam conduzidas tanto quanto possível, por normas jurídicas preestabelecidas, seja para cidadãos como para órgãos estatais. Todavia, o Estado de direito não consegue cumprir seus objetivos e valores somente com a produção de normas pelo Legislativo, na resolução das disputas jurídicas, levando ao plano da prática, à luta pela estabilização e desenvolvimento do direito, ao exigir dos órgãos jurisdicionais a interpretação das normas jurídicas. (PEREIRA, 2014, p.18)

Assim, como incumbência das cortes superiores de justiça esta autora acrescenta que:

Ainda que predomine a ideia de que cabe aos tribunais a resolução de casos particulares, eles devem pensar tal função a partir da realização da justificação normativa com pretensão de universalidade, os chamados precedentes. Em outras palavras, o entendimento que possa ser aplicado em todos os sucessivos casos concretos semelhantes. Caso contrário, a resposta jurisdicional dada aos litigantes será a de um governo de homens e não efetivamente de um governo de direito, que tem por fim a realização da justiça, na sua dimensão formal. (PEREIRA, 2014, p.18) (grifo nosso)

A autora prossegue argumentando que:

A prática de seguir precedentes assim se apresenta como critério de racionalidade e imparcialidade para atuação dos juízes e para estabilização e desenvolvimento do Direito. O precedente, ao resolver um caso passado, e pretender orientar e regular, casos futuros, em situações semelhantes, impõe uma restrição ao processo de tomada de decisão judicial pelo juiz subsequente, que ao dever respeito ao precedente formado, precisa demonstrar razões que superem a razão ali dotada ou, que distinga o caso daquele já decidido. (PEREIRA, 2014, p.18)

Pereira $(2014$, p. 19) lembra que a adoção dos precedentes, "como modelo de universalismo na justificação das decisões judiciais, em contraposição ao particularismo, produz certa controvérsia no cenário normativo institucional". Porém, no que se refere ao STJ pondera que:

Dentre os argumentos favoráveis à criação de uma corte de justiça que adota os precedentes na prática jurisdicional, como o STJ, encontra-se: garantia da previsibilidade e da confiança justificada dos cidadãos nos atos dos poderes públicos, a igualdade de tratamento, a otimização das atividades jurisdicionais, a redução de custos judiciais e de número de processos a ser julgados, o desenvolvimento coerente do direito entre outros. (p. 19)

Conforme pensamento de Pereira (2014, p. 19) ao STJ incumbe a função de assegurar a uniformidade da jurisprudência como elemento indispensável para a realização do direito fundamental à igualdade perante o direito, devendo em sua atividade judicante:

(...) dedicar-se a resolver (...) recursos especiais interpostos em face de decisões que tenham sido proferidas em sentido contrário à jurisprudência firmada pelo próprio STJ ou quando inexistir uma doutrina jurisprudencial (leia-se um estoque de razões universalizáveis de normas jurídicas), já

\footnotetext{
${ }^{22}$ Toda atividade estatal subordinada aos comandos do direito. Deve contribuir para a paz social, proporcionando condições de civilidade, liberdade e segurança jurídica nas relações manifestadas no meio comunitário.
} 
produzidas pelo próprio STJ sobre leis que ainda não foram objeto de análise.

Voltando-se ao relato da assessora de ministro na entrevista, após a constatação de que não há precedente do STJ sobre o tema e da autorização do ministro para que 0 assessor estude o caso, a matéria pode ser discutida entre os assessores:

Às vezes eu estou responsável por um processo, mas eu gostaria de discuti com o meu colega se ele entendeu da mesma forma que eu esta matéria, às vezes agente entra em discussão com os próprios colegas do mesmo gabinete: eu estou escrevendo sobre isto, o que você acha disso...?

A distribuição dos processos nos gabinetes é feita considerando-se a área de direito de competência das Seções e Turmas de julgamento do Tribunal. A seleção dos processos entre os assessores pode ser realizada pelo Chefe de Gabinete ou pelos assessores, inclusive no acervo eletrônico do gabinete. Quanto à necessidade de estudo e pesquisa sobre a matéria dos processos, a assessora esclareceu que isto é particularmente relevante quando o STJ ainda não se manifestou sobre o assunto:

Dentro do processo tem temas diversos, às vezes um mesmo processo trata de títulos de crédito, de desconsideração da personalidade jurídica, de vários temas. Às vezes envolve um tema só, às vezes envolve só propriedade intelectual. É um campo muito vasto. Às vezes envolve prescrição e propriedade intelectual, mas aí naquele caso concreto agente lê e fala: 'neste tema o STJ não se manifestou ainda sobre isto, sobre este ponto de vista, sobre este tema específico, às vezes, um assunto com outro interligado'

Percebe-se que no trabalho do assessor a busca por casos processuais sem precedente de julgamento no Tribunal, desencadeia novas situações de necessidade de busca à informação jurídica, conforme as palavras da assessora: "É uma nova situação, por exemplo, prazo prescricional numa situação $x$ que é a situação deste caso concreto, se conversa com o ministro: 'Excelência tem este tema aqui que não se encontrou precedentes'”. A identificação destes casos é confirmada com a realização pelos assessores, de uma pesquisa prévia sobre o tema, para verificar se há jurisprudência do STJ, que pode ser seguida da solicitação de uma pesquisa na Biblioteca do Tribunal:

\begin{abstract}
Cada assessor pesquisa para poder indicar e conversar com o ministro, já preparado (...) já tem que fazer uma pesquisa prévia para falar: 'Excelência este tema aqui, realmente não encontramos jurisprudência'. Pesquisa individualmente na intranet, no campo de pesquisa de precedentes, de temas já julgados. Aí, o que eu peço; o que agente pede por fora, que agente pede para a Biblioteca, é assim, este tema com intersecção com este outro. Não tem alguma coisa sobre isto? Às vezes agente pede: 'Não tem um artigo, nenhuma pessoa de nome já escreveu sobre isto?' Às vezes não tem em livros. Às vezes tem livros sobre um ponto e outro sobre o outro, mas, não tem ao mesmo tempo sobre os dois, e aí agente tem que estudar e procurar fazer uma interpretação, muitas vezes, depende do caso.
\end{abstract}

Fazendo-se a associação entre as características do trabalho do assessor e o trinômio operacional do Sense-Making de Brenda Dervin, se nota no relato da usuária, que esta atividade profissional envolve inúmeras situações de necessidade de informação jurídica, seguido de uma lacuna ou gap, ocorrendo a busca para uso com a aplicação na atividade judicante do Tribunal. Percebe-se, ainda, que em determinadas situações existe dificuldade de encontrar informações específicas. 
Nestas ocasiões, ao ser indagado se o material que a Biblioteca forneceu foi o único no qual a assessora encontrou a informação aplicada no embasamento da proposta de voto, ela confirmou que sim:

\begin{abstract}
Às vezes já aconteceu num tema que ninguém escreveu sobre isto, que não tem no cotidiano, que agente não encontra em livros sobre direito empresarial ou direito civil, enfim tem um ponto no universo e de repente alguém da Biblioteca que eu pedi a pesquisa encontra um artigo, um parágrafo no meio de um livro. Às vezes agente na correria porque está fazendo muito trabalho, tem prazos e tudo, e eles ajudam bastante, eu só tenho a elogiar o trabalho da Biblioteca. Às vezes eles encontram alguma coisa que talvez num livro que você olha pelo título e no índice não tem a informação e o servidor da Biblioteca que ficou encarregado de fazer a pesquisa para mim leu, se preocupou em dá uma lida em alguns tópicos e achou um parágrafo e disse: Você não estava querendo era sobre este assunto, eu achei aqui um parágrafo aqui perdido num universo'. Já aconteceu isso, eu só tenho a elogiar.
\end{abstract}

No que se refere à pesquisa na BDJur, foi perguntado à assessora sobre que tipo de informação ela busca exatamente, considerando que para a necessidade de informação dela deve ter uma diferença entre solicitar a pesquisa no setor de pesquisa e ir direto na BDJur:

$\mathrm{Na}$ BDJur eu vou em busca de livros que já estão em pdf porque eu já posso olhar por minha conta aqui mesmo. Mas, às vezes tem uns livros antigos que não estão na BDJur e que eu precisaria mesmo parar e sentar e folhear, página por página, não só o sumário. E eu vou precisar descer e procurar os livros, aí eu peço [na Seção de Pesquisa da Biblioteca]. É uma coisa mais específica que não identifique pelo sumário na BDJur.

Ao ser indagada se realizava pesquisa de legislação na BDJur, a assessora confirmou enfaticamente que: "Não. É doutrina, doutrinadores mesmo de peso, de autores respeitados no mundo jurídico, para embasar bem o voto" Outro fator relacionado à busca de informação questionado, foi sobre o tempo, necessário para início de elaboração do estudo e análise, até a redação do voto pela assessora, e o tempo de espera do retorno da solicitação de pesquisa na Biblioteca: "Geralmente eu peço num dia para que nos próximos dois dias eu tenha uma boa conclusão sobre o tema". O tempo necessário para estudo dos temas relatado pela assessora é em média de três dias. Vale acrescentar que este processo de estudo e análise do tema, desencadeia para a assessora, novas situações de necessidade de informação, constatando-se o processo cognitivo de atribuição de sentido à informação recuperada para solução do problema, da abordagem , Sense-Making de Brenda Dervin. De fato, a usuária confirmou que no decorrer destes três dias vão surgindo ideias com novas solicitações à Biblioteca.

\footnotetext{
Muitas vezes eu leio uma determinada pesquisa e estudando o caso concreto chego a uma conclusão que o embasamento seria mais robusto por um outro ponto de vista e volto a contatar o servidor: 'olha eu te pedi este ponto $\mathrm{x}$ mas estudando o caso aqui eu posso desenvolver mais um parágrafo sobre o ponto y'. E aí volto a pedir um ponto ou mais ao longo da semana. Eu converso com o servidor da Biblioteca três ou quatro dias mesmo que eu faça outros trabalhos paralelamente, eu vou estudando, pensando, refletindo, chego em casa reflito, penso, durmo, acordo. $O$ assessor tem isso, assim, que a gente respira o caso. Você acaba vai dormir pensando se é isso mesmo tal... Você não só ler e pronto, conclui (grifo nosso)
}

Conforme a abordagem do trinômio operacional do Sense-making constata-se nitidamente neste depoimento que após a situação de necessidade de informação 
no trabalho do assessor, desencadeia-se a fase da lacuna definida por Dervin (1983) como processo empírico no qual o usuário vivencia a ausência de informação, ou lacuna cognitiva de necessidade de informação, seguida do consequente processo de busca e, de atribuição de sentido na recuperação, utilização e apropriação da informação. Assim, a assessora, a partir da leitura e análise da informação encontrada, constrói com base na experiência pessoal acumulada e significados interiorizados, a relevância de dada informação na tomada de decisão no contexto específico do caso jurídico a ser fundamentado. Evidencia-se, ainda, segundo Dervin (1983), no relato da assessora a atividade humana de observação, interpretação e compreensão como comportamento interno (cognitivo), e externo (atitudes, reações em face do meio social) que permite ao indivíduo construir e projetar seus movimentos, suas ações e sentimentos no tempo e espaço. Vale acrescentar que, as sensações ou os sentimentos acompanham todas as etapas de busca à informação, isto é, desde o início da pesquisa, ao selecionar e visualizar as informações recuperadas, ao selecionar quais informações usar e quais descartar e, ao avaliar se as informações obtidas foram suficientes ou se há necessidade de prosseguir na busca.

Em todos os movimentos da busca à informação podem ocorrer simultaneamente, ou não, sentimentos de incerteza, alívio, confusão, otimismo, dúvida, frustração, desapontamento, confiança, satisfação e outros. Assim, os sentimentos ou sensações no relato da assessora durante o mover-se em direção à solução de problemas relacionadas à busca de informação são resumidos no pensamento da assessora: "Sem dúvida o assessor acaba que fica emocionalmente envolvido. Ah! Tenho que descobrir a resposta".

A realização da busca à informação como barreira a ser ultrapassada através de pontes cognitivas com produtos de informação impressos ou digitais ou, outros indivíduos produzem como resultado final uma modificação causada entre o grau de conhecimento anterior e posterior à situação de necessidade de informação. No processo de busca à informação traçado pela assessora, ela confirmou que solicita pesquisa na Biblioteca, e realiza pesquisa na BDJur e na jurisprudência do STJ e STF, não referindo-se a outras fontes de informação e pesquisa. Esclareceu ainda que a busca à doutrina é realmente realizada na BDJur, havendo porém caso de pesquisa em livros próprios "para ajudar no voto que estou fazendo esta semana".

Ao ser indagado se a usuária considerava que o trabalho do assessor é totalmente voltado para a pesquisa à informação ela assinalou que: "É, para poder fazer um trabalho de excelência", acrescentando que isto se deve, principalmente, à particularidade de cada caso a ser fundamentado: "É. tem de ser estudado o ponto do tema tal, mas sob o ponto de vista daquele caso, das peculiaridades daquele caso, o que aconteceu nas outras instâncias, enfim, daquele caso concreto. $E$, é isso, a gente pesquisa bastante para entregar uma coisa bem feita". Quanto ao uso efetivo da informação obtida no trabalho do assessor, ao ser questionado se eram feitas citações dos autores, foi mencionada a aplicação direta da informação no texto: "Isso. Tudo bem fundamentado, citando o nome do autor. Às vezes no meio do corpo do voto destacamos trechos em alguns votos, às vezes tem um parágrafo de um livro que é interessante que se aplica perfeitamente à hipótese, destacamos trechos."

$\mathrm{Na}$ tentativa de citar um trecho de informação fornecida pela Biblioteca ou encontrada na BDJur pela assessora na fundamentação do voto, foi solicitado à mesma da possibilidade de indicar o trecho no texto do voto. Contudo, não foi 
possível exemplificar com precisão, para citação nesta pesquisa, o uso de determinado trecho obtido de uma fonte de pesquisa fornecida pela Biblioteca ou pela BDJur, na aplicação e citação no texto do voto, porque a usuária teve dificuldade em recordar, sendo inviável devido tanto ao número de votos realizados como à quantidade de informação pesquisada, recuperada, analisada e aplicada na redação dos mesmos. Contudo a assessora declarou estar satisfeita com os serviços da Biblioteca: "Eu gosto muito do serviço deles eu acho essencial, acho muito bom".

Vale acrescentar informações sobre outros aspectos do trabalho realizado no gabinete, fornecidas pela assessora. Foi esclarecido que há outros profissionais no gabinete que realizam o trabalho de redação do texto das decisões monocráticas, como decisões que o ministro assina sem levar para o colegiado. A usuária confirmou que ela também trabalha na redação de sugestões para este outro tipo de texto, porém, em menos quantidade em relação ao trabalho com os votos de ministro. Foi relatado que a necessidade de busca à informação no trabalho com as decisões monocráticas é menor "porque já tem um precedente, então a gente não costuma pedir doutrina na Biblioteca". Vale, ainda, acrescentar do relato da assessora, no que se refere ao julgamento da matéria do processo, o fato de que ao ser identificado:

(...) um processo que já foi julgado pela Quarta Turma ou que eles levaram a julgamento e teve muito debate e, eles entendem que o tema é tão relevante a ponto de ter que ser debatido pela outra Turma que julga a mesma matéria que é direito privado, eles se reúnem na Segunda Seção que são os cinco [ministros] da Terceira com os cinco da Quarta [turmas].

Por último, é importante frisar além da constatação da necessidade de informação jurídica e da busca, mormente na BDJur, para realização do trabalho do assessor, a função que cabe à BDJur no acesso efetivo à informação. Neste sentido, a abordagem Sense-making como parte integrante da Metodologia do lbict para Avaliação de Produtos e Serviços de Informação permite analisar as tarefas de interpretação, formulação e aprendizagem envolvidas no processo de busca de informação pelo assessor e de como eles percebem, compreendem e sentem suas interações com instituições, produtos, mensagens e situações, no uso da informação Daí porque a descrição e compreensão da real necessidade e comportamento de busca da informação do usuário deve considerar a visão, vivência e problemas do indivíduo como elementos significantes no desenvolvimento de produtos de informação jurídica na Web.

\subsubsection{Produtos e serviços de informação da Biblioteca Ministro Oscar Saraiva do Superior Tribunal de Justiça}

Os produtos e serviços fornecidos pela Biblioteca do STJ objetivam atender a necessidade de informação dos ministros, assessores, servidores e demais usuários da comunidade jurídica.

Os serviços de informação oferecidos pela Biblioteca são

Pesquisa de Doutrina e Legislação - realização de pesquisas de doutrina e legislação e levantamentos bibliográficos em bases de dados; realzação de Pesquisa Virtual, por e-mail, para o usuário que não obteve sucesso na pesquisa realizada no catálogo on-line da Biblioteca - RVBI; 
Pesquisa e fornecimento do texto integral de doutrina ou legislação na BDJur;

Pesquisa em bases de dados - consulta a base de dados jurídicas eletrônicas na intranet como a Biblioteca Digital Fórum de Direito e Governet;

Empréstimo especial para ministros, magistrados e juízes convocados e aquisição de obras para gabinetes e unidades administrativas, para subsidiar atividades jurídicas e técnico-gerenciais;

Empréstimo de itens bibliográficos - documentos do acervo;

Fornecimento de cópias - reprográficas e digitais de artigos de periódicos, capítulos de livros, legislação e jurisprudência;

* Intercâmbio de duplicatas - doação para bibliotecas públicas de obras duplicadas.

Os produtos de informação jurídica são:

Sumários de Livros: divulga o conteúdo dos livros da Biblioteca;

Artigos Jurídicos - seleção do sumário do último número das revistas jurídicas recebidas pela Biblioteca. A cópia de artigos é obtida assinalando-se aqueles de interesse na página da revista visitada e enviando o pedido eletronicamente.

Atos Normativos do STJ - divulga os atos publicados em Imprensa Oficial, que sejam de interesse do STJ.

Clipping de Legislação - divulga o texto integral de atos oficiais do STJ, Conselho da Justiça Federal, Conselho Nacional de Justiça, Ministério da Justiça, Ministério Público Federal, Ordem dos Advogados do Brasil, Presidência da República, Tribunais Regionais Federais, Tribunais Superiores e Tribunal de Contas da União.

Códigos - links para o inteiro teor dos códigos nacionais.

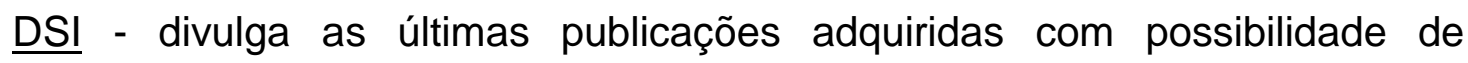
pesquisa

Publicações Institucionais - possibilita acesso às publicações institucionais na página do Portal, por meio de pesquisa no Repositório Institucional e no site de Publicações Seriadas. No Repositório Institucional, são encontradas as coleções da BDJur com publicações administrativas e históricas. Na pesquisa de Publicações Seriadas no site, o público tem acesso às coletâneas, revistas e demais publicações editadas em série pelo Tribunal.

(Regulamento da Biblioteca do STJ, 2014, p. 6)

$\mathrm{O}$ uso de recursos tecnológicos possibilitou criar e desenvolver a Biblioteca Digital Jurídica (BDJur) como produto de informação jurídica na Web. A BDJur integra a Web 2.0, onde a internet é a plataforma, a informação é colaborativa e o acesso é democrático. (Bibloteca Digital Jurídica - BDJur, p. 2-3) 


\subsubsection{Biblioteca Jurídica do Superior Tribunal de Justiça - BDJur como produto de informação disponível na Web}

A Biblioteca Digital Jurídica do Superior Tribunal de Justiça, BDJur, foi criada em 2004, como iniciativa de acesso livre à informação, visando contribuir para a democratização e acessibilidade à informação jurídica em inteiro teor, visando armazenar, preservar, disseminar e tornar acessíveis documentos jurídicos digitais. É gerenciada pela Biblioteca Ministro Oscar Saraiva, "tendo como principais objetivos facilitar e promover o acesso à informação jurídica de interesse dos usuários, principalmente de ministros, desembargadores convocados e servidores do STJ". No universo jurídico, cabe ressaltar que o acesso à justiça evita a impunidade, e prejuízo para a economia do país. Nesta linha de pensamento, a BDJur ao tornar disponível e acessível a informação jurídica, em tempo hábil, para a comunidade jurídica, possibilita a ministros, magistrados, advogados, servidores públicos e demais usuários, acelerar ações de alguma forma relacionadas à atividade judicante no país Com isto "está colaborando para diminuir a lentidão da justiça, fazendo com que o país possa ser mais justo e cumpridor das normas legais". (BRASIL. SUPERIOR TRIBUNAL DE JUSTIÇA, 2015, p. 11).

$\mathrm{Na}$ implantação da BDJur buscou-se parcerias com organizações nacionais, como o Instituto Brasileiro de Informação em Ciência e Tecnologia, IBICT, e a Escola de Comunicações e Artes da Universidade de São Paulo, ECA/USP e, internacionais como a Universidade do Minho, responsável pela implantação do repositório em Portugal, os quais forneceram informações para elaboração do projeto e implantação do sistema. (BRASIL. SUPERIOR TRIBUNAL DE JUSTIÇA, 2015, p. 13)

O projeto de criação da BDJur "Em direção à implantação da Biblioteca Digital Jurídica - BDJur", idealizado por uma bibliotecária do quadro funcional da Biblioteca do STJ, foi concluído em maio de 2004, com o planejamento de etapas a serem executadas até março de 2005. Em dezembro de 2004 iniciou-se a inclusão dos primeiros documentos e, a partir de março de 2005, foram disponibilizadas, em pouco espaço de tempo, as coleções "Atos Normativos do STJ", "Repositório Institucional", "Links Jurídicos" e "Juristas Renomados", para acesso público. De acordo com diretrizes estabelecidas do projeto inicial, o sistema da BDJur deveria ser desenvolvido com base na filosofia do acesso livre, uma iniciativa pioneira na área do Poder Judiciário. Foram, então, analisados na ocasião, os softwares livres "Nou Rau", "Phonesis" Greenstone e DSpace. Este último foi escolhido para gerenciar o acervo digital da BDJur, por possuir padrões de interoperabilidade, interface amigável, versão em português, além de possibilitar a gestão de ampla variedade de documentos digitais. Após análise dos requisitos e funcionalidades do DSpace, foram realizadas customizações no software, sobretudo, nos formulários de entrada de dados e nas opções de pesquisa simples e avançada, a fim de ajustá-lo às necessidades dos usuários do STJ. Posteriormente, a BDJur migrou para novas versões do DSpace, realizando inovações e aumentando a capacidade de processamento e disponibilização da informação para o usuário. (BRASIL. SUPERIOR TRIBUNAL DE JUSTIÇA, 2015, p 13)

No desenvolvimento da BDJur a possibilidade do DSpace gerenciar diversos

tipos de conteúdos viabilizou a participação de outros setores do STJ na alimentação e gestão da BDJur, conforme mostra o Quadro 12. 
QUADRO 12 - Unidades do STJ nvolvidas na gestão e alimentação da BDJur

\begin{tabular}{|c|c|}
\hline Unidades do STJ & Responsabilidades \\
\hline Biblioteca Ministro Oscar Saraiva & $\begin{array}{l}\text { Gerência da BDJur, alimentação e gestão dos } \\
\text { seguintes tipos de documentos: } \\
\text { - } \quad \text { Atos administrativos } \\
\text { - } \quad \text { Doutrina (livros, artigos, palestras, entre } \\
\text { outros) } \\
\text { - Produção bibliográfica dos Ministros e } \\
\text { servidores do STJ } \\
\text { - Publicações e documentos produzidos pelo } \\
\text { STJ }\end{array}$ \\
\hline $\begin{array}{l}\text { Coordenadoria de Gestão } \\
\text { Documental }\end{array}$ & $\begin{array}{l}\text { Alimentação e gestão das coleções Atas do STJ e } \\
\text { Atas do TFR }\end{array}$ \\
\hline Coordenadoria de Memória e Cultura & Alimentação e gestão de fotografias de obras de arte \\
\hline Diretoria-Geral & \multirow{8}{*}{$\begin{array}{l}\text { Submissão de atos para publicação no Boletim de } \\
\text { Serviço do STJ }\end{array}$} \\
\hline Secretaria de Documentação & \\
\hline Secretaria de Administração & \\
\hline Secretaria de Orçamento e Finanças & \\
\hline Secretaria de Controle Interno & \\
\hline Secretaria de Gestão de Pessoas & \\
\hline $\begin{array}{l}\text { Secretaria de Serviços Integrados de } \\
\text { Saúde }\end{array}$ & \\
\hline $\begin{array}{l}\text { Escola Nacional de Formação e } \\
\text { Aperfeiçoamento de Magistrados }\end{array}$ & \\
\hline
\end{tabular}

*Fonte: BRASIL. Extraído de: SUPERIOR TRIBUNAL DE JUSTIÇA. Secretaria de Documentação. Biblioteca Digital Jurídica do STJ, p. 13-14: BDJur 10 anos, 2015

A BDJur é especializada em Direito. Dados estatísticos do acervo da BDJur indicam que em 2015, existem mais de 85 mil documentos digitais, nos formatos de texto e multimídia, incluindo os atos administrativos do STJ, artigos de revistas, capítulos de livros, obras raras, palestras, discursos, fotografias, trabalhos acadêmicos, documentos produzidos pelas unidades do Tribunal além de outros documentos de importância no universo jurídico.. O crescimento do acervo da BDJur pode ser visto no Figura 12. 


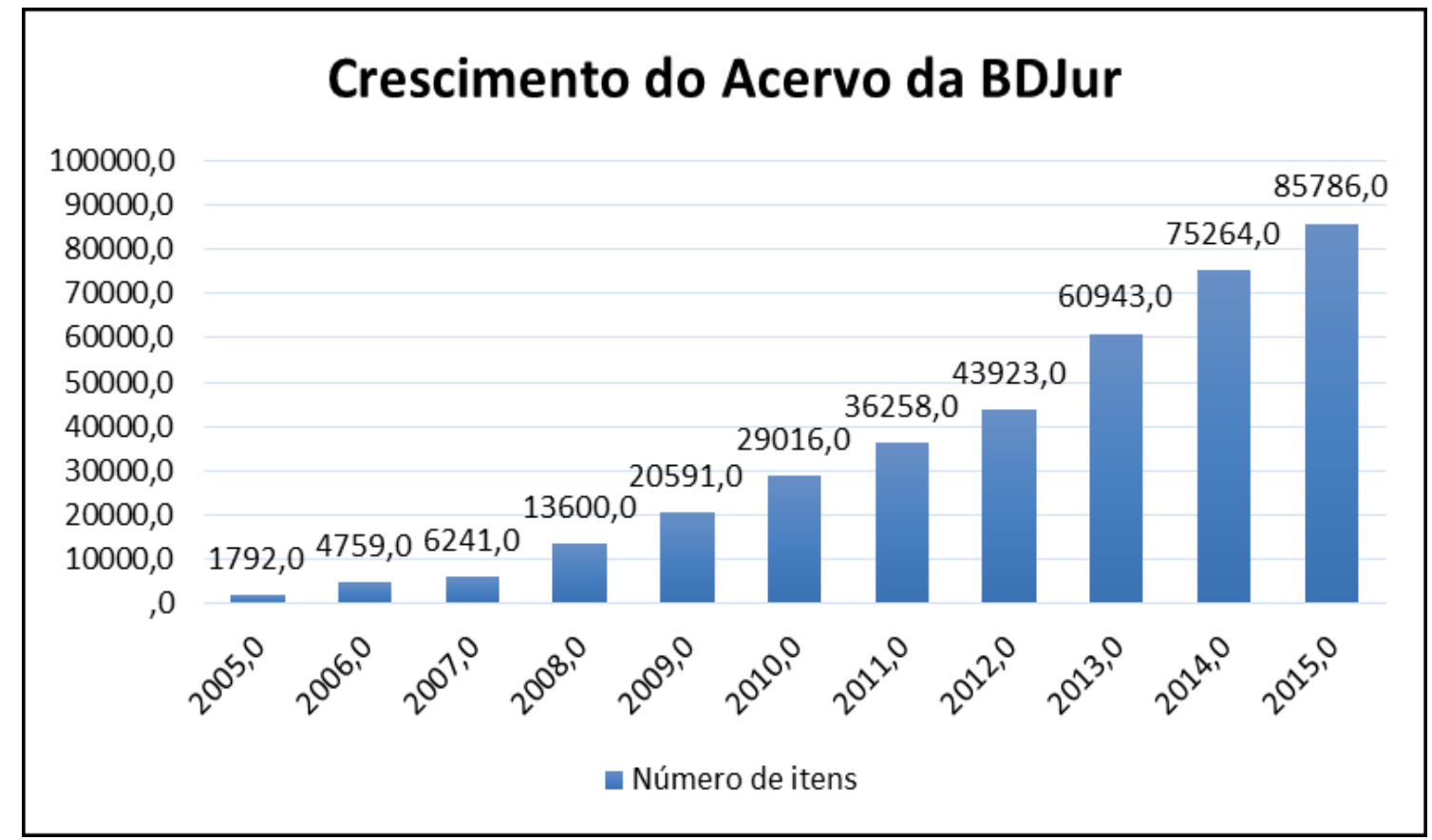

Fig. 12 - Crescimento do acervo da BDJur*

*Fonte: Extraído de: BRASIL. SUPERIOR TRIBUNAL DE JUSTIÇA. Secretaria de Documentação. Biblioteca Digital Jurídica do STJ, p. 14 : BDJur 10 anos, 2015 (dados extraídos em novembro de 2015)

Esse crescimento é resultado da inclusão de documentos realizada pelos bibliotecários e pela migração de bases de dados existentes no STJ, de atos administrativos, que utilizavam softwares proprietários, criados pelo STJ:

- Atos Oficiais do STJ: migração em 2005 contendo 2.279 documentos;

- Boletim de Serviço do STJ: migração em 2007 contendo 8.528 documentos;

- Atos Normativos do TFR: contém 1.574 documentos, com migração iniciada em 2013. e inclusão manual dos atos pela equipe da BDJur.

(BRASIL. SUPERIOR TRIBUNAL DE JUSTIÇA, 2015, p. 15)

Segundo informação da Biblioteca do STJ, publicada em livro lançado em 2015, por ocasião dos dez anos da BDJur, ela "é um dos repositórios digitais jurídicos mais acessados do mundo". Em 2011, foi classificada em 17ª posição entre 1.200 repositórios institucionais no mundo. A pesquisa foi realizada pelo Conselho Superior de Pesquisas Científicas (CSIC), principal agência estatal dedicada à pesquisa científica e tecnológica da Espanha e terceira maior da Europa. Esta pesquisa avaliou o tamanho do repositório e a quantidade de itens rastreados pelos motores de busca, entre outros critérios. (BRASIL. SUPERIOR TRIBUNAL DE JUSTIÇA, 2015, p. 15)

A Figura 13 ilustra o crescimento significativo do uso da BDJur a partir do ano de criação: 


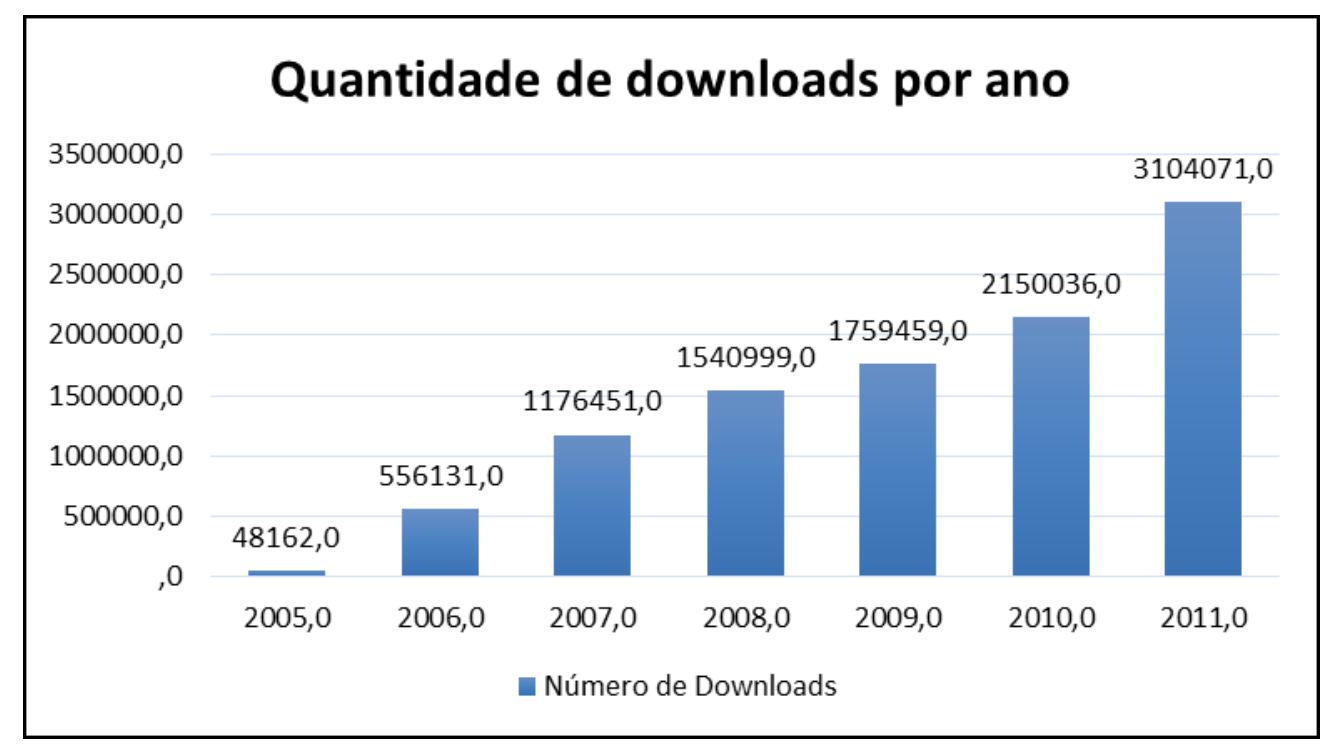

Fig. 13 - Número de downloads realizados na BDJur (2005-2011)*

*Fonte: Extraído de: BRASIL. SUPERIOR TRIBUNAL DE JUSTIÇA. Secretaria de Documentação. Biblioteca Digital Jurídica do STJ, p. 15 : BDJur 10 anos, 2015 (dados extraídos em novembro de 2015)

A Seção de Biblioteca Digital Jurídica informou que devido a inconsistências apresentadas nas estatísticas do sistema da BDJur entre 2012 e 2015, não foi possível apresentar o número de downloads desse período.

A divulgação da BDJur ocorreu no evento "Justiça para todos", realizado em Brasília em abril de 2005, visando levar as atividades do STJ ao conhecimento do cidadão comum, no esforço de maior proximidade com a sociedade. Na ocasião, foram fornecidas orientações ao público sobre como utilizar o novo produto de informação digital. Nesse mesmo ano, a BDJur foi apresentada pela bibliotecária autora do projeto de criação, na Conferência Internacional sobre Publicações Eletrônicas, ELPUB2005, na Katholieke Universiteit Leuven, Bélgica, com o trabalho intitulado "Consortium BDJur - Bibliothèque Digitale Juridique: adoption du DSpace dans le Pouvoir Judiciaire Brésilien"

\section{1.3.1 Infraestrutura tecnológica}

O software utilizado pela BDJur é o DSpace, escolhido após levantamento e análise dos principais softwares para criação de repositórios digitais, cujas características estão relacionadas no projeto de criação da BDJur. A principal vantagem do DSpace é a facilidade de adaptação ao contexto das organizações, permitindo a gestão de grande variedade de documentos digitais. Trata-se de um software livre desenvolvido pelo Massachusets Institute of Technology (MIT), nos Estados Unidos, em parceria com a Hewlett-Packard (HP), cuja finalidade é preservar, gerenciar e permitir o acesso a todos os tipos de objetos digitais, incluindo textos, imagens, áudios e vídeos. Atualmente, o DSpace é um sistema amplamente utilizado, tanto por organizações públicas quanto privadas. Segundo o Registry of Open Access Repositories (2015), mais de 1.500 repositórios utilizam o software em todo o mundo. Com o intuito de facilitar e promover a interoperabilidade com outros sistemas, o DSpace segue padrões e protocolos internacionais. (BRASIL. SUPERIOR TRIBUNAL DE JUSTIÇA, 2015, p. 19) 
O esquema de metadados utilizado pela BDJur é o Dublin Core. Os metadados das coleções do repositório foram definidos de acordo com as especificidades e formatos dos conteúdos armazenados. (BRASIL. SUPERIOR TRIBUNAL DE JUSTIÇA, 2015, p. 19)

\section{Segundo a Seção de Biblioteca Digital}

O DSpace permite a atribuição de identificadores persistentes, como o handle e o DOI (Digital Object Identifier), para cada documento publicado no sistema, o que contribui para garantir o acesso e a preservação dos documentos a longo prazo. O STJ optou pela utilização de um servidor local, criado pelo próprio Tribunal, para atribuição de identificadores para os itens publicados na BDJur, com estrutura similiar ao handle, padrão mantido pela Handle System. O DSpace adota o OAI-PMH (Open Archives Iniciative Protocol for Metadata Harvesting), protocolo que permite a coleta de metadados da BDJur por outros repositórios. Além disso, esse protocolo permite que a BDJur realize a coleta de metadados de outros repositórios, utilizando a ferramenta de Harvesting do próprio DSpace. O OAI-PMH, portanto, possibilita a interoperabilidade entre os repositórios, ampliando o acesso e visibilidade dos conteúdos armazenados (BRASIL. SUPERIOR TRIBUNAL DE JUSTIÇA, 2015, p. 19).

No sentido de aprimorar e desenvolver a interface com o usuário, a BDJur passou por diversos processos de atualização de software e mudanças de layout. Em 2005, com a versão DSpace 1.3.2, foi feita a implementação de melhorias nos formulários de pesquisa, entre outras. Em 2007 com a versão DSpace 1.4, foi reformulado o layout, "buscando maior satisfação dos seus usuários, com a implementação de melhorias na pesquisa e no acesso aos documentos". No ano de 2015, a BDJur lançou nova versão, "com layout mais moderno e dinâmico, além de melhorias na pesquisa e na apresentação dos conteúdos" utilizando a versão DSpace 4.2. (BRASIL. SUPERIOR TRIBUNAL DE JUSTIÇA, 2015, p. 20).

As atualizações com novas versões de software na BDJur encontram-se reunidas no Quadro 13

QUADRO 13 - Histórico de atualizações das versões do DSpace da BDJur*

\begin{tabular}{|c|c|c|}
\hline Ano & Versão anterior & Versão atualizada \\
\hline 2005 & 1.2 & 1.3 .1 \\
\hline 2006 & 1.3 .1 & 1.3 .2 \\
\hline 2007 & 1.3 .2 & 1.4 \\
\hline 2008 & 1.4 & 1.5 .2 \\
\hline 2015 & 1.5 .2 & 4.2 \\
\hline
\end{tabular}

*Fonte: Adaptado de: BRASIL. SUPERIOR TRIBUNAL DE JUSTIÇA. Secretaria de Documentação. Biblioteca Digital Jurídica do STJ, p. 20 : BDJur 10 anos, 2015

De acordo com a Seção de Biblioteca Digital Jurídica, "os principais objetivos das atualizações do software da BDJur foram a implementação dos novos recursos, além da correção de bugs e implantação de melhorias no layout para facilitar a 
navegação e pesquisa dos conteúdos do repositório". Assim, "em 2009 ocorreu a implantação de novo layout da BDJur, mantendo a versão 1.5.2 do DSpace". No ponto de vista da Seção de Biblioteca Digital Jurídica: "As constantes atualizações das versões do DSpace têm contribuído para a evolução dos repositórios que o utilizam. Desse modo, a evolução do software tem favorecido o crescimento da BDJur, com a ampliação das coleções e o aumento do número de acessos ao repositório". (BRASIL. SUPERIOR TRIBUNAL DE JUSTIÇA, 2015, p. 20).

As imagens dos layouts utilizados pela BDJur ao longo de dez anos encontram-se no Anexo 12

\subsubsection{Expansão e desenvolvimento da BDJur : aspectos históricos}

Não obstante os desafios enfrentados na etapa preliminar de criação, a BDJur seguiu uma trajetória evolutiva, buscando acompanhar os avanços tecnológicos, em consonância com a necessidade de informação da comunidade jurídica e sociedade Assim, tanto no âmbito interno, como no exterior ao Tribunal, a BDJur foi ocupando espaço à medida que adquiriu responsabilidades e funções na organização, preservação e disseminação da informação jurídica em ambiente digital. Pouco tempo depois de sua criação, a BDJur, passou a ser fonte oficial de publicação dos atos do Boletim de Serviço, por meio da Portaria n. 112 de 18.07.2007.Tal crescimento ocorreu também quanto à expansão do acervo e coleções em quantidade e variedade Assim, em 2007, disponibilizou obras raras do acervo da Biblioteca do STJ, digitalizadas em parceria com o Ministério da Educação, por meio de projeto financiado pela UNESCO. Em 2008, por ocasião das comemorações dos 60 anos da Biblioteca Ministro Oscar Saraiva, do STJ, foi lançado o In Totum Portal de Periódicos Jurídicos de Livre Acesso, que se tornaria, posteriormente, na coleção de Artigos de Acesso Aberto, parte integrante do acervo de Doutrina da BDJur. No ano seguinte, em 2009, tornou-se a primeira biblioteca digital a atuar como provedora de dados da Rede de Informação Legislativa e Jurídica - LexML, gerenciada pelo Senado Federal. Neste mesmo ano, é classificada na 49a posição no ranking mundial de repositórios digitais, elaborado pelo Conselho Superior de Investigações Científicas da Espanha - CSIC, alcançando a melhor colocação entre os repositórios nacionais. Em 2010, a BDJur disponibiliza o conteúdo de 38 revistas jurídicas nacionais, ampliando o seu acervo com 2.750 artigos. (BRASIL. SUPERIOR TRIBUNAL DE JUSTIÇA, 2015, p. 17)

Por sua vez, em 2011 ganhou destaque internacional ao ser classificada em $17^{\circ}$ lugar no ranking anual do Conselho Superior de Investigações Científicas CSIC, da Espanha, que avaliou 1.120 repositórios digitais de todo o mundo. Neste mesmo ano, obteve o $2^{\circ}$ lugar entre os repositórios dos países da América Latina. Além de iniciar a divulgação de artigos doutrinários da BDJur no Facebook, atingindo números expressivos de acessos e compartilhamentos. No ano seguinte, 2012, as coleções de atos administrativos da BDJur passam a trazer o texto compilado das normas incluindo o histórico completo de alterações. Em 2013 foi criada a coleção Galeria de Artes, como parte do Repositório Institucional, a fim de divulgar as várias obras (pinturas, fotografias e esculturas) que compõem o acervo iconográfico do STJ. Ainda neste ano, passou a ser obrigatória a inclusão, na BDJur, do trabalho de conclusão de curso dos servidores bolsistas de pós-graduação lato sensu, conforme dispõe a Orientação Normativa GDG n. 1 de 7.05.2013. (BRASIL. SUPERIOR TRIBUNAL DE JUSTIÇA, 2015, p. 17) 
Em 2015 o post de divulgação da Bibliografia elaborada pela BDJur sobre o novo Código de processo civil, atinge o número de 163.200 usuários do Facebook, com mais de 1.100 compartilhamentos. A resposta positiva do público reforça o êxito da coleção Bibliografias Selecionadas, um dos produtos presentes no acervo de Doutrina da BDJur. No decorrer deste ano, chega à quantidade de 104 revistas jurídicas disponibilizadas, com mais de 30.000 artigos. Dessa forma, em 2015 a BDJur completou 10 anos com um dos maiores acervos digitais jurídicos do Brasil, disponibilizando documentos em vários formatos, entre textos, imagens, vídeos e áudios. (BRASIL. SUPERIOR TRIBUNAL DE JUSTIÇA, 2015, p. 17)

Cabe mencionar, a importância do projeto da BDJur no âmbito administrativo do STJ e a dimensão do alcance do mesmo com a perspectiva, ainda na etapa inicial da criação da BDJur, da ideia de formar um consórcio de bibliotecas digitais, em parceria com outras organizações afins. Para tanto, foi publicado o Ato n. 278, de 22.09 2004, que incluía o Consórcio BDJur (Rede de Informações Digitais do Poder Judiciário) entre os projetos estratégicos aprovados pelo Presidente do STJ. A ideia era implantar bibliotecas digitais similares à BDJur nos órgãos do Poder Judiciário e integrá-las em único portal, permitindo pesquisas unificadas nos seus acervos digitais. O projeto estratégico de criação do Consórcio BDJur foi apresentado, no Salão de Conferências, na presença do Presidente do STJ, para os servidores do Tribunal, bibliotecários de demais órgãos do Poder Judiciário e auxiliares da Justiça. (BRASIL. SUPERIOR TRIBUNAL DE JUSTIÇA, 2015, p. 17)

Posteriormente, o Regulamento do Consórcio BDJur foi aprovado pelo Presidente do STJ, com a publicação da Resolução n. 14, de 3.08.2005. O Consórcio BDJur foi apresentado em sessão ordinária do Conselho da Justiça Federal em São Paulo, com a finalidade de divulgar a iniciativa aos presidentes dos Tribunais Regionais Federais e convidá-los a compor o Consórcio. Em 2006, a BDJur foi apresentada ao Presidente do STJ, no Salão Nobre do Tribunal, por ocasião da assinatura do Acordo de Cooperação Técnica do Consórcio BDJur firmado com o Ministério Público do Estado da Paraíba. Por fim, em cerimônia realizada na Biblioteca do Senado Federal, o Vice-Presidente do STJ, no exercício da Presidência, e o Presidente do Senado, assinaram o Acordo de Cooperação Técnica do Consórcio BDJur firmado entre os dois órgãos. A parceria reforçou 0 compromisso da BDJur com a ampliação do acesso à informação jurídica e legislativa.

\subsubsection{Organização da informação na BDJur}

A BDJur foi criada com as coleções "Atos Normativos do STJ", "Repositório Institucional", "Links Jurídicos" e "Juristas Renomados" e, ao longo da sua história, teve uma evolução significativa no que se refere ao tamanho do seu acervo. Dados de 2015 indicam o total de 19 coleções, com mais de 85 mil documentos. De acordo com a Seção de de Biblioteca Digital Jurídica:

O software da BDJur apresenta um modelo de organização da informação estruturado em comunidades, coleções e itens, no qual as comunidades agrupam as coleções e as coleções armazenam os itens. Essa estrutura hierárquica permite a organização do acervo, facilita a navegação e a recuperação dos documentos no repositório. 
Assim, a BDJur possui três acervos principais: Atos Administrativos, Doutrina e Repositório Institucional. As coleções pertencentes a cada uma são:

\begin{tabular}{l|l|l}
\hline * Atos Administrativos & \multicolumn{1}{|c}{ - Doutrina } & Repositório Institucional \\
\hline - Atos Normativos da & - Artigos de Acesso Aberto & - Atas do STJ \\
ENFAM & - Artigos de Acesso Restrito & - Atas do TFR \\
- Atos Normativos do & - Libliografias Selecionadas & - Eventos \\
STJ & - Obros Digitais & - Pareria de artes \\
- Atos Normativos do & - Palestras & assessoria jurídica \\
TFR & - Produção Intelectual dos & \\
- Boletim de Serviço & Ministros do STJ & \\
do STJ & - Produção Intelectual dos & \\
& - Servidores do STJ & \\
& - Sumários de Livros & \\
\hline
\end{tabular}

O conteúdos específicos das coleções da BDJur, são descritos a seguir.

Atos administrativos - acervo constituído pelas normas do Tribunal divulgadas nos meios de comunicação oficiais de publicação, reunindo as seguintes coleções:

- Boletim de Serviço do STJ (BS): fonte oficial dos atos de natureza interna, os atos do boletim são publicados diretamente na BDJur, que se tornou veículo oficial de publicação por meio da Portaria n. 112 de 18.07.2007, revogada pela Instrução Normativa STJ/GP n. 12 de 12.08. 2015.

- Atos Normativos do STJ: normas do tribunal publicadas no Diário Oficial da União (DOU) e no Diário da Justiça Eletrônico do STJ (DJE).

- Atos Normativos da Enfam: normas da Escola Nacional de Formação e Aperfeiçoamento de Magistrados (Enfam).

- Atos Normativos do TFR: atos do extinto Tribunal Federal de Recursos (TFR).

Doutrina - acervo constituído por documentos doutrinários reunidos e disponibilizados nas seguintes coleções:

- Artigos de Acesso Aberto: artigos de revistas jurídicas nacionais e estrangeiras, com conteúdo disponível para o público em geral.

- Artigos de Acesso Restrito: artigos de revistas jurídicas nacionais e estrangeiras, com conteúdo restrito ao público interno do STJ, em respeito aos contratos firmados com as editoras.

- Bibliografias Selecionadas: bibliografias elaboradas pela Biblioteca do STJ que divulga fontes de informação sobre temas jurídicos.

- Livros Digitais: obras publicadas por instituições públicas, editoras comerciais e outros editores.

- Obras Raras: obras jurídicas publicadas entre os séculos XVII e XX, pertencentes ao acervo de obras raras da Biblioteca do STJ.

- Palestras: vídeos ou textos de palestras sobre temas jurídicos.

- Produção Intelectual de Ministros do STJj: artigos, livros, capítulos, prefácios, sumários de livros, trabalhos acadêmicos, palestras de ministros ativos e aposentados do STJ. Esse material é incorporado à BDJur em atendimento a atribuição da Secretaria de Documentação 
estabelecida no art. 45, Inciso III, do Regimento Interno do Superior Tribunal de Justiça.

- Produção Intelectual de Servidores do STJ: artigos, livros, trabalhos de conclusão de cursos de especialização, dissertações e teses, produzidos pelos servidores do STJ, nos cursos de pós-graduação custeados pelo Tribunal. O bolsista deverá ceder os direitos para publicação na BDJur, conforme estabelecido na Instrução Normativa STJ/GDG n. 16., de 10.07. 2015.

- Sumários de Livros: sumários das obras incorporadas ao acervo físico da Biblioteca do STJ, com o objetivo de divulgar e facilitar a pesquisa do conteúdo das obras.

- Textos Jurídicos: documentos relacionados à área jurídica, enviados por magistrados, juristas e outros operadores do direito. Os trabalhos são selecionados pela Comissão Especial para Seleção, Aquisição e Desfazimento de Materiais Informacionais, Cesad, com base nas diretrizes constantes no documento "Critérios para submissão de trabalhos para publicação na Bdjur"

Repositório Institucional - acervo que reúne publicações e documentos produzidos pelo STJ, descritos nas coleções:

- Atas do STJ: atas das Sessões de julgamento e do Conselho de Administração do Superior Tribunal de Justiça.

- Atas do TFR: atas das Sessões de Julgamento e do Conselho de Administração do extinto Tribunal Federal de Recursos.

- Eventos do STJ: vídeos e textos de palestras de eventos promovidos pelo Superior Tribunal de Justiça.

- Galeria de Artes: imagens das obras de arte pertencentes ao Superior Tribunal de Justiça, doadas por artistas que realizaram exposições no Espaço Cultural do STJ.

- Pareceres da Assessoria Jurídica do STJ: pareceres emitidos pela Assessoria Jurídica do Superior Tribunal de Justiça

(BRASIL. SUPERIOR TRIBUNAL DE JUSTIÇA, 2015, p. 25).

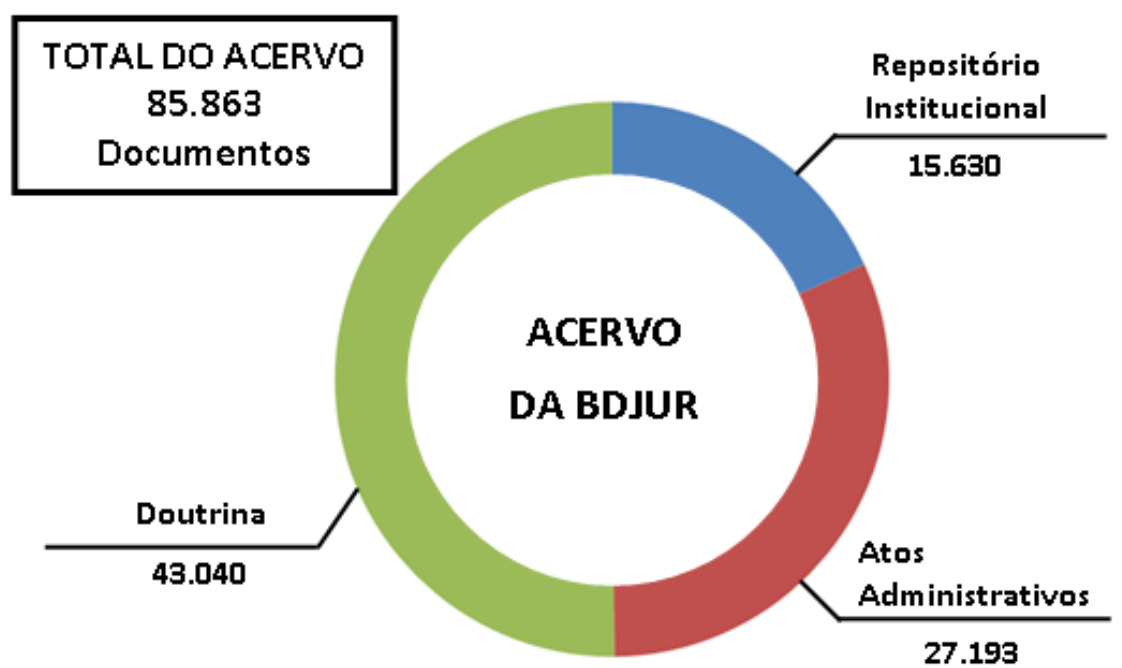

Fig. 14 - Acervo da BDJur - Fonte: Brasil Superior Tribunal de Justiça, 2015. 
A seleção dos documentos que compõe o acervo da BDJur é realizada pela Cesad $^{23}$, com base nos critérios de seleção estabelecidos pela Biblioteca do STJ (BRASIL. SUPERIOR TRIBUNAL DE JUSTIÇA, 2015, P. 24).

\subsubsection{Indexação e Tipos de Pesquisa}

No universo extenso do acervo da BDJur, seja em função da quantidade de documentos como da variedade temática, "a representação apropriada dos conteúdos constitui recurso imprescindível para facilitar a recuperação dos itens do repositório". (BRASIL. SUPERIOR TRIBUNAL DE JUSTIÇA, 2015, P. 32).

Indexação de conteúdos - A representação temática dos documentos da BDJur é realizada com uma metodologia híbrida, com indexação automática pelo sistema usando linguagem natural e também pelos bibliotecários, com uso de linguagem controlada, o Vocabulário Controlado Básico (VCB), da Rede Virtual de Bibliotecas do Congresso Nacional (RVBI). São utilizados ainda outros vocabulários controlados, na etapa de tradução dos conceitos e termos. Para os atos administrativos e demais documentos produzidos pelo Tribunal, utiliza-se o Vocabulário Jurídico de Jurisprudência do STJ. Em função das especificidades dos atos administrativos do STJ e considerando que os vocabulários controlados ora utilizados não representam a cobertura de assuntos dessa coleção, encontra-se em processo de construção, pela equipe da Biblioteca do STJ, um vocabulário para o controle da terminologia dos conteúdos desses documentos. (BRASIL. SUPERIOR TRIBUNAL DE JUSTIÇA, 2015, p. 32)

Os assuntos dos documentos da BDJur são representados nos seguintes campos:

- Assuntos: termos autorizados pelos vocabulários controlados

- Outros assuntos: termos não autorizados, descritos nos vocabulários controlados como termos equivalentes (sinônimos, siglas, apelidos de leis, etc). No VCB, por exemplo, para o descritor Direito do consumidor os termos não autorizados são: Direito da relação de consumo e Direito do consumo. Nesse caso, Direito do consumidor é incluído no campo Assunto, e os termos Direito da relação de consumo e Direito do consumo são incluídos no campo outros assuntos.

- Resumo: os resumos são elaborados quando há necessidade de complementar a indexação ou, de esclarecer o assunto abordado pelo documento.Todos os documentos em língua estrangeira devem conter resumos, a fim de facilitar a compreensão e a recuperação dos conteúdos.

(BRASIL. SUPERIOR TRIBUNAL DE JUSTIÇA, 2015, p. 32-33)

Portanto, além da indexação elaborada pelos bibliotecários, a indexação automática dos documentos realizada pelo sistema, possibilita a recuperação do texto completo por meio de linguagem natural. Nesse caso, a busca é feita pelo campo pesquisa geral, que permite a recuperação das informações de todos os metadados e a íntegra dos documentos. A importância do processo de indexação é destacada pela Seção de Biblioteca Digital Jurídica:

Os mecanismos de representação de assuntos empregados pela BDJur visam proporcionar precisão na recuperação dos documentos, bem como

${ }^{23}$ A comissão foi instituída pela Portaria GDC n. 555, de 25 de agosto de 2014. 
aumentar a capacidade de busca de conteúdos relevantes. Portanto, para que o usuário localize a informação mais adequada às suas necessidades, é fundamental que os documentos estejam devidamente descritos e indexados. Além disso, o sistema deve ter uma organização lógica e recursos de pesquisa apropriados. (BRASIL. SUPERIOR TRIBUNAL DE JUSTIÇA, 2015, p. 33)

Acrescenta ainda que:

Os processos de indexação utilizados na BDJur bem como as opções de pesquisa oferecidas pelo sistema têm contribuído para o aumento nos níveis de precisão na recuperação dos documentos do repositório. A variedade, a especificidade e a constante atualização dos assuntos tratados no contexto da informação jurídica representam desafios aos profissionais que atuam na representação temática.

Tipos de Pesquisa A BDJur oferece aos usuários diferentes filtros e opções de pesquisa para maior precisão na busca das informações. A página de resultados da pesquisa apresenta opções de filtros para exibição dos itens recuperados (Figura 15). É possível filtrar os resultados por relevância, título, data de depósito e data de publicação. O sistema também permite a ordenação dos resultados de forma crescente ou decrescente e a definição da quantidade de registros exibidos por página. O buscador da BDJur foi configurado para recuperar tanto variações de termos recorrentes nos documentos jurídicos, como o uso de sinais de pontuação, diacríticos, e outros símbolos (BRASIL. SUPERIOR TRIBUNAL DE JUSTIÇA, 2015, p. 33)

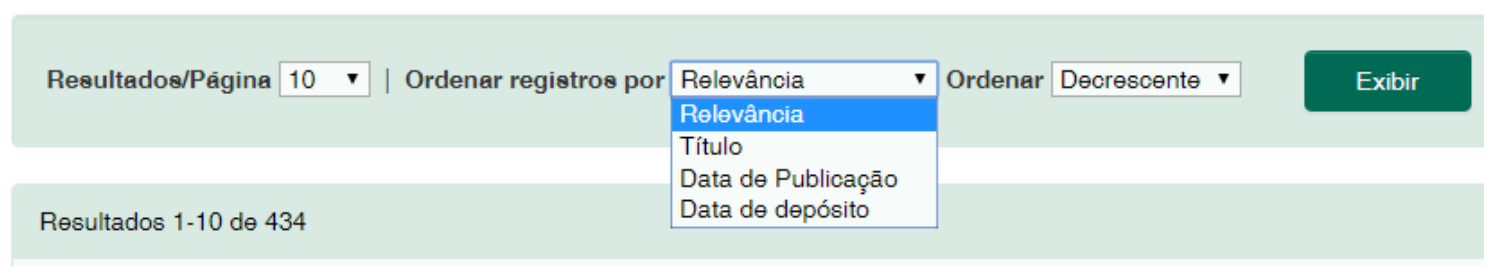

Fig. 15 - Opções de filtros para exibição dos itens recuperados na página de resultados da pesquisa

$\mathrm{Na}$ BDJur há três opções de pesquisa: Simples, Avançada e Listar por. (Anexo 13)

Pesquisa simples - Os formulários deste tipo de pesquisa foram customizados de acordo com os tipos de materiais disponibilizados no repositório. Há um link para acesso às Dicas de pesquisa, com orientações para a utilização dos campos do formulário, além de link para o módulo de Pesquisa avançada. .A BDJur apresenta também, um formulário para pesquisa no módulo Todas as coleções. Nesse formulário, é possível realizar pesquisa por meio da combinação de campos e da utilização de lógica booleana.

Pesquisa avançada - $O$ acervo e coleções da BDJur também podem ser acessados por meio do link disponível abaixo dos formulários de Pesquisa simples,

Pesquisa Listar por - permite ao usuário navegar pelos índices coleção, data, autor, título e assunto, disponíveis na página inicial e nas coleções.

(BRASIL. SUPERIOR TRIBUNAL DE JUSTIÇA, 2015, p. 34-40) 


\title{
8.1.3.5 Gestão dos atos administrativos
}

A BDJur é o repositório oficial dos atos administrativos do STJ. As normas do Tribunal, divulgadas nos veículos oficiais de publicação, são reunidas e disponibilizadas nas coleções: Boletim de Serviço do STJ, Atos normativos do STJ, Atos Normativos da Enfam e, Atos Normativos do TFR: Estas coleções são alimentadas e gerenciadas pela Biblioteca do STJ, exceto o Boletim de Serviço, cuja alimentação é realizada pelas unidades do Tribunal responsáveis pelas publicações, cabendo à unidade gestora da BDJur a sua revisão, aprovação e administração. Os atos administrativos estão em constante modificação, resultado do processo inevitável de adequação às necessidades das instituições e da sociedade, o que gera um número significativo de mudanças, que podem ocorrer no texto das normas do STJ:classificadas como alterações, retificações, revogações, e outros tipos

- sem efeito: ocorre quando um ato normativo tem todos os seus efeitos anulados por norma mais recente. A anulação atinge o ato desde o início da validade, retrocedendo à data de vigência do ato anulado. A designação sem efeito abrangerá também termos sinônimos como anulado e invalidado.

- revogação: consiste na anulação integral dos efeitos jurídicos do ato normativo em virtude da edição de norma revogadora, o que invalida a sua aplicação e anula os seus efeitos posteriores à publicação do novo ato. A revogação pode ocorrer no todo, quando o ato é anulado por completo, ou parcialmente, quando parte de um ato normativo (artigo, parágrafo, inciso, alínea) é revogado.

- alteração: refere-se à situação em que o texto da norma tenha sido modificado, no todo ou em parte, por outro ato normativo.

- retificação: consiste na correção de erros ou omissões no texto de uma norma por meio da publicação de um novo ato.

- republicação: trata-se de nova publicação de todo o texto da norma para efetuar correções na redação originalmente publicada ou para dar ampla publicidade ao texto da norma.

(BRASIL. SUPERIOR TRIBUNAL DE JUSTIÇA, 2015, p. 46-47)

A relevância desta responsabilidade para atividade judicante do Tribunal é evidenciada pela Seção de Biblioteca Digital Jurídica:

\begin{abstract}
Esse contexto evolutivo dos atos administrativos requer uma ordenação que facilite ao usuário a consulta ao texto vigente das normas e ao histórico das modificações ocorridas desde sua publicação. Em vista disso, a gestão dos atos é de suma importância para o bom funcionamento das atividades administrativas e judicantes do Superior Tribunal de Justiça, pois garante maior confiabilidade às informações constantes na base de dados e facilita a identificação da vigência e das modificações do texto das normas. (BRASIL. SUPERIOR TRIBUNAL DE JUSTIÇA, 2015, p. 47)
\end{abstract}

Para a gestão das normas do STJ, a BDJur adota os seguintes procedimentos:

A) Compilação - consiste em reunir num único texto todas as alterações que uma determinada norma tenha sofrido durante a sua vigência. Visa facilitar e dar agilidade a consulta de fontes de informação legislativa. $O$ texto compilado simplifica a consulta ao texto vigente e à redação anterior da norma. Os atos são compilados toda vez que sofrem alteração, supressão, revogação ou inclusão de parte da norma (artigo, parágrafo, inciso, alínea), com vista a atualização da redação. O texto compilado é elaborado pela equipe técnica da BDJur e serve de referencial para 
consulta, não substituindo o texto original da norma, que é mantido no sistema juntamente com o texto compilado. (BRASIL. SUPERIOR TRIBUNAL DE JUSTIÇA, 2015, p. 47)

A proposta de compilação dos atos do STJ foi elaborada em 2012, com base na experiência de outras organizações públicas, destacando-se o trabalho realizado pela Presidência da República, Câmara dos Deputados e Senado Federal. Na análise destas experiências, foram identificados dois tipos de textos compilados: a) texto multivigente: contém a redação atualizada até a última alteração, mantendo todas as versões dos dispositivos desde a publicação da norma. b) texto monovigente: traz a redação atualizada da norma ocultando as versões anteriores dos dispositivos. Enquanto o texto multivigente oferece o histórico de modificação da norma, até a versão atual, possibilitando ao usuário uma análise da situação da norma em determinado período, por outro lado, o texto monovigente é mais conciso, porém não permite que o usuário saiba o texto vigente em determinada data, mostrando apenas a redação vigente do momento. (BRASIL. SUPERIOR TRIBUNAL DE JUSTIÇA, 2015, p. 47-48)

Na compilação dos atos do STJ, a Seção de Biblioteca Digital Jurídica optou pela utilização do texto multivigente, por se tratar da modalidade mais completa e que melhor atende aos objetivos do Tribunal. Assim, após o dispositivo (artigo, parágrafo, inciso ou alínea) alterado, são incluídas notas de compilação, cujos tipos são: a) alteração de dispositivos: modificação da redação de dispositivo por outro ato normativo; b) alteração com inclusão de dispositivo: acréscimo de novo dispositivo ao texto do ato; c) alteração com supressão de dispositivo: retirada de dispositivo por força de outro ato normativo; d) alteração com acréscimo de informações ao dispositivo: inclusão de informações na redação de dispositivo. Neste caso, 0 ato alterador não apresenta a nova redação completa, somente menciona a informação acrescida. (BRASIL. SUPERIOR TRIBUNAL DE JUSTIÇA, 2015, p. 48-50)

B) Controle de vigência e de modificações A fim de advertir o usuário quanto às modificações ocorridas na vigência e no texto dos atos, são incluídas informações nos metadados, no texto dos arquivos e na página de resultados de pesquisa. Para isso, são adotados os seguintes procedimentos:

- $\quad$ na norma modificadora: indicação para a norma modificada

- na norma modificada: são indicados os tipos de situação: alterado, revogado, revogado parcialmente, sem efeito e retificado. No texto da norma: a situação é indicada com a inclusão de uma marca d'agua no canto superior esquerdo da página; é disponibilizado link para a norma modificadora no cabeçalho. Nos resultados da pesquisa a inclusão de imagens indica a situação dos atos revogados e sem efeito. Para os atos republicados por incorreção no original é feita a substituição pelo texto republicado, no qual consta a informação de republicação, sinalizada com asterisco, e rodapé com as datas da publicação do ato original e da republicação: A fim de facilitar o acesso aos atos referenciados, são incluídos links para a legislação citada no texto da norma.

(BRASIL. SUPERIOR TRIBUNAL DE JUSTIÇA, 2015, p. 50-51)

Conforme assinalado pela Seção de Biblioteca Digital Jurídica, a BDJur com a responsabilidade de administração dos atos administrativos, atua no sentido de disponibilizar estrategicamente a informação jurídica precisa e em tempo hábil para a atividade judicante do STJ:

Os procedimentos adotados na gestão dos atos administrativos armazenados na BDJur visam indicar a vigência dos atos e dos seus 
dispositivos, de modo a proporcionar maior precisão e agilidade na consulta às normas. Portanto, a gestão dos atos constitui um instrumento facilitador, que beneficia tanto os ministros e servidores do STJ, que consultam as normas em suas atividades judicantes e administrativas, como a comunidade jurídica em geral, que acessa a BDJur em busca dos atos normativos do Tribunal. (BRASIL. SUPERIOR TRIBUNAL DE JUSTIÇA, 2015, p. 54)

\subsubsection{Política de acesso à informação e proteção de direitos autorais}

Com o advento da Web, as bibliotecas de natureza pública são confrontadas com diversos obstáculos legais, em especial no domínio dos direitos de autor, devido à possibilidade de digitalizar e disponibilizar os seus acervos para otimizar o acesso público à informação. Tratar de direitos autorais no ambiente virtual é tema contemporâneo que envolve a compreensão do Direito, o qual deve atender as necessidades e transformações sociais e culturais. Dessa maneira, torna-se importante considerar aspectos relativos a esta questão da realidade, que permitam às bibliotecas tornar a informação disponível e acessível nesse contexto informático, de forma regulamentar. Isto porque cabe às bibliotecas preservarem os direitos autorais dos autores das obras constantes de seus acervos. Nesse sentido, na Biblioteca do STJ foram previstas providências com este fim:

O respeito à legislação de direitos autorais é um princípio adotado pela BDJur desde a sua origem. O documento Em direção à implantação da Biblioteca Digital Jurídica - BDJur: projeto de criação, de maio de 2004, já continha uma seção dedicada ao assunto, em que foram analisadas as implicações legais da divulgação de criações intelectuais em ambiente digital. No que diz respeito aos direitos autorais, no documento consta que: 'A abrangência e os tipos de objetos multimídia a serem disponibilizados na Biblioteca Digital Jurídica - BDJur serão alvo de discussão e preocupação neste projeto, juntamente com os problemas relativos ao tratamento de direitos autorais (Lei 9610/98)' (BRASIL. SUPERIOR TRIBUNAL DE JUSTIÇA, 2015, p. 41).

$\mathrm{Na}$ BDJur, a gestão de direitos autorais dos conteúdos disponibilizados é realizada por meio de autorizações ou contratos firmados com os detentores desses direitos. Conforme o nível de autorização, a BDJur disponibiliza documentos de acesso aberto, que podem ser visualizados pelo público em geral, e documentos de acesso restrito, que podem ser acessados somente pelo público interno do STJ, mediante o uso de login e senha de rede do Tribunal, da seguinte forma:

acesso aberto: são disponibilizados sem restrição de acesso os documentos cujos direitos tenham sido cedidos à BDJur, obras em domínio público ou documentos cuja permissão de acesso tenha sido estabelecida por norma do STJ. Em relação aos conteúdos doutrinários, os autores e editores concedem os direitos de acesso por meio da assinatura de termos de autorização para disponibilização na BDJur. No que se refere às normas do STJ, o art. $4^{\circ}$ da Instrução Normativa STJ/GP n. 12 de 12.08.2015 determina os atos de acesso livre.

acesso restrito: é estabelecido em contratos ou autorizações concedidas pelos detentores dos direitos autorais. No que diz respeito aos atos administrativos do STJ, essa restrição é determinada pelo art. $5^{0}$ da Instrução Normativa STJ/GP n. 12.08.2015.

(BRASIL. SUPERIOR TRIBUNAL DE JUSTIÇA, 2015, p. 41). 
Por sua vez, as permissões de acesso aos conteúdos adquiridos de editores comerciais são estabelecidas nos contratos firmados pelo STJ. São exemplos de cláusulas contratuais relacionadas à disponibilização de obras na BDJur:

- - a contratada deverá permitir que os arquivos sejam submetidos e disponibilizados na Biblioteca Digital Jurídica do STJ (BDJUR) ou em sistemas similares internos.

- - a contratante se compromete a não ceder ou transferir os direitos oriundos deste contrato a terceiros sem a autorização expressa e por escrito da contratada;

- - a contratante se compromete a reconhecer a propriedade intelectual da contratada com relação ao serviço e aos direitos autorais desta, não utilizando o serviço para fins não autorizados expressamente pela contratada.

- (BRASIL. SUPERIOR TRIBUNAL DE JUSTIÇA, 2015, p. 41).

Outro caso de restrição de acesso na BDJur é o dos pareceres da Assessoria Jurídica do STJ. "As permissões de acesso adotadas para esses documentos são definidas pela unidade do Tribunal responsável por sua elaboração, considerando o nível de sigilo do conteúdo analisado". (BRASIL. SUPERIOR TRIBUNAL DE JUSTIÇA, 2015 , p. 42). Já os trabalhos de conclusão de curso de pós-graduação dos servidores do quadro funcional do STJ, custeados pelo Tribunal, também terão os direitos cedidos para publicação na BDJur, conforme termo de responsabilidade assinado pelo bolsista, constante na Instrução Normativa STJ/GDG n. 16 de 10.07.2015:

Pelo presente termo, comprometo-me a observar as normas e
procedimentos referentes à concessão de bolsa de pós-graduação
(Instrução Normativa STJ/GDG n. 16, de 10/7/2015) e, em especial
comprometo-me a: (...) e) autorizar a publicação e divulgação do meu
Trabalho de Conclusão de Curso no sítio da Biblioteca Digital Jurídica
(BDJur) do STJ. (BRASIL. SUPERIOR TRIBUNAL DE JUSTIÇA, 2015, p.
42).

BDJur oferece ainda acesso livre aos sumários de livros incorporados ao acervo físico da Biblioteca do STJ. A fim de esclarecer ao usuário que a obra não está disponível na íntegra, é incluída a seguinte informação no campo Notas: "Divulgação dos sumários das obras recentemente incorporadas ao acervo da Biblioteca Ministro Oscar Saraiva, do STJ. em respeito à Lei de direitos autorais, não disponibilizamos a obra na íntegra". (BRASIL. SUPERIOR TRIBUNAL DE JUSTIÇA, 2015, p. 42).

A BDJur dispõe de dois tipos de licenças que são assinadas diretamente no sistema no momento da submissão dos documentos:

- Licença de publicação não-exclusiva: aplica-se no caso de autoarquivamento, em que o próprio autor submete o documento para publicação na BDJur. Essa licença estabelece que 0 autor concede à BDJur “(...) o direito nãoexclusivo de reproduzir, converter, comunicar e/ou distribuir o documento entregue (incluindo o resumo/abstract) em formato digital ou impresso e em qualquer meio." A licença também isenta a BDJur de responsabilidades sobre violações a direitos de terceiros por aquele que se declara autor da obra. Do mesmo modo, a BDJur se compromete a reconhecer de forma clara a autoria dos documentos e a não realizar alterações que estejam fora do escopo da licença. 
- Licença para publicação no Boletim de Serviço do STJ: concedida no caso dos atos administrativos publicados do STJ, nos termos da Instrução Normativa STJ/GP n. 12 de 12.08.2015.

(BRASIL. SUPERIOR TRIBUNAL DE JUSTIÇA, 2015, p. 42-43).

Percebe-se assim a observância dos estatutos legais sobre direitos autorais na BDJur. Isto porque, ao mesmo tempo em que o usuário tem ao seu dispor um marco legal que garante o direito à informação, existe em concomitância, o direito de autor, originando dessa contraposição, questões complexas que podem envolver interesses econômicos e éticos. Neste quesito, a BDJur considera que:

\begin{abstract}
Em comparação com as bibliotecas tradicionais, a gestão de direitos autorais no ambiente digital deve ser ainda mais rigorosa, uma vez que a rapidez de acesso, a possibilidade de compartilhamento instantâneo dos dados e a contínua evolução da tecnologia podem causar danos irreversíveis, e requerem, portanto, a criação de mecanismos de controle igualmente dinâmicos. Nesse contexto, a BDJur adota modelos de gestão que permitem a ampliação do acesso aos conteúdos digitais e, ao mesmo tempo, garantem que os direitos dos envolvidos na criação desses documentos sejam sempre respeitados. (BRASIL. SUPERIOR TRIBUNAL DE JUSTIÇA, 2015, p. 43).
\end{abstract}

\title{
8.1.3.7 Preservação digital do acervo
}

Segundo a Seção de Biblioteca Digital Jurídica, os impactos das mudanças tecnológicas e o crescimento dos acervos digitais reforçam a necessidade das bibliotecas adotarem estratégias de preservação buscando garantir a integridade da informação e seu acesso ao longo do tempo. A BDJur utiliza estratégias que contribuem para garantir a preservação digital do acervo. A maioria dessas estratégias está apoiada nos recursos oferecidos pelo DSpace, que é um software voltado à preservação digital, constituindo importante instrumento na garantia da permanência do acesso aos conteúdos da BDJur. Para Márdero Arellano (2008, p. 139) apud (BRASIL. SUPERIOR TRIBUNAL DE JUSTIÇA, 2015, p. 44): "o DSpace estende-se para uma variedade maior de tipos de materiais e possui mais opções de preservação de objetos digitais.".A BDJur utiliza as seguintes estratégias de preservação digital:

- migração: inclui a atualização das versões do software da BDJur e a conversão de formatos de arquivos proprietários para formatos adequados à preservação;

- encapsulamento: o DSpace codifica e encapsula metadados descritivos, administrativos e estruturais, utilizando o protocolo METS, Metadata Encoding \& Transmission Standard (Metadados de Codificação \& Padrão de Transmissão). O padrão METS funciona como pacote de informação OAIS, que possibilita o empacotamento das informações dos itens referentes à:

- representação: representação da informação, com o uso do Dublin Core;

- proveniência: origem do objeto;

- contexto: agrupamento de metadados e arquivos do item;

- referência: uso do identificador persistente;

- invariabilidade: garantia de que o objeto não foi alterado;

- padronização: padronização dos formatos de arquivo armazenados no repositório. a BDJur adota formatos de arquivo adequadas à preservação, como o pdf/a. 
- metadados de preservação: na BDJur são utilizados metadados para registrar os formatos de arquivo, a política de acesso (direitos autorais), além do registro de informações de proveniência do item, que incluem data de disponibilização e responsabilidade pela inclusão/alterações do item;

- link persistente: para cada item publicado na BDJur, é criado um identificador único, que é gerado por servidor de endereços desenvolvido pelo STJ, com estrutura similar aos identificadores mantidos pela handle system.

- (BRASIL. SUPERIOR TRIBUNAL DE JUSTIÇA, 2015, p. 45).

Por último, cabe acrescentar que além das estratégias mencionadas, a área de Tecnologia da Informação do STJ realiza backups de segurança dos dados em servidor local, visando à preservação do acervo da BDJur A Seção de Biblioteca Digital Jurídica assinala que: "Para garantia efetiva de preservação e segurança dos objetos digitais, é necessário que as estratégias utilizadas pela BDJur sejam formalizadas por meio de uma política que sirva como instrumento legal para a gestão segura dos documentos do repositório". (BRASIL. SUPERIOR TRIBUNAL DE JUSTIÇA, 2015, p. 45).

\subsection{Análise do Questionário da BDJur}

O questionário eletrônico foi enviado para 30 assessores de ministros dos quais 27 responderam. Contudo, cinco assessores foram excluídos desta pesquisa por responderem apenas a primeira página do questionário (questões de n.1 a 8), totalizando 22 assessores participantes. As respostas obtidas com o questionário eletrônico reuniram dados demográficos e quantitativos sobre: a) identificação do perfil do usuário, incluindo o perfil demográfico e perfil profissional; b) habilidade e experiência para acessar a informação jurídica na Web. c) uso proporcionado pelo produto ao usuário quanto ao conteúdo, operacional e tempo de resposta de acesso à informação jurídica; d) análise do campo aberto do questionário eletrônico de avaliação quantitativa. e) sugestões dos usuários para melhoria da BDJur como produto de informação disponível na Web.

\subsubsection{Identificacão do perfil do usuário (questões de.1 a 11)}

As questões de 1 a 11 do questionário eletrônico visaram representar o perfil dos assessores de ministro com características demográficas e profissionais.

\subsubsection{1) perfil demográfico do usuário (questões de 1 a 5)}

Reúne os dados e informações pessoais dos assessores. A Tabela 01 apresenta a faixa de idade dos assessores que participaram da pesquisa, sendo observado que a maior concentração está entre 11 assessores, na faixa de idade entre 41 a 50 anos.

Tabela 01 - Faixa Etária

\begin{tabular}{l|cc} 
Categoria de Resposta & Freqüência & Percentual \\
\hline $1 . A-20$ a 30 anos & 1 & $4,55 \%$ \\
$1 . B-31$ a 40 & 6 & $27,27 \%$ \\
\hline $1 . C$ - 41 a 50 & 11 & $50,00 \%$ \\
$1 . D-51$ a 60 & 3 & $13,64 \%$ \\
\hline 1.E - Acima de 60 anos & 1 & $4,55 \%$ \\
Total geral & 22 & $100,00 \%$
\end{tabular}


Observou-se também que seis assessores estão entre 31 a 40 anos, três assessores possuem entre 51 a 60 anos e, que a frequência decresce consideravelmene nas duas faixas etárias limítrofes, com um assessor na faixa etária entre 20 a 30 anos e um assessor com idade acima de 60 anos. Somando-se as três últimas faixas etárias da Tabela 01 , constata-se que 15 assessores de ministro têm mais de 41 anos de idade, podendo-se inferir, portanto, que estes assessores se encontram num período de consolidação da carreira.

Estes dados podem ser visualizados na Figura 16

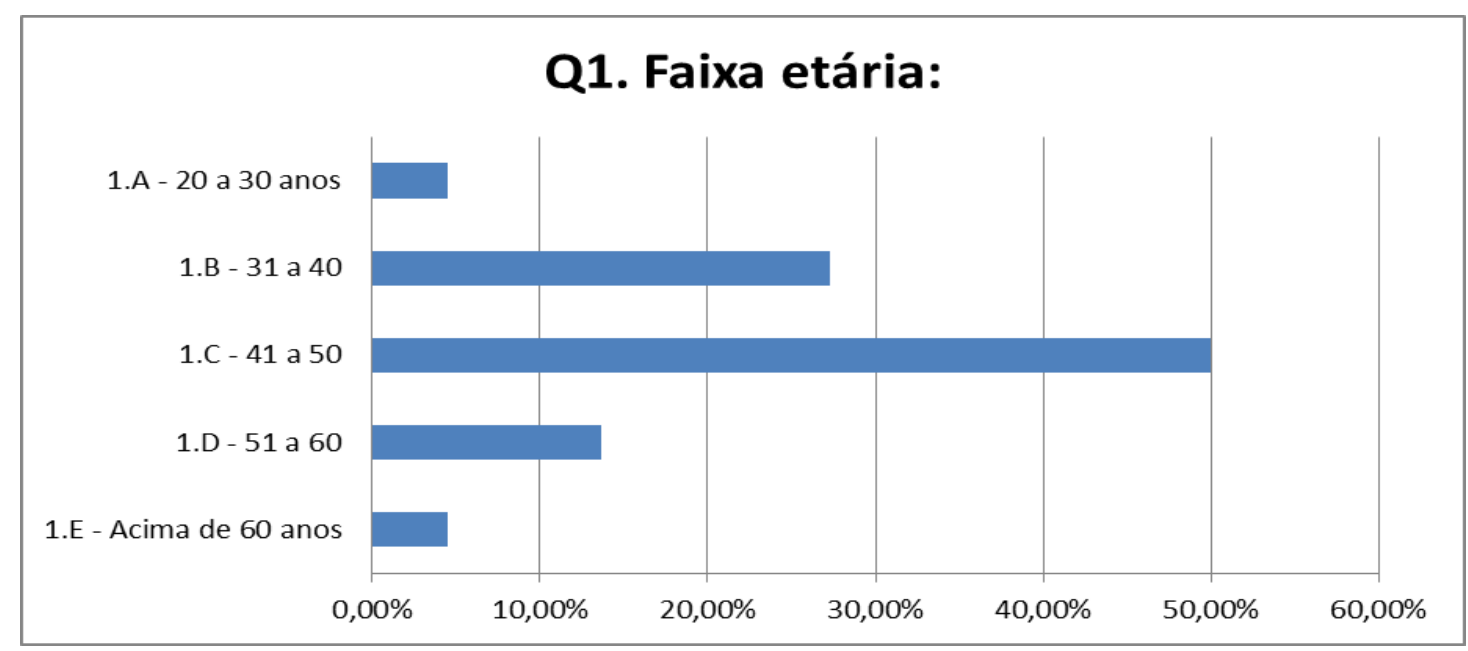

Fig. 16- Faixa etária

$\mathrm{Na}$ Tabela 02 fica evidenciada uma distribuição praticamente equitativa no exercício da função, entre assessores e assessoras de ministro, sendo que os 22 respondentes estão distribuídos entre 12 homens e 10 mulheres.

Tabela 02 - Sexo

\begin{tabular}{l|cc} 
Categoria de Resposta & Freqüência & Percentual \\
\hline 2.A - Masculino & 12 & $54,55 \%$ \\
2.B - Feminino & 10 & $45,45 \%$ \\
\hline Total geral & 22 & $100,00 \%$
\end{tabular}

A Figura 17 ilustra este resultado:

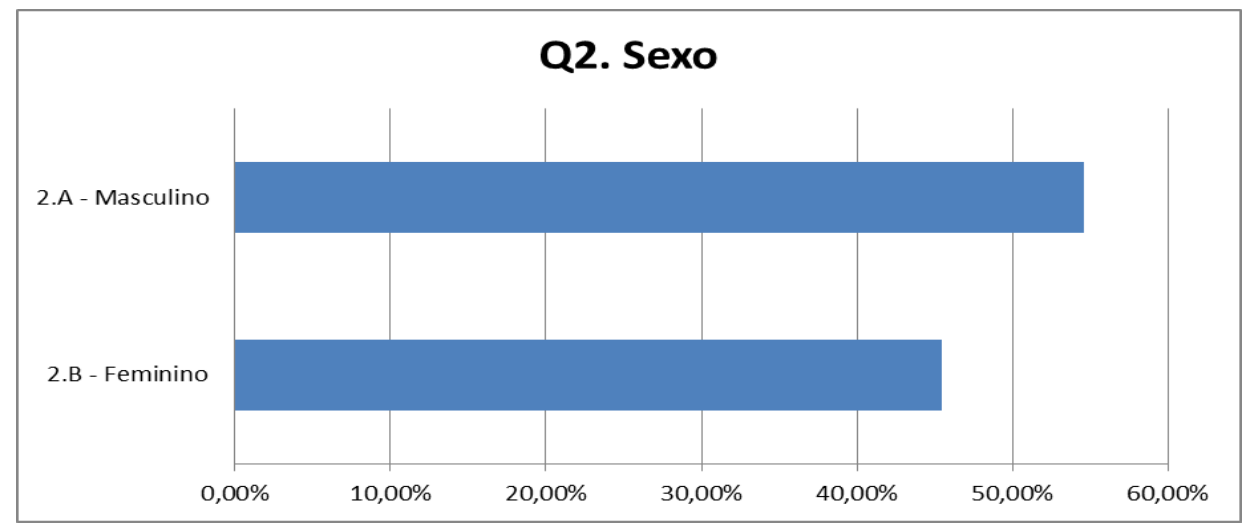

Fig. 17- Sexo 
A Tabela 03 traz o nível de formação mais elevado dos assessores, sendo apurado que a maioria, ou seja, 16 assessores possui curso de especialização, enquanto um concluiu o mestrado e, cinco possuem graduação como grau de formação mais elevado.

Tabela 03 - Nível de Formação

\begin{tabular}{l|cc} 
Categoria de Resposta & Freqüência & Percentual \\
\hline 3.A - Graduação & 5 & $22,73 \%$ \\
3.B - Especialização & 16 & $72,73 \%$ \\
\hline 3.C - Mestrado & 1 & $4,55 \%$ \\
3.D - Doutorado & 0 & $0,00 \%$ \\
\hline 3.E - Pós-doutorado & 0 & $0,00 \%$ \\
\hline Total geral & 22 & $100,00 \%$
\end{tabular}

As frequências obtidas levam a concluir no investimento realizado pelos assessores na atualização profissional, corroborando a literatura desta pesquisa sobre a necessidade constante de estar a par dos avanços doutrinários e filosóficos do direito, como área do conhecimento científico, voltado para a concretização do efetivo acesso à justiça na sociedade. Estes dados podem ser vistos na Figura 18:

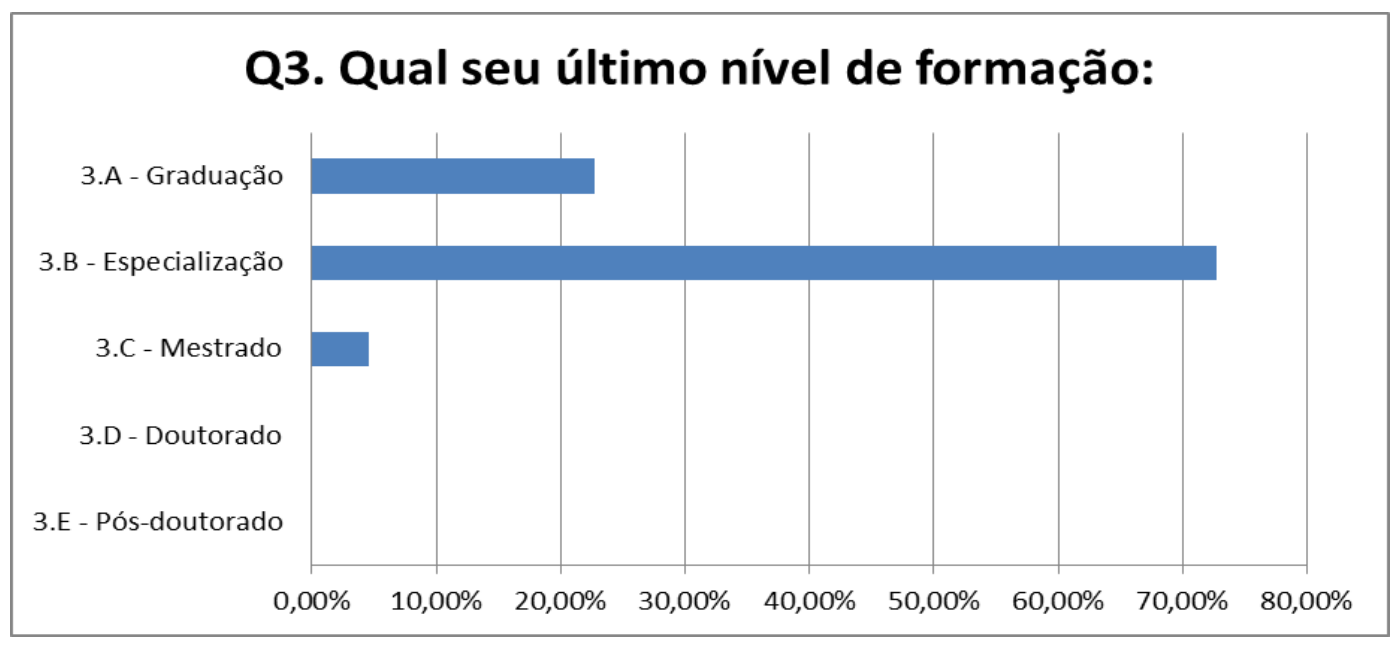

Fig. 18- Nível de formação

A Tabela 04 contém o ano de conclusão do nível de formação mais recente entre os respondentes, predominando a primeira década do milênio, entre 2001 a 2010 como período de maior concentração de conclusão dos cursos. Considerandose o percentual dos assessores cujo nível de formação mais alto é de pósgraduação, percebe-se que a maioria dos assessores respondentes buscou manterse atualizado, em época recente.

Tabela 04 - Ano de conclusão do último nível de formação

\begin{tabular}{l|cc} 
Categoria de Resposta & Freqüência & Percentual \\
\hline 4.A - Antes de 1970 & 0 & $0,00 \%$ \\
4.B - Entre 1971 e 1980 & 0 & $0,00 \%$ \\
\hline 4.C - Entre 1981 e 1990 & 0 & $0,00 \%$ \\
4.D - Entre 1991 a 2000 & 4 & $18,18 \%$ \\
\hline 4.E - Entre 2001 a 2010 & 15 & $68,18 \%$ \\
4.F - Entre 2011 a 2014 & 3 & $13,64 \%$ \\
\hline Total geral & 22 & $100,00 \%$
\end{tabular}


Estes dados encontram-se ilustrados na Figura 19

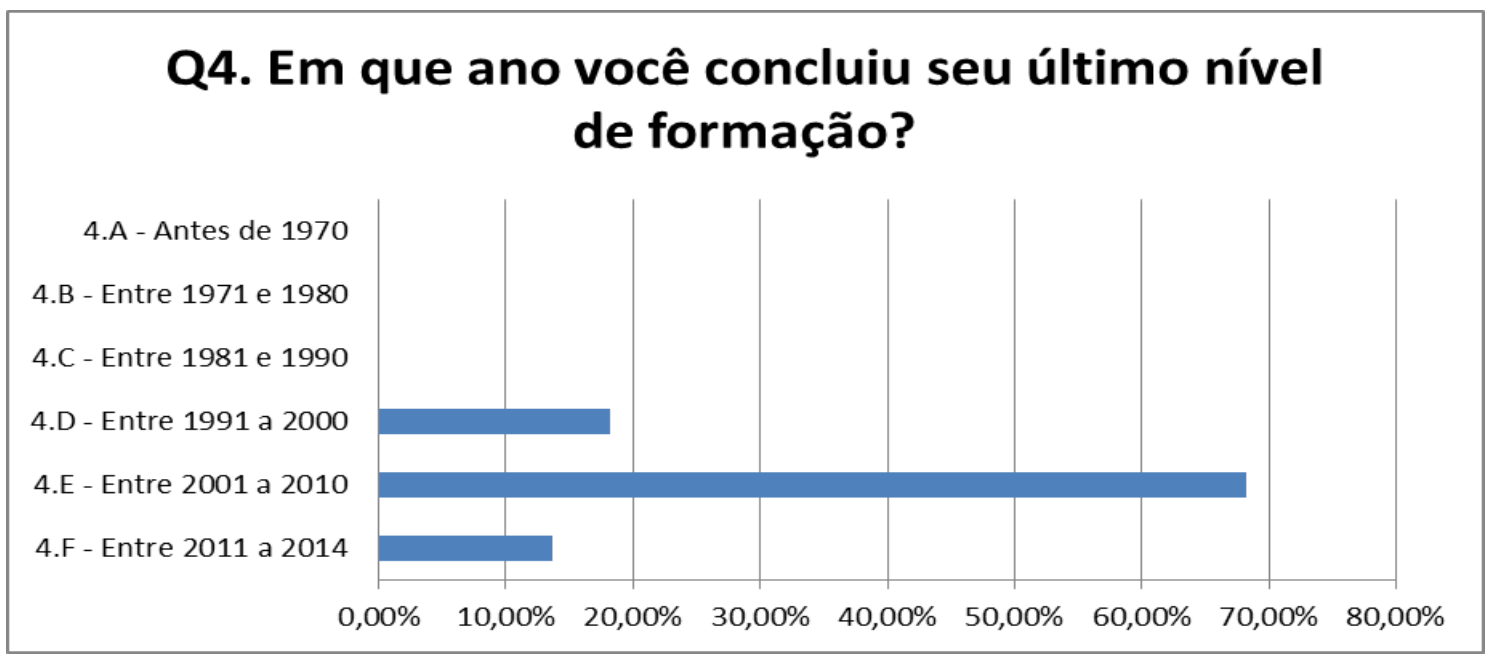

Fig. 19 - Ano de conclusão do último nível de formação

De acordo com a Tabela 05, verificou-se que todos os assessores são graduados em direito, não havendo ocorrência de segunda graduação em outra área do conhecimento. Cabe acrescentar, contudo, que na realidade jurídica, o trabalho de defesa de determinadas causas complexas contemporâneas nos tribunais, torna importante o conhecimento técnico em áreas como meio ambiente, medicina, economia e outras, por meio da formação adicional de uma segunda graduação.

Tabela 05 - Áreas de formação profissional

\begin{tabular}{l|cc} 
Categoria de Resposta & Freqüência & Percentual \\
\hline 5.A - Direito & 22 & $100,00 \%$ \\
5.B - Outra área do & 0 & $0,00 \%$ \\
conhecimento: & 22 & $100,00 \%$
\end{tabular}

Na Figura 20, estes dados estão ilustrados em forma gráfica:

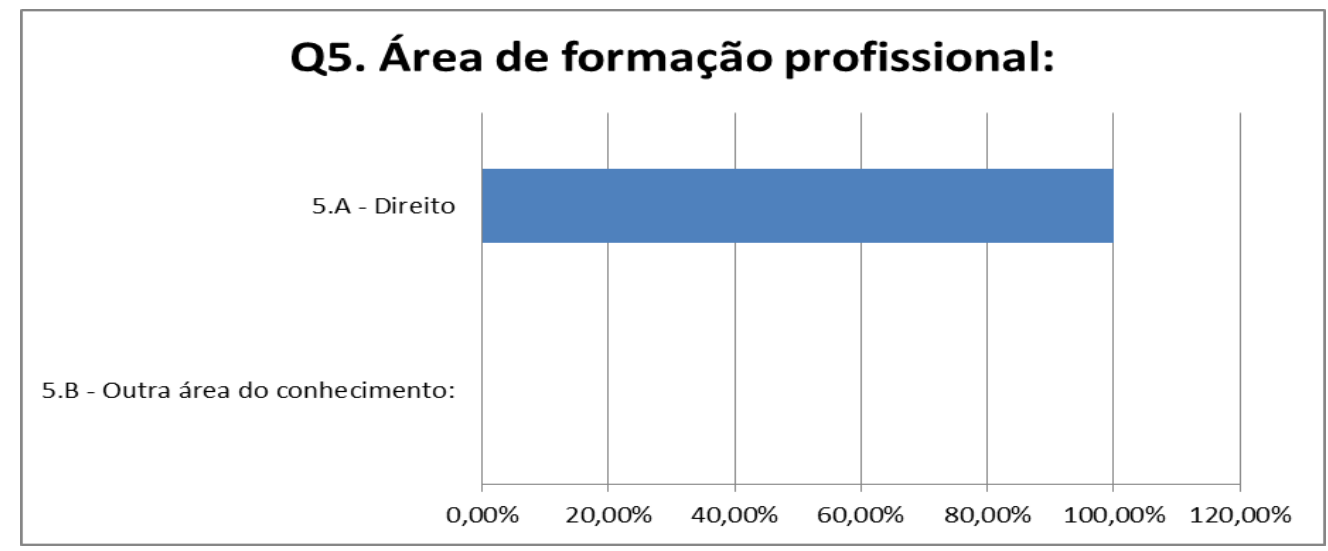

Fig.20 - Áreas de formação profissional

\subsubsection{2) perfil profissional do usuário (questões 6 a 9)}

Visou descrever aspectos relativos ao exercício e desempenho efetivo do cargo de assessor no Tribunal. 
A Tabela 06 elenca o tempo de exercício no cargo de assessor de ministro no Tribunal, mostrando que 11 respondentes exercem a função de assessor de ministro há mais de dez anos. Três assessores têm entre sete e oito anos de atuação; dois assessores contam com cinco a seis anos no cargo; outros dois exercem o cargo entre nove a dez anos, enquanto um assessor está na função entre um a dois anos. Os dados confirmam a antiguidade destes assessores no Tribunal, podendo-se concluir que aqueles que têm entre um a dois anos ou três a quatro anos no cargo, pertencem a novos gabinetes de ministro criados em função da aposentadoria de outros ministros, ou de gabinetes desembargadores convocados.

Tabela 06 - Tempo na função de assessor de ministro

\begin{tabular}{l|cc} 
Categoria de Resposta & Freqüência & Percentual \\
\hline 6.A - Menos de um ano & 0 & $0,00 \%$ \\
6.B - Um a dois anos & 1 & $4,55 \%$ \\
\hline 6.C - Três a quatro anos & 3 & $13,64 \%$ \\
6.D - Cinco a seis anos & 2 & $9,09 \%$ \\
\hline 6.E - Sete a oito anos & 3 & $13,64 \%$ \\
6.F - Nove a dez anos & 2 & $9,09 \%$ \\
\hline 6.G - Acima de dez anos & 11 & $50,00 \%$ \\
Total geral & 22 & $100,00 \%$
\end{tabular}

Estes dados podem ser percebidos com a ajuda da Figura 21

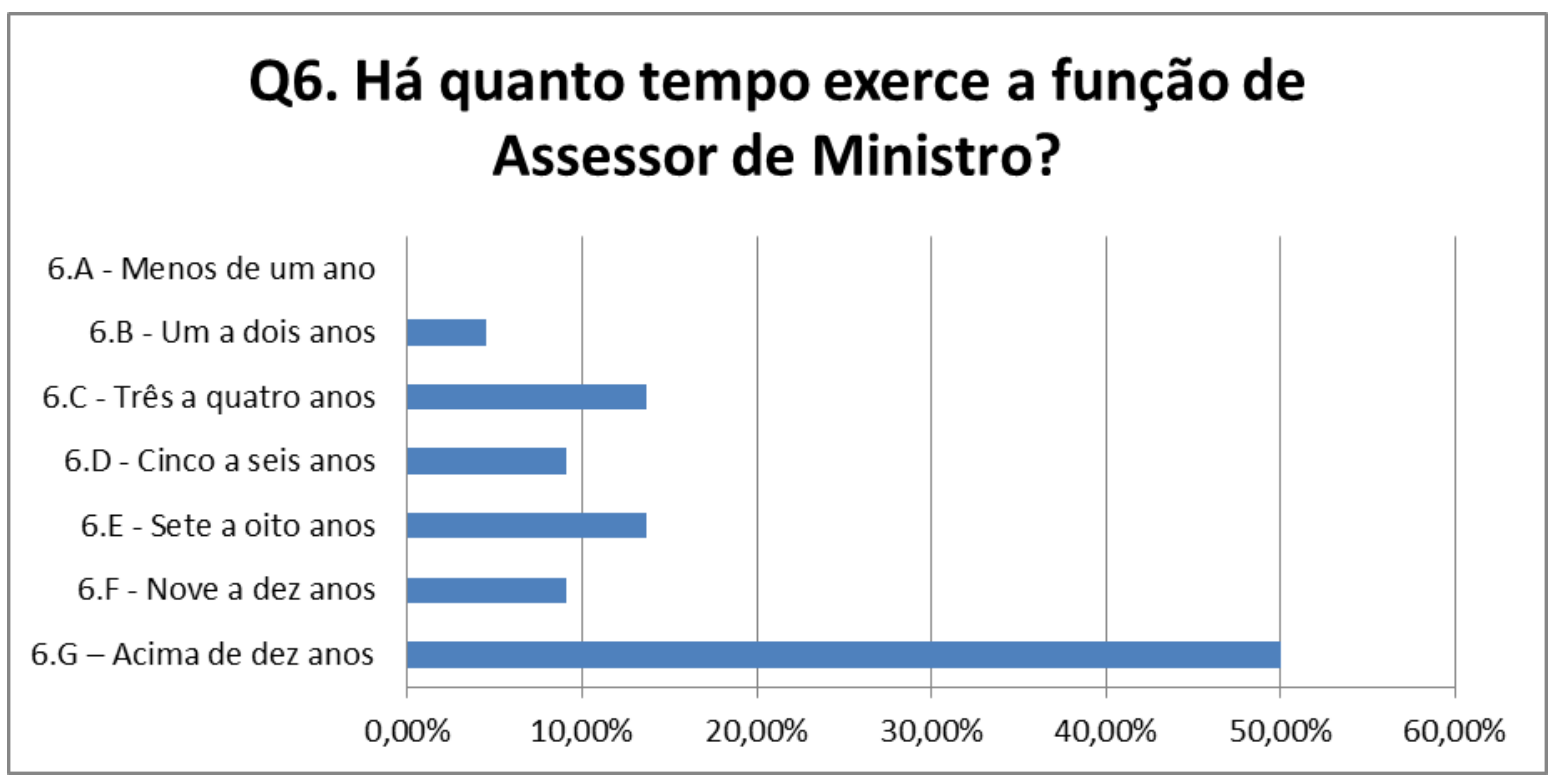

Fig. 21- Tempo na função de assessor de ministro

No que se refere ao vínculo empregatício do assessor no Tribunal, a Tabela 07 mostra que 14 assessores são servidores públicos do quadro funcional do STJ, havendo também sete servidores públicos, requisitados de outros órgãos da Administração Pública, enquanto um assessor declarou não possuir vínculo com a Administração Pública. 
Tabela 07 - Vínculo empregatício no STJ

\begin{tabular}{l|c|c}
\multicolumn{1}{c|}{ Categoria de Resposta } & Freqüência & Percentual \\
\hline 7.A - Servidor público do quadro funcional do STJ & 14 & $63,64 \%$ \\
7.B - Servidor público cedido de outro órgão da & 7 & $31,82 \%$ \\
Administração Pública & & \\
\hline 7.C - Cargo em comissão sem vínculo com a & 1 & $4,55 \%$ \\
Administração Pública & 0 & $0,00 \%$ \\
\hline 7.D - Outro: Por favor especifique: & 22 & $100,00 \%$
\end{tabular}

De acordo com a Figura 22, a situação funcional do assessor no Tribunal está distribuída da seguinte forma::

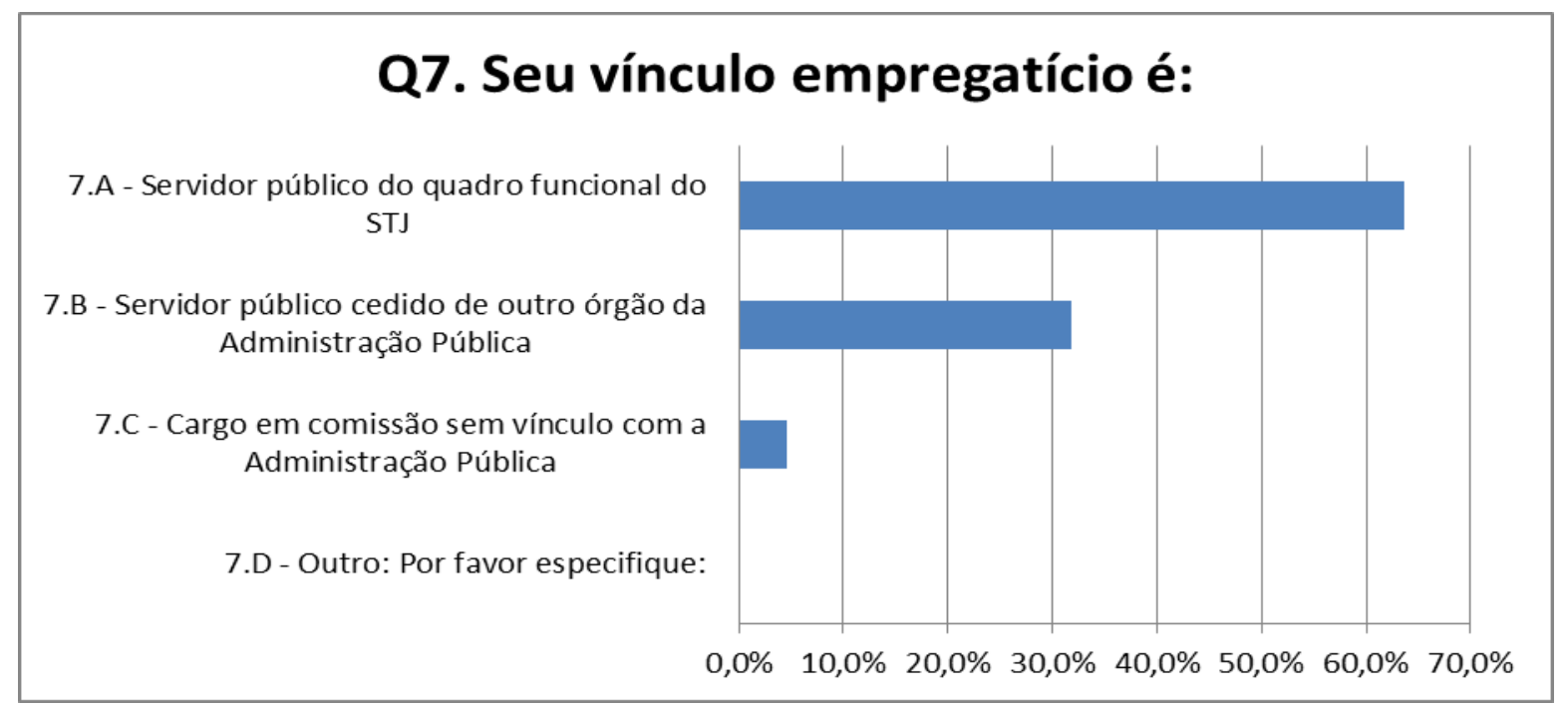

Fig. 22- Vínculo empregatício no STJ

A questão 8 averiguou o gabinete no qual o assessor exercia a função no Tribunal. Esta pergunta visava ao controle de retorno de respostas de cada gabinete, não sendo objetivo desta pesquisa nomear os gabinetes e sim confirmar, com o retorno dos questionários respondidos, aqueles gabinetes que participaram ou, não participaram da pesquisa, possibilitando inclusive o reenvio do questionário ou o contato por telefone, insistindo-se na resposta do assessor. Teve-se como resultado que dos 30 gabinetes, 27 participaram da pesquisa, confirmando-se o gabinete no qual cada respondente exercia a função de assessor. Nos três gabinetes restantes não se obteve retorno, a despeito do reenvio do questionário eletrônico e das tentativas de contato telefônico, bem como de reiteradas solicitações para que o questionário fosse respondido.

A Tabela 08 contem a distribuição dos assessores segundo a área do direito de competência dos gabinetes, sendo que no Tribunal esta especialização jurisdicional está dividida em três Seções de Julgamento, constituídas cada uma, por dez gabinetes, que, por sua vez, se sudividem em duas Turmas de Julgamento compostas de cinco gabinetes cada, no total de seis Turmas, responsáveis pelo julgamento de matéria sobre direito público e previdenciário; direito privado; e direito penal, respectivamente. Observou-se que o maior número de respostas foi de nove assessores que trabalham na área do direito público e previdenciário, seguido de 
oito assessores que trabalham com o direito privado e, por último, cinco assessores que trabalham com o direito penal.

Tabela 08 - Área de atuação profissional em relação às áreas do Direito das Seções e Turmas de Julgamento do STJ.

\begin{tabular}{l|lr}
\hline Opções de resposta & \multicolumn{2}{l}{ Respostas } \\
\hline 9.A - Direito público e previdenciário & $\mathbf{4 0 , 9 1 \%}$ & 9 \\
\hline 9.B - Direito privado & $\mathbf{3 6 , 3 6 \%}$ & $\mathbf{8}$ \\
\hline 9.C - Direito penal & $\mathbf{2 2 , 7 3 \%}$ & 5 \\
\hline Total & & $\mathbf{2 2}$ \\
\hline
\end{tabular}

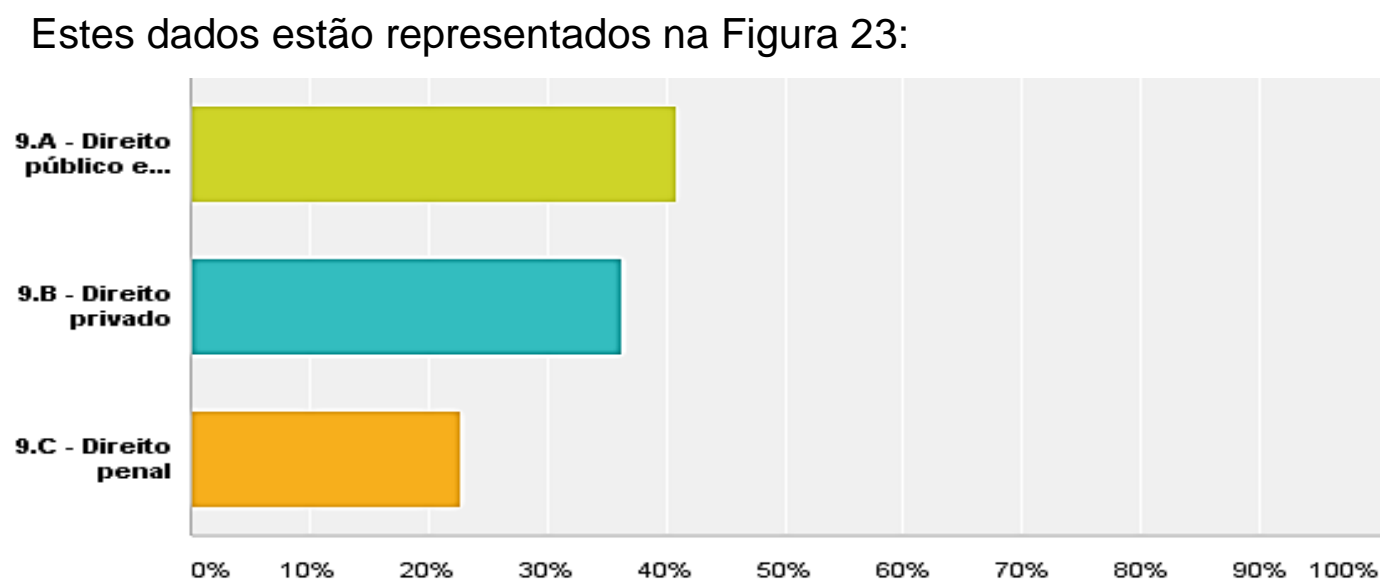

Fig. 23- Área de atuação profissional em relação às áreas do Direito das Seções e Turmas do STJ.

\subsubsection{Habilidade e experiência para acessar a informacão jurídica na Web (questões 10 a 13)}

Nesta etapa do questionário eletrônico, as questões de n.10 a n.13 focaram sobre o comportamento de busca à informação jurídica, incluindo aspectos relativos à habilidade e experiência do assessor com produtos de informação digitais, bem como o conhecimento, utilização e frequência de busca à informação na BDJur pelos assessores, para realização de seu trabalho no Tribunal

A Tabela 09 discrimina como o assessor de ministro considera o próprio nível de experiência na busca à informação jurídica em bases de dados, de modo geral. $O$ resultado que obteve maior índice de resposta foi de 14 assessores, que avaliaram como bom o próprio nível de experiência na busca em bases de dados jurídicas. A seguir, cinco assessores avaliaram que neste quesito possuem nível excelente de experiência; enquanto dois responderam possuir nível regular; e, um considerou insuficiente o nível de experiência que possui para realizar buscas à informação jurídica em bases de dados. 
Tabela 09 - Nível de experiência na busca em bases de dados jurídicas

\begin{tabular}{|l|lr}
\hline Opçöes de resposta & Respostas \\
\hline 10.A - Excelente & $\mathbf{2 2 , 7 3 \%}$ & 5 \\
\hline 10. B - Bom & $\mathbf{6 3 , 6 4 \%}$ & 14 \\
\hline 10. C - Regular & $\mathbf{9 , 0 9 \%}$ & 2 \\
\hline $10 . D-$ Insuficiente & $\mathbf{4 , 5 5 \%}$ \\
\hline Total & & 22 \\
\hline
\end{tabular}

A menor frequência observada nas respostas de três assessores que consideraram como regular ou insuficiente, sua experiência para realizar buscas em bases de dados, leva a inferir, de acordo com relatos complementares colhidos durante as entrevistas, que há assessores que pesquisam a matéria jurídica no acervo da biblioteca do gabinete do ministro, ou em sua coleção particular. Tal comportamento de busca de informação jurídica na literatura impressa pode ocorrer nos gabinetes porque possuem bibliotecas de médio porte com acervos particulares dos ministros, além das coleções de livros e periódicos de direito existentes nas instalações físicas dos gabinetes onde os assessores trabalham.

O nível de experiência considerado pelos assessores na busca de informação em bases de dados está expresso na Figura 24.

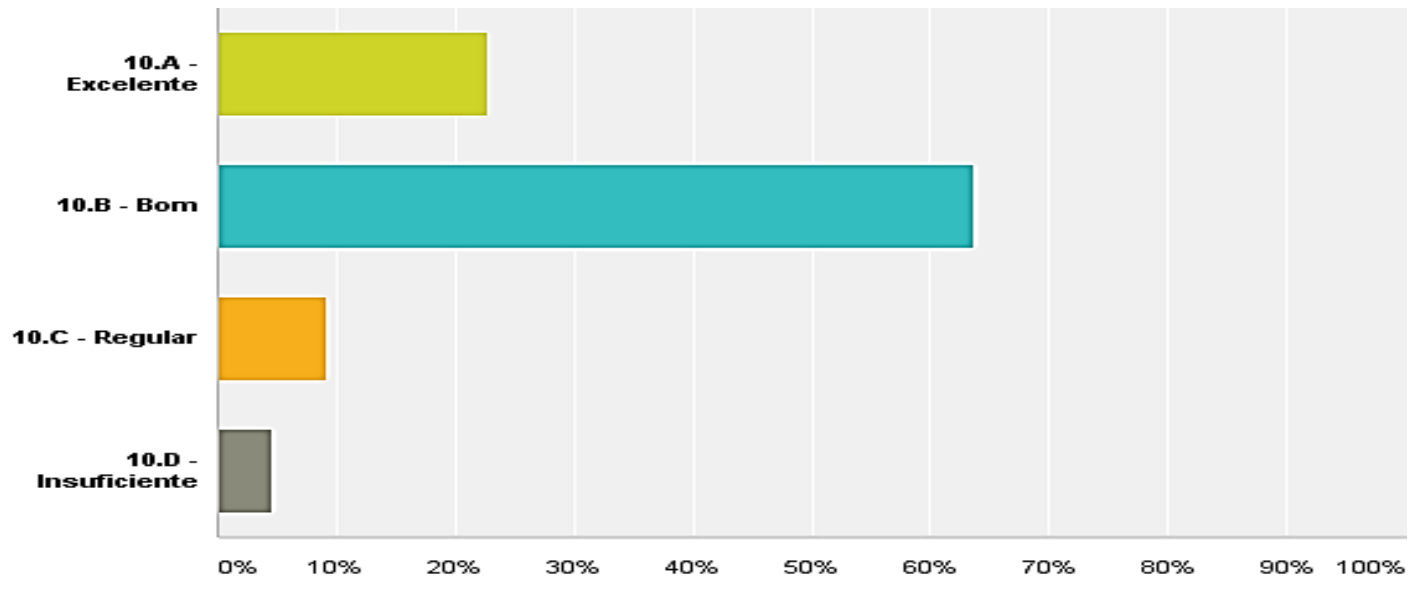

Fig. 24 - Nível de experiência na busca em bases de dados jurídicas

A Tabela 10 discrimina as bases de dados de informação jurídica na internet /intranet que os assessores costumam pesquisar, para realização do seu trabalho no Tribunal. Nesta questão, houve 17 assessores que responderam e 10 que não mencionaram nenhuma base de dados. Observa-se que enquanto alguns citaram bases de dados específicas outros fizeram menção à pesquisa ao assunto jurisprudência. A predominância da pesquisa à jurisprudência evidencia a necessidade de busca dos precedentes ou julgados dos tribunais sobre matérias específicas e casos concretos julgados, que formam o entendimento emitido pelos tribunais em decisões judiciais. Este entendimento forma a jurisprudência a ser seguida em outros julgamentos posteriores de casos similares, visando à uniformidade de aplicação da justiça na sociedade. Neste sentido, foi referido o uso 
do Sistema de Jurisprudência do STJ que é disponibilizado por uma unidade administrativa do STJ e que utiliza um vocabulário controlado próprio para indexação da jurisprudência do STJ. A pesquisa a este sistema do STJ foi confirmada por 13 respondentes.

Observou-se, ainda, que a BDJur foi mencionada por quatro assessores na pesquisa a artigos jurídicos e ao acervo de atos administrativos. A Biblioteca do STJ foi mencionada por cinco assessores como base de dados na intranet/internet em função da pesquisa ao acervo ser feita no catálogo on line do Sistema Aleph da Rede Virtual de Bibliotecas do Senado Federal, da qual a Biblioteca do STJ faz parte. Assim, a pesquisa é feita no catálogo on line que remete para a busca no acervo de livros e periódicos impressos da Biblioteca do STJ. Nota-se, por outro lado, que um assessor afirmou pesquisar sites de tribunais na busca de jurisprudência, bem como a biblioteca da ministra, para pesquisar doutrina, revelando que raramente usa a Biblioteca do STJ. Isto aponta para a importância de considerar os usuários potenciais da Biblioteca e, que pode haver demandas específicas de informação a serem identificadas.

Tabela 10 - Bases de dados de informação jurídica na internet/intranet usadas no desempenho da atividade profissional pelos assessores

\begin{tabular}{|c|c|c|}
\hline $\mathbf{N}^{\circ}$ & Respostas & Data \\
\hline 1 & Pesquisa de jurisprudência e biblioteca STJ/Senado & $31 / 3 / 1518: 31$ \\
\hline 2 & STJ (sistema de jurisprudência e BDJUR - raramente, STF e Google. & $19 / 3 / 1520: 56$ \\
\hline 3 & $\begin{array}{l}\text { STF, repercussão geral no STF, STJ, repetitivos no STJ, jurisprudência do } \\
\text { extinto TFR, BDJUR, GOOGLE e outros. }\end{array}$ & $19 / 3 / 1520: 49$ \\
\hline 4 & CONJUR & $19 / 3 / 1520: 49$ \\
\hline 5 & $\begin{array}{l}\text { Jurisprudência do STJ, jurisprudência do STF, Biblioteca Ministro Oscar } \\
\text { Saraiva, BDJur }\end{array}$ & 13/3/15 19:28 \\
\hline 6 & Jurisprudência interna; Jurisprudência externa e Biblioteca digital & $13 / 3 / 1518: 38$ \\
\hline 7 & Bases de dados sobre legislação e jurisprudência do STJ/STF & 13/3/15 15:06 \\
\hline 8 & JURISPRUDENCIA PESSOAL E JURISPRUDENCIA EXTERNA (INTRANET) & $12 / 3 / 1517: 44$ \\
\hline 9 & Jurisprudência do STJ/STF; biblioteca - livros e artigos jurídicos & $12 / 3 / 1515: 48$ \\
\hline 10 & Jurisprudencia & $11 / 3 / 1521: 54$ \\
\hline 11 & Acervo da biblioteca do STJ e pesquisa jurisprudencial no site do STJ. & $11 / 3 / 1521: 16$ \\
\hline 12 & Jurisprudência & $11 / 3 / 1521: 07$ \\
\hline 13 & Jurisprudência do STJ, do STF, senado federal, para leis, outros & $11 / 3 / 1520: 51$ \\
\hline 14 & $\begin{array}{l}\text { Jurisprudência do gabinete. Jurisprudência do STJ. Jurisprudência unificada } \\
\text { dos TRFs pelo site do CJF. Artigos jurídicos e atos normativos da BDJur. }\end{array}$ & $11 / 3 / 1520: 05$ \\
\hline 15 & $\begin{array}{l}\text { Sites de Tribunais, Pesquisas doutrinárias utilizo geralmente a biblioteca da } \\
\text { Ministra e, raramente, a do STJ. }\end{array}$ & $11 / 3 / 1519: 50$ \\
\hline 16 & $\begin{array}{l}\text { Jurisprudência (jurisprudência do STJ e informativo de jurisprudência), } \\
\text { processos, biblioteca (atos administrativos e consulta ao acervo) }\end{array}$ & 3/3/15 17:46 \\
\hline 17 & $\begin{array}{l}\text { Jurisprudência dos Tribunais locais e dos Tribunais Superiores e do STF, } \\
\text { Jurisprudência dos Tribunais de Contas (Estaduais e da União); } \\
\text { Jurisprudência das instâncias julgadoras administrativas (por exemplo, CARF) }\end{array}$ & 20/1/15 17:16 \\
\hline
\end{tabular}

A questão 12 focou sobre o conhecimento, utilização e frequência de busca à informação na BDJur pelos assessores, para realização de seu trabalho no Tribunal. Os dados reunidos na Tabela 11 indicam que todos os respondentes conhecem a BDJur. Enquanto um assessor afirmou que conhecia e realizava pesquisa na BDJur 
antes de trabalhar no Tribunal, por outro lado, quatro responderam que conheciam a BDJur, passando a utilizá-la somente após o ingresso no Tribunal. Dos respondentes, o número de assessores que afirmou conhecer e utilizar a BDJur foi de nove assessores, enquanto quatro declararam conhecer mas não utilizar a BDJur. Outros quatro assessores informaram que conheceram a BDJur somente após ingressarem no Tribunal.

Tabela 11 - Conhecimento e utilização da BDJur

\begin{tabular}{|c|c|c|}
\hline \multirow{2}{*}{$\begin{array}{l}\text { Opções de resposta } \\
\text { 12.A - Conhecia e realizava pesquisas antes de trabalhar no STJ }\end{array}$} & \multicolumn{2}{|c|}{ Respostas } \\
\hline & $4,55 \%$ & 1 \\
\hline 12.B - Conhecia e passou a realizar pesquisa somente após ingressar no STJ & $18,18 \%$ & 4 \\
\hline 12.C - Conhece e realiza pesquisa & $40,91 \%$ & 9 \\
\hline 12.D - Conhece, mas não realiza pesquisa & $18,18 \%$ & 4 \\
\hline 12.E - Conheceu somente quando ingressou no STJ & $18,18 \%$ & 4 \\
\hline 12.F - Não conhece & $\mathbf{0 , 0 0 \%}$ & 0 \\
\hline Total & & 22 \\
\hline
\end{tabular}

Estes dados mostram que a BDJur tem um índice significativo de utilização no contexto do Tribunal. Contudo, a evidência de que há assessores que conhecem, mas não utilizam a BDJur pode ser função de hábitos e comportamentos consolidados daqueles, cuja habilidade de busca à informação estão concentrados no acervo existente no gabinete ou, que priorizam fontes impressas de informação, como já relatado em respostas anteriores do questionário eletrônico. O conhecimento e utilização da BDJur como produto de informação jurídica disponível na $W e b$ pode ser visto na Figura 25.

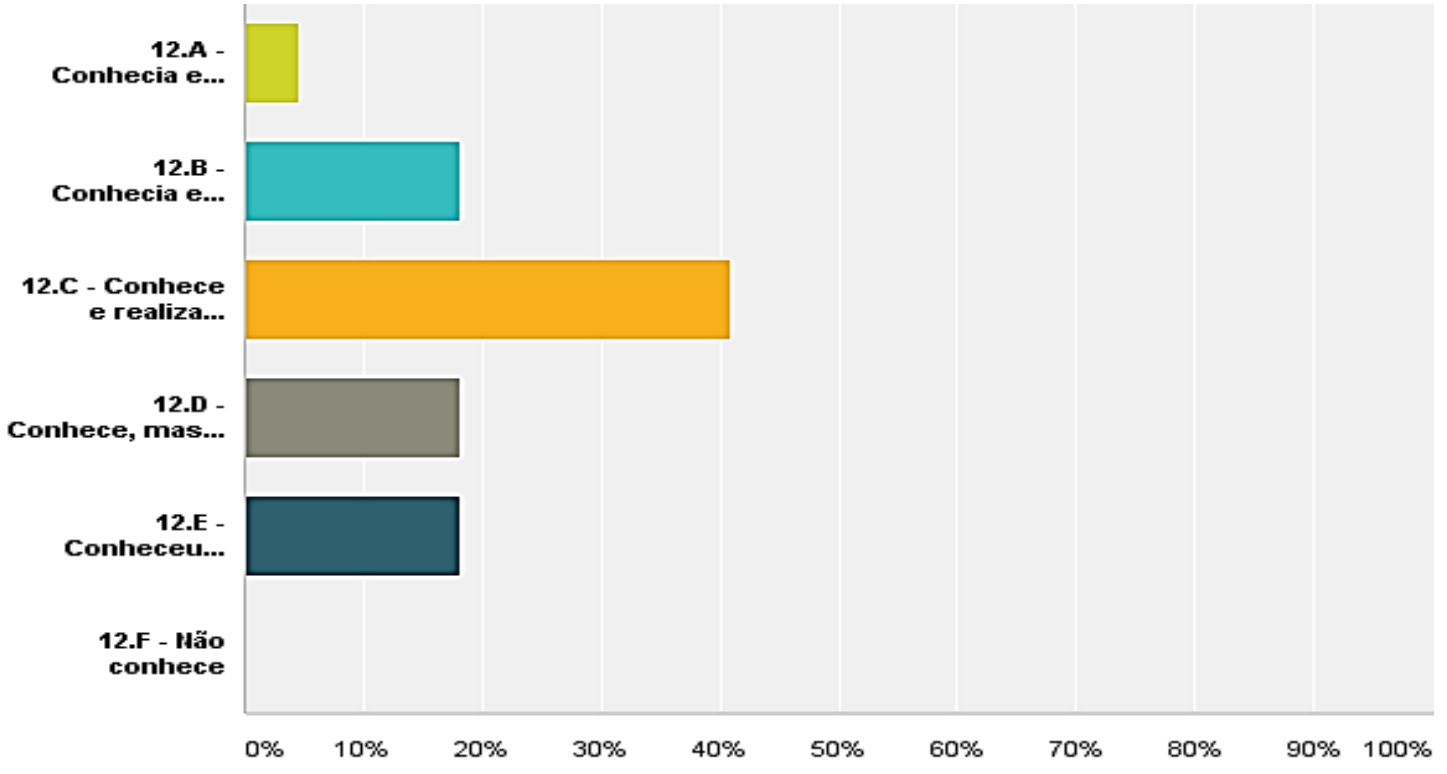

Fig. 25 - Conhecimento e uso da BDJur como produto de informação disponível na Web. 
A Tabela 12 demonstra como o assessor tomou conhecimento da existência da BDJur. A forma de conhecimento de maior incidência com 12 respondentes foi por meio do acesso à página Web do STJ. O conhecimento através da Biblioteca do SJT vem logo em seguida, para oito assessores. A indicação da BDJur por um colega de trabalho foi apontada por um assessor, bem como a comunicação em eventos como congressos, seminários, por outro respondente. Verificou-se a ausência de resposta sobre o conhecimento da BDJur através de link existente em outra página Web, bem como através de citação na literatura, assim como também na resposta aberta "outro", referente a alternativas de conhecimento da BDJur diferentes das opções no questionário.

Tabela 12 - Forma que conheceu a BDJur

\begin{tabular}{|c|c|c|}
\hline \multirow{2}{*}{$\begin{array}{l}\text { Opções de resposta } \\
\text { 13.A - Acesso na página web do STJ }\end{array}$} & \multicolumn{2}{|c|}{ Respostas } \\
\hline & $54,55 \%$ & 12 \\
\hline 13.B - Através da Biblioteca do STJ & $\mathbf{3 6 , 3 6 \%}$ & 8 \\
\hline 13.C - Indicação de colega de trabalho & $4,55 \%$ & 1 \\
\hline 13.D - Link existente em outra página web & $\mathbf{0 , 0 0 \%}$ & 0 \\
\hline 13.E - Citação na literatura & $\mathbf{0 , 0 0 \%}$ & 0 \\
\hline 13.F - Comunicação em eventos (congressos, seminários, workshops) & $4,55 \%$ & 1 \\
\hline 13.G - Outro: Especificar: & $\mathbf{0 , 0 0 \%}$ & 0 \\
\hline Total & & 22 \\
\hline
\end{tabular}

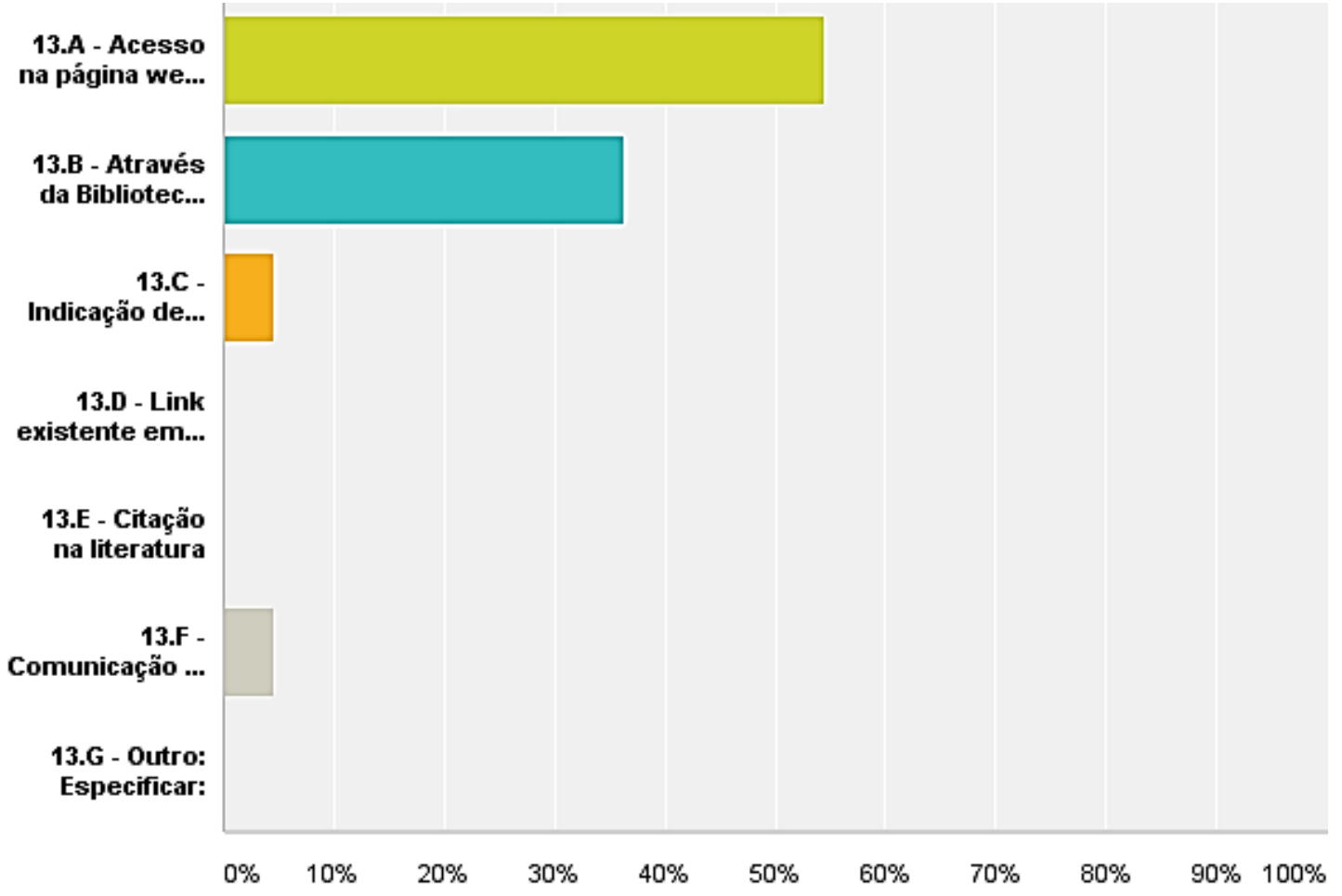

Fig. 26 - Forma de tomada de conhecimento da BDJur (respondidas: 22; em branco: 5) 
Cabe acrescentar que, não obstante a BDJur seja conhecida no meio jurídico, há assessores que ainda não a utilizam, ou utilizam pouco por desconhecerem as formas de pesquisa e os recursos disponíveis para acesso à informação, conforme exposto na análise da questão aberta sobre sugestões dos assessores para a BDJur. É possível inferir, portanto, que ocorram situações similares no ambiente externo do Tribunal, tornando-se importante ações de divulgação da BDJur com vistas ao uso do potencial que dispõe para acesso à informação jurídica. Neste sentido, seja para o assessor de ministro, seja para a comunidade jurídica de modo geral, opções de acesso como link existente em outras páginas Web, pode consistir tanto como mecanismo de divulgação, como forma de acesso providente ou ocasional, ao conteúdo informacional da BDJur, estrategicamente disponível em situações de necessidade e busca de informação que, certamente, contribuiriam para ampliar seu raio de alcance, estendendo seu uso efetivo.

Outro ponto a ser considerado é que a BDJur é uma biblioteca digital jurídica que atingiu destaque internacional em 2011 obtendo $17^{\circ}$ lugar no ranking anual do Conselho Superior de Investigações Científicas - CSIC, da Espanha, concorrendo com 1.120 repositórios digitais de todo o mundo além de no decorrer deste mesmo ano, ser classificada em 2o lugar entre repositórios dos países da América Latina. Percebe-se assim, a importância da realização de estudos e abordagens científicas publicados em artigos de periódicos, sobre recursos tecnológicos e de conteúdo de informação que caracterizam a BDJur no tema da biblioteca digital, em áreas da Ciência da Informação como disseminação da informação, transferência do conhecimento científico e outros. Isto incluirá a BDJur na literatura científica de área interdisciplinar entre direito e biblioteconomia. Uma iniciativa neste sentido, foi a apresentação da BDJur no XXV Congresso Brasileiro de Biblioteconomia e Documentação, CBBD em 2013 e no .XXVI Congresso Brasileiro de Biblioteconomia e Documentação, CBBD em 2015,

Por último cabe acrescentar a realização da divulgação de artigos doutrinários da BDJur no facebook, atingindo números expressivos de acessos e compartilhamentos, não incluída no questionário eletrônico como forma do assessor tomar conhecimento da BDJur.

\subsection{3) Uso proporcionado pelo produto ao usuário quanto ao conteúdo, operacional, e tempo de resposta (questões 14 a 25)}

Nesta parte do questionário que incluiu as questões 14 a 25, de acordo com a Metodologia do lbict, para o levantamento de dados quantitativos sobre o grau de satisfação do usuário, foram considerados aspectos relativos ao resultado que o uso da BDJur proporciona ao assessor, quanto ao conteúdo da informação jurídica disponível, os recursos operacionais, e o tempo de resposta às pesquisas realizadas pelos assessores.

8.2.3.1) Conteúdo da informação jurídica (questões 14, 15, 16, 18, 23, 24)

A Tabela 13 traz os dados sobre os tipos de informação jurídica disponível nas coleções da BDJur pesquisadas pelo assessor, para realização do seu trabalho no Tribunal, em relação ao grau de frequência: 
Tabela 13 - Tipo de informação jurídica pesquisada na BDJur em relação ao grau de frequência

\begin{tabular}{|c|c|c|c|c|c|}
\hline & Frequentemente & Ocasionalmente & Raramente & Nunca & Total \\
\hline $\begin{array}{l}\text { 14.A - Atos Normativos } \\
\text { (STJ, Enfam. TFR) }\end{array}$ & $\begin{array}{r}31,82 \% \\
7\end{array}$ & $\begin{array}{r}27,27 \% \\
6\end{array}$ & $\begin{array}{r}27,27 \% \\
6\end{array}$ & $\begin{array}{r}13,64 \% \\
3\end{array}$ & 22 \\
\hline 14.B - Doutrina & $\begin{array}{r}27,27 \% \\
6\end{array}$ & $\begin{array}{r}36,36 \% \\
8\end{array}$ & $\begin{array}{r}36,36 \% \\
8\end{array}$ & $\begin{array}{r}\mathbf{0 , 0 0} \% \\
0\end{array}$ & 22 \\
\hline $\begin{array}{l}\text { 14.C - Jurisprudência } \\
\text { comentada publicada em } \\
\text { livrofrevista }\end{array}$ & $\begin{array}{r}22,73 \% \\
5\end{array}$ & $\begin{array}{r}27,27 \% \\
6\end{array}$ & $\begin{array}{r}\mathbf{4 0 , 9 1 \%} \\
9\end{array}$ & $\begin{array}{r}\mathbf{9 , 0 9 \%} \\
2\end{array}$ & 22 \\
\hline 14.D - Parecer & $\mathbf{0 , 0 0 \%}$ & $27,27 \%$ & $\begin{array}{r}27,27 \% \\
6\end{array}$ & $\begin{array}{r}45,45 \% \\
10\end{array}$ & 22 \\
\hline
\end{tabular}

Os dados indicam que o conteúdo da coleção de "doutrina" é o mais buscado por 14 assessores para realização do seu trabalho, conforme constatado também nas entrevistas. Por outro lado, oito assessores responderam que raramente realizam este tipo de busca na BDJur, o que pode estar relacionado com a prática manifestada por alguns de ter como fonte de pesquisa, o acervo da biblioteca particular do ministro existente nos gabinetes ou, a coleção de livros pertencentes aos assessores nos seus locais de trabalho. Quanto ao conteúdo da coleção "atos normativos" verificou-se que sete assessores declararam realizar frequentemente este tipo de busca, enquanto seis a fazem raramente, inferindo-se que isto provavelmente esteja relacionado a casos, cuja matéria jurídica em pauta não seja fundamentada no trabalho do assessor, por atos normativos exarados. pelo STJ, Enfam, e TFR. Nota-se que "jurisprudência comentada publicada em livro/revista" raramente é pesquisada por nove assessores, confirmando informação obtida na Seção de Biblioteca Digital e na Seção de Pesquisa da Biblioteca, que este tipo de pesquisa é realizado principalmente no Sistema de Jurisprudência do STJ Estes dados foram ilustrados na Figura 27

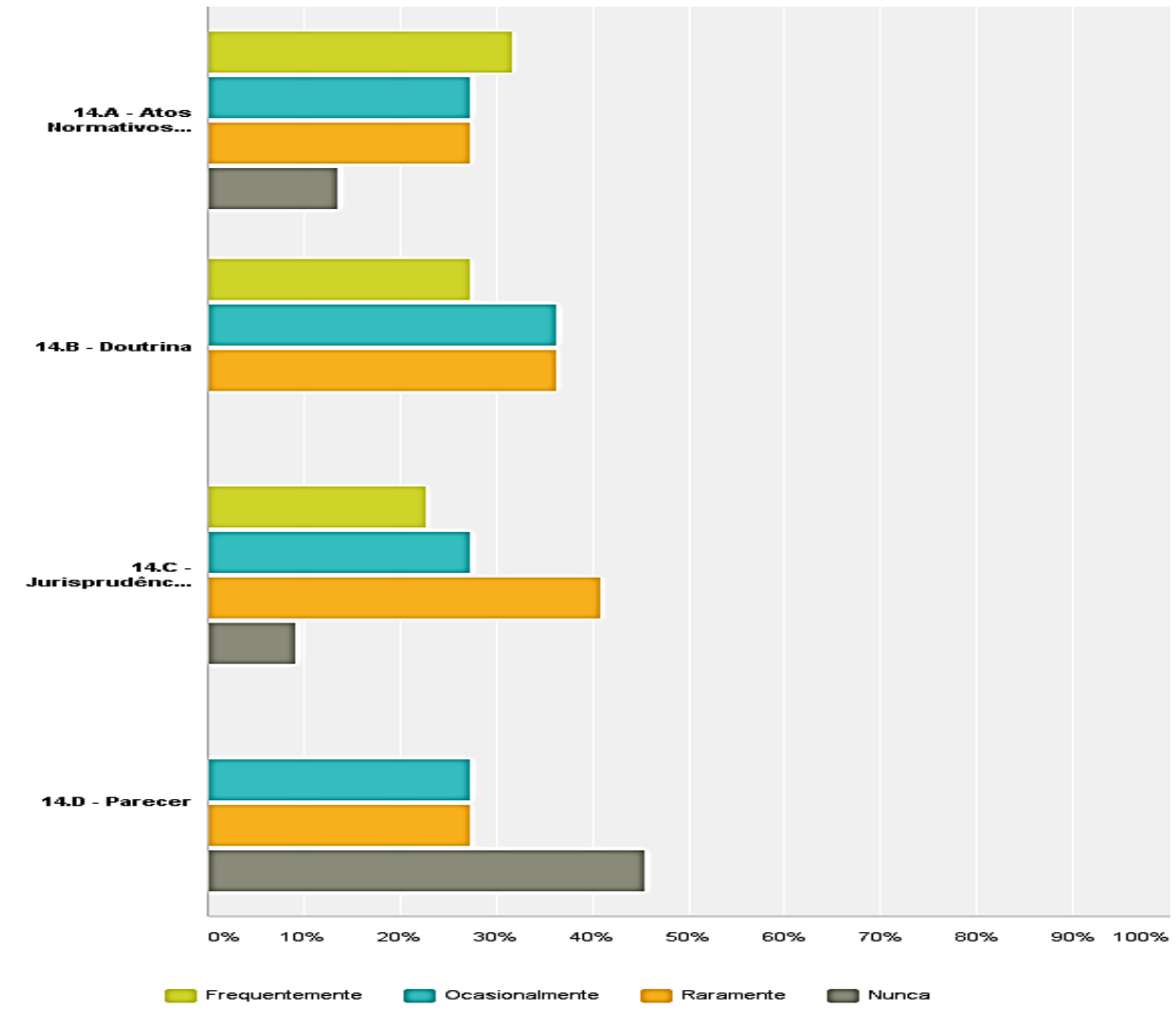

Fig. 27 - Tipo de informação jurídica pesquisada na BDJur em relação ao grau de frequencia. 
A questão 15 abordava o grau de importância da informação jurídica (doutrina, legislação, jurisprudência comentada e parecer) existente na BDJur, para o desempenho da atividade profissional do assessor, expostos na Tabela 14:

Tabela 14 - Grau de importância da informação na BDJur, para desempenho da atividade profissional do assessor

\begin{tabular}{|c|c|c|c|c|c|}
\hline & $\begin{array}{l}\text { Muito } \\
\text { importante }\end{array}$ & Importante & $\begin{array}{l}\text { Pouco } \\
\text { importante }\end{array}$ & $\begin{array}{l}\text { Nada } \\
\text { importante }\end{array}$ & Total \\
\hline 15.A - Doutrina & $\begin{array}{r}54,55 \% \\
12\end{array}$ & $\begin{array}{r}31,82 \% \\
7\end{array}$ & $\begin{array}{r}13,64 \% \\
3\end{array}$ & $\begin{array}{r}\mathbf{0 , 0 0} \% \\
0\end{array}$ & 22 \\
\hline 15.B - Legislação & $\begin{array}{r}45,45 \% \\
10\end{array}$ & $\begin{array}{r}31,82 \% \\
7\end{array}$ & $\begin{array}{r}22,73 \% \\
5\end{array}$ & $\begin{array}{r}\mathbf{0 , 0 0 \%} \\
0\end{array}$ & 22 \\
\hline $\begin{array}{l}\text { 15.C - Jurisprudência comentada } \\
\text { publicada em livrof revista }\end{array}$ & $\begin{array}{r}\mathbf{3 6 , 3 6 \%} \\
8\end{array}$ & $\begin{array}{r}\mathbf{3 6 , 3 6 \%} \\
8\end{array}$ & $\begin{array}{r}27,27 \% \\
6\end{array}$ & $\begin{array}{r}\mathbf{0 , 0 0} \% \\
0\end{array}$ & 22 \\
\hline 15.D - Parecer & $\begin{array}{r}\mathbf{0 , 0 0} \% \\
0\end{array}$ & $\begin{array}{r}54,55 \% \\
12\end{array}$ & $\begin{array}{r}\mathbf{3 1 , 8 2 \%} \\
7\end{array}$ & $\begin{array}{r}13,64 \% \\
3\end{array}$ & 22 \\
\hline
\end{tabular}

Nota-se que a "doutrina" é o tipo de informação de maior importância registrada, seguida de "legislação" e de "jurisprudência comentda publicada em livros e revistas". Verificou-se que os "pareceres" foram considerados pelos assessores como de menos relevância na realização do seu trabalho no Tribunal, não ocorrendo nenhuma frequência no conceito "muito importante", havendo ainda sete assessores que consideram este tipo de informação "pouco importante", além de ser o tipo de informação jurídica que teve a única ocorrência no conceito "nada importante". A figura 28 ilustra a comparação entre os quatro tipos de informação jurídica em relação à importância atribuída pelos assessores para fundamentação do seu trabalho.

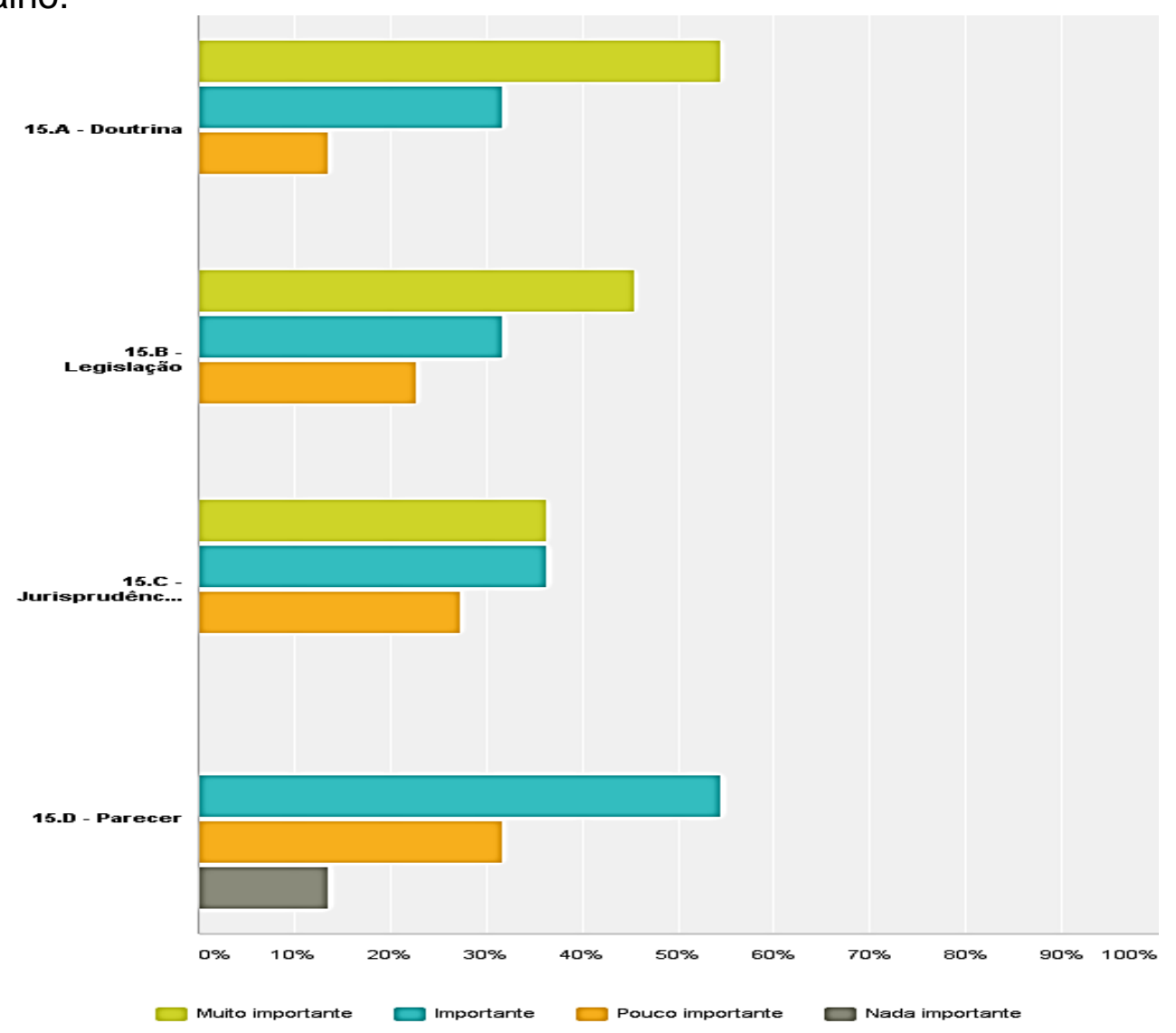

Fig. 28 - Grau de importância da informação na BDJur, para desempenho da atividade profissional 
$\mathrm{Na}$ questão 16, os assessores expressaram com qual finalidade e frequência utilizam a informação jurídica encontrada na BDJur, na execução do seu trabalho no STJ. Constatou-se que as coleções da BDJur são frequentemente usadas por 21 assessores, em quatro funções relacionadas ao trabalho do assessor, destacandose a finalidade de realizar "análise e fundamentação da matéria do processo judicial", conforme foi confirmado nas entrevistas, no trabalho de análise da matéria e redação da proposta de voto a ser submetido ao ministro. A aplicação do conteúdo da informação disponível na BDJur para "citação no processo judicial" obteve menores índices de aplicação, com nove respondentes declarando nunca aplicarem esta informação com este fim. Verificou-se, também que seis e nove assessores, respectivamente, utilizam a informação disponível na BDJur no processo cognitivo de busca à informação, para "sanar dúvida sobre questão específica do direito" e para "atualização sobre legislação específica", duas situações que caracterizam os momentos do trinômio operacional do Sense-Making nas etapas de situação, lacuna e uso da informação. Isto indicou que a BDJur proporciona confiabilidade como fonte de informação jurídica, para realização do trabalho dos assessores.

Tabela 15 - Finalidade e frequência de utilização da informação da BDJur no desempenho da atividade profissional do assessor

\begin{tabular}{|c|c|c|c|c|c|}
\hline & Frequentemente & Ocasionalmemte & Raramente & Munca & Total \\
\hline $\begin{array}{l}\text { 16. A - Análise e } \\
\text { fundamentaçãa da matéria } \\
\text { do processo judicial }\end{array}$ & $\begin{array}{r}36,36 \% \\
8\end{array}$ & $\begin{array}{r}36,36 \% \\
8\end{array}$ & $22,73 \%$ & $\begin{array}{r}4,55 \% \\
1\end{array}$ & 22 \\
\hline $\begin{array}{l}\text { 16. B - Citação na redação } \\
\text { do Relatório do Processo } \\
\text { Judicial }\end{array}$ & $\begin{array}{r}4,55 \% \\
1\end{array}$ & $\begin{array}{r}22,73 \% \\
5\end{array}$ & $\begin{array}{r}31,82 \% \\
7\end{array}$ & $\begin{array}{r}40,91 \% \\
9\end{array}$ & 22 \\
\hline $\begin{array}{l}\text { 16.C - Citação em outra } \\
\text { parte do Processo Judicial }\end{array}$ & $\begin{array}{r}4,55 \% \\
1\end{array}$ & $\begin{array}{r}27,27 \% \\
6\end{array}$ & $\begin{array}{r}40,91 \% \\
9\end{array}$ & $\begin{array}{r}27,27 \% \\
6\end{array}$ & 22 \\
\hline $\begin{array}{l}\text { 16.D - Sanar dúvida sobre } \\
\text { questão específica do direito }\end{array}$ & $27,27 \%$ & $40,91 \%$ & $27,27 \%$ & $\begin{array}{r}4,55 \% \\
1\end{array}$ & 22 \\
\hline $\begin{array}{l}\text { 16.E-Atualização sobre } \\
\text { legislaçâo especifica }\end{array}$ & $22,73 \%$ & $\begin{array}{r}36,36 \% \\
8\end{array}$ & $27,27 \%$ & $13,64 \%$ & 22 \\
\hline
\end{tabular}

Esta situação encontra-se ilustrada na Figura 29:

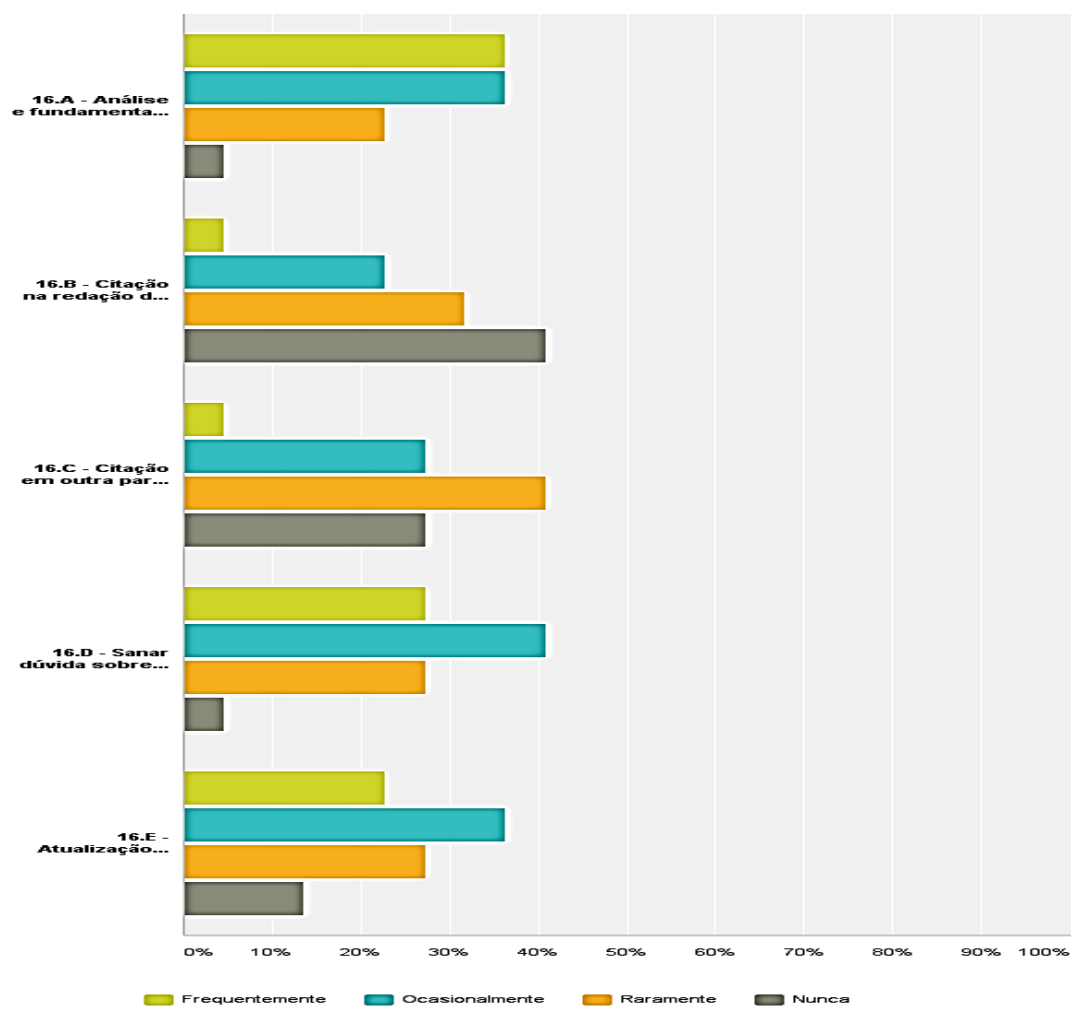

Fig. 29 - Finalidade e frequência de utilização da informação da BDJur no desempenho da atividade profissional do assessor 
A Tabela 16 mostra a escala de conceitos atribuídos pelos assessores à BDJur, considerando a necessidade de busca e uso da informação jurídica para desempenho do seu trabalho

Tabela 16 - Indicador atribuído à BDJur, versus necessidade de busca e uso da informação no desempenho da atividade profissional do assessor

\begin{tabular}{l|lr}
\hline Opções de resposta & Respostas & 3 \\
\hline 18.A - Muito alto & $\mathbf{1 3 , 6 4 \%}$ & 7 \\
\hline 18.B - Alto & $\mathbf{3 1 , 8 2} \%$ & 7 \\
\hline 18.C - Médio & $\mathbf{3 1 , 8 2 \%}$ & 5 \\
\hline 18.D - Baixo & $\mathbf{2 2 , 7 3 \%}$ & $\mathbf{2 2}$ \\
\hline Total & & 7 \\
\hline
\end{tabular}

Verificou-se que há equivalência entre os indicadores "alto" e "médio" como maiores ocorrências para sete assessores, em ambos os casos. Para três assessores este conceito foi "alto", inferindo-se que trata-se daqueles usuários que utilizam muito o conteúdo da BDJur na realização do seu trabalho, considerando-a como fonte principal na procura por tema específico do direito e comprovação de sua publicação na literatura. Por outro lado, o indicador "baixo" atribuído por cinco assessores, aponta para a necessidade de realização de estudos de usuários no sentido de averiguar as reais causas de não uso da BDJur por usuários considerados potenciais, mesmo sabendo-se que há assessores que centralizam suas buscas à informação no acervo dos gabinetes nos quais trabalham. É fundamental investigar se para estes usuários, o não uso da BDJur estaria relacionado ao desconhecimento do conteúdo informacional das coleções da BDJur ou, devido a dificuldades de uso dos recursos existentes e, porque ela não está incluída no comportamento e na estratégia principal de busca à informação jurídica por estes assessores. A Figura 30 ilustra estas ocorrências:

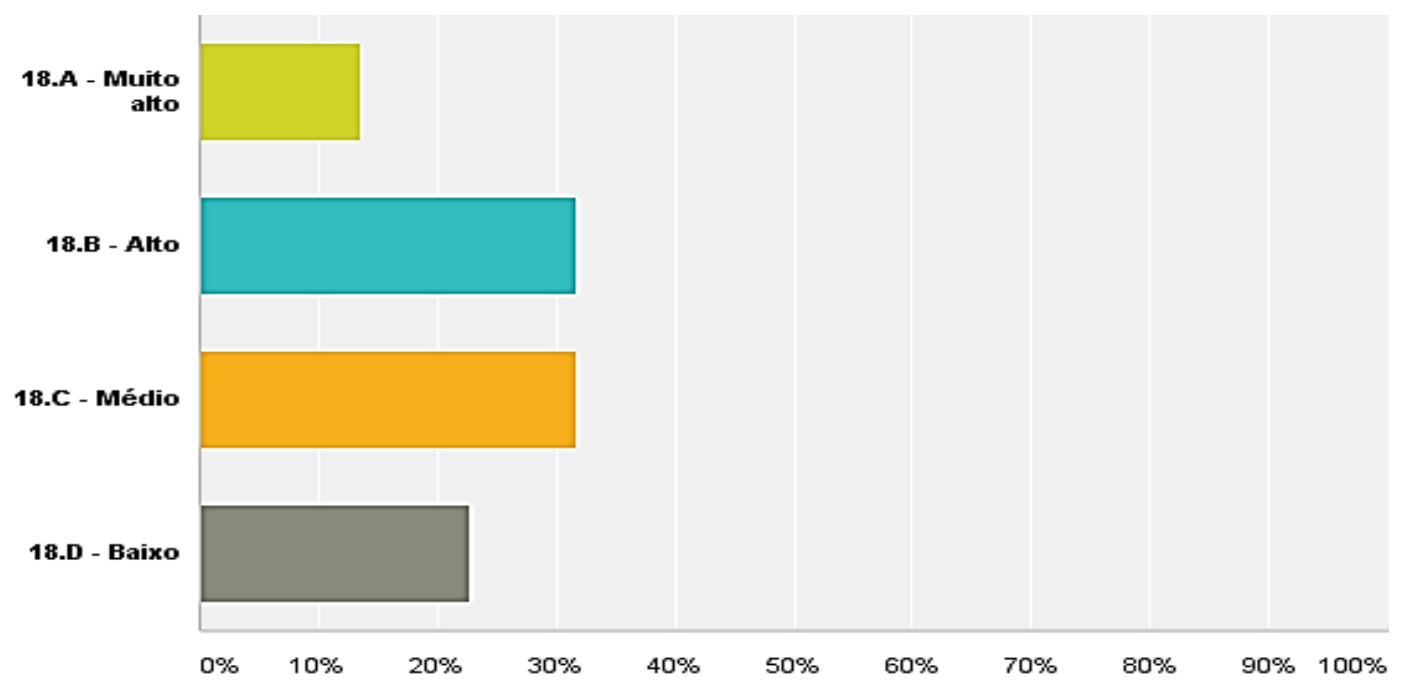

Fig. 30- Indicador atribuído à BDJur, versus necessidade de busca e uso da informação no desempenho da atividade profissional 
$\mathrm{Na}$ questão 23 os assessores declararam o grau de satisfação em relação ao conteúdo das páginas que compõem a BDJur, constatando-se que 14 assessores estão "satisfeitos" como maior ocorrência verificada. Três declararam-se "muito satisfeitos", ao passo que cinco encontram-se "pouco satisfeitos". Mais uma vez, o número de assessores pouco satisfeitos, neste sentido, aponta para a necessidade de investigações das causas, visando à soluções de determinados problemas ou, o atendimento de demandas específicas, por exemplo. Chama atenção o fato de que nenhum assessor afirmou estar "insatisfeito" neste sentido, levando a inferir, com base nesta última situação, que a BDJur apresenta requisitos cuja qualidade do conteúdo e desempenho do sistema se mostram efetivos, para a maioria dos respondentes, na busca e suprimento da informação jurídica.

Tabela 17 - Grau de satisfação em relação ao conteúdo das páginas da BDJur

\begin{tabular}{|c|c|c|}
\hline Opções de resposta & Respost & \\
\hline 23.A - Muito satisfeito & $13,64 \%$ & 3 \\
\hline 23.B - Satisfeito & $63,64 \%$ & 14 \\
\hline 23.C - Pouco satisfeito & $22,73 \%$ & 5 \\
\hline 23.D - Insatisfeito & $\mathbf{0 , 0 0 \%}$ & 0 \\
\hline Total & & 22 \\
\hline
\end{tabular}

Esta avaliação do usuário está evidenciada na Figura 31

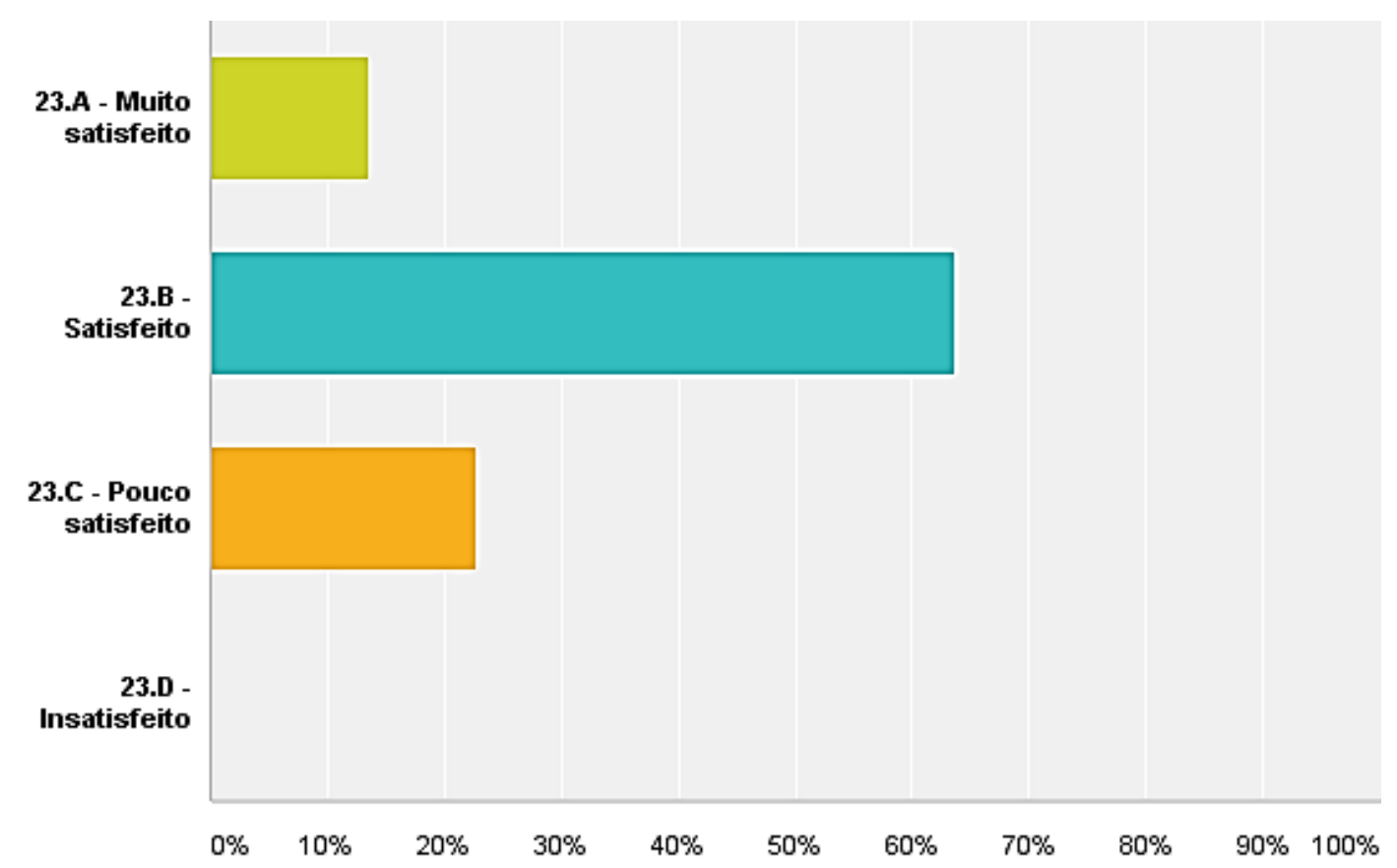

Fig. 31 - Grau de satisfação em relação ao conteúdo das páginas da BDJur 
Em relação ao fato dos textos explicativos existentes na BDjur direcionarem a pesquisa do assessor no acesso à informação buscada, a Tabela 18 demonstra que 16 assessores responderam positivamente e, contrariamente, seis responderam negativamente. As respostas negativas leva a inferir na necessidade de revisão e aprimoramento de aspectos relativos à sintaxe, clareza ou precisão da redação dos textos explicativos referentes aos recursos e estratégias de pesquisa da BDJur e, que seria importante neste sentido, ouvir do assessor onde situam-se as principais barreiras e dificuldades subjacentes ao resultado negativo expressado.

Tabela 18 - Textos explicativos da BDJur para pesquisa à informação

\begin{tabular}{c|lr}
\hline Opções de resposta & Respostas & \\
\hline $24 . A-\operatorname{Sim}$ & $\mathbf{7 2 , 7 3} \%$ & 16 \\
\hline $24 . B$ - Não & $\mathbf{2 7 , 2 7 \%}$ & 6 \\
\hline Total & & $\mathbf{2 2}$ \\
\hline
\end{tabular}

Os resultados obtidos, foram transpostos para a Figura 32:

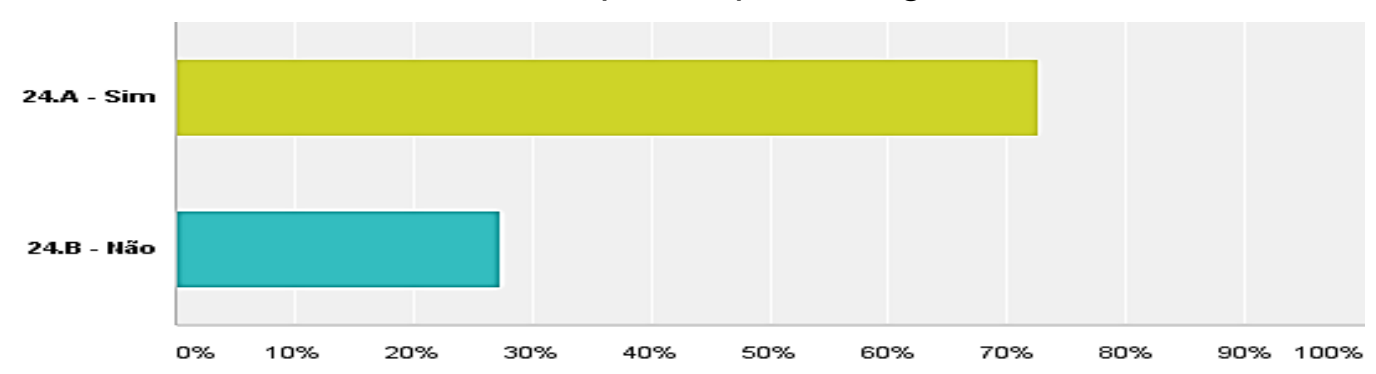

Fig. 32 - Textos explicativos da BDJur para pesquisa à informação

\subsubsection{Aspectos operacionais de utilização da BDJur pelo assessor (questões $\underline{17,19,20,21,22)}$}

A frequência com que o assessor realiza buscas na BDJur está explanada na Tabela 19, cujos dados indicam que a maior ocorrência registrada por 13 respondentes é a busca de informação com periodicidade "irregular". Entre vários fatores, tal fato pode estar relacionado com a necessidade de informação específica do assessor, que tanto pode levá-lo a realizar inúmeras buscas no mesmo dia para comprovar se determinada informação foi publicada ou não na literatura - como relatado numa entrevista com um assessor - como também, ser decorrente da necessidade de busca de informação na ocasião de fundamentação e construção do modelo ou proposta de voto para o ministro, não sendo necessário neste sentido, a busca com maior frequência à BDJur, fato, possivelmente reforçado pelo resultado de que nenhum participante declarou realizar buscas diariamente. Ademais, quatro assessores responderam que realizam buscas semanalmente, enquanto cinco 0 fazem mensalmente. Outro resultado a destacar é que nenhum respondente afirmou não utilizar a BDJur. 
Tabela 19 - Frequência de busca à informação na BDJur

\begin{tabular}{c|lr}
\hline Opções de resposta & Respostas & 0 \\
\hline 17.A - Diária & $\mathbf{0 , 0 0 \%}$ & 4 \\
\hline 17. B - Semanal & $\mathbf{1 8 , 1 8 \%}$ & 5 \\
\hline 17. - Mensal & $\mathbf{2 2 , 7 3 \%}$ & 13 \\
\hline 17.D - Irregular & $\mathbf{5 9 , 0 9 \%}$ & 0 \\
\hline 17.E - Não utilizo & $\mathbf{0 , 0 0 \%}$ & $\mathbf{2 2}$ \\
\hline Total & & \\
\hline
\end{tabular}

33:

Estes dados ao serem transformados em gráfico, podem ser vistos na Figura

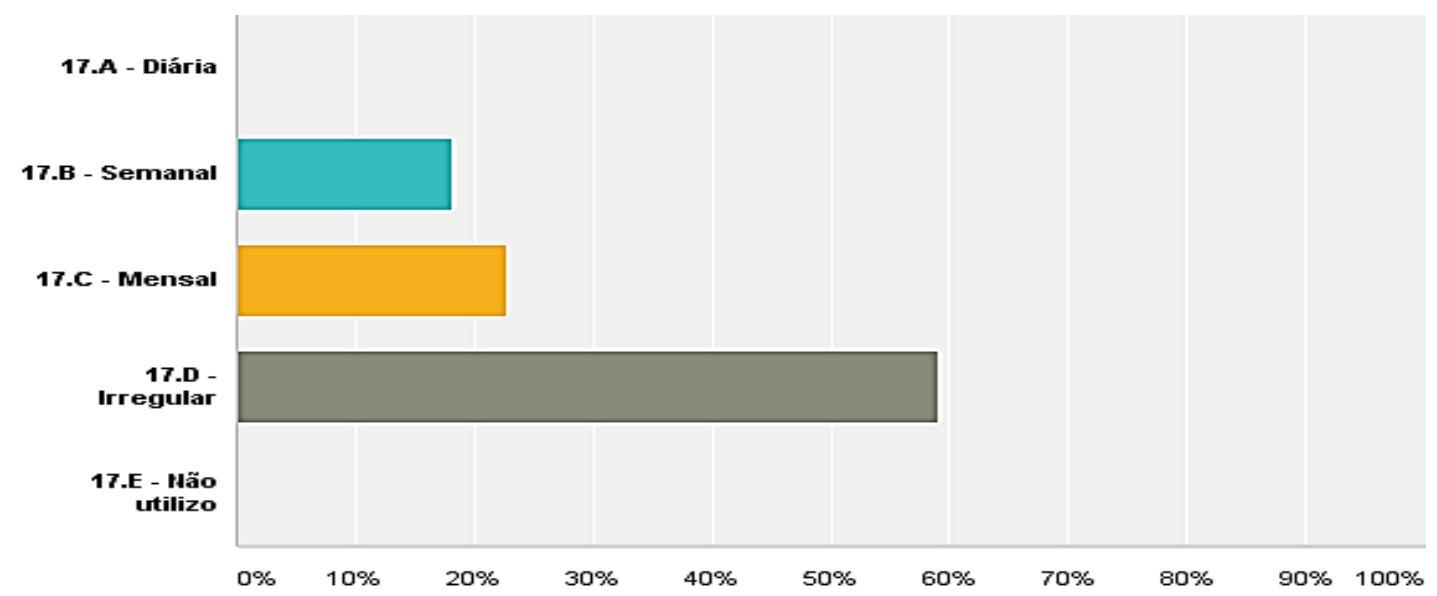

Fig. 33 - Frequência de busca à informação na BDJur

Em relação à média do número de tentativas realizadas pelos assessores para localizar a informação jurídica durante a busca na BDJur, o resultado mais expressivo e satisfatório foi de "duas a quatro tentativas", conforme registrado na Tabela 20:

Tabela 20 - Número de tentativas para localizar informação na BDJur

\begin{tabular}{c|lr}
\hline Opçőes de resposta & Respostas & \\
\hline $19 . A-$ Uma & $\mathbf{4 , 5 5 \%}$ & $\mathbf{2 0}$ \\
\hline 19. B - Duas a quatro & $\mathbf{9 0 , 9 1 \%}$ & 1 \\
\hline 19.C - Mais de cinco & $\mathbf{4 , 5 5 \%}$ & $\mathbf{2 2}$ \\
\hline Total & & \\
\hline
\end{tabular}

$\mathrm{Na}$ Figura 34, percebe-se que, praticamente, houve unanimidade nas respostas dos assessores, quanto ao número de duas a quatro tentativas realizadas na busca à Informação jurídica na BDJur, constatando-se o resultado positivo de 
acesso à informação e a facilidade de navegação na página. Houve um caso em que apenas uma tentativa foi suficiente, enquanto em outro, foi necessário mais de cinco tentativas, para localizar a informação demandada:

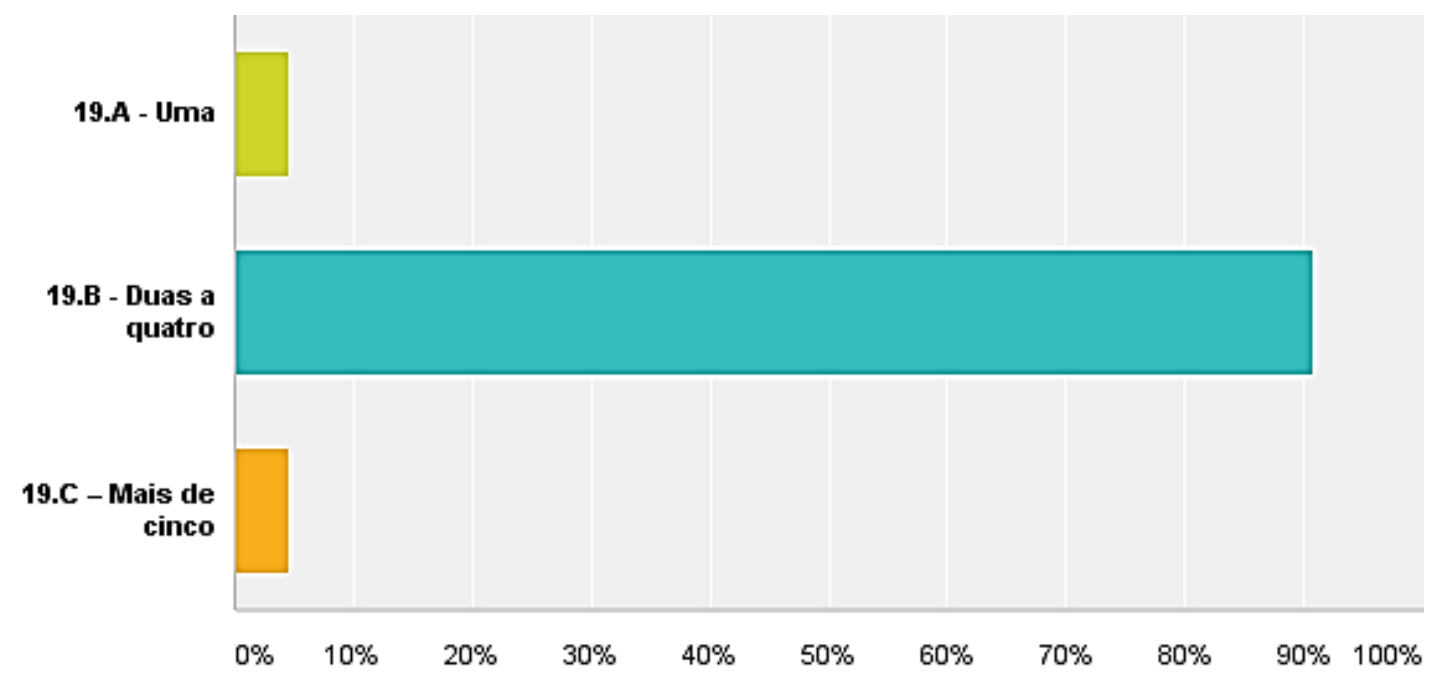

Fig. 34 - Número de tentativas para localizar informação na BDJur

Com a questão 20 objetivou-se relacionar o número de tentativas com o grau de dificuldade para realização das buscas, observando-se que não há correlação entre estas duas variáveis, uma vez que nenhum assessor considera que o número de tentativas que realiza na busca seja devido a algum grau de dificuldade existente no processo de busca. Constata-se, assim, tanto que estes respondentes conhecem a BDJur como produto de acesso à informação, como também que a interface da BDJur propicia certo grau de facilidade de pesquisa. A maior frequência de respostas mostra que 11 assessores declararam ter grau de dificuldade "médio" para realização das buscas na BDJur, enquanto dois declararam ter grau de dificuldade "alto". O grau de dificuldade "muito alto" não obteve incidência entre os assessores participantes.

Tabela 21 - Grau de dificuldade para realização da busca na BDJur

\begin{tabular}{l|lr}
\hline Opções de resposta & \multicolumn{2}{|c}{ Respostas } \\
\hline 20. A - Muito alto & $\mathbf{0 , 0 0}$ & 0 \\
\hline 20. B - Alto & $\mathbf{9 , 0 9 \%}$ & 2 \\
\hline $20 . C$ - Médio & $\mathbf{5 0 , 0 0 \%}$ & 11 \\
\hline $20 . D$ - Não estão relacionadas à dificuldade no processo de busca. & $\mathbf{4 0 , 9 1 \%}$ & 9 \\
\hline $20 . E$ - Estão relacionadas à dificuldade no processo de busca. Especificar: & $\mathbf{0 , 0 0 \%}$ & 0 \\
\hline Total & & $\mathbf{2 2}$ \\
\hline
\end{tabular}

Estes dados são visualizados de forma mais clara, com a ajuda da Figura 35: 


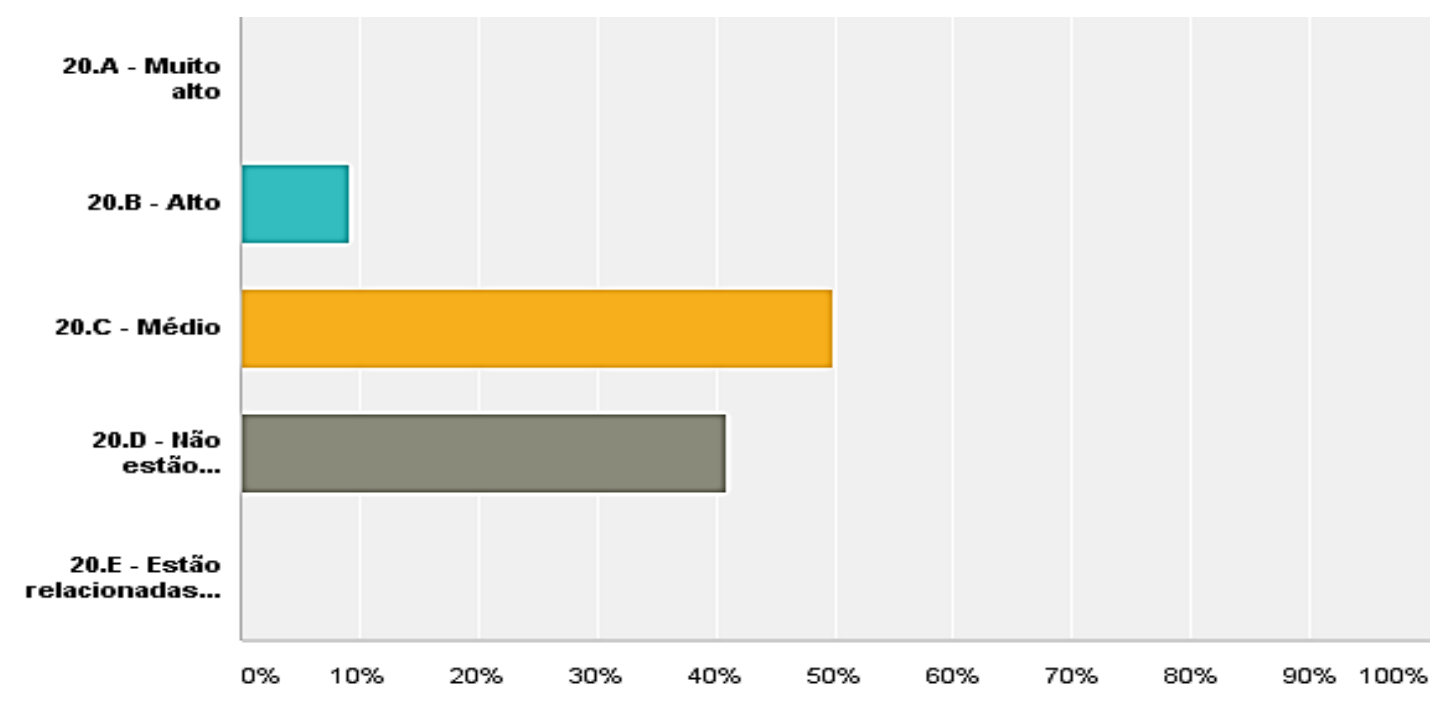

Fig. 35 - Grau de dificuldade para realização da busca na BDJur

$\mathrm{Na}$ questão 21, objetivou-se saber se o assessor havia realizado busca na BDJur cuja informação não fora encontrada. Constatou-se que o maior índice de resposta de 13 assessores foi de "não", significando que encontraram a informação demandada. Em contrapartida, nove confirmaram que "sim", ou seja, obtiveram resultado negativo na busca. Neste caso, alguns assessores alegaram que não recordavam exatamente a informação, enquanto outros especificaram o tipo de informação não encontrada, cujas respostas foram transcritas e categorizadas na análise dos campos abertos do questionário eletrônico, realizada no item 8.2.4 desta pesquisa (ver Tabela 29). Os dados relativos ao resultado positivo e negativo da busca à informação na BDJur está representado na Tabela 22:

Tabela 22- Tipo de resultado da busca à informação na BDJur

\begin{tabular}{l|lr}
\hline Opções de resposta & \multicolumn{2}{|l}{ Respostas } \\
\hline 21 .A - Não & $\mathbf{5 9 , 0 9 \%}$ & 13 \\
\hline 21 B - Sim. Por favor especifique qual: & $\mathbf{4 0 , 9 1 \%}$ & 9 \\
\hline Total & & $\mathbf{2 2}$ \\
\hline
\end{tabular}

A representação gráfica destes dados encontra-se na Figura 36:

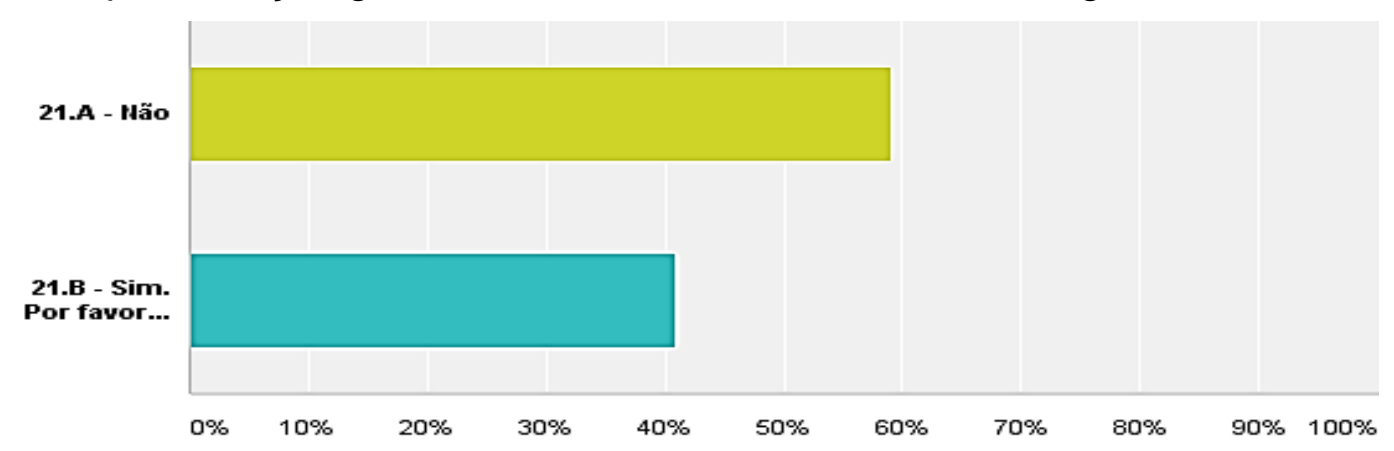

Fig. 36 - Tipo de resultado da busca à informação na BDJur 
Quanto às dificuldades encontradas no acesso à informação jurídica em relação às coleções da BDJur, a questão 22 incluiu a frequência de situações de busca pelo assessor por atos normativos e doutrina que não foram encontrados, além de obtenção de resultado de doutrina não relevante, constantes na Tabela 23:

Tabela 23 - Dificuldades encontradas no acesso à informação jurídica na BDJur

\begin{tabular}{l|c}
\hline Opções de resposta & Respostas \\
\hline 22.A - Atos Normativos (STJ, ENFAM, TFR) não encontrados & $\mathbf{4 , 5 5 \%}$ \\
\hline 22.B - Doutrina não encontrada & $\mathbf{4 0 , 9 1 \%}$ \\
\hline 22.C - Doutrina não relevante & $\mathbf{1 8 , 1 8 \%}$ \\
\hline 22.D - Nenhuma & $\mathbf{2 7 , 2 7 \%}$ \\
\hline 22.E - Outras. Por favor especifique: & $\mathbf{9}$ \\
\hline Total & $\mathbf{9 , 0 9 \%}$ \\
\hline
\end{tabular}

De acordo com os dados da Tabela 23, nove assessores declararam que não encontraram a doutrina demandada, enquanto quatro consideraram como dificuldade no acesso à informação buscada, o resultado da pesquisa apresentar doutrina não relevante e, para um respondente a dificuldade foi relativa a atos normativos (STJ, ENFAM, TRF) buscados e não recuperados. Observa-se que, inversamente, para seis assessores, não houve dificuldade de acesso à informação jurídica em nenhuma coleção da BDJur. As ocorrências verificadas em cada situação de busca da Tabela 23 evidenciam a necessidade constante de proceder à avaliação do produto de informação pela biblioteca como etapa do desenvolvimento e manutenção deste, comparando-se o objetivo estabelecido com o fornecimento do produto e os resultados alcançados pelos usuários. A opção de campo aberto desta questão "Outras. Por favor especifique" foi transcrita no item 8.2.4 desta pesquisa (ver Tabela 29).

Estes resultados foram ilustrados na Figura 37:

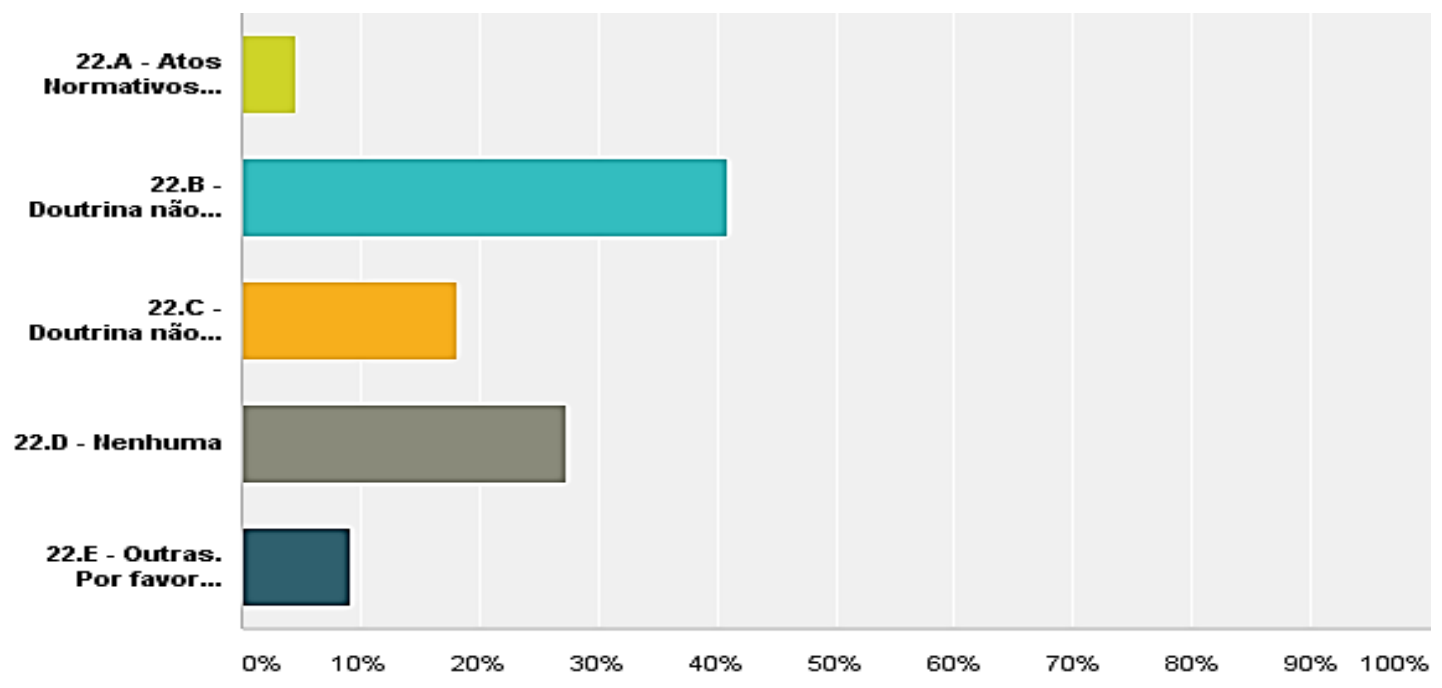

Fig. 37 - Dificuldades encontradas no acesso à informação jurídica na BDJur 


\subsubsection{3) Tempo de resposta de acesso à informação jurídica (q. 25)}

Os assessores expressaram sua avaliação sobre o tempo de resposta das pesquisas realizadas na BDJur, avaliando entre "rápido" e "razoável" o tempo de retorno de resposta das buscas. As ocorrências ficaram divididas entre estas duas velocidades de resultado das buscas, predominando o tempo de resposta "razoável", para quatorze assessores, seguido do tempo de resposta "rápido", para oito respondentes. Não houve resposta para as velocidades "eventualmente lenta" e "frequentemente lenta"

Tabela 24 - Tempo de resposta da BDJur

\begin{tabular}{l|r}
\hline Opçöes de resposta & \multicolumn{2}{|l}{ Respostas } \\
\hline 25.A - Rápida & $\mathbf{3 6 , 3 6 \%}$ \\
\hline 25. B - Razoável & $\mathbf{6 3 , 6 4 \%}$ \\
\hline 25. - Eventualmente lenta & $\mathbf{0 , 0 0 \%}$ \\
\hline 25.D - Frequentemente lenta & $\mathbf{0 , 0 0} \%$ \\
\hline Total & 0 \\
\hline
\end{tabular}

Observa-se o tempo de resposta da BDJur avaliado pelos assessores, graficamente representado na Figura 38:

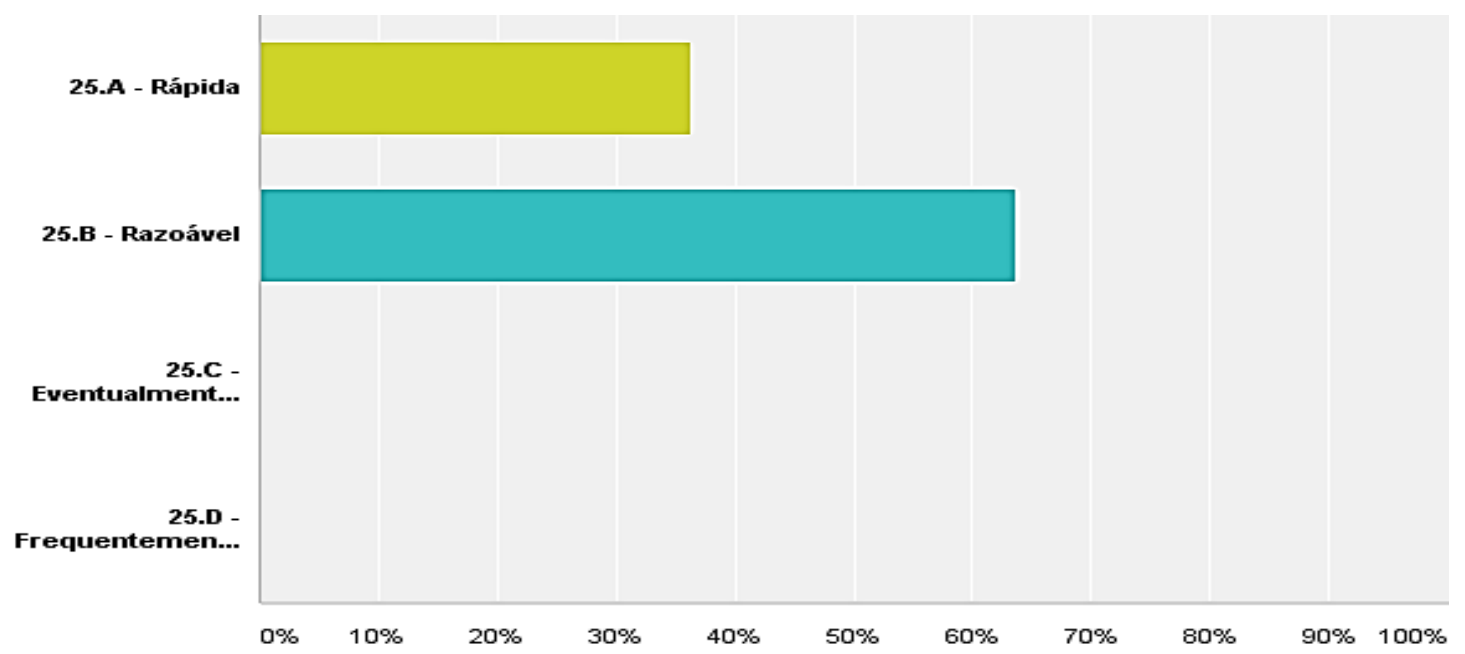

Fig. 38 - Tempo de resposta da BDJur

Foi realizado o cruzamento entre a variável referente às três áreas do direito das Seções e Turmas do STJ correspondentes à atuação profissional do assessor, com a frequência e tipologia de informação das coleções da BDJur pesquisadas por eles, para realização do seu trabalho no Tribunal. Os dados obtidos mostram que nas três áreas do direito - direito público e previdenciário; direito privado; e direito penal - houve equivalência de frequência de busca à informação nas coleções de Atos administrativos (STJ, Enfam e TFR), Doutrina, e Jurisprudência comentada em 
livros e revistas. Inversamente, os menores índices obtidos nas três áreas de trabalho dos assessores estão relacionados à busca por "parecer". A Tabela 25 e a Figura 39 apresentam este cruzamento entre a questão 9 e questão 14:

Tabela 25 - Cruzamento da Tabela 09 - Área de atuação profissional nas áreas do direito das seções e turmas do STJ X Tabela 14 - Tipo de pesquisa na BDJur em relação ao grau de frequência.

14.A - Atos Normativos (STJ, Enfam, TFR)

\begin{tabular}{|c|c|c|c|c|c|c|c|c|c|c|}
\hline & \multicolumn{2}{|c|}{ Frequentemente } & \multicolumn{2}{|c|}{ Raramente } & \multicolumn{2}{|c|}{ Ocasionalmente } & \multicolumn{2}{|c|}{ Nunca } & \multicolumn{2}{|c|}{ Total geral } \\
\hline & Quant. & $\%$ & Quant. & $\%$ & Quant. & $\%$ & Quant. & $\%$ & Quant. & $\%$ \\
\hline $\begin{array}{l}\text { 9.A - Direito público } \\
\text { e previdenciário }\end{array}$ & 3 & 33,3 & 3 & 33,3 & 3 & 33,3 & 0 & 0,0 & 9 & 100 \\
\hline 9.B - Direito privado & 2 & 25,0 & 2 & 25,0 & 1 & 12,5 & 3 & 37,5 & 8 & 100 \\
\hline 9.C - Direito penal & 2 & 40,0 & 1 & 20,0 & 2 & 40,0 & 0 & 0,0 & 5 & 100 \\
\hline Total geral & 7 & 31,8 & 6 & 27,3 & 6 & 27,3 & 3 & 13,6 & 22 & 100 \\
\hline \multicolumn{11}{|c|}{ 14.B - Doutrina } \\
\hline & \multicolumn{2}{|c|}{ Frequentemente } & \multicolumn{2}{|c|}{ Raramente } & \multicolumn{2}{|c|}{ Ocasionalmente } & \multicolumn{2}{|c|}{ Nunca } & \multicolumn{2}{|c|}{ Total geral } \\
\hline & Quant. & $\%$ & Quant. & $\%$ & Quant. & $\%$ & Quant. & $\%$ & Quant. & $\%$ \\
\hline $\begin{array}{l}\text { 9.A - Direito público } \\
\text { e previdenciário }\end{array}$ & 3 & 33,3 & 2 & 22,2 & 4 & 44,4 & 0 & 0,00 & 9 & 100 \\
\hline 9.B - Direito privado & 2 & 25,0 & 4 & 50,0 & 2 & 25,0 & 0 & 0,00 & 8 & 100 \\
\hline 9.C - Direito penal & 1 & 20,0 & 2 & 40,0 & 2 & 40,0 & 0 & 0,00 & 5 & 100 \\
\hline Total geral & 6 & 27,3 & 8 & 36,4 & 8 & 36,4 & 0 & 0,00 & 22 & 100 \\
\hline \multicolumn{11}{|c|}{ 14.C - Jurisprudência comentada publicada em livro/revista } \\
\hline & \multicolumn{2}{|c|}{ Frequentemente } & \multicolumn{2}{|c|}{ Raramente } & \multicolumn{2}{|c|}{ Ocasionalmente } & \multicolumn{2}{|c|}{ Nunca } & \multicolumn{2}{|c|}{ Total geral } \\
\hline & Quant. & $\%$ & Quant. & $\%$ & Quant. & $\%$ & Quant. & $\%$ & Quant. & $\%$ \\
\hline $\begin{array}{l}\text { 9.A - Direito público } \\
\text { e previdenciário }\end{array}$ & 2 & 22,2 & 3 & 33,3 & 4 & 44,4 & 0 & 0,0 & 9 & 100 \\
\hline 9.B - Direito privado & 2 & 25,0 & 2 & 25,0 & 2 & 25,0 & 2 & 25,0 & 8 & 100 \\
\hline 9.C - Direito penal & 1 & 20,0 & 4 & 80,0 & 0 & 0,0 & 0 & 0,0 & 5 & 100 \\
\hline Total geral & 5 & 22,7 & 9 & 40,9 & 6 & 27,3 & 2 & 9,1 & 22 & 100 \\
\hline \multicolumn{11}{|c|}{ 14.D - Parecer } \\
\hline & \multicolumn{2}{|c|}{ Frequentemente } & \multicolumn{2}{|c|}{ Raramente } & \multicolumn{2}{|c|}{ Ocasionalmente } & \multicolumn{2}{|c|}{ Nunca } & \multicolumn{2}{|c|}{ Total geral } \\
\hline & Quant. & $\%$ & Quant. & $\%$ & Quant. & $\%$ & Quant. & $\%$ & Quant. & $\%$ \\
\hline $\begin{array}{l}\text { 9.A - Direito público } \\
\text { e previdenciário }\end{array}$ & 0 & 0,0 & 1 & 11,1 & 5 & 55,6 & 3 & 33,3 & 9 & 100 \\
\hline 9.B - Direito privado & 0 & 0,0 & 1 & 12,5 & 1 & 12,5 & 6 & 75,0 & 8 & 100 \\
\hline 9.C - Direito penal & 0 & 0,0 & 4 & 80,0 & 0 & 0,0 & 1 & 20,0 & 5 & 100 \\
\hline Total geral & 0 & 0,0 & 6 & 27,3 & 6 & 27,3 & 10 & 45,5 & 22 & 100 \\
\hline
\end{tabular}




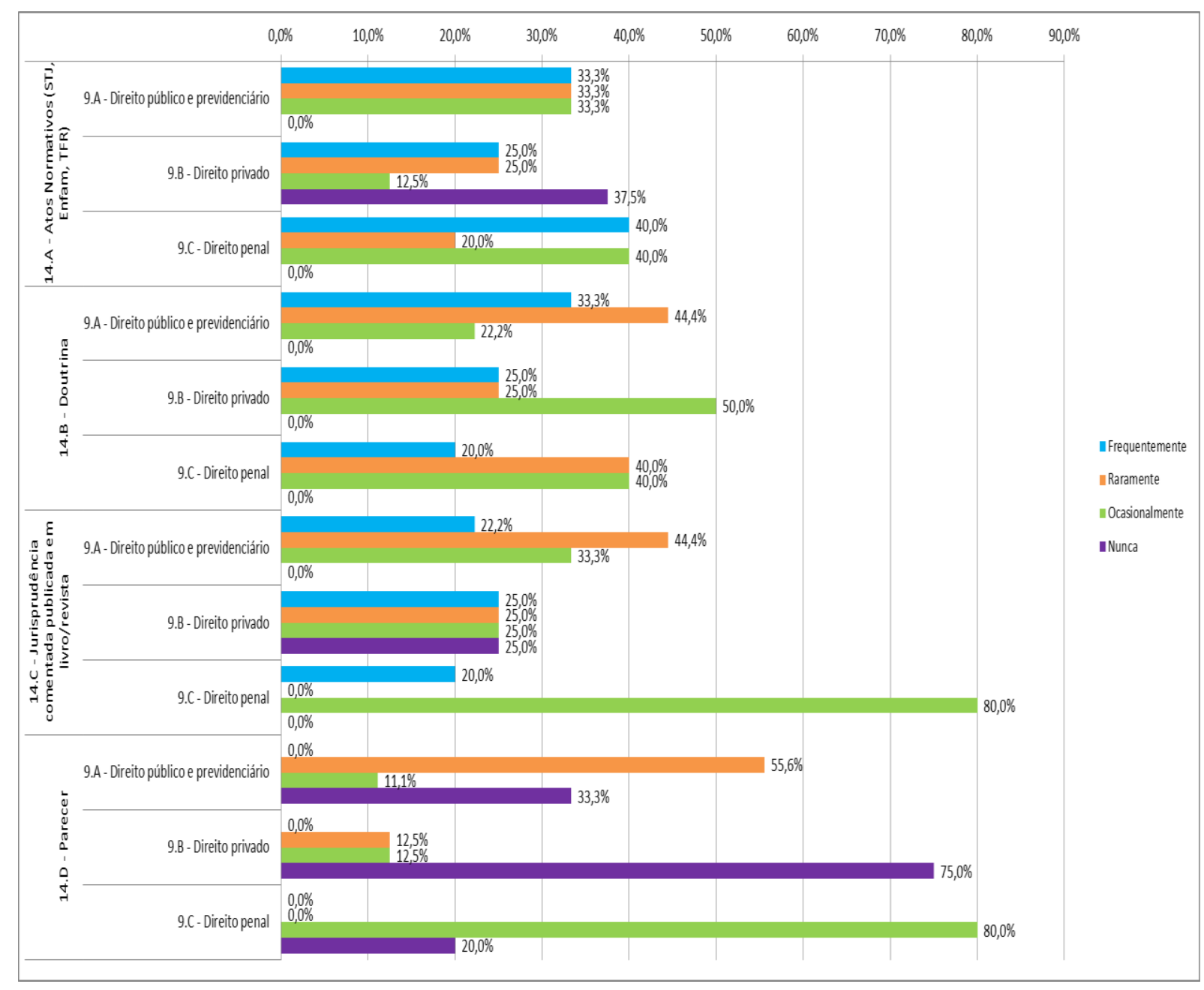

Fig. 39 - Cruzamento das Tabelas 09 - Área de atuação profissional nas áreas do direito das seções e turmas do STJ X Tabela 14 - Tipo de pesquisa na BDJur em relação ao grau de frequência.

O segundo cruzamento realizado (entre a questão 09 e a questão 15) visou apurar se havia diferença entre o grau de importância na tipologia de informação jurídica existente nas coleções da BDJur, para realização do trabalho do assessor, em função das áreas do direito público e previdenciário; direito privado; e direito penal. Conforme os resultados obtidos comprovam, nas três áreas do direito, as coleções Doutrina, Legislação e Jurisprudência comentada em livros e revistas obtiveram índices de frequência decrescentes, e sem diferenças significativas, entre si, respectivamente. Este resultado se apresentou similar ao cruzamento de variáveis anterior, com frequências proporcionais ao total de assessores de cada área do direito, provavelmente devido ao fato de haver na área de direito público e previdenciário maior número de respondentes, seguida da área de direito privado e, por último a área de direito penal. Vale acrescentar que os "pareceres" não foram considerados "muito importantes" nas três áreas do direito, por todos os assessores, sendo, contudo, considerados "importantes" por seis assessores da área de direito público e previdenciário e três assessores em cada área de direito privado e direito penal 
Tabela 26 - Cruzamento da Tabela 09 - Área de atuação profissional nas áreas do direito das seções e turmas do STJ X Tabela 15 - Grau de importância da informação na BDJur, para desempenho da atividade profissional.

\begin{tabular}{|c|c|c|c|c|c|c|c|c|c|c|}
\hline \multicolumn{11}{|c|}{ 15.A - Doutrina } \\
\hline \multirow{4}{*}{$\begin{array}{l}\text { 9.A - Direito público } \\
\text { e previdenciário } \\
\text { 9.B - Direito } \\
\text { privado }\end{array}$} & \multicolumn{2}{|c|}{$\begin{array}{c}\text { Muito } \\
\text { importante }\end{array}$} & \multicolumn{2}{|c|}{ Importante } & \multicolumn{2}{|c|}{$\begin{array}{c}\text { Pouco } \\
\text { importante }\end{array}$} & \multicolumn{2}{|c|}{$\begin{array}{c}\text { Nada } \\
\text { importante }\end{array}$} & \multicolumn{2}{|c|}{ Total geral } \\
\hline & Quant. & $\%$ & Quant. & $\%$ & Quant. & $\%$ & Quant. & $\%$ & Quant. & $\%$ \\
\hline & 4 & 44,4 & 4 & 44,4 & 1 & 11,1 & 0 & 0,0 & 9 & 100 \\
\hline & 4 & 50,0 & 3 & 37,5 & 1 & 12,5 & 0 & 0,0 & 8 & 100 \\
\hline 9.C - Direito penal & 4 & 80,0 & 0 & 0,0 & 1 & 20,0 & 0 & 0,0 & 5 & 100 \\
\hline Total geral & 12 & 54,5 & 7 & 31,8 & 3 & 13,6 & 0 & 0,0 & 22 & 100 \\
\hline \multicolumn{11}{|c|}{ 15.B - Legislação } \\
\hline & \multicolumn{2}{|c|}{$\begin{array}{c}\text { Muito } \\
\text { importante }\end{array}$} & \multicolumn{2}{|c|}{ Importante } & \multicolumn{2}{|c|}{$\begin{array}{c}\text { Pouco } \\
\text { importante }\end{array}$} & \multicolumn{2}{|c|}{$\begin{array}{c}\text { Nada } \\
\text { importante }\end{array}$} & \multicolumn{2}{|c|}{ Total geral } \\
\hline & Quant. & $\%$ & Quant. & $\%$ & Quant. & $\%$ & Quant. & $\%$ & Quant. & $\%$ \\
\hline \multirow{4}{*}{$\begin{array}{l}\text { 9.A - Direito público } \\
\text { e previdenciário } \\
\text { 9.B - Direito } \\
\text { privado } \\
\text { 9.C - Direito penal } \\
\text { Total geral }\end{array}$} & 4 & 44,4 & 4 & 44,4 & 1 & 11,1 & 0 & 0,0 & 9 & 100 \\
\hline & 4 & 50,0 & 0 & 0,0 & 4 & 50,0 & 0 & 0,0 & 8 & 100 \\
\hline & 2 & 40,0 & 3 & 60,0 & 0 & 0,0 & 0 & 0,0 & 5 & 100 \\
\hline & 10 & 45,5 & 7 & 31,8 & 5 & 22,7 & 0 & 0,0 & 22 & 100 \\
\hline \multicolumn{11}{|c|}{ 15.C - Jurispr } \\
\hline & \multicolumn{2}{|c|}{$\begin{array}{c}\text { Muito } \\
\text { importante }\end{array}$} & \multicolumn{2}{|c|}{ Importante } & \multicolumn{2}{|c|}{$\begin{array}{c}\text { Pouco } \\
\text { importante }\end{array}$} & \multicolumn{2}{|c|}{$\begin{array}{c}\text { Nada } \\
\text { importante }\end{array}$} & \multicolumn{2}{|c|}{ Total geral } \\
\hline & Quant. & & Quant. & $\%$ & Quant. & $\%$ & Quant. & $\%$ & Quant. & $\%$ \\
\hline \multirow{4}{*}{$\begin{array}{l}\text { 9.A - Direito público } \\
\text { e previdenciário } \\
\text { 9.B - Direito } \\
\text { privado } \\
\text { 9.C - Direito penal } \\
\text { Total geral }\end{array}$} & 3 & 33,3 & 5 & 55,6 & 1 & 11,1 & 0 & 0,0 & 9 & 100 \\
\hline & 3 & 37,5 & 2 & 25,0 & 3 & 37,5 & 0 & 0,0 & 8 & 100 \\
\hline & 2 & 40,0 & 1 & 20,0 & 2 & 40,0 & 0 & 0,0 & 5 & 100 \\
\hline & 8 & 36,4 & 8 & 36,4 & 6 & 27,3 & 0 & 0,0 & 22 & 100 \\
\hline \multicolumn{11}{|c|}{ 15.D - Parecer } \\
\hline & \multicolumn{2}{|c|}{$\begin{array}{c}\text { Muito } \\
\text { importante }\end{array}$} & \multicolumn{2}{|c|}{ Importante } & \multicolumn{2}{|c|}{$\begin{array}{c}\text { Pouco } \\
\text { importante }\end{array}$} & \multicolumn{2}{|c|}{$\begin{array}{c}\text { Nada } \\
\text { importante }\end{array}$} & \multicolumn{2}{|c|}{ Total geral } \\
\hline \multirow{5}{*}{$\begin{array}{l}\text { 9.A - Direito público } \\
\text { e previdenciário } \\
\text { 9.B - Direito } \\
\text { privado } \\
\text { 9.C - Direito penal } \\
\text { Total geral }\end{array}$} & Quant. & $\%$ & Quant. & $\%$ & Quant. & $\%$ & Quant. & $\%$ & Quant. & $\%$ \\
\hline & 0 & 0,0 & 6 & 66,7 & 2 & 22,2 & 1 & 11,1 & 9 & 100 \\
\hline & 0 & 0,0 & 3 & 37,5 & 4 & 50,0 & 1 & 12,5 & 8 & 100 \\
\hline & 0 & 0,0 & 3 & 60,0 & 1 & 20,0 & 1 & 20,0 & 5 & 100 \\
\hline & 0 & 0,0 & 12 & 54,5 & 7 & 31,8 & 3 & 13,6 & 22 & 100 \\
\hline
\end{tabular}

$\mathrm{Na}$ Figura 40, estes dados tornam-se mais facilmente verificados: 


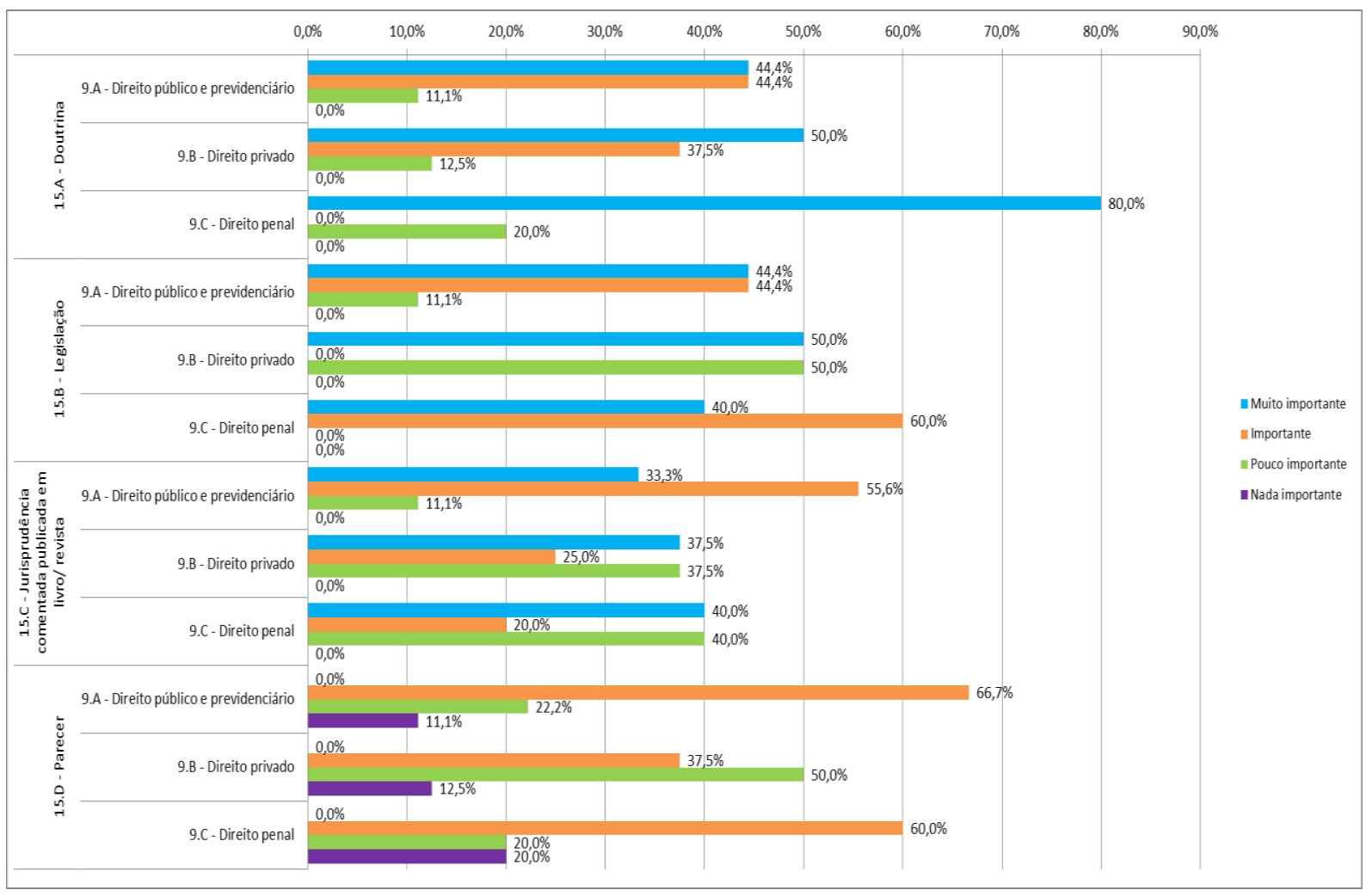

Fig. 40 - Cruzamento da Tabela 09 - Área de atuação profissional nas áreas do direito das seções e turmas do STJ X Tabela 15 - Grau de importância da informação na BDJur, para desempenho da atividade profissional

O cruzamento da questão 09 e questão 17 teve por objetivo averiguar a frequência de realização das buscas pelos assessores, em relação às áreas do direito público e previdenciário; direito privado; e direito penal, constantes na Tabela 27.

Tabela 27 -. Cruzamento da Tabela 09 - Área de atuação profissional nas áreas do direito das seções e turmas do STJ X Tabela 17 - Frequência de busca à informação na BDJur

\begin{tabular}{lccccccccc}
\hline \multicolumn{7}{c}{$\mathbf{1 7}$ - Com que periodicidade realiza buscas na BDJur? } \\
\hline & \multicolumn{2}{c}{ Semanal } & \multicolumn{2}{c}{ Mensal } & \multicolumn{2}{c}{ Irregular } & \multicolumn{2}{c}{ Total geral } \\
& Quant. & $\%$ & Quant. & $\%$ & Quant. & $\%$ & Quant. & $\%$ \\
$\begin{array}{l}\text { 9.A - Direito público } \\
\text { e previdenciário }\end{array}$ & 0 & 0,00 & 2 & 22,2 & 7 & 77,8 & 9 & 100 \\
$\begin{array}{l}\text { 9.B - Direito } \\
\text { privado }\end{array}$ & 2 & 25,0 & 2 & 25,0 & 4 & 50,0 & 8 & 100 \\
9.C - Direito penal & 2 & 40,0 & 1 & 20,0 & 2 & 40,0 & 5 & 100 \\
Total geral & 4 & 18,2 & 5 & 22,7 & 13 & 59,1 & 22 & 100 \\
\hline
\end{tabular}

Este procedimento permitiu verificar que o resultado de maior ocorrência foi a de realização de pesquisa com periodicidade "irregular", apontada pelos assessores que trabalham na área de direito público e previdenciário, seguida da área de direito privado. Na área de direito penal, nota-se a equivalência entre a periodicidade "semanal" e "irregular". O resultado total dos dados obtidos indica que a periodicidade "irregular" corresponde à média que obteve maior frequência, quando se considera as três áreas conjuntamente, seguida da periodicidade "mensal" e 
"semanal", esta última com menor índice de ocorrência. Isto leva a confirmar o resultado de que a periodicidade da realização de pesquisa à BDJur esteja relacionada à situação de necessidade ocasional e fortuita, porém recorrente, de fundamentação do voto de ministro. Os dados deste cruzamento encontram-se representados na Figura 41:

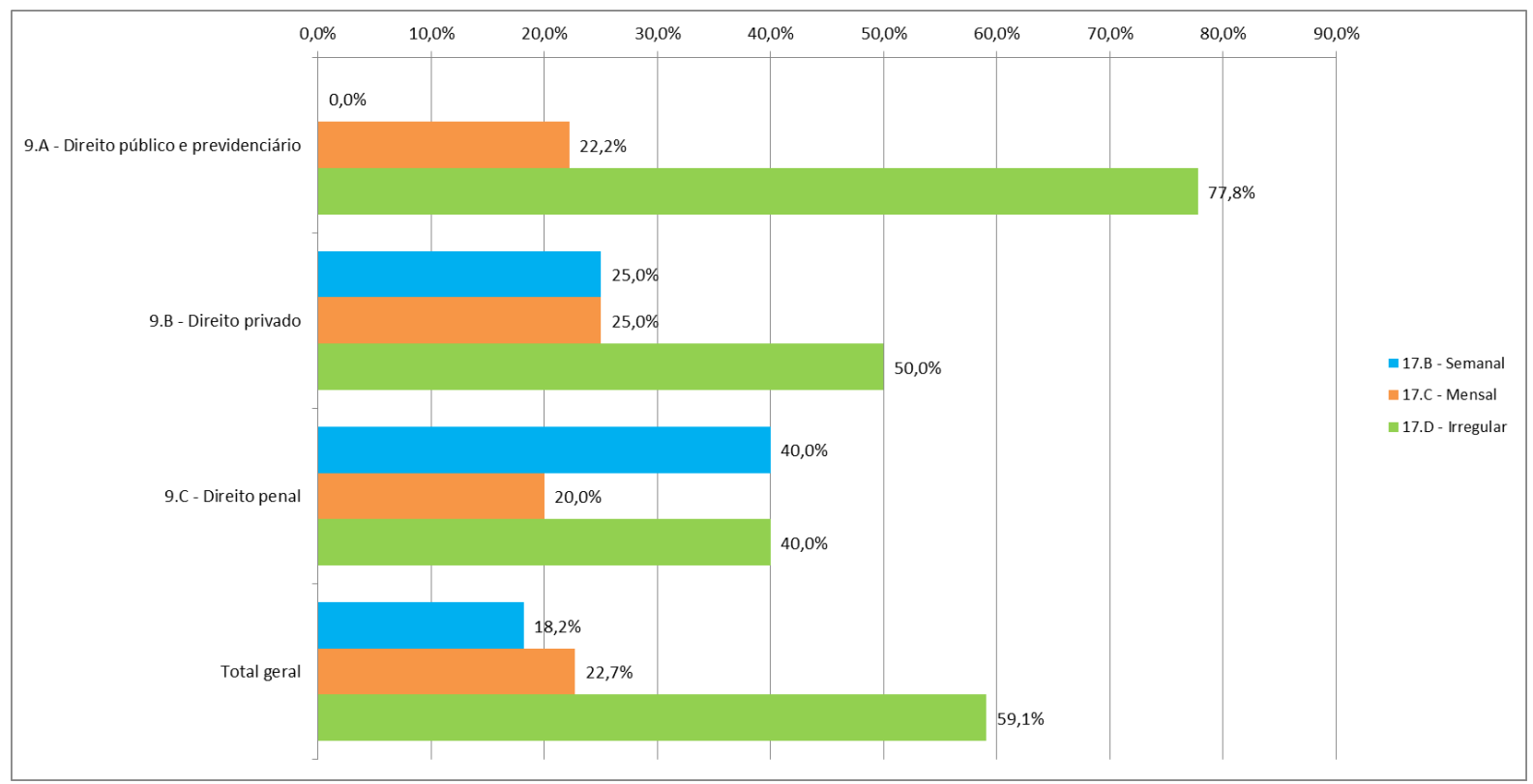

Fig. 41 - Cruzamento da Tabela 09 - Área de atuação profissional nas áreas do direito das seções e turmas do STJ X Tabela 17 - Frequência de busca à informação na BDJur

Realizou-se, por último, o cruzamento entre a questão nove e a questão 21 , com o fim de observar se as buscas na BDJur, onde a informação jurídica não foi encontrada, ocorria em maior ou menor frequência nas áreas do direito de atuação do assessor Observou-se que, não obstante a área de direito público e previdenciário, contar com maior número de respondentes que as áreas de direito privado e direito penal, ocorreu equivalência de resultados positivos na recuperação da informação demandada pelos assessores da direito público e previdenciário e direito penal. Diferentemente, a área de direito privado registrou o maior índice de informação buscada e não recuperada pelos assessores.

Tabela 28 - Cruzamento das Tabelas 09 - Área de atuação profissional nas áreas do direito das seções e turmas do STJ X Tabela 21 - Ocorrência de informação não encontrada na BDJur

\begin{tabular}{|c|c|c|c|c|c|c|}
\hline \multicolumn{7}{|c|}{21 - Você já buscou alguma informação na BDJur que não tenha sido encontrada? } \\
\hline & \multicolumn{2}{|c|}{ Não } & \multicolumn{2}{|c|}{$\operatorname{Sim}$} & \multicolumn{2}{|c|}{ Total geral } \\
\hline & Quant. & $\%$ & Quant. & $\%$ & Quant. & $\%$ \\
\hline $\begin{array}{l}\text { 9.A - Direito público } \\
\text { e previdenciário }\end{array}$ & 7 & 77,8 & 2 & 22,2 & 9 & 100 \\
\hline $\begin{array}{l}9 . \mathrm{B} \text { - Direito } \\
\text { privado }\end{array}$ & 2 & 25,0 & 6 & 75,0 & 8 & 100 \\
\hline 9.C - Direito penal & 4 & 80,0 & 1 & 20,0 & 5 & 100 \\
\hline Total geral & 13 & 59,1 & 9 & 40,9 & 22 & 100 \\
\hline
\end{tabular}


No cômputo geral, observa-se na Figura 42, que nas três áreas do direito o indicador predominante foi satisfatório na recuperação da informação buscada na BDJur.

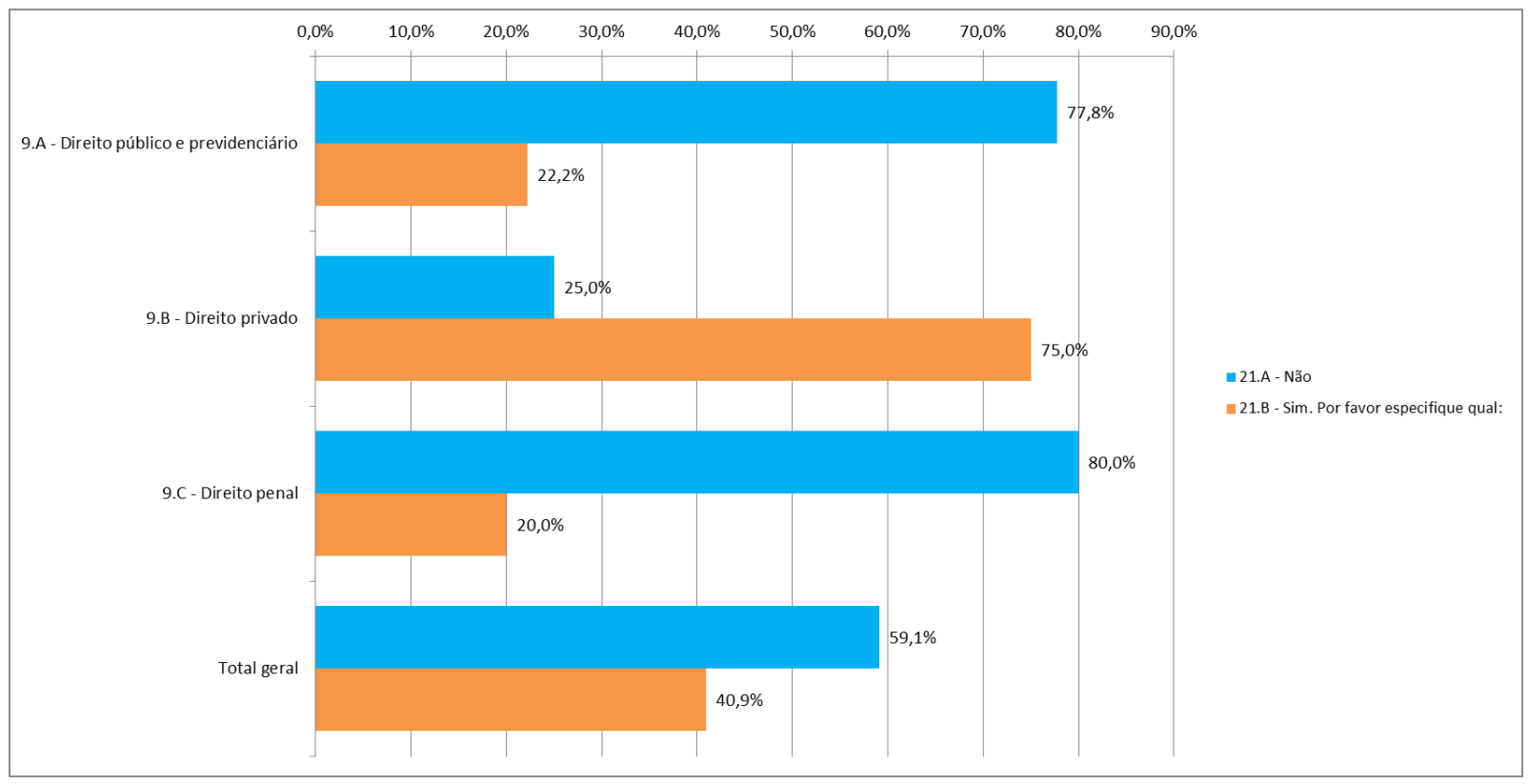

Fig. 42 - Cruzamento das Tabelas 09 - Área de atuação profissional nas áreas do direito das seções e turmas do STJ X Tabela 21 - Ocorrência de informação não encontrada na BDJur

\subsubsection{Análise do campo aberto do questionário da avaliação quantitativa}

Dentre as perguntas do questionário eletrônico que apresentavam campo aberto, observou-se que aquelas que foram respondidas pelos usuários visavam averiguar se houve alguma situação específica de busca à informação que não foi encontrada, bem como se houve dificuldades no acesso à informação jurídica, devido à ocorrência de conteúdo não encontrado, inexistente ou não relevante nas coleções da BDJur; conforme transcrito na Tabela 29:

Tabela 29 - Análise do campo aberto do questionário eletrônico da avaliação quantitativa

\begin{tabular}{|c|c|}
\hline \multirow{3}{*}{$\begin{array}{l}\text { Categorização das observações dos usuários no campo de pergunta aberta } \\
\text { Dificuldades encontradas no acesso à informação jurídica } \\
\checkmark \text { Muitas vezes o acesso é negado, mesmo informando usuário e } \\
\text { senha }\end{array}$} & Ocorrências \\
\hline & \\
\hline & 01 \\
\hline$\checkmark \quad$ Pouco utiliza & 02 \\
\hline Tipo de Informação jurídica não encontrada & \\
\hline $\begin{array}{l}\checkmark \text { Comentários doutrinários em relação a leis especiais (ex: Lei da } \\
\text { Propriedade Indutrial) }\end{array}$ & 01 \\
\hline$\checkmark \quad$ Não lembra da pesquisa específica & 02 \\
\hline Portarias específicas de TJ's estaduais & 01 \\
\hline Doutrina & 01 \\
\hline $\begin{array}{l}\checkmark \text { Diversas doutrinas. A base de dados doutrinárias precisa ser } \\
\text { aumentada para abranger também livros e revistas antigos }\end{array}$ & 01 \\
\hline$\checkmark$ Total & 9 \\
\hline
\end{tabular}


As respostas indicaram principalmente aspectos referentes à importância do aumento da cobertura do acervo de doutrina da BDJur, ressaltando inclusive artigos de periódicos retroativos, bem como de livros antigos, assim como doutrina com comentários a leis especiais. Esta necessidade específica comprova que no âmbito do Direito, a informação jurídica de décadas anteriores continua válida para a aplicação da lei e da jurisprudência a casos concretos, transcorridos e solucionados à época de vigência destas doutrinas. Dito em outras palavras, há leis que atravessam o tempo e permanecem válidas, sendo importante para os operadores do direito, de forma geral, na busca à informação jurídica, encontrar análises e interpretações da época sobre matérias jurídicas específicas que se aplicaram a determinado caso. Outro ponto percebido é que ao lado de uma demanda ativa pela BDJur, manifestada entre assessores, há em paralelo uma demanda reprimida ou potencial, expressada por outros, seja pelo desconhecimento da tipologia de informação e documentos jurídicos existentes na BDJur, seja pela falta de domínio das estratégias de busca e demais fatores ligados ao comportamento de necessidade e uso da informação.

\subsubsection{Sugestões dos usuários para melhoria da BDJur}

Q28: Que recomendações você faria para melhoria da BDJur que não foram abordadas neste questionário? (Respondidas: 09 - Em branco:18)

Tabela 30 - Recomendações do usuário para melhoria da BDJur

\begin{tabular}{|c|c|c|}
\hline $\mathbf{N}^{\circ}$ & Respostas & Data \\
\hline 1 & $\begin{array}{l}\text { Facilitação de acesso fora do STJ. Geralmente dá algum erro quando se tenta } \\
\text { abrir artigos com acesso remoto. }\end{array}$ & 31/3/15 18:31 \\
\hline 2 & Propor mais treinamento para os usuários do STJ & $19 / 3 / 1520: 56$ \\
\hline 3 & Facilitar o acesso e senhas. & 19/3/15 20:49 \\
\hline 4 & $\begin{array}{l}\text { Creio seja necessário divulgar melhor essa ferramenta tão poderosa que temos e } \\
\text { é subaproveitada. }\end{array}$ & 13/3/15 19:28 \\
\hline 5 & $\begin{array}{l}\text { Nenhuma no presente momento. É essencial o acesso, com maior frequência, ao } \\
\text { BDJur para embasar uma adequada recomendação. }\end{array}$ & 13/3/15 15:06 \\
\hline 6 & $\begin{array}{l}\text { Divulgação do conteúdo disponível porque pouca gente conhece e usa. } \\
\text { Informação clara de que conteúdo tem acesso restrito e do que é público. }\end{array}$ & $11 / 3 / 1521: 16$ \\
\hline 7 & $\begin{array}{l}\text { Creio que os servidores do Tribunal deveriam ser melhor orientados quando ao } \\
\text { uso e alcance da BDJur. Em regra utilizo doutrina impressa da biblioteca da } \\
\text { própria Ministra por não ter conhecimento adequado acerca da utilização e } \\
\text { alcance da BDJur. É possível por meio digital ter acesso integral à doutrina, por } \\
\text { exemplo? Ou o BDJur é apenas um meio de pesquisa dos títulos e artigos que } \\
\text { estão na biblioteca física? As pesquisas que realizei me possibilitaram ver apenas } \\
\text { o índice dos livros, por isso não tenho informação acerca do real alcance da } \\
\text { BDJur. }\end{array}$ & 11/3/15 19:50 \\
\hline 8 & $\begin{array}{l}\text { Evitar a repetição sucessiva da senha, situação que ocorre em algumas } \\
\text { oportunidades }\end{array}$ & 3/3/15 17:46 \\
\hline 9 & Aumento do banco de doutrina. & 10/2/15 16:46 \\
\hline
\end{tabular}

Dentre as sugestões dos assessores para melhoria da BDJur, destacam-se as referentes à necessidade de ampliar a divulgação sobre a mesma como fonte de informação jurídica bem como, treinamento do usuário, sobre a utilização dos recursos e estratégias de busca para acesso à informação. Isto mostra que ações de divulgação da BDJur, consistem em pontos promissores com retorno praticamente imediato no crescimento significativo em quantidade e qualidade de utilização pela demanda potencial dos assessores de ministro Foi apontada também a 
necessidade de identificação dos conteúdos de acesso público e restrito como facilitador de acesso à informação. Notou-se, ainda, a insatisfação de alguns usuários quanto a situações de dificuldade de acesso à BDJur fora do STJ, e com a repetição de senha para acesso a conteúdos Por último, foi acrescentada a necessidade de aumento da coleção de doutrina, fator indispensável na BDJur, considerando-se que na área do direito ocorre o crescimento vertiginoso e incessante da produção do conhecimento jurídico.

Cabe acrescentar que o questionário eletrônico e as entrevistas foram realizados no decorrer do período de utilização e vivência do usuário com a interface de busca na BDJur, anterior à disponibilizada a partir de novembro de 2015, no site do STJ Nesta pesquisa, trata-se da interface da BDJur mais amplamente utilizada pelos assessores no decorrer de um período de sete anos, cujo estudo certamente reúne tecnologia, organização e utilização da BDJur como referencial teórico e prático para aprimoramento e melhoria de funcionalidades e conteúdos $\mathrm{A}$ disponibilização da nova interface foi realizada em concomitância com a conclusão e fechamento desta pesquisa. Neste sentido, os resultados desta pesquisa poderão ser fonte de informação para os gestores da BDJur na elaboração de análises comparativas e verificação da solução, ou não, de problemas ou dificuldades anteriormente elencados pelos assessores de ministro, com a implantação da nova interface

\subsubsection{Análise descritiva do questionário eletrônico}

A análise descritiva das respostas do questionário eletrônico reúne os dados demográficos e quantitativos obtidos sobre: a) identificação do perfil do usuário, incluindo o perfil demográfico e perfil profissional; b) Habilidade e experiência para acessar a informação jurídica na Web. c) Uso proporcionado pelo produto ao usuário quanto ao conteúdo, operacional e tempo de resposta de acesso à informação jurídica; d) Análise do campo aberto do questionário eletrônico de avaliação quantitativa. e) Sugestões dos usuários para melhoria da BDJur como produto de informação disponível na Web.

Dos 30 assessores de ministros mais antigos em cada gabinete de ministro do Tribunal, 27 responderam, ocorrendo que cinco foram excluídos desta pesquisa por responderem apenas a primeira página do questionário (questões de n.1 a 8), totalizando 22 assessores participantes. Os resultados se referem aos participantes, podendo ser extensíveis à população no que se refere à necessidade imprescindível de busca de informação doutrinária, legislativa e jurisprudencial, na realização do trabalho de assessor de ministro na atividade judicante do Tribunal. Esta inferência tornou-se possível, considerando-se as funções inerentes a todo assessor de ministro, estabelecidas em norma do STJ, de realizar a pesquisa da matéria jurídica tratada nos processos, conforme discriminado no Ato $\mathrm{n}^{\circ} \mathbf{2 0 7}$, de 12 de junho de 1995, Artigo 11, Inciso II: "Aos assessores de ministro incumbe: examinar os autos conclusos ao Ministro e pesquisar a legislação, doutrina e jurisprudência referentes à matéria versada em cada processo" (SUPERIOR TRIBUNAL DE JUSTIÇA, 1995) Outro ponto de apoio para esta inferência foi a observação de que a busca à informação jurídica doutrinária e legislativa pode ser, habitualmente, realizada pelos assessores na BDJur, no acervo do gabinete ou, solicitada à Seção de Pesquisa da Biblioteca do STJ. Mormente à BDJur, constatou-se ser um produto de informação jurídica na Web considerado positivamente pelos assessores como de confiabilidade 
na busca e recuperação da informação jurídica e, até mesmo, preferencialmente utilizado por alguns assessores como fonte principal de informação para realização do seu trabalho

Quanto ao perfil dos usuários respondentes, verificou-se que há proximidade no quantitativo de homens (12) e de mulheres (10) exercendo a função. A faixa etária preponderante foi acima de 41 anos de idade. Todos participantes responderam que são formados em direito, não possuindo segunda graduação em outra área. Em relação ao nível de pós-graduação predominou a especialização lato sensu para $16(72,7 \%)$ assessores. No que se relaciona ao tempo de exercício na função de assessor de ministro, 11 (50\%) confirmaram que estão no cargo há mais de 10 anos, sendo que 14 (63,4\%) são servidores do quadro funcional do STJ.

Quanto às áreas principais do direito de competência jurisdicional das três Seções e seis Turmas do Tribunal - as quais incluem os gabinetes dos ministros relativas ao trabalho dos assessores, foi observado que a maior quantidade de respondentes, $40,9 \%(\mathrm{~N}=9)$ atua com processos das áreas de direito público e previdenciário; 36,4\% ( $\mathrm{N}=8)$ trabalham com processos da área de direito privado; e, $22,7 \%(\mathrm{~N}=5)$, com processos de natureza penal. O nível de experiência próprio na realização de pesquisa a bases de dados jurídicas na internet foi considerado pela maioria dos assessores, $86,4 \%(\mathrm{~N}=19)$, como boa ou excelente.

Entre as principais formas dos assessores tomarem conhecimento da BDJur destacam-se a página Web do STJ $(54,6 \%, N=12)$ e a Biblioteca do STJ $(36,4 \%$, $\mathrm{N}=8$ ). Em relação à frequência de pesquisa realizada pelo assessor na BDJur para realização do seu trabalho no Tribunal, sobressaiu-se a busca de "doutrina" realizada "frequentemente" por 14 assessores. Por outro lado, há assessores que têm como fonte de pesquisa, o acervo da biblioteca particular do ministro existente nos gabinetes ou, a própria coleção de livros nos seus locais de trabalho. A pesquisa aos "atos normativos" do Tribunal é "frequentemente" realizada por sete assessores, enquanto seis a fazem "raramente", inferindo-se que isto provavelmente esteja relacionado a casos, cuja matéria jurídica em pauta não fosse fundamentada no trabalho do assessor, por atos normativos exarados. pelo STJ, Enfam, e TFR. Notase que a busca por "jurisprudência comentada publicada em livro/revista" "raramente" é pesquisada por nove assessores, confirmando informação obtida na Seção de Biblioteca Digital e na Seção de Pesquisa da Biblioteca, que este tipo de pesquisa é realizado principalmente no Sistema de Jurisprudência do STJ, fato também constatado nas respostas de campo aberto da questão n.11 do questionário eletrônico (ver Tabela 11). Este é um padrão recorrente nas três áreas do direito de atuação dos gabinetes, evidenciado no cruzamento entre a frequência de busca à informação jurídica realizada na BDJur para atuação profissional dos assessores em relação às áreas do direito de competência jurisdicional das Seções e Turmas do STJ das quais os gabinetes fazem parte.

No que tange ao grau de importância da informação jurídica - doutrina, legislação, jurisprudência comentada publicada em livro/revista e parecer -, para o desempenho da atividade profissional do assessor, pesquisada nas coleções da BDJur, destacou-se o acervo de "doutrina" como o tipo de informação "muito importante" e "importante", seguida pela pesquisa no acervo de "legislação", enquanto "jurisprudência comentada" publicada na literatura foi considerado menos importante. Por outro lado, os "pareceres" não foram considerados "muito 
importantes" por nenhum assessor na realização do seu trabalho no Tribunal, além de ser considerado "pouco importante" para sete assessores e "nada importante" para três assessores. Realizando-se o cruzamento entre o grau de importância da informação jurídica na BDJur, atribuído pelo assessor para realização do seu trabalho, em relação às áreas do direito público e previdenciário; direito privado; e direito penal, os resultados evidenciaram que, "doutrina" foi considerada "muito importante" nas três áreas de trabalho com destaque para a área do direito penal. Por sua vez, "legislação" foi considerada "muito importante" pelos assessores que trabalham com o direito público e previdenciário e direito privado, e "importante" para aqueles do direito penal. "Jurisprudência comentada publicada em livros/revistas", foi considerada "importante" entre os assessores do direito público e previdenciário", Cabe acrescentar que este cruzamento possibilitou observar que, embora os "pareceres" fossem considerados menos importantes para a realização do trabalho por dez assessores, não consistindo em coleção específica na BDJur, contrariamente, eles foram considerados por 12 assessores como "importantes" para a realização do seu trabalho.

Constatou-se que as coleções da BDJur são frequentemente usadas por 21 assessores respondentes, em quatro funções relacionadas ao trabalho do assessor, destacando-se a finalidade de realizar "análise e fundamentação da matéria do processo judicial", conforme foi também confirmado nas entrevistas, no trabalho de análise da matéria e redação da proposta de voto a ser submetido ao ministro. A aplicação do conteúdo da informação buscada na BDJur para "citação no processo judicial" obteve menores índices de aplicação, com nove respondentes declarando nunca aplicarem esta informação com este fim. Verificou-se, também que seis e nove assessores, respectivamente, utilizam a informação disponível na BDJur no processo cognitivo de busca à informação, para "sanar dúvida sobre questão específica do direito" e para "atualização sobre legislação específica", duas situações que caracterizam os momentos do trinômio operacional do Sense-Making nas etapas de situação, lacuna e uso da informação.

No que se refere à necessidade de busca e uso da informação jurídica na BDJur para o desempenho do trabalho, os indicadores de valor "alto" e "médio atribuídos à BDJur, obtiveram ocorrências idênticas para sete assessores, em ambos os casos. Para três assessores este conceito foi "muito alto", inferindo-se que trata-se daqueles usuários que utilizam muito o conteúdo das coleções da BDJur, considerando-a como fonte principal na procura por tema específico do direito. Por outro lado, o indicador "baixo" atribuído por cinco assessores, pode indicar que a BDJur não está incluída no comportamento e na estratégia principal de busca à informação jurídica destes assessores.

No que tange à busca da informação na BDJur, 40,9\% dos assessores $(\mathrm{N}=9)$ relataram ter buscado informação na BDJur e não a encontraram. Destes, dois terços $(\mathrm{N}=6)$ são assessores que atuam com processos na área do direito privado. Entre esses casos de informação não encontrada houve relatos de falta de informações sobre doutrinas e comentários doutrinários, portarias específicas dos Tribunais de Justiça Estaduais, dificuldade de acesso e outros.

Dentre as principais barreiras apontadas no acesso à informação jurídica na BDJur destacou-se 40,9\% ( $N=9)$ de respostas para 'doutrina não encontrada'; $18,2 \%$ $(\mathrm{N}=4)$, para 'doutrina não relevante'; enquanto, inversamente, $27,3 \% \quad(\mathrm{~N}=6)$ declararam não ter encontrado "nenhuma" dificuldade neste sentido. Por sua vez, a regularidade da realização de buscas na BDJur pelos assessores, ocorre com 
frequência geralmente irregular, sendo que: quatro assessores responderam realizar buscas semanalmente; 5 , mensalmente; e 13, sem regularidade específica.

Os assessores manifestaram-se positivamente sobre o grau de satisfação em relação ao conteúdo das páginas da BDJur, registrando-se que $77,3 \%$ dos respondentes $(\mathrm{N}=17)$ declararam-se satisfeitos ou muito satisfeitos. Também, $72,7 \%$ $(\mathrm{N}=16)$ consideram que os textos explicativos existentes na BDJur direcionam a pesquisa no acesso à informação. Em referência ao tempo de resposta das pesquisas, $63,6 \% \mathrm{~N}=14$ ) dos respondentes julgaram que é "razoável", enquanto $36,4 \%(\mathrm{~N}=8)$ julgaram como "rápido". Ninguém considerou que o tempo de resposta das pesquisas é "frequentemente" ou "eventualmente lento".

Nas questões de resposta de campo aberto foram mencionadas as dificuldades encontradas no acesso à informação jurídica principalmente em função de senha e login e de informação jurídica não encontrada como comentários à legislação específica ou doutrina antiga. Dentre as sugestões dos usuários para melhoria da BDJur destacam-se a necessidade de ampliar a divulgação sobre o potencial e conteúdo da BDJur, bem como de realizar treinamento do usuário. A identificação dos conteúdos de acesso público e restrito foi apontada como facilitador de acesso à informação. Notou-se, ainda, a insatisfação de alguns usuários quanto a situações de dificuldade de acesso à BDJur fora do prédio do

STJ, e com a repetição de senha para acesso a conteúdos Por último, foi acrescentada a necessidade de aumento da coleção de "doutrina", fator de suma importância considerando-se que no direito ocorre o crescimento vertiginoso e incessante do conhecimento jurídico

Cabe acrescentar que o questionário eletrônico e as entrevistas foram realizados no decorrer do período de utilização e vivência do usuário com a interface de busca na BDJur, anterior à disponibilizada a partir de novembro de 2015, no site do STJ. Trata-se da interface da BDJur utilizada pelos assessores no decorrer de um período de sete anos, Neste sentido, os resultados desta pesquisa poderão ser fonte de informação para os gestores da BDJur na elaboração de análises comparativas e verificação da solução ou, persistência de problemas ou dificuldades anteriormente elencados pelos assessores de ministro, com a implantação da nova versão. A disponibilização da nova interface foi realizada em concomitância com a conclusão e fechamento desta pesquisa, destacando-se como melhorias alcançadas, divulgadas pela Seção de Biblioteca Digital no site do STJ: layout mais intuitivo, fácil de navegar e com melhor apresentação dos conteúdos; novas configurações e campos de pesquisa, que oferecem maior precisão na recuperação dos conteúdos; correção de problemas com login e de outros erros apresentados na versão anterior; e, interação com o usuário, com o fornecimento de formulário de avaliação da BDJur e envio de sugestões.

\subsection{Análise das entrevistas}

O padrão de comportamento do usuário na busca e uso da BDJur foi extraído das ocorrências dos incidentes críticos positivos e negativos, identificados com a análise das entrevistas, realizadas com a aplicação do Método Micro moment time line interview. 


\subsubsection{Padrão geral dos incidentes críticos}

A marcação dos incidentes críticos possibilitou a obtenção de padrões positivos e negativos em relação ao trinômio operacional do Sense-making (situação, lacuna e uso) na BDJur como produto de informação jurídica. No padrão positivo foi realmente destacada a importância da BDJur no trabalho do assessor de fundamentação de matéria jurídica relacionada à atividade judicante do Tribunal. Cabe acrescentar que, a despeito dos assessores entrevistados terem sido selecionados dentre aqueles que conheciam e utilizavam a BDJur, acrescenta-se que na resposta ao questionário eletrônico observou-se que havia assessores que não utilizavam a BDJur, o que poderia ser incluído como padrão negativo, sendo detectado uma demanda reprimida, devido a constatação de fatos como a menor frequência de uso da BDJur, ou o desconhecimento da BDJur por parte de alguns assessores, ou ainda, o uso de outras fontes de pesquisa existentes nos próprios gabinetes e nos acervos particulares dos assessores.

\section{- Padrão positivo do momento "Situação"}

Com a realização da entrevista foi constatado a presença do padrão positivo situação correspondente a real necessidade de buscar informação jurídica em doutrina, publicada em livros e artigos de periódico, legislação e atos administrativos do STJ, disponíveis na BDJur, no trabalho de assessor de ministro, relativo à atividade judicante do STJ.

\section{- Padrão negativo do momento "Situação"}

Não foi identificado um padrão negativo no momento "situação"

\section{- Padrão positivo do momento "Lacuna”}

Os usuários declararam que tiveram sucesso e estão satisfeitos em encontrar a informação que buscaram na BDJur; constataram que o insucesso na busca ocorre devido à estratégia inadequada de pesquisa individual; confirmaram que obtém sucesso seja quando a procura é feita por data, número e argumento; confirmaram a velocidade de resposta; escolhem a BDJur por saber encontrar a informação e racionalizar o trabalho de busca; constatam a existência, ou não, de doutrina publicada sobre temas específicos da área do Direito, com o resultado negativo da pesquisa na BDJur; existe muitas resoluções no que diz respeito a julgamento de processos repetitivos, que sabem encontrar na BDJur; relataram a capacidade de alcance e bom funcionamento da BDJur em regiões do interior do país; assinalaram que a busca da informação jurídica na BDJur, possibilita encontrar doutrina atualizada, pertinente e consistente sobre o assunto buscado, de autores renomados da área do Direito; no trabalho de elaboração do modelo de voto, busca na BDJur encontrar formas de interpretar legislação e, doutrinadores da área do direito que tenham a mesma linha de entendimento e posicionamento do ministro sobre determinado tema; a busca na BDJur possibilita encontrar temas pouco explorados no STJ ou, escassamente publicados na área do Direito; confirmaram priorizar ou concentrar suas buscas à informação jurídica na BDJur, em relação à outras bases de dados externas ao Tribunal; consideram a BDJur como melhor lugar para pesquisar questões doutrinárias e institucionais e, como canal fácil de pesquisa que apresenta solução com agilidade. 


\section{- Padrão negativo do momento "Lacuna"}

Em geral, não foi identificado um padrão negativo no momento "lacuna". Contudo foram feitas observações sobre necessidade de aprimorar a indexação do conteúdo e a representação dos assuntos da doutrina publicada em livros e artigos de periódicos da BDJur; e, a dificuldade de pesquisa na interface da BDJur por usuários de maior faixa etária, incluindo o usuário externo e ministro do Tribunal.

- Padrão positivo do momento "Uso"

O maior grau de satisfação dos assessores de ministro apontado com o uso da informação envolveu: o uso de uma tese mais atualizada, um argumento que não tinha pensado anteriormente, na elaboração da matéria principal do voto; fundamentar a linha de pensamento sobre o tema com nomes de autores renomados, jurisconsultos e juristas na doutrina da área do Direito; para corroborar na linha de entendimento da matéria; encontrar nova diretriz no encaminhamento da matéria; saber que encontrará quantidade de doutrina que necessita para realizar seu trabalho; solucionar o sentido do voto; fundamentar uma decisão e ideia prédeterminada; realmente sanar uma dúvida; fazer uma citação; reforçar e desenvolver um argumento; no trabalho de elaboração do modelo de voto do ministro, encontrar na BDJur, formas de interpretar legislação e, doutrinadores da área do direito com a mesma linha de entendimento e posicionamento do ministro sobre determinado tema, aumentando o respaldo, significando que não se trata de uma posição isolada, além de atribuir mais valor; foi considerada positiva a comprovação do pressuposto inicial de que não havia doutrina publicada sobre um tema específico, na doutrina na área do Direito, com a pesquisa desse assunto na BDJur.

\section{- Padrão negativo do momento "Uso"}

Em geral, não foi identificado um padrão negativo no momento "uso". Entretanto, foi relatado como negativo, não poder fazer uso da informação devido à inexistência de abordagem de um determinado assunto na área do Direito.

\subsection{Análise da usabilidade (Heurísticas de Nielsen)}

A análise da usabilidade incluiu aspectos das dez heurísticas ou princípios de usabilidade, possibilitando ao assessor expressar circunstâncias de interface de busca e navegação na BDJur, como produto de informação jurídica disponível na Web. De acordo com Nielsen (2005a, 2005b) apud Rocha e Souza (2011, p. 26), "os próprios usuários" podem realizar esta análise, resultando na participação destes não somente na análise quantitativa e qualitativa, mas também na análise de usabilidade, corroborando que, nos três procedimentos da Metodologia do IBICT, o ator principal foi o assessor de ministro. São apresentados aspectos, referentes a nove heurísticas, sobre a interface homem-máquina elencados na questão 26 do questionário eletrônico, enviado aos assessores de ministro dos gabinetes do STJ. Nesta terceira abordagem da Metodologia do IBICT, foi solicitado aos assessores de ministro que respondessem o que consideravam verdadeiro na interface da BDJur, de acordo com sua vivência de interação de busca e acesso à informação, em relação a aspectos de cada uma das nove heurísticas, que compõem o checklist elaborado por Rocha e Souza (2011), baseado nas heurísticas de Jakob Nielsen ( ). Neste sentido, foi seguido, nos moldes da Metodologia do IBICT, o agrupamento de duas heurísticas que tratavam do mesmo tema, em uma só: controle de erros pelo 
usuário e previsão de erros, resultando no número de nove heurísticas, do total de dez. (ver Anexo 8)

Cabe acrescentar, que durante a realização do pré-teste do questionário eletrônico com os bibliotecários e o chefe da Seção de Biblioteca Digital Jurídica do STJ, foi recomendado que as alternativas da questão $n$. 26 fossem redigidas de forma suscinta e clara, sobre o significado e conteúdo de cada heurística. Seguindose esta orientação, os enunciados das heurísticas do checklist de Rocha e Souza (2011, p 76-80) foram adequados para a realidade institucional do STJ e, focados para o contexto de trabalho dos assessores de ministro, visando facilitar a compreensão sobre as características de cada heurística, tornando viável a análise de aspectos técnicos da interação com a BDJur, pelos assessores de ministro, contemplando e preservando, contudo, o conteúdo original das heurísticas. A seguir, são apresentados os enunciados das nove heurísticas do checklist elaborado por Rocha e Souza (2011, p. 76-80) na Metodologia do IBICT, seguidos dos enunciados elaborados na questão 26 do questionário eletrônico enviado para os assessores de ministro nos gabinetes:

Heurística 1: Clareza e visibilidade do status do sistema ou site - O sistema deve informar o que ele oferece, quais as suas características temporais, especiais e temáticas, para não criar falsas expectativas.

- Apresenta clareza nas informações gerais quanto à navegação e sobre o conteúdo disponibilizado.

Heurística 2 - Linguagem - A linguagem do sistema deve ser clara, objetiva, utilizando conceitos, palavras e frases familiares para o usuário, não utilizando jargões de sistema.

- Utiliza linguagem objetiva com uso de palavras, frases e conceitos exatos.

Heurística 3 - Autonomia e controle do usuário - o sistema deve permitir que o usuário tenha autonomia para iniciar, interromper, continuar, desfazer, corrigir as ações por ele comandadas.

- Possibilita ao usuário autonomia para iniciar, interromper, continuar, desfazer e corrigir as ações realizadas no sistema.

Heurística 4 - Padronização e consistência - Os elementos de interface de um sistema ou portal devem seguir o mesmo padrão de localização, formato e estética em suas diversas páginas.

- Apresenta padronização e identidade visual em todas as páginas do sistema.

Heurística 5 - Prevenção de erros - O sistema deve ser desenvolvido para evitar ou reduzir o número de erros no uso de uma interface. Quando ocorrerem, o sistema deve emitir mensagens de erros claras informando onde ocorre o problema orientando o usuário como reparar o erro.

- As mensagens de erro exibidas pelo sistema são explicativas e objetivas.

Heurística 6 - Reconhecimento em lugar de lembrança - o sistema deve minimizar a sobrecarga de memória do usuário, desenvolvendo a interface Web com relações de uma tela para outra facilmente reconhecíveis.

- A navegabilidade facilita a conexão e interação entre as páginas do sistema. 
Heurística 7 - Flexibilidade e eficiência - O sistema deve ser desenvolvido de forma a atender os diversos níveis de experiência dos usuários.

- Permite a realização de pesquisas conforme diferentes níveis de experiência do usuário.

Heurística 8 - Estética e minimalismo - Os elementos apresentados devem ser realmente necessários para atender a finalidade da interface, utilizando-se cores apenas para categorizar, diferenciar e destacar, e não para dar informação, especialmente a informação quantitativa, observando-se o uso máximo de 5 a 7 cores diferentes, com o objetivo de melhorar a acuidade visual do usuário.

- Utiliza cores adequadas nas páginas e textos e, legibilidade quanto ao tamanho das letras, texto e títulos.

Heurística 9 - Ajuda e documentação - A operacionalização do sistema deve ser autoexplicativa, sem necessidade do auxílio de documentação ou do sistema de ajuda, utilizando os recursos de interface gráfica, como balões de ajuda, para explicar como realizar uma operação.

- Permite navegação auto-explicativa ao usuário, exibindo ajuda quando necessário para realizar uma operação.

A Tabela 31 reúne os dados referentes à análise heurística do grau de facilidade do relacionamento do assessor de ministro com a interface da BDJur. Constatou-se que 20 assessores responderam a questão selecionando aquelas heurísticas com as quais concordavam sobre a interface da BDJur, confirmando as características e aspectos técnicos elencados nas heurísticas, na interação com a BDJur;

Tabela 31: Heurísticas em relação à facilidade de relacionamento do usuário com a interface da BDJur

\begin{tabular}{|c|c|}
\hline \multirow{2}{*}{$\begin{array}{l}\text { Opções de resposta } \\
26 . H 1 \text { - Apresenta clareza nas informações gerais quanto a navegação e sobre o conteúdo } \\
\text { disponibilizado. }\end{array}$} & Respostas \\
\hline & $59,09 \%$ \\
\hline 26.H2 - Utiliza linguagem objetiva com uso de palavras, frases e conceitos exatos. & $59,09 \%$ \\
\hline $\begin{array}{l}\text { 26.H3 - Possibilita autonomia ao usuário para iniciar, interromper, continuar, desfazer e corrigir } \\
\text { açóes realizadas no sistema. }\end{array}$ & $59,09 \%$ \\
\hline 26.H4 - Apresenta padronização e identidade visual em todas as páginas do sistema. & $50,00 \%$ \\
\hline 26.H5 - As mensagens de erros exibidas pelo sistema são explicativas e objetivas. & $13,64 \%$ \\
\hline 26.H6 - A navegabilidade facilita a conexão e interação entre as páginas do sistema. & $\mathbf{3 6}, \mathbf{3 6} \%$ \\
\hline $\begin{array}{l}26 . \mathrm{H} 7 \text { - Permite a realização de pesquisas conforme diferentes niveis de experiencia dos } \\
\text { usuários. }\end{array}$ & $40,91 \%$ \\
\hline $\begin{array}{l}26 . \text { H8 - Utiliza cores adequadas nas páginas e textos e. legibilidade quanto ao tamanho das } \\
\text { letras, textos e títulos. }\end{array}$ & $\mathbf{3 6}, \mathbf{3 6} \%$ \\
\hline $\begin{array}{l}26 . H 9 \text { - Permite navegação autoexplicativa ao usuário, exibindo ajuda quando necessária para } \\
\text { realizar uma operação. }\end{array}$ & $27,27 \%$ \\
\hline 26.10 - Outra. Por favor especifique: & $\mathbf{9 , 0 9 \%}$ \\
\hline$=$ respo & \\
\hline
\end{tabular}

Conforme se observa, dentre as heurísticas que obtiveram maior índice positivo de resultados os usuários consideraram que a BDJur: "apresenta clareza nas informações gerais quanto à navegação e sobre o conteúdo disponibilizado"; $(59,1 \%, N=13)$; "utiliza linguagem objetiva com uso de palavras, frases e conceitos exatos" (59,1\%, $\mathrm{N}=13)$; "possibilita ao usuário autonomia para iniciar, interromper, continuar, desfazer e corrigir as ações realizadas no sistema" (59,1\%, N=13); e, "apresenta padronização e identidade visual" $(50 \%, \mathrm{~N}=11)$. Os pontos menos bem avaliados referem-se às "mensagens de erro exibidas pelo sistema" $(13,6 \%, N=3)$ e 
a "navegação autoexplicativa" (27,3\%, N=6). Na opção, "Outra. Por favor, especifique", do questionário, dois usuários não selecionaram nenhuma heurística: o primeiro respondeu que "pouco utiliza" a BDJur; enquanto o segundo, respondeu que "não realiza pessoalmente a pesquisa". Estes resultados expressos na Figura 43 evidenciam o reconhecimento dos padrões de avaliação das nove heurísticas na interface da BDJur, incluindo aspectos técnicos e tecnológicos como padrões ideais da interface homem-máquina, sob a perspectiva dos assessores.

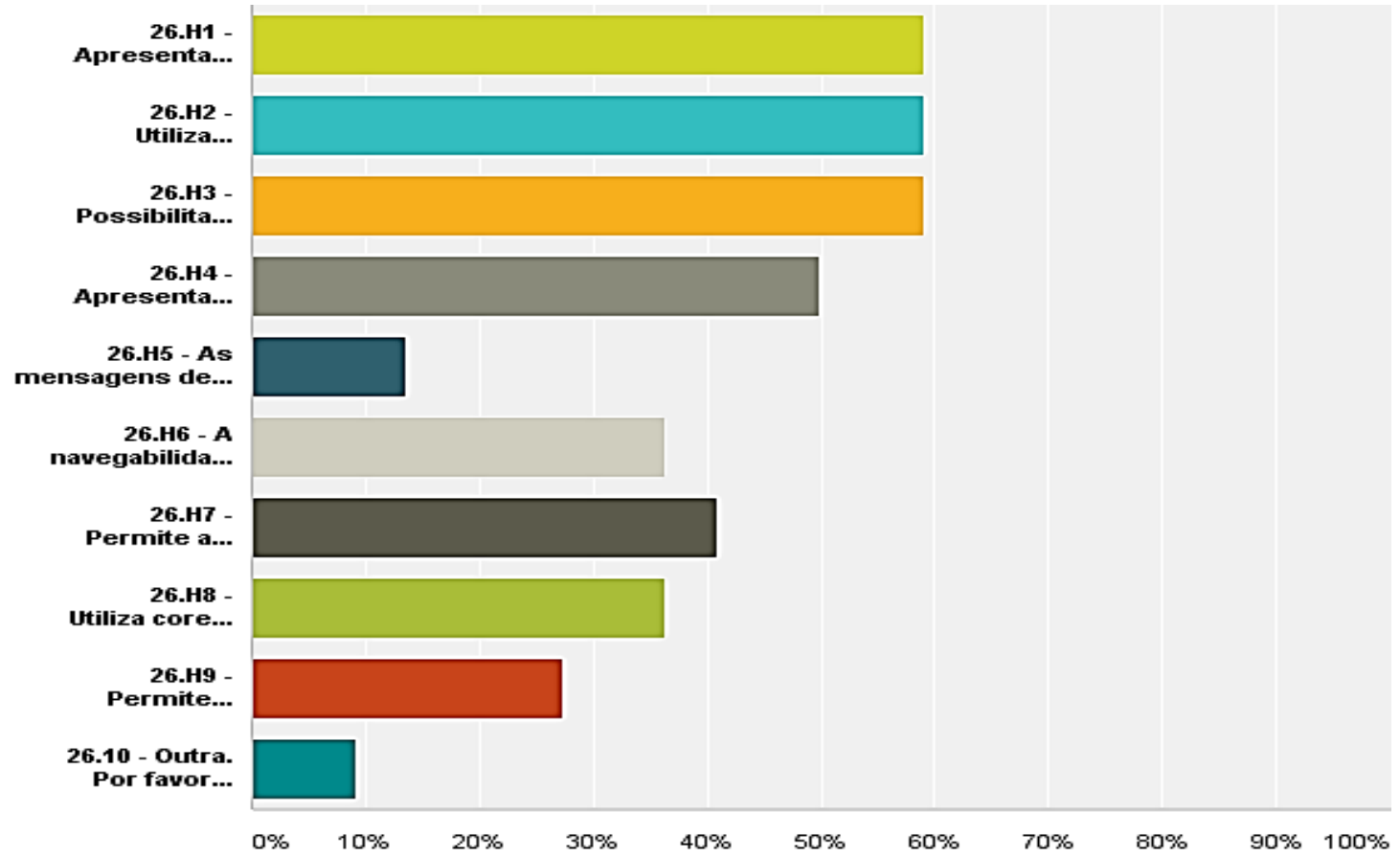

Fig. 43 - Análise heurística no relacionamento do usuário com a interface da BDJur

\subsection{Tipologia de avaliação da BDJur realizada pela Biblioteca do STJ}

De acordo com informações fonecidas pela Seção de Biblioteca Digital (2015), foi realizado um estudo de usuários, em maio de 2007, pela então, Coordenadoria de Biblioteca Digital, disponibilizando-se um questionário na intranet, para saber o nível de satisfação do usuário com a BDJur. Neste período a BDJur obteve "um índice geral de satisfação de 84\%". Entretanto, o setor considera importante a avaliação contínua no processo de desenvolvimento da BDJur afirmando que: "a BDJur deve realizar, de forma sistemática, estudos similares". Cunha (2015, p. 8) ao prefaciar o livro sobre a BDJur lançado pela Biblioteca do STJ, assinala que cabe investigar o que ainda não foi ofertado ao usuário na BDJur além de, tentar identificar os não usuários e as razões pelas quais essas pessoas não utilizam o potencial informacional da BDJur. Segundo lembra Cunha (2015, p. 9) no prefácio deste livro, no início da implantação de bibliotecas digitais as ações estavam focadas em possibilitar novos usos do conteúdo antigo. No entanto, lembra que isto é exatamente o oposto da ideia de biblioteca digital. Contudo este autor defende que, quando a produção da informação digital alcançar altos níveis, então, a biblioteca digital terá atingido a maturidade e reconhecimento público.

De acordo com a Seção de Biblioteca Digital aspectos de avaliação da BDJur estão relacionados com a interação com o usuário, conforme relatado a 
seguir: "A melhoria da interação com o usuário é um propósito da nova BDJur, disponibilizada em novembro de 2015. Assim, foram criadas três funcionalidades que oferecem informações a respeito do repositório e, visam coletar opiniões para o aperfeiçoamento da BDJur":

Avalie a BDJur: formulário eletrônico de avaliação que tem como objetivo coletar informações acerca do uso da biblioteca digital, a fim de apontar o grau de satisfação do usuário e identificar as suas necessidades de informação. As perguntas do questionário estão relacionadas à eficácia das buscas realizadas, à utilidade dos conteúdos encontrados, ao grau de dificuldade da pesquisa, aos tipos de usuário e ao nível de qualidade dos produtos e serviços oferecidos. Ademais possui um campo de preenchimento livre, para coleta de sugestões e críticas.

Estatísticas: relatório estatístico que apresenta o total de acessos por tipo de usuário (interno e externo), tanto geral quanto das comunidades e coleções.

Perguntas frequentes: lista de perguntas mais frequentes sobre a BDJur que visa esclarecer as principais dúvidas dos usuários.

(BRASIL. SUPERIOR TRIBUNAL DE JUSTIÇA, 2015, p.17-18 )

Constata-se que estas funcionalidades representam novas alternativas relativas ao processo de avaliação da BDJur, diretamente relacionadas à motivação e disponibilidade do usuário em responder, espontaneamente, ao formulário disponível na página. Contudo, conforme visto na literatura deste trabalho, é necessário também considerar no processo de avaliação do produto de informação disponível na Web, a iniciativa da própria instituição em realizar com regularidade, a avaliação do produto de informação, explorando em profundidade as possibilidades abrangentes e eficazes de técnicas e metodologias de avaliação, mormente aquelas com enfoque no usuário.

\subsection{Análise do Pressuposto}

O estudo da problemática tratada nesta pesquisa apresentou como pressuposto que: "a utilização de técnicas e metodologias adequadas para avaliar produtos de informação é fundamental para dar visibilidade à Biblioteca". Para verificação desta assertiva, na parte final do questionário, a questão n. 27, visou analisar a existência, ou não, de correspondência entre o pressuposto da pesquisa e a repercussão do processo de avaliação da BDJur, na Biblioteca do STJ, segundo o ponto de vista do assessor de ministro. Partindo-se da linha de raciocínio contida no pressuposto, e a possível implicação na forma como a Biblioteca do STJ é vista pelo assessor de ministro, foi indagado se: a) A interação constante da BDJur com o usuário possibilita o aprimoramento da interface, funcionalidade e conteúdo apresentado; b) É importante que a BDJur realize avaliação periódica das críticas e sugestões dos usuários encaminhadas por e-mail; c) Um formulário eletrônico permanente de avaliação disponibilizado na página da BDJur contribui para aprimorar os serviços oferecidos; d) A utilização de técnicas e metodologias adequadas para avaliar produtos de informação é fundamental para dar visibilidade à Biblioteca Na pergunta foi incluída, a opção de resposta aberta.

No resultado expresso na Figura 44 os maiores índices de resposta apontaram que $77,27 \%$ dos respondentes considerou importante que a Seção de Biblioteca Digital avaliasse as sugestões e críticas enviadas por e-mail pelos assessores; Ao passo que, 72,73\% "concordaram" e 18,18\% "concordaram parcialmente", com o enunciado da opção D da questão 27, que indagava sobre o 
pressuposto desta pesquisa de que "a utilização de técnicas e metodologias adequadas para avaliar produtos de informação é fundamental para dar visibilidade à biblioteca". Estes dados revelam que o pressuposto foi satisfatoriamente verificado, no caso da BDJur, com o reconhecimento pelo assessor de que o emprego de técnicas e metodologias adequadas para avaliar produtos de informação pode contribuir positivamente para ampliar a visibilidade da Biblioteca. Neste sentido, os objetivos e o pressuposto da pesquisa possibilitaram responder à pergunta de como os produtos de informação, da Biblioteca do STJ concorrem para subsidiar a fundamentação doutrinária e legislativa da atividade judicante, conforme a necessidade específica de informação jurídica.

Quanto à opção c da questão 27 referente à contribuição de formulário permanente de avaliação disponibilizado na página da BDJur para aprimorar os serviços oferecidos, o percentual dos respondentes que "concordaram" foi de 59,09" e daqueles que "concordaram parcialmente" foi de 27,27\%. Nota-se, também, o

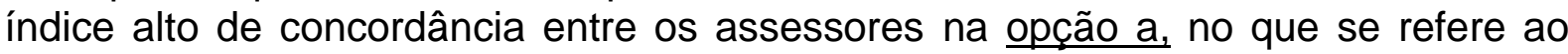
fato da interação constante da BDJur com o usuário possibilitar o aprimoramento da interface, funcionalidade e conteúdo conforme ilustra a Figura 44:

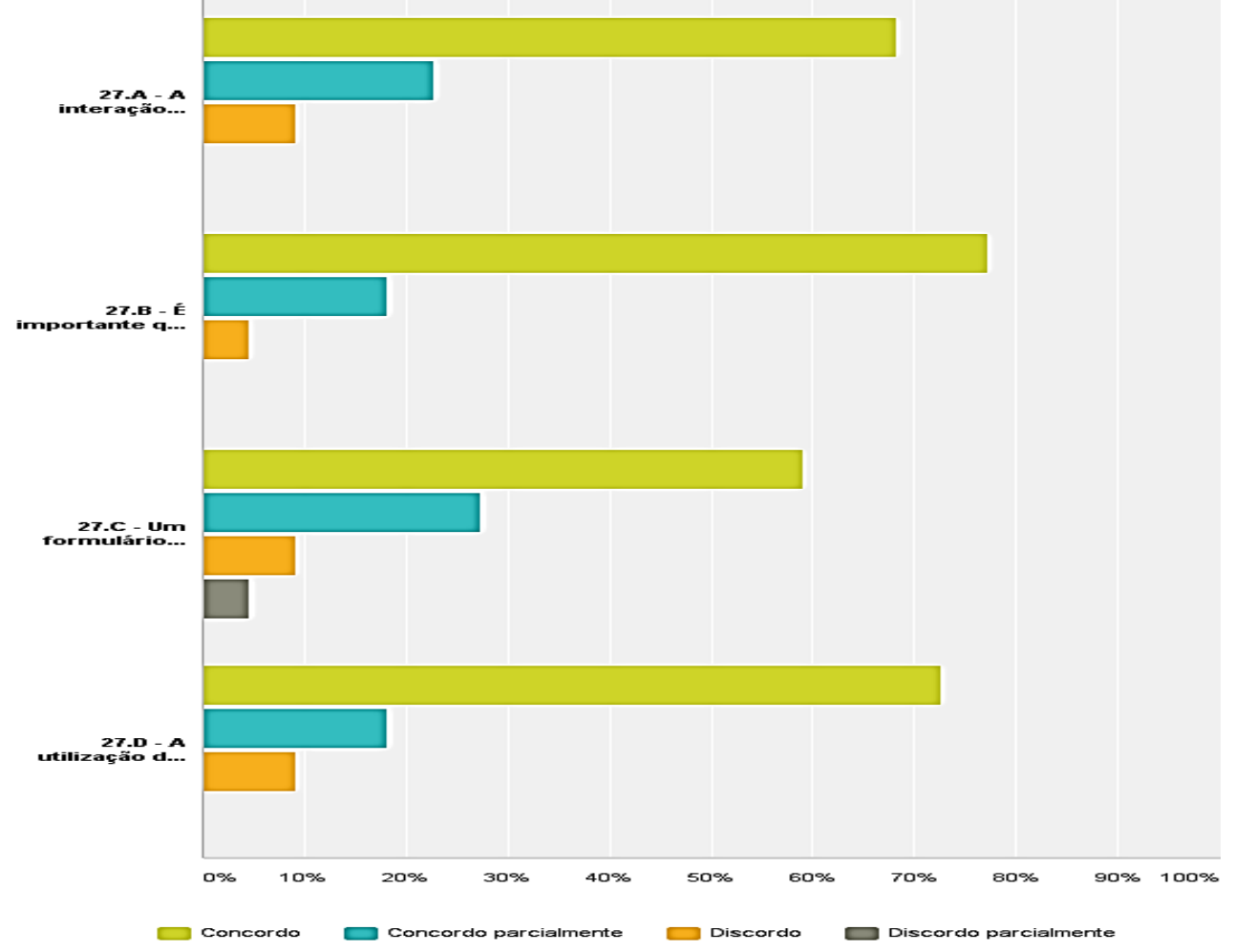

Fig. 44- Importância do processo de avaliação da BDJur 
Tabela 32 - Importância do processo de avaliação da BDJur

Q27: No que se refere ao processo de avaliação da BDJur pelo usuário do STJ, como produto de informação jurídica da Biblioteca, você considera que

\begin{tabular}{|c|c|c|c|c|c|}
\hline & Concordo & $\begin{array}{l}\text { Concordo } \\
\text { parcialmente }\end{array}$ & Discordo & $\begin{array}{l}\text { Discordo } \\
\text { parcialmente }\end{array}$ & Total \\
\hline $\begin{array}{l}\text { 27.A - A interação constante da } \\
\text { BDJur com o usuário possibilita o } \\
\text { aprimoramento da interface, } \\
\text { funcionalidade e conteúdo } \\
\text { apresentado }\end{array}$ & $\begin{array}{r}\mathbf{6 8 , 1 8 \%} \\
15\end{array}$ & $\begin{array}{r}22,73 \% \\
5\end{array}$ & $\begin{array}{r}9,09 \% \\
2\end{array}$ & $\begin{array}{r}\mathbf{0 , 0 0} \% \\
0\end{array}$ & 22 \\
\hline $\begin{array}{l}\text { 27.B - É importante que a BDJur } \\
\text { realize avaliação periódica das } \\
\text { críticas e sugestốes dos usuários } \\
\text { encaminhadas por e-mail }\end{array}$ & $\begin{array}{r}77,27 \% \\
17\end{array}$ & $\begin{array}{r}18,18 \% \\
4\end{array}$ & $\begin{array}{r}4,55 \% \\
1\end{array}$ & $\begin{array}{r}0,00 \% \\
0\end{array}$ & 22 \\
\hline $\begin{array}{l}27 . C \text { - Um formulário eletrônico } \\
\text { permanente de avaliação } \\
\text { disponibilizado na página da BDJur } \\
\text { contribui para aprimorar os } \\
\text { serviços oferecidos }\end{array}$ & $\begin{array}{r}\mathbf{5 9 , 0 9 \%} \\
13\end{array}$ & $\begin{array}{r}27,27 \% \\
6\end{array}$ & $\begin{array}{r}9,09 \% \\
2\end{array}$ & $\begin{array}{r}4,55 \% \\
1\end{array}$ & 22 \\
\hline $\begin{array}{l}\text { 27.D - A utilização de técnicas e } \\
\text { metodologias adequadas para } \\
\text { avaliar a BDJur é fundamental para } \\
\text { dar visibilidade à Biblioteca }\end{array}$ & $\begin{array}{r}72,73 \% \\
16\end{array}$ & $\begin{array}{r}18,18 \% \\
4\end{array}$ & $\begin{array}{r}9,09 \% \\
2\end{array}$ & $\begin{array}{r}\mathbf{0 , 0 0} \% \\
0\end{array}$ & 22 \\
\hline
\end{tabular}

Outro ponto a destacar do pressuposto desta pesquisa é a contribuição da aplicação de metodologias de avaliação de produtos de informação para analisar características da BDJur como produto de informação disponível na Web, contemplando além de fatores específicos de uma biblioteca digital jurídica - como tempo e número de acesso, cobertura das coleções, qualidade do conteúdo e outros - fatores de comportamento informacional do usuário como a vivência de situações de necessidade de informação, os procedimento de busca e o valor da informação na tomada de decisão no trabalho do assessor. Para Lancaster (1996, p. 303): "frequentemente o valor da informação para o indivíduo é visto em termos da medida com que ela reduz a incerteza" E, para as organizações, este autor afirma que 0 valor da informação está relacionado à contribuição para o alcance dos seus objetivos junto à sociedade, fato verificado no trabalho do assessor de ministro, no que se refere à realização da atividade judicante do STJ na sociedade.

Ademais, se conhecer fatores intrínsecos ao desempenho de uma biblioteca digital é um pré-requisito para esforços de melhoria deste produto de informação, evidentemente, cada técnica ou metodologia de avaliação possui abordagens que enfocam determinados aspectos, priorizando o produto de informação ou o usuário. De modo mais amplo, Katter (1969, p. 36), lembra que planejamento e avaliação de produtos de informação estão intrinsecamente relacionados, uma vez que o planejamento e reestruturação de produtos baseiam-se em avaliações, assim como a avaliação é resultante de necessidades e objetivos do planejamento. Corroborando o pressuposto desta pesquisa a Seção de Biblioteca Digital considera que as alternativas de avaliação da BDJur, disponibilizadas na nova interface de 2015, contribuem para dar visibilidade à BDJur, o que refletirá diretamente na visibilidade da Biblioteca do STJ, conforme transparece na afirmativa: 
O crescimento do acervo aliado à qualidade e diversidade dos conteúdos armazenados ao longo desses dez anos fez com que a BDJur se tornasse um dos principais repositórios digitais jurídicos do Brasil. As melhorias apresentadas pela nova versão da BDJur contribuirão para a ampliação da visibilidade e aumento da quantidade de acessos ao repositório. (BRASIL. SUPERIOR TRIBUNAL DE JUSTIÇA, 2015, p. ) (grifo nosso)

Vale acrescentar que, a avaliação do produto de informação visa abordar com o trinômio de necessidade, busca e uso da informação, aspectos ambientais (o que, onde e quem) e causais (porque, como e quão bem), ultrapassando o foco nos custos, desempenho tecnológico e funcional, possibilitando o inter-relacionamento mais amplo destas e outras medidas. Neste sentido, a exploração de metodologias para realizar avaliação de produtos com maior número de requisitos, pode representar ponto estratégico de visibilidade para a Biblioteca do STJ

Por último, vale acrescentar o pensamento de Santos ... [et al] (2010, p.2) que ao indagar "como demonstrar a visibilidade da biblioteca na lógica da rede?", relaciona este fenômeno.ao processo de organização e disponibilização da informação na Web, "link principal entre a biblioteca física e a internet". Para Santos ... [et al] (2010, p.7) isto está ligado, dentro do gerenciamento da biblioteca, aos "processos de trabalho" do bibliotecário. Direcionando tal pensamento para a avalição de produtos de informação, pode-se compreender que, como parte do processo de trabalho nas bibliotecas, a utilização de técnicas e metodologias adequadas para avaliar produtos de informação pode contribuir na visibilidade da biblioteca"

\subsection{Considerações sobre a aplicação da Metodologia do lbict na análise da BDJur}

A aplicação da Metodologia do IBICT nesta pesquisa consistiu no desafio de congregar o interesse maior de examinar um instrumental - o qual combina, na sua estrutura operacional, métodos e técnicas de avaliação consolidadas na literatura de diversas áreas do conhecimento - que possibilita avaliar, de forma global, o desempenho com a oferta de produtos e serviços de informação, ou seja, a contrapartida da Biblioteca do STJ na comunidade jurídica e sociedade, ao propósito de uma pesquisa científica de análise específica, cujos procedimentos metodológicos incidem sobre parte do sistema composto de usuários, produtos e serviços de informação jurídica, na realidade do STJ. Nos domínios da pesquisa científica, tal trajetória sistematizada pode tanto significar imergir numa realidade ou situação específica, visando compreender determinadas particularidades, como depreender do resultado obtido, a compreensão extensiva e generalizável à totalidade da situação.

Neste sentido, o emprego da Metodologia do IBICT nesta pesquisa, mostrouse muito profícuo, possibilitando conhecer com maior nível de detalhamento, em relação a outras metodologias de avaliação, a realidade de trabalho e o desempenho profissional do assessor de ministro do STJ, em relação à busca de informação jurídica na BDJur, para fundamentação da atividade judicante. Naturalmente, a aplicação extensiva da Metodologia do IBICT aos demais produtos e serviços da Biblioteca, bem como a outros usuários internos e externos, pode ampliar, consideravelmente, a base de conhecimento acumulada na Biblioteca, ao longo de mais de meio século de existência, tanto sobre a necessidade de informação e o comportamento informacional do usuário operador do direito, como 
sobre a adequação da oferta de produtos e serviços à real necessidade de informação jurídica destes usuários na sociedade. Outro ponto importante, é a possibilidade de sistematizar tanto o novo conhecimento obtido com a aplicação extensiva da Metodologia a outros produtos e serviços de informação da Biblioteca, como também o conhecimento tácito adquirido por bibliotecários na Biblioteca, ao longo do tempo, sobre os usuários,

Cabe mencionar que, a aplicação da Metodologia no estudo sobre a necessidade, busca e uso da informação do assessor de ministro, pode ser consideravelmente ampliada, contemplando outros assessores de ministro, somando-se resultados àqueles obtidos com a realização desta pesquisa. Isto porque, além de haver outros assessores trabalhando nos gabinetes, ocorreu o acréscimo de cargos de assessor de ministro, durante a realização desta pesquisa, acontecendo ainda, mudanças na ocupação do cargo de assessor, em função da substituição de ministros que se aposentam ou assumem a presidência e vicepresidência do Tribunal. Neste aspecto, cabe destacar que, no estudo preliminar da pesquisa sobre a realidade de trabalho do assessor, foram feitos contatos informais e entrevistas iniciais com assessores e, com bibliotecários que lidam com este usuário na demanda de pesquisas jurídicas, percebendo-se na ocasião, que as exigências do cargo e o rítmo de trabalho do assessor podem interferir no índice de participação deste, em pesquisas de avaliação. Considerou-se principalmente as experiências anteriores de estudos de usuário sobre produtos e serviços de informação realizadas pela Biblioteca do STJ, com resultado de baixo índice de resposta. Isto foi, de fato, constatado após o envio do questionário desta pesquisa, sendo necessário entrar em contato com alguns assessores, solicitando a resposta do mesmo. Tal fato pode estar relacionado à necessidade de sensibilizar o usuário, de modo geral, sobre a importância do processo de avaliação dos produtos e serviços de informação jurídica e, neste sentido, aplicar metodologias que inovem na aproximação e diálogo entre biblioteca e usuário.

Outro ponto a destacar, é que a realização das entrevistas na abordagem qualitativa da Metodologia do IBICT também pode encontrar desafio similar, em virtude de haver assessores que não recordam o caso de necessidade, busca e uso da informação indispensável para caracterizar a vivência completa de sucesso ou insucesso na recuperação da informação demandada. Tal fato, provavelmente, pode estar associado à quantidade de informação pesquisada pelo assessor constantemente, tornando impossível memorizar todo o processo, de forma a descrevê-lo integralmente. Aqui também está presente a barreira do tempo disponível, além de outras relacionadas à motivação e interesse em participar da entrevista, não obstante a colaboração de algus assessores neste sentido. No caso desta pesquisa, foi constatada essa situação em relação à realização das entrevistas, não sendo possível a apresentação em forma de porcentagem, dos padrões positivos e negativos do uso da BDJur, devido ao número de entrevistas que efetivamente ocorreram, ser menor que o recomendado pela Metodologia do IBICT, para quantificação do percentual dos resultados. Não obstante esta dificuldade, a pesquisa teve êxito na identificação de padrões reais e significativos, positivos e negativos, presentes nos momentos 'situação', 'lacuna' e 'uso', observados na busca à informação jurídica na BDJur, pelos assessores de ministros participantes, a partir das entrevistas realizadas.

Dessa forma, dentro do propósito demarcado desta pesquisa, tal dificuldade não consistiu em empecilho à descoberta destes padrões que evidenciaram as 
condições de uso da BDJur, pelos assessores de ministro participantes. Isto, devido às características da Metodologia que pode revelar padrões positivos e negativos de uso do produto de informação, tanto de natureza subjetiva ou, coletiva. Dito em outras palavras, no recorte desta pesquisa referente ao uso da BDJur, na realidade de trabalho do assessor de ministro, na atividade judicante do STJ, as entrevistas realizadas permitiram entrever que a 'situação' de necessidade de informação jurídica específica, ocorre, de modo geral, para os assessores de ministro, inclusive para os não participantes da pesquisa, devido à função que todos desempenham na fundamentação da atividade judicante nos gabinetes dos ministros. Por outro lado, os momentos 'lacuna e 'uso', mostraram-se essencialmente subjetivos, conseguindo-se identificar diferentes padrões positivos e negativos na supressão da necessidade de informação jurídica pelos assessores entrevistados. Este nível de individualização da análise do comportamento informacional dos assessores entrevistados, revelou a lógica da trajetória por eles traçada na busca à informação, incluindo: resultados, efeitos, consequências, obstáculos (outcomes); confusão, desordem, 'tentativa e jeito de alcançar a informação' (muddles), além de intuição, 'peneiração'; incluindo ainda, emoções envolvidas no percurso como ansiedade, angústia, alívio e satisfação, caracterizando as condições de uso da BDJur.

A quantidade de dados e informações obtidos sobre o comportamento cognitivo, atitudes e reações dos assessores na busca à informação na BDJur , com os recursos da Metodologia do IBICT, indicam que o ideal seria entrevistar cada usuário, o que se torna impossível. Por outro lado, a análise das entrevistas no sentido de categorizar conjuntamente os padrões positivos e negativos, dos três momentos da vivência de necessidade de informação, quantificando os percentuais, aumenta a precisão na verificação da ocorrência de comportamentos comuns, num grupo de usuários. Pode-se, então, inferir com a abordagem qualitativa da Metodologia do IBICT, a necessidade de conscientização do usuário de que o momento dedicado à entrevista, pode reverter em ganho de tempo no acesso final à informação jurídica, uma vez que a Biblioteca presencia, diretamente, as condições anteriores e posteriores revividas pelo assessor, no momento do uso do produto ou serviço em questão. Isto, certamente, poderá contribuir para embasar e agilizar a tomada de decisão da Biblioteca, no caso de adequações do produto que se fizerem necessárias. Neste sentido, com a realização das entrevistas se obtem sucesso na descrição da vivência do assessor na busca à informação jurídica, porém ela pode demandar um tempo considerável para se concretizar, sendo necessário está em contato permanente com o assessor para que ele relembre a situação no todo. Se isto pode representar uma dificuldade na realidade de uma pesquisa científica com tempo determinado de realização, por outro lado, certamente não representa dificuldade na aplicação da Metodologia na Biblioteca, quando o serviço pode ser feito por uma equipe de bibliotecários, no tempo que for necessário, independente de limitações

Cabe acrescentar, que na condução desta pesquisa, procurou-se contornar as dificuldades e desafios surgidos na aplicação de uma metodologia de avaliação de produtos e serviços de informação, com estrutura de cunho abrangente e complexo, ajustando-se procedimentos no sentido de adequar o trabalho de análise com a Metodologia do IBICT, para a realidade institucional da Biblioteca do STJ. Outro ponto a destacar, é que ainda não há registro de outros casos de aplicação da Metodologia, que permitissem um exame comparativo com outras unidades de informação congêneres, ou não. Como a Metodologia foi criada recentemente, ainda 
não é possível conhecer todos os desafios ligados à sua aplicação, nas diversas realidades das unidades de informação, para atender tanto o contexto macro como o contexto microorganizacional. Vale ressaltar ainda, que a aplicação da Metodologia com outros usuários internos e com os usuários externos da Biblioteca do STJ, agregaria contribuição importante no desenvolvimento da BDJur, a exemplo do ocorrido no IBICT, ao realizar a avaliação pública dos próprios serviços e produtos de informação, com a aplicação da Metodologia. Contudo, a dimensão deste campo de pesquisa representa um trabalho de grande porte, na prática a ser distribuído e operacionalizado por vários setores e equipes de trabalho da organização, responsáveis pela gestão de um ou mais produtos ou serviços de informação. Assim, como atividade profissional, a avaliação de produtos e serviços de informação estará incorporada aos processos internos das unidades de informação.

Por fim, observou-se que a Metodologia do IBICT possui grande potencial avaliativo, operacionalizado pela integração de informações quantitativas e qualitativas, verbais e não verbais, associadas a padrões heurísticos de usabilidade de produtos e serviços de informação, priorizando o usuário neste processo.

\section{CONCLUSÃO}

Os resultados da pesquisa possibilitaram identificar na prática informacional de usuários assessores de ministro, como a Biblioteca Digital Jurídica, BDJur - um produto de informação da Biblioteca Ministro Oscar Saraiva do STJ, disponível na Web - concorre para subsidiar a atividade judicante, de acordo com a necessidade específica de informação jurídica, na fundamentação doutrinária e legislativa de matéria processual, no contexto do Superior Tribunal de Justiça. Ficou evidenciado, na missão de organizações como os tribunais, o sentido da atividade judicante ou jurisdicional na busca do cidadão pelo acesso à justiça na sociedade. Constatou-se que a satisfação dessa demanda jurídica no âmbito do STJ, está relacionada com a efetiva projeção da interpretação constitucional exarada desta Corte de justiça - os precedentes, súmulas e jurisprudência - nos tribunais e juízes de instâncias inferiores, em nível nacional. Neste sentido, no processo de avaliação de um produto de informação jurídica que visa tornar disponível a doutrina e legislação necessárias à atividade judicante e administrativa do STJ tornou-se imprescindível conhecer a instituição que é formadora de opinião no universo jurídico e que institui a política judiciária no país.

Nos gabinetes de ministros das Seções de Julgamento do STJ, o trabalho do assessor de ministro relacionado à atividade judicante é de fundamentação temática do processo com informação doutrinária, legislativa e jurisprudencial. Foi possível identificar a relação entre a atividade judicante desempenhada nos gabinetes de ministros e a necessidade de informação juridica dos assessores de ministro na fundamentação da redação do voto a ser submetido ao parecer do ministro. Nesta realidade, cabe à Biblioteca Ministro Oscar Saraiva, como unidade de informação pertencente ao STJ, a tutela de um bem comum imaterial, o acesso à informação jurídica, tornando disponível doutrina e legislação específica na BDJur, numa contribuição à atividade judicante. Foi possível constatar que a informação juridica disponível na BDJur é aplicada na fundamentação da atividade judicante no trabalho do assessor de ministro e, que a busca de informação na BDJur é relevante para a realização do trabalho do assessor. 
A aplicação da Metodologia de Avaliação de Produtos e Serviços de Informação desenvolvida no Instituto Brasileiro de Informação Científica e Tecnológica, lbict, publicada em 2011, consistiu numa experiência precursora no contexto do Poder Judiciário. Foi constatada a grande possibilidade de análise sobre aspectos de necessidade, busca e uso da informação pelos assessores, propiciada pela convergência inovadora de abordagens presentes na Metodologia. $\mathrm{O}$ enfoque quantitativo da metodologia mostrou, quanto ao uso e grau de satisfação do usuário, que a BDJur foi considerada positivamente pelos assessores, como produto de informação jurídica disponível na Web de confiabilidade na busca e recuperação da informação jurídica, sendo utilizado preferencialmente, em alguns casos, como fonte principal de informação para realização do seu trabalho. A aplicação desta informação jurídica é realizada pelo assessor na análise e fundamentação da matéria do processo judicial, para sanar dúvida sobre questão específica do direito e atualização sobre legislação. No que se refere ao grau de satisfação do usuário, destaca-se entre outros aspectos a importância das coleções de doutrina e legislação frequentemente pesquisadas na realização do trabalho e, a satisfação dos assessores com o conteúdo das páginas da BDJur. As principais barreiras encontradas no acesso à informação jurídica são casos de doutrina não encontrada e dificuldade de acesso à BDJur. O tempo de resposta foi considerado dentro de uma média de velocidade razoável, sendo descartada a lentidão na recuperação da informação.

A abordagem qualitativa da metodologia evidenciou aspectos de valor, cognição, movimentos e percursos de busca e uso da informação pelo assessor, na vivência de uma situação de necessidade de informação para tomada de decisão no trabalho, com base no trinômio operacional do Sense-making de Brenda Dervin. (situação, lacuna e uso) e, no Micro moment time line interview, identificando-se nas três etapas do trinômio operacional, a prática informacional do assessor para a realização do trabalho, no contexto do STJ. Foi confirmado o valor cognitivo e prático da informação jurídica recuperada na BDJur para fundamentação da redação do texto da proposta do voto a ser encaminhada para apreciação dos ministros. O resultado da análise com a técnica dos Incidentes críticos de John C. Flanagan, indicou como padrão positivo do momento "situação" a real necessidade de buscar informação jurídica em doutrina, publicada em livros e artigos de periódico, legislação e atos administrativos do STJ, disponíveis na BDJur, no trabalho do assessor de ministro, relativo à atividade judicante nas três Seções de Julgamento do STJ. Não foi identificado padrão negativo no momento "situação".

Obteve-se como padrão positivo do momento "lacuna" o sucesso e satisfação dos assessores no processo de busca, ao encontrar a informação demandada na BDJur seja quando a procura é feita por data, número e argumento; ao perceber que as dificuldades encontradas estão também relacionadas à própria estratégia de busca do assessor e, pela velocidade de resposta. Além disso, no comportamento de busca à informação jurídica os assessores escolhem a BDJur como fonte de pesquisa, destacando-se alguns motivos ou objetivos:

- certeza de encontrar a informação bem como resoluções de julgamento de processos repetitivos.

- racionalizar o trabalho de busca; confirmando a existência, ou não, de doutrina publicada sobre temas específicos da área do Direito, através do resultado negativo da pesquisa. 
- capacidade de alcance e bom funcionamento da BDJur em regiões do interior do país.

- disponibiliza doutrina atualizada, pertinente e consistente sobre o assunto de autores renomados da área do Direito;

- no trabalho de elaboração do modelo de voto, busca na BDJur encontrar formas de interpretar legislação e, doutrinadores da área do direito que tenham a mesma linha de entendimento e posicionamento do ministro sobre determinado tema;

- a busca na BDJur possibilita encontrar temas pouco explorados no STJ ou, escassamente publicados na área do Direito;

- prioriza ou concentra buscas à informação jurídica na BDJur, em relação à outras bases de dados externas ao Tribunal;

- considera a BDJur como melhor lugar para pesquisar questões doutrinárias e institucionais e, como canal fácil de pesquisa que apresenta solução com agilidade.

Não foi identificado um padrão negativo no momento "lacuna". Contudo foram feitas observações sobre necessidade de aprimorar a indexação do conteúdo e a representação dos assuntos da doutrina publicada em livros e artigos de periódicos disponíveis na BDJur e, a dificuldade de pesquisa na interface da BDJur por usuários de maior faixa etária, incluindo o usuário externo e ministro do Tribunal.

No padrão positivo do momento "uso", a aplicação da informação pelos assessores de ministro na fundamentação dos temas jurídicos dos processos judiciais, envolveu o valor na interpretação e apropriação da informação, em relação não só à linha de raciocínio do assessor, como ao entendimento do ministro do gabinete no qual o assessor trabalha, sobre a matéria: Assim, o uso da informação encontrada pelo assessor de ministro na BDJur possibilitou:

- o uso de uma tese mais atualizada; corroborar a própria linha de entendimento da matéria; encontrar nova diretriz no encaminhamento da matéria; fundamentar uma decisão e ideia pré-determinada ou realmente sanar uma dúvida; fazer uma citação; aplicar doutrina que necessita em quantidade suficiente, para realizar o trabalho;

- fundamentar a linha de pensamento sobre o tema com nomes de autores renomados, jurisconsultos e juristas na doutrina da área do Direito;

- solucionar o sentido do voto; obter um argumento que não tinha pensado anteriormente, na elaboração da matéria principal do voto; reforçar e desenvolver um argumento no trabalho de elaboração do modelo de voto do ministro,

- encontrar na BDJur, formas de interpretar legislação e, doutrinadores da área do direito com a mesma linha de entendimento e posicionamento do ministro sobre determinado tema, aumentando o respaldo, significando não tratar-se de posição isolada, além de atribuir mais valor no embasamento do voto;

- comprovar a noção preliminar da inexistência de doutrina publicada sobre determinado tema, na área do Direito, com a pesquisa desse assunto na BDJur.

Em geral, não foi identificado um padrão negativo no momento "uso" na aplicação da abordagem qualitativa da metodologia com as entrevistas. Contudo, quanto a isto, cabe mencionar que o resultado obtido na abordagem quantitativa da metodologia, ou seja, com os questionários, apontam que há assessores que não utilizam a BDJur possuindo outro comportamento de busca à informação, usando a informação do acervo da biblioteca particular do ministro no gabinete ou, do próprio 
assessor. Isto poderia ser visto como um padrão negativo de uso por usuários potenciais relacionado seja pelo desconhecimento sobre a BDJur, como a outros fatores não investigados nesta pesquisa, que levam esses assessores não incluir na estratégia de busca da informação jurídica, o uso da informação disponível na BDJur

A análise heurística de usabilidade de Jakob Nielsen, como última etapa da aplicação da Metodologia do lbict nesta pesquisa, permitiu identificar aspectos concernentes à interação homem-máquina, tendo em vista o paradigma contemporâneo de busca direta da informação realizada pelo assessor na BDJur, como produto disponível na Web. A sondagem da opinião dos assessores a respeito de nove padrões considerados ideais na interface de todo produto de informação, quando direcionados à BDJur, indicaram que as heurísticas com maior índice positivo de resultado foram: clareza nas informações gerais quanto à navegação e conteúdo; utilização de linguagem objetiva com uso de palavras, frases e conceitos exatos; possibilidade de autonomia sobre ações realizadas no sistema; e, padronização e identidade visual. As heurísticas menos bem avaliadas se referem às mensagens de erro exibidas pelo sistema e à navegação autoexplicativa.

Em suma, a aplicação da Metodologia para Avaliação de Produtos e Serviços de Informação do lbict foi decisiva para compreender a partir da soma de diferentes prismas, como o usuário vê e usa a BDJur. Foi realizada a descrição da BDJur, como um produto de informação disponível na Web, focalizando no momento da experiência de utilização deste produto de informação e da vivência do processo de busca à informação, o comportamento relatado pelo assessor de ministro, em relação à situação, lacuna e uso da informação jurídica na realização do seu trabalho. Foram identificados os incidentes críticos, positivos e negativos, em relação aos três momentos relacionados à utilização da BDJur. Foi possível verificar o grau de satisfação do assessor de ministro com o conteúdo e recursos da BDJur. $\mathrm{E}$, a usabilidade do produto em relação às heurísticas como padrões avaliativos do grau de interação entre assessor e BDJur, ou interação homem-máquina no ambiente da Web. A combinação dos três métodos ofereceu maior consistência e integridade dos resultados advindos do olhar do assessor, sobre a relação entre a necessidade de informação jurídica e a atividade judicante desempenhada nos gabinetes de ministro no trabalho do assessor, e sobre o impacto da informação jurídica na atividade judicante do STJ.

O pressuposto desta pesquisa de que a utilização de técnicas e metodologias adequadas para avaliar produtos de informação é fundamental para dar visibilidade à Biblioteca foi satisfatoriamente confirmado entre praticamente todos os assessores Naturalmente, do mesmo modo que ocorre nas unidades de informação de modo geral, no âmbito da unidade de informação jurídica, a avaliação de produtos de informação tem potencial para: a) fornecer suporte amigável ao usuário, isto é, facilitar os procedimentos necessários para acesso à informação; b) refinar o conteúdo de acordo com as necessidades de informação do usuário c) conceder a palavra ao usuário, principalmente aquele que utiliza o produto; d) usar dados e informações para aprimorar, inovar, substituir ou desativar produtos de informação.

Tal perspectiva da finalidade do processo de avaliação permite superar a visão tradicionalmente compreendida de que se trata de uma etapa do gerenciamento do produto de informação que pode prescindir de uma realização sistemática. Isto assume maior relevância quando se compreende que para realização de qualquer mudança no produto de informação jurídica disponível na Web é necessário investigar junto ao usuário. Evidência disto foi a opinião dos 
assessores da importância da Sessão de Biblioteca Digital avaliar as sugestões sobre a BDJur enviadas por eles via e-mail. Certamente, a prática da realização de avaliação do produto de informação consiste, muitas vezes, num desafio dentro da organização. Assim, o esforço investido neste sentido se converte em aprendizagem para a unidade de informação. Para a Sessão de Biblioteca Digital no desenvolvimento da interface da BDJur é importante a interação com o usuário

Foram registrados elogios à BDJur e evidenciado o seu reconhecimento como fonte estratégica de informação para o trabalho de assessor de ministro na atividade judicante do Tribunal. No acervo de doutrina composto por artigos de revista e livros, foi bastante destacado a busca e uso da informação jurídica, na fundamentação e redação da proposta do modelo ou minuta de voto dos ministros, elaborado pelos assessores. É importante salientar que há assessores que, na busca à informação jurídica, dão prioridade à BDJur em relação a outras bases de dados jurídicas, enquanto para outros, observou-se o hábito desenvolvido e consolidado de busca e uso da informação, firmemente concentrado na BDJur.

Uma das contribuições desta pesquisa pode ser a perspectiva de redimensionamento da avaliação como etapa contínua do planejamento do produto de informação, vital em todo o seu ciclo de vida, ou seja, deve ser realizada desde a criação, desenvolvimento, implantação e no decorrer de mudanças do produto, dirigindo de fato o percurso e acompanhando toda a existência deste, inclusive evidenciando as causas do seu fim, quando for o caso. Isto porque o processo de avaliação é a fonte onde se obtém diretamente as respostas sobre objetivos e benefício alcançados pelo produto de informação junto aos usuários Outra colaboração desta pesquisa se delineia com a possibilidade de contribuir com o fundamento teórico sobre o avanço do desenvolvimento de metodologias de avaliação de produtos de informação inovadoras que enriqueçem a base de conteúdo da coleta de dados, como momento de diálogo entre organização e usuário. Numa perspectiva aplicada, a contribuição consiste em mostrar a importância da seleção de metodologias de avaliação que ampliem e ao mesmo tempo confiram maior precisão no conhecimento envolvido no processo de necessidade, busca e uso de informação do usuário no meio jurídico. De modo geral, esta pesquisa pode realçar a percepção da viabilidade de novas alternativas para conhecer universos individuais dos usuários na prática e vivência da necessidade, busca e uso da informação no contexto organizacional. De modo específico, espera-se que esta pesquisa contribua para o principal objetivo do processo de avaliação da BDJur que é ajustar o produto de informação jurídica às reais necessidades do usuário. 


\section{RECOMENDAÇÕES}

Os produtos de informação na Web passam por transformações em consonância com 0 avanço dos recursos tecnológicos, originando novas necessidades de informação nos usuários. Nesta conjuntura, torna-se necessário que haja metodologias com novos requisitos para avaliação de produtos com abordagens que dirijam o olhar para circunstâncias ainda inexploradas de necessidade, busca e uso da informação. Na prática da avaliação do produto de informação, a atitude da unidade de informação de "permanente sensor das necessidades informacionais em uma instituição, exige uma sistematização dos perfis de necessidades e sua constante atualização, devido a sua natureza cambiante", com flexibilidade e agilidade (ALMEIDA, 2011, p. 13). Nesta perspectiva, destaca-se, outrossim, que:

- No contexto organizacional do STJ, ocorrem mudanças regulares no período de dois anos devido à investidura de ministros nos cargos da presidência e vicepresidência do Tribunal, ocasionando a desativação do gabinete do ministro designado e a instalação de outro na vaga remanescente. Este fato também ocorre em função da aposentadoria dos ministros, havendo casos de convocação de desembargadores para digirir o gabinete, sendo que nestas ocasiões o quadro funcional se altera com a convocação de outros servidores e assessores internos e externos. Constata-se, assim, que ocorre a renovação com certa frequência de usuários, evidenciando a contribuição da avaliação de produtos de informação no estudo do perfil dos usuários e suas necessidades de informação;

Em relação à aplicação da Metodologia para Avaliação de Produtos e Serviços de Informação do lbict (ROCHA e SOUZA, 2011) nesta pesquisa, acrescenta-se que:

$>$ Em função das mudanças que ocorrem nos gabinetes, como também no aumento recente do número de assessores de ministros, a avaliação qualitativa com a abordagem do trinômio operacional do Sense-making de Brenda Dervin e a realização de entrevistas com a técnica do Micro moment time line interview, naturalmente ampliará a base de conhecimento do perfil do assessor à medida que converge para o usuário individualmente um "sensoriamento" com maior possibilidade de obter nitidez e precisão na percepção da necessidade, comportamento e uso da informação.

> As heurísticas de Jakob Nielsen podem contribuir para uma análise aprofundada e técnica da BDJur porque permitem verificar detalhadamente com inúmeros requisitos, fatores e aspectos de funcionalidade incluídos em cada uma, conforme visto na revisão de literatura, o que ultrapassaria os objetivos desta pesquisa. Esta análise também investiga, na interface do produto de informação, o grau de gravidade do problema, o impacto na dificuldade do usuário em contorná-lo e a persistência do problema, não abordados nesta pesquisa, em função da participação direta do usuário, compreendendo-se que este nível de análise técnica é explorado pelo pessoal de Tecnologia de Informação, TI, responsável pelo desenvovimento técnico da BDJur e pelos bibliotecários da Seção de Biblioteca Digital do STJ. A realização desta análise heurística pormenorizada por profissionais especializados, certamente traria considerável resultado na detecção e solução de problemas com alto nível de precisão. Assim como também os resultados da análise heurística com os usuários, se mostrou bastante 
revelador podendo consistir em fonte de informação de excelência para verificar se há correspondência entre as respostas dos usuários e a necessidade de realizar ajustes no funcionamento da BDJur ou, para validar a solução de um determinado problema;

> Observou-se que há assessores que não conhecem os recursos de recuperação da informação jurídica na BDJur e que consideraram importante o fornecimento de orientação neste sentido;

> Na medida do possível, a aplicação da Metodologia do Ibict para avaliação de outros produtos e serviços de informação da Biblioteca do STJ, indubitavelmente adicionaria valor ao conhecimento acumulado na Biblioteca do STJ sobre as necessidades e práticas informacionais dos usuários, com maior quantidade de requisitos de análise;

$>$ O novo formulário de avaliação disponível na BDJur proporciona facilidade e agilidade de resposta do usuário, cujo conteúdo pode ser mais compreendido com os resultados obtidos na avaliação do produto de informação, possibilitando o momento de aprendizagem e de proximidade real com o usuário, consistindo num canal de comunicação com a instituição;

- Em relação à Metodologia do lbict se considera que associar à avaliação do produto os Fatores Críticos de Sucesso (FCS) como requisitos essenciais ou, fatores-chave, para fornecer produtos na Web focados na necessidade de informação do usuário, estenderia o campo de investigação com agregação de requisitos importantes à uma metodologia de avaliação de natureza intrinsecamente híbrida. 
11 ANEXOS 


\section{ANEXO 1 \\ EXEMPLO DE FORMULÁRIO COMPLETO NO FORMATO DE APRESENTAÇÃO NO SITE DO PORTAL DO IBICT}

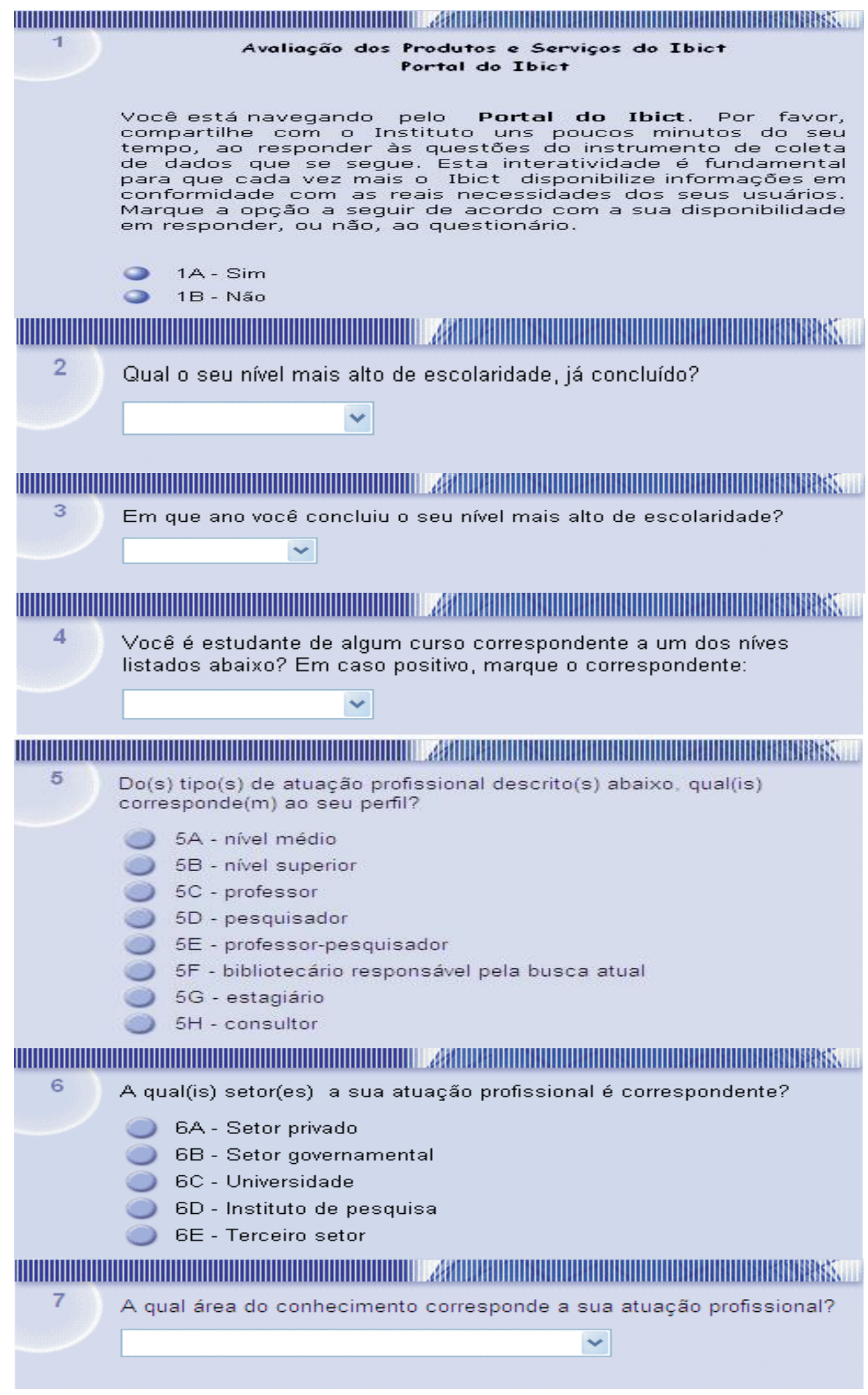




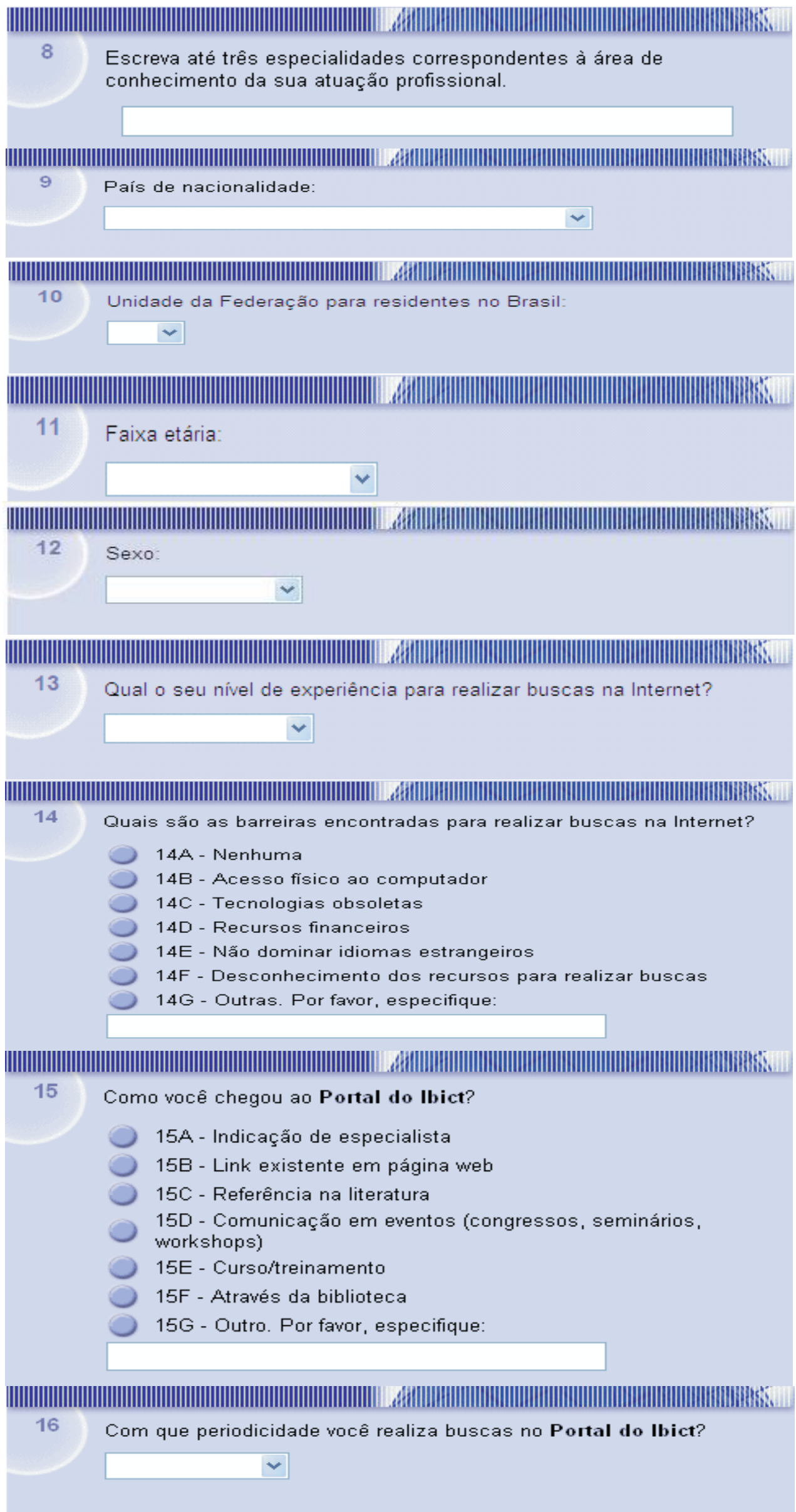




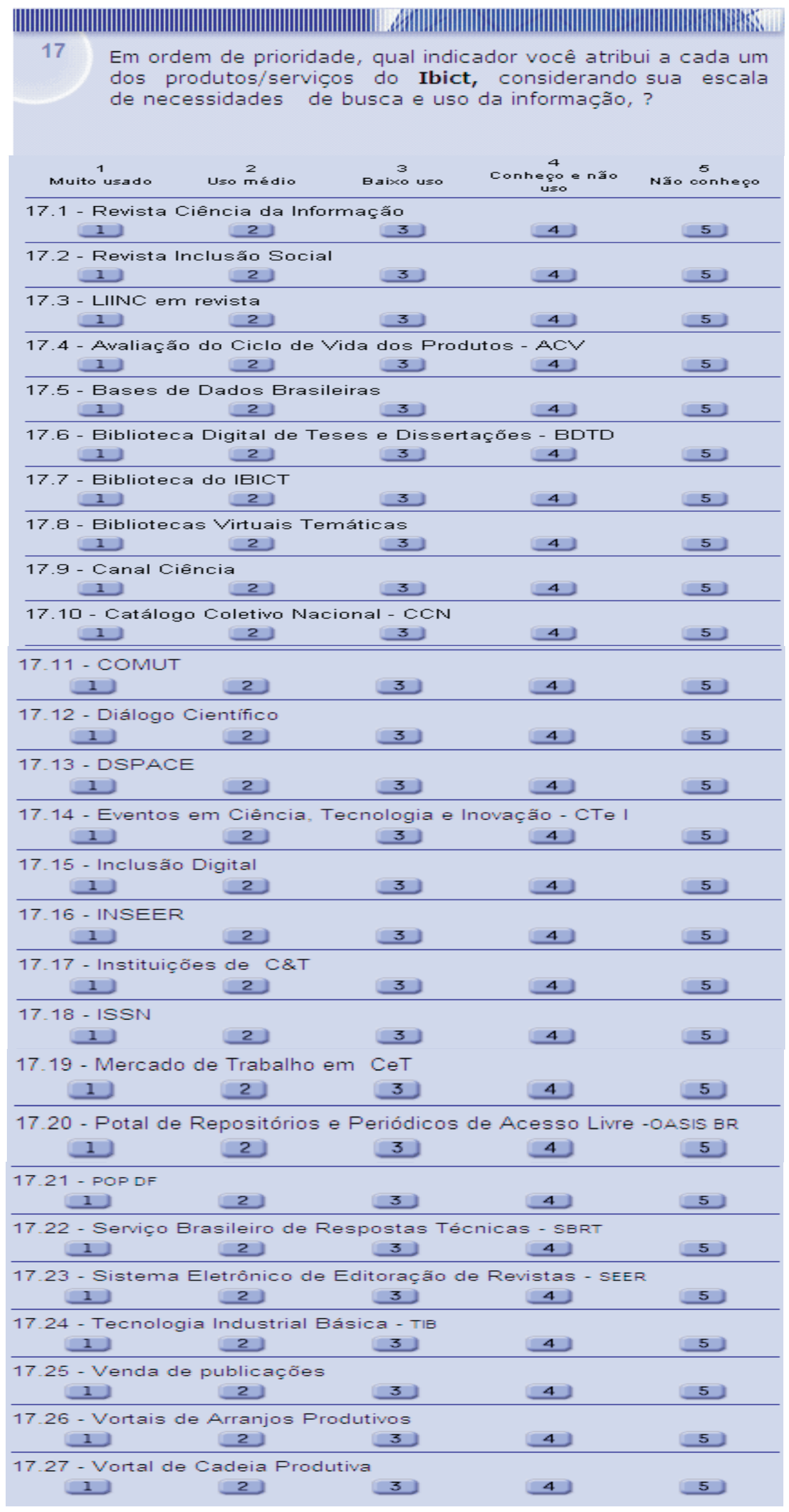




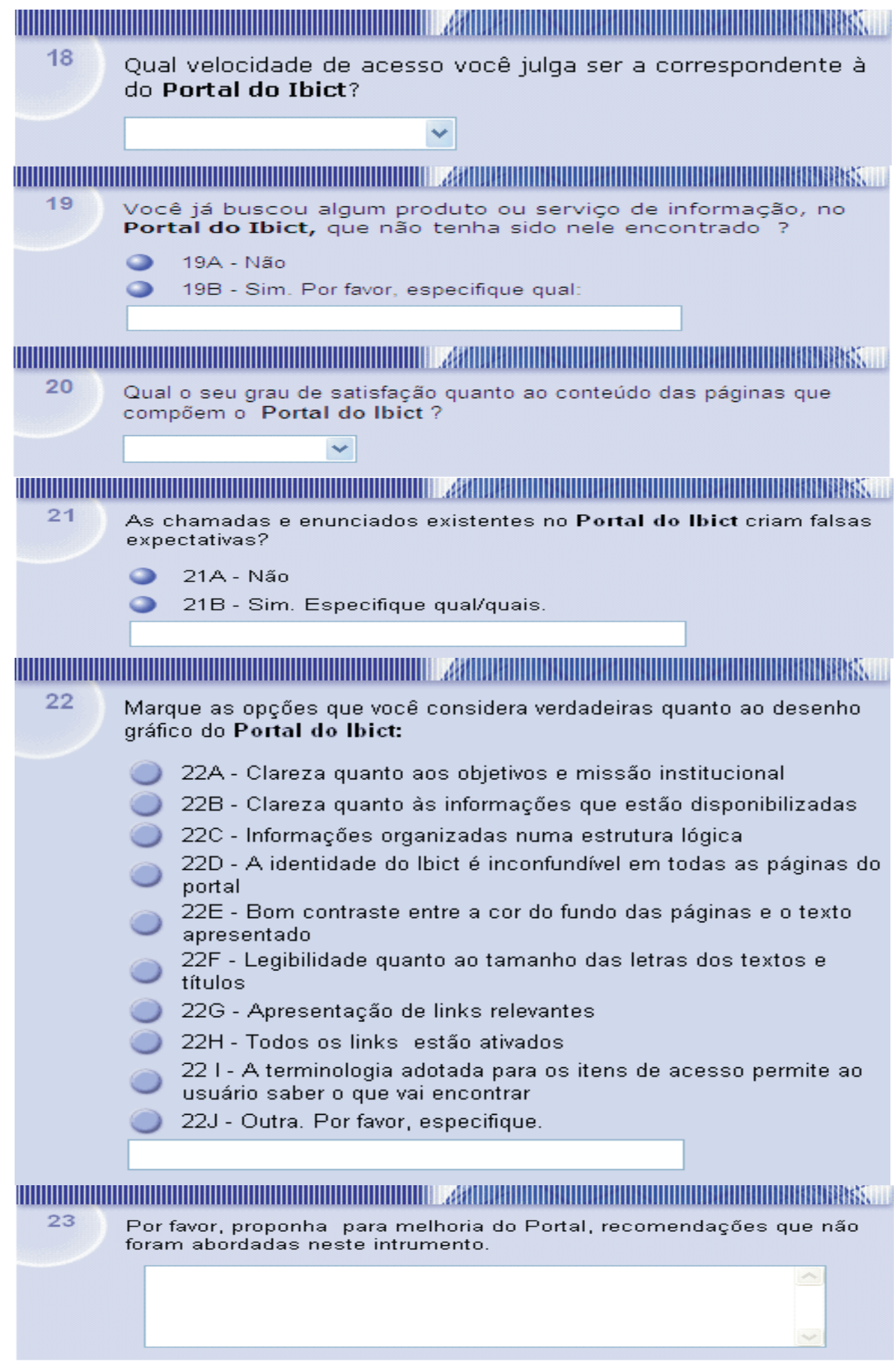

||||||||||||||||||||||||||||||||||||||||||||||||||||||||||||||||||||||||||||||||||||||||. Obrigado por participar! 


\section{ANEXO 2 \\ EXEMPLOS DAS VARIÁVEIS ESPECÍFICAS DOS FORMULÁRIOS ELETRÔNICOS DOS PRODUTOS CCN E COMUT}

Apresentam-se apenas as questões específicas dos produtos CCN e COMUT. As questões com as variáveis demográficas dos usuários presentes no Anexo 1 (respectivamente de 2 a 14) são idênticas para todos os produtos e por essa razão não constam no presente anexo.

\section{Exemplo de variáveis específicas do $\mathrm{CCN}$}

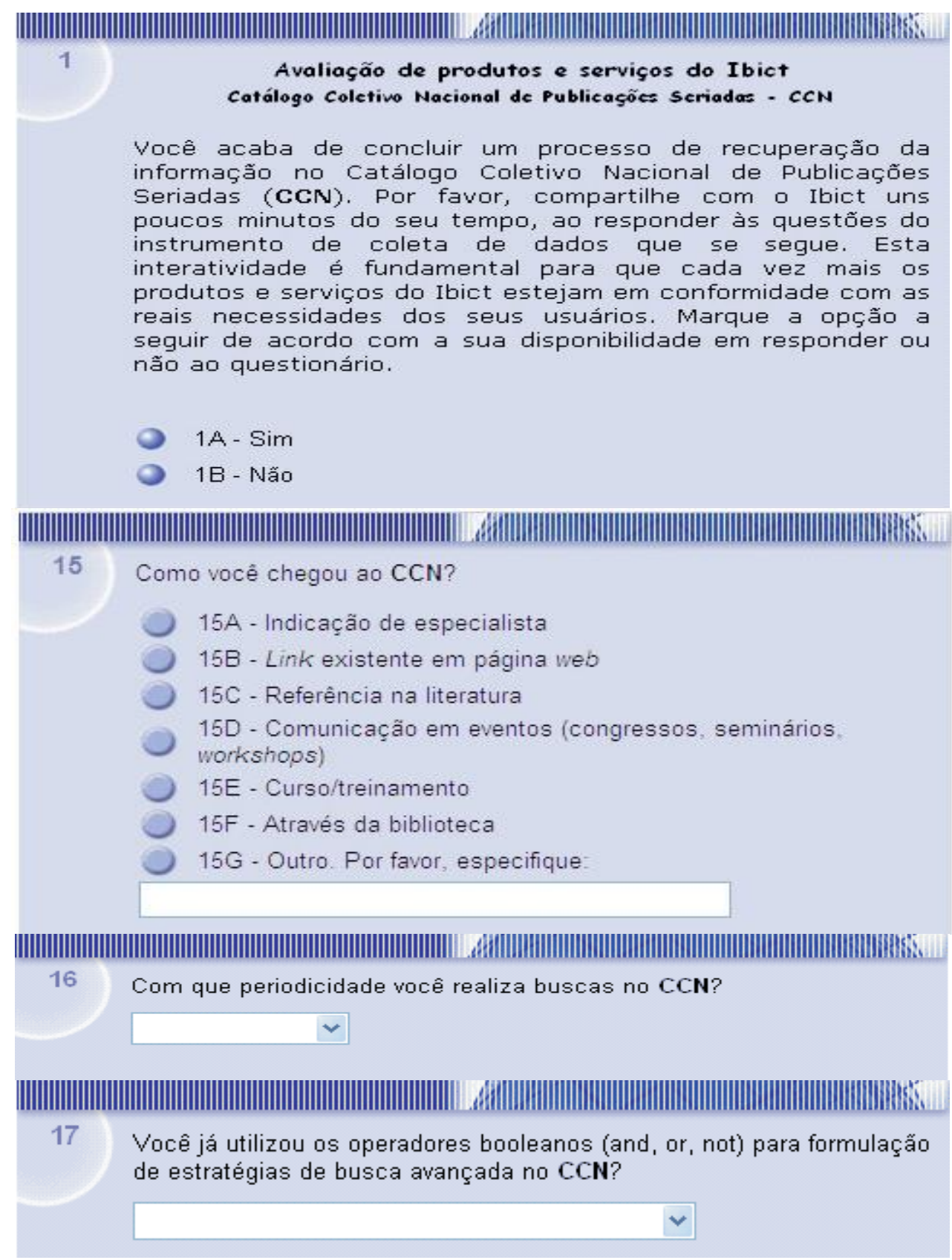




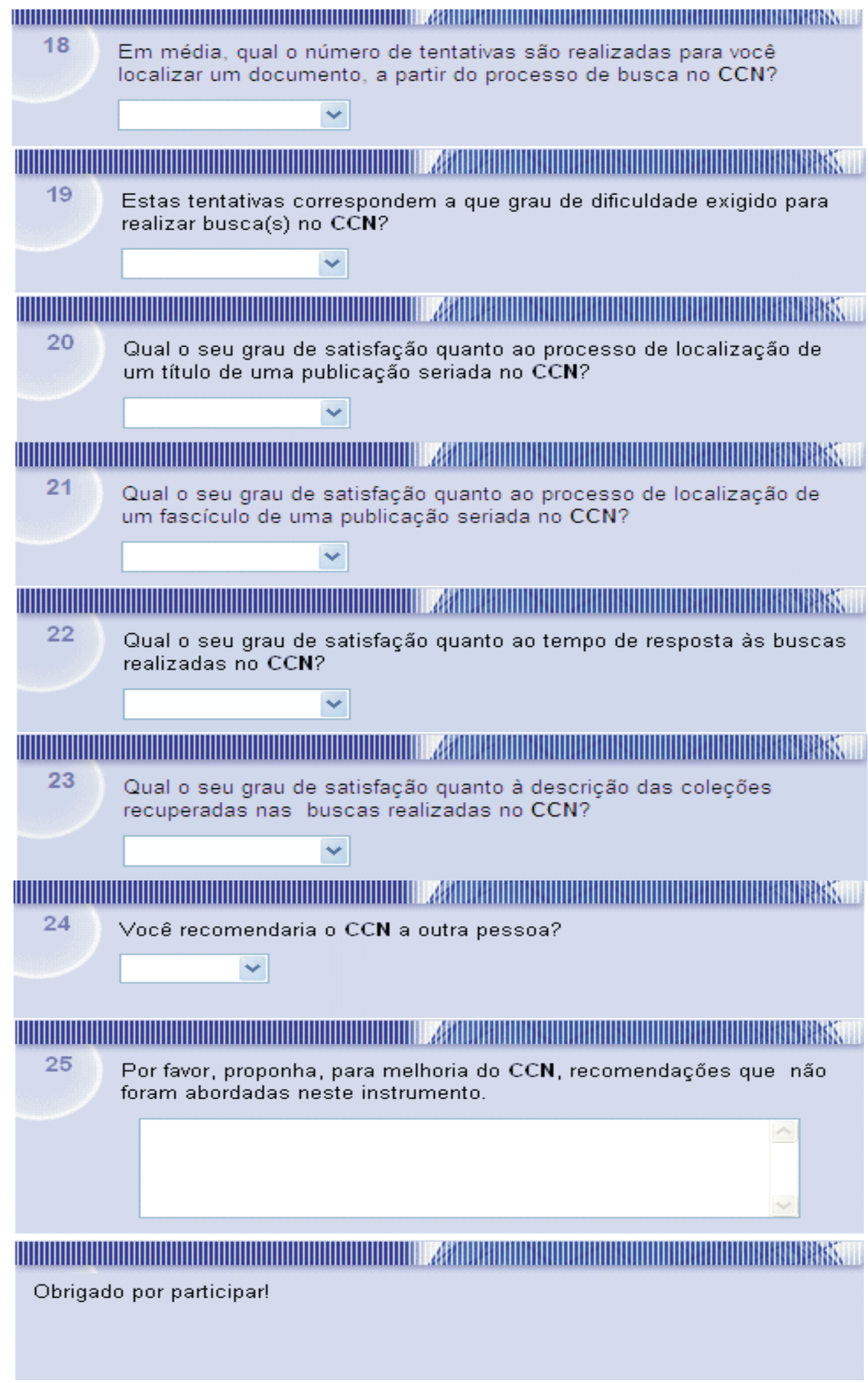




\section{ANEXO 3 \\ EXEMPLOS ALEATÓRIOS DE RESULTADOS DE ANÁLISE DOS FORMULÁRIOS DE AVALIAÇÃO QUANTITATIVA (PORTAL DO IBICT)}

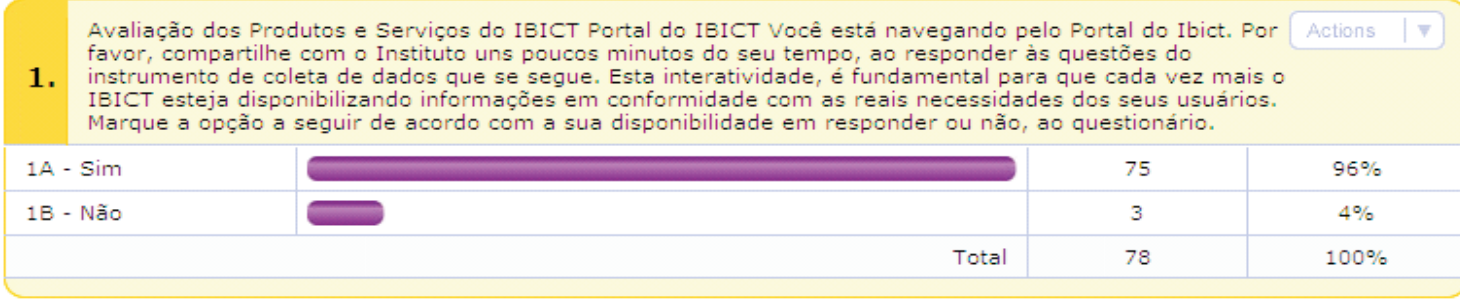

2. Qual o seu nível mais alto de escolaridade, já concluído?

2A - Nivel médio
$2 B$ - Nivel superior
$2 C$ - Especialização
$2 D$ - Mestrado
$2 E$ - Doutorado
$2 F-$ Pós-doutorado

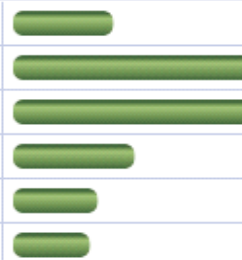

\begin{tabular}{|c|c|c|}
\hline \multicolumn{2}{|c|}{} & Actions \\
\hline & 13 & $\mathbf{\nabla}$ \\
\hline 37 & $32 \%$ \\
\hline 37 & $32 \%$ \\
\hline 16 & $14 \%$ \\
\hline & 10 & $9 \%$ \\
\hline otal & 2 & $2 \%$ \\
\hline
\end{tabular}

3. Em que ano wocê concluiu a nível mais alto de escolaridade?

\begin{tabular}{|l|l|l|l|}
\hline Antes de 1950 & & 0 & $0 \%$ \\
\hline 1951 & & 0 & $0 \%$ \\
\hline 1952 & 0 & 0 & $0 \%$ \\
\hline 1952 & 1954 & 0 & $0 \%$ \\
\hline
\end{tabular}

4. Você é estudante de algum curso correspondente a um dos níves listados abaixo? Em caso positivo, 4. marque o correspondente:

$4 \mathrm{~A}$ - Superior

4B - Especialização

$4 \mathrm{C}$ - Mestrado

4D - Doutorado

4E - Pós-Doutorado

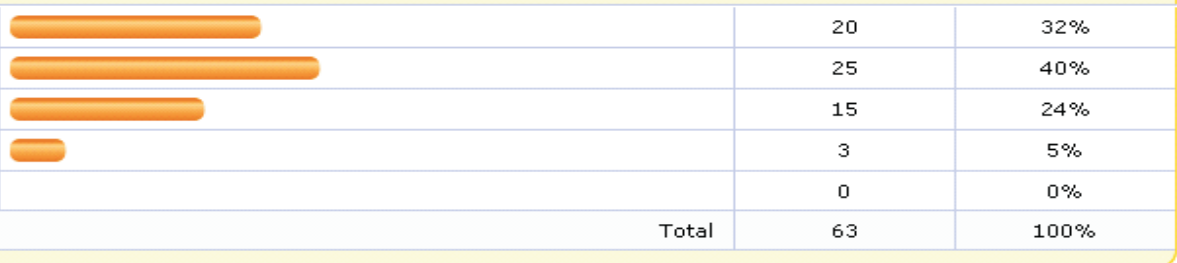

5. Do(s) tipo(s) de atuação profissional descrito(s) abaixo, qual(is) corresponde(m) ao seu perfil?

5 A - nível médio

$5 B$ - nivel superior

$5 C$ - professor

$5 D$ - pesquisador

$5 E$ - professor

pesquisador

$5 F$ - bibliotecário

responsável pela

$5 \mathrm{G}$ - estagiári

$5 \mathrm{H}$ - consultor

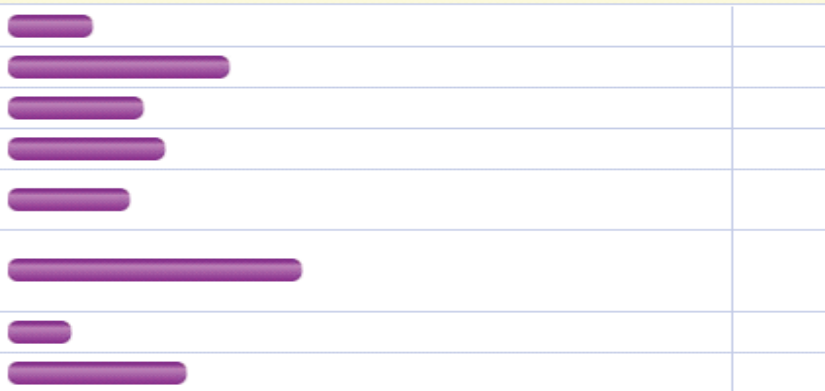

\begin{tabular}{|c|c|}
\hline 10 & $9 \%$ \\
\hline 31 & $28 \%$ \\
\hline 18 & $16 \%$ \\
\hline 21 & $19 \%$ \\
\hline 15 & $14 \%$ \\
\hline 42 & $38 \%$ \\
\hline 7 & $6 \%$ \\
\hline 24 & $22 \%$ \\
\hline
\end{tabular}

6. A qual(is) setor(es) a sua atuação profissional é correspondente?

6A - Setor privado

$6 \mathrm{~B}-$ Setor

governamental

6C-Universidade

6D - Instituto de

pesquisa

6E - Terceiro setor

\begin{tabular}{|l|c|c|}
\hline & 23 & $21 \%$ \\
\hline & 48 & $43 \%$ \\
\hline & 51 & $46 \%$ \\
\hline & 20 & $18 \%$ \\
\hline
\end{tabular}




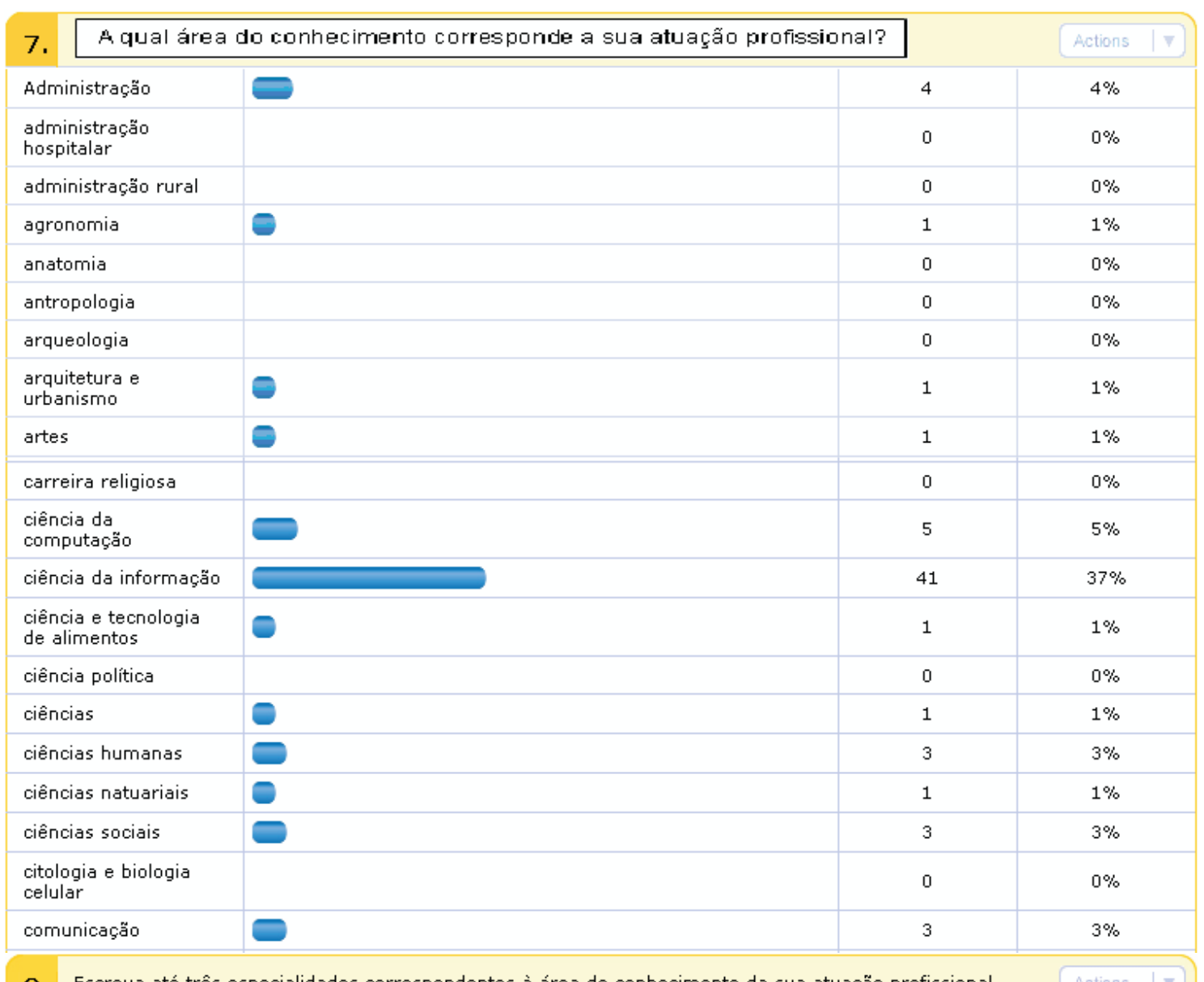

8. Escreva até três especialidades correspondentes à área de conhecimento da sua atuação profissional. Actions View 97 Responses

9. País de nacionalidade:

\begin{tabular}{|c|c|c|c|}
\hline AALAND ISLANDS & & 0 & $0 \%$ \\
\hline AFGHANISTAN & & 0 & $0 \%$ \\
\hline ALBANIA & & 0 & $0 \%$ \\
\hline ALGERIA & & 0 & $0 \%$ \\
\hline AMERICAN SAMOA & & 0 & $0 \%$ \\
\hline BOUVET ISLAND & & 0 & $0 \%$ \\
\hline BRAZIL & $\Longrightarrow$ & 110 & $96 \%$ \\
\hline $\begin{array}{l}\text { BRITISH INDIAN } \\
\text { OCEAN TERRITORY }\end{array}$ & & 0 & $0 \%$ \\
\hline BRUNEI DARUSSALAM & & 0 & $0 \%$ \\
\hline BULGARIA & & 0 & $0 \%$ \\
\hline BURKINA FASO & 0 & 1 & $1 \%$ \\
\hline
\end{tabular}




\begin{tabular}{|c|c|c|c|c|}
\hline 10. & Unidade da Federaçẫo para residentes no Brasil & & Actions & $\mid \nabla$ \\
\hline $\mathrm{AC}$ & & 0 & $0 \%$ & \\
\hline AL & P & 1 & $1 \%$ & \\
\hline AM & & 0 & $0 \%$ & \\
\hline AP & & 0 & $0 \%$ & \\
\hline BA & $\longrightarrow$ & 4 & $4 \%$ & \\
\hline $\mathrm{CE}$ & 0 & 2 & $2 \%$ & \\
\hline DF & $\longrightarrow$ & 17 & $15 \%$ & \\
\hline ES & O & 1 & $1 \%$ & \\
\hline Go & $\bigoplus$ & 3 & $3 \%$ & \\
\hline MA & 0 & 2 & $2 \%$ & \\
\hline$M G$ & $\longrightarrow$ & 9 & $8 \%$ & \\
\hline MS & 0 & 1 & $1 \%$ & \\
\hline MT & 0 & 2 & $2 \%$ & \\
\hline PA & 0 & 2 & $2 \%$ & \\
\hline $\mathrm{PB}$ & & 0 & $0 \%$ & \\
\hline
\end{tabular}

\begin{tabular}{|c|c|c|c|}
\hline Faixa etária: & & & \multirow{2}{*}{ Actions | v } \\
\hline $11 \mathrm{~A}$ - Até 20 anos & 0 & 3 & \\
\hline $11 B-21-30$ & $\longrightarrow$ & 32 & $28 \%$ \\
\hline $11 C-31-40$ & $\Longrightarrow$ & 27 & $24 \%$ \\
\hline $11 D-41-50$ & $\Longrightarrow$ & 29 & $26 \%$ \\
\hline $\begin{array}{l}\text { 11E - Acima de } 50 \\
\text { anos }\end{array}$ & $\longrightarrow$ & 22 & $19 \%$ \\
\hline & Total & 113 & $100 \%$ \\
\hline
\end{tabular}

12. Sexo:

12A - Masculino 12B - Feminino

\begin{tabular}{|c|c|c|}
\hline & 38 & $35 \%$ \\
\hline 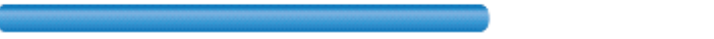 & 72 & $65 \%$ \\
\hline Total & 110 & $100 \%$ \\
\hline
\end{tabular}

13. Qual o seu nivel de experiência para realizar buscas na Internet?

\begin{tabular}{|l|}
\hline $13 \mathrm{~A}$ - Muito alto \\
$13 \mathrm{~B}$ - Alto \\
$13 \mathrm{C}$ - Médio \\
$13 \mathrm{D}$ - Baixo \\
$13 \mathrm{E}$ - Muito baixo \\
\hline
\end{tabular}

\begin{tabular}{|c|c|c|}
\hline 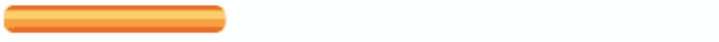 & 31 & $28 \%$ \\
\hline 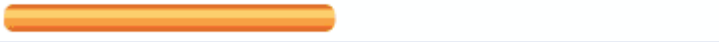 & 48 & $43 \%$ \\
\hline$\square$ & 31 & $28 \%$ \\
\hline 6 & 1 & $1 \%$ \\
\hline 0 & 1 & $1 \%$ \\
\hline Total & 112 & $100 \%$ \\
\hline
\end{tabular}


14. Quais são as barreiras encontradas para realizar buscas na Internet?

$14 \mathrm{~A}$ - Nenhuma

14B - Acesso físico ao computador

$14 \mathrm{C}$ - Tecnologias

obsoletas

14D - Recursos

financeiros

14E - Não dominar idiomas estrangeiros $14 \mathrm{~F}$ -

Desconhecimento dos recursos para realizar buscas

14G - Outras. Por favor, especifique: View Responses

\begin{tabular}{|l|l|l|}
\hline & 54 & $48 \%$ \\
\hline & 7 & $6 \%$ \\
\hline & 8 & $7 \%$ \\
\hline & 9 & $8 \%$ \\
\hline & 37 & $33 \%$ \\
\hline
\end{tabular}

\section{Respostas abertas do item 14:}

\section{Respostas abertas do item 14}

\section{$25 \checkmark$ Per Page}

1-10 of 10 Responses Select Page: First | Previous | Next | Last

Quais sấo as barreiras encontra das para realizar buscas na Internet?

\section{Response}

Variedade de buscadores, falta de padrão e normas

Desconhecimento de alguns recursos.

SOA. Saas, e Web Soluções

Impaciência

falta de reciclagem para aperfeicoamento

Estabilidade dos sites buscados

Desconheco algumas normas e metodologias

tempo

15. Como você chegou ao Portal do Ibict?

$15 \mathrm{~A}$ - Indicação de especialista

15B - Link existente em página web

$15 \mathrm{C}$ - Referência na literatura

$15 \mathrm{D}$ - Comunicação

em eventos

(congressos,

seminarios,

workshops)

$15 \mathrm{E}$

Curso/treinamento

$15 \mathrm{~F}$ - Através da biblioteca

$15 G$ - Outro. Por

favor, especifique:

View Responses

\begin{tabular}{|l|c|c|}
\hline & 17 & $15 \%$ \\
\hline & 20 & $18 \%$ \\
\hline & 16 & $14 \%$ \\
\hline & 13 & $12 \%$ \\
\hline & 13 & $12 \%$ \\
\hline
\end{tabular}

16. Com que periodicidade você realiza buscas no Portal do lbict?

$16 \mathrm{~A}$ - Diária

$16 \mathrm{~B}$ - Semanal

$16 \mathrm{C}$ - Mensal

16D - Anual

16E - Irregular

\begin{tabular}{|c|c|c|}
\hline 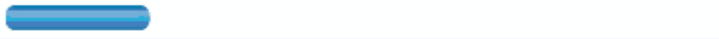 & 19 & $17 \%$ \\
\hline 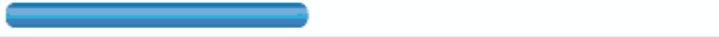 & 44 & $39 \%$ \\
\hline 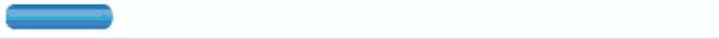 & 13 & $12 \%$ \\
\hline$\theta$ & 1 & $1 \%$ \\
\hline 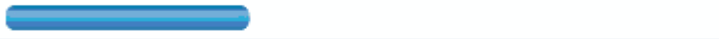 & 35 & $31 \%$ \\
\hline Total & 112 & $100 \%$ \\
\hline
\end{tabular}


17. Em ordem de prioridade, qual indicador você atribui a cada um dos produtos/serviços do Ibict, considerando sua escala de necessidades de busca e uso da informação, ?

Top number is the count selecting the option.
Bottom $\%$ is percent the total respondents selecting the option.

17.1 - Revist

Ciência da

17.2 - Revist

Inclusão Social

17.3 - LIINC em

revista

17.4 - Avaliação do

Ciclo de vida dos

Produtos - ACV

17.5 - Bases de

Dados Brasileiras

17.6 - Biblioteca

Digital de Teses e

Dissertações - BDTD

17.7 - Biblioteca

do IBICT

17.8 - Bibliotecas

Virtuais T

17.9 - Canal Ciência

17.10 - Catálogo

Coletivo Nacional -

$\mathrm{CCN}$

17.11 - COMUT

17.12 - Diálogo

Científico

\subsection{3 - DSPACE}

17.14 - Eventos em

Ciência, Tecnologia

e Inovação - CTe I

17.15 - Inclusão

Digital

17.16 - INSEER

17.17 - Instituições

de C\&T

Conheço e não uso

Não conheço

$$
47
$$

47

Uso médio

Baiko uso

124

\begin{tabular}{r|r|r|}
\hline 15 & 8 & 13 \\
\hline
\end{tabular}

\begin{tabular}{r|r|r|}
\hline 5 & $22 \%$ & \\
$5 \%$ & 16 & 21 \\
\hline
\end{tabular}

21

\begin{tabular}{|r|r|}
\hline $7 \%$ & $12 \%$ \\
\hline 31 & $30 \%$ \\
\hline $30 \%$ & $29 \%$ \\
\hline
\end{tabular}

$6 \%$

\begin{tabular}{r|r}
6 & 19 \\
$6 \%$ & $19 \%$
\end{tabular}

\begin{tabular}{r|r|}
19 & 15 \\
$9 \%$ & $15 \%$
\end{tabular}

\begin{tabular}{|c|}
\hline $\begin{array}{l}6 \\
\%\end{array}$ \\
\hline
\end{tabular}

\begin{tabular}{r|r}
6 & $18 \%$ \\
$6 \%$ & 18
\end{tabular}

\begin{tabular}{|r|r|r|}
\hline 15 & 24 & 36 \\
\hline$\%$ & $24 \%$ & $36 \%$ \\
\hline
\end{tabular}

$6 \%$

\begin{tabular}{|r|r|r|}
\hline 30 & 28 & \\
$29 \%$ & $27 \%$ & $14 \%$ \\
\hline & &
\end{tabular}

18

\begin{tabular}{r|r|}
21 & $36 \%$ \\
$21 \%$ & 48
\end{tabular}

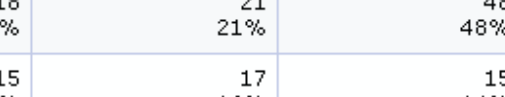

\begin{tabular}{|r|r|r|r|r|}
\hline 30 & 28 & 15 & 17 & 15 \\
\hline 46 & $27 \%$ & $14 \%$ & $16 \%$ & $14 \%$ \\
\hline $44 \%$ & 31 & 11 & 6 & 10 \\
\hline 19 & $30 \%$ & $11 \%$ & $6 \%$ & $10 \%$ \\
\hline & 30 & 20 & 19 & 12 \\
\hline
\end{tabular}

$44 \%$

\begin{tabular}{r|r}
19 & 30 \\
$19 \%$ & $30 \%$
\end{tabular}

\begin{tabular}{r|r}
21 & 28 \\
$20 \%$ & $27 \%$
\end{tabular}

\begin{tabular}{r|r}
$30 \%$ & 20 \\
\hline & $20 \%$ \\
\hline
\end{tabular}

\begin{tabular}{r|r}
28 & 21 \\
$27 \%$ & $20 \%$
\end{tabular}

\begin{tabular}{|r|r|r|}
\hline 21 & 19 & 1 \\
\hline $20 \%$ & 19 & $12 \%$ \\
\hline
\end{tabular}

\begin{tabular}{|r|r|r|r|r|}
21 & 28 & 21 & 19 & 15 \\
\hline $20 \%$ & $27 \%$ & $20 \%$ & $18 \%$ & $14 \%$ \\
\hline 7 & 19 & 16 & 31 & 27 \\
\hline $7 \%$ & $19 \%$ & $16 \%$ & $31 \%$ & $27 \%$ \\
\hline
\end{tabular}

\begin{tabular}{|r|r|r|r|r|}
28 & 26 & 15 & 14 & 21 \\
\hline $7 \%$ & $25 \%$ & $14 \%$ & $13 \%$ & $20 \%$ \\
\hline
\end{tabular}

\begin{tabular}{|r|r|r|r|r|}
23 & 21 & 25 & 24 & 12 \\
$22 \%$ & $20 \%$ & $24 \%$ & $23 \%$ & $11 \%$ \\
\hline
\end{tabular}

\begin{tabular}{|r|r|r|r|r|}
\hline 5 & 16 & 16 & 32 & $11 \%$ \\
\hline $5 \%$ & $16 \%$ & $16 \%$ & $32 \%$ & $32 \%$ \\
\hline
\end{tabular}

\begin{tabular}{r|r|r|r|r|}
\hline $5 \%$ & $16 \%$ & $16 \%$ & $32 \%$ & $32 \%$ \\
\hline 10 & $7 \%$ & 17 & 29 & 36 \\
$10 \%$ & $7 \%$ & $17 \%$ & $29 \%$ & $36 \%$ \\
\hline
\end{tabular}

\begin{tabular}{r|r|r|r|r|}
\hline 17 & 21 & 22 & 23 & 18 \\
$17 \%$ & $21 \%$ & $22 \%$ & $23 \%$ & $18 \%$ \\
\hline
\end{tabular}

\begin{tabular}{|r|r|r|r|r|}
\hline 10 & 14 & 23 & 32 & 21 \\
\hline $10 \%$ & $14 \%$ & $23 \%$ & $32 \%$ & $21 \%$ \\
\hline
\end{tabular}

\begin{tabular}{|r|r|r|r|r|}
\hline 5 & 14 & 24 & 25 & $21 \%$ \\
\hline $5 \%$ & $14 \%$ & $24 \%$ & $26 \%$ & $31 \%$ \\
\hline
\end{tabular}

1

17.18 - ISSN

17.19 - Mercado de

Trabalho em Ce

17.20 - Potal de

Repositórios e

Periódicos de Acesso

Livre -OASIS BR

17.21 - POP DF

17.22 - Serviço

Brasileiro de

Respostas Técnicas -

SBRT

17.23 - Sistema

Eletrônico de

Editoração de

Revistas - SEER

17.24 - Tecnologia

Industrial Básica -

TIB

17.25 - Venda de publicações

17.26 - Vortais de Arranjos Produtivos

17.27 - Vortal de

Cadeia Produtiva

\begin{tabular}{r|r}
11 & 1 \\
$12 \%$ & $16 \%$ \\
\hline
\end{tabular}

\begin{tabular}{r|r|r|}
18 & $16 \%$ \\
$18 \%$ & $16 \%$
\end{tabular}

\begin{tabular}{r|r|}
15 & 25 \\
$\%$ & $27 \%$
\end{tabular}

\begin{tabular}{r|r|r|r|}
15 & 25 & 25 & 16 \\
$16 \%$ & $27 \%$ & $27 \%$ & $17 \%$ \\
\hline 16 & 29 & 26 & 12 \\
$16 \%$ & $29 \%$ & $26 \%$ & $12 \%$ \\
\hline 15 & 19 & 29 & 25 \\
\hline $15 \%$ & $19 \%$ & $30 \%$ & $26 \%$ \\
\hline
\end{tabular}

\begin{tabular}{|r|r|r|r|}
\hline 23 & 16 & $30 \%$ & $26 \%$ \\
\hline $2 \%$ & $15 \%$ & 25 & 25 \\
\hline
\end{tabular}

\begin{tabular}{|r|r|r|r|}
\hline $22 \%$ & 16 & 25 & 25 \\
\hline 12 & $15 \%$ & $24 \%$ & $24 \%$ \\
\hline & 18 & 19 & 49 \\
\hline
\end{tabular}

\begin{tabular}{|r|r|r|r|r|}
\hline 3 & 12 & 18 & 19 & 49 \\
$3 \%$ & $12 \%$ & $18 \%$ & $19 \%$ & $49 \%$ \\
\hline
\end{tabular}

\begin{tabular}{|r|r|r|r|r|}
\hline 4 & 10 & 15 & 27 & 42 \\
$4 \%$ & $10 \%$ & $15 \%$ & $28 \%$ & $43 \%$ \\
\hline
\end{tabular}

\begin{tabular}{r|r|r|r|r|}
\hline 10 & 24 & 16 & 29 & $43 \%$ \\
\hline $10 \%$ & $24 \%$ & $16 \%$ & $29 \%$ & $22 \%$ \\
\hline
\end{tabular}

\begin{tabular}{|r|r|r|r|r|}
\hline 5 & 8 & 16 & $29 \%$ & $22 \%$ \\
\hline $5 \%$ & $8 \%$ & $16 \%$ & 24 & 47 \\
\hline 4 & 18 & 28 & $24 \%$ & $47 \%$ \\
\hline $4 \%$ & $18 \%$ & $27 \%$ & 27 & 25 \\
\hline 3 & $9 \%$ & 15 & $26 \%$ & $25 \%$ \\
\hline 4 & $7 \%$ & $15 \%$ & 25 & 45 \\
\hline $4 \%$ & $7 \%$ & 19 & $26 \%$ & 49 \\
\hline & & $19 \%$ & 23 & $48 \%$ \\
\hline
\end{tabular}


18. Qual velocid ade de acesso você julga ser correspondente à do Portal do lbict?

$18 \mathrm{~A}$ - rápida

$18 \mathrm{~B}$ - razoável

$18 \mathrm{C}$ - eventualmente

lenta 180 - frequentemente
lenta

19. Você já buscou algum produto ou serviço de informação, no Portal do Ibict, que não tenha sido nele 19. encontrado?

19 A - Não

198 - Sim. Por favor, especifique qual: View Responses

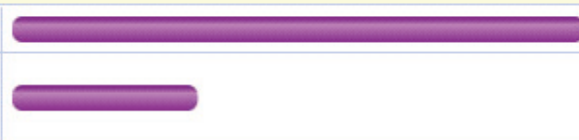

\begin{tabular}{|c|}
\hline ?? \\
\hline \\
\hline
\end{tabular}

\begin{tabular}{|c|}
\hline $41 \%$ \\
\hline $48 \%$ \\
\hline $9 \%$ \\
\hline $2 \%$ \\
\hline $100 \%$ \\
\hline
\end{tabular}
Actions $|\nabla|$

\begin{tabular}{|c|c|c|}
\hline & 81 & $77 \%$ \\
\hline & 24 & $23 \%$ \\
\hline Total & 105 & $100 \%$ \\
\hline
\end{tabular}

20. Qual o seu grau de satisfação quanto ao conteúdo das páginas que compõem o Portal do Ibict ? $20 \mathrm{~A}$ - muito baixo 208 - baixo $20 c$ - médio 200 - alto

$20 \mathrm{E}$ - muito alto

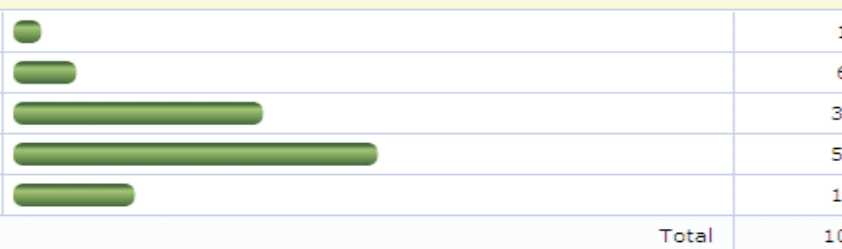

\begin{tabular}{|c|c|}
\hline 1 & $1 \%$ \\
\hline 6 & $6 \%$ \\
\hline 35 & $32 \%$ \\
\hline 52 & $48 \%$ \\
\hline 15 & $14 \%$ \\
\hline 109 & $100 \%$ \\
\hline
\end{tabular}

21. As chamadas e enunciados existentes no Portal do Ibict criam falsas expectativas?

21A - Nä

$21 \mathrm{~B}-$ Sim. Especifique qual/quais.

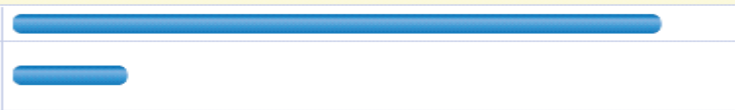

Total Actions | 7 Ulew Responses

22. Marque as opções que você considera verdadeiras quanto ao desenho gráfico do Portal do Ibict:

22A - Clareza

quanto aos

objetivos e missão

institucional

22B - Clareza

quanto às

informações que

estão disponibilizadas

$22 \mathrm{C}$ - Informações organizadas num

estrutura lógica

22D - A identidade do

Ibict é inconfundivel

do portal

22E - Bom contraste

entre a cor do fundo das páginas e o texto

apresentado

$22 \mathrm{~F}$ - Legibilidade

quanto ao tamanho das letras dos texto e títulos

22G - Apresentação de links relevantes

$22 \mathrm{H}$ - Todos os links estão ativados

22 I - A terminologia adotada para os itens de acesso permite ao usuario saber o que

vai encontrar

22] - Outra. Por favor, especifique.

View Responses

\begin{tabular}{|c|c|c|}
\hline 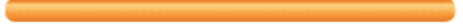 & 65 & $60 \%$ \\
\hline & 64 & $59 \%$ \\
\hline & 49 & $45 \%$ \\
\hline 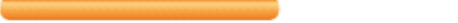 & 39 & $36 \%$ \\
\hline 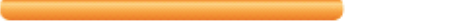 & 49 & $45 \%$ \\
\hline 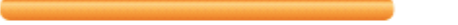 & 57 & $52 \%$ \\
\hline$\longrightarrow$ & 60 & $55 \%$ \\
\hline$\longrightarrow$ & 26 & $24 \%$ \\
\hline 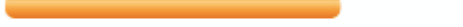 & 48 & $44 \%$ \\
\hline$\Longrightarrow$ & 8 & $7 \%$ \\
\hline
\end{tabular}

23. Por favor, proponha para melhoria do Portal, recomendações que não foram abordadas neste intrumento.

View 42 Responses

Obrigado por participar! 


\section{ANEXO 4 \\ RESPOSTAS DO CAMPO ABERTO DO FORMULÁRIO DA AVALIAÇÃO QUANTITATIVA (PORTAL DO IBICT)}

Results Overview: Open Ended Responses

Filter: No filter applied (42 Response(s) Returned)

《Return to Results Overview

Display $50 \vee$ Per Page

Displaying 1-42 of 42 Responses Select Page: First | Previous | Next | Last

23. Por favor, proponha, para melhoria do Portal, recomendaçổes que năo foram abordadas neste instrumento.

3 Falta uma padronização, em todos os aspectos, nas páginas.

4 Informaçōes sobre convênios para conseguir publicaçöes do IBICT para acervos de bibliotecas de outros Estados.

5 Rever o processo de recuperaçäo da informaçäo na Biblioteca de teses e dissertaçôes, Por exemplo busca - "Ciencia da Informaçäa" - vem tudo de ciência e informaçăo... encontro dificuldade na recuperação da informaçăo,

6 Mudar menos o Portal; atualizar os links.

OASIS - deve ser melhor apresentado, tipo Scielo

7 Normalização entre os produtos (visual) Manter padrōes aonde se enquadre.

8 Há necessidade de um "Quem é Quem", a exemplo das outras UPs do MCT.

9 Gostaria que a Base do ISSN se tornasse de acesso público.

10 não há na págna principal o enderço e o contato telefôncio do instituto. A parte central do portal com as repostagens é muito longa.

11 Possibilidade de aumento do tamanho das fonte para facilitar leitura

No Comut, só encontro as informaçōes se tiver a descrição exata das fontes (periódicos, etc). Poderia ter busca por palauras chave, autor, tituloe

12 outros elementos de descriçäo do trabalho procurado. Tambem poderia ter refinamento de busca, com especificaçoes de determinados assuntos. Obrigada

13 Recomendo apenas que haja mais estabilidade da página de consulta a CCN por diversas vezes näo consigo utilizar este serviço. No mais acredito falte divulgaçäo dos serviços do IBICT junto às pós graduaçôes e seus alunos. Vocês tem importantes serviços a oferecer e muita gente nem sabe.

A aquisiçäo por parte de instituiç̧oses de ensino deveriam ser mais aggilizadas, principalmente com produtos comercializados unicamente pelo IBICIT cito como exemplo a CDU.

15 sem mais para o momento Sugiro sempre dispor links nas notícias para coisas que estejam on-line, 0 LinNC em revista por exemplo, tem o tópico sobre o lançamento mas nao tem o link pra a revista que está on line

17 IBICT, deveria dar suporte técnico às demais instituiçōes governamentais pelo menos, Centro de Documentaçäo/Informaçäo e Bibliotecas.Assim cc esses orģăos criariam uma rede de informação e documentaçăo.

180 instrumento é de signficativa importância, de itens criteriosos e relevantes para o que se propōe

19 Foram todos adequados as minhas expectativas

20 divulgaça por e-mail; o que é a empresa e o objetivo 
Melhorar a terminologia para os itens de acesso.

23 กวัo tem

24 jjkkjkjkj

25 Uma estrutura melhor para as notícias. Divisão do tópico 'Produtos e serviços', atualmente é muito extenso. Destaque para os periódicos do instituto.

26 Web Solução Porta

0 IBICT trabalha com a informação, então deve mostrá-las de forma clara, acessível, o importante não é colocar milhões de informações, mas permitir que elas estejam claras, não é a quantidade de informação e sim a qualidade da informação, por que dificultar, não consegui as informações que

27 necessito. Para saber sobre um congresso por exemplo tenho que colocar a data, eu näo sei, estou entrando no site para saber, quais sã̃o os próximos que serão realizados no próximo semestre. Espero conrtribuir para a melhoria os serviços prestados. Obrigada pelo canal de contato. Atenciosamente Rosení

280 catálogo de vendas deveria mostrar a capa de cada item para melhor direcionamento à compra.

29 resumo das obras que estão á venda.

Parabéns!

Nos últimos anos houve uma melhoria na velocidade de acesso, entre uma página e outra, o que nos satisfaz.

Sugestăo: Comut/Solicitação - diminuição de telas até a finalização do pedido

Quando cancelo um pedido os "Motivos" poderiam ser melhorados; quando um pedido for "cancelado" poderia dispara um e-mail avisando.

At

Sueli

31 Inserção de um link para a Biblioteca do Congresso.

32 Seria importante criar uma mala diretas com as notícias veiculadas no IBICT.

33 Poderia melhorar a usabilidade e a arquitetura da informação.

34 Ainda não posso recomendar, porque estou iniciando meus acessos agora.

35

Atualização de informações referente aos cursos demestrado e doutorado na área de CI.Quando, onde,como fazer etc

Correção para dois erros gramaticais, no texto:

"Esta interatividade, é fundamental para que cada vez mais o IBICT esteja disponibilizando informaçóes em conformidade com as reais necessidades dos seus usuários."

36 1) A frase "Esta interatividade é fundamental...", pois não se separa sujeito do verbo

2) Correção com exclusäo do gerúndio "... o IBICT disponibilize informaçōes..."

i)

37 chat on line

Algumas correçöes no CCN, relativas ao registro de algumas coleçöes da Bibliotecas, Isto é, lançamentos diferenciados da mesma coleçäo. EX. Lançamento numérico - por uma Biblioteca, e Lançamentos com "X" por outra Biblioteca.

Outra correçäo - relativa a Periódicos que dispöem de suplementos em quantidade relevante.

Algumas bibliotecas lançam toda a informaçäo numérica dos fascículos e suplementos juntos, Outras bibliotecas procedem separadamente - o registro.

38 Desta forma, dificultam a busca do fascículo.

Também, nẵo compreendo porque todos a Coleçäo de Periódicos da Bireme, näo está incluído no CCN. Ex. Pulmäo,RJ - periódico lançado no registro

da Bireme, e näo encontrado no registro do $\mathrm{CCN}$.

Efetivamente, deve ocorrer com outros títulos.

Cordialmente, Ana

Os serviços do Ibict requerem melhor divulgaçäo e acesso interativo mais dinâmico, entre eles, o serviço de comutaçäo bibliográfica com metodologia bastante burocrática e morosa. Além da comunidade acadêmnica, o público emn geral (profissionais e especialistas) precisa ser também um alvo estratégico como meio de desenvolvimento cientifico e tecnológico dessa comunidade que desconhece, na sua maioria, a importante atuação política do

Ibict, Na ausência de estratégia, esta avaliaçäo, por exemplo, foi pouco, ou quase nenhuma, divulgada e Ibict tem sido historicamente pouco transparente em suas divulgaçổes, limitadas até mesmo entre profissionais da informaçăo. Tais limitaçōes naturalmente produziräo poucas recomendaçöes ou muitas outras deixaräo de ser recebidas. Desconhecendo as lacunas e realidade do mercado, Ibict e seus programas diretores precisan corresponder aos anseios maiores da sua comunidade e sociedade em geral. A análise de perfil de usuário é uma ferramenta poderosa que deve ser utilizada apropriamente.

40 nada de mais

41 para a melhoria do lbict via online ou no msn OK?bjus!

42 Seria interessante acrescentar um RSS no portal.

Jisplay $50 \vee$ Per Page

Jisplaying 1-42 of 42 Responses Select Page: First | Previous | Next | Last 


\section{ANEXO 5 \\ EXEMPLO DE ANÁLISE DO CAMPO ABERTO DO FORMULÁRIO ELETRÔNICO DE AVALIAÇÃO QUANTITATIVA DO PORTAL DO IBICT}

\begin{tabular}{|c|c|}
\hline $\begin{array}{c}\text { CATEGORIZAÇÃO DAS OBSERVAÇÕES DOS USUÁRIOS NO CAMPO DE } \\
\text { PERGUNTA ABERTA } \\
42 \text { OBSERVAÇÕES }\end{array}$ & OCORRÊNCIA \\
\hline $\begin{array}{l}\text { Demanda de novos produtos/serviços: } \\
\begin{aligned} \checkmark & \text { Informações sobre "quem é quem" no IBICT; } \\
\checkmark & \text { Informações sobre os cursos de graduação e pós-graduação em Ciência da } \\
& \text { Informação; } \\
\checkmark & \text { Informações sobre associações científicas } \\
\checkmark & \text { Informações sobre agências de fomento; } \\
\checkmark & \text { Produção de bibliografias especializadas; } \\
\checkmark & \text { Permitir o acesso ao ISSN pela Internet; } \\
\checkmark & \text { Disponibilizar RSS feeds ( }{ }^{*} \text { ); } \\
\checkmark & \text { Criar uma rede de informação entre IBICT e outros centros de informação e } \\
& \text { documentação; } \\
\checkmark & \text { Criar uma base de dados sobre notícias, com interface de busca. }\end{aligned}\end{array}$ & 10 \\
\hline $\begin{array}{l}\text { Sobre a venda de publicações: } \\
\qquad \begin{array}{l}\text { Possibilitar a visualização das obras, elaborar o resumo e promover a } \\
\text { rapidez no processo. }\end{array}\end{array}$ & 2 \\
\hline $\begin{array}{l}\text { Sobre arquitetura da informação: } \\
\qquad \begin{array}{l}\checkmark \text { Melhorar a arquitetura do tópico dos produtos e dos serviços; } \\
\checkmark \quad \text { Melhorar a arquitetura das informações do portal em geral. }\end{array}\end{array}$ & 3 \\
\hline $\begin{array}{l}\text { Sobre as notícias: } \\
\qquad \begin{array}{ll}\checkmark & \text { Melhorar a organização das notícias; } \\
\checkmark & \text { Fazer a revisão gramatical; } \\
\checkmark & \text { Separar as notícias mais efêmeras das mais duradouras; } \\
\checkmark & \text { Melhorar a qualidade da resolução das fotos das notícias. }\end{array}\end{array}$ & 7 \\
\hline$\checkmark \quad$ Adequar a linguagem do portal a todos os níveis de usuários. & 1 \\
\hline$\checkmark \quad$ Atualizar os links. & 1 \\
\hline$\checkmark \quad$ Aplicar soluções web no portal & 1 \\
\hline$\checkmark \quad$ Aumentar o tamanho da fonte & 1 \\
\hline$\checkmark$ Tornar mais visíveis a missão e os objetivos do IBICT & 1 \\
\hline$\checkmark$ Melhorar a navegação & 1 \\
\hline$\checkmark \quad$ Adequar a terminologia aos diversos níveis de usuários & 1 \\
\hline$\checkmark \quad$ Melhorar a clareza e a qualidade das informações & 1 \\
\hline$\checkmark \quad$ Disponibilizar link para a biblioteca do Congresso e Câmara Federal & 1 \\
\hline TOTAL & 42 \\
\hline
\end{tabular}


ANEXO 6

EXEMPLO DE GRÁFICOS GERADOS PELO SOFTWARE ZOOMERANG A PARTIR DA AVALIAÇÃO QUANTITATIVA POR FORMULÁRIO ELETRÔNICO (PORTAL DO IBICT)

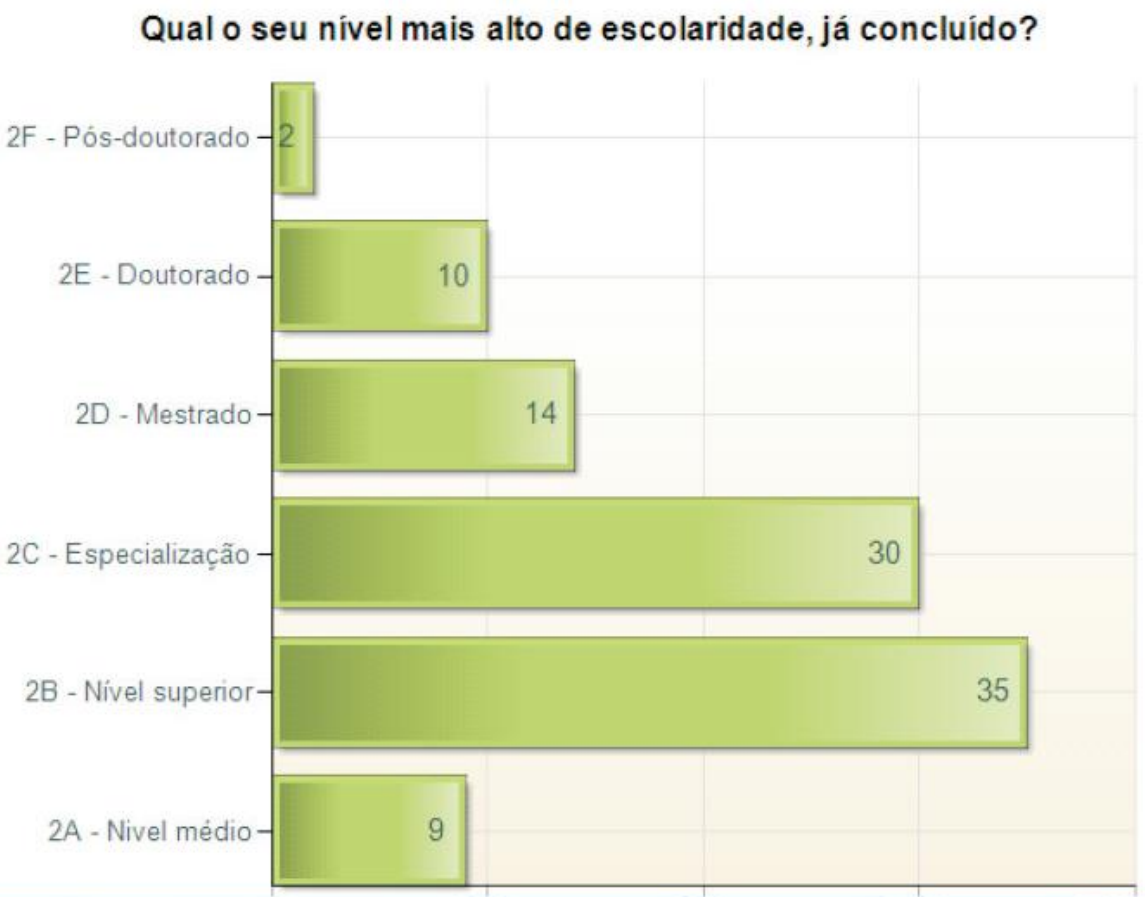

A qual(is) setor(es) econômico(s) a sua atuação profissional é correspondente?

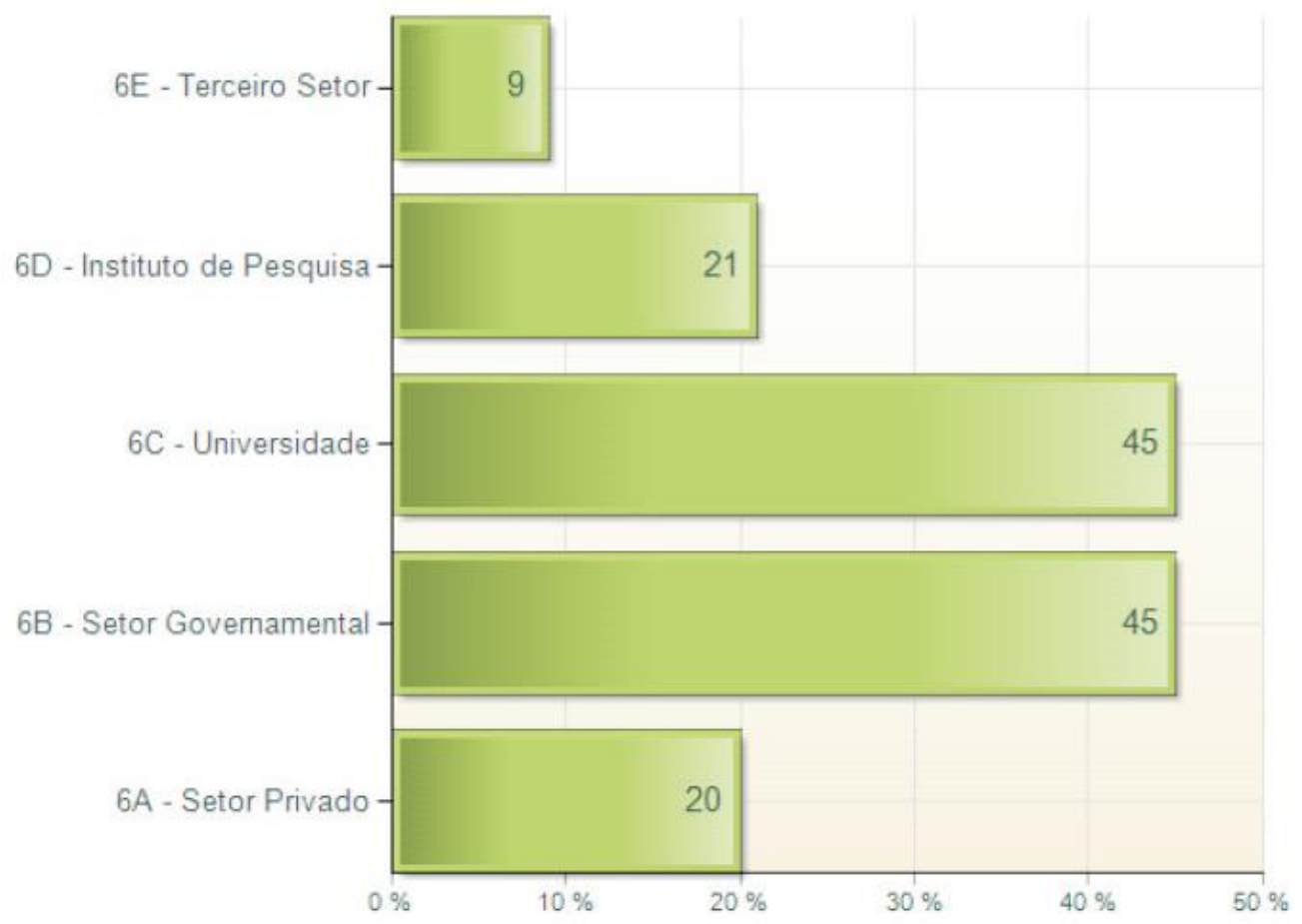


Você já buscou algum produto ou serviço de informação, no Portal do lbict, que näo tenha sido nele encontrado?

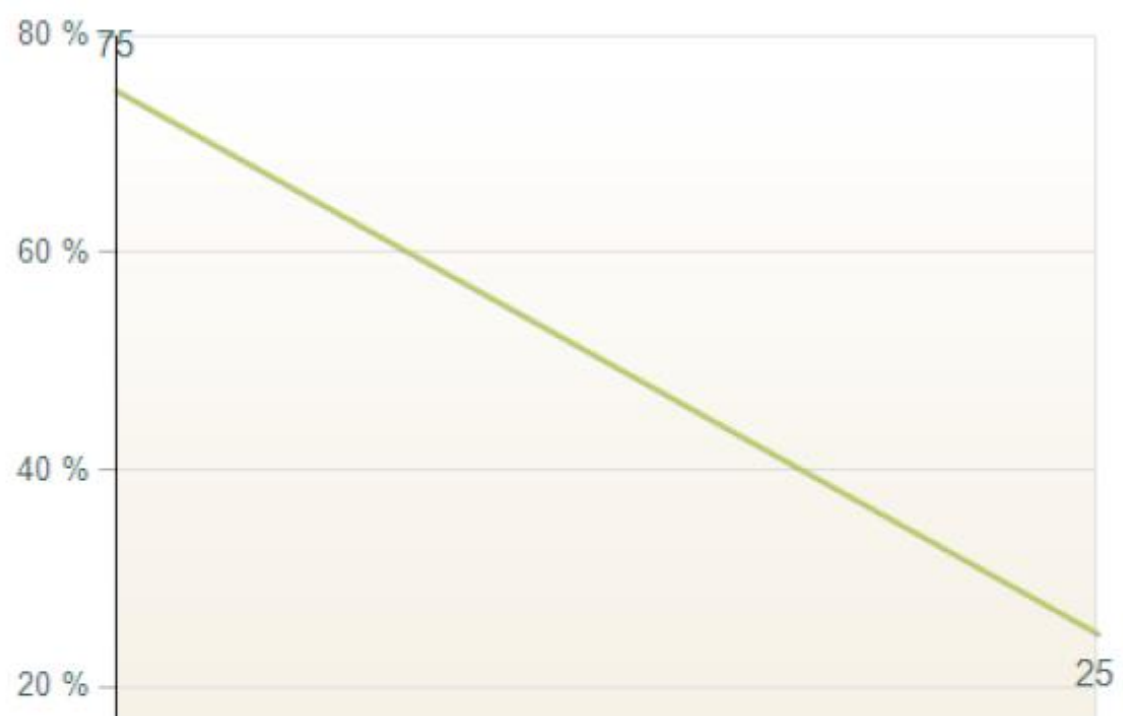

Qual o seu grau de satisfação quanto ao conteúdo das páginas que compōem o Portal do lbict ? $\square 20 \mathrm{~A}$ - muito baixo $\square 20 \mathrm{~B}$ - baixo $\square 20 \mathrm{C}$ - médio $\square 20 \mathrm{D}$ - alto $\square 20 \mathrm{E}$ - muito alto

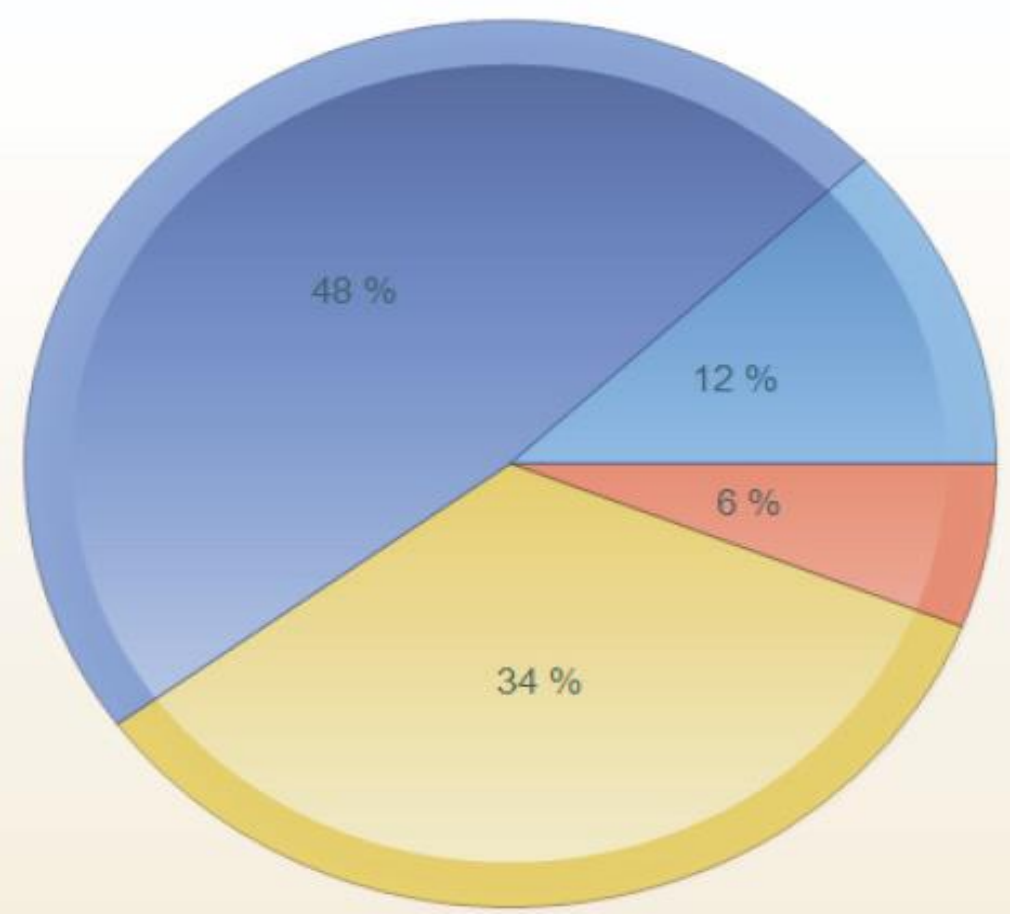




\section{Gráficos com cruzamentos de dados:}
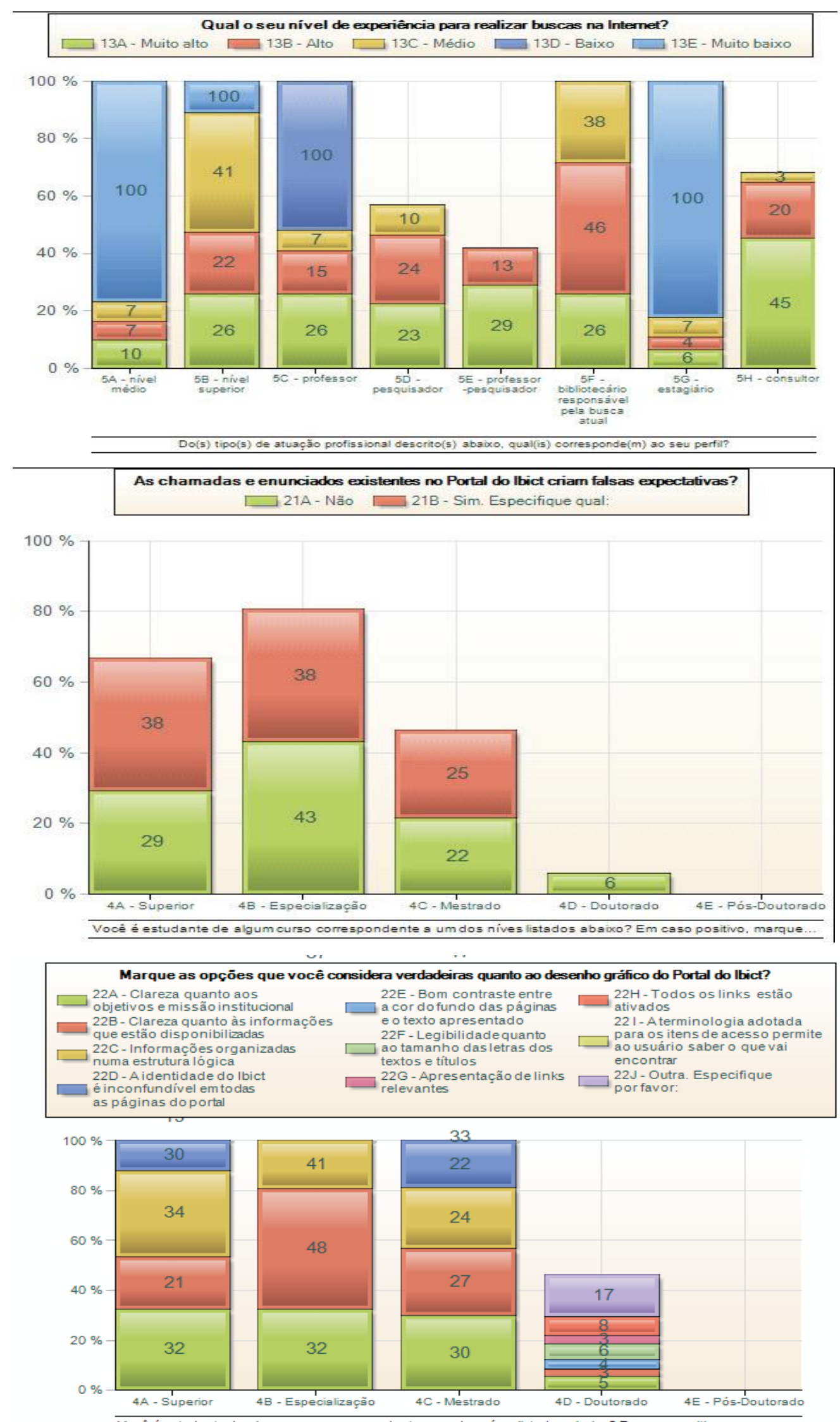

Vocé é estudante de slgum curso correspondente a um dos nives listados abaíco? Em caso positivo, marque o.... 


\section{ANEXO 7 \\ CHECKLIST PARA APLICAÇÃO DAS HEURÍSTICAS DE JACOB NIELSEN PARA ANÁLISE DO PORTAL E SITES DOS PRODUTOS DO IBICT (CHECKLIST PARA AVALIAÇÃO DA INTERFACE HOMEM-MÁQUINA A PARTIR DAS HEURÍSTICAS DE NIELSEN)}

\section{NOME DO PRODUTO OU SERVIÇO}

Avaliar a gravidade do problema, a partir da sua frequência; do seu impacto, considerando o grau de dificuldade do usuário em contornar o problema e da sua persistência, sem possibilidade de ser contornado.

\begin{tabular}{|c|c|c|c|c|c|}
\hline \multirow{3}{*}{$\begin{array}{l}\text { 1 - Clareza e visibilidade do status do } \\
\text { sistema ou site. } \\
\text { o sistema deve informar o que ele } \\
\text { oferece, quais as suas características } \\
\text { temporais, espaciais e temáticas, } \\
\text { para não criar falsas expectativas. } \\
\text { Da mesma forma, usuário não } \\
\text { pode se sentir perdido e tem que ser } \\
\text { informado constantemente do que está } \\
\text { acontecendo durante a navegação. }\end{array}$} & \multirow[t]{3}{*}{$\begin{array}{l}\text { No. DE OCORRENCIAS- } \\
\text { URL E COMENTARIOS }\end{array}$} & \multicolumn{4}{|c|}{$\begin{array}{l}\text { GRAVIDADE DO } \\
\text { PROBLEMA }\end{array}$} \\
\hline & & 1 & 2 & 3 & 4 \\
\hline & & & & & \\
\hline
\end{tabular}

\section{CHECKLIST PARA APLICAÇÃO DAS HEURÍSTICAS DE JACOB NIELSEN PARA ANÁLISE DO PORTAL E SITES DOS PRODUTOS DO IBICT}

\section{NOME DO PRODUTO OU SERVIÇO}

Avaliar a gravidade do problema, a partir da sua frequência; do seu impacto, considerando o grau de dificuldade do usuário em contornar o problema e da sua persistência, sem possibilidade de ser contornado.

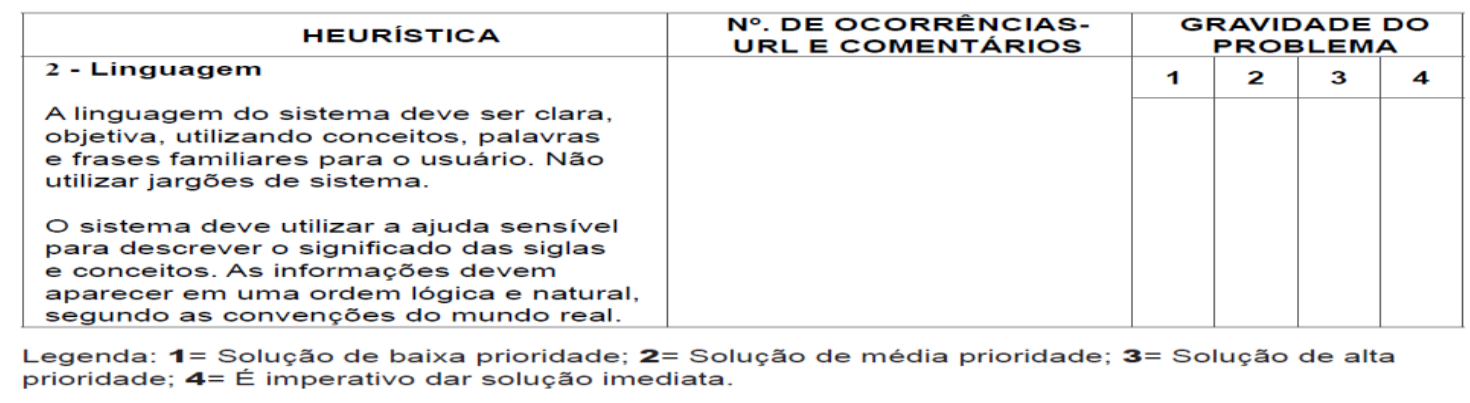

\section{CHECKLIST PARA APLICAÇÃO DAS HEURÍSTICAS DE JACOB NIELSEN PARA ANÁLISE DO PORTAL E SITES DOS PRODUTOS DO IBICT}

\section{NOME DO PRODUTO OU SERVIÇO}

Avaliar a gravidade do problema, a partir da sua frequência; do seu impacto, considerando o grau de dificuldade do usuário em contornar o problema e da sua persistência, sem possibilidade de ser contornado

\begin{tabular}{|c|c|c|c|c|c|}
\hline \multirow{3}{*}{$\begin{array}{l}3 \text { - Autonomia e controle do usuário } \\
\text { o sistema deve permitir que o } \\
\text { usuario tenha autonomia para iniciar, } \\
\text { interromper, continuar, desfazer, } \\
\text { corrigir as açães por ele comandadas, } \\
\text { como abortaroperações erradas e } \\
\text { retornar ao estado anterior. }\end{array}$} & \multirow[t]{3}{*}{$\begin{array}{l}\text { No. DE OCORRENCIAS- } \\
\text { URL E COMENTÁRIOS }\end{array}$} & \multicolumn{4}{|c|}{$\begin{array}{l}\text { GRAVIDADE DO } \\
\text { PROBLEMA }\end{array}$} \\
\hline & & 1 & 2 & 3 & 4 \\
\hline & & & & & \\
\hline
\end{tabular}

Legenda: 1 = Solução de baixa prioridade; $2=$ Solução de média prioridade; $3=$ Solução de alta prioridade; 4 = É imperativo dar solução imediata. 


\section{CHECKLIST PARA APLICAÇÃO DAS HEURÍSTICAS DE JACOB NIELSEN PARA ANÁLISE DO PORTAL E SITES DOS PRODUTOS DO IBICT}

\section{NOME DO PRODUTO OU SERVIÇO}

Avaliar a gravidade do problema, a partir da sua frequência; do seu impacto, considerando o grau de dificuldade do usuário em contornar o problema e da sua persistência, sem possibilidade de ser contornado

\begin{tabular}{|c|c|c|c|c|c|}
\hline HEURISTICA & $\begin{array}{l}\text { No. DE OCORRENCIAS- } \\
\text { URL E COMENTARIOS }\end{array}$ & \multicolumn{4}{|c|}{$\begin{array}{l}\text { GRAVIDADE DO } \\
\text { PROBLEMA }\end{array}$} \\
\hline \multirow{2}{*}{$\begin{array}{l}4 \text { - Padronização e consistência } \\
\text { Os elementos de interface de um } \\
\text { sistema ou portal devem seguir o } \\
\text { mesmo padrão de localizaça, formato } \\
\text { e estética em suas diversas páginas. } \\
\text { Um elemento não deve ser utilizado } \\
\text { para identificar mais de um significado, } \\
\text { nem dois elementos diferentes para } \\
\text { identificar um único significado. }\end{array}$} & & 1 & 2 & 3 & 4 \\
\hline & & & & & \\
\hline
\end{tabular}

Legenda: $\mathbf{1}$ = Solução de baixa prioridade; $\mathbf{2}=$ Solução de média prioridade; $\mathbf{3}=$ Solução de alta prioridade; $\mathbf{4}=$ É imperativo dar solução imediata.

\section{CHECKLIST PARA APLICAÇÃO DAS HEURÍSTICAS DE JACOB NIELSEN PARA ANÁLISE DO PORTAL E SITES DOS PRODUTOS DO IBICT}

\section{NOME DO PRODUTO OU SERVIÇO}

Avaliar a gravidade do problema, a partir da sua frequência; do seu impacto, considerando o grau de dificuldade do usuário em contornar o problema e da sua persistência, sem possibilidade de ser contornado

\begin{tabular}{|l|c|c|c|}
\hline \multicolumn{1}{|c|}{ HEURÍsticA } & No. DE OCORRENCIAS- & \multicolumn{2}{|c|}{ GRAVIDADE DO } \\
PROBLEMA
\end{tabular}

Legenda: $\mathbf{1}$ = Solução de baixa prioridade; $\mathbf{2}$ =Solução de média prioridade; $\mathbf{3}=$ Solução de alta prioridade; 4 = É imperativo dar solução imediata.

\section{CHECKLIST PARA APLICAÇÃO DAS HEURÍSTICAS DE JACOB NIELSEN PARA ANÁLISE DO PORTAL E SITES DOS PRODUTOS DO IBICT}

\section{NOME DO PRODUTO OU SERVIÇO}

Avaliar a gravidade do problema, a partir da sua frequência; do seu impacto, considerando o grau de dificuldade do usuário em contornar o problema e da sua persistência, sem possibilidade de ser contornado

\begin{tabular}{|c|c|c|c|c|c|}
\hline \multirow{3}{*}{$\begin{array}{l}\text { HEURístICA } \\
\text { 6 - Reconhecimento em lugar de } \\
\text { lembrança } \\
\text { o sistema deve minimizar a sobrecarga } \\
\text { de memória do usuário. A interface Web } \\
\text { deve ser desenvolvida de tal forma } \\
\text { que mantenha as relaçães de uma tela } \\
\text { para outra, facilmente reconhecidas. } \\
\text { Os icones e denominações utilizados } \\
\text { devem ter forte relação semântica com } \\
\text { sua função. }\end{array}$} & \multirow[t]{3}{*}{$\begin{array}{l}\text { No. DE OCORRENCIAS- } \\
\text { URL E COMENTÁRIOS }\end{array}$} & \multicolumn{4}{|c|}{$\begin{array}{l}\text { GRAVIDADE DO } \\
\text { PROBLEMA }\end{array}$} \\
\hline & & 1 & 2 & 3 & 4 \\
\hline & & & & & \\
\hline
\end{tabular}

Legenda: $\mathbf{1}$ = Solução de baixa prioridade; $\mathbf{2}=$ Solução de média prioridade; $\mathbf{3}=$ Solução de alta prioridade; $4=$ É imperativo dar solução imediata. 


\section{NOME DO PRODUTO OU SERVIÇO}

Avaliar a gravidade do problema, a partir da sua frequência; do seu impacto, considerando o grau de dificuldade do usuário em contornar o problema e da sua persistência, sem possibilidade de ser contornado

\begin{tabular}{|c|c|c|c|c|c|}
\hline HEURISTICA & $\begin{array}{l}\text { No. DE OCORRENCIAS- } \\
\text { URLE COMENTÁRIOS }\end{array}$ & \multicolumn{4}{|c|}{$\begin{array}{l}\text { GRAVIDADE DO } \\
\text { PROBLEMA }\end{array}$} \\
\hline 7 - Flexibilidade e eficiência & & 1 & 2 & 3 & 4 \\
\hline $\begin{array}{l}\text { O sistema deve ser desenvolvido de forma a } \\
\text { atender aos diversos niveis de experiência } \\
\text { dos usuários. Para isso, deve permitir que } \\
\text { os usuários mais experientes acelerem sua } \\
\text { interaça com o sistema, como por exemplo, } \\
\text { criar atalhos. }\end{array}$ & & & & & \\
\hline
\end{tabular}

Legenda: $\mathbf{1}=$ Solução de baixa prioridade; $\mathbf{2}=$ Solução de média prioridade; $\mathbf{3}=$ Solução de alta prioridade; $\mathbf{4}=$ É imperativo dar solução imediata.

\section{CHECKLIST PARA APLICAÇÃO DAS HEURÍSTICAS DE JACOB NIELSEN PARA ANÁLISE DO PORTAL E SITES DOS PRODUTOS DO IBICT}

\section{NOME DO PRODUTO OU SERVIÇO}

Avaliar a gravidade do problema, a partir da sua frequência; do seu impacto, considerando o grau de dificuldade do usuário em contornar o problema e da sua persistência, sem possibilidade de ser contornado

\begin{tabular}{|c|c|c|c|c|c|}
\hline \multirow[b]{3}{*}{$\begin{array}{l}8 \text { - Estética e minimalismo } \\
\text { Os elementos apresentados devem ser aqueles } \\
\text { realmente necessários para que a finalidade da } \\
\text { interface seja atendida; evitar que os textos e o } \\
\text { design falem mais do que o usuário necessita saber. } \\
\text { No uso das cores, restrinja no máximo a } 5 \text { ou } 7 \\
\text { cores diferentes. Tentar utilizar cores apenas para } \\
\text { categorizar, diferenciar e destacar, e náo para dar } \\
\text { informaça, especialmente a informaça quantitativa. } \\
\text { Lembrar de utilizar os recursos que possibilitam a } \\
\text { melhoria da acuidade visual do usuário. }\end{array}$} & \multirow[t]{4}{*}{$\begin{array}{l}\text { No. DE } \\
\text { OCORRENCIAS- } \\
\text { UURLEE } \\
\text { COMENTAERIOS }\end{array}$} & \multicolumn{4}{|c|}{$\begin{array}{l}\text { GRAVIDADE } \\
\text { PROBLEMMA }\end{array}$} \\
\hline & & 1 & 2 & 3 & 4 \\
\hline & & & & & \\
\hline $\begin{array}{l}\text { Tentar aplicar os principios de Gestalt na organização } \\
\text { dos objetos da interface no que tange a sua } \\
\text { semelhança, proximidade boa continuidade lógica. } \\
\text { Isto com a finalidade de a interface não ter aspecto } \\
\text { desorganizado e amontoado. }\end{array}$ & & & & & \\
\hline
\end{tabular}

\section{CHECKLIST PARA APLICAÇÃO DAS HEURÍSTICAS DE JACOB NIELSEN PARA ANÁLISE DO PORTAL E SITES DOS PRODUTOS DO IBICT}

\section{NOME DO PRODUTO OU SERVIÇO}

Avaliar a gravidade do problema, a partir da sua frequência; do seu impacto, considerando o grau de dificuldade do usuário em contornar o problema e da sua persistência, sem possibilidade de ser contornado

\begin{tabular}{|c|c|c|c|c|c|}
\hline \multirow[b]{3}{*}{$\begin{array}{l}9 \text { - Ajuda e documentação } \\
\text { É necessário que a operacionalização } \\
\text { do sistema seja autoexplicativa, } \\
\text { sem necessidade de auxilio de } \\
\text { documentação e sistema de } \\
\text { ajuda. Quando for necessária } \\
\text { uma explicaça para realizar uma } \\
\text { operação, utilize uma interface } \\
\text { gráfica, como, por exemplo, os balões } \\
\text { de ajuda. }\end{array}$} & \multirow[t]{3}{*}{$\begin{array}{l}\text { No. DE OCORRENCIAS- } \\
\text { URL E COMENTARIOS }\end{array}$} & \multicolumn{4}{|c|}{$\begin{array}{l}\text { GRAVIDADE DO } \\
\text { PROBLEMA }\end{array}$} \\
\hline & & 1 & 2 & 3 & 4 \\
\hline & & & & & \\
\hline
\end{tabular}

Legenda: $\mathbf{1}=$ Solução de baixa prioridade; $\mathbf{2}=$ Solução de média prioridade; $\mathbf{3}=$ Solução de alta prioridade; $4=$ É imperativo dar solução imediata. 


\section{ANEXO 8 \\ CHECKLIST PARA APLICAÇÃO DAS HEURÍSTICAS DE JACOB NIELSEN PARA ANÁLISE DO PORTAL E SITES DOS PRODUTOS DO IBICT}

\section{NOME DO PRODUTO OU SERVIÇO}

Avaliar a gravidade do problema, a partir da sua frequência; do seu impacto, considerando o grau de dificuldade do usuário em contornar o problema e da sua persistência, sem possibilidade de ser contornado

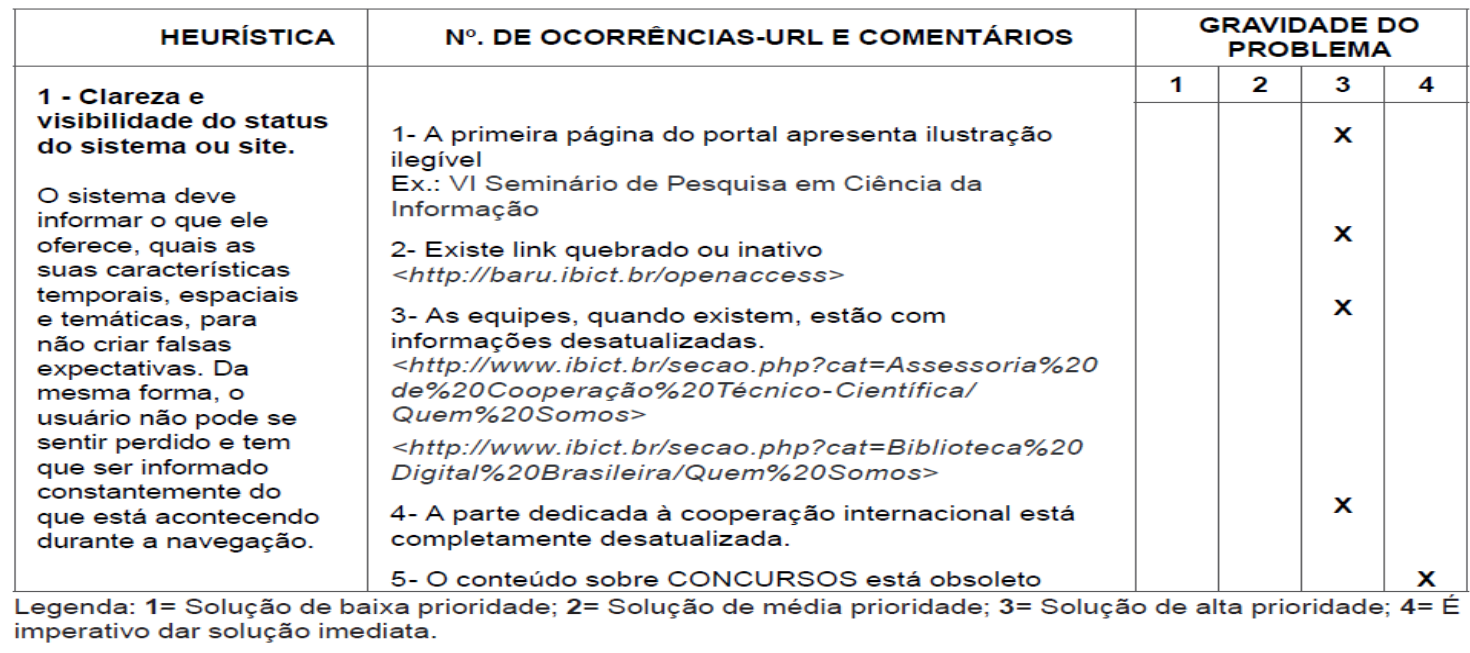

\section{CHECKLIST PARA APLICAÇÃO DAS HEURÍSTICAS DE JACOB NIELSEN PARA ANÁLISE DO PORTAL E SITES DOS PRODUTOS DO IBICT}

\section{NOME DO PRODUTO OU SERVIÇO}

Avaliar a gravidade do problema, a partir da sua frequência; do seu impacto, considerando o grau de dificuldade do usuário em contornar o problema e da sua persistência, sem possibilidade de ser contornado

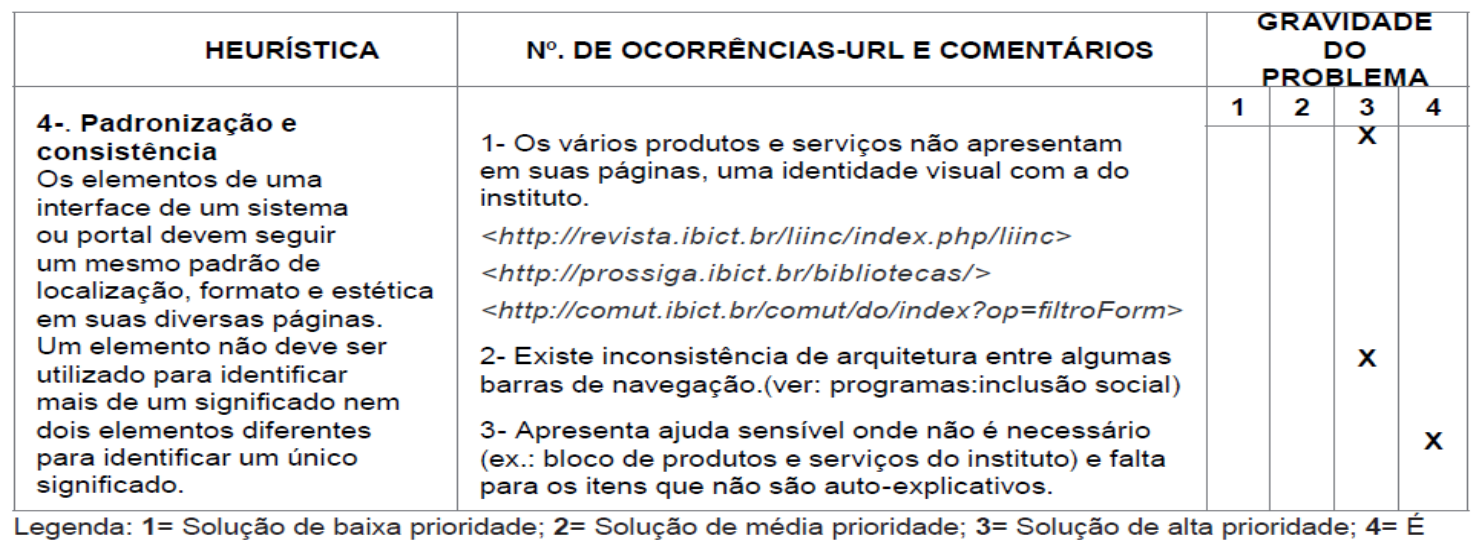

imperativo dar solução imediata. 


\section{ANEXO 9 \\ CARTA DE APRESENTAÇÃO E QUESTIONÁRIO ELETRÔNICO DA BDJUR}

\section{1 - CARTA DE APRESENTAÇÃO}

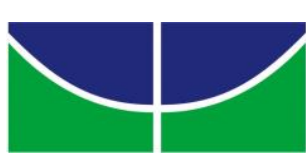

Universidade de Brasília

Faculdade de Ciência da Informação (FCl)

Brasília, de

de 2015.

Prezado(a) Assessor(a) de Ministro,

Como servidora desta Corte, estou realizando uma pesquisa de doutorado na Universidade de Brasília, UnB, sob o tema: Avaliacão de produtos de informacão jurídica do Tribunal da Cidadania: um enfoque da Ciência da Informação.

Esse estudo tem como objetivo reunir dados sobre o assunto, junto à Biblioteca do Superior Tribunal de Justiça e aos Gabinetes dos Ministros do Tribunal, para aplicação de uma metodologia da Ciência da Informação de avaliação de produtos de informação, a fim de:

- obter visão contextualizada das práticas informacionais dos assessores de ministro e as condições de uso dos produtos oferecidos;

- conhecer o grau de satisfação dos assessores de ministro e a extensão do acesso e uso dos produtos de informação jurídica;

- analisar a usabilidade dos produtos de informação oferecidos e interação com a interface do sistema.

Para que esta pesquisa alcance resultados satisfatórios, é imprescindível que V.Sa. participe, compartilhando um pouco de tempo para responder ao questionário enviado. Adianto que os dados serão tratados estatisticamente, sem menção de identidade dos respondentes.

Ressalto que o resultado do trabalho será oferecido à direção da Biblioteca desta Egrégia Corte como sugestão para o aperfeiçoamento dos produtos fornecidos pela Unidade.

$\mathrm{Na}$ certeza de contar com sua indispensável participação, antecipadamente agradeço pela atenção dispensada.

Para responder o questionário, Clique aqui

Atenciosamente, 


\section{2 - QUESTIONÁRIO ELETRÔNICO}

OBJETIVO:

Esta é uma pesquisa de doutorado da Universidade de Brasília que visa analisar características da Biblioteca Digital Jurídica do STJ, BDJur, em relação ao grau de satisfação dos usuários e a extensão do acesso e uso de produtos de informação jurídica aplicando uma metodologia de avaliação de produtos de informação. Sua colaboração é imprescindível para o êxito da pesquisa. Solicito, assim, que compartilhe o seu tempo para fornecer as informações requeridas neste questionário sobre a navegação na BDJur. Os dados serão tratados estatisticamente, sem identificação dos respondentes.

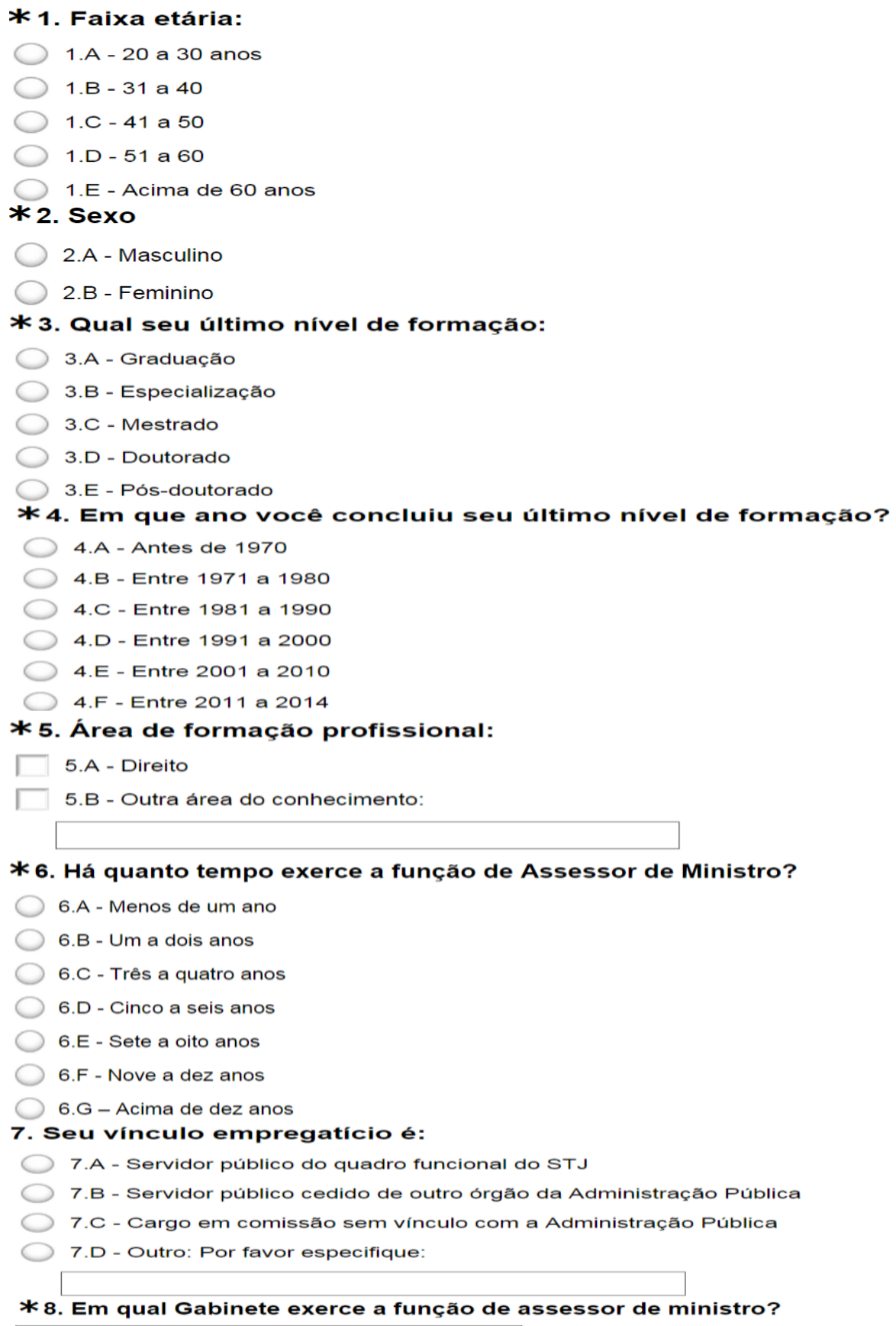

* 5. Área de formação profissional:

D.A - Direito

5.B - Outra área do conhecimento:

* 6. Há quanto tempo exerce a função de Assessor de Ministro?

6.A - Menos de um ano

6.B - Um a dois anos

6.C - Três a quatro anos

6.D - Cinco a seis anos

6.E - Sete a oito anos

6.F - Nove a dez anos

6.G - Acima de dez anos

7. Seu vínculo empregatício é:

7.A - Servidor público do quadro funcional do STJ

7.B - Servidor público cedido de outro órgão da Administração Pública

7.C - Cargo em comissão sem vínculo com a Administração Pública

7.D - Outro: Por favor especifique:

* 8. Em qual Gabinete exerce a função de assessor de ministro? 
* 9. Qual(is) área(s) do Direito, em relação às áreas das Seções e Turmas do STJ, correspondem a sua atuação profissional:

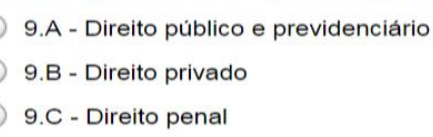

* 10. Como considera seu nível de experiência para realizar buscas em bases de dados jurídicas?
10.A - Excelente
10.B - Bom
10.C - Regular
10.D - Insuficiente

11. Cite as bases de dados de informação jurídica na internet /intranet que você costuma pesquisar, para realização do seu trabalho no STJ:

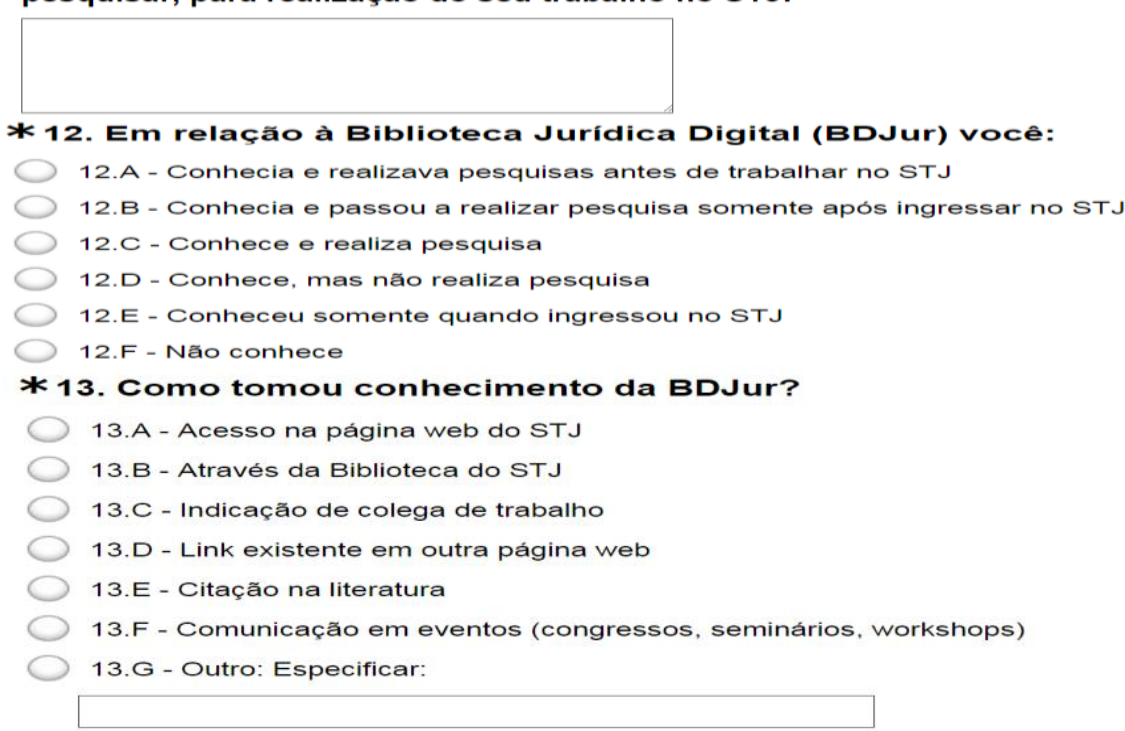

* 14. Selecione o(s) tipos de pesquisa, em relação ao grau de frequência, que você realiza na BDJur, para seu trabalho como assessor de gabinete no STJ:

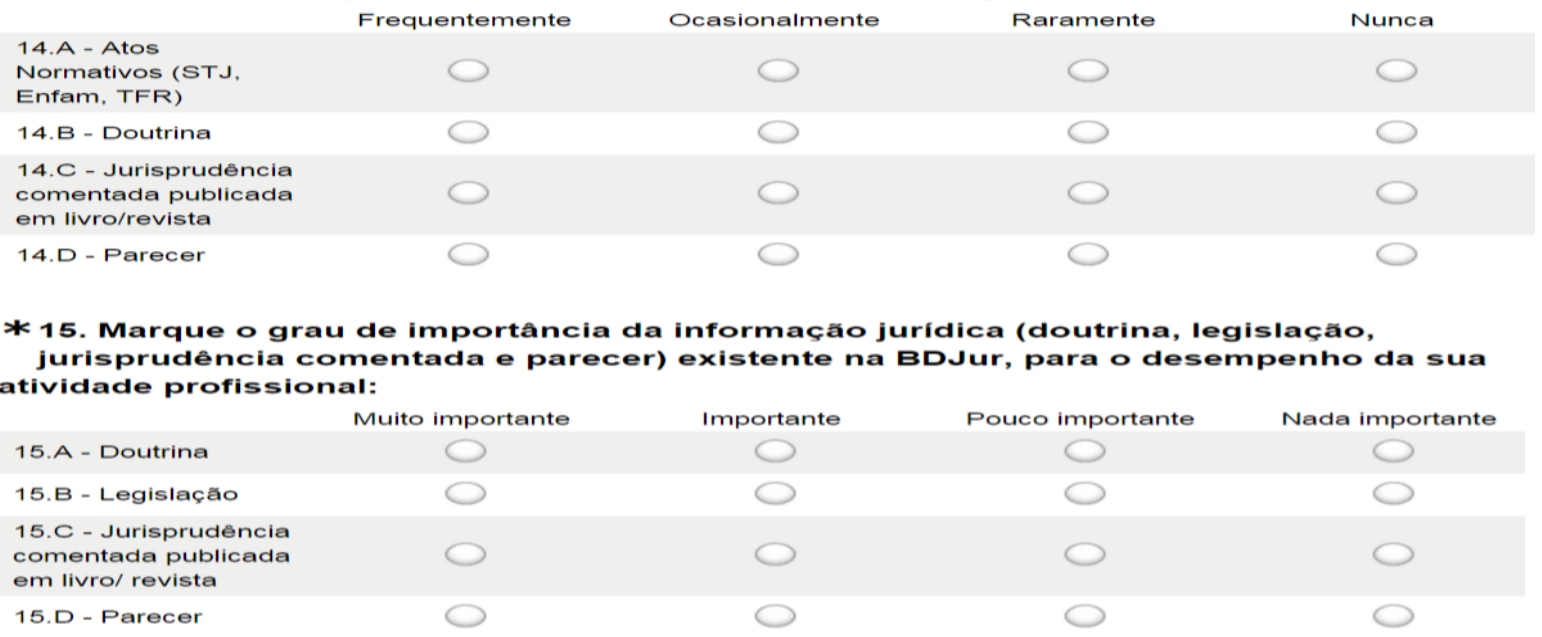


* 16. Com qual finalidade e frequência você utiliza a informação jurídica encontrada na BDJur, na execução do seu trabalho no STJ?

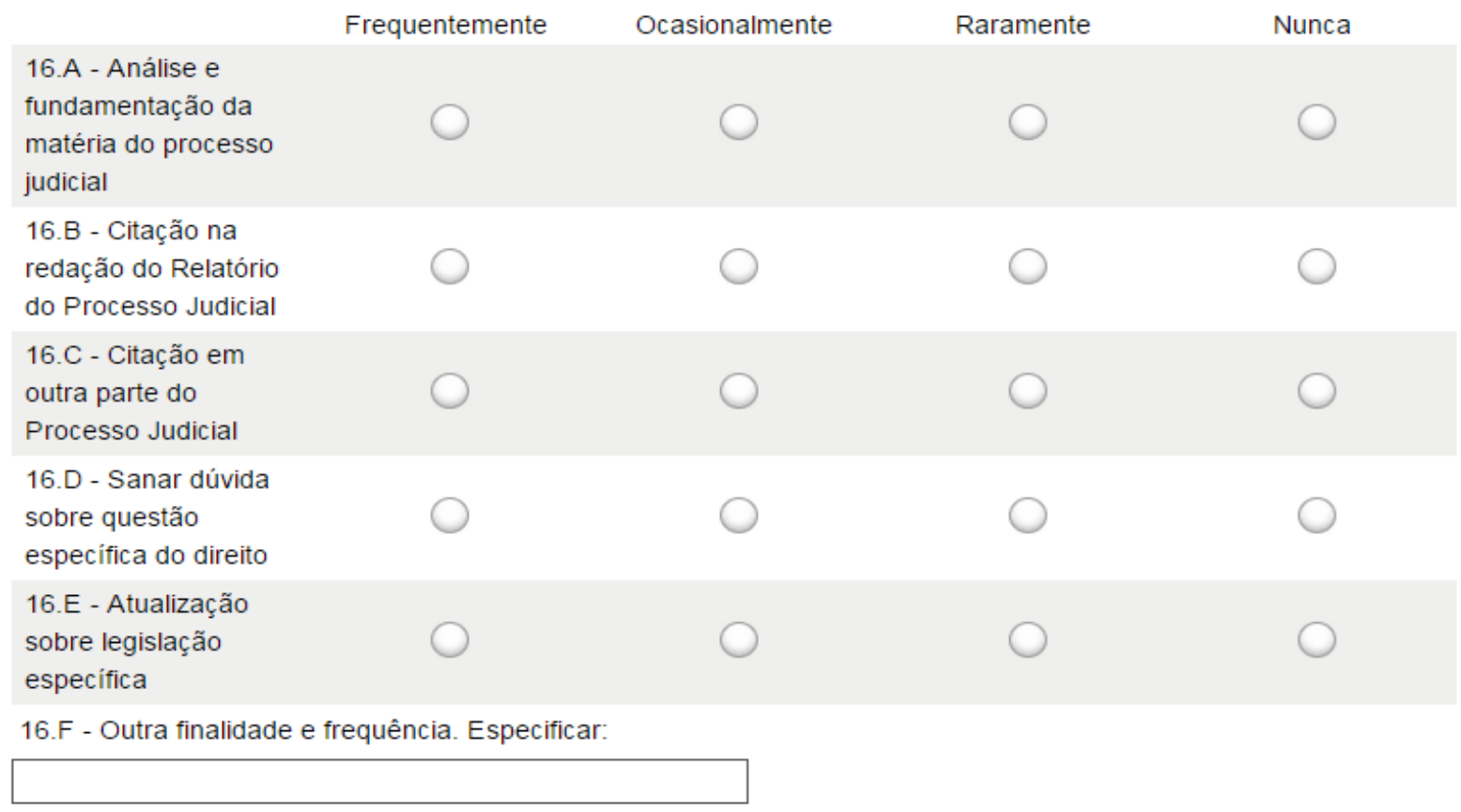

* 17. Com que periodicidade realiza buscas na BDJur:
17.A - Diária
17.B - Semanal
17.C - Mensal
17.D - Irregular
17.E - Não utilizo

* 18. Qual indicador você atribui à BDJur considerando sua escala de necessidade de busca e uso da informação jurídica no seu trabalho?
18.A - Muito alto
18.B - Alto
18.C - Médio
18. D - Baixo

* 19. Em média, qual o número de tentativas realizadas para você localizar a informação jurídica no processo de busca na BDJur:
19.A - Uma
19.B - Duas a quatro
19.C - Mais de cinco

* 20. Estas tentativas correspondem a que grau de dificuldade necessário para realização da busca:

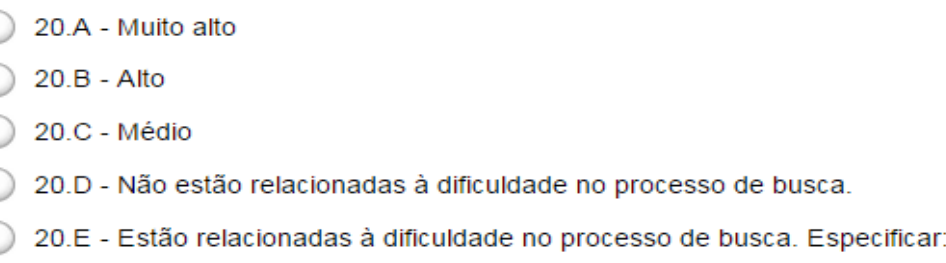


*21. Você já buscou alguma informação na BDJur que não tenha sido encontrada?

21.A - Não

21.B - Sim. Por favor especifique qual:

* 22. Aponte as dificuldades encontradas no acesso à informação jurídica na BDJur:

22.A - Atos Normativos (STJ, ENFAM, TFR) não encontrados

22.B - Doutrina não encontrada

22.C - Doutrina não relevante

22.D - Nenhuma

22.E - Outras. Por favor especifique:

* 23. Qual seu grau de satisfação em relação ao conteúdo das páginas que compōem a BDJur:
23.A - Muito satisfeito
23.B - Satisfeito
23.C - Pouco satisfeito
23.D - Insatisfeito

*24. Os textos explicativos existentes na BDjur direcionam a sua pesquisa no acesso à informação buscada?
24.A - Sim
24.B - Não
25.A - Rápida
25.B - Razoável
25.C - Eventualmente lenta
25.D - Frequentemente lenta

* 25. Como você julga o tempo de resposta das pesquisas realizadas na BDJur:

* 26. Marque somente a(s) opção(öes) que considera verdadeira(s) sobre a interface da BDJur:

[ 26.H1 - Apresenta clareza nas informações gerais quanto a navegação e sobre o conteúdo disponibilizado.

- 26. H2 - Utiliza linguagem objetiva com uso de palavras, frases e conceitos exatos.

[ 26.H3 - Possibilita autonomia ao usuário para iniciar, interromper, continuar, desfazer e corrigir ações realizadas no sistema.

26.H4 - Apresenta padronização e identidade visual em todas as páginas do sistema

— 26.H5 - As mensagens de erros exibidas pelo sistema são explicativas e objetivas.

[ 26.H6 - A navegabilidade facilita a conexão e interação entre as páginas do sistema

[26.H7 - Permite a realização de pesquisas conforme diferentes niveis de experiência dos usuários.

- 26. H8 - Utiliza cores adequadas nas páginas e textos e, legibilidade quanto ao tamanho das letras, textos e títulos.

[ 26.H9 - Permite navegação autoexplicativa ao usuário, exibindo ajuda quando necessária para realizar uma operação.

— 26.10 - Outra. Por favor especifique: 
*27. No que se refere ao processo de avaliação da BDJur pelo usuário do STJ, como produto de informação jurídica da Biblioteca, você considera que:

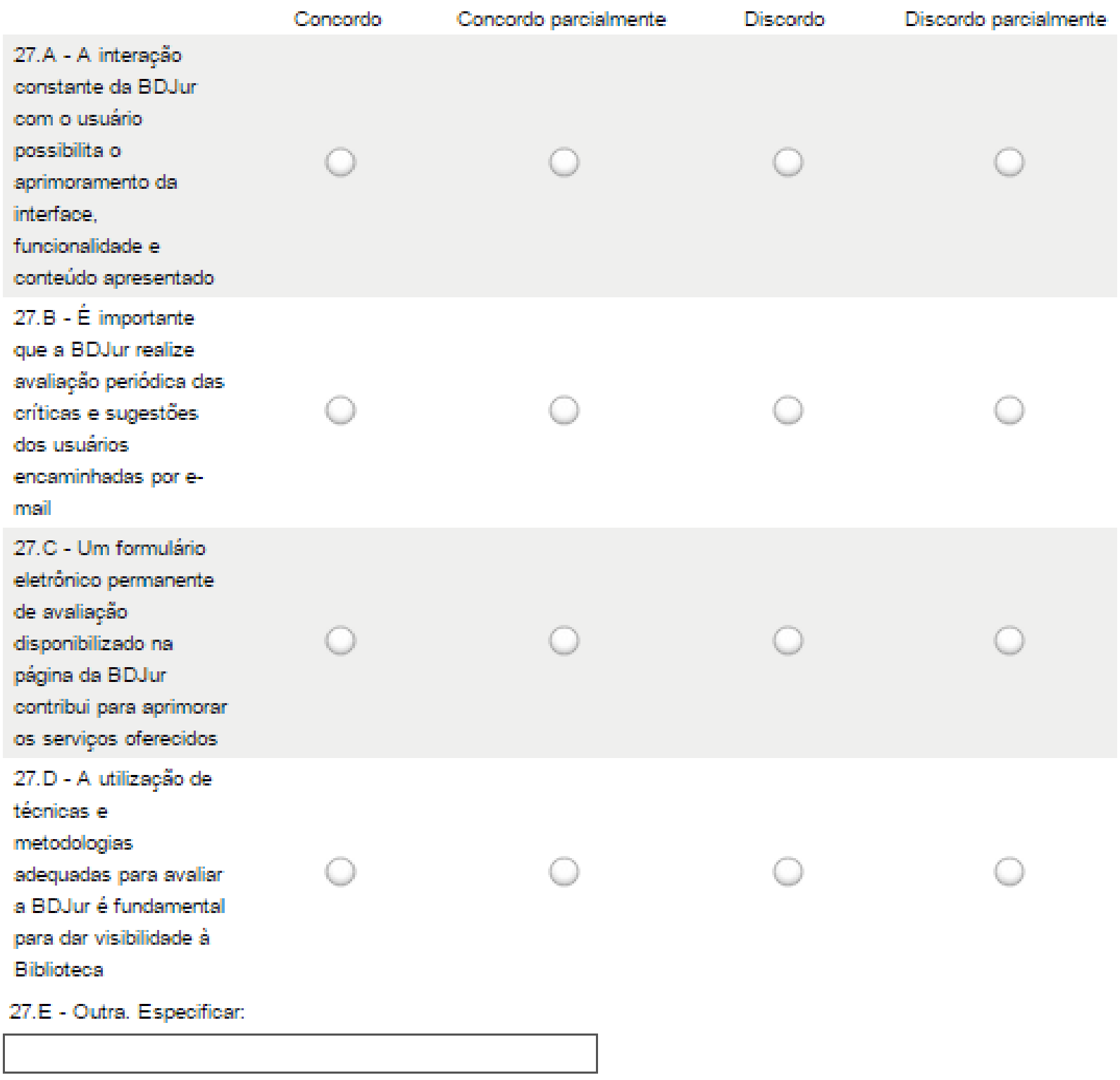

28. Que recomendaçôes você faria para melhoria da BDJur que não foram abordadas neste questionário? 


\section{ANEXO 10 \\ ROTEIRO PARA REALIZAÇÃO DAS ENTREVISTAS}

Visa descrever a vivência de uma determinada busca à informação utilizando a BDJur. Trata-se de uma pesquisa de usuário que poderá trazer insumos para melhorias dos serviços da Biblioteca. Não haverá identificação dos respondentes nem dos gabinetes.

1 - SITUAC̄ÃO - (O momento de necessidade de busca na BDJur)

Questão 1.1: Que tipo de trabalho específico você estava fazendo que demandou a busca de informação na BDJur?

Questão 1.2: Para que você precisava da informação? (que problema você precisava solucionar com a recuperação da informação?)

2 - BUSCA -

Questão 2.1: Que tipo de informação (categoria) você buscou para suprir a pesquisa? (conceito, legislação, doutrina, outras)

Questão 2.2: Por que você escolheu a BDJur como fonte de pesquisa?

Questão 2.3: Nessa situação específica de pesquisa você obteve sucesso ou insucesso no resultado?

Questão 2.4: Quais os sentimentos que esse resultado Ihe trouxe? (alívio, irritação, impaciência, satisfação, outros)

$3-\underline{\text { USO }}$ -

Questão 3.1: Com a pesquisa em mãos, como, de forma, você a utilizou no seu trabalho ou tomada de decisão? (citação, desenvolveu uma ideia, comprovação)

Questão 3.2: Considerando todas as etapas da pesquisa, que valor você atribuiria à informação recuperada? (básica, subsidiária, essencial)

Questão 3.3: Você recorreu a outras fontes de informação durante a pesquisa? Quais?

Questão 3.4: Quais suas sugestões para que a BDJur atenda mais plenamente as suas necessidades de informação? 
01. Relato de entrevista com a marcação de variáveis denominadas incidentes críticos (positivos ou negativos) com a aplicação do método Micro moment time line interview, da abordagem Sense-Making.

\section{Perfil do usuário}

Graduado em direito. É servidor público do quadro funcional do STJ exercendo a função de assessor de ministro há mais de dez anos. É lotado na Segunda Seção, com atuação profissional na área de direito privado.

\section{Contextualização da entrevista}

Foi informado ao assessor sobre a importância da avaliação de produtos de informação jurídica em bibliotecas como fonte de informação para o processo decisório de aprimoramento destes produtos. Isto, na perspectiva de adequação dos produtos às reais necessidades dos assessores dos gabinetes dos ministros, na busca, acesso e uso da informação jurídica em seu trabalho na atividade judicante do Tribunal. A pesquisa sobre a BDJur foi contextualizada como parte de trabalho de pós-graduação na UnB, com aplicação de uma nova metodologia especificamente desenvolvida para avaliar produtos e serviços de informação e, que estava sendo aplicada pioneiramente numa instituição do Poder judiciário. Foi esclarecido ao usuário que, além do questionário eletrônico previamente enviado aos gabinetes, a metodologia incluía a realização de entrevista com foco no comportamento de busca e uso da informação jurídica no processo de construção do conhecimento e dos movimentos que ocorrem dentro deste processo, ou parte dele.

Isto, porque a metodologia está centrada na vivência do assessor na busca à informação, recomendando que o entrevistado relate uma experiência de busca e uso de informação jurídica na BDJur, como produto de informação a ser estudado na pesquisa de pós-graduação, com aplicação da Metodologia do IBICT para Avaliação de Produtos e Serviços de informação. Foi esclarecido que o resultado da pesquisa de pós-graduação poderia posteriormente, servir de insumo para a Biblioteca do STJ em processos decisórios sobre a BDJur. Foi explicado que a vivência de busca de informação tem início no fato que gerou a necessidade da informação jurídica. Então, foi solicitado que o assessor de ministro relatasse a experiência de busca e uso da informação a partir do fato desencadeador chamado de situação.

\section{Relato do entrevistado}

\section{Situação}

Necessitava levantar subsídios para preparar e fundamentar um modelo de decisão para auxiliar no voto da ministra. Sabia que nem sempre a informação está disponível nos gabinetes e foi buscar na BDJur, por considerá-la como ferramenta para encontrar os dados, visando elaborar a alegação pertinente sobre o assunto e encaminhar à ministra para análise. Esclareceu tratar-se de situação de um serviço tipicamente de assessoria. Relatou uma situação específica em que buscava a confirmação da existência, ou não, de determinado assunto tratado na doutrina ou em legislação, que considerou um assunto de natureza impossível no Direito: 
"O que é impossível? Aquilo que a lei não diz por que é óbvio". "(..) tinha certeza que nenhum livro (...) dizia isso, por que não precisa dizer por que é óbvio". "Então é óbvio que ninguém vai tratar do óbvio, mas se tinha que ter certeza".

\section{Lacuna}

O entrevistado entrou na BDJur recentemente, no início de novembro de 2015, para realizar essa busca, pesquisando doutrina (autor e título) e atos administrativos, não encontrados no Sistema Justiça do tribunal, enfatizando que "há muita coisa de resolução no que diz respeito a julgamento de processos repetitivos" que sabe encontrar na BDJur. Relatou que após pesquisar a doutrina por autor e título na BDJur, prefere lê o material na Biblioteca do Tribunal. Relatou que escolhe a BDJur por saber encontrar a informação e racionalizar o trabalho de busca:

"particularmente por que eu acho que talvez seja ela a única que tem. Na verdade é uma forma de eliminar um trabalho prévio. Você já diagnostica no que diz respeito aos livros aquilo que pode interessar, aí eu anoto as referências e vou lá e vejo somente aquilo (...) [que vai ser utilizado] (...) do que diferentemente seria chegar na frente de uma prateleira, tem aquela quantidade massacrante de livro e você começa a abrir um por um (...)".

Relatou que realiza busca na BDjur e na Biblioteca do Tribunal. Ao buscar a informação jurídica publicada em doutrina ou legislação sobre o tema específico que considerou impossível encontrar, relatou que não obteve resultados, conforme pressupôs anteriormente. Relatou que após realizar inúmeras buscas, considerou que a busca na BDJur foi satisfatória por confirmar a inexistência de abordagem e de publicação sobre o assunto que buscava, afirmando que:

"Não achei. Eu fui várias vezes (...)". "Veja só como é positivo, um exemplo negativo". "Mesmo com o meu levantamento prévio eu devo ter gasto mais do que umas oito horas lá dentro, lendo, lendo, olhando, olhando e não consegui achar. Não consegui." Confirmou que: "Não é falha do sistema é por que não existe doutrina sobre isto".

Mencionou que no início da busca sentiu a sensação de angústia: "a angústia é: será que eu estou aqui com o argumento certo para o que eu preciso? Então, ela é um momento prévio antes de você começar a digitar". Porém, confirmou que a sensação de angústia não estava relacionada à BDJur, "absolutamente". Em relação às sensações vivenciadas no processo cognitivo de busca de informação, relatou que:

"É a interpretação prévia... Como é que se desenvolve a coisa? Você recebe uma demanda que é colocada nos seguintes termos. Daí você pensa assim, o que devo eu fazer? Que argumentos usar para melhor encontrar isto aqui? Então, na verdade é um momento de raciocínio, de elaboração, prévio. Você fala assim: acho que esse, ou esse, ou tais caminhos são os mais adequados. Você vai testando o primeiro; pode ser que não tenha sucesso; o segundo; você combina entre eles. Então, ele é prévio a angústia está aí (...)."

Argumentou que teve a sensação de "frustração, mas não com a biblioteca, frustração com os doutrinadores" do Direito. Porém, considerou que a inviabilidade da existência de abordagem do tema pesquisado na literatura justificava por si só ausência de resultados da pesquisa, demonstrando a preocupação e responsabilidade de confirmar este fato. Em função disso, expôs que a vivência 
deste processo de busca suscitou "uma dualidade de sentimento tanto a frustração, como confirmar o que você já antevia".

Relatou que pesquisa na BDJur doutrina publicada em livros, artigos de revista e os atos administrativos. Prioriza a busca na BDJur e na Biblioteca do STJ, em relação à pesquisa a bases de dados externas ao tribunal. Confirmou que na busca à BDJur obtém sucesso seja quando "procura por data, número e argumento". "Quando você não encontra usando estas coisas, é por que em geral não está lá". Neste sentido está satisfeito com a pesquisa na BDJur.

\section{Uso}

Usou o resultado da busca para constatar sua tese de inexistência de abordagens do tema, na literatura do Direito. Considerou o resultado da busca como insucesso, evidenciando uma lacuna no Direito, mesmo sabendo previamente da inexistência da informação, refletindo: "Por que um dia pode aparecer alguém que escreva sobre o óbvio. O interessante não é isso. É como é que uma tese tratando sobre o óbvio chega até aqui, isto é interessante".

Ademais explicou que no trabalho de elaboração do modelo de voto da ministra, busca na BDJur encontrar formas de interpretar legislação e, doutrinadores da área do direito que tenham a mesma linha de entendimento e posicionamento da ministra sobre determinado tema, pois isto "aumenta o respaldo" e "significa que não é uma posição isolada", além de "dá mais valor".

02. Identificação dos incidentes críticos que surgiram a partir da entrevista com o assessor de ministro como usuário da BDJur (definição de padrões)

\section{Padrão positivo do momento "Situação"}

Com a realização da entrevista foi constatado o padrão positivo de situação correspondente à necessidade de buscar informação jurídica em doutrina, legislação e, atos administrativos do STJ, disponíveis na BDJur.

\section{Padrão negativo do momento "Situação"}

Não foi identificado um padrão negativo no momento "situação"

\section{Padrão positivo do momento "Lacuna"}

O usuário considera que encontrará a informação que busca na BDJur. Pesquisa na BDJur consultando o documento digital e também, selecionando o resultado da busca em forma de referência bibliográfica, para consulta dos itens selecionados, no acervo bibliográfico da Biblioteca do STJ.

\section{Padrão negativo do momento "Lacuna"}

O usuário não localizou a informação jurídica desejada porque ela inexiste na literatura da área do Direito.

\section{Padrão positivo do momento "Uso"}

Considerou positiva a comprovação do pressuposto de que não havia doutrina publicada sobre o tema na doutrina na área do Direito.

\section{Padrão negativo do momento "Uso"}

Não fez uso da informação. 


\section{ENTREVISTA 11.2}

01. Relato de entrevista com a marcação de variáveis denominadas incidentes críticos (positivos ou negativos) com a aplicação do método Micro moment time line interview, da abordagem Sense-Making.

\section{Perfil do usuário}

Graduada em direito. É servidora pública do quadro funcional do STJ exercendo a função de assessora de ministro há quase dez anos. É lotada na Primeira Seção, com atuação profissional na área de direito público e previdenciário.

\section{Contextualização da entrevista}

Ver texto explicativo com esclarecimentos à usuária sobre a pesquisa de pósgraduação, antes do início da entrevista no Anexo 11.1.

\section{Relato da entrevistada}

\section{Situação}

Necessitava pesquisar sobre um assunto específico, "o princípio da proibição de retrocesso" para auxiliar nas teses da matéria principal, e acabara de realizar momentos antes do início desta entrevista, a pesquisa sobre o tema, na BDJur. Informou que apanhou livros na Biblioteca do STJ sobre o assunto e vários artigos de periódico, na pesquisa da BDJur. Relatou que "a maioria das vezes que eu consultei a Bdjur não foi para a minha matéria fim que essa eu tenho muito material. Eu trabalho aqui com direito previdenciário e direito administrativo" e sim sobre temas específicos. Explicou que, "na maioria das vezes, eu já tenho um acervo muito grande de direito administrativo e direito previdenciário, inclusive atualizado, seja ele do ministro" e particular da assessora. Esclareceu ainda que "os livros não conseguem acompanhar as teses novas com a mesma velocidade com que os artigos conseguem".

\section{Lacuna}

Confirmou que obteve sucesso após realizar a busca na BDJur sobre este tema específico que precisava encontrando vários artigos jurídicos. Ficou satisfeita com o resultado da busca na BDJur porque:

"Inclusive porque, o que acontece, se você for ver os livros, eles são grandes e não são muito específicos. Artigo de revista é, então, se eu jogar aqui direito previdenciário e proibição de retrocesso, eu vou achar artigo de revista não livro. $O$ livro eu vou pegar [o assunto de forma] geral. Então, no meu campo específico, que é direito previdenciário, eu só vou encontrar nos artigos jurídicos, sendo bem mais específico 'proibição de retrocesso no direito previdenciário', lá eu vou encontrar nos artigos de revista o que eu não vou encontrar nos livros, porque os livros são gerais, são enormes, são sobre muitos assuntos".

Em relação ao processo cognitivo de busca e de estratégia de pesquisa associado às sensações vivenciadas na pesquisa à informação jurídica na BDJur descreveu que: 
"Com frequência eu tenho sucesso na pesquisa e o sentimento, é de assim, é possível funcionar? E outra vantagem do artigo é a rapidez. Se você tem uma dúvida aqui, agora, já quer terminar o processo agora, está com aquela ideia mais ou menos na cabeça... É sensacional que, em menos de um minuto, você já tenha acesso aos melhores doutrinadores, com artigos 'superatualizados', com ideias que você nem pensou, porque você ainda estava lendo livros antigos da matéria. Os artigos são da última semana, das duas últimas semanas. E deu dez minutos e você está com seu voto pronto, citando vários outros. É sensacional! É a modernidade ao nosso favor. Eu não sou muito, assim, tecnológica, mas nessas horas eu fico."

Complementou destacando que a pesquisa que realiza na BDJur, traz resultados que dispensam a solicitação de pesquisa na Biblioteca do STJ e a consulta do material selecionado, tendo "descido cada vez com menos frequência", nas instalações físicas da Biblioteca:

"Eu ligo lá, e falo: olha, pode fazer uma pesquisa de livros? O pessoal que me atende, [responde]: achei alguns artigos e vou mandar. Eu até já encontrei estes artigos e bom, você pode suspender a pesquisa porque os artigos, eu já encontrei. $E$ é muito melhor você não trabalhar com tanto papel. E esse acesso à informação é realmente sensacional como eu falei."

Assinalou que escolhe a BDJur, entre outras bases de dados jurídicas porque: "Eu acho que é por funcionar mesmo. E não é de agora. Quando eu trabalhava [em outro tribunal] [que] não tem mesmo esta estrutura de biblioteca que nós temos aqui e, portanto, nós não focávamos tanto nesta parte doutrinária e sim na parte de jurisprudência. Então, lá [nesse tribunal], era assim".

Referiu-se, espontaneamente, vivências anteriores de busca à informação jurídica na BDJur, quando ainda não ingressara no STJ.

"Mas, quando eu fui fazer a minha monografia de graduação, ainda, quando eu trabalhava lá [no outro tribunal], eu usei a Bdjur daqui [do STJ]. Eu liguei aqui eles fazem também por telefone, mandam por e-mail e você recebe a pesquisa e tira cópia, porque eu não era servidora daqui, tirei cópia por fora, de algumas coisas. Então, funcionou mesmo, e normalmente quando eu recebo pedido de ajuda de colega: Ah! quem tiver livros que possa me emprestar, estou fazendo um trabalho sobre isso", eu sempre indico, não precisa dos meus livros não.

Mencionou, ainda espontaneamente, a realização da pesquisa na BDJur por familiares residentes em outras regiões do país: "[Eles] tem muita dificuldade de acesso [à informação jurídica] lá e, eles usam a Bdjur no Sul de Minas”, (...) [que] passou a ter internet, wi-fi, há pouco tempo. Então, não chega mesmo informação, $e$ esse do BDJur é o que as pessoas acessam com frequência, pelo menos a minha família, que eu indico.

Prosseguiu afirmando que não tem dificuldades com estratégias de busca e pesquisa na BDJur, relacionando problemas neste sentido, com barreiras de hábito de uso, em função da faixa etária do usuário, conforme explicou:

"Eu confesso que não sei se porque (...) uso e já fui treinada por ela, 'criada' por ela (...) eu, realmente não tenho muita dificuldade, mas, por exemplo, o meu pai que é um pouco mais velho, ele diz assim: 'Ah! lá fala que é autoexplicativo, mas, eu sinto algumas dificuldades'. Às vezes, na hora de preencher ele acha que é mais informação, aquela questão assim de quando é Resolução, Portaria ou Artigo (...). Porque talvez fosse mais focado aqui para a gente. Ele por ser mais velho, ele diz 
isso, quando ele vê tem aquele monte de Resolução (...) 'é cansativo'. Ele que não deve estar sabendo". (...) Eu não tenho a menor dificuldade. É problema dele mesmo.

Confirmou que estava satisfeita com o funcionamento da BDJUr, observando, mais uma vez, a dificuldade em relação ao comportamento de busca na BDJur, para usuários de faixa etária mais elevada:

Quando eu entrei aqui, o ministro não se adaptou e ele é um devorador de livros. Já tentei algumas vezes mostrar para ele [que há livros na BDJur]. [Ele responde que não tem sucesso nas buscas]. Então é a única coisa que eu vejo. Eu não tenho problema nenhum. Mas vejo isso.

\section{Uso}

Usou o resultado da pesquisa ao tema específico que buscava na BDJur para consolidar o fundamento da ideia que desenvolveu na literatura do Direito, afirmando que: "meu trabalho com a Bdjur são para assuntos específicos que vão me auxiliar nas teses da matéria principal". Ademais, acrescentou ainda que:

"Normalmente, eu uso quando eu já tenho a tese feita, a ideia feita. Eu só quero nomes fortes para corroborar, para ter nome de peso, para ajudar na minha [ideia], mas, o que eu sou surpreendida, que eu estou dizendo, principalmente com artigos, é que a gente não consegue ler todas as revistas, acompanhar com tanta frequência. Às vezes, a ideia que eu tenho na cabeça é de um livro que eu li a algum tempo, de uma matéria que eu estudei na faculdade, alguma coisa assim. Com frequência, eu procuro só para corroborar e fortificar, deixar fortalecido meu entendimento e sou surpreendida com uma tese mais recente, mais atual, um argumento que eu não tinha pensado, porque meu estudo vem de mais tempo, então a conclusão normalmente já está feita, a linha de raciocínio já está feita. No primeiro momento é só para buscar nomes de peso para fortalecer o meu trabalho. Mas com frequência eu sou surpreendida com ideias novas, argumentos novos que eu não tinha antes".

Concordou que ao ler ideias novas nos artigos jurídicos, pode mudar sua ideia inicial sobre o assunto: "Ou mudar ou fortalecer ainda mais, assim como: eu não pensei nesse terceiro argumento, nessa terceira saída".

Considerou que encontrar os artigos de periódico atualizados, consistentes e pertinentes é importante para o trabalho de assessoria no processo judicial: "É muito importante, principalmente para o gabinete deste ministro". Explicou que há gabinetes no tribunal que trabalham dando mais ênfase à jurisprudência. Por sua vez no gabinete que trabalha, busca-se, além da jurisprudência, o conhecimento jurídico doutrinário publicado em livros e artigos de periódicos. Enfatizou que: "Essa informação é muito importante. É o máximo de doutrina possível; de doutrinadores, possivel".

Acrescentou, ainda que, as diretrizes do gabinete para realização do trabalho dão destaque à fundamentação da matéria do voto do ministro com o uso da doutrina de autores renomados na área do Direito: "É uma especificidade do Ministro [que] diz que [o] Tribunal [é] de vanguarda, de trazer ideias novas, (...) que você vai ter que pesquisar (...) discutir o precedente [jurisprudência] e, só tem como discutir com outros nomes, com a doutrina". 
Reforçou que utiliza para realização do seu trabalho de assessora, livros e artigos de revista, evidenciando o peso da doutrina em relação à jurisprudência no uso da informação jurídica: "Tem a pesquisa de jurisprudência, mas aí já é outro caso, não é doutrinária. A biblioteca do ministro é muito grande e, na minha área específica, a minha acaba sendo também, tenho alguns livros".

02. Identificação dos incidentes críticos que surgiram a partir da entrevista com o assessor de ministro como usuário da BDJur (definição de padrões)

\section{Padrão positivo do momento "Situação"}

Com a realização da entrevista foi constatado o padrão positivo de situação correspondente à necessidade de buscar informação jurídica em doutrina publicada em livros e artigos de periódicos disponíveis na BDJur.

\section{Padrão negativo do momento "Situação"}

Não foi identificado um padrão negativo no momento "situação"

\section{Padrão positivo do momento "Lacuna"}

A usuária tem sucesso na busca da informação jurídica na BDJur, encontrando doutrina atualizada, pertinente e consistente sobre o assunto que necessita de autores renomados da área do Direito.

\section{Padrão negativo do momento "Lacuna"}

Não foi identificado um padrão negativo no momento lacuna.

\section{Padrão positivo do momento "Uso"}

1. Usou uma tese mais atualizada, um argumento que não tinha pensado anteriormente na elaboração da matéria principal do voto.

2. Fundamentou a linha de pensamento sobre o tema com nomes de autores renomados, jurisconsultos e juristas na doutrina da área do Direito, para corroborar na linha de entendimento da matéria.

3. Encontrou uma nova diretriz no encaminhamento da matéria.

4. Sabe que encontrará quantidade de doutrina que necessita para realizar seu trabalho.

\section{Padrão negativo do momento "Uso"}

Não foi identificado um padrão negativo no momento uso. 


\section{ENTREVISTA 11.3}

01. Relato de entrevista com a marcação de variáveis denominadas incidentes críticos (positivos ou negativos) com a aplicação do método Micro moment time line interview, da abordagem Sense-Making.

\section{Perfil do usuário}

Graduada em Direito e, possui especialização em Direito. É servidora pública cedida de outro órgão da Administração Pública, exercendo a função de assessora de ministro há quase dez anos. É lotada na Terceira Seção, com atuação profissional na área de direito penal.

\section{Contextualização da entrevista}

Ver texto explicativo com esclarecimentos à usuária sobre a pesquisa de pósgraduação, antes do início da entrevista no Anexo 11.2 e 11.3 .

\section{Situação}

\section{Relato da entrevistada}

O fato gerador da necessidade de informação foi encontrar "matéria relacionada a direito penal, processual, mais doutrina, algumas vezes atos normativos aqui do Tribunal, quando preciso, bastante doutrina". Relatou que "literalmente" realiza a busca na BDJur para: "subsidiar voto do ministro. Encontrar melhor fundamentação, encontrar jurisprudência, geralmente artigos doutrinários, bibliografias".

\section{Lacuna}

Pesquisa na BDJur porque considera que "nas questões institucionais, eu acho que é o melhor lugar para pesquisar; nas questões doutrinárias porque é um canal fácil que pode dar solução de forma mais ágil". Pesquisa na BDJur, "matéria relacionada ao direito penal, processual, mais doutrina, algumas vezes atos normativos aqui do Tribunal quando preciso, bastante doutrina". Em relação a estratégia de busca na BDJur, confirmou que teve "muitas pesquisas de sucesso. De insucesso talvez por conta da dificuldade de algum tipo de argumento de pesquisa, dificuldade em conseguir tornar aquela pesquisa mais específica num assunto muito pontual'.

Descreveu sensações experimentadas durante o processo de busca de informação e, a atribuição de sentido ao resultado da pesquisa, mencionando que quando encontra a informação tem o sentimento:

"De alívio...; alívio de ter encontrado alguma coisa que eu procurava, ainda que não seja no sentido que eu pensava, mas ter alguma informação sobre aquele assunto, que às vezes é um assunto pouco trabalhado, pouco decidido aqui no STJ, então o principal sentimento de alívio".

Referiu-se a consulta a outras fontes de pesquisa, a livros do acervo do ministro, do próprio gabinete e:

"às vezes agente precisa de uma versão mais atualizada também, às vezes eu peço para descer na Biblioteca, buscar, como já sei qual é o livro, às vezes pesquiso no Google, quando é uma coisa que não está conseguindo mesmo, ou na pesquisa de 
jurisprudência do CJF que pega todos os TRFs, numa questão que não foi tratada aqui no STJ, que está começando ainda e, também esse sistema [BDJur], ele é mais uma possibilidade dentro destas fontes de pesquisa."

Atribuiu importância à pesquisa na BDJur em função do tema específico a ser encontrado: "depende da dificuldade da questão, ou da ausência de abordagem sobre a questão". A pesquisa na BDJur foi considerada essencial pela assessora na busca de "resoluções, atos internos, algumas questões que são específicas que não há como pesquisar fora daqui".

$\mathrm{Na}$ estratégia de seleção dos termos para realização da busca à informação jurídica, a assessora acrescentou como sugestão para aprimoramento da BDJur:

"Eu acho que a indexação é sempre muito importante. Deixar assim o máximo esmiuçado do que trata aquele artigo para que, quando agente for pesquisar, facilite a pesquisa. Esta parte da indexação tanto na jurisprudência, como na pesquisa doutrinária, eu acho muito importante. Que as pessoas que indexam consigam resumir assim, do que se trata, indexar direitinho eu acho que isto é muito importante, encontrar os termos mais exatos e mais técnicos.

Uso

Usa o resultado da busca para reforçar e desenvolver um argumento e, determinar o sentido do voto, em função da dificuldade da questão, ou da ausência de abordagem sobre $o$ assunto.

02. Identificação dos incidentes críticos que surgiram a partir da entrevista com os assessor de ministro como usuário da BDJur (definição de padrões)

\section{Padrão positivo do momento "Situação"}

Com a realização da entrevista foi constatado o padrão positivo de situação correspondente à necessidade de buscar informação jurídica em doutrina publicada em livros e artigos de periódicos, atos normativos e bibliografias disponíveis na BDJur.

\section{Padrão negativo do momento "Situação"}

Não foi identificado um padrão negativo no momento "situação".

\section{Padrão positivo do momento "Lacuna"}

Considera a BDJur como melhor lugar para pesquisar questões doutrinárias e institucionais e, como canal fácil de pesquisa que apresenta solução com agilidade.

\section{Padrão negativo do momento "Lacuna"}

Relatou necessidade de aprimoramento em relação à representação dos assuntos com a indexação.

\section{Padrão positivo do momento "Uso"}

Relatou que a informação foi útil na execução do seu trabalho para:

- Solucionar o sentido do voto;

- Fundamentar uma decisão e ideia pré-determinada;

- Realmente sanar uma dúvida;

- Eventualmente fazer uma citação;

- Reforçar um argumento, ou até para desenvolver um argumento, um fundamento.

Padrão negativo do momento "Uso"

Não foi identificado um padrão negativo no momento "uso". 


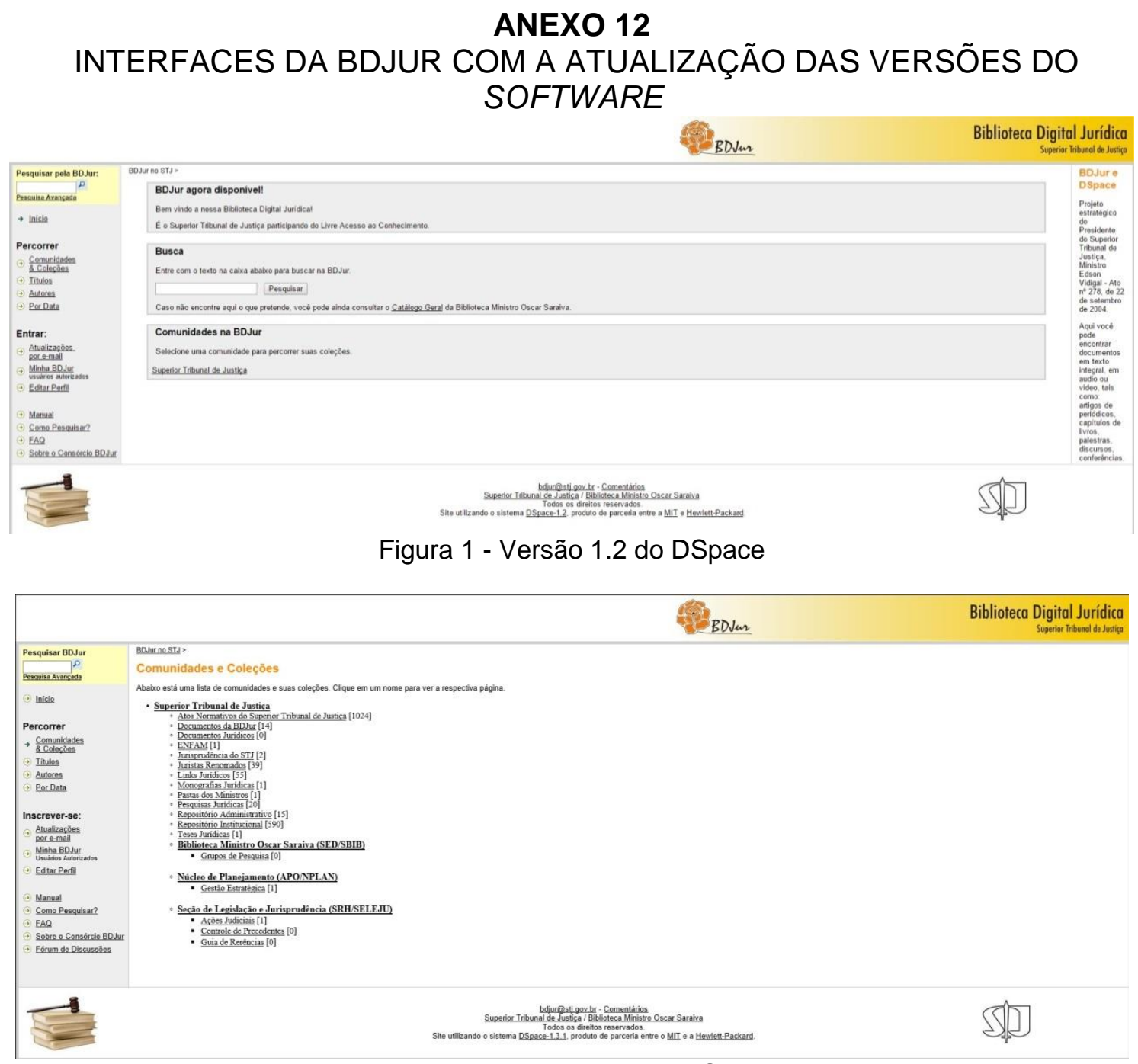

Figura 2 - Versão 1.3.1 do DSpace

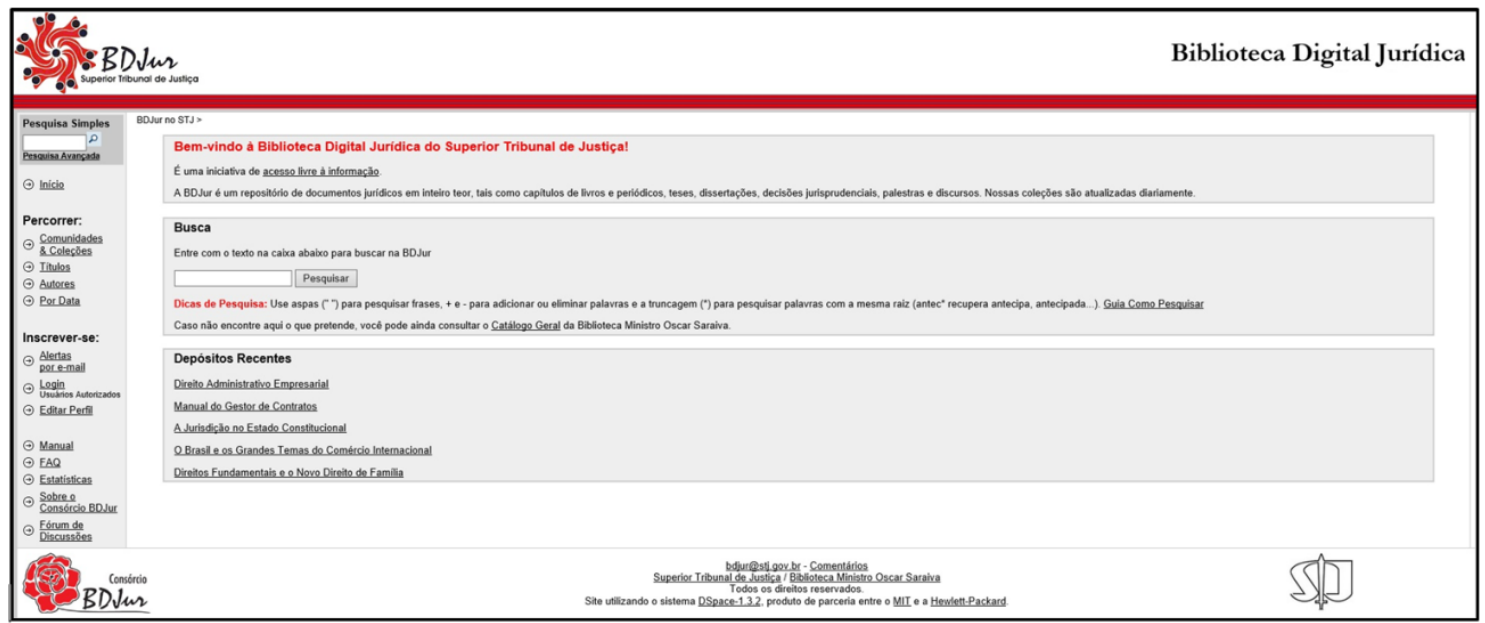

Figura 3 - Versão 1.3.2 do DSpace 


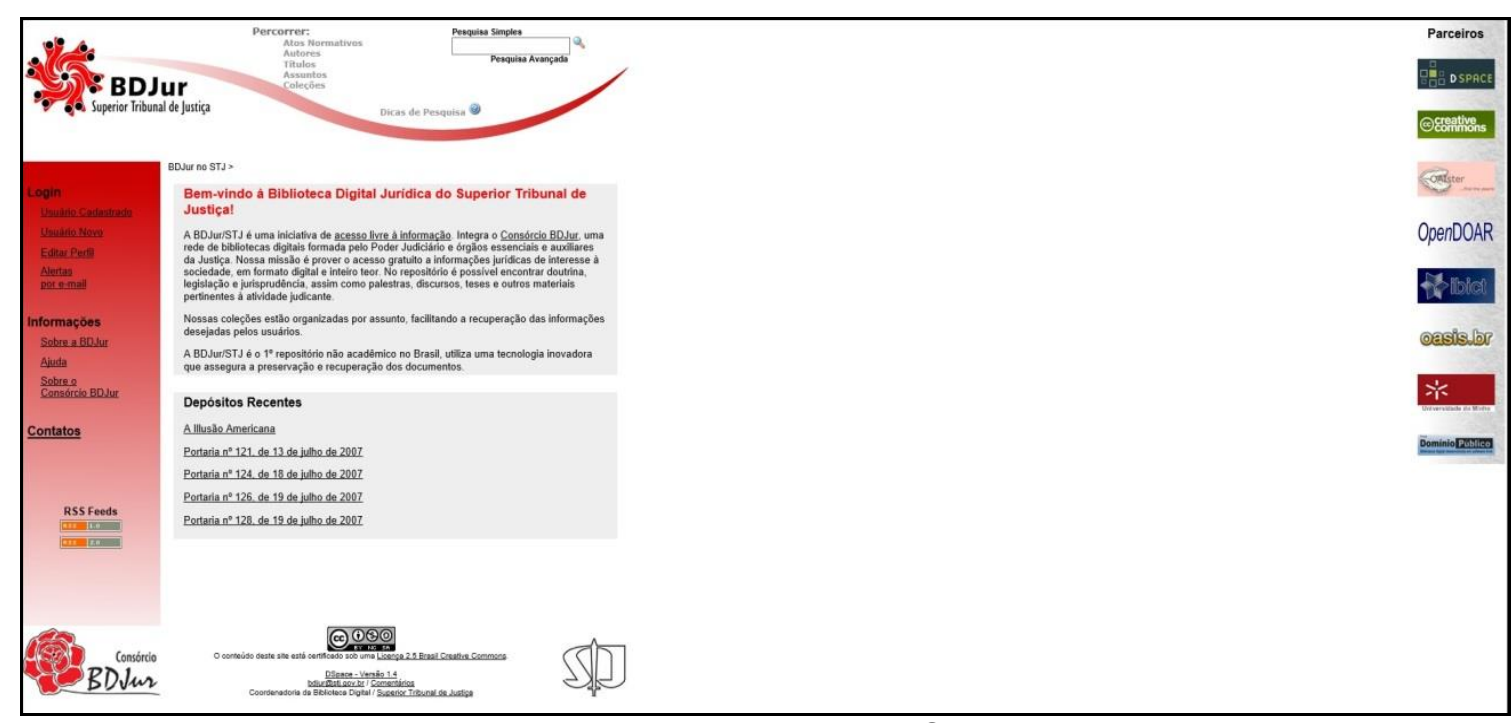

Figura 4 - Versão 1.4 do DSpace

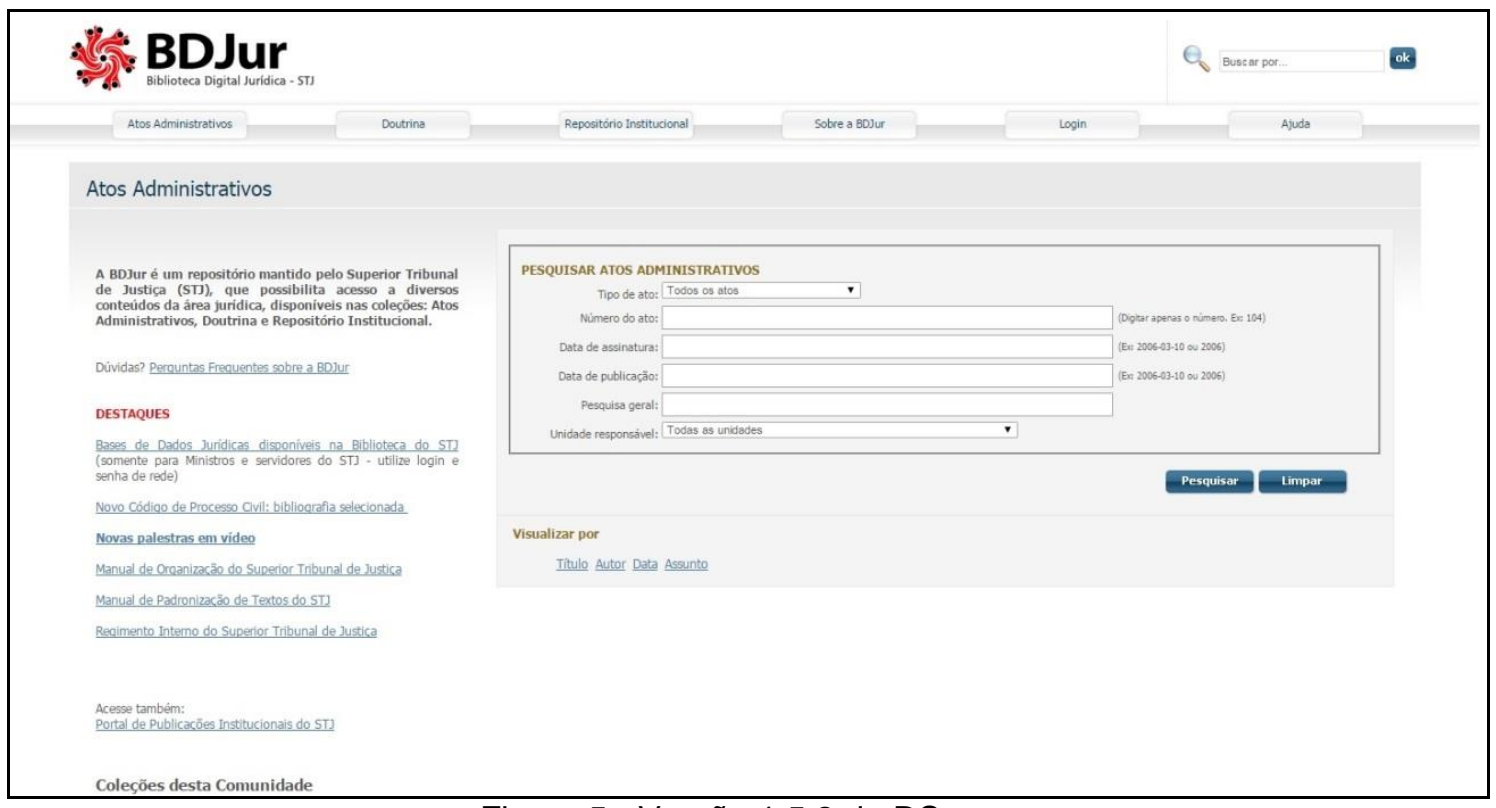

Figura 5 - Versão 1.5.2 do DSpace

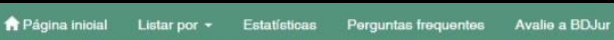

e STJ

BDJur

A BDJur é um repositório mantido pelo Superior Tribunal de Justiça (STJ), que possibilita acesso a diversos conteúdos da áreá

juridica, disponiveis nas coleçōes: Atos Administrativos, Doutrina e Repositorio Institucional.

Página Inicial

Q. Pesquisar em

(t) ATOS ADMINISTRATIVOS

Boletim de Serviço $\theta$ Atos Normativos do STJ, da ENFAM $\theta$ do extinto TF

DOUTRINA

19. Livros, antigos, palestras e outros conteúdos doutrinários

ST] REPOSITÓRIO INSTITUCIONAL DO STJ

TODA A BDJUR

Pesquisar em todas as ooleçoes.

Regimento Interno do STJ Atualizado até a Emenda 17/12/2014

Publicaçōes Institucionais Textos do STS

rienta a elaboraçáa de Manual de Organizạ̣ão do Dscoreve as competênolias as unidades administrativas do STJ

Figura 6 - Versão 4.2 do DSpace 


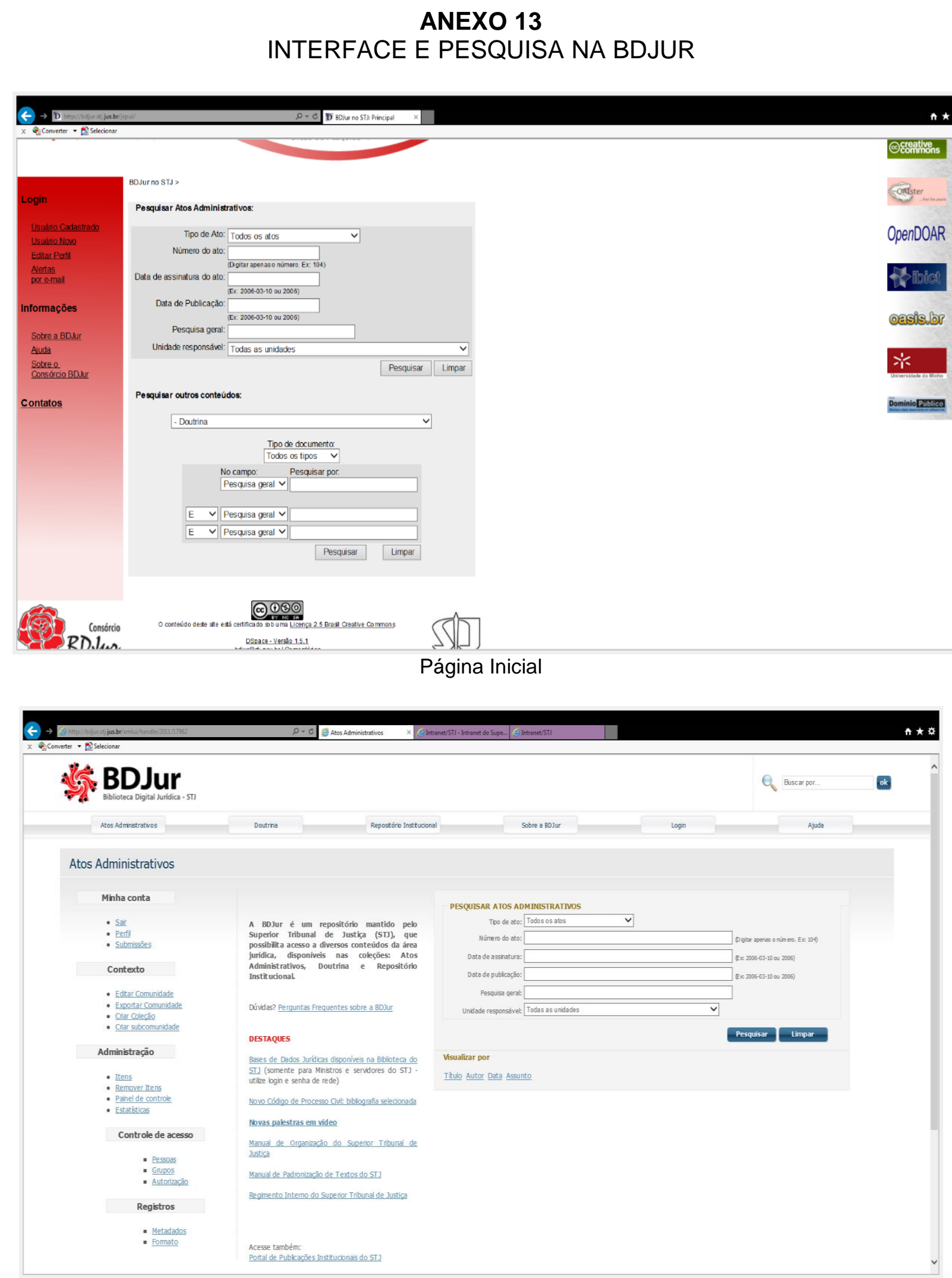

Pesquisa na coleção Atos Administrativos 


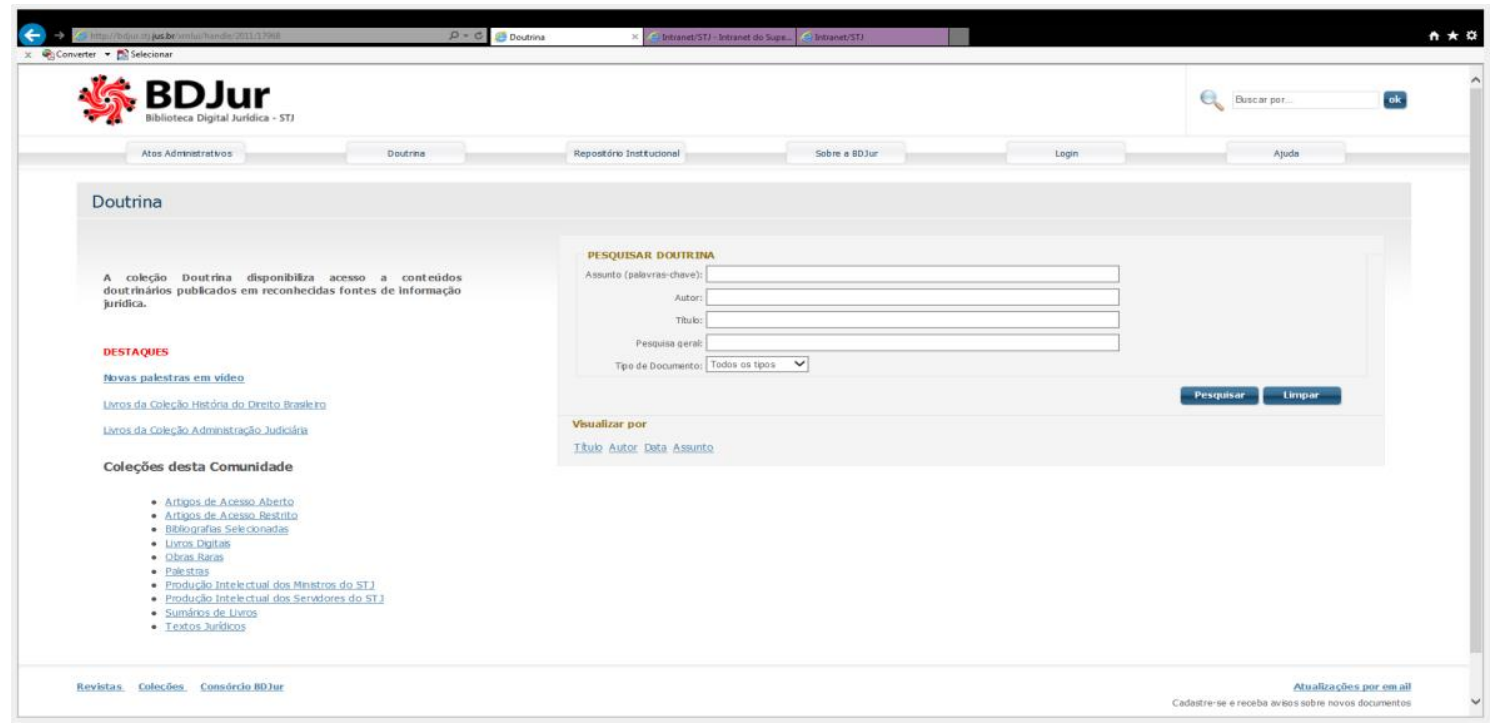

Pesquisa na coleção Doutrina

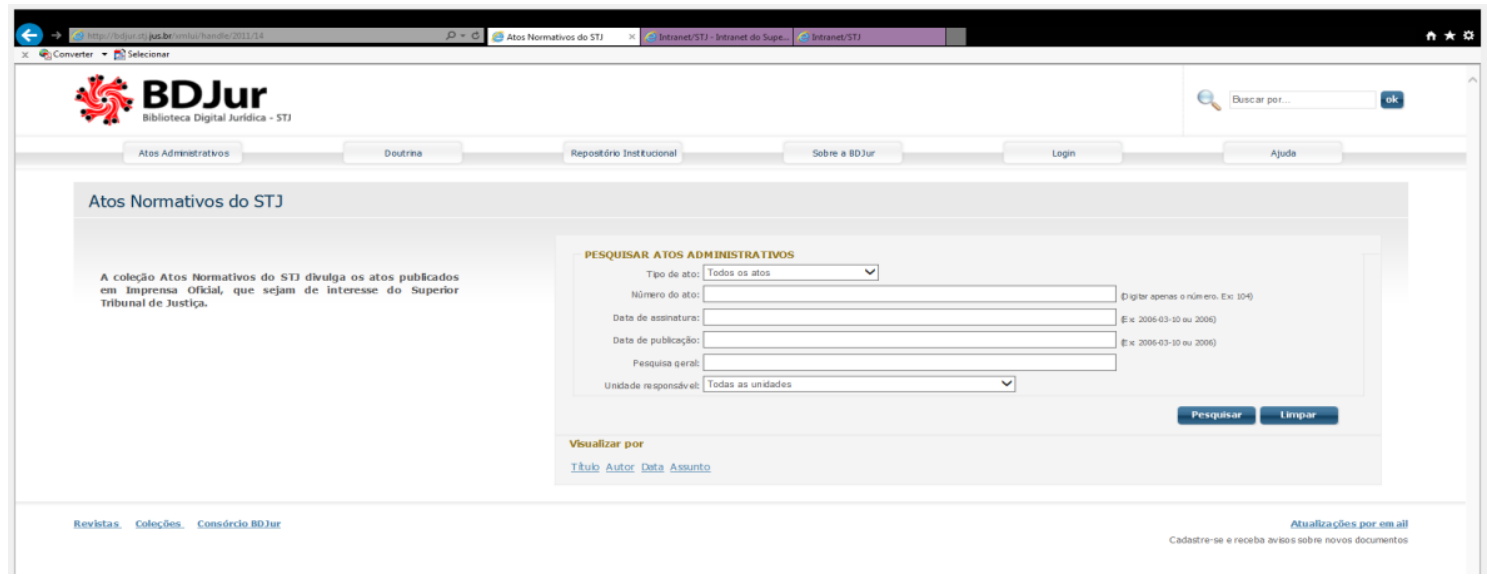

Pesquisa dos Atos Normativos do STJ

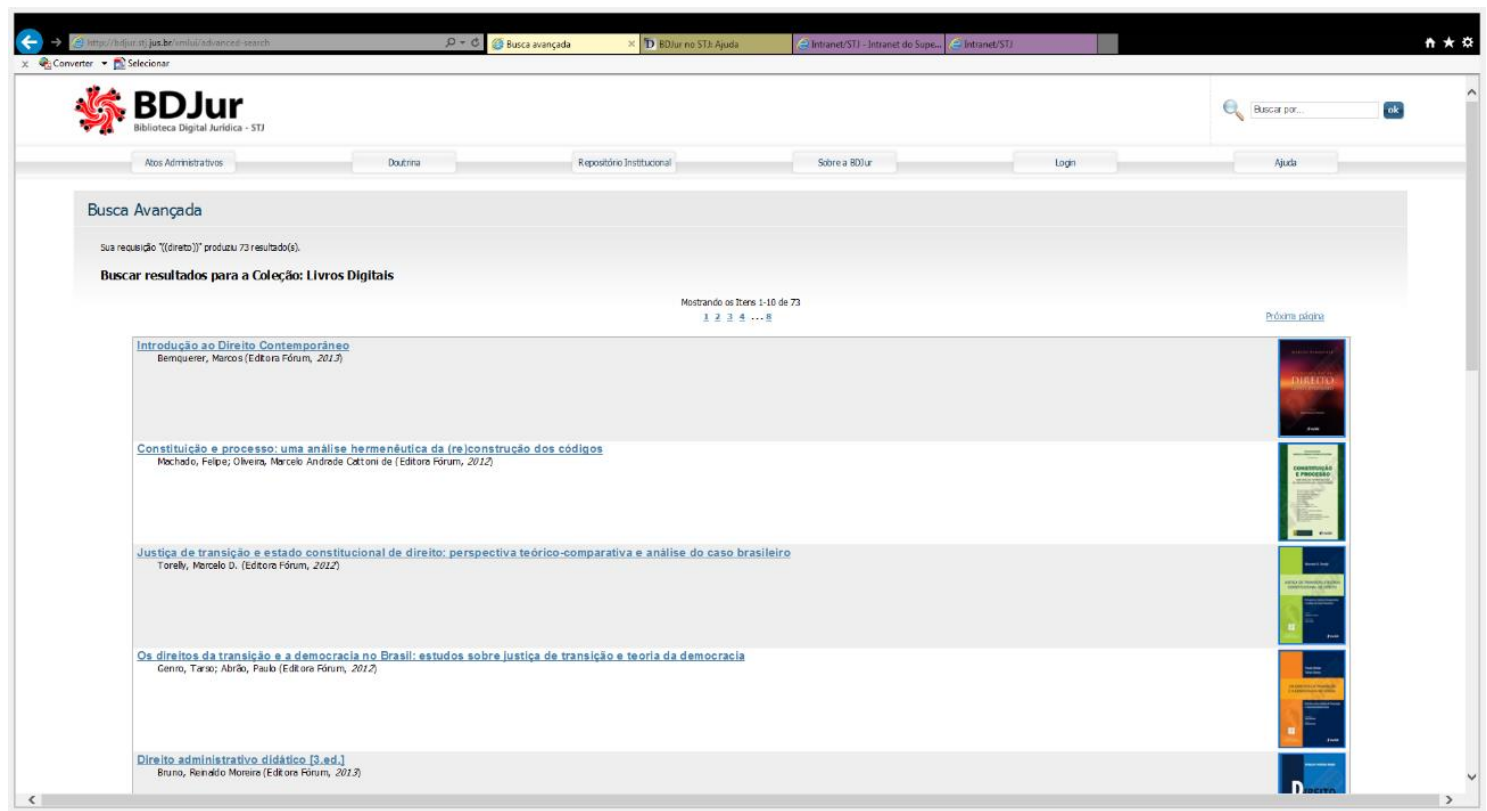

Busca avançada com resultado de pesquisa de doutrina 


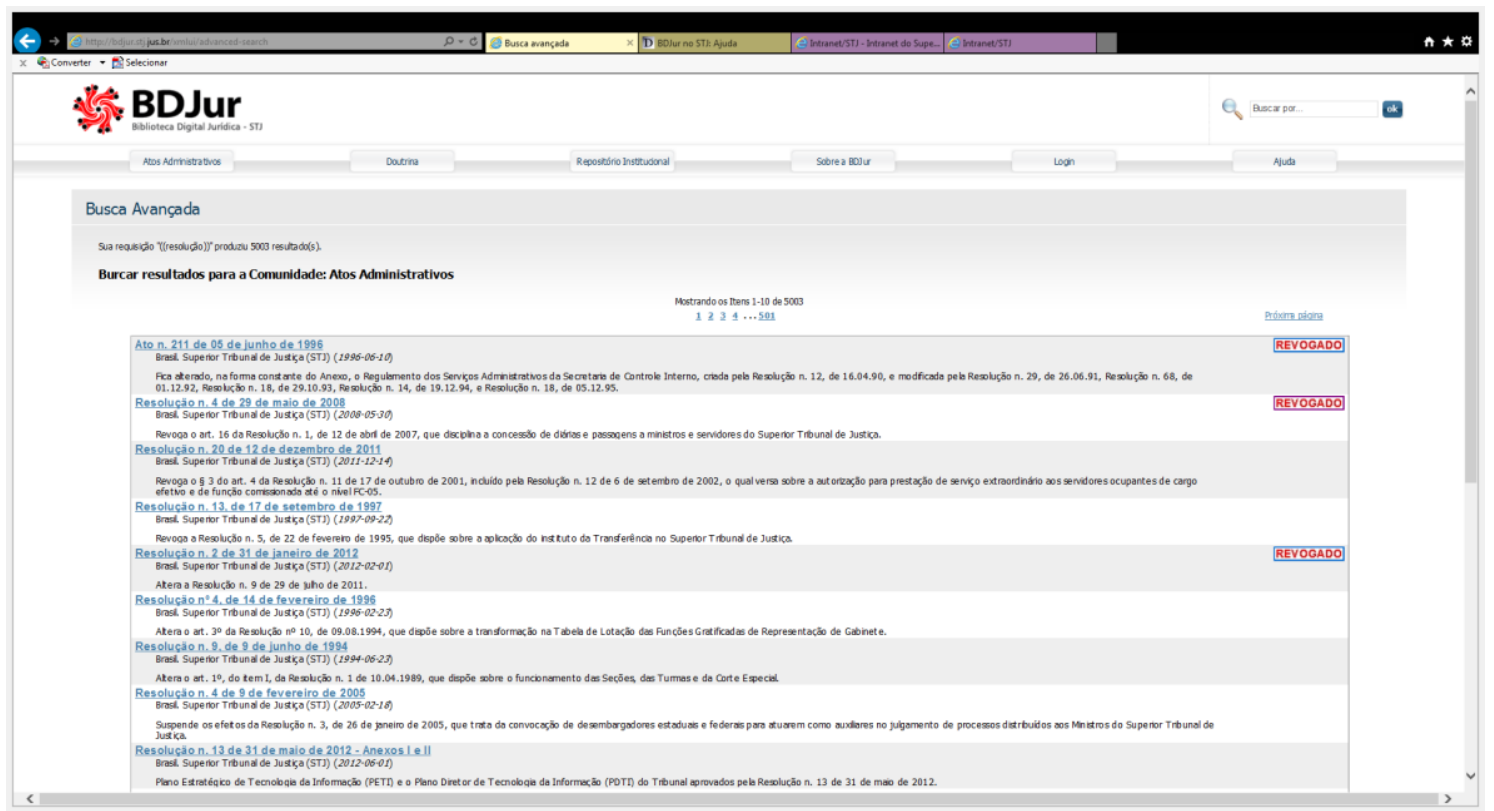

Busca avançada com resultado de pesquisa de Atos administrativos

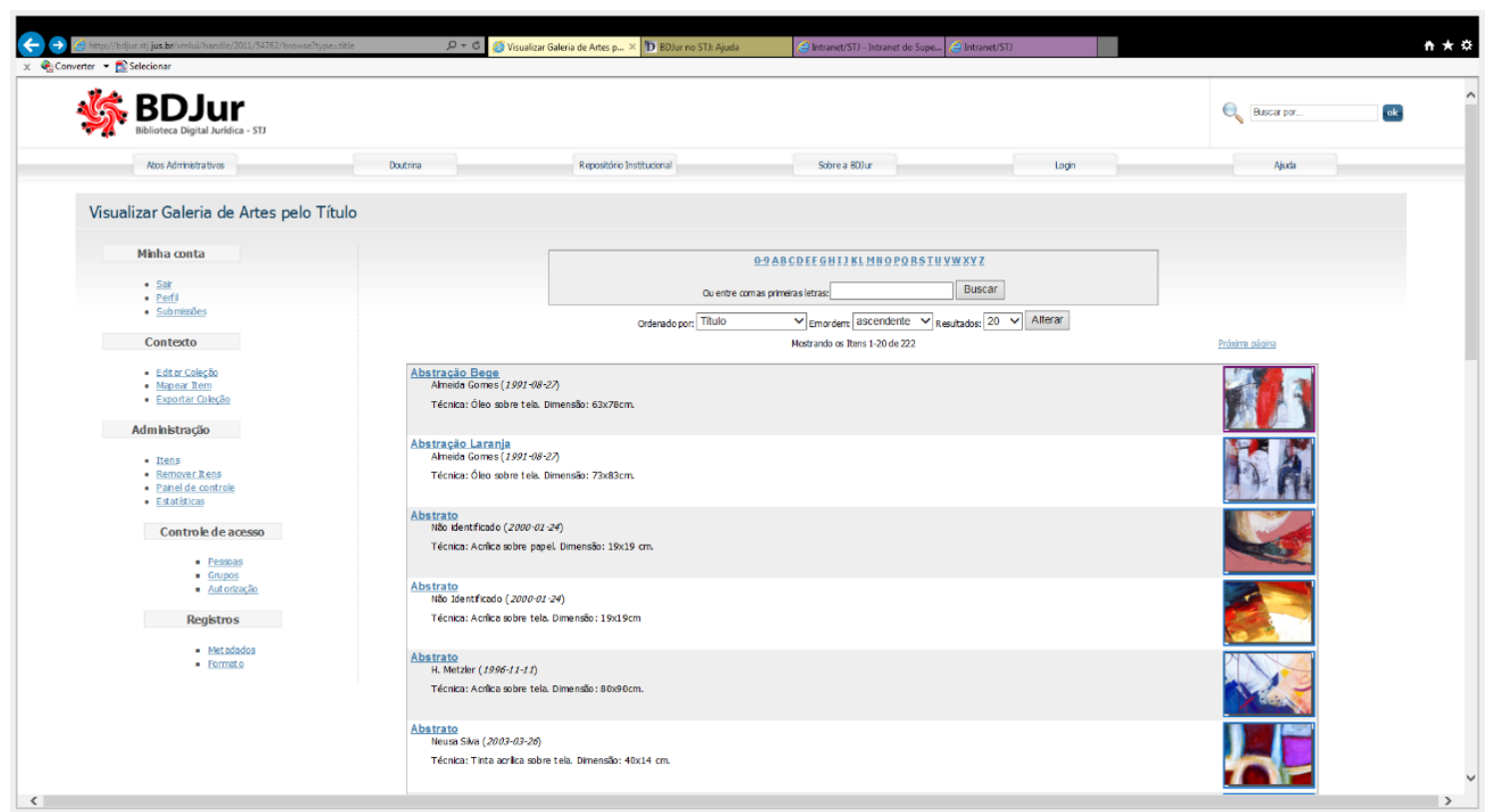

Pesquisa na Galeria de Artes 


\section{BIBLIOGRAFIA CONSULTADA}

AGARWAL, Naresh Kumar. Making sense of sense-making: tracing the history and development of Dervin's Sense-Making Methodology. Disponível em: http://gslis.simmons.edu. Acesso em 16 set. 2012.

ALMEIDA, Maria Cristina Barbosa de. Planejamento de bibliotecas e serviços de informação. 2. ed. Brasília: Briquet de Lemos/Livros, 2011.

ALONSO, Cecília Andreotti Atienza. A informação jurídica face às comunidades da área do direito e a dos fornecedores da informação jurídica. In: CIBERÉTICA: SIMPÓSIO INTERNACIONAL DE PROPRIEDADE INTELECTUAL, INFORMAÇÃO E ÉTICA, 1998, Florianópolis. Anais... Florianópolis, 1998. Disponível em: $<h t t p: / / w w w . c i b e r e t i c a . i a c c e s s . c o m . b r / p o r t u g u e s /$ main.html>.

AMERICAN LIBRARY ASSOCIATION, Chicago. Presidential Comittee on Information Literacy: final report. Chicago, ALA, 1989. Disponível em: <http://www.ala.org/ala/mgrps/divs/acrl/publications/whitepapers/presidential.cfm>. Acesso em: 29 mar. 2013.

ANDRADA, José Bonifácio Borges de. Prefácio [da Classificação decimal de direito]. In: CARVALHO, Doris de Queiroz. Classificação decimal de direito. 4. ed. rev. e atual. Brasília: Presidência da República, 2002. (versão eletrônica) Disponível em: http://www4.planalto.gov.br/centrodeestudos/galeria-de-fotos/arquivos-importados/ arquivos-pdf/classificacao-decimal. Acesso em: 18 dez. 2013.

AQUINO, Simone Azevedo Bandeira de Melo, CAMPOS, Ana Jéssica Souza. Usabilidade da interface de sites e-commerce. Revista Eletrônica Multidisciplinar Pindorama do Instituto Federal de Educação, Ciência e Tecnologia da Bahia, v.1, n.1, ago, 2010. Disponível em: www.revistapindorama.ifba.edu.br

ARAÚJJO, Angela Maria Albuquerque de; ALMEIDA, Orlando de. Profissional da informação jurídica: produtividade e canais de divulgação. In: ENCONTRO NACIONAL DE INFORMAÇAO E DOCUMENTAÇAO JURIDICA, 4, 1992, São Paulo. Anais ... São Paulo, 1992, 365 p. 318-328.

ARAÚJO, Carlos Alberto Ávila et al. A Ciência da Informação na visão dos professores e pesquisadores brasileiros. Informação \& Sociedade, João Pessoa, v. 17, n.2, p. 95108, maio/ago. 2007.

Carlos Alberto Ávila; PEREIRA Giselle Alves; FERNANDES Janaína Rosário. A contribuição de B. Dervin para a Ciência da Informação no Brasil. Encontros Bibli: Revista Eletrônica de Biblioteconomia e Ciência da Informação, Florianópolis, v. 14, n. 28, p. 57-72, 2009.

Carlos Alberto Ávila. A Ciência da Informação como uma ciência social. Ci. Inf., Brasília, v. 32, n. 3, p. 21-27, set./dez. 2003.

ARRUDA, Alvin. Manual de direito processual civil. São Paulo, Revista dos Tribunais. 2006. 2 v.

ATIENZA, Cecília Andreotti. Documentação jurídica: introdução à análise e indexação de atos legais. Rio de Janeiro: Achiamé, 1979. 266 p.

AUGUSTO, Ruy Rosado de Aguiar. Prefácio. In: PASSOS, Edilenice; BARROS, Lucivaldo Vasconcelo Fontes de informação para pesquisa em direito. Brasília: Briquet de Lemos Livros, 2009. $170 \mathrm{p}$. 
BACELLAR, Roberto Portugal. Juiz servidor, gestor e mediador. Brasília: Escola Nacional de Formação e Aperfeiçoamento de Magistrados Ministro Sálvio de Figueiredo Teixeira, 2013. 133 p.

BALBOA, A. C. El incidente critico como tecnica para recolectar datos. In: Metodos Cualitativos para estudiar a los usuarios de la informacion. Mexico: UNAM, Centro Universitario de Investigaciones Bibliotecologicas. 2008. 212 p. Disponível em: http://bibliotecadigital.org/jspui/bitstream/001/384/8/978-607-02-0768-6.pdf

BAPTISTA, Sofia Galvão; CUNHA, Murilo Bastos da. Estudos de usuários: visão global dos métodos de coleta de dados. Perspectivas em Ciência da Informação, Belo Horizonte, v. 12, n. 2, p. 168-184, maio/ago. 2007.

BARITÉ, Mario; GUIMARÃES CHAVES, José Augusto. Guia metodológico para el acceso, el análisis y la organización temática de documentos jurídicos. Montevideo: Universidad de la Republica. Comisión Central de Educación Permanente, 1999. $161 \mathrm{p}$.

BARROS, Lucivaldo Vasconcelos. Fontes de informação jurídica. In: PASSOS, Edilenice (Org.). Informação jurídica: teoria e prática. Brasília: Thesaurus, 2004, p. 201-225.

Lucivaldo Vasconcelos. O papel do bibliotecário na efetividade do direito constitucional à informação. Senatus, Brasília, v. 7, n. 1, p. 64-67, jul., 2010.

BAUENS, M. The cybrarians manifesto: towards a new organizational model for corporate libraries (on-line). Disponível em: http://worf.ubalt.edu Acesso em: 03 abr. 2003.

BELTRAME, Mariana. Organização da justiça e do Ministério Público. Disponível em: http://academico.direito-rio.fgv.br. Acesso em 29 mar. 2013.

BEVILÁCQUA, Clovis. Soluções práticas de direito. Rio de Janeiro, Freitas Bastos, 1929. v. 4.

BIBLIOTECAS JURIDICAS: a serviço da justiça. Disponivel em: http://acessohot. blogspot.com.br/2-11/09/bibliotecas-juridicas-serviço-da.html. Acesso em 22 fev. 2013.

BORGES, Mônica Erichsen Nassif. A abordagem contemporânea sobre a cognição humana e as contribuições para os estudos de usuários da informação. Cadernos BAD, n. 2. p. 74-81, 2005.

Mônica Erichsen Nassif. O essencial para a gestão de serviços e produtos de informação. Revista Digital de Biblioteconomia e Ciência da Informação, Campinas, v.5, n. 1, p. 115-128, jul/dez. 2007.

BORKO, H. Information science: what is it? American Documentation, jan. 1968.

BOYCE, Bert; KRAFT, Donald H. Principles and theories in information science. Annual Review of Information Science and Technology (Arist). v. 20, p. 153-178, 1985.

BRACKS, Mauricio Vieira. Apresentação. In: CARVALHO, Doris de Queiroz. Classificação decimal de direito. 4. ed. rev. e atual. Brasília: Presidência da República, 2002. Disponível em: http://www4.planalto.gov.br/centrodeestudos/galeriade-fotos/arquivos-importados/arquivos-pdf/classificacao-decimal. Acesso em: 18 dez. 2013.

BRASIL, Celestina Vitória Moraes. Prefácio. In: 0 direito e suas instâncias linguísticas. Porto Alegre: Sergio Antonio Fabris Ed., 2002. 104p. p. 15-17.

BRASIL. Superior Tribunal de Justiça. Assessoria de Modernização e Gestão Estratégica. Manual de planejamento estratégico: 2010-2014. Brasília (DF), 2012. 
. Biblioteca Ministro Oscar Saraiva. Brasília (DF), 2009. folheto. 6 p.

Biblioteca Digital Jurídica - BDJur, Brasília (DF), 2007, 4 p.

. Biblioteca Ministro Oscar Saraiva. Regulamento. Brasília (DF), 2012. 42 p.

. Núcleo de Educação à Distância. Regimento Interno do STJ - Cidadania

em movimento : módulo 1. Curso à distância. Conteudistas: José Pereira dos Santos, Fernanda Rios Amorim; Desenhistas de interface para EAD: Andrea Marques Solter de Azevedo, Luanna Nakamotome. Brasília (DF), 2012. Disponível em: http://www.stj.jus.br.

. Presidência. Ato no 207, de 12 de junho de 1995. Brasília (DF), 1995. Disponível em: http://bdjur.stj.jus.br.

. Presidência. Resolução n. 7, de 17 de junho de 2004. Brasília (DF), 2004. Disponível em: http://bdjur.stj.jus.br

Regimento Interno. Brasília (DF), Disponível em: http://www.stj.jus.br . Secretaria de Documentação. Biblioteca Digital Jurídica do STJ : BDJur 10 anos. Brasília (DF), DF, 2015.

Video Institucional, 2. 2013.

CAPPELLETTI, Mauro; GARTH, Bryant. Acesso à justiça. Porto Alegre: Editora Fabris, 1988. $168 \mathrm{p}$.

CARVALHO, Ivam Lira de. Eficácia e democracia na atividade judicante. Rev. do Instituto de pesquisas e estudos: divisão jurídica. São Paulo, n. 31, p. 279-284, abr./jul., 2001 Disponível em: http://www.ite.edu.br/ripe arquivos/ripe31.pdf\# page=276 Acesso em: 6 abr. 2014.

CHEUK, B.; DERVIN, B. A. Qualitative Sense-Making Study of the information seeking situations faced by professionals in three workplace contexts. EJC/REC, v. 9, n. 2,3,4, 1999. Disponível em: http://communication.sbs.ohio-state.edu/ sensemaking/art/artabscheukdervin99ejoc.html. Acesso em 4 jan. 2014.

CHISNALL, P. M. Pesquisa mercadológica. São Paulo: Saraiva, 1980.

CINTRA, Anna Maria Marques. Subjetividade e interdisciplinaridade na biblioteconomia. Transinformação, v. 8, n. 3, p. 32-43, set./dez., 1996.

CLAVER, E. et al. The performance of information systems through organizational Culture. Information. Technology \& People, v.3, n. 14, p. 247-260. 2001

COELHO, Edison Francioni. Aspectos formais dos atos normativos: linguagem jurídica. Brasília: OAB Ed. 2005, 248 p.

COSTA, Luciana Ferreira da; SILVA, Alan Curcino Pedreira da; RAMALHO, Francisca Arruda. (Re)visitando os estudos de usuário: entre a "tradição" e o "alternativo. DataGramaZero - Revista de Ciência da Informação, v.10, n.4, ago. 2009. Disponível em: http://www.dgz.org.br/ago09/Art 03.htm. Acesso em: 5 mar. 2016.

CRUZ, Fernando William; CUNHA, Murilo Bastos da et al. Um modelo para mapeamento de necessidades e usos de informação musical. Perspectivas em Ciência da Informação, v.16, n.2, p.207-227, abr./jun. 2011.

CUNHA, Murilo Bastos da. Das bibliotecas convencionais às digitais: diferenças e convergências. Perspectivas em Ciência da Informação, v. 13, n.1, p. 2-17, jan./abr. 2008.

Disponível

em:

http://portaldeperiodicos.eci.ufmg.br/index.php/pci/article/view/221/388. 
. Murilo Bastos da. Fontes jurídicas. In: Manual de fontes de Informação. Brasília: Briquet de Lemos / Livros, 2010. p. 126-147.

Murilo Bastos da. Metodologias para estudo dos usuários de informação cientifica e tecnológica. R. Bibliotecon. Brasília, v. 10, n. 2, p. 5-19, jul./dez. 1982.

DAMIÃO, Regina Toledo, HENRIQUES, Antonio. Curso de português jurídico. 10. ed. São Paulo: Atlas, 2007. 301 p.

DELGADO, Maurício Godinho. Os princípios na estrutura do direito. Rev. TST, Brasília, v. 75 , n. 3, jul./set., p. 17-34, 2009. Disponível em: http://aplicacao.tst.jus.br/ dspace/bitstream/handle/1939/13660/001 mauriciogodinhodelgado.pdf?sequence=1.

Acesso em: 14 jan. 2014.

DERVIN, Brenda; NILAN, Michael, Information needs uses. Annual Review of information Science and Tech (ARIST), volume 21, 1986.

DINIZ, Maria Helena. Curso de direito civil brasileiro. 18. ed. São Paulo: Saraiva. v. 1, 2002.

DUDZIAK, Elisabeth Adriana. Information literacy: princípios, filosofia e prática. Ciência da Informação, Brasília, v. 32, n. 1, p. 23-35, jan./abr. 2003. Disponível em:<http://revista.IBICT.br/index.php/ciinf/article/view/123/104>. Acesso em: 01 abr. 2013.

DUTRA, Ademar. Metodologias para avaliar o desempenho organizacional : revisão e proposta de uma abordagem multicritério. Revista Contemporânea de Contabilidade, v. 2, n. 1, jan./jun. 2005.

ESPÍRITO Santo, Carmelita do ... et al. Visibilidade da biblioteca especializada na Web através da gestão por processos. In: SEMINÁRIO INTERNACIONAL DE BIBLIOTECAS DIGITAIS, 2, 2010 e SEMINÁRIO NACIONAL DE BIBLIOTECAS UNIVERSITÁRIAS, 16, 2010, Rio de Janeiro. Anais ... Rio de Janeiro, 2010, p. 1-12. Disponível em: http://www.sibi.ufrj.br/snbu2010/pdfs/orais/final 462.pdf.

Fachin, Odília Fundamentos de Metodologia. 4ํ․ ed. São Paulo: Saraiva, 2003

FAQUETI, M. F; OHIRA, M. L. B. A Internet como recurso na educação: contribuições da literatura. Revista ACB, Florianópolis, v. 4, n. 4, p. 47-63, 1999.

FAZENDA, Ivani Catarina. Integração e interdisciplinaridade no ensino brasileiro. São Paulo: Loyola, 1979. 198 p.

FERINI, Viviane do Amaral. Dicionário terminológico bilíngue francês-português de termos jurídicos: tratamento terminográfico e reflexões sobre terminologia bilíngue. Dissertação (mestrado - Unesp), 2006. 324 p.

FERREIRA, Sueli Mara Soares Pinto. Design de biblioteca virtual centrado no usuário: a abordagem sense-making para estudos de necessidades e procedimentos de busca e uso da informação. Ci. Inf., Brasília, v. 26, n. 2, maio/ago., 1997.

Sueli Mara Soares Pinto. Novos paradigmas e novos usuários de informação. Ci. Inf., Brasília, v. 25, n. 2, 1995.

FLANAGAN, John C. A técnica do incidente crítico. Arquivos Brasileiros de Psicologia Aplicada. Rio de Janeiro, v. 25, n. 2, p. 99-141, abr./jun. 1973.

FOGL, Jiri. Relation of the concepts "information" and "knowledge". International fórum on information and documentation, The Hague, v. 4, n. 1, p. 21-24, 1979.

FRIEDE, Reis. Percepção científica do direito. Revista Forense, v. 402, n. 105, mar./abr., p. 253-277, 2009. 
GOMES, Orlando. Conteúdo de classe do direito civil. In: MACHADO NETO, A. L. (Org.). O direito e a vida social: leituras básicas de sociologia jurídica. São Paulo: Ed. Nacional ; Ed. da Unesp, 1966. 209 p. p. 141-145. (Biblioteca Universitária. Série 2. Ciências Sociais, n. 18. Direção Florestan Fernandes).

GONÇALVES, Marcio. Abordagem Sense-Making na Ciência da Informação: uma breve contextualização. Rev. Dig. Bibl. Ci. Inf., Campinas, v. 9, n. 2, p. 1-11, jan./jun. 2012. Disponível em: http://www.sbu.unicamp.br/seer/ojs/index.php/sbu rci/index

GONÇALVES, Marcos Rogério; GOUVEIA, Sônia Mara; PETINARI, Waldinéa Sonia. A informação como produto de alto valor no mundo dos negócios. CRB-8 Digital, São Paulo, v. 1, n. 1, p. 43-54, jul. 2008. Disponível em: http://www.crb8.org.br/ojs.

Marcos Rogério; SANTOS, Valéria Silva. A biblioteca jurídica como fonte de conhecimento decisório. CRB-8 Digital, São Paulo, v. 2, n. 2, p. 4-11, set. 2009. Disponível em: http://revista.crb8.org.br.

GONZALEZ de GOMEZ, M. N. Os problemas filosóficos da informação. Revista de Ciência da Informação e Documentação, v. 4, p. 3-29, 2013.

GRIZZUTI, Gustavo Félix. A função social da linguagem jurídica através dos tempos. Revista de estudios literarios. Universidad Complutense de Madrid, n. 33, 2006.

GROSSI, Paolo. O ponto e a linha. História do Direito positivo na formação do jurista do nosso tempo. Rev. Sequência, v. 51, p. 31-45, dez., 2005.

GUBERT, Pablo. A linguagem do direito: rotina e evolução. Curitiba: Juruá, 2004. 155 p.

GUSMÃO, Camila. Organização da justiça e do Ministério Público. Disponível em: http://academico.direito-rio.fgv.br. Acesso em 29 mar. 2013.

GUSMÃO, P. D. Introdução à ciência do direito. 22. ed. Rio de Janeiro: Forense, 1997.

GYRÃO, Maria Lucia. A ideia de justiça em Hannah Arendt. 2. ed. Rio de Janeiro: Ed. do autor, 2007. $181 \mathrm{p}$.

HORTINHA, Joaquim. E-marketing: um guia para a nova economia. Lisboa: Silabo, 2001. $238 p$.

HOUAISS, Antônio. Dicionário Houaiss da Língua Portuguesa. Rio de Janeiro, Ed. Objetiva, 2001.

INFOPEDIA: Jakob Nielsen. Porto: Porto Ed., 2003-2013. Disponível em: http://www.infopedia.pt. Acesso em: 22 mar. 2013.

INSTITUTO BRASILEIRO DE INFORMAÇÃO EM CIÊNCIA E TECNOLOGIA. Sobre o IBICT: histórico. Disponível em: http://www.IBICT.br. Acesso em 20 jul. 2013.

ISO 9241. International Organization for Standardization. Disponível em: https://en.wikipedia.org/wiki/ISO 9241.

JAPIASSU, H. Interdisciplinaridade e patologia do saber. Rio de Janeiro: Imago, 1976.

KATTER, R. V. Design and evalution of information systems. Annual Review of Information Science and Technology, v. 4, p. 31-70, 1969.

KERLINGER, Fred N. Metodologia da Pesquisa em Ciências Sociais: um tratamento conceitual. 9ำ reimpressão. São Paulo: Editora Pedagógica e Universitária LTDA, 2003. $346 \mathrm{p}$ 
KELSEN, Hans. Jurisprudência normativa e sociológica. In: MACHADO NETO, A. L., MACHADO NETO, Zahidé (Org.) .0 direito e a vida social: leituras básicas de sociologia jurídica. São Paulo: Ed. Nacional ; Ed. da Unesp, 1966. 209 p. p. 16-20. (Biblioteca Universitária. Série 2. Ciências Sociais, n. 18. Direção Florestan Fernandes)

KREMER, Jeannette M. A técnica do incidente crítico. R. Esc. Bibliotecon. UFMG, Belo Horizonte, v. 9, n. 2, p. 165-176, set. 1980.

LANCASTER, F. W. Avaliação de serviços de bibliotecas. Brasília: Briquet de Lemos, 2004.

LAKATOS, Eva Maria, MARCONI Marina de Andrade. Fundamentos de metodologia científica. 5. ed. São Paulo: Atlas 2003. 311 p.

LAURINDO, Fernando José Barbin. Tecnologia da informação: eficácia nas organizações. São Paulo: Futura, 2002. 247 p.

LAZZARIN, Sonilde Kugel. As razões sociológicas da expansão do poder judiciário no mundo contemporâneo. Espaço Jurídico, Joaçaba, v. 10, n. 2, p. 191-212, jul./dez. 2009.

LEVACOV, Marília. Biblioteca virtual: ®volução? Ci. Inf., Brasília, v. 26, n. 2, p. 258-268,

Marília. Bibliotecas virtuais. In: MARTINS, Francisco Menezes; SILVA, Juremir Machado da (Org.). Para navegar no século XXI: tecnologias do imaginário e cibercultura. Porto Alegre: Sulina; EDIPUCRS, 1999. 294 p. p. 261-286.

LÉVY-BRUHL, Henri. Os fatores da evolução do Direito. In: MACHADO NETO, A. L.; MACHADO NETO, Zahidé (Org.). O Direito e a vida social: leituras básicas de sociologia jurídica. São Paulo: Ed. Nacional, Ed. da Unesp, 1966. 209 p. p. 87-93. (Biblioteca Universitária. Série 2. Ciências Sociais, n. 18. Direção Florestan Fernandes)

LINTON, Ralph. A cidade e o Direito. In: MACHADO NETO, A. L.; MACHADO NETO, Zahidé (Org.). $O$ direito e a vida social: leituras básicas de sociologia jurídica. São Paulo: Ed. Nacional, Ed. da Unesp, 1966. 209 p. p. 11-15. (Biblioteca Universitária. Série 2. Ciências Sociais, n. 18. Direção Florestan Fernandes).

LOUREIRO, Regina Célia Campagnoli. A especialidade do bibliotecário jurídico: bases para uma interação com o usuário operador do direito. Infolegis, Brasília, DF, 2005. Disponível em: <http://www.infolegis.com.br/loureiro-especialidade.htm>. Acesso em 12 fev. 2013.

MARINONI, Luiz Guilherme. O STJ enquanto corte de precedentes. São Paulo: Revista dos Tribunais, 2014. 284 p.

MACIEL, Anna Maria Becker. Para o reconhecimento da especificidade do termo jurídico. Tese (Doutorado em Letras) - Universidade Federal do Rio Grande do Sul, 2001, $258 \mathrm{f}$.

MACIEL, Cristiano et al. Avaliação heurística de sítios na Web. In: VII ESCOLA DE INFORMÁTICA DO SBC-CENTROOESTE, 2004, Cuiabá. SUCESU-MT, 2004 Conferência: Sociedade do Conhecimento. Cuiabá: PAK Multimídia, 2004.

McGARRY, Kevin. O contexto dinâmico da informação: uma análise introdutória. Brasília: Briquet de Lemos, 1999

MINAYO, M. C. S. \& SANCHES, O. Quantitative and qualitative methods: opposition or complementarity? Cad. Saúde Públ., Rio de Janeiro, v.3, n. 9, p. 239-262, jul./sep., 1993. 
MIRANDA, Ana Cláudia Carvalho de Miranda. A política de desenvolvimento de coleções no âmbito da informação jurídica. In: PASSOS, Edilenice (Org.). Informação jurídica: teoria e prática. Brasília: Thesaurus, 2004. p. 137-152.

MIRANDA, Antonio. Ciência da informação: teoria e metodologia de uma área em expansão. Organizado por Elmira Semeão. Brasília: Thesaurus, 2003. 212 p.

MITIDIERO, Daniel. Cortes superiores e cortes supremas: do controle à intepretação, da jurisprudência ao precedente. São Paulo: Ed. Revista dos Tribunais, 2013. 141 p.

METCHKO, Dulce Maria Bastos. Demandas de usuários de bibliotecas : revisão de literatura. Educ. rev., Curitiba, n.1, jan./dec. 1981. Disponível em: http://dx.doi.org/10.1590/0104-4060.021. Acesso em 6 mar. 2016.

MODAHL, Mary (2000). Now or never : how companies must change today to win the battle for Internet consumers. New York: Harper Business.

MORAES, Alexandre de. Direito constitucional. São Paulo: Atlas, 2013. 940 p.

MORRIS, Ruth. Toward a user-centered information service. Journal of the American Society for Information Science, v. 45, n. 1, p. 11-30, 1994.

MUELLER, Suzana Pinheiro Machado. O periódico científico. In. CAMPELLO, Bernadete Santos; CENDÓN, Beatriz Valadares; KREMMER, Jeannette Marguerite (Org.). Fontes de informação para pesquisadores e profissionais. Belo Horizonte: Ed. UFMG, 2000.319 p.

NASCIMENTO, L. M. B.; GUIMARÃES, José Augusto Chaves. Documento jurídico digital: a ótica da diplomática. In: Edilenice Passos. (Org.). Informação jurídica: teoria e prática. Brasília: Thesaurus Editora, 2004, v. , p. 7-23.

NIELSEN, J. Technology transfer of heuristic evaluation and usability inspection. Disponível em: http:/www.nngroup.com/articles/technology-transfer-of-heuristicevaluation/. 1995.

\& Sons, 1994.

J.; MACK, R L. Usability inspection methods computer. New York ; Jonh Wiley

NORONHA, Fernando. Direito e sistemas sociais: a jurisprudência e a criação de direito para além da lei. Florianópolis: Ed. Da UFSC, 1988. 208 p.

OHIRA, Maria de Lourdes Blatt et al. Profissional da informação jurídica: três décadas de produção bibliográfica. In: ENCONTRO NACIONAL DE INFORMAÇAO E DOCUMENTAÇAO JURIDICA, 6, 1998, Florianópolis. Anais ... Florianópolis, 1998. Disponível em: http://www.ciberetica.iaccess.com.br/portugues/main.htm.

- Maria de Lourdes Blatt, ORENGO, Cynthia Moura. SELL, Maria Aparecida. A informação jurídica e seus usuários: Biblioteca da Procuradoria da República no Estado de Santa Catarina. In: ENCONTRO NACIONAL DE INFORMAÇÃO E DOCUMENTÇÃO JURÍDICA, 5, 1996, Porto Alegre. Anais... Porto Alegre, 1996. Disponível em: http://www.ufrgs.biblioteca/arb. Acesso em: 3 mar. 2013.

OLIVEIRA, Francisco Djalma, SUAIDEN, Emir. Identificação e análise do comportamento informacional como instrumento de aprendizagem corporativa. In: TARAPANOFF, K. Aprendizado organizacional: contextos e propostas, v. 2. Curitiba, Ibpex, 2011.

OLIVEIRA, Maria Madalena Fernandes Caetano. A interdisciplinaridade aplicada em projetos pedagógicos no ensino superior. 2002. 286 f. Dissertação (Mestrado em Pedagogia). Faculdade de Educação, Universidade de Brasília, Brasília. 
PÁDUA, Clarindo Isaías Pereira da Silva. Avalição heurística. Palestra proferida pelo autor. 2012.

PASSOS, Edilenice. Bibliotecario jurídico: Mapeamento de sua produção bibliográfica. In: Informaçao jurídica: teoria e pratica. Edilenice Passos (org.). Brasilia: Thesaurus, 2004. 237 p. 189-200.

Edilenice. A biblioteconomia jurídica no século XXI. In: SEMINÁRIO NACIONAL DE DOCUMENTAÇÃO E INFORMAÇÃO JURÍDICA, 2, 2010, Brasília. Anais... Brasília, 2010.

Edilenice. O futuro da biblioteca jurídica. In: I Encontro das Bibliotecas da 4a Região e I Reunião do Grupo de Automação de Bibliotecas da 4a Região, Porto Alegre (RS), 02 maio 2005. Disponível em: http://www.infolegis.com.br/futuro-bibliotecajuridica.htm. Acesso em 21 fev. 2013. (não paginado).

Edilenice, BARROS, Lucivaldo Vasconcelos. Fontes de informação para pesquisa em direito. Brasília: Briquet de Lemos Livros, 2009. 170 p.

PEREIRA, Paula Pessoa. Legitimidade dos precedentes: universalidade das decisões do STJ. São Paulo : Revista dos Tribunais, 2014. 174 p.

PETRI, Maria José Constantino. Manual de linguagem jurídica. São Paulo: Saraiva, 2008. 238 p.

PINHEIRO, Lena Vania Ribeiro. Ciência da Informação: desdobramentos disciplinares, interdisciplinaridade e transdisciplinaridade. In: GONZÁLEZ DE GÓMEZ, Maria Nélida; DILL ORICO, Evelyn Goyannes (Org.). Políticas de memória e informação. Natal: EDUFRN, 2006. p. 111-142

PINHEIRO. Antônio Fernando G; MOURAO, Henrique César; RASO, Ulisses de Vasconcelos. Modernidade na prática da advocacia. Agenda PMR, v. 1, n.1, out. 2006.

RABELO, Ernane Correa. Comportamento informacional e evocação de notícias: estudo de caso com estudantes de comunicação social. Tese (doutorado - Escola de Ciência da Informação da UFMG), 2008. 245 p.

RABELLO, Rodrigo; CAIADO, Beatriz Coelho. Produtos e serviços de informação : estudos de usos e usabilidades. Brasília: Ibict, 2014. 212 p.

RADOS, Gregório J. Varvakis; VALERIM, Patrícia; BLATTMANN, Ursula. Valor agregado a serviços e produtos de informação. Disponível em: http://www.ced.usfc.br/ ursula/papers/valor.html. Acessado em 24.11.2004

REALE, Miguel. Lições preliminares de direito. São Paulo: Saraiva, 2006. 391 p.

RENDÓN ROJAS, Miguel Ángel. Bases teóricas y filosóficas de la bibliotecología. México: Universidad Nacional Autónoma de México, Centro de Investigaciones Bibliotecológicas, 1998. 148 p.

REZENDE, Ana Paula de. Centro de informação jurídica eletrônico e virtual. Ci. Inf., Brasília, v. 29, n. 1, p. 51-60, jan./abr. 2000.

Ana Paula de. Pesquisa jurídica em fontes eletrônicas. In: PASSOS, Edilenice (Org.). Informação jurídica: teoria e prática. Brasília: Thesaurus, 2004. p. 173-188.

REZENDE, Martha Izabel de Souza Duarte. Gerenciamento da informação e do conhecimento no escritório de advocacia. In: CIBERÉTICA. SIMPÓSIO INTERNACIONAL DE PROPRIEDADE INTELECTUAL, INFORMAÇÃO E ÉTICA, 1, 1998, Florianópolis, Anais..., Florianópolis, 1998. 
ROCHA, Eliana da Conceição; SOUSA, Márcia de Figueiredo Evaristo de. Metodologia para avaliação de produtos e serviços de informação. Brasília: Instituto Brasileiro de Ciência e Tecnologia, 2011. 81 p.

ROCHA, Lucylene Valerio. Análise da busca, uso e avaliação dos serviços da biblioteca pelos assessores de ministros do Supremo Tribunal Federal em relação às suas necessidades de informação jurídica. Dissertação (Mestrado) Universidade de Brasília, Faculdade de Ciência da Informação, 2011, 129 f.

ROSA, Regina Celia; CRIVELLARI, Helena Maria Tarchi. Caracterização do trabalho bibliotecário no campo jurídico em Belo Horizonte. In: ENCONTRO NACIONAL DE PESQUISA EM CIÊNCIA DA INFORMAÇÃO, 8, Salvador... Anais... Salvador, 2007.

SALDANHA, Nelson. Da teologia à metodologia: secularização e crise no pensamento jurídico. Belo Horizonte: Del Rey, 1993. 133 p.

SANTIAGO, Antonio Edilberto Costa; BARREIRA, Maria Isabel Sousa. Competência informacional jurídica: habilidades em pesquisa jurídica. In: CONGRESSO BRASILEIRO DE BIBLIOTECONOMIA, DOCUMENTAÇÃO E CIÊNCIA DA INFORMAÇÃO: Sistemas de informação, multiculturalidade e inclusão social, 24, 2011, Alagoas. Anais... Alagoas, 2011. Disponível em: http://febab.org.br/congressos /index.php/cbbd/xxiv/paper/viewFile/566/448. Acesso em 30 mar. 2013.

SANTOS, José Pereira dos. Aspectos da estrutura e funcionamento do STJ. Brasília, Superior Tribunal de Justiça, 14 abr. 2014. Entrevista concedida a Maria de Fátima Coelho Castro.

SARACEVIC, Tefko. The concept relevance in information science: a historical review. In: SARACEVIC, Tefko. Introduction to information science. New York, Bowker, 1970, p. 111-150.

SAYÃO, Luís Fernando. Modelos teóricos em ciência da informação: abstração e método científico. Ci. Inf., Brasília, v. 30, n. 1, p. 82-91, jan./abr. 2001.

Afinal, o que é biblioteca digital?. REVISTA USP, São Paulo, n.80, p. 6-17, dez./fev. 2008-2009.

SERRA, Liliana Giusti. Bibliotecas digitais: conceitos e planejamento. 2013. Disponível em: https://ebuco.bc.ufg.br/up/220/o/Mini curso Bibliotecas Digitais.pdf

SICHES, Luís Recasens. Forças sociais que atuam sobre a legislação. In: MACHADO NETO, A. L.; MACHADO NETO, Zahidé (Org.). O direito e a vida social: leituras básicas de sociologia jurídica. São Paulo: Ed. Nacional, Ed. da Unesp, 1966. 209 p. p. 87-93. (Biblioteca Universitária. Série 2. Ciências Sociais, n. 18. Direção Florestan Fernandes).

SILVA, Andréia Gonçalves. Fontes de informação jurídica: conceitos e técnicas para o profissional da informação. Rio de Janeiro: Interciência, 2010b. 227 p.

SILVA, Bruno. Cargos jurídicos. Disponível em: http://www.concursos.brunosilva. adv.br. Acesso em 27 mar. 2013.

SILVA, Edevaldo Alves da. Prefácio. In: O Direito na Sociedade da Informação. São Paulo: Atlas, 2007. 333 p. p. x-xvii.

SOW, Marilene Mendes. Informação Jurídica: contribuições da arquitetura e organização da informação no âmbito da Câmara dos Deputados. In: CONGRESSO BRASILEIRO DE BIBLIOTECONOMIA, DOCUMENTAÇÃO E CIÊNCIA DA INFORMAÇÃO, 25, 2013 E SEMINÁRIO NACIONAL DE DOCUMENTAÇÃO E INFORMAÇÃO JURÍDICA, 4, 
2013, Florianópolis. Anais... Florianópolis, 2013. Disponível em: http://portal.febab.org.br/anais/article/viewFile/389/389

STERNE, Jim. World Wide Web marketing. New York: Bookseller, 2000. 398 p.

SUAIDEN, Emir. Apresentação. In: ROCHA, Eliana da Conceição, SOUSA, Márcia de Figueiredo Evaristo de. Metodologia para avaliação de produtos e serviços de informação. Brasília: Instituto Brasileiro de Ciência e Tecnologia, 2011a. 81 p. p. $21-31$.

Emir José. A dimensão social do conhecimento. Scire. v. 13, n. 1, ene./jun., 2007, ., Emir José. A responsabilidade social e informacional no âmbito do Brasil. Revista EDICIC, v. 1, n. 1, p. 27-37, jan./mar. 2011b. Disponível em: http://www.edicic.or/revista/. Acesso em 2013.

SYTIA, Celestina Vitória Moraes. O direito e suas instâncias linguísticas. Porto Alegre: Sergio Antonio Fabris Ed., 2002. 104 p.

TAMMARO, Anna Maria; SALARELLI, Alberto. A biblioteca digital. Brasília: Briquet de Lemos, 2008, $378 \mathrm{p}$.

TORRES, Elisabeth Fátima; MAZZONI, Alberto Angel; ALVES, João Bosco da Mota. A acessibilidade à informação no espaço digital. Ci. Inf., v. 31, n. 3, 2002. p. 83-91.

TRUJILLO FERRARI, Alfonso. Metodologia da ciência. 3. ed. Rio de Janeiro : Kennedy, 1974.

TULL, Donald S.; HAWKINGS, Del. L. Market research: meaning, measurement and method: a text with cases. New York: MacMillan, 1976, 736 p.

WEBER, Adriana; CHEDID, Luciano. Noções introdutórias de teoria geral do processo. 2. ed. Porto Alegre: Livraria do Advogado, 2004. 160 p.

YIN, Robert K. Seis fontes de evidências: pontos fortes e pontos fracos: estudo de caso: planejamento e métodos. 2005, p. 113. 